\title{
Mau Mau crucible of war: Statehood, national identity and politics in postcolonial Kenya
}

Nicholas Kariuki Githuku

Follow this and additional works at: https://researchrepository.wvu.edu/etd

\section{Recommended Citation}

Githuku, Nicholas Kariuki, "Mau Mau crucible of war: Statehood, national identity and politics in postcolonial Kenya" (2014). Graduate Theses, Dissertations, and Problem Reports. 5677.

https://researchrepository.wvu.edu/etd/5677

This Dissertation is protected by copyright and/or related rights. It has been brought to you by the The Research Repository @ WVU with permission from the rights-holder(s). You are free to use this Dissertation in any way that is permitted by the copyright and related rights legislation that applies to your use. For other uses you must obtain permission from the rights-holder(s) directly, unless additional rights are indicated by a Creative Commons license in the record and/ or on the work itself. This Dissertation has been accepted for inclusion in WVU Graduate Theses, Dissertations, and Problem Reports collection by an authorized administrator of The Research Repository @ WVU.

For more information, please contact researchrepository@mail.wvu.edu. 


\title{
MAU MAU CRUCIBLE OF WAR: STATEHOOD, NATIONAL IDENTITY AND POLITICS IN
} POSTCOLONIAL KENYA

\author{
by \\ Nicholas Kariuki Githuku \\ Dissertation submitted to the Eberly College of Arts and Sciences \\ at West Virginia University \\ in partial fulfillment of the requirements \\ for the degree of \\ Doctor of Philosophy \\ in \\ History
}

Approved by

Dr. Robert Maxon, Committee Chairperson

Dr. Joseph Hodge

Dr. Robert Blobaum

Dr. Jeremia Njeru

Dr. Tamba M'bayo

Department of History

Morgantown, West Virginia

2014

Keywords: war, statehood, stateness, security, mentalité, national identity, psychosociological anxieties

Copyright 2014 Nicholas Kariuki Githuku 


\begin{abstract}
The postcolonial African state has been the subject of extensive study and scrutiny by various scholars of great repute such as Colin Legum, Crawford Young, Robert H. Jackson and Carl G. Rosberg, Pierre Englebert and Jean- François Bayart to name but a few. Crawford Young's work is especially interesting because of the manner in which he treats the process of state formation. Crawford Young traces the process to the early beginning of European colonization and focuses on the legacy of the colonial state after independence. Colonial appendages of old European states were, for some metropolises, no longer economically viable or sustainable and/or consistent with new post-world War I and II principles such as the right of all peoples to selfdetermination and decolonization, and were, thus, abandoned. Overall, however, perhaps because of the simplicity of the process of state formation in Africa through European agency, the everyday realities of the nature of the African state and lived experiences remain rather elusive still. Nevertheless, this body of work that has benefitted disproportionately from the contribution of political scientists cannot be underestimated. At the same time though, the manner in which this process has been approached by such authors employs methodological perspectives in political science that overlook or undermine attempts at determining the manner in which the making, or unmaking, and evolution of post-colonial African states is viewed and contested from below. Historians employing empirical information based on archival evidence can make such a bottom-up analysis that is cognizant of popular views or dissent affecting the political evolution of these states possible. While there have been a few country-specific studies, there's room for more scrutiny of how African states have evolved since independence paying closer attention to popular forces from below. This study demonstrates that the late colonial experience in Kenya was the foetal crucible of the postcolonial state. It does this with specific reference to the Mau Mau war. This follows from the argument that the Mau Mau decade was Kenya's defining moment marked by widespread societal rupture embodied by the Mau Mau conflict. This war represented a caesura in which Kenya's future was contested between competing imperial and indigenous ideological constructions of the state: colonial liberal and conservative, and indigenous dissent borne of an existential struggle for survival. The study examines these ideological strands, but focuses more acutely on the basic convictions and moral thought or subliminal ideology of Mau Mau while, at the same time, touching on both its immediate and long-term practical (land, labour, institutional and political) policy implications. Lastly, it is an analytical catalogue of the legacy of Mau Mau dissent in post-independent Kenya. As such, it is an analysis of its bequest to the present and, thus, considers the war as an unresolved philosophical conflict. By so doing, this study suggests a lineage of political demands or grievance and socioeconomic struggle in Kenya today couched on the basic need for survival, which harks back to the Mau Mau political dissent and war.
\end{abstract}




\section{Dedication}

To Wangai, Wendo and Josie, for their remarkable patience, moral support and their enduring love. 


\section{Acknowledgements}

This study would not have been possible without the continued moral and financial support from Eberly College of Art and Sciences and the Department of History at West Virginia University. More specifically, I have the chair of the department, Dr. Elizabeth Fones-Wolf and the Director of Graduate Studies, Dr. Joseph Hodge, for providing financial support that ensured multiple visits to crucial archival holdings to gather information in farflung places. The UK National Archives, the Library of Congress in Washington DC, Churchill Archives Centre (Cambridge), Rhodes House in Oxford, the Jomo Kenyatta Memorial Library at the University of Nairobi and the Kenya National Archives were scrupulously searched, studied and utilized thus making this work possible. I also wish to thank the British Institute in Eastern Africa for enabling me to make a vital last visit to the British National Archives and the Kenya National Archives in 2013 through its postgraduate Research Grant.

Most special thanks go to my academic supervisor, Dr. Robert Maxon, for his patient guidance and superb direction backed by many years of experience studying East Africa and Kenya in particular. It was a great honor and pleasure to have worked and brought this work to fruition under his supervision. 


\section{Table of Contents}

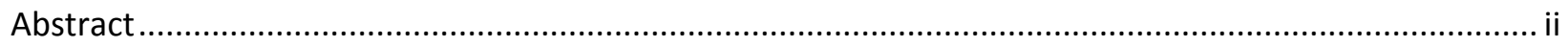

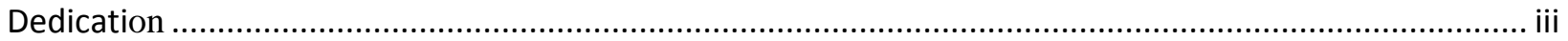

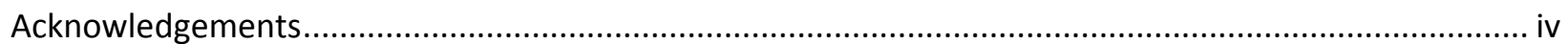

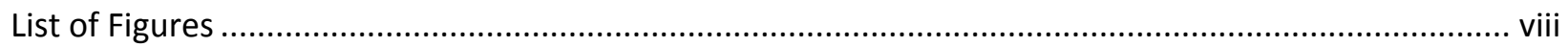

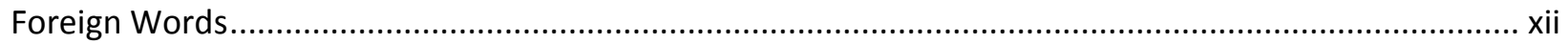

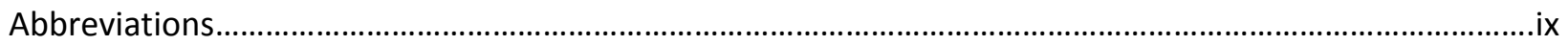

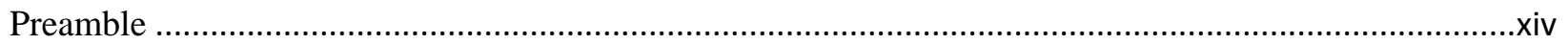

Chapter I - Inside the Mau Mau Mind: "Returning the Imperial” Gaze in Centennial Perspective .............. 1

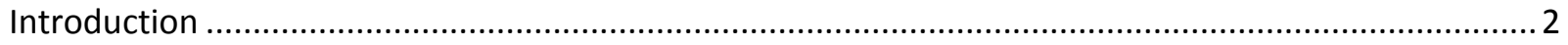

Mau Mau War: Backwards, Going Forward ................................................................................... 7

Crucible of War: The Quest for a Holistic Mau Mau Present.............................................................. 8

A Centennial Perspective: Getting Inside the Mau Mau Mind ......................................................... 10

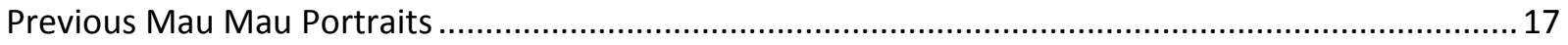

The National and Imperial British Backdrop …................................................................................. 19

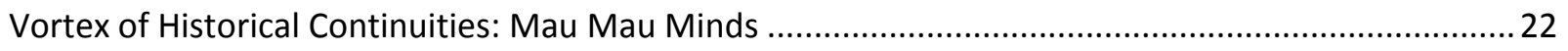

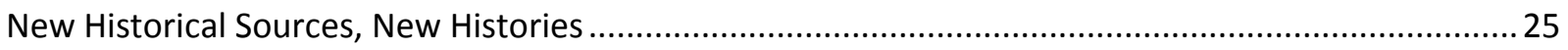

Subliminal Ideology against Criminal Foundations of the Colonial State ...........................................27

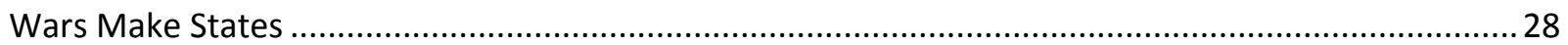

Chapter II - White Man's Land: The Colonial Foundations and Legal Architecture of the Kenyan State .. 38 Colonial Sinews of State Power: The Criminal Loss of Naboth's Vineyard, Labor and his Monetization48 Chapter III - Colonial Rupture: African Experiential Anxiety of Transformation in Time, Space and Place,

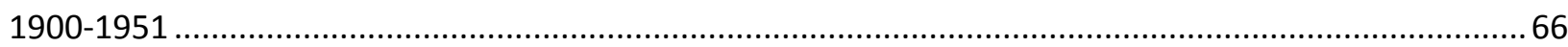

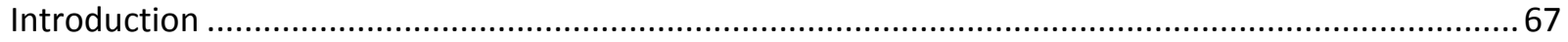

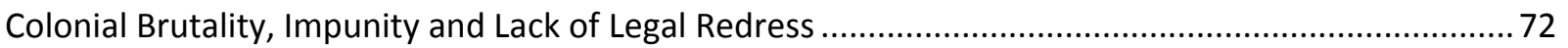

Legal Restraints on African Resources and Livelihoods: Food and Livestock ..................................... 75

The Cost of Modernization: Unjust State Requisition and Assault on African Land Rights .................... 84

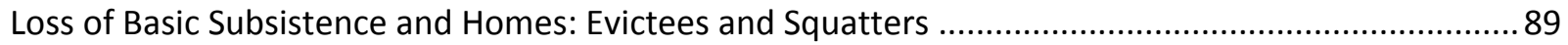

Protests against Colonial Legal Strictures, Absence of Human Rights and African Underdevelopment 98

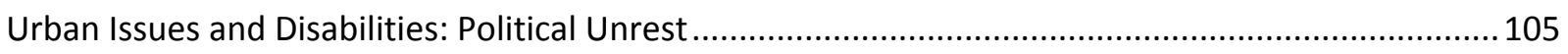

The Colonial Assault on African Cosmos, Traditional Lifestyles and Values .......................................110

Explanations of African Discontent: The Badly Flawed, the Proximate and the Brazenly Ugly............113 
The Imperial Catastrophe of Relative Deprivation: Towards an Understanding of Narratives of African

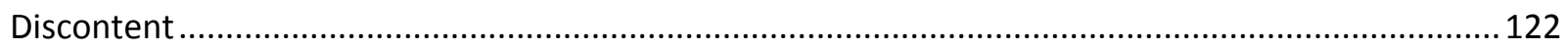

The Production of Mentalité of Struggle: Mau Mau Minds in Chrysalis...........................................127

Languishing Minds: The Psychology of Oppression Illustrated...................................................... 130

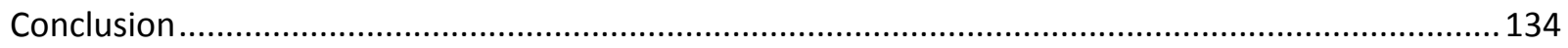

Chapter IV - '52 Minds on Kenya's Destiny: The view from "the above" ............................................138

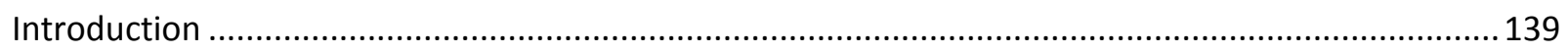

Imperial Imbrication of Existential Struggle: The Micro-economics of Bread and Butter .................... 141

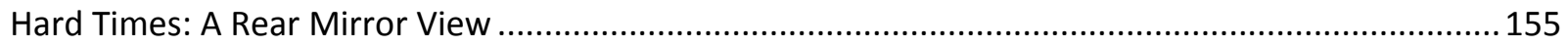

Colonial Origins of Mau Mau Minds: Some Earnest Observations .................................................... 158

In the Court of Global Public Opinion: The Official Mind on Mau Mau...............................................163

Mau Mau Minds from “The Above”: A Nightmarish View...............................................................172

Defeating the Physical Mau Mau of the Forest: An Ever Stern Imperial Glare ................................. 182

Chapter V - Drudgery in Pyrrhic Victory: Whither the Fruits of Independence? ................................... 198

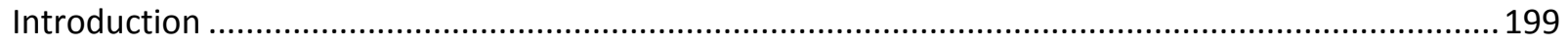

"Uhuru na Taabu": Shunted Track to Independence Decried ............................................................ 199

The Ghost of Mau Mau Lurks: A Tarrying Reverie on Independence's Eve.......................................210

Face-off: Kenyatta and the Remnants of Mau Mau Forest Fighters..................................................2 216

Onwards Ye "Gallant" Soldiers: Odes to the Colonial Ideology of Order ...........................................220

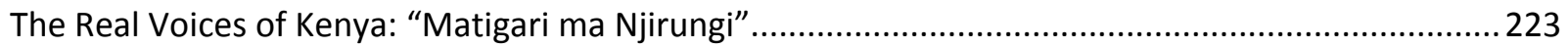

Petitions and Complaints to the President: A Multitude of Cries from Below ...................................227

University Students: A Tertiary Decibel of Discontent Rejoins ........................................................248

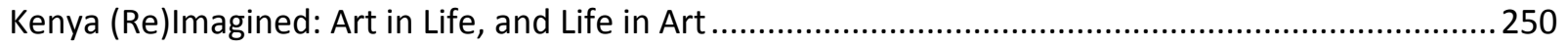

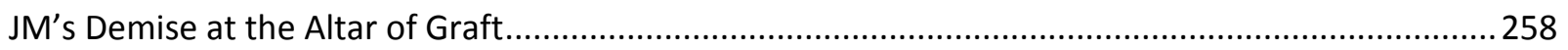

Conclusion: Mau Mau Bread and Circus Affair as a National Political Staple....................................2 271

Chapter VI - Matigari ma Njirungi: Bifurcation, Atomization and Survival of the Mentalité of Struggle .277

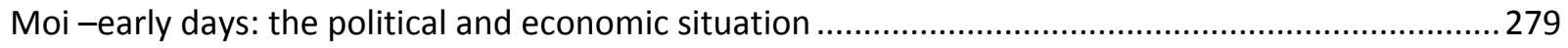

Flood Gates of New Dissent Open: The Attempted ‘82 Kenya Air Force............................................291

Pambana: Academic Debate on Kenyan Peasantry and the Mwakenya Decade..............................2296

Jolted into Political Action: The Church as a Critical Public ….......................................................... 315

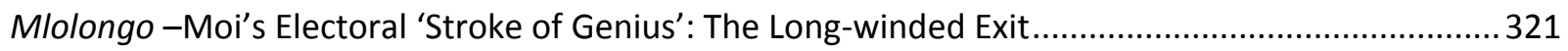

"Pambana!" With one Voice: The Veil of Multiparty Democracy and Atomization of Opposition.......322 
Saba Saba Days and After: Amplified Voices for Political Reforms Betrayed. .333

After Surviving Woes Foreign and Domestic With Cash: Politics of Atomization and Bifurcation ........343

The People's Voice After Political Atomization and Bifurcation ....................................................... 347

What the Common Man Needed: Liberation by Surgeon Mau Mau Freedom Fighters ...................... 356

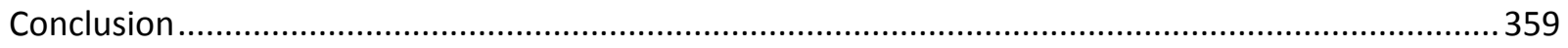

Chapter VII - Bado Mapambano, Solidarity Forever: Latter Day Travails of Critical Publics.....................362

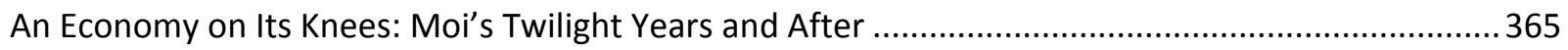

New Government, Same Old Systemic Rot: Kibaki's Elusive Mop-up ...............................................369

A Harvest of Workers' Strikes: Universities Academic Staff Union (UASU), Teachers, Doctors and

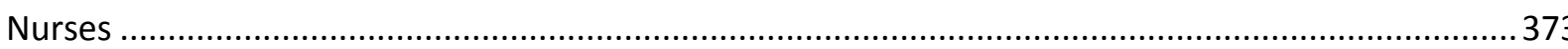

Neo-Mau Maus of the Mind: Mungiki, Saboat Defense Force (SLDF) and the Mombasa Republican

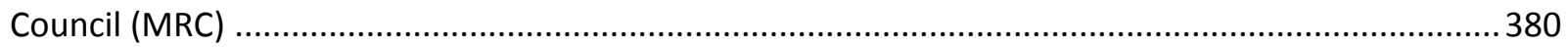

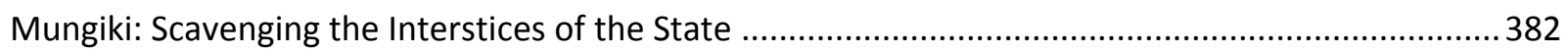

The Sabaot Land Defense Force: "All the Men are Gone” .................................................................. 387

MRC: The Secessionist "Pwani si Kenya” Campaign ............................................................................. 391

"Matatizo" in Popular Youth Culture: Music and Social Change in Kenya ......................................... 402

Nuggets of Mentalité in an Age of eDemocracy ......................................................................... 417

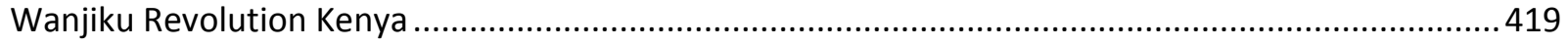

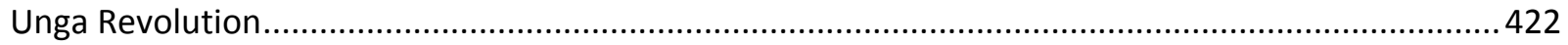

Pawa254: Harnessing Art for Social Impact and Beyond ............................................................ 424

Conclusion:

Chapter VIII - The Long Kenyan Century: A People's Elusive Quest for "the Good Life" ........................430

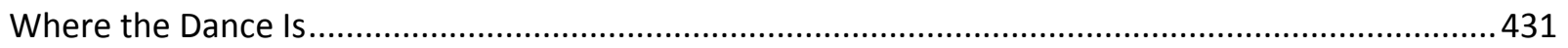

Kenya in the Making: An Amorphous Postcolonial State .............................................................. 436

Statehood? The Security and Surveillance State versus "Stateness" ..................................................440

Popular Statehood: Human Rights, Dignity and Decency ................................................................ 444

Epilogue -Remedying the Illegality of Colonial Legality: A Very Tall Order...................................... 448 


\section{List of Figures}

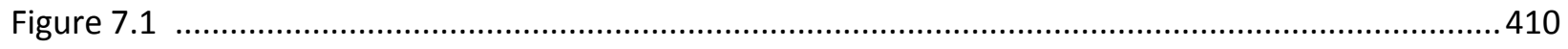

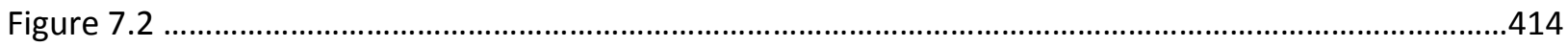

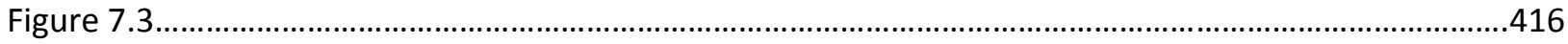

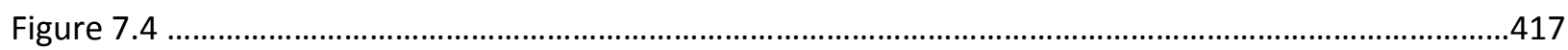

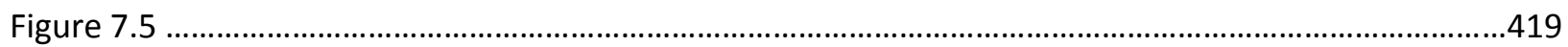

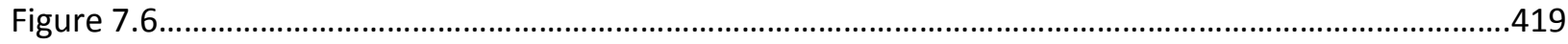

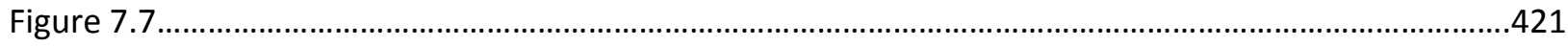

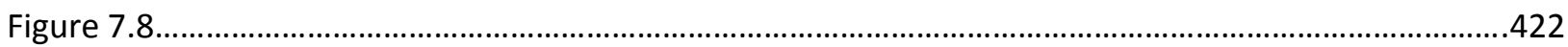




\section{Abbreviations}

$\begin{array}{ll}\text { AUMO } & \text { African Unofficial Members Organization } \\ \text { BNA } & \text { British National Archives } \\ \text { CBK } & \text { Central Bank of Kenya } \\ \text { CKRC } & \text { Constitution of Kenya Review Committee } \\ \text { CO } & \text { Colonial Office } \\ \text { CRO } & \text { Commonwealth Relations Office } \\ \text { CRPPK } & \text { Committee for the Release of Political Prisoners in Kenya } \\ \text { DC } & \text { District Commissioner } \\ \text { DN } & \text { Daily Nation } \\ \text { DO } & \text { District Officer } \\ \text { DP } & \text { Democratic Party (of Kenya) } \\ \text { DYM } & \text { Dini ya Msambwa } \\ \text { FORD } & \text { Forum for the Restoration of Democracy } \\ \text { EAD } & \text { East African Department } \\ \text { EAS } & \text { East African Standard } \\ \text { EEMO } & \text { European Elected Members Organization } \\ \text { ESAF } & \text { Enhanced Structural Adjustment Facility } \\ \text { FCO } & \text { Foreign and Commonwealth Office } \\ \text { FGM } & \text { Female Genital Mutilation } \\ \text { GB } £ & \text { British pounds } \\ \text { GSU } & \text { General Service Unit }\end{array}$




\begin{tabular}{ll} 
H/C & High Commissioner \\
HMG & His/Her Majesty's Government \\
HMSO & His/Her Majesty's Stationery Office \\
HRW & Human Rights Watch \\
IFIs & International Financial Institutions \\
IMF & International Monetary Fund \\
JKML & Jomo Kenyatta Memorial Library \\
KADU & Kenya African Democratic Union \\
KAF & Kenya Air Force \\
KANU & Kenya African National Union \\
KAU & Kenya African Union \\
KCA & Kikuyu Central Association \\
KDF & Kenya Defense Force \\
KLC & Kenya Land Commission \\
KLFA & Kenya Land and Freedom Army \\
KNA & Kenya National Archives \\
KNUT & Kenya National Union of Teachers \\
Ksh & Kenya shilling \\
LegCo & Legislative Council \\
LoC & Library of Congress \\
MP & Member of Parliament \\
MRC & Mombasa Republican Council \\
MWAKENYA Union of Nationalists to Liberate Kenya \\
NCCK & National Council of Churches of Kenya \\
NGOs & Non-Governmental Organizations \\
PC & Provincial Commissioner \\
PM & Prime Minister \\
RHO & Bodleian Library of Commonwealth and African Studies at Rhodes House \\
SAP & Structural Adjustment Program \\
SLDF & Sabaot Land Defense Force \\
SNS & Social Networking Sites \\
\hline
\end{tabular}




$\begin{array}{ll}\text { SofS } & \text { Secretary of State } \\ \text { SWB } & \text { Subjective Well-Being } \\ \text { UASU } & \text { Universities Academic Staff Union } \\ \text { UMOJA } & \text { United Movement for Democracy in Kenya } \\ \text { UoN } & \text { University of Nairobi } \\ \text { US(A) } & \text { United States of America } \\ \text { VAT } & \text { value-added-tax } \\ \text { VoK } & \text { Voice of Kenya } \\ \text { WB } & \text { World Bank } \\ \text { WHO } & \text { World Health Organization }\end{array}$




\section{Foreign Words}

Bado Mapambano

Baraza

Chupa na ndebe

Harambee

Jua Kali

Kipande

Majengo

Majimboism

Mama Mboga

Mashaka

Masikini

Matata

Matatizo

Matatu

Matigari ma Njirungi

Mgogoro

Mkokoteni

Nyayo

Pambana

Pwani/Mwambao

Uhuru

Uhuru na kazi

Uhuru na taabu

Unga

Wananchi

Wapwani
Struggle on/the struggle is still on

Open-air dialogue or meeting of a few people

empty bottles and metallic containers (collectors)

Political slogan that means "pulling together"

Sweltering hot (reference to informal economic sector)

Metalic plate/laminated registration document

Informal urban settlements/slums

Regionalism/federalism

Vegetable vendor

Problems/doubts

The poor

Troubles/problems

Problems

Public transport taxi

Remnants of Mau Mau freedom fighters

Tumult

Pushing cart

Foot-prints

Struggle

Coastal region of Kenya

Independence/Freedom

Freedom and work

Freedom and problems

Maize flour

Citizens

Coastal people 


\section{Preamble}

Few words... are used more loosely than the word "Civilization." What does it mean? It means a society based upon the opinion of civilians. It means that violence, the rule of warriors and despotic chiefs, the conditions of camps and warfare, of riot and tyranny, give place to parliaments where laws are made, and independent courts of justice in which over long periods those laws are maintained. That is Civilization - and in its soil grow continually freedom, comfort and culture. When Civilization reigns, in any country, a wider and less harassed life is afforded to the masses of the people. The traditions of the past are cherished, and the inheritance bequeathed to us by former wise or valiant men becomes a rich estate to be enjoyed and used by all.

The central principle of Civilization is the subordination of the ruling authority to the settled customs of the people and to their will as expressed through the Constitution. ... There is freedom: there is law; there is love of country; there is a great measure of good will between classes: there is a widening prosperity. There are unmeasured opportunities of correcting abuses and making further progress.

Winston S. Churchill, “Civilization,” Chancellor's Address, University of Bristol, $2^{\text {nd }}$ July 1938. 


\section{Chapter I - Inside the Mau Mau Mind: "Returning the Imperial" Gaze in Centennial Perspective}

\section{Preamble}

Somewhere in the Moonward, or Sunward, so to speak;

A span or two to Eastward, then Southward by a streak,

Was heard to blare of tomtom a shameless epic wail,

At fancy of some Lion who had whisked his blooming tail

Plumb thro' a nest of hornets, nor never dreamt the hive

Had such a trick to mind him how were that tail alive.

And it seems the skies were blathering while every wind-god swore

The pities would have curdled to hear the Beastie roar.

All offered salve and comfort, said never done was Wrong,

But some requiting Themis should venge it to her song;

Should smite the pesting dwarfies and heal the giant's mighty bruise,

Louis Selmer, Boer Lyrics (New York: Abbey Press, 1903), 3. 


\section{Introduction}

The postcolonial African state has been the subject of extensively study and scrutiny by many scholars such as Colin Legum, Crawford Young, Robert H. Jackson and Carl G. Rosberg, Pierre Englebert and Jean- François Bayart to name but a few. Crawford Young's work is especially interesting because of the manner in which he treats the process of state formation. ${ }^{1}$ Crawford Young traces the process to the early beginning of European colonization and focuses on the legacy of the colonial state after independence. Colonial appendages of old European states were, for some metropolises, no longer economically viable or sustainable and/or consistent with new post-world War I and II principles such as the right of all peoples to selfdetermination and decolonization, and were, thus, abandoned. Overall, however, perhaps because of the simplicity of the process of state formation in Africa through European agency, the everyday realities of the nature of the African state and lived experiences remain rather elusive still.

Nevertheless, this body of work that has benefitted disproportionately from the contribution of political scientists cannot be underestimated. At the same time though, the manner in which this process has approached by such authors employs methodological perspectives that overlook or undermine attempts at determining the manner in which the making, or unmaking, and evolution of post-colonial African states is viewed and contested from below. A bottom-up perspective that is cognizant of popular views or dissent affecting the political evolution of these states has been lacking. While there have been a few country-specific studies there's room for more scrutiny of how African states have evolved since independence paying closer attention to popular forces from below. This study was conducted with this as its intended goal with reference to the postcolonial political history of the Kenyan state.

Generally, independence was followed by a second African revolution. The first had been the arbitrary and artificial manner in which these now decolonized states of the 1960s had been

\footnotetext{
${ }^{1}$ Crawford Young, The African Colonial State in Comparative Perspective (New Haven: Yale University Press, 1994); Colin Legum, Africa since Independence (Bloomington: Indiana University Press, 1999);; Robert H. Jackson and Carl G. Rosberg, Personal Rule in Black Africa: Prince, Autocrat, Prophet, Tyrant (Berkeley: University of California Press, 1982); Pierre Englebert, State Legitimacy and Development in Africa (Boulder: Lynne Rienner, 2002); Pierre Englebert, Africa: Unity, Sovereignty and Sorrow (Boulder: Lynne Rienner Publishers, 2009); Jean- François Bayart, Stephen Ellis and Béatrice Hibou (trans. Stephen Ellis) The Criminalization of the State in Africa (Bloomington: Indiana University Press, 1999); Jean-François Bayart, The State in Africa: The Politics of the Belly (Cambridge: Polity Press, 2009).
} 
"imagined" in the minds of European statesmen since the Berlin conference in 1884 and in the first few decades of the $20^{\text {th }}$ century. It was in Berlin that the political future of the African continent was determined. The continent was divided between the main European powers, which drew up spheres of interest that were to be mutually exclusive and respected among the powers. Groups of people who had previously resided in autonomous indigenous political polities of various forms, were now lumped together, or were divided by new international borders. Most of these boundaries remained the same after independence and continue to exist today. But despite this seeming simplistic explanation of the origins and formation of the African state, there is more about this process that is complex and intricate. Moreover, the implications of the process go beyond political independence of the 1960s. For now, let it suffice to point out that it is critical of note that former European colonies evolved uniquely with regard to the political; the economic; and the social and cultural, which is why it is important to undertake country-specific studies.

The study of the origin of the African state, in some respects, is relatively simpler in comparison to its European counterpart. For one, it has not been the subject of competing theories of genesis that have characterized the study of the former. For this same reason, however, the study of the genesis of the African state does not lend itself easily to the theoretical formulations advanced to understand the origins of the European state. Instead, as stated, it can be understood as the product of various forms of European imperialism. The different formulations with regard to the European and African state are discussed further below.

Kenya is a good example of imperial state formation with significant and far-reaching post-colonial implications. As a direct result of the Berlin conference, it became part of British East Africa. ${ }^{2}$ Later, on July $23^{\text {rd }} 1920$, it was declared a crown colony open to British settlers

\footnotetext{
${ }^{2}$ It is worthwhile to observe that while East Africa and Kenya in particular were not on the Berlin agenda, the scramble of the region was hastened by German designs on territorial interests against British claims. The competing claims of the two imperial powers were finally settled in the Heligoland-Zanzibar Treaty, which was signed in 1890. Under this treaty Britain conceded Heligoland (two small islands in the North Sea off the mouth of the River Elbe) and the Caprivi Strip (between today's Botswana and Zambia) to Germany, whilst Germany agreed to drop claims in Uganda and around Kismayu. As part of the British protectorate in East Africa the people of Kenya were given diplomatic and military protection from other third parties mainly Britain's European imperial competitors. In the meantime, at the close and start of the $19^{\text {th }}$ and $20^{\text {th }}$ centuries, respectively, British agents were busy extracting treaties from various African chiefs and carrying out military expeditions where it was necessary to effectively subjugate the region, commence and consolidate Britain's position, rule and authority.
} 
even before their actual physical presence and without a numerical majority, thus becoming one of the few tropical territories designated as "white man's country." ${ }^{3}$ Like most colonies, a nascent African nationalism developed towards the end of the second decade of the twentieth century with the growth of political consciousness among the colonial peoples. In the intervening period between the creation of the colony and eventual independence, this political consciousness intensified leading to a two-pronged push for independence. One was radical and violent while the other was more moderate and constitutional. However, both coincided with the broader, international political climate resulting in the granting of independence in 1963. Kenya was at last an independent state.

As a political project, the Kenyan state is a product of competing British colonial ideological constructions. Its early beginnings reach back to 1895 and the early 1900 s extending to the post-World War II period, which was characterized by the subsequent wind of change culminating to the decolonization process. It is a process that continued after political independence against the background of the Cold War atmosphere. In its totality, the contested making and/or unmaking of the Kenyan state has remained largely an unexplored subject.

Kenya was designed and constructed after the political and economic image or imagination afforded by British white settler supremacy. Before the outbreak of anti-colonial movements in Kenya in general and Mau Mau in particular, "the colonial world ... rested on a mental construction of social separations. Rulers and ruled were distinguished, and differentially valued, by race." ${ }^{4}$ Under this ideological conservatism, Africans were thought of as inherently primitive and innately different.

On the other hand, liberal administrators and some settlers viewed them as "retarded children who promised well as modern men." These mutually opposed colonial ideologies were already in dialogue with conservatives favoring the propping up of reformed tribal authority and liberals trusting in the gradual improvement of the African when the Mau Mau war broke onto

\footnotetext{
${ }^{3}$ That is, for large scale settlement of British farmer population mainly soldiers being rewarded for their service during the First World War.

4 John Lonsdale, “Mau Mau's of the Mind: Making Mau Mau and Remaking Kenya," Journal of African History 31 (1990): 401

5 Ibid.
} 
the scene. ${ }^{6}$ The war represented anti-colonial African thought, which called into question and challenged the colonial social order and power relations.

In a sense, therefore, the un/making of Kenya can and should be understood in terms of a reconsidered and rework of the Braudelian notion of history as the longue durée. This study is an analysis of the unfolding of Kenya's post-independence history as an interpenetration of radical ruptures; stubborn durabilities and sudden breaks and remarkable continuities. ${ }^{7}$ The flow and ebb of the history of the Kenyan state is seen as the sum of unpredictable ruptures and subsequent catastrophes such as British imperial conquest and fluid moment of colonial establishment; the early beginnings of African political consciousness; the Indian Question and the struggle for white supremacy; the Mau Mau war; decolonization; and the consequences of imperial collapse among other momentary events that have had gigantic and enduring consequences in its postcolonial evolution. ${ }^{8}$

In this regard, the political instability illustrated by the post-election violence following the 2007 polls; the emotive "majimbo" or federalist debate; the proliferation of violent ethnic militia; and spiraling violent crime figures all indicate that the making of Kenya (statehood and national integration) remains an unachieved aspiration. At the same time, Kenyans remain locked in an existential uncertainty and mentalite as the majority of the people struggle with the mundane demands of day-to-day living that echoes anti-colonial sentiments. ${ }^{9}$

\footnotetext{
${ }^{6}$ lbid.

${ }^{7}$ Grzegorz Ekiert, The State Against Society: Political Crises and their Aftermath in East Central Europe (Princeton: Princeton University press, 1996), xi. encompass the totality of the lived experiences of everyone in the family, at school, in the workplace, in the community and in the process of governance that in turn defines what is or should be the legitimate province of the historian. It is no wonder that at Odhiambo associates the definition of this intellectual territory with Emmanuel Le Roy Ladurie who, together with French historians of the Annales School including Philippe Ariès and Lawrence Stone developed the analytical term, "mentalité collective." According to Gertude Himmelfarb, The Idea of Poverty: England in the Early Industrial Age (London: Faber and Faber, 1984), 11, the term, as used by these historians and associated cultural anthropologists such as Clifford Geerz and Mary Douglas, suggests the production of ideas, values, attitudes and beliefs by infrastructure or structures. Mentalité, as used in this particular study will refer to the same notion of there being a relationship between material institutions in life or infrastructure and ideology whereby material conditions of life structure mentalité, and therefore, can only be
} 
In other words, to understand contemporary Kenya and the political challenges that it faces, it is necessary to understand the transition from colonialism to independence in Kenya, cast in sharp perspective by the outbreak of Mau Mau and its legacy. The war represented a lost opportunity to reconfigure the socioeconomic formation; the political order; and power structure. This research studies the circumstances under which Kenya attained independence. It makes the argument that Kenya's colonial experience, particularly the last fifteen years, and its entire postcolonial political history are contiguous. It is this nexus that I have tried to capture through a re-worked use of longue durée analysis.

In effect, I argue and demonstrate that the Kenyan state is the sum all specific experiences and identifiable critical historical junctures and disjunctures; radical ruptures; institutional and structural inventions; and a series of major political crises and events that in spite of their varying degrees of significance, have had gigantic and enduring consequences. Among them include the radical historical rupture of British imperialism of African societies at the dawn of colonialism; its policy and institutional consequences; the Mau Mau war and sudden decolonization as catastrophic events; the Kenya Air Force attempted coup of 1982; and the underground anti-state resistance movement of the 1980s; and the demand for political pluralism that led to the unrest of the 1990s.

Put differently, it is possible to draw a connection between the Mau Mau rebellion and more recent social phenomena such as the violence meted out by and against ethnic militia in the 2000s such as Mungiki, Sabaot Land Defence Force and the political schism along ethnic lines played out in intermittent ethnic clashes. This study considers all these movements, among other militia, and political events in the evolution of the state as constituting an unbroken historical ideological lineage of dissent or alternative popular statehood. It does this on the strength of vast and varied empirical evidence relied upon to weave ideological connections of grievance

understood in terms of mentalities. Thus used, it is an unequivocal attempt at arranging Kenyan history around the metaphor of struggle hence seeing it as "a moral enterprise," as proposed by Odhiambo: a moral enterprise against the injustice of colonialism; against poverty, ignorance and disease; against the foreignization of cultural ecology; against the intervention of alien ideas in the indigenous discourses on nation-building. At the risk of being branded Manichean or bifocal, this study offers an unapologetic and singular rendition of Kenya's national history around the metaphor of stuggle; of "matatizo" (problems) and ensuing "mgogoro" (tumult) of everyday people responding to the process of state formation and state policies. 
between these movements. The subsequent argument demonstrates the relevance of this historical analysis for contemporary Kenya.

\section{Mau Mau War: Backwards, Going Forward}

As noted above, there is a glaring and pressing intellectual need for a critical assessment of the making of Kenya in the crucial Mau Mau war. ${ }^{10}$ The war has not been adequately examined as a conflict fought over the construction of the state going backwards to the dawn of colonialism and forwards to assess it postcolonial legacy. At the heart of the mind of this movement was the desire to configure the colonial state with regard to socio-economic and political spheres of life. In this sense, the Mau Mau war not only brought ambiguous ideologies and, as a result of the war, political, labor and land colonial policies to the fore, but these same issues were the basis of violent contestation in the field of battle. It is perhaps the most controversial historical event in Kenyan history. It has been the subject of academic and political controversy. As a result, analysis of the war is rather episodic, and therefore, simplistic. It is for this reason that I set about to examine it simultaneously as a critical juncture of Kenya's anti-British movements and a crucial tipping point affecting Kenya’s postcolonial evolution.

I posit the argument that this phenomenon continues to affect post-independence politics, national identity and the evolution of the contemporary Kenyan state. Therefore, the novelty of this work lies in its interpretation of the war as a defining moment affecting Kenya's socioeconomic and political trajectory. As the epitome of the everyday struggle for survival out of which the war was born, "Mau Mau" is an ever present reality in contemporary Kenya as it was before independence. This is an interpretation that has long been obstructed by a nebulous intellectual debate characterizing the production of Mau Mau knowledge. There has been a glut of information regarding its national or ethnic nature or extent and scope; whether it was a success or failure; what its objectives and ideals were; and its ownership as an event and historical subject. This research has attempted to rise above this hindrance, with the benefit of previous debates and episodic views, interpretations to do the following:

\footnotetext{
${ }^{10}$ The word "crucible" used in the title and throughout this study refers to the Mau Mau war as a critical, crucial and violent state-building crisis. It also refers to subsequent significant constitutional and institutional changes occasioned by this series of socio-economic and political crises triggered by the need to violently reconfigure the state favorably. Specifically, the term refers to the Mau Mau war as a critical and crucial turning point in Kenya's political history.
} 
i. Examine the various competing ideological constructions of statehood sharpened by the war and their policy implications, which have affected Kenya's political trajectory since the 1950s.

ii. Analyze the significance or implications of this ideological contest with regard to statehood, nation-building and integration and politics in Kenya today.

iii. "Presence" Mau Mau or situating "Mau Mau" in contemporary Kenya. That is, by identifying and examining the locus of similar dissent expressing discontent or manifestation of the mentalite of struggle with regard to the socio-economic and political configuration of the postcolonial state.

These objectives of the study have, simultaneously, been the reason for, and also necessitated, a new, if radical, "longue durée" view of Mau Mau.

\section{Crucible of War: The Quest for a Holistic Mau Mau Present}

Hardly enough can be said about how the history of Mau Mau war has been beleaguered by opposing views about whether it was a nationalist movement or not; about what its contested place in Kenya's history should be; and about what its causes were. In innumerable instances, the subject has attracted emotionally charged personal and ethnic idiosyncrasies about who owns this history, or who can or cannot write about it. Odhiambo in his aptly titled article, "The Production of History in Kenya," on the Mau Mau debate captures the sorry subjectivism of it all.

Moreover, Mau Mau history was suppressed under the Kenyatta and Moi regimes. So even after independence, as when it happened in the 1950s, it suffered from competing and distortive claims and counterclaims. This has featured former Mau Mau fighters, some of whom are still landless, whose continuous cry to both society and state has been that they have been forgotten; featured people who view themselves as the only ones fit to write this history from their firsthand experience; featured Kikuyu intellectuals such as Maina wa Kinyatti who view it as the highest peak of Kenyan nationalism, or others who have accused scholars from western Kenya of relegating it to secondary significance; and Kikuyu elites who have sometimes appropriated this history as an exclusively Kikuyu movement thus excluding every other Kenyan 
individual and ethnic group from enjoying the fruits of independence. ${ }^{11}$ To further problematize this, Daniel Branch has, not so long ago, offered new insights of this phenomenon showing just how inter-penetrable loyalist and Mau Mau-fighter categories were. ${ }^{12}$

When one considers the deliberate official colonial obfuscation of the movement as atavistic, savage and a reaction to psychic insecurity, what emerges is a dissipated representation of Mau Mau history. ${ }^{13}$ With a rather uncharacteristic pessimism absent in his later intellectual contribution to the debate, Odhiambo argued that not everybody needs this history, and this could be right. Further, Odhiambo stated that there are various consumer components of different Mau Mau pasts. Similarly, Lonsdale explored the imaginative meanings of Mau Mau invented by white conservatives and liberals against their black opponents in the context of divergent and fearful ambitions of shaping Kenya's future. ${ }^{14}$

This study takes these arguments into account. However, it propounds the view that Mau Mau was a seminal moment in which the Kenyan state was in the throes of formation. By so doing, it casts the war as the epitome of the quest for popular statehood or "stateness." The study, therefore, attempts to detail the continued struggle for the full measure of "uhuru" in the absence of which life is just but an attempt to survive precariously and in never-ending uncertain times. In opposition to this is the postcolonial Kenya nation-building project that has benefited the political class and those well-placed to benefit from state patronage networks.

Unlike most historical analysis of Mau Mau, this work does not concern itself on the causes and effects of the war. In so far as it does, it is with the aim of unraveling its deeper ideological and subliminal foundations of the movement and many others before and after it. In the same breath, it does not concern itself with the question of whether the conflict was a

\footnotetext{
${ }^{11}$ E.S Odhiambo, "The Production of History in Kenya: The Mau Mau Debate," Canadian Journal of African Studies 25, (1991): 301-304. The cited quotation in this article is from Maina wa Kinyatti, "Mau Mau: The Peak of African Nationalism in Kenya," Kenya Historical Review 5 (1977): 287-311.

12 Daniel Branch, Defeating Mau Mau, Creating Kenya: Counterinsurgency, Civil War, and Decolonization (New York: Cambridge University Press, 2009).The book's main thesis is convincing. It is rooted in sound theoretical analysis first applied in ethnic conflicts in Eastern Europe by Stathis Kalyvas. Its introduction suffices in drawing this connection.

${ }^{13}$ Lonsdale, "Mau Mau's of the Mind," 410.

14 Ibid., 395-396, 401, 404-411, 420-421; also see Odhiambo, "The Production of History," 302-303.
} 
nationalist or Kikuyu civil war. Instead, it views the struggle as an emblematic representation and culmination of anti-colonial, and a precursor of postcolonial, movements in Kenya.

As such, the use of the term "Mau Mau" with regard to the postcolonial era is generic. It is used to refer to the war's ideological legacy or lineage of grievance. Archival and other evidence from popular culture (music, art, graffiti and creative arts like cartoons, novels and paintings) is adduced, and an incisive discussion of public criticism is relied upon, to bolster this bold assertion. ${ }^{15}$ Furthermore, the study is not about the place of Mau Mau in Kenya's history, prominent or otherwise. Rather, it ponders on the more problematic question of situating it in the present through historical analysis. In addition to the foregoing, the most important question that presents itself for consideration is not why or who should write Mau Mau history and for whom but, rather, one about the unboundedness of the phenomenon going backwards and forward. Put differently, some of the questions I am concerned with include; why it happened when it did (discussed in chapters three and four); how it was dealt with and with what implications for postcolonial Kenyan politics, national identity and statehood (chapters four and five); and whether the congenital struggle, which it epitomized was dealt with by political independence with finality. ${ }^{16}$

\section{A Centennial Perspective: Getting Inside the Mau Mau Mind}

The Mau Mau war constitutes a turning point in Kenya's history. At one level, it stands out as a generic event or an epitome of anti-colonial movements that prefigured it including the Kolloa Affray and Elija Masinde's “Dini ya Msambwa” (DYM). It is, as such, a symbolic representation of the cumulative African experience of half a century under harsh and oppressive British imperial domination. At another level, it constitutes a critical juncture in the country's historical trajectory. ${ }^{17}$ It was, in this sense, a manifest state-building crisis. Subsequently, it

\footnotetext{
${ }^{15}$ With regard to popular songs especially those rendered in Swahili or Sheng (a mixture of various Kenyan languages, Kiswahili and English) I have exercised authorial discretion and translated them rather liberally. This has been done with little interest in the direct and literal translation. Instead, in re-writing the lyrics into English, I was more interested in the hidden nuances and, therefore, relied more on the context, in as far as the everyday social and pertaining historical realities of the day, in which they were composed or performed is concerned. The "translation" of various song lyrics is closer to an interpretation as I worked through them as scholars would other primary sources of analysis.

${ }^{16}$ I have argued throughout this study that the mentalite or Mau Mau spirit of struggle survived the war of the 1950 s and continue to animate and inspire political discontent in postcolonial Kenya.

${ }^{17}$ The term "critical juncture" is used as defined by Ruth Berins Collier and David Collier in the chapter, "The African State at the End of the Twentieth Century: Parameters of the Critical Juncture," The African State at a
} 
triggered significant reforms that produced distinct institutional and ideological legacies that served to further strengthen the colonial state. The war occasioned a period of rapid reforms characterized by the colonial creation of institutions and deployment of far-reaching constitutional and land reforms to counter the apogee of anti-colonial sentiment. This was with the result of institutional stasis in the postcolonial state because these changes were carried over and consolidated even after independence.

Therefore, this is one of the most distinct characteristics of this Mau Mau war crucible of state formation. After all, as a violent manifestation of the ground swell of African discontent in British East Africa, it forced critical decisions in London and Nairobi. In its wake, there were newly instituted state structures that have since persisted. Here, it is crucial to observe that measures such as the strengthening of the provincial administration, qualitative electoral politics and the Swynnerton land consolidation program including the million acre schemes were implemented with relative uniformity around the colony even though they were triggered by, and more effectively carried out, in Central Province, which was the theatre of the war.

Further, this centennial view of Mau Mau represents a radical departure in another way. It constitutes an attempt to deconstruct Mau Mau as evil and an anathema. Thus, this study was conducted as an intellectual retrieval exercise that contextualizes the movement within the fifty or so years of British colonial rule. It argues that the war, and the widespread anti-colonial discontent it exemplified, was shaped by the colonial state surveillance in lethal combination with an emasculating architecture of land, labor and associated laws and policies. I have, therefore, explained the war as an attempt at challenging, in order to reconfigure, colonially inaugurated social relations of power to create an equitable political economy. Archival sources relied upon confirm that the war was a symptomatic and highly symbolic moment of colonial subjects returning the imperial gaze. That is, a reaction to colonial modernization through the investment and wielding of force that produced a restrictive space-time, physical and psychological environment, experienced by imperial subjects. The war was a demonstration of just how far Africans were willing to go to navigate this new imperial physical-time and psychological oppression dimension.

Critical Juncture: Between Disintegration and Reconfiguration (eds.) Leonardo A. Villalon and Phillip A. Huxtable (London: Lynne Rienner, 1998), 6. 
Colonial capitalism, law, order and associated modalities of state surveillance, individual land holding, Christianity and westernization, education, labor relations and taxation, all had produced an exclusive modern space dominated and enjoyed by the British and Indians. ${ }^{18}$ The fledgling colonial political economy was unapologetically racially segregated. In less than fifty years of colonialism, Kenyans, not just the Kikuyu, had been violently forced out of their egalitarian pre-colonial world ordered by an unwritten but mutually binding code of civic virtue and reciprocal moral socio-economic responsibility. This relatively idyllic pre-European order characterized by economic security was ruptured and its distinct "ecological arenas - forests, hills and plains ..." reordered to pave way for a colonial landscape constructed to conform to modern Western logic. ${ }^{19}$

Whereas this world had consisted of hunters, cultivating and hunting peoples and herders operating within pre-European agrarian and pastoral modes of production, it was jarred into a competitive, rigid and policed field where Africans were not only pitted against white settlers, Indians and Arabs, but also against each other. The acquisitive nature of the white settlers also meant that the African ecological arena was not only drastically altered but also dramatically curtailed. As Lonsdale notes, their land was alienated by "capital," which was the axe with which to cut a path through political jungles as well as nature's. ${ }^{20}$ African land was considered to be tabula rasa inviting the colonial state to exploit and order it through the establishment of new relations between capitalists and a few skilled workers.

\footnotetext{
${ }^{18}$ Here "modalities of colonial state surveillance" is used with the same meaning as in Spurgeon Thompson's, "Returning the Gaze: Culture and the Politics of Surveillance in Ireland," International Journal of English Studies 2 (2002): 96-97. It refers, in the context of colonial Kenya between 1900 and 1940, to the physical presence of the military and paramilitary force and the deployment of force; designation of tribal reserves and units of administration such as locations, divisions and provinces; a system of individual registration and related pass laws restricting imperial subjects to specific tribal locales; the recording and processing of information in intelligence documents and in administrative reports and official correspondence between officials on the ground in different parts of the colony and Nairobi, and between Nairobi and London; as well as various imperial commission reports. 19 John Lonsdale, "The Conquest State, 1895-1904," A modern History of Kenya, 1895-1980, (ed.) William R. Ochieng' (London: Evan Brothers, 1989), 6. The physical apparatus of empire namely roads, the railway, harbors, new towns, forts and stockades, plantations among other incursions on the landscape were constructed at a heavy cost for the pre-European African socio-economic order. This was part and parcel of the "crucial control of the landscape" linking it to greater economic authority and ultimately, open the land for white settlement. See Glenn Hooper, (ed.) Landscape and Empire, 1770-2000 (Burlington: Ashgate Publishing Company, 2005), 8-11. ${ }^{20}$ Lonsdale, "The Conquest State, 25.
} 
Further, Lonsdale observes that the colonial state was a cartographer and maps were its images of order. ${ }^{21}$ White settlers filled these inviting albeit dangerous spaces with roads, fields and boundary beacons all the while with misplaced hope "for a contented black labor on quiet farms with mortgages ...."22 This happened in the first colonial occupation between 1895 and 1930s. The sum of all the above constituted "order" through British imperial eyes imposed on subjects by fiat. In this colonial matrix, imperial subjects were locked or trapped in subservient subject positions held together by a restrictive architecture of laws, policies and racial attitudes. ${ }^{23}$

During the second colonial occupation between the late 1930s and the post-Second World War era, Africans were subjected to even further colonial restrictions and intensive public works, occasioned by the demands of more developed capitalist settler agriculture and the needs of the metropolitan economy. ${ }^{24}$ This was perpetrated through policies that placed greater emphasis on colonial development and welfare. This second phase of the imperial gaze was characterized by even more ambitious state intervention and intrusion that included the infamous terracing campaign; the eviction of squatters who had provided the labor required by white farmers to tame the land in the white highlands; further restrictions on the growth of cash crops in Central Province; and the confiscation of African livestock. Here, it is crucial to note that these were measures borne out of colonial state logic of what was best for Africa agriculture while at the same time presiding over an "order" in which the best land was owned by white settlers.

With regard to the colonial assault on their livestock, squatters called it "kifagio," the sweeping broom, which is symbolic of being forced out of every possible prior habitation and practice through the imposition of a new mode of production -that is, colonial capitalism. This explains why both Cooper and Lonsdale see post-war colonial policies as representative of a

\footnotetext{
21 Ibid.

22 Ibid.

${ }^{23}$ Thompson, "Returning the Gaze," 99.

24 The term second colonial occupation is attributed to Lonsdale, "Conquest state." Of course, the term was coined much earlier by Lonsdale and D.A Low, "Introduction," in History of East Africa, Vol. 3 eds. D.A Low and Alison Smith (Oxford: Oxford University Press, 1976), 13. Colonial development and welfare with the needs of the metropolitan economy at the fore was accompanied by the decision of the British imperial government to settle more white people in the white highlands. This enclave was also protected through financial and agro-economic privilege; was accompanied by mechanization of production in white estates and thereby, the expulsion of manual squatter labor from the highlands. Also see E.S Odhiambo, "The Formative Years, 1945-55," Decolonization and Independence in Kenya, 1940-93, (eds.) Bethwell A. Ogot and William R. Ochieng' (London: James Currey, 1995),
} 29. 
whirlwind of change. This was characterized by the adoption, by both the state and settlers, of a rationalized labor system with both labor and land organized precisely around the cycle of the settler crops. This was an official ideology oriented toward systematic social development, which consigned squatters to categorical oblivion. ${ }^{25}$

According to Cooper, these policies resulted in a clash of ideologies with Africans being accused of overgrazing and haphazard cultivation. Such colonial policies buffeted Kikuyu squatters in Olenguruone in the Rift Valley and besieged people living in similar socioeconomic arrangements in the colony in places like Kitale; and confined wage earning slum dwellers in Nairobi into dreadfully squalid landscapes characterized by misery. These spatial displacement and restrictions corresponded with official categories, both liberal and conservative, of Africans as savages and retarded children. ${ }^{26}$

On the other hand, Kikuyu oathing, which is an idiom and counter-ideology of resistance, was a form of mimicry and early beginning of the African returning the gaze. Similarly, DYM and its Kolloa corollary were fantasies calculated to look back into imperial eyes with the same or even greater intensity in a bid to destabilize and cancel the differences of power in the colonial state. $^{27}$ What these anti-colonial movements had in common was imitating the colonial state in an attempt to challenge the imposed colonial politico-economic order. The Kikuyu anti-imperial ideology was, therefore, contemporaneous with similar anti-colonial responses elsewhere in Kenya, especially in the 1950 s.

Taking note of this, both Odhiambo and Ogot observe that the period between 1945 and 1955 was an age of "matatizo" (social restlessness and the struggle for survival). As such, it quite naturally, resulted to "mgogoro" (tumultuous agitation) characterized by pronounced urban poverty, hunger in settler farms and general labor and political unrest in Kenya. ${ }^{28}$ Africans were imbued by the mentalite of struggle. This is what prompted a rethinking of the history of the colonial past of the previous fifty years. The result was that they were caught busily reworking

\footnotetext{
${ }^{25}$ Frederick Cooper, "Review Article: Mau Mau and the Discourses of Decolonization," Journal of African History 29 (1988): 318.

${ }^{26}$ Ibid., 318-319 and Lonsdale, "Mau Maus of the Mind," 401.

27 Thompson "Returning the Gaze," 99-102

${ }^{28}$ Odhiambo, "The Formative Years," 26.
} 
the interstices of the colonial order to accommodate this hard past and the dim future through strikes, demonstrations and struggle for autonomy. ${ }^{29}$

This was an era of the fear of final loss of access to, and security in, the White Highlands by Luo squatters in Kisumu/Londiani district, Gikuyu in Nakuru and Naivasha districts, Nandi and Bukusu in Trans Nzoia and Uasin Gishu districts. ${ }^{30}$ This is also what explains the major strikes in Mombasa that involved thousands of workers demanding higher pay and benefits. But this was not the beginning of unionized labor agitation by Africans. From the 1920s the Kavirondo Taxpayers Welfare Association, a purely Luo and Luhya organization, was involved in a bid to protect peasants from African economic restrictions. Oginga Odinga also formed the Luo Thrift and Trading Corporation, which aimed at providing not only political solutions to Luo social and economic disabilities, but also establishing an alternative vision for the future. ${ }^{31}$ At this time, Odinga was also involved in successfully opposing compulsory land consolidation and reclamation measures. In Western Kenya, the North Kavirondo Central Association was founded in response to the fears that had risen over land security following the discovery of gold in Kakamega in 1931. It also promoted social and economic advancement for its members.

Among the Bukusu in Bungoma district, land was also the main problem as it became acute in 1946 when restrictions were placed upon squatters. They believed that Trans Nzoia district was their ancestral land which was stolen from them by the white settlers. Bukusu squatters constituted the majority of the squatters in this region who experienced full exploitation under the colonial system. ${ }^{32}$ Some Bukusu responded to this through DYM, a Christian syncretic religious movement, which sought the expulsion of Europeans from Kenya and the rejection of European civilization. Its leader, Elija Masinde, led the movement in protest against the colonial order to uproot the Mexican marigold weed for which he was convicted and imprisoned in 1945. After his release in 1947, he "openly advocated for the use of violence, urging the Babukusu, at several rallies, to take up arms and fight the colonialists." ${ }^{33}$ He was arrested but the movement

\footnotetext{
29 Ibid.

30 Ibid.

31 lbid., 30.

32 This is well-captured by the respective chapter contributions by Bethwell A. Ogot, "Mau Mau and Nationhood: the Untold Story," and John Lonsdale, "Mau Mau and Nationhood,"in Mau Mau and Nationhood: Arms, Authority and Narration eds. E.S Odhiambo and J. Lonsdale (Oxford: James Currey, 2003).

33 Ogot, Ogot, "Mau Mau and Nationhood," 14.
} 
continued to demand the return of Bukusu land and expulsion of the British from Kenya. Elija Masinde, and his lieutenant Joash Walumoli, were deported to Lamu and remained in detention until the end of the State of Emergency ended in 1960.

At the same time, an adherent of the movement in East Pokot in northern Baringo, Lukas Pkech, was promoting DYM's activities there. Around 1949, Pkech was prophesying that the British would soon be expelled. On 24 April 1950, he organized young Pokots, armed with spears and shields, and confronted the government forces at Kolloa in East Pokot at dawn, which resulted in his own death and those of three Europeans and that of twenty eight of his followers. This event has gone down in the annals of Kenya's colonial history as the Kolloa Affray that marked Pokot defiance led by a self-proclaimed prophet and a band of three hundred followers against "all that the colonial system stood for; its concept of law and order, its concept of authority and its ontology." 34 This is a classic description and example of Africans returning the imperial gaze.

In view of the above, the immediate historical context against which Mau Mau war was born was characterized by similarly spirited colony-wide anti-colonial movements. These were inspired by the socioeconomic and political flux caused by the imposition of disruptive modernity at a breakneck speed. This produced a modern political space, which Africans, in organizing themselves and embarking on various forms of resistance, were trying to navigate. For this reason, Mau Mau cannot be considered in isolation but can, and should, be best understood as the culmination of these African attempts at bargaining through various means for a niche in this new space and their own place in time. As the section on historiographical review below attempts to show, this interpretation of Mau Mau, while it has been alluded to in the past, has not been studied empirically.

This study has tried to close this gap in the body of Mau Mau historiography using archival material to experientially link, not only these anti-colonial movements, but also postindependence dissent and clamor for popular statehood. Herein, then, Mau Mau war is representative of anti-colonial movements that prefigured it. Secondly, "Mau Mau" will also refer to the war's ideological legacy of resistance or dissent which is traced throughout Kenya's

\footnotetext{
34 Ibid., 14-15.
} 
post-independent history through critical analysis of available evidence. This stands in stark contrast with how this sensitive subject has been approached by a constellation of Mau Mau research experts in the past.

\section{Previous Mau Mau Portraits}

Kenyan history is characterized by an exuberant historiography covering the colonial period. Nevertheless, much less has been done to examine the postcolonial state seen as a flawless continuum with the colonial. Only recently have historians, for instance, Caroline Elkins, David Anderson and Daniel Branch, started juxtaposing these two periods of Kenyan history albeit in a limited way. ${ }^{35}$ This can partly be attributed to the fact that post-independent history has been characterized by an unsettled and unsettling debate among nationalist historians and other Kenyan history specialists over the nature of Mau Mau; its success and extent, or scope, national or otherwise; over its objectives and ideals; and even the ownership of Mau Mau as a historical subject.

Much energy has been expended on the question of whether this conflict was a national movement of liberation or a sectarian civil war among the Kikuyu, whether or not it was a success, what its ideals, aims and objectives were, whether it is needed as a history and if so, to what ends. This has pitted Kikuyu historians and intellectuals such as Maina wa Kinyatti and Mukaru Nga'ng'a against other academics such as Ogot and Odhiambo. ${ }^{36}$

Be that as it may, let it suffice to note that preoccupation with this debate has contributed to a considerable hiatus in Kenyan historiography regarding the contextual, immediate and long term significance of Mau Mau. Secondly, and as a direct result of the foregoing observation,

\footnotetext{
${ }^{35}$ Caroline Elkins, Imperial Reckoning: The Untold Story of Britain's Gulag in Kenya (New York: Henry Holt and Co., 2005); David Anderson, Histories of the Hanged: The Dirty War in Kenya and the End of Empire (New York: W.W. Norton, 2005; and Branch, Defeating Mau Mau.

36 This early debate and historiography includes contributions such as Maina wa Kinyatti,"Mau Mau: The Peak of African Nationalism in Kenya," Maina wa Kinyatti, Thunder From the Mountains: Mau Mau Patriotic Songs (London: Zed Press, 1980); Maina wa Kinyatti, Mau Mau: A Revolution Betrayed (London: Vita Books, 2000); Mukaru Ng'ang'a, "Mau Mau, Loyalists and Politics in Murang'a, 1952-1970," Kenya Historical Review 5 (1977): 365-84. Odhiambo, "The Production of History," 301 admits that the debate around Mau Mau in the late seventies and nineteen eighties was marked by subjectivism on all sides, and on his own part. The finer point of this debate is not well documented but its outlines can be deciphered by access and analysis of early compilations of Historical Association of Kenya conference papers especially from the 1981 and 1986 conferences. It can also be further examined by conducting interviews with senior history academics from that period of Kenyan intellectual history such as Professors Bethwell Ogot, William Ochieng', Godfrey Muriuki and Vincent G. Simiyu among others as well as from newspaper sources published around that time.
} 
revisionist history countering imperial depictions of Mau Mau war, while it does exist, is in fragmented disarray. ${ }^{37}$ Lonsdale and Odhiambo observe that there are various Mau Mau pasts waiting for their own historians: home guards, loyalists, British soldiers involved in it and so on. ${ }^{38}$ As such, this lingering preoccupation and debate has tended to focus on various segmented Mau Mau histories at the expense of a cogent problematization of Mau Mau with an overarching singular motif that views it as a struggle for survival in an increasingly modernizing space and landscape. ${ }^{39}$

This is what this study does. While appreciating its multifaceted complexity, Mau Mau is seen as a movement that captured the fluid atmosphere symptomatic of a colonial society at a crossroads between pre-European and colonial orders. This omission of an overarching or longue durée perspective of Mau Mau as a crucible of war, in which Kenya was forged, represents a gap in the literature that this study seeks to address.

Moreover, this gap has been exacerbated by the fact that documentation of this conflict has until recently remained hidden in classified colonial records. Some of this collection still is. In this regard, I have made an attempt to minimize this gap with the benefit of available primary data that has been recently declassified. The use of this new archival material has been in light of a broader reflection of emerging scrutiny and perspectives of the so-called "new imperial history." 40

\footnotetext{
${ }^{37}$ That is, while there was an attempt to correct the colonial characterization of Mau Mau revolt as an atavistic and savage reaction to modernity, proof of some defect in the ethno-psychology of the Kikuyu male, there was no consensus among nationalist historians about the overall significance of this violent struggle.

${ }^{38}$ This is the gist of the Lonsdale article in which he says there were various sometimes incompatible meanings of Mau Mau. "Mau Maus of the Mind," 395, 420-421. Also see Odhiambo, "The Production of History in Kenya," 302. ${ }^{39}$ There is a huge body of literature, for example Tabitha Kanogo, Squatters and the Roots of Mau Mau (Nairobi Heinmann, 1987); David W. Throup, Economic and Social Origins of Mau Mau (London: James Currey, 1987); Robert Buijtenhuijs, Mau Mau Twenty Years After: The Myth and the Survivors (The Hague: Mounton \& Co., 1973); Wunyabari O. Maloba, Mau Mau and Kenya: An Analysis of a Peasant Revolt (Nairobi: East African Educational Publishers, 1993); Robert B. Edgerton, Mau Mau: An African Crucible (The Free Press, New York, 1989); and Carl Rosberg and John Nottingham, The Myth of "Mau Mau:" Nationalism in Kenya (New York: Praeger, 1966) to name but a few works dedicated to various aspects of this prominent event in the struggle for independence in Kenya. The bulk of this literature is concerned with the root causes of this war, its nature, scope and internal Kikuyu ethnic dynamics and the role played by women freedom fighters among other questions.

40 "New imperial history" refers to an approach of writing British national and imperial history highly influenced by Saidian cultural analysis or the "cultural turn" of the early 1990s, and therefore, the work of Edward W. Said,
} 


\section{The National and Imperial British Backdrop}

I have endeavored to treat the Mau Mau war as part and parcel of Kenya's experience within the broader subject of British national and imperial history. As a political, economic and social phenomenon, the British Empire (along with other European empires) greatly shaped the contemporary world as we know it. The Empire developed in tandem and overlapped between the $17^{\text {th }}$ and the $19^{\text {th }}$ century with the emergence of Britain as a nation-state in Europe. At the same time, informal economic influence and/or direct political control in the imperial periphery led to the emergence of independent states including the United States of America, Canada, Australia, Singapore, Malaysia, Egypt and India not to mention most of the sub-Saharan countries.

With regard to the former process viz. - the emergence of Britain as a state of remarkable continental and international stature, various historians have focused on different aspects of this process that is relevant to this study. In The Sinews of Power: War, Money and the English State, 1688-1783, John Brewer propounds that war with the French between 1688 and 1783 led to the creation of an aggressive, powerful and expanding fiscal military state in Britain. ${ }^{41}$ Lawrence Stone's An Imperial State at War: Britain From 1689 to 1815, a collection of papers, further interrogates, along similar lines, the circumstances under which the British state came into existence. ${ }^{42}$ In Britons: Forging the Nation 1707-1837, Linda Colley makes a similar argument

Orientalism (New York: Vintage Books, 1979). According to Antoinette Burton, it is an approach of writing British history that appreciates "thinking with and through the nation," which has gained a lot of appeal since the 1990 s. Burton, After the Imperial Turn : Thinking with and Through the Nation (ed.) Antoinette Burton (Durham: Duke University Press, 2003) 2, defines the "imperial turn" as the accelerated attention to the impact of the empire on metropolitan society in the wake of decolonization and feminism in the 1970s and 1980s. At the same time, this new perspective draws inspiration from by Frantz Fanon's eloquent formula that Europe is the creation of the 3rd world. That as Europe encountered the extra-European world, its self-image and identity was altered. By bringing the story of empire back into traditional British history and vice versa, new light has been shed on what it meant to be British, for example. The work of Ann Laura Stoler and Frederick Cooper, "Between Metropole and Colony: Rethinking a Research Agenda," in The Tensions of Empire eds. Frederick Cooper and Ann Laura Stoler (Berkeley: University of California Press, 1997) has also heavily influenced this approach. Their work advocates for the placement of the metropole and colony in a single analytic field/frame of reference, which the proposed study seeks to do with regard to the crucial laying of the critical legal and socio-economic foundations of the postcolonial state in the 1950s in particular and the colonial period in general.

41 John Brewer, The Sinews of Power: War, Money and the English State, 1688-1783 (Cambridge: Harvard University Press, 1988). This corresponds with the argument made by Charles Tilly, The Formation of National States in Western Europe (Princeton: Princeton University Press, 1975) and his "War Making and State Making as Organized Crime," in Bringing the State Back In eds. Peter B. Evans, et. al., (Cambridge: Cambridge University Press, 1985) that war makes states.

42 Lawrence Stone, An Imperial state at War: Britain From 1689 to 1815 (London \& New York: Routledge, 1994). 
stating that imperial competition between the two leading European powers, Britain and France, led to the forging of a distinct British identity in the $18^{\text {th }}$ century. ${ }^{43}$

These three books show the significance of imperialism in the development of British identity, state and emergence as a relatively cohesive political unit. They also draw attention to war as coagulating and forging force that often times brings about the emergence of nationstates. Although this is not always the rule, it is under similar imperial circumstances that former dominions and colonies such as the U.S.A. and India emerged, respectively. They were inaugurated against the backdrop of rising tensions and conflict or the crucible of war in the case of the former. This British imperial historical background is instructive. The Mau Mau war standing, as it does, at the juncture of the colonial and postcolonial period, is a vortex at the crux of the formation and evolution of the Kenyan state.

Fred Anderson's Crucible of War: The Seven years' War and the Fate of Empire in British North America, 1754-1766 extensively explains how the United States of America emerged in the process of breaking the shackles of British dominance or rule. It is an examination of the broad circumstances, besides the War of Independence, that set the stage for the United States of America which became a republic in 1776. Anderson argues that the Seven Years' War was the defining moment in US history since it led to the unraveling of the British Atlantic Empire. ${ }^{44}$ The Indian equivalent of Anderson's Crucible of war is Yasmin Khan's The Great Partitions: The Making of India and Pakistan which documents how the dissolution of the British Raj was intrinsically intertwined with the partition and thereby, the forging of India and Pakistan. ${ }^{45}$ The example of U.S.A, India and Pakistan highly influenced this study that is about the formation and evolution of the Kenyan state within the same general background of British imperialism and the Mau Mau war in particular.

Colonial Kenya is an exceptional example of a British imperial possession earmarked for development as a white man's country. This was in line with the principal conviction and ideology that Britain and its acquisitions like New Zealand, Australia and Jamaica were

\footnotetext{
43 Linda Colley, Britons: Forging the Nation, 1707-1837 (New Haven and London: Yale University Press, 1992).

${ }^{44}$ Fred Anderson, Crucible of War: The Seven Years' War and the Fate of Empire in British North America, 17541766 (New York: Vintage, 2000).

${ }^{45}$ Yasmin Khan, The Great Partitions: The Making of India and Pakistan (New Haven: Yale University Press, 2007).
} 
culturally and morally contiguous with the metropolis. This was underscored by the classic justification for imperialism: the mission to civilize barbaric and savage societies. This is an imperial theme that is brilliantly captured and explored by Catherine Hall's Civilizing Subjects: Metropole and Colony in the English Imagination 1830-1867. ${ }^{46}$ There were intellectual and policy debates occasioned by Mau Mau that mirror the racial ideologies between liberals and conservatives as discussed by Hall. These were between settler hardliner conservatives and selfstyled "liberals" epitomized by Group-Captain L.R. Briggs and Michael Blundell, respectively, to which missionaries added their voices as well as middle-of-the-path observers like General George Erskine.

In addition to this was the ideology or mentalité of survival that drove anti-colonial movements in general, and Mau Mau in particular. Unlike their counterparts in Birmingham and London who were disillusioned by the cumulative effect of the Morant Bay Rebellion (1865) and the Indian Sepoy mutiny (1857), white conservative colonialists following the outbreak of Mau Mau, were unapologetic in their bid for the re-imposition of white power. ${ }^{47}$ "Liberals" too persevered in their bid to make Kenya a country that would secure their continued economic dominance in the face of the Mau Mau war. Unlike in Jamaica where the rebellion of former African slaves forcefully brought the spatial realities and geo-cultural indifference of the "other" home, whites in colonial Kenya persisted in their pursuit of their imagined white man's country.

In view of these imperial parallels, it important to understand the persistence, in the construction of the Kenyan state, of the imagination of white man's country or the triumph of the colonial ideology after Mau Mau was brutally crushed even after independence. There was, though, a subtle shift in the construction of Kenya as a white man's country to a more "accommodating" multicultural state albeit one that, besides favoring settlers, now admitted the African big man to privilege and power.

Thomas Metcalf's work too, contributes greatly to the understanding of the imperial jockeying between conservative and liberal administrators. This is with respect to the British Raj

\footnotetext{
${ }^{46}$ Catherine Hall, Civilizing Subjects: Colony and Metropole in the English Imagination, 1830-1867 (Chicago: University of Chicago Press, 2002).

47 Lonsdale, "Mau Maus of the Mind," 421.
} 
in a bid to construct the sub-continent after contending images of Britain's "other" self. ${ }^{48}$ Ideologies of the Raj is an important reference because it shows that the British Empire had no standard ideological template for governing its colonies, which led to liberal and conservative elements in official administrative or informal capacities developing different and usually contradictory policies.

Drawing parallels with the Kenyan colonial experience has led to the appreciation of the fact that this British imperial project was no exception. Contesting imperial ideologies were thrust forth by the Mau Mau war, which was itself, a violent challenge to the making of Kenya as a white and African big man's country. The war amplified earlier anti-colonial sentiments and pushed the issues of land, rationalized labor and African political representation to the fore. It was symbolic of the ideological conflagration, which now played out in the actual physical field of battle. The 1950s decade and the Mau Mau "Emergency" was the "halftime" of the British imperial effort to impose an exploitative state-building project from above thus inaugurating Kenya's long century of violence. ${ }^{49}$

\section{Vortex of Historical Continuities: Mau Mau Minds}

According to the veteran Kenyan historian B.A Ogot, the years between 1956 and 1963 were decisive.$^{50} \mathrm{He}$ argues that the struggle against Mau Mau exacted a heavy political price, accommodations and compromise gestures from the British imperialists. As part and parcel of the fight against Mau Mau, the colonial government instituted the Swynnerton Plan for the development of agriculture in the African reserves; the Lyttelton and later Lancaster House Constitutions; the Carpenter minimum wage reforms; and the Lidbury civil service equal pay for equal work review of terms. There was also a limited extension of rationed franchise and increased African representation in the Legislative Council during and after the Mau Mau Emergency (1952-1960). These developments were, in effect, triggered by the Mau Mau ferment amid a groundswell of latent discontent in East Africa. This then suggests that this war was, indeed, the crucible in which the postcolonial state emerged in the early 1960s.

\footnotetext{
48 Thomas R. Metcalf, Ideologies of the Raj (New York: Cambridge University Press, 1997).

49 John Lonsdale, "Compromised Critics," in Religion and politics in Kenya: Essays in Honor of a Meddlesome Priest ed. Ben Knighton (NewYork: Palgrave, 2009), 58.

${ }^{50}$ Bethwell A. Ogot, "The Decisive Years, 1956-1963," in Decolonization \& Independence in Kenya: $1940-93$ eds. B.A Ogot and W.R. Ochieng' (London: James Currey, 1995).
} 
According to Ogot, after Mau Mau, Kenya could not exactly return to the colonial status quo ante. In part, this study set out to collate various archival evidence that make a direct or indirect connection between these socio-economic and political reforms and the war. A second ambitious objective was to try and document the competing bottom-up (popular) and elite (topbottom) state-constructed ideologies in postcolonial Kenya. The assessment of the manner in which these latter day colonial reforms were implemented before and after independence, proves that Mau Mau hopes in particular, and general African aspirations, were not met. I have offered and supported the argument that relative deprivation and denial of popular socio-economic and political aspirations including human dignity and human rights; self-reliance; and civic responsibility and liberties represented by the war, resulted in an ideological lineage of dissent throughout the postcolonial period.

My study, like Odhiambo, posits that the colonial struggle of Kenyan people for civil liberties, peasant self-reliance, civic responsibility and human rights had the opposite effect. It "yielded" a more assured imperial gaze in the form of capture of state power by an African elite. After independence, the postcolonial state remained, as ever, dependent on Britain. The Kenyan state was a gate-keeper state in which the role of the African elite was to control the inward and outward flow of capital in the form of foreign investments and aid, payment of exports and multinational corporation profits. ${ }^{51}$

As a result, the nature of the Kenya state to date remains contested along the same grain as in the 1950s. This, in turn, has dictated the nature of the country's politics and affected national integration and identity. The aspirations of the crucial formative years between 1945 and 1955, which informed the war of independence, still remain. It is in this sense that the war is herein seen as a critical conjuncture and a meeting point for all the forces of history, economic, social and ideological, that have shaped Kenya's long century. This study proposes that this period in Kenya's history is not only critical for the understanding of Kenya's past but also going forward into the $21^{\text {st }}$ century.

The struggle that characterized Kenya's formative years is still on. There was general turmoil and ferment not only among the Kikuyu but also elsewhere. These years were

\footnotetext{
${ }^{51}$ Daniel Branch, Kenya: Between Hope and Despair, 1963-2011 (Yale: Yale University Press, 2011$), 122$.
} 
characterized by a general uproar in reaction to forced land consolidation in the Rift Valley, the rise of religious syncretic movements among the Kipsigis and Luo and fear among the Bukusu over their land and grazing rights in the Pokot highlands. It was a period of "matatizo" and "matata" throughout the colony. There was a general undercurrent to rework the interstices of the colonial order to accommodate a hard past and the dim future beyond Central Province where the Mau Mau conflict was confined. ${ }^{52}$ The East Africa Royal Commission, 1953-55 unveiled the groundswell of Mau Mau minds. ${ }^{53}$ It is little wonder that sweeping reforms, like the Swynnerton land consolidation plan, in the wake of the war, left only a few regions in the colony untouched.

While it offers a refreshing new perspective of Mau Mau, this view is not entirely unprecedented. John Lonsdale recognized the need to reconstruct the colonial image of "an evil Mau Mau." For him, this meant reconstructing past boundaries of morally valid knowledge and power. According to Lonsdale, Mau Mau was a dreadful reality: "a pathological image of the right social group relations which ought to order colonial life. These relations were ...in disarray, between ...what once had been and the mirage of what they might become."54 Lonsdale's interpretation of this colonial struggle confers upon it a historically redemptive quality.

The Mau Mau struggle was for self-mastery, respectability, patriotic virtue, for the working of their own salvation in agrarian labor and over the moralities of class formation. ${ }^{55} \mathrm{It}$ was an opportunity for the white ruling class to dissolve race as a strategy of survival in the face of the fundamental challenge of the imaginative structures of race and tribe underwritten by the colonial order. Instead, the subsequent violent historical rupture of colonial society resulted in divided contemplation of the future that invited new appropriations of the past. The whites, according to Lonsdale, chose to continue writing their own history and that of the African people. Ultimately, the remaking of Kenya after the war was decided by others. It was re/constructed by metropolitan Britain and the new African ruling elite and not those who sought to reconfigure the socioeconomic and political colonial order. Indeed, those who fought colonial

\footnotetext{
52 Odhiambo, "The Formative Years," 26.

53 The commission was charged with the duty of investigating the potentially explosive atmosphere characterized by restlessness, heightening political agitation and discontent in the region against the background of the Mau Mau war. Across the board, Africans, not only in colonial Kenya but elsewhere, expressed their displeasure with the colonial state and status quo especially the issue of loss of land.

${ }^{54}$ Lonsdale, "Mau Maus of the Mind," 404.

55 Ibid., 417.
} 
"order" would reenter society to find that they were still landless in a rural world now realigned by land consolidation and freehold title. ${ }^{56}$ This was true at the end of the war, the final days of colonial rule and the dawn of independenc. Significantly, it has also been perpetuated long after "freedom" was won.

This is an observation that others have made. William Ochieng' pointed out that in his independence speech, President Jomo Kenyatta did not even mention the people who laid down their lives for the struggle. ${ }^{57}$ For Ochieng', this shows that the new independent African government did not commit itself to a revolutionary break with the past, which is what the Mau Mau war sought. The war was an attempt at such far-reaching socioeconomic and political transformation of society and, for them and most Kenyans, this is what independence meant. Ochieng' sees Kenyatta's rule as a new-styled colonial governorship with his close cohorts and the Kikuyu as the new Europeans. ${ }^{58}$ In the early days of the postcolonial state the newly uprooted weed of race as a strategy of survival was replaced by the equally divisive seed of ethnicity.

The latter took the place of race as the basic point of reference in the state's authoritative allocation of resources and strategy of socio-economic and political survival. For Ochieng' this is why Kenyatta's ex-Vice-President Oginga Odinga was convinced that even with an African president, it was still not yet "uhuru."59 Yet, while this is a valid observation, it is a rather rhetorical oversimplification of the historical continuity between the colonial and postcolonial state. To remedy this observation, this study marshals copious empirical evidence to show how the Kenyatta and Moi governments perpetuated the making of Kenya into a big man's country and with what implications for both political eras and beyond.

\section{New Historical Sources, New Histories}

This empirical investigation has only been made possible by continuing declassification of previously sensitive information covering this period of Kenya's history. Indeed, this has already spawned new work that is at the juncture of national and imperial history. Caroline Elkins Britain's Gulag and David Anderson's Histories of the Hanged are good examples. The

\footnotetext{
56 Ibid., 420.

57 William R. Ochieng, "Independent Kenya's Develoment Strategies," in Decolonization \& Independence in Kenya, 1940-93 eds. B.A Ogot and W.R. Ochieng (London: James Currey, 1995), 92.

58 Ibid., 102.

${ }^{59}$ Ajuma Oginga Odinga, Not Yet Uhuru: The Autobiography of Oginga Odinga (London, Heinemann, 1967).
} 
former is a detailed account of the British response to the Mau Mau struggle with specific attention given to internment camps. It deals with the gory counter-insurgency tactics and methods chosen by the British military, intelligence and colonial police to put out the rebellionvillagization, torture, de facto detention, screening and rehabilitation and beating among others.

It is, so far, the most comprehensive study of British counter-insurgency measures and policy. Elkins relied on archival data as well as oral interviews of former fighters and detainees. However, she was criticized by, among others, Anderson and Branch for focusing on the nationalist representation of the Mau Mau war. It is also worth mentioning that the book did not offer any insights on the significance of the war and counter-insurgency in postcolonial Kenya.

Anderson cast the Mau Mau fighters in an entirely new light using available archival information detailing over a thousand court trials of Mau Mau fighters. This study detailed the reasons why the "accused" got involved in the struggle in their own words as they testified in their trials, which is a powerful rendition of Mau Mau voices speaking from their graves. In addition, it classified individual Mau Mau into those operating in the city of Nairobi; the Aberdare, Mt. Kenya and other forests; and the more specific case of the Lari Massacre on the outskirts of Nairobi. The book ends with a compelling reflection of the aftermath of the warhow the police state was to be dismantled; rehabilitation of detainees; and return to normalcy and what that meant. This marked the inclination towards historical reflection on the significance of the war for contemporary Kenya. This new reflective approach to the study of Mau Mau is one that has, in a way, inspired greatly my interest in an inquiry that is solely dedicated to the war's postcolonial implications. ${ }^{60}$

In his book Defeating Mau Mau, Branch studied the loyalist element of the Mau Mau revolt. This book too ends with a note on its postcolonial significance. However, for the most part, it foregrounded the loyalists in this defining event. To its credit though, it also looked at the complex dynamics of what the author, largely, viewed as a Kikuyu civil war. It focused on what being a loyalist really meant beyond broad social categories and ahistorical observations. Branch argued that loyalists participated in the counter-insurgency because of their own experience of

\footnotetext{
60 David Anderson, Histories of the Hanged: Britain's Dirty War in Kenya and the End of Empire ((London: Phoenix, 2005).
} 
the violence. At the end of the book there is a disproportionately short reflection on the implications of an appreciation of loyalist histories on the trajectory of the postcolonial state. ${ }^{61}$

These include the predominance of loyalists in institutions of both the colonial and postcolonial state as well as the impact on Kikuyu political thought and householder ethics. Branch observed that civil war and counterinsurgency became exercises in state-building just as both Britain and the United States have their origins in conflict and violence. He also noted that postcolonial loyalist domination and imposition of the "ideology of order" found continuity in the Mwai Kibaki era. This, however, is not a detailed study that catalogues the evolution of this ideology in the post-independent era. In developing my research scope, I wanted to be able partially contribute to an understanding of the said "ideology of order" by focusing more on the counter-ideology of popular statehood and struggle for mundane needs of everyday life. The two have competed for mastery since the 1950s and much earlier.

\section{Subliminal Ideology against Criminal Foundations of the Colonial State}

The building-the-nation imperative, uhuru (freedom) and fruits of this freedom -land, employment, education and healthcare, civil liberties and civic responsibility- which were the omnibus rallying cry for the struggle against British colonialism, have remained elusive even after independence. The first decade seemed promising and the long struggle for uhuru, which was sometimes violent, was somewhat vindicated. But that is as far as the success story goes.

For that reason, Kenya has, since independence, limped down the road of liberation as a modern African state with the threat of revolutionary violence ever looming. While enjoying relative success compared to its neighbors, the country has teetered precariously on the edge of violent conflict. This is wrongly viewed as a result of the ferment of ethnic conflict that threatens to tear the state apart. In this study, I posit that ethnic conflict is but a symptom of a much deeper structural violence rooted in unresolved historical problems and criminal injustices that stem from the colonial era.

After the precipitous violent experience in 2007/8, much was done at the practical level of national politics, the intervention of the international community and the search for a new constitutional order. However, much more needs to be done by way of taking stock of the

\footnotetext{
${ }^{61}$ Branch, Defeating Mau Mau.
} 
circumstances under which the Kenyan state was formed throughout its colonial experience with emphasis on the 1950s as the key center-point. Elusive political stability and nation-building and integration cannot be realized without drawing lessons from such a historical reflection, which, albeit, has so far not been undertaken. If there has been a single most important justification for this study, and from which I have drawn much inspiration and courage to undertake it, then this is it. This inquiry of how the circumstances under which the Kenyan state was formed continue to be relevant today has not been disappointing. In the chapters that follow I have advanced the following pillars of my argument supported by empirical archival evidence:

i. That Kenya's colonial legal architecture propelled the state on a socio-economic and political trajectory dominated by either white or African big men (chapter two).

ii. That the introduction of colonial capitalism and attendant modernity jarred African societies, which began an existential struggle that continues in Kenya today (chapter three).

iii. That the Mau Mau struggle among other anti-colonial movements contested the capitalist order and colonial state, which they sought to reconfigure favorably (chapters three and four).

iv. That the institutional and structural reforms enacted in response to Mau Mau laid the foundations for the postcolonial state and postcolonial order, which have never been overturned since (chapters four and five).

v. That Mau Mau's anti-colonial ideological legacy of dissent continues to contend against the official ideology of law and order represented by the ruling elite (chapter five).

vi. That the pervasive ideology of tribalism, shared by ordinary Kenyans and the elite, has recalibrated the real nature of politics in Kenya that is about the everyday struggles of survival. As a result, the ideology of tribalism inhibits national integration in Kenya (chapter six).

\section{Wars Make States}

The making of the generic African state was deliberate and artificial. It was a product of imperial fiat. As such, it does not fit within the ambit of dominant theories of the origins of the state such as neo-Marxism or liberal theory. In this wise, the formation of the state in Africa stands in stark contrast to how European states were formed towards the end of the Middle Ages. 
The "architects" of the process in Europe did not set out to create a state per se. The European state has its origins and foundations in local and regional alliances of dynasties with agents of capital or, in some instances, specific individuals and merchants. In Europe, the state emerged as result of intricate and mundane societal processes of more or less ordinary people negotiating economic and other changes in their milieux. In Europe, the state emerged as a result of people reacting to exogenous factors such as the peaking of long distance trade in the fifteenth century. Subsequent structural changes and institutional innovations, according to Hendrik Spruyt, led to the emergence of the state unit as a fundamental logic of organization. ${ }^{62}$

The state in Europe, therefore, emerged from the interactions and power relations between plenipotentiary actors that were either entities such as the church or its representatives, empires or its agents such as kings, towns and their denizens. This was a relatively allaccommodating process that was at once vertical, horizontal and bottom-up evolutionary process dictated to by naturally occurring needs of society. It was, as in the case of Africa, a top-bottom imposition. Rather, it incorporated different layers and sections of society. It was also, more or less, a state-formation process stimulated by local and simple dynamics and mundane everyday concerns of ordinary people acting on their own behalf.

The modern state in Africa stands in stark contrast. It was an imposition and a grafting of the European state on pre-European African structures and institutions. ${ }^{63}$ Put differently, the state in Africa was constructed after its European image. The African state was forged out of a process of European imperial imagination. In addition, the obvious deliberate human agency in the

\footnotetext{
${ }^{62}$ Hendrik Spruyt, The Sovereign State and its Competitors (New Jersey: Princeton University Press, 1994).

${ }^{63}$ I recognize that this remark is bound to whip up accusations or criticism for making what seems to be a sweeping generalization or over-simplification of European state formation. However, it is worth noting that this is expected especially from neo-Marxist, neo-Durkheimian and neo-Weberian political scientists who are more systemic in their analysis of state formation. This study, far from employing such perspectives that cast the process as having been unilinear, predetermined and inevitable, draws inspiration from the micro-level and microhistory approaches for a better understanding of the genesis of European states and their African counterparts by extension. Unlike the abstract systemic and anachronistic approaches, Spruyt and Osvaldo Raggio, "From the Natives' Point of View: Microhistory, Local Politics, and the State," a paper presented at Clark Library conference (Los Angeles, 1997), argue that the modern European state has its foundations in intricate and humble societal processes of more or less ordinary people negotiating economic and other societal changes occurring in their milieux. The only caution here is acknowledging that this perspective, as employed in this study, does not preclude systemic dynamics in the process. Linda Colley in Britons aptly captures the interaction of the top-down and bottom-up processes behind the emergence of the British nation-state. This explains the study's focus on popular notions or ideologies of statehood with anti-colonial movements exemplified by Mau Mau as the watershed challenging official constructions of the state since the 1950s to the present.
} 
process serves to further complicate the utility of the conventional theoretical framework outlined above which explains state formation in the European context.

Moreover, Tilly's argument that wars in Europe were crucial to the state-making process is important. It can be applied as a theoretical framework in the context of the Mau Mau war. ${ }^{64}$ Seen through this theoretical lens, the war is the crucible of the Kenyan state. Up until the 1950s, the development of the Kenya colony had taken place along the lines of European racial dominance. Despite the classic imperial justification, European presence in the colony had nothing to do with civilizing the African or governing the colony in trust until such a time that political power would pass to the Africans.

Rather, the British were there to stay. Colonial rule was justified by, and is thereby best understood as, British self-definition as a civilizing superior "us" against an inferior African "other." This explains the construction of the colonial state as a white man's colony that in turn explains the outbreak of the Mau Mau war. It is also within this context that nascent African nationalism and political consciousness culminating in the struggle for independence should be understood. In the same breath, Kenya's post-independence political history should also be understood as a continuation of the neo-imperial liberal state project. That is, the continued attempt by Western governments to propagate democratic institutions, values and principles of governance on a global scale in countries where these have not evolved locally.

At the heart of this project is the refashioning of the relationship of the state with the market economy with the aim of reducing the role of the former as a regulator of the latter. In essence, the free market ideology of "invisible hand" is supposed to order activity in a free market economy. Agents of this process are Bretton Woods institutions, the World Trade Organization, the European Union and cultural experts but, more so, Western governments in general. As such, post-independent Kenya can be seen to be effectively under British, or more precisely, Anglo-American economic influence with regard to trade and bilateral relations. Here, it is instructive to note that "decolonization" was under continued and unstinting Western tutelage within the context of the Cold War. Consequently, discontent with the state has

\footnotetext{
64 Tilly, "War Making and State Making as Organized Crime," 169-170. Tilly's main thesis is that "war makes states."
} 
remained with the same intensity of the 1950 and 1960s if not more. This unbroken and increasing decibel of discontent and resistance against the state is what this study has sought to document.

African dissent was the spark that lit political consciousness at the end of the second decade of the $20^{\text {th }}$ century. It did not take Africans long to feel the negative effects of the colonial system and its interference on how they conducted their everyday lives. Chapter two discusses the legal, policy and institutional structure of the making of Kenya as a white man's land. This structure included land and labor laws that enabled the British to "legally" alienate African land, curb their agency and grossly infringe on their freedoms and rights. It argues that at their very core, these laws were, and still are, morally and legally questionable. They were, indeed, criminal. They erected an extractive and exploitative surveillance state in which Africans were not citizens but subject-chattels. This colonial structure was the stage upon which the violent backlash of the Mau Mau war played out. The war can, and should be seen, as the ultimate expression of outrage at the mixed bag of opportunities, but importantly, also challenges that colonial order established by the legal production of illegality.

Chapter three foregrounds further the breakout of the war in the 1950s. It also demonstrates that whereas only the Kikuyu were involved in this conflagration, involved experiential and spatial grievances were felt across the colony in varying degrees. In this chapter, I scrutinize the impact of this colonial architecture on Africans; how it was viewed in their eyes and how it was experienced from below. I argue that the colonial existential struggle, that is, the physical anguish, emotional and psychological anxiety occasioned by new rural and urban colonial spaces and telekinesis of colonial capital, which radically transformed African societies, is what produced the Mau Mau war. I posit the argument that the effect of this legal production and social construction of illegality was the creation of many Mau Maus of the mind. These were in embryo and at different levels of ferment when the war broke out in the 1950s in central province of the colony.

This is a theme taken up in the fourth chapter. Unlike traditional Mau Mau studies, I foreground not the actual physical war itself but, rather, ' 52 minds elsewhere in the colony that were airing grievances cut from the same fabric that caused the violence. The work of the East Africa Royal Commission that was conducted as the violent drama unfolded, offers a snapshot of 
these Mau Mau minds in embryo in the form of testimonies asking for the righting of colonial injustices. Of course, little was done to remedy this other than the various "accommodations" made such as agrarian reforms espoused in the Swynnerton Plan; review of the minimum wage, working conditions and registration; review of civil servant salaries to reflect equal pay for equal work between different races; increase in African representation in the legislative council; and constitutional reforms extending them the right to vote. The emphasis here is that whereas the war provided an opportunity for a fresh start, it had the exact opposite effect.

The counterinsurgency measures and policies outlined above were in themselves colonial state-building and strengthening measures. So while they were part and parcel of the decolonization process and independence, they effectively hoodwinked Africans' high expectations. Measures and policies such as reforming the provincial administration, an institution of social and political control, only served to significantly strengthen the state on the eve of independence. Indeed, it was rewarding the colonial state apparatus in large part because of the role it played in the war against Mau Mau. ${ }^{65}$ These institutional measures and their postindependent continuities are proof of the triumph of the colonial system. Together, they represent a pact-of-domination that cushioned the demise, if not simply perpetuated colonial rule. ${ }^{66}$ These changes were aimed at repressing Mau Mau phenomenon, both physical and the mind. This state of affairs only served to strengthen the prevailing order although minimal concessions and compromises including independence were made. Overall, Kikuyu loyalists and moderate politicians, among them Kenyatta who were amenable to the colonial project, provided the personnel to postcolonial state institutions. The end result was a security or surveillance state. This postcolonial Kenyan state has been keener on political control and reactionary response to crises as opposed on the provision of public welfare.

As a result, at the eve of independence, the threat or another break out was real. After all, the war had given the Colonial Office room in which to make reality conform to the prior image of officials and forge Kenya's future as modern and agricultural. ${ }^{67}$ At the practical long-term implementation of this effort was the Swynnerton Plan for land consolidation followed by the

\footnotetext{
65 David Branch and Nicholas Cheeseman, "The Politics of Control in Kenya: Understanding the BureaucraticExecutive State, 1952-78," Review of African Political Economy 33 (2006): 15.

66 This term, "pact-of-domination" is deployed here as used by Branch and Cheeseman. Ibid., 11.

${ }^{67}$ Cooper, "Mau Mau and the Discourses of Decolonization," 320.
} 
million acre settlement scheme after independence. There was also a practical policy aim of these reforms calculated to reorder the political economy thereby building up a substantial middle class of all races to be the back bone of the country, which then became the ideological foundation of the post-colonial state. ${ }^{68}$ This was the so-called "official wisdom." 69 This meant that political independence was nothing more than a massive and brilliant deception. This is what forms the subject of the next chapter, five. Therein, I posit that people's popular expectations were shunted: that "social justice and redress" served rewarded white settlers as opposed to Africans who had lost their lands to the former in the first place. This then sets the background against which follows a discussion of the lurking ghost of Mau Mau proper and legacy of dissent in the Kenyatta years.

The main thesis in chapter five is that independence was a pyrrhic victory for grassroots forces of popular statehood. I advance the argument that the deliberate process of decolonization was a well-calculated and considered policy to ensure flawless continuity of the colonial order. The manner in which it was designed co-opted a friendly Kenyan African elite to whom power was entrusted. A close eye of scrutiny, however, was maintained in both Nairobi through the British High Commission in constant correspondence with the Foreign Office in London. This case is built with benefit of various archival sources from the Kenya National Archives and the British National Archives including diplomatic archives in the latter.

The notion of decolonization was at best a remodeling of the colonial state. It is a wellaccepted fact that there was configuration of interests between moderate African elites and British commercial concerns that supported a capitalist development program. ${ }^{70}$ Instead of dwelling on this reality, the aim of chapter five is not to examine these institutional continuities. Rather, I humanize the assessment of this legacy of British imperialism by highlighting what these institutional continuities meant for ordinary Kenyans' political and socioeconomic aspirations and ambitions.

\footnotetext{
${ }^{68}$ Lonsdale, "Mau Maus of the Minds," 409. Also see Branch and Cheeseman, "The Politics of Control in Kenya," 17, who make this same observation attributing it to Mau Mau legacy and, consequently, "the colonial government's attempts to create a loyal middle-class as part of the counter-insurgency effort."

69 Lonsdale, "Mau Maus of the Mind," 409.

70 Branch and Cheeseman, "The Politics of Control in Kenya," 25.
} 
This chapter, therefore, focuses on popular and radical post-independent dissent. This discontent fed on the groundswell of formidable challenges that faced the people whose independence hopes had been spurned. It highlights soaring unemployment, continued land hunger and the unbridled desire among Kenyans for the fruits of independence. This postindependent bitterness is captured by the slogan "uhuru na taabu" (freedom and suffering). The chapter relies on correspondence between colonial administrators in Nairobi important aspect of which were forwarded to London. It is from this flow of information that it emerges that the ghost of Mau Mau lurked even after the movement was "crushed."

It is worth mentioning here that chapter five benefitted a lot from the hitherto untapped collection of files from the Office of the President in the KA series of the Kenya National Archives. Whereas these files consist of "Complaints and Petitions" to the president for beneficent intervention, they acted as an important source for state intelligence gathering. Kenyatta's independent government had stumbled upon a voluntary channel of state surveillance. In the face of formidable challenges and increasing criticism the government resorted to entreaties, threats and the laissez-faire ideology and exhortation that independence did not mean freebies; the call for hard work; and the need for order. Sections of society tended to imbibe this propaganda while the bulk of the people remained adamant. I have used numerous illustrations and stories of disgruntled everyday people who voiced their grievances and skepticism. The pervasive mentalité of struggle is also reflected in postcolonial literature a selection of which is extensively cited. The prevalent hue and cry is cast against grand corruption that wracked the Kenyatta regime. This template and approach is replicated in the analysis of the Moi and Kibaki years in chapters six and seven.

Chapter six follows the same mold used in the previous one but in the context of the Moi regime albeit having to cope with scant archival sources. Political dissent and discontent in the first ten or so of Moi's rule was difficult to voice especially after the failed 1982 attempted coup, which forced political opposition underground. This, however, stands in stark contrast with the fairly well-documented groundswell of popular opposition in the early 1990s that resorted to the atomization and bifurcation dissenting voices as the Moi regime struggled to cling onto power. In this chapter, therefore, the reader will find a brief discussion of the recalibration of the deep politics of bread and butter to ethnicized politics. 
This, it is argued, came at the high price of intermittent violent ethnic conflict and bloodshed especially since the early 1990s. This recalibration of deep politics in Kenya fostered divisiveness and weakened nation-building with regard to integration of various ethnic group components that constitute the Kenyan population. The last chapter, seven, is an analysis of the Kibaki administration with special attention paid to continued workers' travails (teachers and university professors and support staff); focus on groups fighting historical injustices that touch upon the emotive issue of land alienation and socioeconomic marginalization; as well as nuggets of the spirit of struggle as expressed through new avenues of the expression of political dissent and social communication such as Facebook and Twitter.

Overall, as observed above, the ultimate objective of this study is achieved. It amplifies the voices of the forgotten in Kenya's history throughout its ruefully long century. Sitting in the middle of the country's historical trajectory, the Mau Mau war is a striking reminder that Kenya has a whole lot unfulfilled dreams. Even after independence, African-led governments are yet to bring the kind of simple changes that most ordinary people have yearned for. It is their take on the state that this research set out to capture in minute detail. The study weaves together harrowing stories into a narrative of the state as experienced from below. It invites readers to enter with the author into the Mau Mau mind, and thereby, peer into the majority of Kenyans' bitter life experience at time ventilated in riotous and bloody street dramas; underground movements; fiery sermons in church and mosques; through music; crime and extortive activity; ethnic clashes over the emotive land issue; and, more recently, through new mediums provided by the information technology revolution.

In following this crowd history of Kenya's history as presented herein, one has reason to hope that readers witness, up close, a people's unwavering aspirations and determination to realize a country of their own making. A nation that they can proudly say they own and belong to. Since this as yet remains a distant aspiration for many, this study serves as a haunting reminder that the struggle is still on. 


\section{Chapter II - White Man's Land: The Colonial Foundations and Legal Architecture of the Kenyan State}

\section{Preamble}

The ...legality ... of an act does not make it a just one.... There is no power that does not attempt to cover its actions with the cloak of legality. The legitimate ones without doubt. In the name of the law, rights can be assured but privileges can also be entrenched. The legitimate aspirations of thousands of people can be repressed and eliminated without contemplation.... Arbitrariness disguised as legality.

Jaume Asens and Gerardo Pisarello, "The Illegality of Power," $17^{\text {th }}$ February 2012. 
One of the kingpins of any imperial quest is the consideration of how to physically subdue and control the environment. This is true of ancient Roman empire-builders or Spanish conquistadores whose "first impulse" to this end "was to read aloud the requerimiento," a written declaration of sovereignty, which was "a spectacularly bold announcement of arrival and ownership."1 This was also the case with regard to the early modern British imperialism between 1600 and 1830 as it was during the late period of colonialism in Africa during at the end of the $19^{\text {th }}$ century and early $20^{\text {th }}$ century. Besides the crucial practical concern with the security and protection of colonies, the other paramount preoccupation was the transformation of the land or landscape. Colonists throughout the history of imperialism shared similar attitudes, beyond taking possession, to make and remake their physical possessions.

Besides being secured, the landscape had to be tamed or be made hospitable through cultivation, planting and other European methods of improvement for example, the building of infrastructure, and remodeled for it to be better controlled as well as well as to be brought to profit or support a settler community. As Glenn Hooper pointedly states, all these were important markers of ownership and authority. ${ }^{2}$ All this required a great deal of arrogance and ruthless confidence on the part of the actual colonial policy architects as well as that of actual settlers who enjoyed the resultant expropriation and exploitation of locals and their land. As already observed in the Spanish example above, the law was an important instrument in, and for, the subversion pre-European order and the inscription of European stipulations to reproduce the desired effect upon this newly acquired space.

The following is a critical examination of the legal, institutional and policy cornerstones of the colonial, and subsequently, postcolonial state. It propounds that contemporary problems that beset the country including land distribution, control and access, and unequal distribution of social services, political configuration featuring competing ethnic elites and ethnicization of politics all stem from this legal and policy blueprint of Kenya as a white and African big man's country. Put differently, that political attitudes and strategies with regard to the attainment and use of state power, land hunger and the perennial question of individual/regional-communal land ownership, and social relations underlined by the increasing gap between the rich and the poor,

\footnotetext{
${ }^{1}$ Glenn Hooper, (ed.) Landscape and Empire, 1770-2000 (Burlington: Ashgate Publishing Company, 2005$), 1$.

2 Ibid., 2.
} 
the obvious difference between Kenya's big man and ordinary wananchi, to a large extent, are influenced by these early beginnings of a deliberate policy of preferment on the basis of race, which was replaced by ethnicity and elite cronyism on the eve of independence. It discusses in outline the central legal, policy and institutional pillars that were erected with flagrant racial bias favoring Asian, but mainly, white Afrikaner and British settlers. Since independence these deeprooted seeds of injustice nested in an unjust colonial legal framework have perpetuated the illegal/irregular allocation of public land in Kenya.

This legal and policy invention and colonial economic intervention exemplifies the construction of criminality by the state since it dispossessed, repressed and eliminated the legitimate land rights as well as disposal of African labor and, therefore, the basic right to livelihood as well as the bastardization, without due reasonable contemplation, of the aspirations of millions of Africans couched in a pre-European mode of life and customary laws. In so doing, arbitrary appropriation and/or expropriation of land was disguised as legality, which this analysis takes issue with. ${ }^{3}$ This discussion of the legal production of an illegal architecture of exploitation with the subsequent restructuring of power relations will be followed by a more detailed assessment of how this new colonial political economy affected and marginalized African populations leading to growing political consciousness. This is discussed in the next chapter that examines and highlights the experience of "illegality "from below"" as a result of the anxiety occasioned by the newly created rural and urban colonial spaces. ${ }^{4}$

That is, by discussing its impact with regard to the alienation of land and labor and associated controls through an examination of everyday experiences of Africans who, as a result of the forceful imposition of this legal and institutional architecture, were rather sharply or quickly ushered into an alien socioeconomic and political order of the colonial capitalist state or modern space to which they were ill-adjusted not to mention that it was systematically rigged against them.

\footnotetext{
${ }^{3}$ The framing and conceptualization of this analysis is thanks to Jaume Asens and Gerardo Pisarello, "The Illegality of Power," $17^{\text {th }}$ February 2012 and the core concept of the International Colloquium on "Norms in the Margins and Margins of the Norm: The Social Construction of Illegality" call for papers by the Royal Museum for Central Africa, Brussels organized by, among others, Jean-François Bayart who is one of the foremost scholars behind the "politics of the belly" paradigm and criminalization of the state approach in the study of African politics.

${ }^{4}$ The phrase "illegality from below" is borrowed from "Norms in the Margins and Margins of the Norm," above.
} 
While the discussion below scrutinizes this architecture, the next chapter attempts to assess the experiential or psychosociological anxieties encountered by African populations as they entered and navigated the newly imposed colonial capitalist complex culminating in the struggle for independence epitomized by the Mau Mau war, which was prefigured by other equally important anti-colonial movements that sought to redefine and reconfigure the colonial state through violence. Such movements like "Dini ya Msambwa" (DYM) and its Pokot corollary, Luo squatters in Kisumu/Londiani district, Nandi and Elkumi in Trans Nzoia and Uasin Gishu districts and the characteristic labor strikes of the 1940s the major one being in Mombasa, were all attempts, as the late Kenyan historian E.S Atieno Odhiambo noted, to rework the legal, policy and institutional interstices of the colonial order to accommodate the hard past and the dim future. But before that, a discussion of this architecture is important as it contributes to a better understanding of these anti-colonial movements and the struggle for independence. Indeed, the central argument at the heart of this work is that these anti-colonial movements were attempts at reconfiguring social relations of power established by these colonial foundations to create a more equitable political economy.

Put differently, it is important to trace or background the genesis of the ideology of resistance inspired by the experiential struggle to eke a living, and the quest for better living standards epitomized by Mau Mau at the height of the anti-colonial struggle, to this early construction of the colonial order. For a long time, anti-colonial movements, not just in Kenya but also elsewhere in Africa, have been merely treated as a reaction or a natural response to colonial rule in a generic sense without an analysis of the intricate specific hot-buttons that generated them. At one level, this has the effect of obscuring the sea change akin to a colonial revolution upsetting the prevailing colonial order. While it was not ideal or idyllic, it was a functional pre-colonial order that was ruptured through the creation of the colonial state. Secondly, it sweeps the complicated and complex production of grievances and African political consciousness against European colonialism under the generic term "African nationalism."

Therefore, there is need to scratch much deeper into the nuts and bolts of the making of "African nationalism." This is done herein by closely scrutinizing the adverse effects of modernization in particular as a result of the legal production and social construction of a colonial landscape, which was facilitated by the colonial legal and policy architecture that 
created a hostile new space which Africans found difficult to navigate or survive within, in the literal sense of the term. With the institution of colonialism, African societies were enveloped by an unfamiliar cultural, physical and moral colonial landscape that occasioned, and was characterized by spatial, psychological, technological, embodied and material anxiety. Anticolonial movements mentioned above, epitomized by the Mau Mau war, were resistance efforts against the erected colonial capitalism complex of surveillance: law and order, institutions and policies, which, taken together, constituted and created an oppressive imperial modern space or landscape. This imposition of adverse modernity, rested on the bedrock of colonial land, labor and taxation policies among other supportive institutional architecture, mechanisms and racial attitudes.

In addition, the resultant fledgling colonial political economy, and/or restructuring of human relations, was not only unapologetically racially segregated but it also ruptured and reordered the pre-European African world socioeconomically. This was not without serious moral, legal and physical implications. The previous, relatively functional, political and socioeconomic pre-colonial order of African peoples was ruptured. As John Lonsdale notes, the physical landscape or ecological arenas of forests, hills and plains were reordered to pave way for a colonial space of plantations and game reserves with protective borders and boundaries where there had been none, forts, keeps and stockades, townships and trading centers, and road and railway networks and harbors all constructed to conform to western logic. 5

Since the country was earmarked as a white man's land that could be settled in indefinitely, "the same kind of institutions" either protecting private property rights or extracting rents that colonialists "lived with in Europe" were introduced. ${ }^{6}$ By focusing on the legal, policy, institutional and physical apparatus of empire erected at a heavy cost for the pre-European socioeconomic and political life, the discussion that follows below acts as the stage upon which the violent backlash of the Mau Mau war played out. Put differently, the war can and should be seen as the ultimate expression of outrage at the mixed bag of opportunities, but importantly, also challenges that the colonial order established by questionable authority and "illegal" or

\footnotetext{
5 John Lonsdale, "The Conquest State, 1895-1904," in A modern History of Kenya, 1895-1980, ed. William R. Ochieng' (London: Evan Brothers, 1989), 6.

${ }^{6}$ Gareth Austin, "The 'Reversal of Fortune' Thesis and the Compression of History: Perspectives from African and Comparative Economic History," Journal of International Development 20 (2008): 996 \& 1000.
} 
unjust framework presented. This criminal and unjust structural and attitudinal edifice was the stage upon which the drama of Mau Mau and its historical antecedents like DYM and postcolonial critical publics would unfold. This colonial architecture, therefore and the violence of the 1950s, act as tragic historical precedents and warning that contemporary policymakers and political leaders should heed to avoid another tipping point of the postcolonial Mau Mau ideology of dissent. It is imperative to observe that anti-colonial movements that culminated and reached the highest crescendo in the Mau Mau moment and the 1950s were the foetal crucible from which the postcolonial state emerged. Ongoing socioeconomic disparities harking back to early colonial times and government policies and attitudes continue to inspire postcolonial dissent and opposition to the state similar to Mau Mau. ${ }^{7}$

While the facts and knowledge of the making of Kenya as a white man's country are well documented, this critical process has, more often than not in the past forty/fifty years, been glossed over. The legal and institutional undertakings of both the British government and colonial administration, first in the East Africa Protectorate and Kenya colony much later, have, so far, not been interpreted as the foundational building blocks of the contemporary state. ${ }^{8}$ Yet, colonial land, labor, taxation and personal registration policies have left an indelible mark in the country's physical and political landscape, and psyche. Political historians and political scientists have barely touched upon this subject from this perspective. This chapter attempts to fill this gap by examining these colonial laws and policies especially those to do with the alienation of African land and labor. Attention is also given to how Africans reacted to, and were affected by, these legal and policy props that resulted in their loss of agency, control and ordering of their own lives and destiny as they wished. It is important to state that the twin loss of African land and labor was an existential and psychic loss since it meant the denial of ownership and control of the two most basic life supports.

Despite the near absolute lack of critical legal scrutiny of these foundational factors and the implications of their illegality viewed from below, several scholars have touched on them in addressing Kenyan history. Among them is Bruce Berman whose collective work studies this

\footnotetext{
7 Post-colonial dissent and critical publics are discussed in chapter 5, 6 and 7.

${ }^{8}$ Throughout the chapter, these two colonial entities referring to present day Kenya, and before 1920, the general area between the Indian Ocean all the way to Lake Victoria encompassing the Great Rift Valley will be referred to as "Kenya."
} 
period. Berman addressed the incursion of colonial capitalism and concomitant modernity into a precolonial indigenous order from a neo-Marxist perspective. He saw this as a process characterized by a crisis of political control since the transition from one mode of production to another was not seamless. Berman, therefore, saw the transition from a precolonial mode of production to a capitalist one in Marxist terms as a process of "articulation." ${ }^{9}$ His study is a highly theoretical analysis that builds its argument through abstract constructions, which, albeit, contribute to an understanding of what happened in this early period of colonization in East Africa. What is important, as Berman noted, is that Kenyan "indigenous societies in which money, surplus commodity production, wage labour and bureaucratic forms of organization were virtually unknown, were subdued and coupled to European forms of capital and the state that already had more than two centuries of development." ${ }^{10}$ Berman ably gave insights into the workings of this phenomenal transformation in a language that borrows heavily from Marxian phraseology such as "formal subsumption of labour," "peasantization of the African population," "structural contradictions of accumulation and control," and "indigenous protocapitalism" among others, all of which are, no doubt, important to this end.

Beyond this, among the numerous interesting findings Berman discussed is the observation that Africans, at the end of the day, "were caught not only within the contradictions of administrative 'development' but also in its gaps and omissions." ${ }^{11} \mathrm{He}$ also noted that in this newly established colonial order, "white settlers were able to shape the state and its policies to meet" demands dictated to by capitalist principles under the tutelage of the metropolitan interests and official government control in Nairobi. ${ }^{12}$ What has been documented is the history of a few colonial officials in London and Nairobi who facilitated this transformation, that of individual "settlers" and agricultural and colonial capitalist establishments that gained ascendance in the new relations of production. As such, “African peasants" remain faceless and their plight, occasioned by this oppressive legal-policy architecture, is as such ignored. Specifically, their everyday experience of anxiety, occasioned by this intricate socioeconomic transformation and

\footnotetext{
${ }^{9}$ This is a concept that admittedly suffers from intellectual controversy but was intended to explain the hierarchical linkage between several modes of production -in this case, capitalist and pre-capitalist African: see Bruce Berman, Control and Crisis in Colonial Kenya: The Dialectic of Domination (London: James Currey, 1990$), 35$. ${ }^{10}$ Berman, Control and Crisis, 35.

${ }^{11} \mathrm{Ibid}$., 305. Berman writes this with reference to the rising numbers of Kikuyu landless flooding back into the already packed reserve when squatters were forced from European farms in the white highlands.

12 Berman, Control and Crisis, 185.
} 
facilitated by this legal-policy framework, is overshadowed by the inherent theoretical abstraction of Berman's analysis. The colonial capitalist architecture of land, labor, taxation and registration laws and policies that make the transition possible is also not discussed in detail if at all or seen for what it was: that is, the legal production or social construction of illegality or, as the Africans whose lives were controlled by it must have experienced and perceived it from beneath, as calculated and pure deceit, a manacling of individual and collective wills upon which was now imprinted a foreign one on the landscape, and curtailment of freedoms accompanied by gradual impoverishment on account of imposed runaway modern wants.

There is, therefore, need to closely examine this legal and institutional structure and its spatial, technological, psychosociological and material implications and impact. This calls for deliberate humanization by peopling such a critical analysis of this period with special focus on inter-racial and ethnic group competition; an assessment of everyday life experiences wrought by this colonial architecture; and, lastly, conducting an examination of possible postcolonial continuities in these terms. What follows, below, is a critical assessment of this legal and policy framework and what it meant for pre-European African societies.

As noted above, such a discussion must be preceded with reference to how scholars viewed it. Besides scholars, perspectives and the understanding of actual participants in, or observers of, this historic process are instructive. This refers to an understanding of colonial state-formation with reference to what colonial officials and settlers thought their role was in administering and building it through pioneer-settler-agriculture. These perspectives are aptly captured in Lonsdale's seminal essay on the conquest state. Lonsdale's book chapter contribution stands out as an impressive work that details the burgeoning of what later becomes the Kenyan state.

Lonsdale started his analysis of how the colonial state and administration was established with the fascinating observation that it sprang from a footpath six-hundred miles long. In the main, he was concerned with how this tremendous transformation was, first and foremost, the result of the colonial investment of force. That is, the deployment of violence by the British on a scale that was locally unprecedented. ${ }^{13}$ In the chapter, Lonsdale recreates for his reader the mood

${ }^{13}$ Lonsdale, "Conquest State," 6. 
of the local African population and their group experiences at the butt end of British punitive military measures: for example, while in the midst of a smallpox epidemic and famine that plagued them, the Maasai also had to deal with land-hungry white strangers keen on appropriating huge chunks of their precious land. At the same time, tough times confronted Kikuyu agriculture as their southward migration was rolled back while Luhya pragmatism occasioned by the need to survive, led to their cooperation with the British. ${ }^{14}$

Importantly, Lonsdale noted how forces of the new political economy produced economic, political and social changes that destroyed traditional patterns of authority and production. As a result, most indigenous societies were thrown into turmoil. ${ }^{15}$ This was underlined by the other category of his analysis that he referred to as the "vulgarization of power" that is comparable to "the illegality of power" as used by Asens and Pisarello. ${ }^{16}$ That is, the result of the imposition of a new class of Africans with the dubious role of recruiting labor and extracting tax for the new colonial masters. This analysis is useful as it demarcated the general outlines within which the question of the colonial foundations of the Kenyan state can be addressed.

Another useful scholar who focused on this crucial time period of Kenya's history is Robert .L. Tignor. ${ }^{17}$ Tignor examines how African lives were affected by the establishment of a colonial system over them. Specifically, he attempted to answer questions such as what they had to do differently and ways in which they remained unchanged and whether British rule was a modernizing influence. This last question provided him with the opportunity to explain different levels of modernization between African groups. While this book noted and compared the plight of the three subject Kenyan peoples with regard to land alienation and labor policy, it does little

\footnotetext{
14 Ibid., 16-22.

15 Ibid., 21 \& 22. The other side of the coin of the changes wrought by the said architecture that is the subject of this chapter is the fact that its imposition entailed the curtailment of indigenous institutions, values, attitudes and customs with deep psychosocial and socioeconomic repercussions for these societies. This is going to constitute the subject of the next chapter, which aims at capturing the day-to-day experiences of these societies in a manner that is, hitherto, unprecedented.

${ }^{16}$ Lonsdale, "Conquest State," 26; and Asens and Pisarello, "Illegality of Power." The latter two note that "law and juridical discourse plays a central in the configuration of power relations" and when this involves the imposition of "a programme of social cutbacks, a police action ...force is needed."

${ }^{17}$ Robert .L Tignor, The Colonial Transformation of Kenya: The Kamba, Kikuyu and the Maasai from 1900 to 1939 (Princeton: Princeton University Press, 1976).
} 
to relate this to the British colonial state-building project as inaugurated within the framework of legal provisions and policies necessitating these essential components of modernization.

Lastly, one must mention the work of Robert Maxon, which focused on the loss and reassertion of the imperial initiative by London vis-à-vis the colonial administration in Nairobi between 1912 and $1923 .{ }^{18}$ This is with regard to outstanding issues including the deportation of Mr. Galbraith Cole, a British settler, but most importantly, settler political rights and ascendancy in the export trade, labor recruitment and land alienation and the attendant legal supports of the last two such as registration of persons and taxation ordinances. Maxon argued that the Colonial Office in London was in control of colonial affairs in Kenya but temporarily lost initiative after the opening of the First World War. It then re-established this authority with the issuance of the Devonshire White paper in 1923 that sought to settle once and for all, the Indian Question. ${ }^{19}$

On the matter of the catering for both the socioeconomic needs/demands of Indians equally as those of British/European setters, the Colonial Office ruled on the paramountcy of African interests of which colonial government was in trust. While Maxon was correct in his analysis regarding both the tacit protection of Africa interests and on the ascendancy of London, what actually transpired in the period that initiative of policy decisions was lost between 1914 and 1923, the granting of almost every settler whim with regard to land, representation and labor, is overlooked. Granted, Maxon ably detailed how colonial governors, at the behest of settlers, enacted land and labor provisions that firmly entrenched the personal and group interests of the latter.

However, it is the cumulative effect of this lapse of authority, which provided the inadvertent opportunity for the completion of the institutional and legal framework guaranteeing settler preponderance for a long time, and, with it, a legacy that would reach well beyond

\footnotetext{
${ }^{18}$ Robert Maxon, Struggle for Kenya: The Loss and Reassertion of Imperial Initiative, 1912-1923 (New Jersey: Fairleigh Dickinson University Press, 1993).

19 This arose out of Indian grievances regarding Indian inability to own land in the so-called "white highlands" that had been set aside for European settlement. There is need to shed more light into the policy and legal structure that led to this furor in the first place. Critical also should be the individual and collective experiences leading to political activism and colonial resistance, which most of the times is veiled by the catalogue and language of "issues" and "grievances." The telling of this individual stories and how they dovetailed into collective narratives of shared suffering under British colonialism, which are understudied underside of colonial history is important. This is because it is what then informs not only anti-colonial resistance movements like DYM and Mau Mau, and labor strikes but also influences visions of an ideal state of these people's choice.
} 
independence that Maxon did not address in great detail. Put differently, Maxon argued that the Devonshire White paper represented the reassertion of policy initiative yet failed to note that this did not translate to a reworking of the legal architecture that was, indeed, pro-the principle of African paramountcy. This concept existed only on paper, literally, whereas arrogant and ruthless white supremacy was the everyday colonial reality as Africans continued to languish under the newly imposed colonial order.

\section{Colonial Sinews of State Power: The Criminal Loss of Naboth's Vineyard, Labor and his Monetization \\ Preferential concessions to setters had begun long before governors Henry C. Belfield,} Charles C. Bowring, and Edward Northey. From the moment Sir Charles Eliot ended his support of Asian settlement in 1902 in favor of that of Europeans, governors were faced with the question of what right, equity and/or law an alien government "with the rights and duties of a protector could assume the ownership of all the land in the country in order to give it away or to sell it for trifling sums to its friends and countrymen ...."20

This, Norman Leys noted, was a question that was "much debated in the houses of public servants in Kenya," and one could perhaps add, one that had preoccupied the British for quite a long time since the 1890s. It is important to outline the evolution of the ever increasing powers and legal overreach in terms of land and labor provisions, not to mention a gamut of ordinances governing other activities such as wildlife and township establishment legislations, since with regard to land, "no precedent could be found in British Colonial and Imperial history for such ...expropriation." ${ }^{21}$ Let it suffice to say that since Sir Charles Eliot and thereafter one governor

\footnotetext{
${ }^{20}$ Norman Leys, Kenya (London: The Hogarth Press, 1926), 159. I came across an interesting memo sent by W.C Bottomley, who was the head of the East African Department at the Colonial Office in London, to Sir Henry Belfield, who had just succeeded Sir Percy Girouard. It is perhaps the best example the gradualism promoting white supremacy. Bottomley says that he was duty bound to honor the promises that had been made to settlers with regard to the Maasai Laikipia plateau reserve, BNA CO 533/193. In addition to this document is another administrative communication, a note from the Secretary of State, Lewis V. Harcourt to Governor Belfield, in which the former writes that the "obligations contracted in 1910" by Sir Percy Girouard, " must ...be discharged," BNA: C0533/115. This perhaps is what leads R. Hyam to write about a "wayward evolution" of Kenya which enabled "settlers to entrench themselves in a way far removed from official intention" -see R. Hyam, "The Colonial Office Mind 1900-1914," Journal of Imperial and Colonial History 8 ( October, 1979): 47.

${ }^{21}$ Leys, Kenya, 159. Further, Leys draws the distinction between the manner in which land was seized in both America and Australia where he notes "European immigration into these countries was one of cultivators of the soil, not, as in East Africa, of people who expected the natives of the country to use the plough and the hoe while they themselves were mere supervisors or even continued to live in England." It is also important to highlight Ley's
} 
after another granted incremental concessions to settlers although this commissioner and Sir Percy Girouard were the most notorious. The latter would state in a report carried in the East African Standard:

We consider that taxation is the only possible method of compelling the native to leave his reserve for the purpose of seeking work. Only in this way can the cost of living be increased for the native, and as we have previously pointed out it is on this that the supply of labour and the price of labour depend.

To raise the rate of wages would not increase but would diminish the supply of labour. A rise in the rate of wages would enable the hut or poll tax of a family, sub-tribe or tribe to be earned by fewer external workers, and as the payment of this tax is avowedly the reason for what labour we have seeking employment it follows that if we increase the rate of remuneration of the individual we decrease the number of individuals necessary to earn a given sum. ${ }^{22}$

The kind of preoccupation with the transformation of the landscape with the requisite need for labor, which was the ultimate marker of ownership and colonial authority alluded to earlier, is quite clear from the above quote. It demonstrates some of the devices or mechanisms that colonial administrators were ready to employ without any due consideration to their implication for Africans or consequent repercussions.

Such settler sympathies and flagrant preferment enacted and protected by the law would reverberate with the views of a later governor, Sir Edward Northey, who in his inaugural address reported in the Standard remarked:

The Protectorate has taken over the ownership of millions of acres of good land and the guardianship of large native populations. Is it our duty to allow these natives to remain in uneducated and unproductive idleness in their so-called reserves? I think not. I believe that our duty is to encourage the energies of all communities to produce from these rich lands the raw products and food-stuffs that the world at large, and the British Empire in particular, require. This can only be done by the encouragement of the thousands of ablebodied natives to work with the European settler for the cultivation of the land and improved stock. I find some of the native reserves not clearly defined. I propose to settle that definitely. Where there are doubt and disputes as to the ownership of land -title and tenure of natives I propose to proclaim the area in question as a reserve; that does not

observation that whereas America and Australia were relatively empty continents, "the arable parts of East Africa were, in 1900, far more thickly populated than the arable parts of Australia at the same time."

22 "Native Labour," East African Standard, $8^{\text {th }}$ February 1913. This was a report on Sir Henry Belfield's remarks at Nakuru agricultural show who was citing the immediate former colonial governor, Sir Percy Girouard. 
mean that I recognize that whole area as belonging to any native tribe or individuals, but it is Crown Land. ${ }^{23}$

Indeed, it was common knowledge that vexing problems such as availability of labor could not be resolved until the colonial authorities fully controlled the country via legal means. ${ }^{24}$

It is such official sentiment, therefore, that colored and inspired legal mechanisms of acquiring, or more aptly, "grabbing” African land and coercing its original inhabitants using various devices such as the hut and poll taxes to work on it. One of the pioneer legal centerpieces that made this possible was the Crown Lands Ordinance of 1902 which made provisions for the sale and leasing of "wasteland and unoccupied" land for a maximum of ninety-nine years. This was a significant improvement of what was the very first in a raft of legal productions of illegal expropriation of African land: that is, the establishment of the East Africa Protectorate under the Foreign Jurisdiction Act of 1890.

As earlier noted above, this piece of legislation did not, make it possible for outright land alienation. As Norman Leys pointed out, the British government still faced the challenge of resolving the issue of what right, in equity or law, it had in its rights and duties of a protector to assume ownership of land that was still, in essence, still foreign. ${ }^{25}$ Britain, as Okoth Ogendo observed, needed the kind of land control in East Africa that would lend "the imperial government the power to acquire title to and deal with the land resources of the region," which is something that this legislation did not quite avail. ${ }^{26}$ Indeed, the declaration of protectorate status over the region took place on June $15^{\text {th }} 1895$ but even this did not quite deliver the desired secure property rights. "Protectorate" status had long been defined by Law Officers of the British Crown as early as 1833 as being a foreign country. As such, it only gave the imperial power "little more than political jurisdiction over the territory" concerned. ${ }^{27}$ It could be said that the British, especially officials at the Foreign Office, were still operating within the moral bounds of a clear bureaucratic conscience and margins of the norm but this would not last long. It would

\footnotetext{
${ }^{23}$ East African Standard, 25 $5^{\text {th }}$ February 1919.

${ }^{24}$ Captain Coney, a Legislative Council member is reported to have said as much in an address to his constituents reported in the East African Standard, 20 ${ }^{\text {th }}$ February 1926.

${ }^{25}$ Leys, Kenya, 157.

${ }^{26}$ H.W.O. Okoth Ogendo, "The Political Economy of Land Law -An Essay in the Legal Organization of Underdevelopment in Kenya, 1895-1974," Ph.D. Dissertation, Law School, Yale University (1978), 40.

27 Ogendo,"The Political Economy of Land Law," 41.
} 
seem that London was not eager to wander from respectful confines defined by the Charter of the Imperial British East Africa Company (IBEAC), "which contained the following words: 'In the administration of justice by the Company to the people of its territories or to any of the inhabitants thereof, careful regard shall always be had to the customs and laws of the class or tribe or nation to which the parties respectively belong, especially with respect to the holding, possession, transfer and disposition of land and goods." 28 This noble position would, however, not last for very long.

The first imperial legal production of illegality mentioned above was rather rustic and barely scratched the surface with regard to land acquisition for European settlement, which was not yet envisioned at this stage of colonization. The first taste of the power of acquiring land through legal force was in the agreement reached between the IBEAC and the Sultan of Zanzibar, the Administrative Agreement of 1895. This gave the British government some measure of indirect control over all lands ceded to it by the Sultan by virtue of a concession agreement signed earlier in 1888 between the latter and IBEAC.

While there were at least ninety-seven treaties signed between IBEAC and tribal functionaries in the hinterland, these carried no rights to African land. Such treaties under the limited political jurisdiction framework only pertained to the protection, rule and government of these tribal authorities (chiefs), their territories, countries, people and subjects by the imperial agent at this time, IBEAC. ${ }^{29}$ The main architects and colonial agents pushing for more concrete commitment for the inscription of European-style property rights in land were men on the ground. The Foreign Office increasingly faced demands from colonial administrators to "abandon its rather legalistic approach to the status of protectorates and assert original title to the land."30

This push then, is what sent the legal production of illegality with regard to the alienation of land and labor in its course with ever-increasing confidence, assertiveness and proportionate African dispossession and disorientation and hence, dissent. In particular, as Sorrenson has

\footnotetext{
28 Leys, Kenya, 206-207.

${ }^{29}$ Ogendo, "The Political Economy of Land Law," 42. This meant that African chiefs ceded to the company the sovereign rights and rights of government over territories, countries, peoples and subjects.

30 Ogendo, "The Political Economy of Land Law," 43.
} 
documented, Commissioner Sir Arthur H. Hardinge's was instrumental in the shift from the assumption of sovereign rights and political jurisdiction of the imperial government under the legal framework that established the protectorate administered by IBEAC to complete territorial sovereignty under the East Africa Protectorate. According to Sorrenson, Hardinge dismissed as juridical fiction the said special status of "protectorate" bestowed by London, the Foreign Office and later the Colonial Office. ${ }^{31}$

As commissioner of the protectorate, Hardinge yearned for power that would enable administrators like himself "to promulgate legislation authorizing the compulsory acquisition of land" for immediate practical purposes such as the construction of the railway beyond the sultan's dominions as well as a system of law that would secure rights to land for settlement for agricultural purposes. ${ }^{32}$ For purposes of the former, constructing the railway from Mombasa to Kisumu, the Indian Land Acquisition Act (1896) was used within the ten-miles where the Sultan of Zanzibar exercised sovereignty but this law was later extended by Hardinge to cover the interior as well. ${ }^{33}$ Whereas the legality of its application within the ten-mile coastal strip is not in question, its extension and application in the appropriation of land up to one mile on each side of the railway track in the interior is quite questionable. ${ }^{34}$

This notwithstanding, to be able to do so, the office of the Commissioner was vested with the authority to undertake this acquisition on behalf of Her Majesty (HM) as per the East Africa Acquisition of Lands Order-in-Council of 1898. At last, Hardinge's argument that African leaders could hardly be said to have sovereignty and juridical authority, and therefore, land rights and territorial control had triumphed with the fleeting but powerful imagination of the landscape through imperial eyes, which was concretized by the magical stroke of the pen.

What is more, Law Officers of the Crown impressed by this sort of imperial reasoning on December $13^{\text {th }} 1899$ revised the Foreign Jurisdiction Act of 1890 in the form of an advisory opinion to now bestow Her Majesty the "power of control and disposition" over unoccupied

\footnotetext{
${ }^{31}$ M.P.K. Sorrenson, Origins of European Settlement in Kenya (Oxford: Oxford University Press, 1968 ), 51.

32 Ogendo, "The Political Economy of Land and Law," 44.

33 This Act is mentioned briefly in Ogendo, Ibid., 44 \& 45.

${ }^{34}$ E.S. Atieno Odhiambo, Siasa: Politics and Nationalism in E.A, 1905-1939 (Nairobi: Kenya Literature Bureau, 1981), 5 notes further that "in order to provide land for the anticipated settlers the administration promulgated the Land Regulations 1897." This legislation drew the distinction between land within the Sultan's dominions and; and elsewhere in the colony.
} 
waste land in the protectorate. ${ }^{35}$ Now even in London, African customs and laws governing the use and control of land were no longer hallowed. The bureaucratic margins of the norms of juridical sovereignty were spilling over driven by an imperial rationalization that pronounced the legal control of African land and the environment. African land was said to be "unoccupied" because of the convenient interpretation of indigenous land tenure as usufructuary. That is, African societies did not legally own land but held it as long as they worked on it. This erroneous understanding of African land tenure in general, and specifically, that of the Kikuyu of central Kenya, would become a massive colonial headache for colonial administrators throughout the rest of their rule. Filing a report for the Department of Agriculture of the Colony and Protectorate of Kenya in the mid nineteen-thirties, V. Liversage, a government agricultural economist, still perpetuated this convenient truth about African communal land tenure. Liversage stated that "usufruct and seigniory are the warp and woof of the Githaka system" of the Kikuyu. ${ }^{36}$ Suffice it to say that the clever invention of the description of uncultivated African land as "unoccupied," and therefore vacant, emboldened colonial administrators further in promulgating laws that further encroached on African land rights and access.

Moreover, African land relations were fit into conceptual categories derived from English common law and the suppression of "the development and adaptation of customary land tenure regimes" paved way for the stripping away of land rights from Africans. ${ }^{37}$ The communal African land holding system was interpreted as being primordial and it was believed by both colonial administrators and agrarian specialists that it was gradually evolving into European-like individual land tenure. Liversage, for example, argued that "communal tenure arises in the beginning of Agricultural development, when land is abundant and, like fresh air, has no exchange value" and that under such a system "land rights are entirely undemarcated, though the

\footnotetext{
${ }^{35}$ H.W.O. Okoth Ogendo, "The Tragic African Commons: A Century of Expropriation, Suppression and Subversion," University of Nairobi Law Journal 1 (2003): 110 and in his "The political Economy of Land and Law," 46 \& 47.

${ }^{36}$ V. Liversage, "Tenure of Native Land in Kenya," $11^{\text {th }}$ September 1933, University of Nairobi: LAMB/1/2/4. Although this document is not signed by Mr. Liversage it has complete passages from one whose authorship is unquestionable dated $16^{\text {th }}$ December 1935, "Tenure of Native in East Africa: The Economic Aspect" found in the same file as the one quoted herein. Liversage went on to publish the book, Land Tenure in the Colonies (Cambridge: Cambridge University Press, 1945) that was lauded by a reviewer in The Economic Journal 55 (December, 1945): 432-434, for not following "the dangerous method of treating questions of land tenure and land usage amongst colonial peoples as though they were something fundamentally different from those arising in more highly articulated economic systems."

37 Ogendo, "The Political Economy of Land and Law," 16 and in his "The Tragic African Commons," 111.
} 
individual will generally be left to enjoy rights of user over the land he has cultivated." 38 In a manner characteristic of most imperial agents who sought to inscribe European institutions of private property, Liversage further observed the following:

The African rural economy today us comparable in several respects with the manorial system which existed throughout Britain and Northern Europe in the Middle Ages. That system, with its sharp restrictions of individual liberty and enterprise, broke down with the spread of a commercial as distinct from subsistence economy. The break down was accompanied by rural disorganization and great hardships to individuals. Numbers of people were divorced from the land and a social problem of the first magnitude was thereby created. The same forces are capable of creating the same problem, in Africa today. ${ }^{39}$

At least, Liversage was realistic enough to observe that land was the "most important element of production" and that the changes "in rural life and organization" that were being wrought by British imperialism were happening "at such a pace that it might appropriately be called a revolution." 40 Others were not so honest with themselves, which perpetuated the rupture of the make-up of pre-colonial African societies that eventually led to the rise of disenchantment a few decades into the $20^{\text {th }}$ century. A good example of the convenient reading of the European institution of private ownership of land in the African tenure system was by Dr. L.S.B Leakey, a British archaeologist and Kikuyu language expert, who argued that "there was individual tenure among the Wa-Kikuyu before the arrival of Europeans." ${ }^{41}$ Attempting to divine what the cause of Kikuyu political agitation was in the late 1930s, Leakey, like many before him who presided over the radical and disruptive agrarian revolution at the turn of the century, argued that precolonial and African held land during colonialism was property that was vested in individuals especially where the Kikuyus had been in recent contact with Europeans. This was in his estimation because native tenure was "automatically beginning to approximate and moulding up in the direction of individual tenure...."42

\footnotetext{
38 Liversage, "Tenure of Native Land in Kenya," 1, UoN: LAMB/1/2/4.

39 Ibid., 4.

40 Ibid., 1.

${ }^{41}$ O.F. Watkins, "Land Tenure: A Reply to Dr. Leakey," East African Standard, October $27^{\text {th }} 1939$, is a critique of two articles written by L.B.S Leakey.

42 Watkins, "Land Tenure: A Reply to Dr. Leakey," East African Standard, October $27^{\text {th }} 1939$.
} 
Of course, similar observations made at the end of the $19^{\text {th }}$ century led to the declaration of vast African land as "waste land" and "unoccupied" by British imperial agents. They could then, with great ease, fail "to recognize the existence of sovereign rulers in indigenous society" and conclude that the colonizing sovereign was the "owner" of the land. ${ }^{43}$ With the adoption of the advisory of the law officers of the crown, "unoccupied" land that was not overseen by a recognizable form of government or appropriated by local sovereigns or individuals could now be declared to be crown lands by HM or be given as grants to individuals for a fee and for any period of time. This provision would later be incorporated in the East African (Lands) Order-inCouncil in 1901, which conferred upon the commissioner of the protectorate power to dispose of all "public lands" on such terms and conditions as he might think fit and only subject to such directions as the secretary of state might give. In what is a remarkable demonstration of the incremental chutzpah on the part of all involved both in London and Nairobi, all the above was followed, in the series of legal production of illegality in 1902 by even greater powers spelled out by the Crown Lands Ordinance that was promulgated by Sir Charles Eliot, Hardinge's successor. It provided "for outright sales of land and leases of 99 years' validity." 44

As part of this new legal cloak, Sir Charles Eliot got considerable leeway in making the rules for the sale and lease of land, something that another senior administrator, Governor Sir Henry Belfield, would later exercise within an even more ambitious revised land alienation framework, the Crown Lands Ordinance of June 1915. Maxon observes that this new ordinance was reconstructed on "broader lines" when compared to the tempered principles on the subject of land laid down by the Colonial Office in 1908 or $1912 .{ }^{45}$ For example, it removed vexatious restrictions of land lease for ninety-nine years, which had hindered development. ${ }^{46}$ It also dropped the requirement of continuous residence on the property by the landholder and made African reserves crown land, which meant that all such land was now under the direct control of the colonial state. Odhiambo observes that this law did not only ensure that the protectorate government had complete control of the land occupied by Africans, "but it was made clear that

\footnotetext{
43 Ibid.

${ }^{44}$ Odhiambo, Siasa, 5.

45 Maxon, Struggle for Kenya, 81.

${ }^{46}$ The emphasis in italics is the present author's: this was only a pretext meant to give settlers security of land ownership as the calculated end was the land being held in perpetuity for generations of settler descendants. The parallels between this plan and the Nazi regime's intentions of creating a one-thousand year Reich, involving the creation of a German lebensraum is striking.
} 
natives had no right to alienate any of the land whether they occupied it or whether it was reserved for their own use." 47

Of course, the legal dispossession of land caused Africans untold fear. Growing African insecurity was exacerbated by the "celebrated case of Wainaina v. Murito" in which Chief Justice Sir Jacob Barth ruled, in 1923, that "“no native rights were reserved" under the Crown Lands Ordinance 1915 and further, considering the Kenya Order-in-Council, 1921 land reserved for the use of native tribes was vested in the Crown. As such then, the Chief Justice ruled, "“all native rights in such reserved land whatever they were under the Gethaka system disappeared, and the natives in occupation of such Crown land became tenants at will of the Crown of the land actually occupied." 48 A memo that sought to clarify the legal position with regard to African land rights and ownership drew reference to this ruling, and quoted the Kenya Colony Order-inCouncil Article 2 (3), which defined crown lands as “... all public lands in the Colony which are for the time being subject to the control of His Majesty, and all lands which shall have been acquired by His Majesty for the public service or otherwise howsoever and shall include all lands occupied by the native tribes of the Colony and all lands reserved for the use of the members of any tribe." 49

As such, on the strength of this definition and Barth's ruling, the acting Attorney General H.C. Willan who drafted this memo in 1939, concluded that, "there could be no legal ownership of land by natives in the Native Reserves and that rights by native law and custom were not recognizable." "W0 What this meant was that Africans had the right of "use" of land as opposed to the "ownership" or "alienation" rights, and thus, "natives had no legal ownership of the land" as this was not provided for in the law. ${ }^{51}$ Indeed, the memo captures everything that was wrong with various legal provisions regarding land, which is reflected in it. One of the legal cul de sacs was with respect to define the nature and extent of African land rights, which the memo deals

\footnotetext{
47 Odhiambo, Siasa, 6. Also see the memorandum prepared by the Acting Attorney General H.C. Willan and circulated to all Provincial Commissioners by H.S Potter, $26^{\text {th }}$ July 1939, UoN: LAMB 1/2/3. It set out the nature of the control vested in the Native Lands Trust Board and the nature of the rights possessed by natives over land in native areas.

${ }^{48}$ Odhiambo, Siasa, 6. Also see, M.P.K. Sorrenson, Land Reform in the Kikuyu Country: A Study in Government Policy (London: Oxford University Press, 1967), 28.

${ }^{49}$ Circular drafted by Acting Attorney General H.C. Willan, $26^{\text {th }}$ July 1939, UoN: LAMB $1 / 2 / 3$.

${ }^{50} \mathrm{lbid}$.

${ }^{51} \mathrm{lbid}$.
} 
with towards the end. The memo acknowledges the difficulty of the question of the rights of Africans especially under native law and custom: thus the drafter does not attempt "to give any definite answer. ${ }^{52}$ The Barth ruling was the zenith of the complete disregard of norms and was, indeed, within the outer limits of the margins of what was the norm.

The case of the Maasai is another good illustration of the suffering and injustice caused by this rather inconsiderate legal regime. According to an East African Standard report, the Maasai move orchestrated by Girouard led to the dislocation of about 10,600 people, 200,000 cows and 1.5 million sheep and goats from the Laikipia plateau. ${ }^{53}$ This simultaneously bears out the illegality of colonial power and also captures the complete disregard of African land rights. It aptly demonstrates the observation of Asens and Pisarello that the legality of an act does not make it a just one, which, in the case of these colonial land alienation devices, was a serious affront for most African societies that lost no time to register their incredulity and outrage. ${ }^{54}$

This series of the said land laws among other future modifications too numerous for individual treatment herein, are instances of the legal production of illegality through which colonial authorities attempted to cover their actions with the cloak of legality. As illustrated in the two examples above, the rights of settler land holders were assured and European privileges entrenched by these laws while the aspirations of thousands of people were repressed and eliminated without contemplation by deliberate and convenient arbitrariness disguised as legality.

Following from the above, it is not difficult to appreciate the core demands behind Mau Mau, land and freedom. Years later, prior to the height of the Mau Mau struggle in the 1950s, Lieutenant Colonel O.F. Watkins, a self-taught student of native tenure, contested Leakey's thesis regarding individual African ownership of land. He did not believe that it was so in 1895 and further, that "the conception of ownership of land is foreign to native ideas. It is a European

\footnotetext{
52 Ibid., 10.

53 See East African Standard, $5^{\text {th }}$ March 1913. Numerous other examples including the high profile case filed by Chief Koinange wa Mbiu in which he sought the reinstatement of family land alienated in Kiambu; that of the relocation of Chief Makimei and his people to Lari, an issue that would lead to the infamous Lari massacre years later, which will be discussed more extensively as part of this study about everyday experiences of ordinary people.

${ }^{54}$ Asens and Pisarello, "Illegality of Power."
} 
legal, feudal notion of the land required to support men-at-arms for the lord." ${ }^{55}$ His enquiries about African land tenure led him to the conclusion that the African was "more simply and severely practical. He wants the right to cultivate the best land obtainable." 56 More importantly, Watkins observed that when he was talking to Africans in 1911 about their land laws, he asked if land could be sold, and the answer was, "how could it [sic]. The land is always there like the air."' Watkins recounts another instance in 1927 when he talked to Africans ten miles outside Nairobi: he told them that land titles would mean the creation of "barons" who would own the land on which the rest of the people would merely live until they were turned off. This statement drew "that roar of uncomprehending laughter. "They couldn't turn us off,", the Africans retorted. "Where would we go [sic] It is not our custom." 57 Watkins concluded the article with the observation that individual tenure in the reserve was for the future and not for the past and that it would evolve gradually "but those who charge themselves with its establishment should be looking, not for analogies with Europe's feudal systems, but for the best way of grafting on a new growth onto the wonderful native social system, which has a place for all, and food for all, and no class hatred or humiliations." 58 On the eve of the Mau Mau war in 1948, in the copy of Mumenyereri newspaper, the leading Kikuyu space for public expression and venting of African grievances, squatters complained that they were "always removed from our original places and left without land for all the land has been taken from us. We are therefore, like wild animals." 59

Permanent absolute and exclusive ownership of land by Europeans was therefore, shocking and unexpected. Some Kiambu Kikuyu under Chief Koinange Mbiu who had also lost clan land to white settlers felt guilty about this loss. "We Kiambu people are to blame for the Europeans entry into Kikuyu country," stated an article that appeared in Mumenyereri. The writer, Chief Koinange Mbiu, argues that initial Kikuyu contact with people like Count Teleki, Ainsworth and Northcote was innocuous blood brotherhood sealing a bond of friendship that

\footnotetext{
${ }^{55}$ Watkins, “Land tenure: A Reply," East African Standard, October $27^{\text {th }} 1939$.

56 Ibid.

57 Ibid.

58 Ibid.

${ }^{59}$ Mumenyereri, $19^{\text {th }}$ April 1948, KNA: MAA/8/106.
} 
made "another person a real brother. Nobody thought wrong of such Europeans because we administered oaths with them."60

Land control that was allowed to such administrators, the writer continues, was in the hope that they would help the Kikuyu to conserve and manage the soil and forests better for the sake of future generations. Chief Koinange is quoted in the letter as having gone a step further to help Europeans to secure African labor on their farms to further cement the agreement, an arrangement that was at the time acceptable: "no one could classify the other as white, black or red." 61 But then Lord Delamere "while he had land that could be occupied by the whole of Kiambu's population," after the Great War "went to South Africa to find out how he could trouble Kikuyu." And "when he returned he arranged a meeting at Ruiru Club of Europeans" where "he advised them to deceive the Kikuyu."62 As a result the Kikuyu were collected and ferried free of charge to the Highlands to work on European farms on which they had been promised prosperity but instead the "Europeans ...occupied their land and forests, they broke the agreement....That was the beginning of Squatters' troubles and evictions. Squatters were made to be like slaves when they settled at other places like Loitoktok, they were also sent away."63 Another Kikuyu newspaper, Muigwithania, likened the understanding between the Kikuyu and the early European settlers to the initial symbiotic relationship between the Muhuti tree and the Mugumo (fig tree). ${ }^{64}$ The paper carries "The Tale of the Muhuti tree and the Mugumo," in which the latter approached the former and asked for "a night's lodging at...Muhuti's village. ...The Muhuti did not refuse" after all, "the homestead was built for travelers."

...The Mugumo entered the village and put away his bundle and rested. And when it got night, the Mugumo went to bed and commenced to let down one little root. Again near morning he commenced and let down another. And when it got light, the Muhuti said to him. 'Friend, why don't you get up and go home?' And the Mugumo said to the Muhuti, 'Friend let me rest; I will go home my friend.' They remained for little [sic] and then the Muhuti said to his friend, 'Why don't you go home?' The Mugumo said to the Muhuti, 'Friend, I am very tired; let me rest ... it is getting dark; I will certainly go home tomorrow; for now I am very, very tired.' Again when it got light the Muhuti said to his

\footnotetext{
${ }^{60}$ Chief Koinange, "Senior Chief Koinange Revealed his Agreement with Europeans," Mumenyereri, $12^{\text {th }}$ July 1948 , KNA: MAA/8/106.

61 Ibid.

62 Ibid.

63 Ibid.

${ }^{64}$ The Mugumo seed starts to thrive on or very near a Muhuti tree, which it soon outgrows and completely subdues.
} 
friend, 'Get up and go home!' The Mugumo then answered harshly for it had now established itself , 'I won't go! Did you not give me this house? And moreover, don't you know that if I were to seize you I would wind myself about you, and you would be unable to wriggle yourself free?' After a little [sic] the Muhuti was mastered by the Mugumo and withered, and the place came to belong to the Mugumo instead of the Muhuti. ${ }^{65}$

The meaning of the above story and its moral appeal to reason are rather obvious. The Kikuyu felt betrayed by the British who had gradually entrenched their position in Kenya through the strength of land laws designed for this express end. Even when the Carter land commission in the early 1930s seemed sympathetic to the plight of the Africans, it was felt that African still did not get the exact or proper compensation of the full extent of their original land that had been alienated. The Mumenyereri letter writer, earlier cited above, complained that "people who were given land were getting about 10 acres of land for one clan instead of the clan's original land ...taken, about 2 or 3 miles in length." This was done so that people could be convinced that the commission had done justice. However, this writer was not so persuaded as he wrote further:

We were opposing these laws because we had no representative (today we have representatives in Councils). We shall never accept these laws until they are revised with our African representatives.

Since that time our people have been roaming about every place worried with difficulties like a person suffering from T.B. They are the people who worked for Europeans very hard. They are feeling like a person who has been robbed of all his clothes. The Europeans cultivate their land while they have no lands of shelter.

These people are now at Olenguruone and many thousands are ex-squatters who have been evicted from farms. This trouble was caused by Lord Delamere to whom these people gave much wealth. ${ }^{66}$

The two examples of Kikuyu strong sense of grievance in the face of unjust British laws speak for themselves. Land for the African was the sole source of sustenance and for it to be swindled by people that were once welcomed and trusted was unthinkable. Chief Njega, the writer of the Muigwithania article, likened land to a woman from whom the Kikuyu had lived on since Ndemi

\footnotetext{
${ }^{65}$ Chief Njega, "The Tale of the Muhuti Tree and the Mugumo," Muigwithania 1 (April, 1929).

${ }^{66}$ Chief Koinange, "Senior Chief Koinange Revealed his Agreement with Europeans," Mumenyereri, $12^{\text {th }}$ July 1948 , KNA: MAA/8/106.
} 
na Mathathi (from time immemorial). Therefore, to lose it to calculating foreigners that they had deemed worthy friends was an unspeakable affront.

Besides the above outline of land laws and the associated labor legal framework manipulated through taxation, revenue collection as a state-building device needs special mention. Taxation was an important component of what was, in effect, a fiscal imperial conquest state. From the onset of active administration of acquired spheres of influence and protectorates, there was an emphasis, from London, of a policy of colonial economic viability and selfsufficiency. The need to collect sufficient revenue to pay for local administration was one of the greatest challenges of colonial rule in Africa especially. ${ }^{67}$ Since governing an empire was costly, as its boundaries expanded, British bueaucracts encouraged their counterparts in colonial capitals to find ways of paying their local expenses without help from British Treasury. ${ }^{68}$ As a result, by the early twentieth century, the bulk of imperial expenditure was funded by revenue raised in the colonies rather than in the metropole. ${ }^{69}$ Part of the East Africa Protectorate (EAP) that later becomes colonial Kenya is a great example of this.

Revenue collection, in light of growing administrative expenditure in the EAP, was a constant source of pecuniary embarrassment for imperial agents running the region on behalf of the British Crown. This was particularly more so considering that, although the British taxpayer had underwritten the construction of the Uganda Railway, the region had been able to pay its way a decade later. ${ }^{70}$ Before 1912, the EAP had depended on annual grants-in-aid. In what highlights the financial tentacles milking African imperial subjects for economic and political life, the colonial state survived, especially between 1908 and 1913, from export revenue built on African peasant production..$^{71}$ The hut and poll taxes instituted by the colonial authorities were economic devices employed to encourage commodity production from African households. Indeed, this economic model only served to effectively undwerwrite and subsidize European settlement. $^{72}$

\footnotetext{
${ }^{67}$ Leigh A. Gardner, Taxing Colonial Africa: The Political Economy of British Imperialism (Oxford: Oxford University Press, 2012), 4.

68 Ibid., 3.

69 Ibid.

${ }^{70}$ Maxon, Struggle for Kenya, 29.

71 Ibid., 30-36 and 135.

72 Ibid., 30.
} 
Moreover, in the wake of the First World War, the African sector of the colonial economy suffered a major setback. At the same time, the EAP was saddled with a portion of the imperial war debt contributing to the region being engulfed in a serious financial crisis in 1919. Yet, the protectorate was badly in need of development finance to extend the communications and railway network during this same period. As if it was not enough that African land and labor, poll and hut taxes had shored up this imperial project at its most crucial statge, colonial officials determined that the way out of this central postwar economic reality was the African cash cow. It was decided that the alternative for raising additional revenue would be realized by placing additional burdens most heavily on the African population and least heavily on European settlers. In effect, once again the African population was underwriting European settlement. Pressed by the seriousness of the revenue situation, and against the wisdom of doing so as well as without London's approval, colonial administrators' decision to raise the rate of hut and poll taxes was made in November 1919. Of course, this was facilitated by the preparation of a policy and legal framework to increase the hut and poll tax rate. As in the past, this was backed up by the firmly held and equally preposterous tenet that this increase would awaken the African, especially ablebodied males, from idleness and subsequent drunkenness and viciousness. After all, it was believed, the Africans "were rich." This as Maxon points out, demonstrated how utterly ignorant the colonial administration was of the economic and social systems of the people over whom they were establishing the imperial architecture of policies and laws. ${ }^{73}$

Apart from policies affecting African land, labor and financial resources, Maxon highlights the importance of another colonial architectural component -viz. the Registration Ordinance. ${ }^{74}$ It was a legal provision that ensured consistent supply of African labor. Approval was obtained within a year of Governor Belfield's dispatch request to London at the end of 1914. ${ }^{75}$ To the legal loss of land and independent individual or group decision-making and direction of labor, was now added the restriction of the free movement of African. This further illustrates control and curtailment of free movement, and therefore, an almost absolute loss of individual and group agency.

\footnotetext{
${ }^{73}$ Ibid., 130-137.

${ }_{74}$ Ibid 85 \& 86.

75 Belfield to Bonar Law, "Native Registration Ordinance, 1915: Statement of Objects and Reasons," $10^{\text {th }}$ June 1915, BNA: CO 533/154.
} 
This law entailed the carrying of identification papers and enactment of pass laws for African males over the age of sixteen. They carried details such as the carrier's name and other identifiers as well as a record of individual labor history. It was a highly effective method of restricting desertion from employment by Africans and assured adequate and consistent labor supply. It is important to emphasize the manner in which it curtailed African agency. It meant that Africans as individuals and groups could not author their own lives, let alone determine their day-to-day activities.

Not only had African societies lost their individual and collective human agency to determine their respective destinies but also their ownership of labor especially with regard to its disposal. Ngugi wa Thiong'o captured this loss of agency when he wrote that, once "the land is taken from away from its owner, and the owner is turned into a worker on the same land." Thus he had no control of his natural and human resources. ${ }^{76}$ Moreover, "the colonial subject has no say over the colonial state; in effect, while he produced, he had no say over the disposal of the final product. The state, therefore, had power over every aspect of his being. ${ }^{77}$

Whereas the Kenyan African had been his own ruler-subject, he was now a subject of a distant but absolute imperial authority. ${ }^{78}$ An amendment of this law in the form of the Masters and Servants Ordinance in 1916 made desertion and other employee offenses cognizable to police who could make arrests without warrants. ${ }^{79}$ Norman Leys notes: “...The fact has to be recorded that the Registration Ordinance has been amended so that now an employer has to take a summons costing half-a-crown in order to prosecute an employee for leaving work without permission, instead of, as formerly, merely sending the particulars to the police, who then conducted the case for him. ... Offense of leaving work without permission is still punishable by a fine of 100 s., equal to six or seven months' wages, or by two months' imprisonment." 80

What is even more interesting is that Leys relates an incident concerning labor, which embodies the general experience as a result of the alienation of African labor. He recounts the fate of a young Bukusu laborer that demonstrates the manner in which Africans were looked

\footnotetext{
${ }^{76}$ Ngugi wa Thiong'o, Something Torn and New: An African Renaissance," (New York: Basic Civitas Books, 2009$), 6$.

77 Ibid.

78 Ibid.

${ }^{79}$ Maxon, Struggle for Kenya, 92.

${ }^{80}$ Leys, Kenya, 12 \&13.
} 
down upon as chattels existing solely to labor for settler profit. Refusing to fill the place most Africans had been thrust into (read, provision of wage labor) a Bukusu boy, a laborer, only referred to as "the Kitosh," fled from his employment after working for eighteen months. When he was apprehended he was fatally flogged. ${ }^{81}$ It is such individual stories and collective narratives of colonial suffering that are rather overlooked by analysis that subsumes them under headings and summary titles such as "issues" and "grievances" leading to African resistance and political consciousness that culminated in the Mau Mau struggle in the 1950s.

Yet another example of colonial architecture favoring white supremacy in colonial Kenya was the settler sense of political entitlement, which paid off when it was approved in $1918 .^{82}$ From this time on, concessions were made by Nairobi and London embracing the idea of elective settler representation as unofficial members in the Legislative Council. The granting of franchise as Bottomley correctly surmised was inspired by an even more ambitious plan. He wrote in 1918, “The settlers are largely from South Africa ...who find themselves cramped by the limitations of administration in a Black Man's country. They have been anxious in the past not only to obtain self-government, or as a first step, a system of representative government which would lead at an early stage to the grant of responsible government ...to secure decisions in such matters as land and labour which would benefit their own interests ...irrespective of the claims of the native population." 83

Not only were Africans now physically shut out from fertile white highlands through exclusivist colonial policy of "color bar"; crammed in flooding reserves; their movement restricted by pass and registration laws; bombarded by numerous taxes; but also ushered into a political space where they enjoyed no privileges or any recognition whatsoever. As a result, African political consciousness burgeoned such that by early 1922, African workers in Nairobi were able to express growing dissatisfaction with the status quo. In an event representing the beginning of a long political struggle around this time regarding the release of Harry Thuku, clamor for his release from what is present day Central Police Station was met with force leading

\footnotetext{
81 Ibid., $178-182$.

82 This pay off was not, however, not implemented until it after it was legislated in 1919 allowing the first elections to take place in 1920. It is significant because it forms it is an important political and legal ingredient in developing Kenya as a white man's land. More specifically, in marks the beginning of active ascendancy of white settler interest in colonial Kenya now that they could make their voice represented and heard in the legislative council. ${ }^{83}$ Bottomley memo of $3^{\text {rd }}$ July 1918, BNA: CO 533/193.
} 
to the massacre of at least 100 demonstrators including their impromptu leader, Mary Muthoni Nyanjiru. Numerous others were injured or maimed among them Nicholas Kariuki Njuguna, the present author's grandfather. ${ }^{84}$

All the while, settlers had unfettered access to colonial state institutions and preferential land, labor, registration and taxation policies to the detriment of Africans in Kenya. In equal proportion, if not more, were the unspoken and undocumented everyday experiences and anxieties of ordinary Africans at the dawn of British colonialism. How white racial supremacy was institutionalized and legitimized; how it was countered by African constitutional African resistance degenerating to Mau Mau warfare in the 1950s; how the colonial order was revised, subsequently; and how independence was ultimately granted ushering a period revealing sediments of these foundational influences, is treated in a more details in the next two chapters.

\footnotetext{
${ }^{84} \mathrm{He}$ worked at the prestigious and, then, a whites-only, Norfolk Hotel, a colonial establishment from where radical settler types had joined in the ensuing melee firing shorts into the mass of protesters. As a result of a gunshot to one of his legs, he had to have it amputated and would have to use one for the rest of his life. In some small measure, this study has been partially inspired by this experience of colonialism so close to home.
} 


\section{Chapter III - Colonial Rupture: African Experiential Anxiety of Transformation in Time, Space and Place, 1900-1951}

Preamble: When a morsel of bean had fallen to the ground ...we had split it amongst ourselves. But a while later, when Cain was asked, "Where is your brother Abel?" he replied, "I am not my brother's keeper."

Paraphrased from Ngugi Thiong'o, Petals of Blood and Genesis 4:9 


\section{Introduction}

British imperialism created an adverse colonial space and a complex modernity. For the most part, this was the result of various legal strictures and related policy and institutional inventions to effect imperial domination. For a long time, the finer details of the harsh experiences and psychological anxieties of Africans inhabiting this imperial legal, policy and attitudinal architecture, have been ignored. African responses to imperialism have been generally discussed under sweeping concepts such as "nationalism" and "resistance." Wars of liberation such as Mau Mau, especially in the colonial era, were deliberately misconstrued and explained away. Since, then there have been attempts made by nationalist historians to debunk the colonial interpretation of Mau Mau as a backward and atavistic movement members of whom were said to be "childlike" and, therefore, unable to adjust to the demands of progress and modernity.

There is need, however, to further examine the subliminal emotional and psychological springs of this expression of discontent through war. Colonial views and explanations of the events of the difficult decade of the 1950s, beamed around the world, not only continue to distort hindsight, but also act as an overbearing historiographical anomaly that needs critical attention. In making the case for the conservation of colonial official records of Kenya in general, and specifically, those of the Emergency period, M.P.K. Sorrenson lamented in 1962 that "it would be a great pity if, because of careless or deliberate destruction of the records, Mr.Corfield was ...left as the sole historical judge of this important period in Kenya's history."1

Sorrenson recognized the importance of historical records that, by the early 1960s, were still scattered throughout the country. Yet, for example, "some important files relating to European settlement around Nairobi (some of the material used by the Carter Commission, ...which appeared to ...contain evidence" that "would justify a re-interpretation of that august body's findings)" were in jeopardy. ${ }^{2}$ Such historical records, bearing firsthand accounts of individuals, clans, communities and ethnic groups that fully trusted the execution of justice with regard to the loss of land by, for instance, the Carter and Hugh Dow commissions, contained distilled and checkered experiences of grievous loss. These narratives of critical African

\footnotetext{
${ }^{1}$ M.P.K. Sorrenson, “A Comment on the Official Records of Kenya," $21^{\text {st }}$ March 1962, KNA: MSS/115/7/36.
}

2 Ibid. 
discontent presented to these dubious colonial commissions of inquiry were testaments to monstrous, embarrassing, undignified deprivations and depredations that Africans endured. The submissions made by various communities, groups and individuals to the Carter and Dow commissions present an opportunity, and evidence, for retrospective examination through which African experiences of land loss and alienation of labor, among other crude and humiliating infractions, can be used to foreground the outbreak of the Mau Mau war. Very little or nothing has been written about the African submissions to the Carter commission so far.

It is also not surprising that there has been a new "discovery" of sensitive government files of the Mau Mau era that, for decades, remained concealed in a secret archive deep in the Buckinghamshire countryside. This shrouding in mystery of the systematic deprivation and depredation of colonial subjects is not a coincidence. It would seem that the colonial official who told Sorrenson "that some Mau Mau records" would "not be made available to the public, not even after fifty years," was not bluffing. ${ }^{3}$ It is, therefore, difficult to reconstruct the oppressive colonial environment and the severity, depth and breadth of African psychological anguish due to this dearth of information. Furthermore, there is a resounding paucity of self-documentation of narratives of suffering by African colonial subjects in Kenya. ${ }^{4}$ Like E.P Thompson's "laboring poor," ordinary farm and factory workers and dispossessed peasants in colonial Kenya "did not leave ...workhouses stashed with documents for historians to work over...."5

As such, the everyday history and experience of ordinary people, before and after independence, has remained invisible and outside the purview of intellectual analyses. The historian has to contend, and be content, working with "archives of the gentry or aristocracy," which in this case means British colonial "archives of oppression" that do not document the view

\footnotetext{
${ }^{3} \mathrm{Ibid}$. Also see "Sins of Colonialists Lay Concealed for Decades in Secret Archive," The Guardian, $18^{\text {th }}$ April 2012 and David M. Anderson, "Mau Mau in the High Court and the 'Lost' British Empire Archives: Colonial Conspiracy or Bureaucratic Bungle?" The Journal of Imperial and Commonwealth History 39 (2011): 699-716.

${ }^{4}$ To creatively circumvent this particular obstacle, I have attempted, in this chapter, to travel back in time and peer into or step inside the African psychology of oppression, experiential anxiety and mentalité of struggle by mining the existing and/or common Kikuyu vocabulary that would have been used to communicate this range of emotional frustration and subsequent re/action. Some of the words relied upon include "uriru" (catastrophe); "nduikaniro" (breaking-point); "mucaayo" (groaning or moaning); "nyarira" (put to shame) and related derivatives of the word such as "nyamara" (to suffer, be in distress and/or poverty, destitute), "nyamaria" (to cause poverty and destitution); "nyarara" (make a mock of, to hate and look down upon) and "nyararia" (to put to shame and to hate or scorn); and "njangiri" (fugitive, vagrant bandit) to mention but a few.

${ }^{5}$ Edward P. Thompson, Customs in Common (Pontypool: The Merlin Press, 1991), 17.
} 
of the majority of the population. ${ }^{6}$ This can be a particularly wearing and uphill task especially considering the nagging and haunting awareness that more incriminating and sensitive "archives of oppression," were systematically destroyed by burning if not "forever" hidden, and who knows-what-else.

This paucity of evidence is a great stumbling block to the endeavor of reconstructing the imperial production of the African psychology of grievance, scrutinizing the experiential anxiety and, quite naturally, the legacy or resultant mentalité of struggle. This is even more daunting a task considering the passage of time. It is difficult to reconstruct and, therefore, reconstitute, to an appreciable measure, accuracy and acuity, the intensity of African emotions, sense of loss and suffering borne of systematic deprivation and shockingly brutal exploitation attendant to the British colonial enterprise in Kenya, or elsewhere for that matter, after the fact and after so many years. Indeed, it is difficult, as it is, for empathetic, perceptive and probing historians to peer and enter the everyday experiences of the present. It is doubly so for historians to truly step inside a people's experiential anxieties when they are far removed in time; and when, what one has are only a few surviving entreaties and petitions to imperial authorities for redress.

Nevertheless, this chapter is a singular effort exploring the African psychology of oppression. The previous chapter already offers a broad legal, policy and attitudinal sketch of assumed racial superiority, and hierarchy of priority in the collective human enterprise of “civilization" and project of modernity. This chapter, despite such hurdles and obstacles outlined above, attempts to reconstruct and capture the resultant shrunken colonial cosmos of dispossessed Africans encroached upon and circumscribed, as it was, by the broad architecture of limiting legal, policy and racial strictures. It argues that Britain's violent rampage and ruthless assault upon African societies determined the nature of social existence and reality and, by extension, the little understood or appreciated boundaries of individual biographies and communal narratives of oppression. ${ }^{7}$

It does this by examining and highlighting some of their individual and group experiences, which inspired anti-colonial movements that prefigured the Mau Mau war. It

\footnotetext{
${ }^{6}$ Ibid. Also see Carlo Ginzburg, The Cheese and the Worms: The Cosmos of a Sixteenth-Century Miller (Baltimore: Johns Hopkins University Press, 1992), xxi.

${ }^{7}$ Hussein Abdilahi Bulhan, Frantz Fanon and the Psychology of Oppression (New York: Plenum Press, 1985$), 37$.
} 
scrutinizes the everyday realities and implications of the colonial architecture. It, therefore, paints, with as fine strokes as possible, the legal production or social construction of illegality as seen, felt and experienced from below. In so doing, it endeavors to present and analyze accounts of experiential anguish and psychological anxiety attendant to the imperial exploitation of the weak by the more powerful; the plunder of the poorly equipped by the better equipped; and the unjust and illegitimate rule of the less organized African majority by the more organized minority. In short, it is an attempt to catalogue the impact of a racially hierarchical colonial capitalism that was tantamount to the imposition of imperial will and greed on African societies. Herein, one will find an account of a hitherto unexhausted Kenyan colonial history in which the wealth and development of Britain depended on the near, if not utter, ruin and underdevelopment of African societies. ${ }^{8}$

The chapter opens with a focus on the mundane everyday experiences of ordinary Africans who inhabited the colonial edifice that acutely curtailed African agency, self-mastery, individual and communal rights and freedoms. This is done to demonstrate the physical anguish and deeply felt psychological anxiety occasioned by the newly created rural and urban colonial spaces in Kenya between 1900 and the early 1950s. ${ }^{9}$ A few brutal incidences of personal violence meted upon Africans who were already institutionally subjected to inhuman situations are discussed in outline. This is followed by an outline of legal restraints and constraints placed upon African resources and livelihoods as well as their very physical bodies in that regard the impacts of which is extensively discussed. Some of these legal and policy measures, resulting to

\footnotetext{
8 Ibid., 38-39.

${ }^{9}$ Here it is important to note that little attempt, especially in this chapter, has been made to encase, as it were, the rendition of these narratives of African experience and discontent in neat and antiseptic chronological and mutually exclusive categories. The present writer is aware of this acutely and only as an author can be and proffers his apologies if the reader finds her/himself oscillating between various dates and time periods. At the same time, there is need to flag the infallible point of fact that human experiences, whatever they may be, cannot be contained in tidy time brackets. Indeed, the task and vocation of history-writing would be banal and unchallenging if it chiefly consisted in the stuffing of themes and subjects into rigid time periods. While it can be traced back to a certain point in time, the onset of imperial catastrophe, the psychology of oppression flows in one seamless time continuum. Whatever little attempt made herein in this regard is to save the reader whatever confusion that might arise as $\mathrm{s} /$ he traces the march of the bitter experience of the vagaries of British imperialism as it reproduces, multiplies and repeats itself copiously in the course of time, colonial and, so-called, "postcolonial." Readers will, therefore, find this to be a time-indivisible narrative of loss of life-sustaining African land as acute, and felt, now as it was 100 years ago; and the humiliating and cheapening misappropriation of labor, inhumane now, as it was then. In other words, consider this to be a small authorial revolt against the linear conception of time that can lead to the sequestration of an otherwise singular human experience.
} 
the grievous curtailment of pre-European African life, are enacted in the early years of colonialism. Nevertheless, the world wars and the Second World War in particular, resulted in even greater policy and legal measures that affected the alignment between Africans and agricultural production and, hence their relationship with, and access to, food. This chapter, therefore, details not only the impact of the early colonial depredations on African lives but also the sea change and hardships accompanying World War II.

Thirdly, I discuss the unjust actions of the colonial state with regard to the pivotal and allimportant issue of land loss and, thereby, immensely "punitive" assault on African land and human rights. It is suggested that this is the inauspicious threshold of contemporary African poverty and underdevelopment that is everywhere manifest today, in both urban and rural settings. In addition, I attempt to present a detailed analysis of how African societies were moved spatially, in time and place, causing literally "untold" chaos, anxiety and suffering. While their world lay in ashen ruins, with their security of reciprocal relationships sundered, the majority of people in African societies were incorporated to the new colonial order and modernity, not only as "third" class citizens, but as imperial subservient or servile subjects. They were also objectified, in the main, as agricultural labor or, at best, low-ranking bureaucratic clerks or coopted junior partners in the colonial enterprise. Thus, African societies were not only moved out of their pre-European relative cosset, but also denied their due place in the modern space and time. It is worth making the bold assertion here that, Mau Mau was not anti-modernity. As an embodiment of anti-colonialism it was, to a certain extent, revulsion to a modernity delimited by a racial hierarchy. While many Africans eagerly altered their way of life, they still found themselves second class citizens. This, no doubt, did more than cause a little rankle. More so because they were the ones making the greatest sacrifices for this project of modernity: their land, labor, taxes and peasant agricultural production (especially that of grains before the First World War).

This therefore, is a discussion of the monumental and deeply felt loss of dwelling spaces, homes, entire villages and loss of everyday sustenance and source of subsistence and, with it, human agency and self-mastery to chart individual, communal and group destiny. It foregrounds a brief examination of how the African pre-European world is ruptured and the unravelling of the 
social fabric and mutual networks of social support. Also discussed herein are the challenges and disabilities attendant to the process of urbanization in as far as it affected Africans.

Towards the end of the chapter, I turn my attention to inaccurate, biased explanations and analyses of narratives of African discontent. Also included in this discussion is a more proximate analysis of the same as related by the Kenyan novelist Ngugi wa Thiong'o who is one of the few of the generation that experienced and witnessed colonial hardships firsthand. The dismemberment of society and socioeconomic hardships occasioned by British imperialism is a theme that has preoccupied Thiong'o in his work. The subsequent section is a proposition: that there is need for a retrospective psychological and analytical revisit in a bid to better understand African narratives of discontent, how they produced the Mau Mau war and the generic mentalité of struggle that was especially pervasive and intense in the 1950s and, thereafter, the shunting and betrayal, of popular expectations at independence and after. Part of this proposal is the ultimate objective of deconstructing or debunking the propaganda dressed-up as critical "professional" psychiatric examination of Mau Mau dissent by Frank Derek Corfield and Dr. John Colin Carothers' colonial pseudopsychology. ${ }^{10}$

Indeed, I argue that to fully appreciate the validity of the armed Mau Mau freedom struggle and the generic mentalité of oppression, this period of Kenyan history (1900-1950) needs to employ cutting edge $21^{\text {st }}$ Century perspectives in the discipline of psychology. I refer to at least two such new psychological analyses and approaches. I close with a case study illustrating the psychology of oppression as a suggestion of how such new perspectives in the discipline figure or apply in shedding the more light on African narratives of languishment as it related to their loss of land. This brief discussion also demonstrates that the mentalite of struggle did not only imbue Mau Mau forest fighters or only a small section of the Kikuyu. This last section also acts as a bridge to a more extensive account and assessment of more widespread ' 52 Mau Mau minds on Kenya's destiny in the next.

\section{Colonial Brutality, Impunity and Lack of Legal Redress}

A good example of individual anguish, to begin this examination, is the Luhya man already mentioned in the previous chapter. The story illustrates the stricture and severity of labor

\footnotetext{
${ }^{10}$ Frank Derek Corfield, The Origins and Growth of Mau Mau, Sessional Paper No. 5 (Nairobi: Government Printer, 1959-60) and John C. Carothers, The Psychology of Mau Mau (Nairobi: Government Printer, 1954).
} 
and registration policy legislations accompanied by a condescending colonial-settler attitude of racial superiority and paternalism. This young worker's rather brutal and fatal experience is important as an example of the ill-treatment of full grown men and women who were looked down upon by their white employees as children. No doubt, such incidences of flogging, or worse, were reenacted in numerous other white-owned settler estates in the country. The thirtyyear old man was accused of riding his white boss's mare to the railway station 17 miles away where he had been sent to run an errand. The white big man, a considerable land owner in the colony, was displeased by this action as the mare was in foal. "Who gave you permission to ride the mare?" asked the master. The young man, finding his master's fury inexplicable by anything he had done, retorted that he had not stolen anything, which his master found impudent. Piqued by his worker's "insolence," the master got hold of the Luhya man, pushing him into a building where he proceeded to flog him with a lash made of double ox-hide. ${ }^{11}$

The beating continued for about fifteen wearisome minutes after which the tired big man asked one of his other employees to finish the job. As this employee was half-hearted about this odd assignment, the master asked another employee to assist with the gruesome task. He too was found wanting and so a third flogger was required. By this time the victim was exhausted and soon fainted. To the white farmer, he was simply playing possum and so he "flung some buckets of water over Kitosh, who then revived." At this point, the master ordered him to be tied up in the store en route to which he was kicked when he fell. "He was tied up with his hands tied behind his back and his legs tired to a stick." After having his dinner, the boss came to check on Kitosh and found that his laborer friends had untied him to ease his pain and so he tied him up again "but tighter" this time around. Visiting Kitosh later that night, the African kitchen staff gave him some water to drink. Kitosh told him that he was suffering and was in so much pain such that he was willing to take his own life with a knife if he had one. He did not have to take his own life because he would soon die at four in the morning. When a medical doctor was called to examine the body, he said that the well-built, and therefore, healthy man, had died as a result

\footnotetext{
${ }^{11}$ Norman Leys, Kenya (London: The Hogarth Press, 1926), 178-179. Leys lived in the colony until 1912 and must have followed the unfolding court case in the media with interest and weighed his opinion against the arising debate in the court of public opinion.
} 
of injuries received in the flogging and kicking. Even if Kitosh had survived, the doctor noted, his fundament would have become gangrenous. ${ }^{12}$ This punishment happened in 1923.

Another case of the total disregard and abuse of African human rights that gained notoriety and drew a lot of controversy was that involved a large land owner, Galbraith Cole, a dozen years before, in 1911. Believing himself to be a victim of stock theft from Africans, Cole was riding in his vast estate armed with a rifle when he "caught sight of a native, some distance away, and hailed him."13 At this point he did not know whether he was one of his own employees or a stranger, and therefore, an intruder into his estate and a potential thief. Then the African bolted. As the European axiom in colonial Kenya was if an African runs away, he must be guilty, Cole did not hesitate to mete out instant justice by opening fire on the man, hitting him the second time. He then "rode up to where he lay and found him shot through the stomach, from which the bowels were protruding." 14 He then searched the general area and found a dead halfskinned and cut up sheep that he thought was his and proceeded back home. Cole took no further steps with regard to this "normal" incidence.

Indeed, it was not until friends of the murdered man found his body and reported the matter to the district officer that the matter came to light. Galbraith Cole "admitted quite frankly in response to" police inquiry of the facts and was soon brought to trial for murder. ${ }^{15}$ In his defense he argued that he had experienced theft of his sheep and referred to the recovered remains of the half-slaughtered one he had found. Villagers denied having stolen the sheep and it was clear that Cole had not established if indeed, the slaughtered sheep was one of his. Cole had a huge estate and it is quite probable that the sheep could have been the African's but he had, somehow, wandered onto Cole's farm. As far as the shooting was concerned, there was no doubt that he had fired to kill with "justifiable" impunity. However, he was unanimously acquitted by the jury of his peers within a week of the beginning of the trial on $31^{\text {st }}$ May 1911 in spite of the fact that it could have, at least, have found him guilty of manslaughter. But colonial Kenya was

\footnotetext{
${ }^{12}$ Leys, Kenya, 178-179.

${ }^{13}$ Ibid., 176.

${ }^{14}$ Ibid. This is an account of the event according to Leys a version that could be disputed or redacted. The circumstances in which the shooting occurred depend on which side of the arising controversy one was. The bare facts of the matter is that an African had trespassed into Cole's farm and was in the process of slaughtering what the latter believed was one of his sheep. There is no way of approximating the truth of the incidence over a hundred years later than when it happened.

${ }^{15}$ Leys, Kenya, 176.
} 
white man's country and, consequently, a place where the legal architecture served settler interests first and foremost with the African relegated to a distant third class citizen.

What is more is that, confined within colonial legal boundaries and policy restrictions and requirements with regard to land ownership, physical movement, traditional leisure activities such as beer-drinking and dances, socio-economic activities like hunting of game for meat or sport and disposal of labor, these two examples were not isolated. They are a microcosm of experiences of everyday colonial oppression that were played out in hidden spaces of suffering and public sites of collective humiliation; the systematic negation and invalidation of the African as a human being or human enough yet, save through his/her "civilizing education;" and alienation and deprivation, defined and underscored, by unequal power relations between, on the one hand, superior government agents and settlers and Africans, on the other. Besides land and labor laws earlier discussed, Africans had to deal with legislations and policies that intruded into all aspects of their lives affecting their very being and identity. There are few things in their previous traditional way of being, ranging from land tenure, disposal of their labor, social structure, organization and hierarchy, and spending of leisure time through beer-drinking and dance that were left untouched by colonial legal innovations that were invented to suit specific circumstances or meet certain needs.

\section{Legall Restraints on African Resources and Livelihoods: Food and Livestock} Indeed, African lives were circumscribed and restricted by all manner of conceivable orders, rules and successive ordinances governing various aspects of human life such the Cattle Cleansing Order (No. 32); Native Authority Ordinance; Native Liquor Ordinance; Sale and Purchase Slaughter Stock Ordinance; Game Ordinances; Land and Water Preservation Ordinances (1929 and 1943); Hide and Skin Trade Ordinance (1948); Native Foodstuffs Ordinance; Forest Ordinances; Fish Protection Ordinance (1939) amongst other innumerable legal productions, most of which were fraudulent. These legal strictures and the attendant attitudes are what then defined African experiences from the inception, or more aptly, the invention of colonialism in Kenya while at the same time engendering white privilege and supremacy in the fledgling political economy. While the key legal inventions were calculated to secure African land and labor, others, such as those that affected African leisure, serviced these, whereas others yet were aimed at the control and management of natural resources such as 
forests, water and wildlife. They were, therefore, avenues for the realization of European "civilization," which was itself a product of the scientific method and ideas. These were in a direct collision course with the African cosmology, customs and ways of being.

As earlier noted, the Second World War exacerbated such legal strictures producing even more constraints, changes and hardships. As a result of the demands of World War II, there were new or miscellaneous legal innovations that addressed specific needs that it occasioned. There were others specific to the modernization project: that is, policy and legal strictures that were a prerequisite for the creation of a supportive infrastructure of an extensive railway network, roads and electric power installations. However, Africans caught up by this legal web, and the resultant colonial system of capital it produced, did not understand all this or draw any such distinctions. The bottom-line, as far as they were concerned, was that the world, as they once knew it, had shifted and/or was in the process of doing so leaving them worse off than they had been.

In its bid to create an "ordered" landscape and "better" organize and manage colonial space, the executive council expressed their support of the statement made by the member of agriculture and natural resources in 1948. This was "to the effect" that "Farm 12, Nyeri, would have to be closed for a considerable period on account of its eroded condition and that on account of its situation it would be desirable that part, or perhaps the whole, of this farm ...be declared as a National Park" especially since it formed a natural corridor regularly used by elephants between Mount Kenya and the Aberdares ${ }^{16}$ Further, the council observed, "for reasons of soil conservation it would be essential, if this farm was to be alienated" and, as a result, "a large proportion of the area ...closed." However, at the same time, these senior colonial administrators drew attention "to the existence of the problem created by the presence of Kibia and his brother and their families, and a note added to the effect that the Governor had examined in detail the question of their removal, but was not yet satisfied, as required by law, that adequate alternative accommodation was available ...."17 This case shows that the colonial authorities were not always ignorant of the important issue regarding the African right of access to land. In this particular instance, this was coupled by the right of access to a salt lick that was within the confines of the designated park that was to be fenced. The council resolved that every effort was

\footnotetext{
${ }^{16}$ Minutes of the meeting of Executive Council, 30 ${ }^{\text {th }}$ January 1948, BNA: FCO 141/5528.

17 Ibid.
} 
to be made to find adequate alternative accommodation for Kibia and his brother, Munyiri, and their families. ${ }^{18}$ Such regard was, however, the exception rather than the rule since similar grave issues concerning land were not always countenanced. More mundane land issues with respect to infrastructure facilitating the penetration of capital and other arising issues were not accorded serious attention.

Of such experiences, Africans could narrate many. Under the Native Foodstuffs Ordinance, for instance, Africans, as part of the Second World War effort and recovery after the war, were prohibited from the purchase and barter of maize, millet, and legumes for the purpose of resale. This law, enacted in the early 1940s, was later extended at a 1943 council meeting to other parts of the country, namely Nyanza, the Rift Valley and the Maasai reserve where the barter of foodstuff was prohibited save with the written permission of the district commissioner. ${ }^{19}$ Needless to say, the control of foodstuffs was an all-important preoccupation at the time for the logistical purpose of efficient execution of war in Europe and other Second World War theatres in Asia and elsewhere. The war effort had, however, occasioned serious shortages especially of maize, wheat flour and bread in the early 1940s squeezing Africans faced with socio-economic hardships even more. Yet, the leading settler-politician of the time, Major Ferdinand Cavendish-Bentinck, at a January 1943 meeting of the executive council, reported to the council that the Agricultural Production and Settlement Board had recommended that the price for maize be raised to Sh.12 a bag at the start of 1943 thus raising the African cost of living. 20

At the same meeting, a member of the council, Mr. R.E. Norton, informed it of a plan devised to stock up the wheat reserves by rationing wheat flour and bread consumed by Europeans and Indians as well as making restricted supplies available for Africans at selected shops thus making the situation even direr. As if this was not enough, there was to be daily rationing of posho (maize meail), which was originally set at two pounds (lbs.). but, which was now to be reduced to one and a half $\mathrm{lb}$. at the beginning of February. In response to food ration

\footnotetext{
18 Ibid., Minutes of the meeting of the Executive Council, $13^{\text {th }}$ February 1948, BNA: FCO 141/5528.

19 Ibid., Minutes of the Meetings of the Executive Council, $8^{\text {th }}$ January 1941 and $25^{\text {th }}$ March 1943, BNA: FCO $141 / 5528$.

${ }^{20}$ This was made clear at the meeting of the Executive Council of $19^{\text {th }}$ January 1943; see Executive Council Meeting Minutes, January to December 1943, BNA: FCO 141/5523.
} 
matters, the council charged Norton and the central wages board to examine the question of alternative foodstuffs, especially sugar and biltong, to take the place of the portion of the maize ration which could no longer be supplied. The proposed reduction in the ration of maize meal was to be given the widest publicity by broadcasting and in the press. ${ }^{21}$ A week later, the Central Wages Board agreed that from the $1^{\text {st }}$ February, the daily ration of maize for conscript labor was to be reduced from two lbs. to 1 and a half. A circular was to be issued containing a list of foodstuffs which could be substituted for maize meal. The council was to consider making it an offense to issue more than one and half lbs. of maize meal to native labor. ${ }^{22}$ It later emerged by the second half of that year that, in the Rift Valley, "many employers did not supplement with other rations the issue of $1 \frac{1}{2} 2 \mathrm{lbs}$. of posho daily." As a result, "a large number of voluntary labourers" were set to leave their employment there. ${ }^{23}$ If the colonial authorities were worried about the plight of the suffering occasioned by these war-measures and food shortage, they were indifferent about it because the worsening maize and wheat situation and then meat, was followed by even more administrative, legal and policy overreach.

Moreover, as early as $4^{\text {th }}$ February 1943 , the council ruled that "all possible maize" was to be "extracted from native areas" and motor vehicles stopped and searched; that a day to be appointed for a search operation led by the director of produce disposal but results of which were to "be the responsibility of the Commissioner of Police...." 24 The search was to take place on the appointed day throughout the colony simultaneously "in order to avoid the transfer of foodstuffs from one hiding place to another...." 25 Further aggravating the food needs of African workers on settler farms, the council noted that "apart from the ration which may be issued to squatters on the days on which they work, no other provision" was "to be made for them or their families who" were supposed to "rely on their own stock and other resources for food." ${ }^{26}$ But the food shortage leading to famine was unforgiving and experienced, not only by African farm hands in

\footnotetext{
${ }^{21} \mathrm{Ibid}$. It is important to also point out that Kenya also faced, in the first half of 1943, a severe food shortage leading to famine.

22 Executive Council Meeting Minutes, $28^{\text {th }}$ January 1943, BNA: FCO 141/5523.

${ }^{23}$ Executive Council Meeting Minutes, $26^{\text {th }}$ July 1943, BNA: FCO 141/5523.

${ }^{24}$ Executive Council Meeting Minutes, $4^{\text {th }}$ February 1943, BNA: FCO 141/5523.

25 Ibid.

26 Ibid.
} 
the settled white highlands, peasant households, urban workers and house servants, but also felt by their employers.

The arising food shortage situation was, without a doubt, dire throughout the 1940s and even after the cessation of World War II hostilities. The colonial state's intelligence reports throughout the 1940s detail African unrest as a result of food shortages triggered by, not only famine, but also a runaway rise in the cost of living. Basic household consumption goods such as sugar, salt, maize and beans were short or erratic in supply. The acute shortage of food, in 1943, prompted the colonial administration to reenact the Native Foodstuffs Ordinance to make people with foodstuffs sell farm produce especially in Embu and Machakos. ${ }^{27}$ The situation was said to be particularly bad in Tharaka, Machakos, Mukogodo and Nyeri. The Kamba of Kangundo, Matungulu and Iveti, which were the three most thickly populated locations in Machakos district, complained bitterly about their lack of food. ${ }^{28}$

The lack of food amongst people in Machakos was feared to be the cause of ill health in the district. Intelligence reports noted that the scarcity of food was beginning to produce ill effects on the population. A special survey made of some of the schools in the region, Miu and Masii, ascertained the extent ill of health that had resulted. In these two schools, particularly Miu, a large proportion of the pupils showed advanced emaciation, and mild malnutrition. ${ }^{29}$ In Nyeri, which would in a few years become one of the epicenters of the Mau Mau war and one of its most intense spots, Chief Nderi reported six deaths that he attributed to starvation. It is significant to note that senior intelligence officers who put out such reports together recognized that in these particular cases, fatalities were as a result of neglect of customary social duties by the neighbors, which played a large part. ${ }^{30}$

The situation was so bad that the Kenya Sisal Growers and the East African Production and Supply Council approached the government for assistance with regard to "the repatriation of labour consequent upon the food shortage and the re-recruitment of labour when the food supply position improved." 31 While to its credit, the council did not approve this request, the pressing

\footnotetext{
27 Intelligence Report, November 1943 \& September 1943, KNA: VQ/16/5.

28 Intelligence Report, April 1943, KNA: VQ/16/5.

${ }^{29}$ Intelligence Report, March 1940, KNA: VQ/16/5.

${ }^{30}$ Intelligence Report, July 1943, KNA: VQ/16/5.

${ }^{31}$ Executive Council Meeting Minutes, $18^{\text {th }}$ February 1943, BNA: FCO $141 / 5523$
} 
food situation resulted in the issuance in a new government law, the Defence (Restriction of Meals) Order, 1943, which frowned upon the wastage of food in restaurants. ${ }^{32}$ It is with a certain air of relief that the financial secretary reported to the executive council in June that year that cassava flour, which substituted maize meal, was being purchased and distributed by local native councils at "the price of 15 cents a pound or, in cases of destitution, free." 33 This apparent "success" of meeting bread and butter needs of Africans notwithstanding, they had, yet, to contend with colonial cunning to satisfy the ever rising demand of meat that was overlaid by quite plausible scientific reasons why Africans had to thin their big herds of cattle and other livestock.

While the executive council was busy trying to balance the staple food needs of the colony and logistical demands made upon it by the war, drought and famine it was, at the same time undertaking an incomparable task. In February 1943, the government undertook, and informed military authorities appropriately to supply, during the next six months, 4,000 head of cattle monthly, which was 1,000 less than was supplied at the time. The council was determined that, if possible, this monthly quota was to be increased to 5,000. ${ }^{34}$ At this same meeting that had struck upon the brilliant idea of colonial-wide food searches due to the dire situation, one of the settler council members, Lord Francis Scott, suggested "that the time had come for the apt of a Food Controller." ${ }^{35}$ The governor's deputy, who was presiding at the meeting, could not agree more. He "expressed the view that the appointment of one person who could devote his whole time to food supply and distribution problems" could "serve a useful purpose...." ${ }^{36}$ To underscore the gravity of the food situation, it is important to note that at a meeting in April, the council not only agreed to form a commission of inquiry into the food shortage but noted that provincial commissioners were to "be instructed to make special efforts to supply the monthly meat quotas from their provinces and to exceed them if possible." ${ }^{37}$ The council felt that

\footnotetext{
32 Executive Council Meeting Minutes, $8^{\text {th }}$ April 1943, BNA: FCO 141/5523. By this time there was famine in several parts of the colony.

${ }^{33}$ Executive Council Meeting Minutes, $3^{\text {rd }}$ June 1943, BNA: FCO 141/5523.

${ }^{34}$ Executive Council Meeting Minutes, $4^{\text {th }}$ February 1943, BNA: FCO 141/5523.

${ }^{35} \mathrm{Ibid}$.

${ }^{36} \mathrm{lbid}$.

${ }^{37}$ Executive Council Meeting Minutes, $3^{\text {rd }}$ April 1943, BNA: FCO 141/5523.
} 
additional supplies of cattle could be drawn from Nyanza Province, especially the Sotik area, and from squatters in the Uasin Gishu and Trans Nzoia districts.

If the disruption of the African economic and social fabric and, indeed, his whole cosmos, held together as it was by the significant role of wealth in cattle, had been spared by the introduction of a money economy, its total destruction was now assured. This was especially because four days after the issue of the first monthly quota, the meat supply figure was revised upwards to 10,000 head of cattle for both civil and military needs. ${ }^{38}$ What had made this ambitious figure possible was a prior consultation meeting between the Executive Council member charged with identifying alternative food sources, Norton, and the livestock controller who was also the director of veterinary services. What is more is that this kind of thing was not new. In 1939, in the name of the soil erosion, Dr. Pole-Evans in his "Report on a Visit to Kenya" published by the Government Printer had made the following recommendation:

If goats and sheep cannot be disposed of by purchasing them from the Natives and turning them into fertilizer or some other useful product, then only one practical course is open viz. - compulsory handing over of all goats and sheep to the Administration, and in place of them supplying the owners with ration cards over a period of five years; the establishment of food depots in the Locations, just as dispensaries are now established, where the natives can be supplied with their ration allow no remission of taxes but rather make the Natives seek work outside the reserves or within the reserves on the work of reclamation. The cattle problem can be dealt with in the same way. ${ }^{39}$

In the same report, Kikuyu petitioners quoted Colin Maher, a soil erosion expert, as having recommended "the elimination of three years or so, of all goats; the limitation of the number of cattle - present and future - by culling to accord with the true carrying capacity of the reserve."40

In view of the above, several observations can be made. One obvious deduction is the casual manner with which the very bedrock of the African traditional moral and political economy was disregarded in favor of the benefit of soil and environmental science, which were suspect, and/or misunderstood, European ideologies for those it was tailored. Secondly, this scientific benefit was not without the opportunistic caveat of undercutting and undermining the

\footnotetext{
${ }^{38}$ Executive Council Meeting Minutes, $8^{\text {th }}$ April 1943, BNA: FCO 141/5523.

${ }^{39}$ As cited in a memorandum from the Kenya Central Association to Lord Hailey, "Petitions \& Memorials: Kikuyu People," $15^{\text {th }}$ April 1940, BNA: CO 533/543/2.

${ }^{40}$ Kenya Central Association to Lord Hailey, "Petitions \& Memorials: Kikuyu People," $15^{\text {th }}$ April 1940, BNA: CO $533 / 543 / 2$.
} 
foundation of African life, which it was calculated to destabilize, but also designed to transmigrate the African in time, place and space in a process that was disorienting. Destocking or the culling of livestock was not only good science but a creative means of inducing African dependence by replacing self-reliance pillars that upheld traditional economy with ration cards and food depots. The overstocking problem was not only dealt with but hordes of African workers were also generated as they had to seek employment outside the reserve or inside it as transformation agents of soil science digging terraces or planting napier grass along river banks. Even the most progressive African, who had but only little doubt about the benefits of the scientific methods of soil erosion and destocking, felt the pinch associated with this transformation from the traditional economy to a modern colonial economy. It was difficult not to resist, if not against partial or wholesale implementation of these ideas, at least, the pace with which they were initiated.

The Kikuyu Central Association (KCA) as early as 1940 expressed concern that the effect of such policies was to lower the African standards of living. The members of the association felt that while the transformation that the population was undergoing was dynamic, the demand for a better standard of living was not, "accordingly standing still." African living conditions were at the same time, "exasperated by the series of harmful locust, "Army Worms" (Ngunga) shortage of rain and crop." ${ }^{41}$ In the memorandum to Lord Hailey, the KCA pointed out that "these problems" were "deeply felt in every household and by many Africans" and they felt "the weight of these changes of mode of life and" wondered "how and when...favourable change" would "take place." ${ }^{\text {" } 22}$ This memo was particularly critical of the fact that any expression of what Africans thought or wanted in this regard was labeled as agitation and their points seditious. Pressed by the demands of the Second World War, however, the colonial administration was oblivious to such concerns and pushed forward with their ambitious, but disastrous, requisition plans, which sowed the seed and watered the growing spirit of African dissent that bloomed and loomed across the geopolitical landscape with the outbreak of the Mau Mau war in the early 1950s.

\footnotetext{
${ }^{41} \mathrm{lbid}$.
}

42 Ibid. 
In order to meet the new impossible figure of 10,000 head of cattle conjured with the connivance of the executive council and the director of veterinary services, 3,150 head were to be raised from Nyanza; 500 raised from Nandi; 300 raised from Kamasia and East Suk; 880 raised from Central Province; 600 raised from squatters in Uasin Gishu and Trans Nzoia; 3000 raised from Maasai etc. a month. The council noted "that it was essential for these fresh quotas to be filled, and that, if necessary, requisitions ...be resorted to. ${ }^{" 43}$ This pressure on livelihoods continued following the war.

Having emerged out of the Second World War with the psychology of a victor but with economic circumstances more resembling those of a defeated country, Britain was literally bankrupt, and faced the prospect of unbridgeable balance-of-payments deficits for years to come. ${ }^{44}$ Indeed, in the first half of the 1950s, Britain still had to contend with various food rations ranging from bread, butter, meat, bacon and ham. Back in Kenya, destocking and agricultural measures were bolstered, in August 1946, by the Cattle Cleansing Order No. 32, which was related to the Fencing Order and Preservation Order. By this time, the steep cost of living in the colony was alarming and, therefore, a great cause of concern.

Thus in February 1948, when the executive council discussed this situation and proposed to increase the price of slaughter cattle, the financial secretary dissented that the price of meat be increased by four cents per $\mathrm{lb}$. and carried the day ${ }^{45}$ When the matter was revisited a week later, the Reverend Leonard J. Beecher, representing African interests, expressed concern "that consumers were seriously perturbed at the rise in the cost of living." ${ }^{46}$ It was suggested that "an investigation be made into the Price Control w/a view to seeing whether it would be possible to restrict the percentages of profit now in force." In the course of 1948, food prices continued to dominate council meetings with that of maize rising from Sh. 12 per bag in 1943 to Sh. 20; that of wheat was fixed at Sh. 32.75 for the top grade; and butter fixed at 2/30 per lb. wholesale for a period of three years, subject to revision downwards or upwards and not to exceed $7.5 \%$ in any year. It is instructive that at this time, the council was sensitive to the security ramifications of a runaway cost of living in the colony because this is when the Emergency Powers Bill was

\footnotetext{
${ }^{43}$ Executive Council Meeting Minutes, $8^{\text {th }}$ April 1943, BNA: FCO 141/5523.

${ }^{44}$ Correlli Barnett, "The Wasting of Britain's Marshall Aid," BBC History (2011).

${ }^{45}$ Executive Council Meeting Minutes, $13^{\text {th }}$ February 1948, BNA: FCO 141/5528.

${ }^{46}$ Executive Council Meeting Minutes, $20^{\text {th }}$ February 1948, BNA: FCO 141/5528.
} 
introduced to the LegCo "to make exceptional provision for the Protection of the Community in cases of Emergency."

This was at the meeting a week before the council advised approval of the publication of this bill. The council then resolved that the African anti-colonial movement, DYM, be declared an "unlawful society" alongside the Society of Jezu Kristo. ${ }^{48}$ A few months later in May, the Kipsigis Central Association "and an associated religion called the "Dini ya Mbojo"" were also declared unlawful societies dangerous to the good government of the Colony, under Sec 69 (2) (ii) of the Penal Code. ${ }^{49}$ This demonstrates that in preparing a legal framework to deal with a security emergency, the colonial administration recognized the adverse impact of the cumulative effect of their various legislations and policies. Even more crucial than the important cattle industry that was the backbone of African traditional economy was the land out of which Africans had been uprooted to pave way for the infrastructural network and financial grid that included power installations, forts and stockades, townships and trading centers, and road and railway networks. Combined, these were the hallmarks of modernization which did not come at a small cost to some sections of African society.

\section{The Cost of Modernization: Unjust State Requisition and Assault on African Land Rights}

The foregoing was not a new issue as specific groups of people were adversely affected by the incursion and imposition of modernization. As early as 1929, Joseph Kangethe, writing on behalf of a group of people, submitted a letter to the Kikuyu newspaper Muigwithania. Kangethe complained about the "width of roads in the country of black people." ${ }^{.50}$ He expressed the community's indignation on account of Limuru road, the construction of which had resulted in the uprooting of food by the public works department. The department had dug 147 feet wide yet, they argued, the governor and the local native council had assured them of 171/2 being required "from the middle of the road." 51 Further, in their consideration, this was a small matter compared to many other things that they had been made to suffer that were wrong from the

\footnotetext{
47 Ibid.

${ }^{48}$ Executive Council Meeting Minutes, $13^{\text {th }}$ February 1948, BNA: FCO 141/5528.

${ }^{49}$ Executive Council Meeting Minutes, $7^{\text {th }}$ May 1948, BNA: FCO 141/5528.

50 "The Width of Roads in the Country of Black People," Muigwithania wa Andu na Bururi wa Gikuyu," Vol. II, No. 1, June 1929, KNA: DC/MKS 10B/13/1.

51 Ibid.
} 
outset but were, nevertheless, carried out in surreptitiously or in an underhand manner. Such things, they said, caused the hearts or spirits of the Kikuyu people to be as though dead or without life. ${ }^{52}$ Put differently, government actions, with regard to laying out infrastructure, were not only unjust and unfair but also dehumanizing and undignifying.

Echoing Kangethe's attempt to capture the plight of the Africans, another Muiguithania contributor paraphrased Lamentations 5:1-10, a prayer of the oppressed asking God to remember the things that people were facing. This contributor, Muorianyoni, beseeched:

Look and see the insults with which we are insulted.

See our inheritance is given to strangers, and our houses made to belong to other races.

We have become orphans as though our fathers were dead....

...We buy our water with money, and our firewood is sold to us.

Those that pursue us are about our necks, we are weary and find no rest ...Servants are better than we....

We obtain our food with great difficulty and distress. ${ }^{53}$

For his part, Kangethe, concluded by confessing that unless a just and fair government addressed the issue the destruction wrought by the construction of the road in Limuru thus demonstrating good will towards Africans and especially future generations, any plan of action it had would be unacceptable.

Similarly, in 1928 residents of Kamaguta protested against the building of an electricity plant at the junction of the Maragua and the Tana River. In as far as they were concerned, the matter had been put paid to at a meeting of the local native council that met in Fort Hall at the beginning of 1928 in the presence of the DC. However, the issue was reopened again at the end of that year. Speaking on behalf of "raia" or peasants at a "baraza" held with the DC on $14^{\text {th }}$ December, Kimani wa Njuku, one of the common people, said that "there were over 10,693 people living ...on this land ..." and after all, when they had first discussed the matter in March, the people had informed the DC that "there was no place ...to hand over for the construction of

\footnotetext{
52 The original in translation reads: ...Maundu maingi maria twikagwo mataagiriire...ki-nguingui maria matumaga ngoro cia Agikuyu cikare taitari muoyo.

${ }^{53}$ Muorianyoni, Muigwithania, Vol. I, No. 4, August 1928. The sentence in italics is the only line added from the original verses. Otherwise, the rest of the words are the exact one used by the original writer, KNA: DC/MKS 10B/13/1.
} 
an electricity plant.” Wrapping up his short speech, Njuku posed, “...Now, from whence has the matter come up again?"54 The DC's response was that in Europe, electricity plants were placed "just wherever the Government" wished and if people were there, they were removed and given another place. Joel Kimunge, another peasant, stood up and said that the people who lived in this particular land could not be removed because they were exceedingly many. ${ }^{55}$

Morevover, Kimunge argued, the land was the only place left to the Kikuyu when the rest of the land passed to the European "chomba" (boss). ${ }^{56}$ The DC, nevertheless, pursued his case: "It is desired that you give it up because the Government requires ... a place in which to put up an electricity plant." Feeling this unrelenting pressure, another peasant farmer, Daudi Githanda, stood up and said that since old times, Kikuyu country was bounded by the Maasai and Kamba and, in colonial times their land from Thika to Maragwa, was in the hands of Europeans. Not even salt licks where Africans fed their livestock were left yet the colonial government was "back upon" them "for the little piece which" it had left them, which is where all the thousands of people gathered at the meeting lived with all their possessions. Why, what did the government want? What was it after? queried Githanda. He continued to say that the people expected such a government to be more understanding and sympathetic in view of the plight of thousands of people that would be affected. ${ }^{57}$ The DC was rigid in his position and said that the building of the electricity plant had been issued as an order and provided for by law. Githanda pressed the people's case exasperating the DC who threatened that if they continued to obstruct the construction of an electricity plant, he would prosecute and charge them in a court of law.

At this juncture, Naaman Njoroge stood up and said: "Bwana, we feel grieved at you because we are in the habit of settling matters together with you and why, therefore, do you bring the matter up again? You (yourself) informed us about this piece of land on $1^{\text {st }}$ March 1928 that a Company wanted it, and now you tell us it is the Government (who want it). This matter appears to us to resemble raiding, for at the time of a raid or war, if a man refuses to part with his cow, it is looted from him by force. And you now wish to loot this land by force, for we, the owners, do not wish to give it up, because in this place there live more than 10,693 people and moreover, all

\footnotetext{
${ }^{54}$ Muigwithania, Vol. I, No. 8, December 1928, KNA: DC/MKS 10B/13/1.

55 Ibid.

56 Ibid.

57 Ibid.
} 
our property is here." ${ }^{, 58}$ By this time, the DC was frothing at his mouth and hurling insults at the people who, hearing what he had to say, decided to disband muttering amongst themselves that this was not a matter of reason and justice but of robbery. ${ }^{59}$

Eventually, the government alienated the land and the electricity plant was constructed where previously stood 200 huts; 335 granaries; and 195 cattle pens belonging to an African community of slightly more than 10,000 people. ${ }^{60}$ More than a mere loss of property, it must have been an emotional displacement from a sentimental physical space and place at the onslaught of colonial modernity. That colonial authorities prioritized a power plant over a “timeless" people's way of life also means that the latter had been supplanted and, somewhat outmoded by modernity. In this sense, in addition to the spatial injustice was a more subtle level of "displacement": that of time evidenced in the clash of the African traditional and the British modern infrastructure. Detailing what this loss meant for the likes of peasants like Njuku, Kimonge, Githanda and Njoroge, the KCA memo noted that on the stretch of the river taken, there was a good ford, where the Kikuyu used to cross to trade with the Wakamba. Now they have to go 20 or 30 miles to another ford where their animals could cross.

Furthermore, since the taking over of the land, many Kikuyu have been arrested and fined heavily, (from 200 shillings upwards) presumably for trying to use the ford. ${ }^{61}$ Kenyatta complained that the valuable land was not willingly surrendered but taken over through coercion and the Kikuyu had, once again, been "deprived forever a further valuable area of fertile land essential for stock raising, grazing and agriculture, as well as a potential source of cheap water power." 62 No compensation or alternative land given in exchange. Furthermore, "the proposed electric light and power station" was "to be a private, dividend paying, undertaking, financed by the proprietors of the large Sisal Mills, and the current generated ...used for their own commercial enterprise." As such, "the power station" would "not be of any advantage to the Africans, whose forced submission" had "robbed them of the valuable land and water, for the

\footnotetext{
58 Ibid.

59 Ibid.

60 This was according to The Kikuyu Central Association memorandum, "Memorandum of the Kikuyu Central Association to the Secretary of State for the Colonies," February 1932, submitted in London by Jomo Kenyatta, BNA: CO 533/422/1.

61 Ibid.

62 Ibid.
} 
benefit of a purely commercial enterprise." The KCA desired to place on record their "most earnest protest against...being called upon by the Government to assist the commercial projects of non-African undertakings in Kenya, by surrendering to them any parcels of...land, large or small, to the lasting detriment of the people...." This consistent preferment of white settlers who had the advantage "of being able to influence the Government to bring pressure upon the Africans" was, more than anything else conceivable, "certain to embitter the relations between the Kikuyu peasants and white immigrants." ${ }^{.63}$

Moreover, the association felt, if the policy under which trading requirements of European concerns "operating for private profit" continued to "enjoy the active support of the Kenya Government, under the claim that their operations" constituted public interest, "then the supposed security of African tribes in their lands" could, "under such conditions, amount to little or nothing." ${ }^{\circ 4}$ The memo went on to note another similar case in which the Kikuyu of south Nyeri had narrowly escaped "another serious appropriation of land... at the hands of a Mauritius Sugar Corporation, or some such European company." ${ }^{\prime 65}$ Also mentioned was the fate of Lazaro Mundia of Mang'u whose land was part of an appropriation of a total of 6805 acres that were taken by the White Sisters from the Kikuyu. It notes further that, there was at the time, a total of 60,000 Kikuyu who had been dispossessed of their lands without compensation thus forcing them "to become wanderers -homeless and landless" who could be seen "...wandering or squatting all over Kenya. This oppression has disgorged the Kikuyu and many" had fled "to the neighbouring tribes, thus causing great loss to the Kikuyu Community." 66 The memo protested the fact that forests and grazing lands that had been part of Kikuyu property were now controlled by the Government Forest Department. Kikuyu who entered the forest to collect firewood were now "treated as trespassers and heavy fines...imposed." The grazing lands were also "almost entirely under control of the Forest Department, or European immigrants, and the Kikuyu" had "to pay very heavy grazing fees, and to accept very inequitable terms of lease, in order to maintain their herds. ${ }^{967}$ There were innumerable similar experiences of spatial injustice across

${ }^{63} \mathrm{Ibid}$.

${ }^{64} \mathrm{Ibid}$.

${ }^{65} \mathrm{Ibid}$.

${ }^{66} \mathrm{lbid}$.

67 lbid. 
the colony some of which will forever remain in the dark since they were "unimportant" to document or, simply, because it was the order of the day.

\section{Loss of Basic Subsistence and Homes: Evictees and Squatters}

Two more examples, similar to the distraught of homelessness visited upon Africans, merit special mention. These are the case of Tigoni evictees and Olenguruone squatters. The former's petitions to the Secretary of State (SofS) for the Colonies, Arthur Creech Jones, in 1947 and 1948, captured their anguish and frustrations: in their own words, they had been "forced to a state of penury." 68 They believed that they had, for years, been "subjected to a series of systematic hardships by the Government and ... White Settlers ... as a result of which as large a number as 22,000 Kikuyu Squatters" had been "forced to a state of penury and want of every description." ${ }^{69}$ Tigoni evictees railed against the introduction by the colonial government, in 1927, of the prohibition to own livestock except goats and sheep adding that even these were taken away from them with further rules of 1939 that whittled numbers down. These measures were made worse by the restriction of the area of land which they could occupy in 1945.

By this time, they further argued, Africans were legally disabled to cultivate more than one acre of land if they had one wife and two acres if they had more. In spite of these measures, they had continued to work on European farms although they felt that "their rights and privileges were whittled down and trampled upon." But the crisis came and the conditions were "made unbearable when the Rules were brought into force in 1945 whereby the ownership of even ...sheep was limited to 15 and that of the land to one or two acres .... This completely broke the hearts and the morale of" the petitioners who now realized the "hopelessness of their plight and organized destruction of their individual and community life."70 This agglomeration of calculated hardships, they felt, struck at the Africans' very existence as they were being pushed to the brink

\footnotetext{
${ }^{68}$ Kikuyu Highlands Ex-squatters Landowners to the Member of Parliament \& United Nations Organization through Honorable retired Arthur Creech Jones Secretary of State, $30^{\text {th }}$ January 1948, BNA: CO 533/543/6. This was a follow-up petition to an earlier one from the same group, the Squatters Association, to the Secretary of State for the Colonies dated $16^{\text {th }}$ July 1947, KNA: MSS/43/6.

${ }^{69}$ Squatters Association to the Secretary of State for the Colonies, $16^{\text {th }}$ July1947, KNA: MSS/43/6.

70 Ibid.
} 
of virtual extinction. "They could see with horror," they said, "their march to slavery and gradual elimination" as a community. ${ }^{71}$

Similarly, the men, women and children of Olenguruone felt that once they were dispossessed and their "original land taken way for white settlers," they were "forced to obey laws framed against" their "interests and detrimental to" their existence. ${ }^{72}$ Their families were breaking down as a result of some of measures like allocating families eight acres of land irrespective of the number of wives or children one had. Further, destocking policies and forced extensive grass-planting "reduced the area available for gardening food crops for their existence: "we are forbidden to grow the crop of our daily use and are forced to plant wheat which does not meet our immediate need," they lamented. Forty acres per family in their view was more of a fair deal. While they approved soil conservation methods, they deplored all other methods detrimental to their existence. ${ }^{73}$ The sum total of all their woes, Njoroge concluded, was the realization of the government's chief aim of making the "settlement a chief source of cheap labor for ...big farms of white settlers..." where they were forced to serve on "very low wages" of eight shillings per month.

In their letter to Creech Jones, Tigoni squatters in Limuru recounted how they were served with eviction notices by their erstwhile masters without even being afforded "an opportunity to harvest their crops of food and, worse still, to take away with them the grain they had already in their granaries. Thousand [sic] of men, women and children, the young and the old were displaced from their homes in most unhappy and distressing circumstances. They did not know and no one else cared to know... where" they could resettle and thus resume their lives. Consequently, they were wandering aimlessly "about the country with no homes to live in, no land to cultivate and no food to eat and no cattle to rear." 74 Attempts to right the injustices meted out by unfair contracts drawn by settlers had been thwarted by the government since 1946 . Tigoni squatters felt that they were being compelled to work whether they liked it or not by the

\footnotetext{
71 Ibid.

72 Undated cable from Ayub Njoroge in Nairobi to Jomo Kenyatta who was in London, KNA: MSS/43/11.

73 Ibid.

${ }^{74}$ Squatters Association to the Secretary of State for the Colonies, $16^{\text {th }}$ July 1947, KNA: MSS/43/6.
} 
force of circumstances created about them and over which they neither had any control nor possessed the freedom to negotiate.

A meeting held in Kiambu with government officials had ended with the arrest and imprisonment of nine of the Tigoni squattters, which was "a source of great annoyance and grief to the thousands" of petitioners. Just when they planned to march to protest outside Government House, they were, against their "wishes and inclination ...forced into ... waiting lorries in large numbers overloading the vehicles" and hauled off to Limuru. During this "freight," about a mile and a half from Limuru, one vehicle overturned as a result of which one man received fatal injuries and died and some 19 persons received serious injuries rendering them incapable to do any work. They found it particularly inhuman for police officers in escort not to attend to the suffering occasioned. They wrote, "Nothing of the kind was done." Injured evictees were left on the spot of the accident. This was an unfathomable callousness parallel of which was "difficult to find in the modern civilized world." 75

Ignored for half a year, the squatters upped the stakes and forwarded their pleas to the United Nations at the beginning of 1948. In this new appeal, they expressed their disbelief at the government's silence about the return of, as they put it, "their food and land" as justice demands. As it were, the government attitude was causing great hardships and the squatter condition was precarious. They were in great sorrow and depressing circumstances of near starvation. ${ }^{76}$ This time, the squatters were emphatic and unflattering: a demoniacal settler government, they wrote, was discriminating against desperate ex-squatters who had refused to continue being poor and starved. They said that they were not willing to continue "to serve on a low wages of Sh. 6/- and Sh. 8/- per month to Settlers Government."77

Indeed, they were by now persuaded that the government and the settlers were one and the same. After all, they alleged, His Excellency the Governor, Sir Philip Mitchell, had just bought a Farm at Subukia in Rift Valley Province called Ndiroi Estate from a Mr. J. Clay. Moreover, the legislative council, they argued, was composed of settlers who were only

\footnotetext{
75 Ibid.

${ }^{76}$ Limuru ex-squatters to the United Nations through Honorable retired Arthur Creech Jones Secretary of State for the Colonies, $30^{\text {th }}$ January 1948, BNA: CO 533/543/6.

77 Ibid.
} 
interested in their property. Relentless, they sent more petitions in the course of the year in April and July. The latter was laden with emotion. Under the subject, "land \& foodstuffs," Tigoni peasants referred to themselves as miserable ex-squatters who were "moanfully outcrying" [sic] and appealing to the United Nations to intervene to end their suffering immediately. ${ }^{78}$ The correspondence between Nairobi and London, however, were rather curt and dismissive of these petitions. ${ }^{79}$ This was the arrogant manner in which such entreaties were dismissed in the period leading up to the outbreak of Mau Mau war one of the bloodiest incidences of which was played out in Lari near Limuru.

But even more important, it is worth noting the confluence of the Tigoni-Limuru squatter grievances with those from Olenguruone. The latter were taken to the Limuru area, which had, as noted, homegrown land problems of its own. It is important to note that when these two strands of related grievance interacted the result, in the 1950s, was explosive. The process of European alienation of Tigoni lands had started in 1906 thus making Limuru "the storm-centre of Kenya's history" towards the end of British rule. ${ }^{80}$ Police in Tigoni demolished 45 huts leaving "270 men, women and children totally homeless and foodless at the time when hunger in Kiambu district is still great," according to a KCA memo to Lord Hailey in $1940 .{ }^{81}$ A decade later, it became increasingly divisive and continued to be a thorny issue causing concern among politicians in London. David Rees-Williams, a minister in the Colonial Office sent his colleague, Member of Parliament Major Lyall Wilkes, a long reply answering why the issue of Tigoni people was complex. He explained that about four Tigoni clans had rejected the "most generous" land proposal put forward as resettlement by the Carter land commission in a designated land in Nyamweru. They continued to refuse "every effort by Government to reach a just and generous settlement of their claim." ${ }^{\prime 2}$ It was the Carter land commission that had proposed this settlement of 1,500 acres at Nyamweru for the 1,000 that the people of Tigoni had lost. The settlement, for Rees-Williams, was, therefore, acre for acre of land that was of equal value. Six other clans accepted the offer as well as the disturbance compensation, but the remaining four clans not only

\footnotetext{
78 Squatters to Members of Parliament and the United Nations, 28 ${ }^{\text {th }}$ July 1948, BNA: CO 533/543/6.

${ }^{79}$ For more on the dismissive and arrogant nature and attitude of various imperial officials see the file labelled

"Petitions: Kikuyu Central Association -Kikuyu Grievances," CO 533/543/6.

${ }^{80}$ Ngugi wa Thiong'o, Petals of Blood (Nairobi: Heinemann, 1977), 100.

${ }^{81}$ KCA to Lord Hailey, $15^{\text {th }}$ April 1940, BNA: CO 533/543/2. An almost similar copy of this same letter is available at the Kenya National Archives, "KCA Papers: Undated Correspondence," KNA: MSS/43/11.

82 D. Rees-Williams to Major Lyall Wilkes, $10^{\text {th }}$ May 1948, BNA: CO 533/543/6.
} 
refused, but in order to prevent Nyamweru being occupied, elders laid a curse upon the place. Offering no practical solutions, Rees-Williams stated that it was clear "that these people" were "not prepared to accept any alternative land even if it were offered to them." There was no valid reason why they could not re-join their fellows at Nyamweru where the land was still available for them. He added that there were, after all, known tribal means of resolving the curse and that need not, therefore, be regarded as an obstacle to their going there. ${ }^{83}$

For Rees-William, the case of Tigoni did not merit any special treatment or attention. After all, as far as compensation was concerned, "the Tigoni people were treated in exactly the same way as others in similar circumstances. Their huts, stores, bananas, yams, wattle etc. and other improvements were all valued at the fair market rates for 1939." ${ }^{\prime 4} \mathrm{He}$, however, clarified that the valuation was done in the absence of the people of the said four clans as they "all refused to show their improvements and even removed their dependents from Tigoni so that their property could not be pointed out." Further, Rees-Williams observed that another discrepancy that could have been a point of protest was the fact that the price for the people's wattle fetched a much higher price than that assessed in 1939 of Sh. 160 per acre for full-grown wattle because the market prices increased. ${ }^{85}$ Like the acting governor of Kenya had counseled a month earlier, Rees-Williams advised against the re-opening of this case especially as "of all the proposals put forward for the settlement of land claims by the Carter land commission, those of the Africans residing at Tigoni 'township' were by far the most generous." 86 The people of Tigoni were, nevertheless, unrelenting in their firm resolve to stay in their hereditary land. ${ }^{87}$

They argued that the move to the new land, Lari in this instance, had been facilitated by bribing Luka W. Kahangara with the post of headmanship. ${ }^{88}$ As a result, thousands of acres had

\footnotetext{
83 Ibid.

84 Ibid.

85 Ibid.

${ }^{86}$ Officer Governing the Government of Kenya to the SofS for the Colonies, $8^{\text {th }}$ April 1948, BNA: CO 533/543/6.

${ }^{87}$ According to David Anderson, Histories of the Hanged: Britain's dirty war in Kenya and the end of Empire (London: Phoenix, 2005), 140-142, the people of Tigoni had been living on the land since it was acquired by Italian Catholic missionaries in April 1906. Anderson says that the Catholic missionary land was "a safe haven of relative stability and prosperity for its Kikuyu residents." As Anderson himself observes, most of these people argued "that they had been living on the land before the Europeans came."

${ }^{88}$ Anderson, Histories of the Hanged, , 142-147, Luka Kahangara had over time emerged as the leading spokesman for the prosperous, industrious, conservative and largely Catholic Kikuyu community at Tigoni. While some of the senior Kikuyu elders had protested the gross simplification of the labyrinthine network of ties of social mutual responsibility when the government recognized the land rights of the Tigoni aramati thus ignoring their ahoi, Luka
} 
been taken away by the government and people forced to Nyamweru Forest Area that was under the control of the said Luka Kahangara in Makimei's location, Lari. The remaining people were categorical in their refusal of this proposition. They argued that the government had barred compensation to the clan right holders and original ownership of land. With regard to the acre for acre proposition, they countered that the quality and quantity trade off overlooked the original land's proximity to Nairobi, which was the chief and central market for all farm produce. ${ }^{89}$

As such, they felt, people's essential dependence on agriculture for their livelihoods were forced to live without any alternative fallback. They also stated that they were not blind to the fact that their plight was due to the clever colonial machinations behind the "idea embraced in ...policy...forcing Africans to seek employment in European farms." As Africans saw it, "the whole policy, officers in all Departments of the Kenya Government" were "vigorously pushing the theory of dispossessing Africans of their land at the time detribalizing them, aiming ultimately at making them not only Tenants at the Will of the Crown, but also useful source of labor supply for the European farming interests in particular."90

Up to and until 1948, the people of Tigoni sent numerous telegrams to the prime minister's Office in London to appeal this case. They reminded the PM of their consistent appeal of the case both "to the local and home government" and showed that they were "strongly opposed" to accept the offered land at Nyamweru as stated in the House of Commons by the SofS on $6^{\text {th }}$ August 1947. In this short note of defiance to London, they were again declaring fully that they would only resume their lives as farmers in their land in Tigoni. ${ }^{91}$

Not only did the greater Limuru area become to focal point of the Olenguruone and Tigoni existential woes but also of those in the general region as well. Apart from the land, deprived but resilient four Tigoni clans and ahoi that despite being part of the Lari move soon found themselves uprooted from their dependence on land, were others in Limuru who found

\footnotetext{
Wakahangara took a more pragmatic view fearing that even the little gains made would be jeopardized by resistance. Luka's move to Lari was "an act of capitulation and betrayal for which some" Tigoni people would never forgive him. It is the ferment of this matter than led to one of the bloodiest incidences during the Mau Mau war, the Lari Massacre and the subsequent retaliation from the colonial state.

${ }^{89}$ Anderson, Histories of the Hanged, 142-147; also see KCA to Lord Hailey, 15th April 1940, BNA: CO 533/543/2.

90 "KCA Papers: Undated Correspondence": MSS/43/11 KCA.

${ }^{91}$ The date of this telegram is unclear but by a stamp of receipt shows that it was received at the Prime Minister's office in London on $13^{\text {th }}$ May 1948, BNA: CO 533/543/6.
} 
themselves landless. Thus, Limuru became a vortex of an ongoing experiential loss and site of bitter dialogue among kith and kin about traditional mutuality and moral obligations that had, for centuries, tied the fate or fortune of individual members of the community together within a vast and permanent bond of reciprocity.

Unlike in the Tigoni case, it did not always pit kindred against each other. The Mugocuko and Nguru clans with land north east of Limuru station were claiming it from Mrs. J.V. Druirs. Njomo Kihika sent, on their behalf, a letter to the PM's office to this effect, imploring him to intervene in moving terms that echoed centuries' old norm of mutual obligation, even from the imperial heart of empire. "We wich [sic] to appeal through you to His Majesty the King, who is our Father and the Father to all and he is looking for one Son [sic] and overlook the other for His mercy on this occasion," Kihika appealed. ${ }^{92}$ Further, he expressed the hope that if the colonial government counterchecked and studied the facts of their claim, which the clans had tabled before the Carter commission in 1932, then they, "landless children of the King," would stand to benefit. A letter bearing the same claim sent to the Carter commission more than fifteen years earlier by the two clans was not so flattering, however.

Back then, the claimants, in as simple a way as they could, tried to explain the cunning and impudent manner Mrs. Druirs forced them out of their land. They also expressed their bitterness of their land being turned into a pig-rearing farm, which was a radical departure to their traditional uses of land previously. This was a microcosm of wonder and dissent associated with the taking up of African land in Uplands and its surroundings by white farmers who were rearing pigs for the Uplands pork and bacon factory in the Limuru region. This is how they recounted their series of woes at the hands of Mrs. Druirs and others:

Mrs. J.V. Duirs came in our Githaka with [sic] a simple way. She started with a little grass hut, and at the same when she was starting, my Father Kihika asked her why she forted [sic] there She said that she is on her journey further on. It is just a few days (she says) [sic] She proceeded with her commerce ....

After a season she started to build a big House, and she asked my Father to supply her with one jug of milk at 15 Rupees per mensem. After she was supplied with milk during 5 seasons (2 1/2 years) She paid only 3 month [sic] and refused with the rest, and at the

\footnotetext{
92 Letter from Mbari ya Mugocoku to the Prime Minister's office, London, $11^{\text {th }}$ February 1949, BNA: CO 533/543/4. What he meant was that, as the father of his imperial subjects, the king was impartial by extending bounty in land to his favorite white "son" in colonial Kenya while ignoring his African son.
} 
same time she start [sic] to discord with my Father and during the same confusion, 30 of our Sheep and Goats and 6 Bulls were taken by her and all our shambas were Given to swine and goats in order that my Father be angry to move away. Still further on 20 huts of our families were burned up, and this make [sic] my Father to leave the place and went a further [sic] place towards West of the same Githaka.

Another European (Farther Diath) captured 2 Bulls \& ... Rams from my Father, and then my Father removed and went a further to East of the Githaka. The last one, was Mr. 'Tigiti' (Impy) and he took away 2 Rams. And this period Mrs. J.V. Duirs who was still making discord with my Father came and burn [sic] all my Father's Villages and drove him off from his Githaka, Since that time up to date, We his childrens [sic] are still suffering for lacking this. ${ }^{93}$

Similar claims and narratives of suffering abound not only in Central Province but farther around the colony. Besides claims made upon land in Nyanza Province by people who were historically the inhabitants of the region, there was the extra big and constant headache for the colonial administration there and in Nairobi. This came from six-hundred Kikuyu families that had settled in the region. This small group of Kikuyu alleged that they had purchased land in the district from original owners but, in 1949, a summary removal notice was issued. While they were not fighting this eviction, they found it difficult to vacate their purchased lands without a refund of the cost so incurred and their destroyed crops compensated accordingly. Otherwise, in their opinion, the colonial government was contravening and ignorant of laws governing removal and compensation. ${ }^{94}$ They felt that the eviction was hurried and overlooked the full compensation of the prized land and destroyed crops and houses.

One of the evictees, Nahashon Mwaura, wrote to the PM's office about an earlier attempt to remove these Kikuyu out of the Kisii region in 1948. Nahashon talked of "the crops of ...Kikuyu who were in custody having been 'forcibly harvested at night' and allegations" of assaults on their wives that had been ignored by the police. ${ }^{95}$ In trying to explain to London what had actually transpired in this operation, the governor told the SofS that there was no substance in the allegation made by Mwaura with regard to the taking of cattle by colonial authorities. "This complaint refers to the compulsory cattle quota supplied to the Livestock Control during

\footnotetext{
93 Various claimant "mbaris" (clans) to the Chairman, the Kenya Land Commission, November 1932, BNA: CO $533 / 543 / 4$.

${ }^{94}$ Njoroge Kagunda Ghandi to the PM, $21^{\text {st }}$ March 1949, BNA: CO 533/543/4.

${ }^{95}$ According to the governor's letter to the Secretary of State, $7^{\text {th }}$ April 1949 , this petition by Nahashon Mwaura was dated $15^{\text {th }}$ December 1948, BNA: CO 533/543/4.
} 
the war, in which the Kikuyu were obliged to make their contributions, together with the Kisii."96 As far as Kagunda's complaint about forced labor in white settler farms was concerned, the governor explained that the "complaint presumably" referred "to the war-time conscription of labor for essential purposes, for which the Kikuyu immigrants were liable, together with the Kisii." 97 Intimating the sentiments of all affected Kikuyu, Kagunda had written to the DC: "We feel very strongly that no good can come by enforcing a removal order against us without previous investigations and if necessary arbitration by a committee of enquiry or arbitration." And further, "We regard Kisii (Bantu) as a party of our Kenya country, and it it [sic] is denied to Kikuyu (Bantu) ...confirms that there is a dual policy of White and Black. The Blacks are being restricted and descriminated [sic], while White Settlers, Indian, Goans and Arbs [sic] move about in freedom about the country (Kenya) unrestricted regarding Education, Representation, Religiouos [sic] and Trading etc. as this is not within, the conception of the British ideals-British commonwealth." 98

What is clear from this is the African awareness and acute sense, as well as painful experience, of flagrant double standards and preferential treatment of white settlers by both the imperial and colonial governments. Indeed, it can be argued that the tragedy that befell Africans was in large measure due to the fact that they were vulnerable illiterate societies and thus unequipped with the availing equipment, power and knowledge of the law. The oppressive and unjust colonial structure effectively took root because Africans did not have lawyers. However, in due time, some of them, like Njomo Kihika above, became alive to new avenues of agency by invoking the same imperial legal system of oppression. To regain agency and fight colonial injustice, some started to argue for equal the application of, and treatment before, the law and fairness with regard to colonial policies. In the absence of uninterested and just redress of their general concerns and specific everyday travails, they confronted the colonial state using a more proactive avenue of legal redress.

One good example is that of the emigrant Kikuyu in south Kavirondo (south Nyanza) on behalf of whom Kagunda wrote, "We are ... unfortunate people ... dispossessed of their lands

\footnotetext{
${ }^{96}$ Governor to the SofS, $7^{\text {th }}$ April 1949, BNA: CO 533/543/4.

97 The governor was responding to an earlier complaint in a petition sent to him on $30^{\text {th }}$ April 1948 from Njoroge Kagunda, Ibid.

98 Letter from Njoroge Kagunda to the DC South Kavirondo, 30 ${ }^{\text {th }}$ April 1948, BNA: CO 533/543/4.
} 
...."99 Insulted, with their inheritance given to perfect strangers; their houses made to belong to other races; having to buy their water with money; their firewood sold to them; weary and finding no help; and unable to navigate the complex and strangulating laws and policies of those that pursued them that were about their necks, Africans sometimes turned to the law and British lawyers. ${ }^{100}$ As an expression of faith in the British colonial "justice" system, and a legal strategy to regain agency, the Kikuyu of Kisii district would eventually seek the services of a Nairobibased advocate. ${ }^{101}$ While this effort was ultimately not successful, there are other similar cases of which more is known about how African communities protested against the colonial legal strictures, absence of human rights and underdevelopment.

\section{Protests against Colonial Legal Strictures, Absence of Human Rights and African Underdevelopment}

Africans, as already noted above, expressed great faith in themselves, at times, to tackle the intricate web of imperial and colonial laws and policies themselves. In retrospect, this was with a great measure or sense of an uncanny understanding of what was at stake. A good illustration is that of Authur Tutu and Stanley Kiama Gathigira who were the President and Secretary of the Progressive Kikuyu Party of South Nyeri District, respectively. This example exemplifies this uncanny legal understanding and strategy to regain African agency. The two officials noted in their memorandum to the SofS that due to the long history of the Kikuyu people's association with the land as hunters, shepherds and cultivators, the "question of the land" filled "the heart [sic] of all, men, women, and children. ${ }^{102}$ Tutu and Gathigira asked the land commission to "try by all means in their power to find some way" that would "destroy the discontent that has arisen" so that they could make peace between all the inhabitants of the country, black and white. As testament to their colony-wide political outlook, they stated further that "all the black peoples of Kenya" were "like the Kikuyu People" in that they were "cultivators and shepherds..." and that "long ago those who shepherded their flocks used to buy

\footnotetext{
99 Undated letter from Njoroge Kagunda to the PM and copied to the SofS and the governor, BNA: CO 533/543/4. 100 These are the words of Muorianyoni who paraphrased Lamentations 5:1-10 in Muigwithania, Vo. VII, No. 4, August, 1928, KNA: DC/MKS 10B/13/1.

101 The PC of Nyanza Province wrote a letter to R. Black Malcomson, $30^{\text {th }}$ October1945 in which he said that the Kikuyu had received permission to plant crops in May of that year and that, at the time, they were not being moved yet, BNA: CO 533/543/4.

102 Authur Tutu and Stanley Kiama Gathigira to the SofS, $10^{\text {th }}$ August 1932, BNA: CO 533/422/1. It creates the impression that it had earlier been submitted to colonial administration and the 1928 land commission.
} 
food from their neighbours." However, food under colonialism had become dear because much of it was being exported and they too were "turning their attention to cultivation. Thus their needs have grown, as have the needs of the cultivating tribes, and we would ask therefore that to each tribe be given enough land to satisfy all their needs," they pressed. ${ }^{103}$ Tutu and Gathigira expressed well-informed concern that areas designated as reserves set apart for them were not sufficient for them to have enough land and flocks for their sustenance as it was in the preEuropean past, which they believed was paralleled in the experience of other ethnic groups in Kenya.

Moreover, turning to attack matters legal and how these affected their everyday lives, they expressed displeasure with the choice of words by the colonial administration. They complained, 'We do not like the word 'RESERVE.' To us it means 'something left over,' 'something held back.' It does not indicate that we owned the land before the Europeans came. We feel therefore that we can have no security or trust when our lands are so described, because to our minds the word would indicate that he who holds back from touching this 'Reserve' may, when need arises, come and take it." ${ }^{104}$ Further, they took issue with the fact that when the said "reserves" were demarcated, people were not informed, nor did they know "that the boundary lines were to be like the walls of a cattle byre. We were told that the Boundary Line was drawn to prevent the Native Peoples from burning the bush. We did not know that our cattle could no longer be allowed to graze there, or go to the salt licks there, or that we ourselves would lack firewood, or a place to build. We were allowed to graze our cattle in these places for a short time, but we did not know that these would be taken from us for ever [sic]."105

From the outset, this statement appears simple. It seems to be all about lack of legal information, which a KCA petition addressed as a calculated African "legal disability." 106 However, hidden within it is a subtle and unspoken subtext of unfair limitation of African mobility as well as strictures that curtailed prior lifestyle and Pre-European African economic activities. At the same time, they registered their bitterness at seeing these same places that were once forest land being cultivated by Europeans and grass lands that had once fattened their cattle

\footnotetext{
${ }^{103}$ Authur Tutu and Stanley Kiama Gathigira to the SofS, 10th August 1932, BNA: CO 533/422/1.

104 Ibid.

105 Ibid.

${ }^{106}$ Kikuyu Central Association to the SofS for the Colonies, February 1932, BNA: CO 533/422/1.
} 
become white owned coffee farms. ${ }^{107}$ Tutu and Gathigira were unafraid to state how the production of illegality was perceived by Africans whom it affected. They believed that various forest ordinances were not designed to prevent the destruction of forests through African slash and burn shifting cultivation but, rather, "that these lands might be given to the Europeans." 108

Subsequently, African suffering was untold. Tutu and Kiama wrote, "We have suffered because our old lands have been taken from us and given to the Europeans, and these things we mention ... are those which have made us to suffer most." ${ }^{109}$ Then followed examples of legal fines that were the result of blind and unforgiving, if ignorant, colonial policies and laws, which disrupted previous African ways of being. For example, they were fined when their cattle crossed lines that had been instituted by the colonial authorities; fined for cutting firewood or timber for building within the forest; while grazing and firewood collection now had to be paid for. The changes wrought on the physical landscape by the imposition of colonial law and order, especially the tampering with the African land tenure and use, had adversely hampered their cultivation. Tutu and Gathigira explained that they were affected by the fact that their cattle and other stock now had "to return to the Reserve."

Yet, before the Europeans took their lands from them, livestock "herds dwelt in the plains where there was plenty of grass nganatha-ini" or the wide open wild common grazings. ${ }^{110}$ Confined at the homestead, cattle now had to compete with the few sheep and goats that were traditionally reared there and grazing and cultivation areas were no longer sufficient, complained the two officials. As such, Africans fortunes were affected significantly. "Each man's portion is so small that he cannot plant coffee nor can he have a large herd and produce butter," Tutu and Gathigira complained. As a result of all these changes, the position of Africans was worse than it was before especially with the encouragement from the authorities for them to plant wattle trees as a source of income. This, they argued, caused further reduction of "the area for food production and grazing. Again...thanks to the help of doctors and nurses, both the Missions and

\footnotetext{
${ }^{107}$ Memorandum from Tutu and Kiama Gathigira to the SofS, $10^{\text {th }}$ August 1932.

108 Ibid.

${ }^{109} \mathrm{lbid}$.

110 Ibid.
} 
of our Government, our population is increasing, and this increase brings about a demand for more grazing land, and more land for cultivation."111

To the above eloquence in relaying the everyday experiences of Africans under new colonial laws and policies four decades after the start of colonial rule, was added an extensive request to reorder boundaries. The two officials furnished the SofS and the land commission with the old boundaries of the now dispossessed people that were not indicated in the colonial maps but which old men knew well enough. These covered Othaya, Tetu, Mathira, Ndia and Gichugu divisions. They also provided a comprehensive list of the names of people who were dispossessed and "driven out of from the villages they had built, and the gardens they had cultivated in the valleys" as a result of "the troubles brought about by the taking away of all the land between the old boundaries and the new ones."112 The affected were, in Othaya Division, 566 people; Tetu, 340; Mathira, 333; Ndia and Gichugu, 104; bringing the total of all affected to 1,343 people who were well known to them but noting that there could have been even others more.

This makes clear the centrality of land in sustaining livelihoods. They argued that since most lands lost had been taken for the public good for townships, government camps, trading centers, schools, hospitals, railways and railway stations, it ought to have been "from both white and black, and not from black alone." "113 They, therefore, called for the restitution of their dispossessed lands, which they felt would ensure that "full justice" was done with regard to their claims and ensure that their needs were fully met. They anticipated, empathetically, that this "in turn would cause grave hardship in many cases" for "settlers who now" occupied these lands who had come "by invitation of the Government" but who would be dispossessed when these reforms would be instituted. To resolve this anticipated problem, they suggested that instead of the government paying compensation to settlers "in equity" which "would bankrupt the country," the best suggestion was to provide land for Africans "out of the Crown Lands" which were available. $^{114}$

\footnotetext{
111 Ibid.

112 Ibid.

113 Ibid.

114 Ibid.
} 
Turning their attention to the Native Land Trust Ordinance, they said that they did not like it for three reasons. One, it did not have a provision through which any African whose land was encroached upon could take up a case against the European party doing so. It also recognized that African lands were under ownership of the Crown, thus making the original owners tenants with the Crown having the last word on issues arising. They, therefore, asked for the ordinance to be amended so that they could take their cases to the High Court. Secondly, it provided Europeans with the privilege of holding "their land as leasehold, or freehold," yet they, "the original owners of the land," had "lost all right in the land except the Tenant Right created by the Lands Trust Ordinance." 115 In this regard, these able African "advocates" requested King George $\mathrm{V}$ to recognize their past ownership, especially considering their faithful service during the Great War and their loyal obedience to him all things of which, in their opinion, should have been rewarded with the grant of their land as freehold "subject to necessary safeguards as to the sale of land to alien races."116

Lastly, they said that most Africans felt insecure since they remained tenants on Crown Land. For these reasons, they expressed the desire to have "the old laws of Native Land Tenure remain," as they were, at the time, "at least ...best suited" for their "customs and needs." They, however, realized that these would "have to be changed to meet changing conditions" but held that "the time for drastic alteration" had "not yet arrived." 117 The two reminded the recipients that King George $\mathrm{V}$ and his government were their trustees and should, therefore, urge the SofS, the governor and the land commission to apply all their powers to decide the land question so that they, their sons and daughters of the land, did not lack their inheritance.

Anticipating some form of legal redress and revision, after the end of the 1928 land commission enquiry, they said its resolutions should be published in Kikuyu and given the widest circulation possible to enable the collection native criticisms of the report. In so doing, their memo pointed at the one legal handicap that allowed the illegal production of illegality that facilitated the creation of Kenya as white man's land. Perhaps, if Africans understood the full implications of various legal constructions that made this possible, political consciousness could

\footnotetext{
115 Ibid.

116 Ibid.

117 Ibid.
} 
have come sooner and would have been more intense earlier than it did in Kenya. But since, laws were never widely circulated or published in vernacular languages, African silence had been misconstrued as either acquiescence or ignorance, which also meant that the African was juvenile and did not know what was good for him.

If anything, it was obvious from all the unjust laws passed, among them the Native Authority Ordinance; the Native Land Trust Ordinance; the Native Registration Ordinance; the Native Passes Law; the Native Squatters Ordinance; the Employment of Natives Ordinance; Native Liquor Ordinance; and Township Residents' Permits, that both the government and NonAfrican representatives on the legislative council were "ignorant of conditions of African life and grievances in Reserves...."118 Yet, the sum of these ordinances obviously concerned and affected the African in his everyday life. For this reason, the KCA, in its extensive 1932 memo to the SofS, submitted in London on its behalf by Jomo Kenyatta, stated that all of these laws should have been published in African languages. It added that, for resolutions and minutes of local native councils to be fully understood by non-English speaking Africans, decisions arrived at should also have been published in vernacular. The failure to do so meant that the cumulative effect of these ordinances, which included restrictions of the freedom of speech, press and right of assembly, was not only not understood but also not known to Africans who used their vernacular languages. According to the KCA, this constituted the creation of "legal disabilities." It was, therefore, "essential that all Laws, Ordinances and Enactments relating to the Government of a Kenya," particularly those touching on Africans, "and all bye-laws and regulations controlling the urban areas, be published in African language, so that all may know the laws of the land" to which they had to conform, "and so ...realize under what Powers legal proceedings" were instituted against them. ${ }^{119}$

With particular regard to the freedom of speech, KCA urged that clauses in the Native Authority Ordinance, under which Africans were denied the right of free speech, free press, and the holding of meetings, be removed arguing that "liberty in these matters" was "the first essential in any democracy," and was "a traditional privilege of all free men under the British flag." To withhold from the Africans this freedom, was to "deny them the elementary rights of

118 KCA memorandum to the SofS, February 1932, BNA: CO 533/422/1.

119 Ibid. 
citizenship," and "a cause of grievance" which militated "against the Kikuyu taking an active part in the civic life of the country for the benefit of all concerned." ${ }^{\prime 20}$ The association was particularly critical of the fact that measures obstructing public meetings inflicted "considerable hardship upon law-abiding citizens" as they were evoked to break up family functions, for example, traditional weddings and beer-drinking parties. The KCA memorandum cited Criminal Case No. 83/29, which was heard at Fort Hall, by a $3^{\text {rd }}$ class magistrate. In this case a Kikuyu named Daniel Kingori, who was also a member of the local native council, was arrested with two others, after being found conversing in a house following an evening meal. After they were convicted, the magistrate ordered the first and second accused to refrain from visiting the third accused. It is such ridiculous restrictions that alarmed the Africans, who were led to think that they are treated as though they were slaves.

But despite such a plausible argument presented by the KCA, the deputy governor argued that, "to understand the laws of Kenya a native would not only have to be an expert Swahili scholar but would also have to attain to a far clearer understanding of legal definitions and distinctions than is compatible with his present stage of unintellectual development." ${ }^{2121}$ Further, the deputy governor doubted whether there was a single "native in Kenya" who would "benefit in the slightest by the monumental work of translating the volumes of the Laws of Kenya, and even if this were done there would still be the work of translating every amendment and every rule. Sundry attempts had been made to summarize some of the Ordinances which most obviously concern the native in his everyday life, such as the Native Authority Ordinance but the attempts were not particularly successful." ${ }^{122}$

The KCA memorandum had specifically criticized the ordinance arguing that the appointment of chiefs in positions of leadership should have been by election as opposed to government nomination. The memo stated that clause 8 (q) of the law be deleted because under it Africans were "deprived freedom of speech, press, holding of meetings" yet they deserved to enjoy the same rights as Europeans and Indians. In addition, the memo called for the abolition of "kipande"; municipal permits; restrictions on ownership of land in townships and highlands;

\footnotetext{
120 Ibid.

${ }^{121}$ A CO document, possibly from the deputy governor in Nairobi to the CO summarizing the contents of Kenyatta's long memorandum, BNA: CO/533/422/1.

122 Ibid.
} 
domestic servants' certificates; and the removal of all restrictions on free movement of Africans. The KCA argued that the cumulative effect of registration, having to obtain special entry permits before entering a town and having to produce a certificate of employment was estrangement of the Africans in their own land since they enjoyed "greater liberty outside their own country than in it." This was a form of control "only accorded to criminals in other countries" and when exacted in Kenya gave "rise to constant hardship and resentment." 123

Beyond this, the KCA called for representation in the legislative council and African representation in the Executive Council. The memo went on to argue that taxation without representation was an unjust principle. Further, for over thirty years, taxes collected from Africans were "spent largely for benefit of non-Africans without knowledge or consent of Africans." Yet, Africans too had needs and urgently needed education and hospital facilities, roads and agricultural improvements. In Nairobi, the taxes were "heavier than many poor Africans" could bear, "for in addition to the Poll tax of 12/- a year, and certain other taxes, those settled in the Native Location" also paid a ground rent of $£ 3$ per year for the land on which they erected their huts yet their wages were very low. In spite of such arguments, African living conditions remained poor as the cost of living skyrocketed raising the concern of both the colonial intelligence apparatus and the legislative assembly.

\section{Urban Issues and Disabilities: Political Unrest}

Housing, in major urban areas and townships, was a serious problem. House rents rose and accommodation was difficult to obtain, while there was a tendency to increase hotel and boarding house prices. Although investigations were launched to examine the cost of living for Africans living in Nairobi, it had, undoubtedly, risen considerably. ${ }^{124}$ The Government Housing Committee, which was also known as the Number Sub-committee, showed that, by 1943, in Nairobi alone, 14,000 Africans were "unhoused" out of a population of 52,000. ${ }^{125}$ Some 12,000 Africans had left the city and its environs as a result of this but especially on account of food shortage with 4,000 of them receiving free railway tickets to do so.

\footnotetext{
${ }^{123}$ KCA to the SofS, February 1932, BNA: CO 533/422/1.

124 Intelligence Report, March 1940, KNA: VQ/16/5.

125 Intelligence Report, March 1943, KNA: VQ/16/5.
} 
Subsequently, strikes were on the rise, especially in Mombasa and Nairobi, throughout the 1940s proving that African poverty was, indeed, the cause of agitation. It proved, as Henry Muoria wrote in Mumenyereri, that when Africans asked for more land, it was because they had none. When they asked for more pay, it is because their pay was not enough. Furthermore, when people asked for the removal of the "kipande," it was because they had seen its drawbacks. When they asked for better housing, it was because they needed it. ${ }^{126}$ As such, Muoria had argued, it was quite obvious that they were agitating because of the treatment they received from Europeans. They, therefore, had a right to ask for whatever they felt they needed. After all, it was natural for any person to long for better living. ${ }^{127}$

Thus, in October 1942 alone, there were, as expected by the authorities, 19 strikes involving over 700 employees. In almost every case, labor made a simple demand for higher wages to meet the extra cost of living and agreed to go back on the understanding that their demands would be considered. It was also noted that the African food shortage seemed likely to be a cause for strikes. With respect to these strikes, another probable cause was that action under the Fact Finding Committee for some form of cost of living bonus had not been implemented earlier. ${ }^{128}$ African taxi drivers also went on strike to protest petrol rationing. ${ }^{129}$ It is telling that a colonial administration that was fond off leveling the standard condemnation of any African protest as political agitation that bordered on the criminal did not do so under these circumstances. Instead, they saw the inherent wisdom of relaxing this official response template. To stimulate meat supplies to Africans and ease the food shortage, the Municipal Native Affairs Officer even suggested the relaxation of rigid health standards and the introduction of camel meat. $^{130}$

Cumulative hardship occasioned African unrest in towns. But urban unrest was not exactly new. It was palpable and had been on the rise since the late 1930s. Indeed, it was the subject of intense debate at the legislative council in the late 1940s. Not everyone in the echelons of colonial authority was convinced that African expression of grievance, distilled as it was in

\footnotetext{
${ }^{126}$ Mumenyereri, "What Shall we do when Europeans Get Self-Government," $10^{\text {th }}$, May 1948, KNA: MAA/8/106.

127 Ibid.

128 Intelligence Report, October 1942, KNA: VQ/16/5.

129 Intelligence Report, August 1943, KNA: VQ/16/5.

${ }^{130}$ Intelligence Report, October 1942, KNA: VQ/16/5.
} 
the cauldron of various experiential hardships, was genuine. The legislative council member for the coast region that was hit by a series of successive labor strikes during this period, S.V. Cooke, criticized and indicted the colonial government for the very perturbing trend of affairs in the country. He castigated the government for its weak and vacillating policy so far as Africans of Kenya were concerned. Cooke felt that the political agitation that was rising and sweeping like a rapid tide throughout African reserves in Kenya was a symptom and not a cause of unrest. ${ }^{131}$

Cooke alleged that arresting people was not the solution to the problem and, in 1939, he had made it his business to see Sir Henry Moore, soon to be the governor of Kenya, about it. As he saw it, the vocal and voluble members of the African community whom the government liked to call agitators were working on fertile soil. It was too easy for them to get support because the government gave them every opportunity on which to thrive: the dissatisfaction and unrest in the colony. After all, the government made little effort to remove the grievances thereby offering them up on a plate to the agitators. When there was trouble these agitators ended up in prison but that was not the right way, Cooke argued, to tackle a problem that was too deep, which had to be tackled at the roots. ${ }^{132}$

Cooke's view was supported by Eliud Mathu, the first African member of the legislative council, who opined that between 1939 and 1948, the African population started to show the government and the world at large that it was alive to the problems in Kenya. This, Mathu thought, was one of the reasons why the government saw "political agitation" among the African community. But it was not political agitation, Mathu argued. What was happening, in his opinion, was that "the brain of the African" had "started to function in a proper way" such that the Africans were becoming conscious that they were members of a society, and as members of that society they wanted to play their full part in the activities of that society. ${ }^{133}$

However, the Chief Native Commissioner, Wyn Harris, dismissed such views and argued that Cooke's motion was unnecessary. Africans, he countered, only had themselves to blame, especially considering three points: one, his labor output had decreased since 1939; two, the

\footnotetext{
${ }^{131}$ Colony and Protectorate of Kenya, Legislative Council Debates (LegCo. Deb.), XXVIII (8 ${ }^{\text {th }}$ January 1948); 684 \& 686.

132 Ibid., 694.

133 Ibid., 714 \& 715.
} 
African trading was uneconomically active; and three, more than ever before, Africans looked to government to supply their wants and gave little thought to the doctrine of self-help. ${ }^{134}$ Harris was of the view that there was a belief that the administration was omnipotent. An attitude prevailed that when there was unrest and where difficulties prevailed, the administration, being omnipotent, could put things right if it wanted to. In his opinion, the Cooke and Mathu view was that the administration was failing in its plain duty unless it removed all causes of dissatisfaction and difficulty from every community. If high wages were demanded by the worker, the administration was to see that high wages were paid; if higher output was required, then the administration had to ensure that every worker worked long and willingly. The administration, according to skeptics, had not only to produce bricks without straw but also produce houses without bricks. If squatters from Naivasha clamored on Government House lawn for land in the Limuru farm area, the administration had to provide farms and, at the same time, "persuade the unfortunate dispossessed European farmers that the whole thing" was "fair and for the best of all possible worlds." That, as far as its critics were concerned, when land was short, the administration, could, of course, make "the desert blossom like the rose...."135

At the same time, however, Harris also conceded that the nature of any administration in the British Colonial Empire was framed in such a way that the rights of the individual and the belief that the individual was more important than the state, was bound to encourage the demand by the governed for more and more share in their government, and if every demand by the governed for more self-government was not immediately met, obviously the governed began to question the bona fides of that government. This could cause lack of confidence but it was itself inherent in a democratic empire, and participation in government was bound to increase the appetite it fed upon. ${ }^{136}$

Mathu snapped on this point to state that this was exactly what the African wanted: a niche in the colonial political economy. Mathu stated that that is what the African wished for when he requested to play a great part in the trade of the country such that when he did not get the trading licenses he felt that there was a certain amount of discrimination thus accusing the

\footnotetext{
134 Ibid., 698.

135 Ibid., 703.

136 Ibid., 700.
} 
government of not giving him the licenses for which he applied. The same applied to the land problem particularly in the Central Province. Mathu said that the legislative council had heard on many occasions that there was congestion in the African land units. That there were more people than the land could hold. According to Mathu, the African always asked, "What is the solution? Give us more land?" The government answered saying that there was no land yet the African saw that there were acres and acres of land lying in the European areas, some of it undeveloped, some with one person on it. "What about that?" Mathu posed. ${ }^{137}$ It was evident in the course of this debate that there was a general agreement between members that the administration was faced with "very, very difficult problems most of which" were economic. As the member for Ukambani, Major Joyce, observed, it was the economic pressure underneath that was causing most of the unrest. It was clear for him that from such unrest arose political agitation, because political agitation had been proved in history as the means whereby unrest was voiced and, in some cases, causes of unrest cured. ${ }^{138}$ While this was an acknowledged and undeniable fact, the government was defensive of its integrity with regard to the matter and its position vacillated between admission of responsibility and resolution and denial in the same breath.

As such, it is no surprise that not very long after the debate, at the end of 1951, Cooke stood on the floor of the legislative council and charged that when the public asked for bread, all they received was a stone. ${ }^{139}$ On $11^{\text {th }}$ May 1951 when the ministry of finance reported to the council on the report of the Cost of Living Commission in November 1948, it stated that it was extremely difficult to pin down the unfortunate and intractable problem of the cost of living. It had the unfortunate habit of changing even while it was under consideration. ${ }^{140}$ Seven months later, the Finance Secretary, V.G. Matthews, echoed the same refrain when he asked members to face the facts: there was no use pretending that it was within the government's power to bring down the cost of living because it was not. ${ }^{141}$ Those charged with duties in relation to the cost of living soon realized the irresistible nature of the forces with which they contending. This irked Cooke who viewed this statement as most defeatist and most shameful. Cooke said that that was "the most untrue statement" that he had heard from a government official in the Council. The

\footnotetext{
137 Ibid., 715.

138 Ibid., 720.

139 Colony and Protectorate of Kenya, LegCo. Deb., XLV (11 $11^{\text {th }}$ December 1951); 783.

140 Colony and Protectorate of Kenya, LegCo. Deb., XLII (11 ${ }^{\text {th }}$ May 1951); 112.

${ }^{141}$ Colony and Protectorate of Kenya, LegCo. Deb., XLV (11 $1^{\text {th }}$ December 1951); 783.
} 
official's statement was in complete disagreement with the Conservative Party in Britain where Churchill had said that there was a compelling need to halt inflation. Cooke also quoted Harold MacMillan, British Minister of Housing and Local Government, who had expressed his hatred for the words "it cannot be done."142

Further, Cooke cited an article carried in the leading organ of educated Africans, Baraza, which had stated that it was all very well for the government to tell the LegCo that the rises were beyond its control or that the government had done all that it could to hold prices down: but the public simply did not believe it, particularly as far as farm produce was concerned. ${ }^{143}$ Cooke also ridiculed the secretary for agriculture's big gaff of stating that the cost of ordinary foodstuffs in Kenya was, as far as he knew, lower than anywhere else in the world. He challenged the secretary to refute that maize, which was the staple food for over $95 \%$ of the people of Kenya, was not cheaper in Uganda and South Africa. ${ }^{144}$ In retrospect, it is apparent that the government did not heed Cooke's ominous warning that people in Kenya bitterly resented the government's attitude to this and similar matters.

\section{The Colonial Assault on African Cosmos, Traditional Lifestyles and Values}

Less than forty years earlier, Sir Percy Girouard, one of the architects of the colonial edifice, eloquently proposed how Africans could be wooed out of their assuring idyllic life of independence, self-reliance and, from the outset, a disproportionate leisure-filled lifestyle of dance, celebration and traditional beer-drinking by increasing the cost of living. ${ }^{145}$ By the early 1930s, the Kikuyu Central Association was demanding freedom for dances. In a memo presented to the British government in London, the association argued that dances, especially the Muthunguci for elderly women and men, was the only recreation available. Commenting on KCA demands, the governor stated that he had no sympathy with the request for unlimited license. As far as dancing was concerned, this open-air pastime commonly led to all sorts of excesses, drunkenness and immorality. ${ }^{146}$ It is worth noting that African traditional dances, especially in the context of colonialism, were the source of communal awakening that offered

\footnotetext{
142 Ibid., 784.

143 Ibid.

144 Ibid., 785.

145 “Native Labor," East African Standard, $8^{\text {th }}$ February 1913. This was a report on Sir Henry Belfield's remarks at the Nakuru agricultural show. He was citing the immediate former colonial governor, Sir Percy Girouard.

${ }^{146} \mathrm{CO}$ document summarizing the contents of Kenyatta's long memorandum, BNA: CO 533/422/1.
} 
some sort of transcendence that transported them from the inanity of their lives to some form of meaning that enabled them to live a day at a time. ${ }^{147}$

But after African peasants had been caught up in the cash-nexus, that is the intricate web of economic devices, such as wages and taxation as well as choking land, labor, conservation amongst a gamut of various other legal strictures, the colonial regime was unwilling to turn back the hand of time. Although finding a logical and manageable balance alleviating the burden of colonial modernity foisted upon African backs was impossible, the overseers of the new colonial order were content that the ultimate objective of instituting private capital and ownership of land had been accomplished. That could not be undone. It could not as that would be a reversal of the gains of the institution of imperial capitalism. The African pre-European world, however, had been undone. Its socioeconomic and political fabric was ruptured, which was also the unspoken cause of African "political agitation." The bulk of this agitation was tied to the issue of land alienation. It is important to stress why land alienation was such a pressing matter.

Land, according Job Muchuchu, an African contributor to Mugwithania, the Kikuyu newspaper, was the breast on which the people suckled. ${ }^{148}$ As such, it was the chief sustenance, "office" and/or "bank" that Africans bequeathed from one generation to another for centuries. According to another contributor to Muigwithania from Nyeri, Charles Ngundo, the land had sustained the children of the Maina and Mwangi generations and had been passed on, since time out of mind, to successive elders by Ndemi and Mathathi who were the very first Kikuyu to live off the land. ${ }^{149}$ For Ngundo, the land was akin to a life bearing sacred sheep, $N g$ 'ondu. It was the communal cow that gave sustenance to the children of Maina and Mwangi. Land, Ngundo wrote, was the primary or principal element in the inheritance apportioned to the Kikuyu by God. ${ }^{150}$

The effect of the alienation of such a precious resource, then, is not left to the imagination. It occasioned untold anxiety and distress because it is not just land that was physically taken away when it was commoditized and individualized. It was the very basis of

\footnotetext{
${ }^{147}$ Waithaka Waihenya and Ndikaru wa Teresia, A Voice Unstilled: Ndingi Mwana'a Nzeki (Nairobi: Longhorn, 2009), 12.

148 Muigwithania, $16^{\text {th }}$ January 1929, Vol. 1. No. 11, KNA: DC/MKS 10B/13/1.

${ }_{149}$ Mugwithania, Vol. 1, No. 12, May 1929, KNA: DC/MKS 10B/13/1.

150 Ibid.
} 
African being that was removed. ${ }^{151}$ As it were, the African soul was gorged out when the land was alienated. Put differently, land alienation had a profound pyschosociological impact upon the African and his socioeconomic and political institutions. The alienation of land turned selfsufficient Africans into wage-labor thus causing one of the most crucial social upheavals of twentieth-century Africa, and one, moreover, fraught with pregnant possibilities for the future of Kenya and the continent beyond. ${ }^{152}$

Further, the other blow that was dealt upon the pre-European world was the systematic decimation of the all-important cattle complex. After land, cattle, sheep and goats were the next most important socioeconomic and political element that held together African life. It is no wonder that livestock was equated to land. A specific number of the former could be used to purchase land thought to be of similar value. As such, African wealth was either valued in land or stock. Even during the early years of colonialism, and much later, livestock continued to be used to store monetary value. Thus, the science of livestock thinning to improve herds and better utilize pastureland, which for obvious reasons was embarked upon with great vigor in the 1930s and 1940s, was a great devastation for Africans. The significance of the cattle complex was not lost to early British observers of African life.

As early as 1908, for instance, Lt. Col. O.F. Watkins thought of the cattle industry as a "cattle cult," which was the corner stone of many pre-European African economies. According to Watkins, cattle formed the woman's marriage price; cattle were paid as blood money or for inter-ethnic raids; cattle were the measure of a man's wealth and social standing; cattle were the investment of savings and the provision for old age; and cattle and women were the main if not the sole inheritances. Cattle, Watkins concluded, were the main object of ambition and the reward of endeavor. ${ }^{153}$ The acquisition and ownership of cattle was regarded as an important indication of wealth and prestige. ${ }^{154}$ Since by custom stock changed hands through loans, bridewealth or insurance against catastrophe between families, clans or even ethnic groups,

\footnotetext{
${ }^{151}$ Ngugi wa Thion'go, Writers in Politics: A Re-engagement with Issues of Literature and Society (James Currey: Oxford, 1997), 108.

152 Ibid., 85.

153 Undated newspaper cutting of an article by O.F. Watkins, "Land Tenure: A reply to Dr. Leakey," found in the Barlow Papers: Kikuyu Land Tenure Notes, JKML: BAR/1/3/3.

154 William R. Ochieng', "Food Production in the Pre-Colonial Period," Themes in Kenyan History (ed.) William R. Ochieng' (James Currey: Ohio University Press, 1990), 27.
} 
bonds of acquaintance, friendship and family were forged and strengthened. ${ }^{155}$ Thus, the removal of these two key economic pillars of traditional society, land and livestock, even without the conversion of the Africans to the labor factor of production, caused inestimable damage. Indeed, the impact consisted in the disintegration of entire ethnic groups and the unraveling of the traditional social fabric and values.

In its submission to the Carter land commission, the Central and South Kavirondo African Chamber of Commerce reiterated the importance of cattle. It stated that the possession of cattle was very important for the life of the Africans as the possession of ready money and estates was to Europeans. It is from this industry that the African drew his livelihood, especially during harsh climactic or economic conditions; paid tax; fed himself and his family; and paid dowry for his sons, bought clothes from the proceeds of ghee and the sale of whole milk. ${ }^{156}$ This pre-European African self-sufficiency was replaced by the reduction of the African as a colonial source of cheap labor that left people even more deprived than they ever were when all they had to contend with were the vagaries of nature and disease. According to a Carter commission witness, Zablon Aduse son of (s/o) Nyandoje, the reduction of the number of cattle that Africans could keep from one-hundred to five per family pauperized people like him. ${ }^{157}$ The sum effect of the imposition British control with regard to land, livestock and the disposal of labor, according to the veteran African novelist, Chinua Achebe, put a knife on the things that held people together. As a result, things fell apart. ${ }^{158}$ This was a process to which some conscientious British administrators and settlers in Kenya were not blind.

\section{Explanations of African Discontent: The Badly Flawed, the Proximate and the}

\section{Brazenly Ugly}

Major General J. Orde Browne was one of a few first hand observers who sought to explain and understand the impact of British colonialism and, by extention, African discontent. Seeing the adverse impact of British colonialism among the Meru, Browne sought to analyze and

\footnotetext{
155 Ibid.

156 Great Britain, "Memorandum. The Native Chamber of Commerce," to the Kenya Land Commission, $6^{\text {th }}$ September 1932, Kenya Land Commission Evidence, III (London: HMSO, 1934), 2145.

157 Oral testimony given by Zablon Aduse s/o Nyandoje's to the Kenya Land Commission at Marenyu in Central Nyanza in Great Britain, Kenya Land Commission Evidence, 2169.

158 Thiong'o, Writers in Politics, 85 \& 127.
} 
document this phenomenal transformation in a book. ${ }^{159}$ Browne aptly captured and described this transformation that, no doubt, caused a great deal of African insecurity, anxiety and distress. The impact of this process was felt unevenly in British Kenya and the social ferment and political consciousness that resulted, likewise, was not the same in intensity in various regions.

What is certain, however, is that colonialism across the board caused, according to Browne, the "disintegration of the tribal soul" or "tribal integrity." For this first hand observer of this transformation, colonialism caused the "gullying of the tribal soul." ${ }^{160}$ It destroyed the preEuropean cohesion individuals, families, fathers, brothers, friends and other social units as a result of domination. The foreign control of virtually all aspects of life exposed the African mind to the disorganizing action of individualism. ${ }^{161}$ The introduction of individualism to Africans was at the expense of their own pre-European principle of mutuality and reciprocity. While individual responsibility was an essential part of African culture, the individual African was secondary to the social system within which s/he operated. In this social context, no one was ever alone, even the unfortunate landless. Mutual dependence meant mutual obligation, which was a way of being that was only clear to those who were keen. ${ }^{162}$

As such, fathers guaranteed that their sons and other dependents including the landless ahoi among the Kikuyu acquired land, which was at no cost and was an inalienable right. ${ }^{163}$ The right to cultivate land was vested in kinship units such as the extended family or clan. ${ }^{164}$ Fatherfigures such as uncles and cousins all contributed towards the bridewealth of their close kin without demur. It was not unusual for family and friends to retaliate if such help was not availed. Kinship also determined how and where one worked, and how much of what range of material goods one had command over. ${ }^{165}$ Seldom, if ever, was labor hired. ${ }^{166}$ It is a fact that, under this organic social organization in traditional African economies, the minimum level of material

\footnotetext{
159 J. Orde Browne, manuscript excerpt, "The Vanishing Tribes of Kenya," 1925, KNA: DC/MRU/1/4/5.

160 Ibid., 8.

161 Ibid., 3.

162 George Dalton, "Traditional Economic Systems," in The African Experience, I eds. John N. Paden and Edward W. Soja (Northwestern University Press: Evanston, 1970), 70.

163 Ibid.

${ }^{164}$ Robert M. Maxon, “Agriculture," Themes in Kenyan History, 29.

165 Dalton, "Traditional Economic systems," 71.

166 Maxon, “Agriculture," 29.
} 
sustenance was guaranteed to all persons. ${ }^{167}$ Pre-European African societies were soldered together by paternal obligations of the provision of sustenance in an unbroken bread-nexus. This mutual responsibility sometimes went beyond bonds of kinship to embrace other ethnic groups ensured that people upon whom others depended reciprocated when needed if catastrophe did not visit them all. The poor in African societies did not have to beg or ask for charity from the welloff people who were usually senior males in society. Instead, wealthy men were bound by duty to provide relief especially in times of dire need. It was a well-balanced system of entitlement through which people gained access to essential food supply. ${ }^{168}$

According to Dalton, the onset of colonialism resulted in the erosion of these attributes of African traditional society replacing the bread-nexus with the colonial capitalist imperatives of a cash-nexus with its insistence on the invisible forces of demand and supply of the prime necessities of life. ${ }^{169}$ The market, introduced by colonialism, became the dispenser of subsistence and sustenance. ${ }^{170}$ The cash-nexus with its institutional, policy and legal supports altered the relationship of people to food. Put differently, colonial capitalism altered and broke-down this relationship between people and food, which was enshrined in systems of power, property and law in African societies. ${ }^{171}$ Therefore, land, which was the basic source of subsistence and sustenance, became the central stage of the struggle for freedom and independence.

By the 1940s, traditional civic virtue was just but a myth, which began to mock the African majority rather than inspire. ${ }^{172}$ African father-figures, big men who were custodians of mutual responsibility and who had been entrusted with the welfare of the community no longer welcomed dependents. Indeed, with the atomization of what was organic communal organization, rapine individualism ensured the expropriation of dependents. Without land and having to sell labor, young men could ill afford food, housing or even dowry and so, they could not marry. This, ultimately, is what led to the growth of African political consciousness and agitation and, when grievances and petitions elicited no official response, the Mau Mau war in

\footnotetext{
167 Dalton, “Traditional Economic Systems," 71.

168 Thompson, Customs in Common, 286.

169 Dalton, "Traditional Economic Systems," 70.

170 Thompson, Customs in Common, 272.

171 Ibid., 287.

172 John Lonsdale, “Mau Maus of the Mind: Making Mau Mau and Remaking Kenya," Journal of African History 31 (1990): 147.
} 
the 1950s. The Mau Mau war ought to be understood against this broad context of the African experience of the social, policy and legal production of injustice and loss of dignity in the colonial political economy.

Transformation in the means of life, and how they were produced, exchanged and shared out, and the social institutions that the whole process gave rise to profound shockwaves in the African body politic. It affected the very quality of life. It affected what and how they ate, spent leisure time if at all they did, when and how they got married, and according to Ngugi wa Thiong'o, how they made love. ${ }^{173}$ Ngugi wa Thiong'o did not exaggerate the psychic impact of colonialism in Kenya. According to Thiong'o, British imperialism affected elements of African life that constituted a universe of moral significance and values that determined the quality of human life and dignity. ${ }^{174}$ After all, even to the British administrative cadres, it was rather obvious that the government interfered in most aspects the African's life: his land, his agriculture, his animal husbandry, his judicial system, his laws, his health and his education among a host of others things that came within the scope of government's activities of instruction and control. ${ }^{175}$ For Browne, this foreign domination was a force of disruption that had spectacular effect akin to gully erosion. Both colonial administrators and missionaries were agents of the disintegration of political and religious ideas augmenting the process of individualization. According to Browne, colonial capitalism and Christianity erected new boundaries that went beyond the family and ethnic groups resulting to social differentiation. As a result, African societies were damaged beyond repair. ${ }^{176}$

Further, Browne argues that what was once organic was transformed into the mechanical and artificial. African authority and power was vulgarized when councils of elders that once presided over communal affairs were replaced by chiefs. Offenders were punished individually and individual murderers were removed instead of making their clans pay up. Colonial agents introduced the outright sale by individuals to other individuals of land, labor and livestock. Individual taxation was introduced. So was cash, which did not breed, except in the post office,

\footnotetext{
173 Thiong'o, Writers in Politics, 67.

174 Ibid.

175 Browne, "The Vanishing Tribes of Kenya," 20.

176 lbid., 6.
} 
as the new medium of exchange. ${ }^{177}$ Cash crops, which were useless until when exchanged for cash, were now grown. The British also introduced individual identification of the African by a system which in their own homeland, they only found necessary for their warriors and their criminals. ${ }^{178}$

Yet, these individualizing efforts did not finish there as already observed. Colonial authorities used cunning policies in an attempt to detach from the family unit one of its important member: the cow. ${ }^{179}$ Afraid of overstocking produced by their insistence on scientific rather than spiritual values, colonial administrators did their best to destroy the cohesion between families by selling their symbols through auction and then acted rather surprised at African response to it all. ${ }^{180}$ Livestock was a sign of usufruct of land and insurance for children and grandchildren.

According to Browne, it was difficult for people like him who were brought up on individualism, to visualize its effects on a traditional economy based on reciprocity. Even more interesting, Browne thought that taking livestock by force was "tantamount...to the commandeering of entailed estates." For Browne, destocking through state agency, for example the police, was an act of war. But unlike cattle taken in war, African livestock taken through destocking were not replaceable. So there developed a state of strain between two loyalties - the African's customary respect of his in-laws and his imposed respect for colonial by-laws. ${ }^{181}$

Although it cannot be said that he had complete comprehension of the full measure of African colonial transformation, Browne criticized his own race for failing to discern the working principle and the institutions of which they were a function and upon which the integrity of African societies depended. He argued that when, through colonial agency, these institutions lost power, the principles which produced and maintained them were called into question, critically examined and since they failed to meet the new need, were discarded as no longer applicable. ${ }^{182}$ Browne thought that this was an unconscious mental process but it was nonetheless

\footnotetext{
177 Ibid., 3.

178 Ibid.

179 Ibid., 4.

180 Ibid.

181 Ibid.

182 Ibid., 1.
} 
real. In a sense, this did manifest itself in the rivalry between young Kikuyu men and big African men who were the traditional authority figures backed up by the colonial power structure.

Despite the fact that this tension was obvious since the late 1920s when colonial transformation was beginning to be felt, this quiet disintegration was obscure to colonial administrators. ${ }^{183}$ Since the British could hardly expect readily to realize the inapplicability of their own rules of life immediately to Africans, resistance and political opposition was explained in terms of obstinacy or racial backwardness of the ruled rather than lack of intelligence or imagination in the ruling. ${ }^{184}$

All this was somewhat clear to Browne and it worried him. Although Browne shared his sentiments with his superiors as evidenced in the existence of his manuscript in official colonial records and published in his book in 1925, it is obvious that his warning below went unheeded. Browne wrote:

Perhaps to the administrative officer the most disturbing symptom of the effect of the European occupation of East Africa is the evident disunity which it has induced in the native tribes, the weakening of the integrating forces, the less of the typically African theory of communal responsibility and mutual help, and of the spiritual principle of the continuity of the past, present and future....

Disintegration is to a certain extent inevitable whenever one race takes upon itself the government of another with a different economy. Local institutions are usually incapable of adapting themselves to new conditions without assistance, and that assistance is not forthcoming because the alien government is generally unaware of the strain to which the indigenous institutions are subjected and indeed frequently unaware of their very existence. ${ }^{185}$

Whatever one might call it; colonial wisdom, intelligence or imagination, it is obvious that the project of building the Kenya colony as a white man's haven had serious legal and policy flaws that the architects were either unaware of or simply ignorant about. What is more is that the rather obvious consequences of colonial laws and policies upon African subjects of the crown were dismissed as political agitation. The alienation of land and labor and erasure of the centrality of the cattle industry in African life had a deleterious effect on pre-European social networks and institutions of mutual obligation and reciprocity.

\footnotetext{
183 This perceptible internal ethnic tension has been comprehensively and extensively studied by Marshall S. Clough, Fighting Two Sides: Kenyan Chiefs and Politicians, 1918-1940 (Niwot: University Press of Colorado, 1990). 184 Ibid.

185 Browne, "The Vanishing Tribes of Kenya," 1.
} 
In turn, this took a psychosociological toll upon the African, which, in a final demonstration of arrogant ignorance after the outbreak of the Mau Mau, was explained by $19^{\text {th }}$ century science as either the African's anatomical deficiency or by theories of culture and personality purporting to account for his "backwardness." ${ }^{\text {"186 }}$ Mental health practitioners like the Kenyan pathologist F.W. Vint, South Africans D.J.F. Laubscher and Wulf Sachs, the French Algerian Antoine Porot and John C. Carothers who, between 1900 and 1960, regarded themselves as authorities on the psychology and behavior of African people, were influenced by the social and political context in which they operated.

Besides their ridiculous anatomical pseudoscience that sought to prove the supposed fundamental inferiority of Africans by adducing data on the morphology of the brain, these colonial psychiatrists ignored the fundamental springs of African political action. Indeed, they argued that the African's alleged moral and intellectual retardation legitimated the colonial political system designed to ensure a plentiful supply of unskilled, segregated, poorly paid laborers. ${ }^{187}$ It is significant that McCulloch, an anthropologist, demonstrated the dated nature of this ethnopyschiatry in its social and political context. However, in view of the foregoing discussion of African experiences conditioned by the oppressive colonial system, it is important to debunk the psychological explanations of Mau Mau by F.D. Corfield and J.C. Carothers. It is important to conclude this discussion of the experiential anxiety of African transformation in time, space and place during colonialism with a commentary on this blotch in colonial Mau Mau historiography. At the same time, it is equally important to do so with reference to recent $21^{\text {st }}$ century trends in the development of the discipline of psychology in order to appreciate the limitations of colonial ethnopsychiatry of the last.

In this regard, Carother's monograph, The Psychology of Mau Mau, is worth singling out for that purpose. Carothers did not dispute that there was a drastic transition that colonial capitalism initiated. He also stated that even European societies were prone to the fluid world of

\footnotetext{
${ }^{186}$ Maurice Lipsedge, "Colonial Psychiatry and 'The African Mind,'” BMJ 312 (1996):1167. This is a book review of Jock McCulloch, Colonial Psychiatry and 'the African Mind' (Cambridge: Cambridge University, 1995) that appeared in the medical journal, $B M J$. Originally founded as the "British Medical Journal," this publication is simply known as "BMJ." ${ }^{187}$ Ibid.
} 
probabilities in the age of industrial modernity. Such change caused social disorganization that was for the most part a phenomenon of a great transition. Great transitions, even in western societies, caused movements that broke up the social systems that controlled and integrated the behavior of people. As such, it was expected that when European influence impinged on the African, his whole cultural machinery was apt to collapse quickly. ${ }^{188}$ To his credit, Carothers recognized that Mau Mau arose from the development of an anxious conflictual situation in people who, from contact with the alien culture, had lost the supportive and constraining influences of their own culture, which caused individual and collective internal conflict. ${ }^{189}$

Carothers thus acknowledged that the great bulk of the population was, in a transitional state and that this was, indeed, psychologically the chief thing that could be said about African societies in Kenya. These then were the points of departure from which Carothers plunged into a lengthy consideration of what were the essential elements of African psychology in transition. ${ }^{190}$ In so doing, Carothers, who was one of the most progressive psychologists and an obvious leader in the area of transcultural psychology, deviated from objective psychological analysis thus tangentially failing to make a significant contribution to his discipline. As McCulloch observes, it is surprising and ironic that Carothers's progressive recommendations for culturally sensitive and humane delivery of mental health care, of which present day psychiatrists might approve, coexisted with racist notions of cognitive and moral inferiority. ${ }^{191}$

In his report of Mau Mau psychology, Carothers repeated insinuations of African racial and moral inferiority and intellectual underdevelopment first enunciated in his contribution, in 1940, to the East African Medical Journal entitled, "Some speculations on insanity in Africans and in general." In the article, he had argued that the African, like adolescents and like European people with schizophrenia, lived in a world of fantasy which he projects on the outside world, while denying personal responsibility for his own actions. In his work, Carothers provided a rationalization for conventional white settler beliefs about "the African." One of the key weaknesses of Carothers's work was his reliance on child rearing practices to explain both

\footnotetext{
188 Carothers, The Psychology of Mau Mau, 6.

189 Ibid., 15.

190 Ibid., 7.

191 Lipsedge, "Colonial Psychiatry."
} 
psychopathic traits and alleged intellectual deficits, including an apparent lack of logic and abstract thought. ${ }^{192}$ In the Psychology of Mau Mau, Carothers attributed the war to the upbringing of Kikuyu men who were spoiled in their early childhood. African infants, Carothers stated, were suckled for a lengthy period, often up to two or even three years. Devoted mothers carried the African male child wherever they went, and handled him with confidence, pandered to all his whims, and fed him on demand. He was thus, for a long period, indulged to a fault and, although his ultimate weaning was relatively abrupt, he must have carried into later life some vague remembrance of a blissful time when the world responded to his slightest whimper to satisfy all his desires. ${ }^{193}$

There was thus, Carothers concluded, a tendency of viewing the past as a Golden Age, hence the need to try and put the clock back. Colonial administrators and white settlers had Carothers to thank for what became one of the most popular explanations of Mau Mau that was broadcast around the world: it was an atavistic movement of crazed nut heads. Put differently, Carothers, while admitting the destabilizing impact of colonial agromodernity, urbanization and erosion and corruption of indigenous African principles and institutions which caused anxiety, argued, at the same time, that Africans had not lost their "magic" modes of thinking. Carothers' report emphasized the role of animistic and magical modes of explanation in producing a childlike mentality and molding the "psychopathic" character of the nationalist rebels, while ignoring the fundamental cause of the Mau Mau uprising, which was the misappropriation of Kikuyu land. ${ }^{194}$ But this is not the basis worth indicting Carothers's judgment because, as stated, he was a product of the social and political context and the times in which he lived.

However, what is worth putting under the microscope is the psychological paradigm of radical or critical psychology within which his work was, approximately, premised. This psychological framework locates the source of distress firmly in the structures of society that lead to oppression and concerns itself with proposing interventions aimed at preventing these from occurring. ${ }^{195}$ That this was the paradigm that informed Carothers is evidenced by Llyod's

\footnotetext{
192 Ibid.

193 Carothers, The Psychology of Mau Mau, 10 \& 11.

194 Lipsedge, "Colonial Psychiatry."

195 Laura McGrath, Paula Reavey and Steven D. Brown, "The Scenes and Spaces of Anxiety: Embodied Expressions
} 
insightful observation on the top-down acceleration of agricultural capitalism and colonial visions for rehabilitation in the wake of the Mau Mau war. Llyod took note of the startling paradox of the colonial visions for reform and a "modern" Kenya, which endorsed the idea that supposedly "detribalized" Kikuyus would be "cured" through a state-organized attempt to "retribalize" them. That is, the attempt by colonial authorities to send them back in time to an idealized communal, agrarian "past," in which they would reconnect to the peacefulness of their "old lives" by being surrounded by their families and elders. ${ }^{196}$ Llyod traced this romantic notion that Kikuyu communities could be teleported back to a prelapsarian existence arranged around the "village" back to both Carothers and Leakey in their contributions to understanding the Mau Mau crisis. ${ }^{197}$ As such, colonial psychology and psychiatric analysis failed to do justice to the particularity of distress and the complexity of the anxious experience wrought by colonial transformation of African societies. It did not go far enough to understand what produced this anxiety and distress because the analysis was dimensional, reductive and generalizing. ${ }^{198}$ For this reason, it is important to revisit this matter with the aim of better understanding the African colonial experience. In so doing, advances and new approaches that have since taken place in the field of psychology must be reflected and employed. What follows below is a brief probe into the manner in which this can be done and thus debunk and deconstruct biased and dated explanations discussed above.

\section{The Imperial Catastrophe of Relative Deprivation: Towards an Understanding of Narratives of African Discontent}

It is imperative and necessary, in light of the foregoing, to employ recently developed analytical approaches for a better understanding of, not only Mau Mau psychology but, also, the experiential cauldron from which was born the spirit of Kenyan nationalism and the struggle of independence. At a very rudimentary level, it is possible to examine, and therefore understand and appreciate, the African experience through the Maslowian North American humanistic

\footnotetext{
of Distress in Public and Private Fora," Emotion, Space and Society 1 (2008): 56.

196 Thomas Llyod, “Making 'Mau Mau': Remaking Kikuyus; Remaking Kenya?” Paper Presented at the Researching the Colonial and Postcolonial Workshop, 41. The emphasis in italics are the current author's.

197 Ibid. Some keen obervers would argue, aptly, that the same can, and should, be said of Browne's analysis in the 1920 s.

198 McGrath et al., "The Scenes and Spaces of Anxiety," 56 \& 57.
} 
dialectic. That is, seeing African's bitter "experience" as the cumulative inner complication of a structure of needs over the course of life. ${ }^{199}$ In this sense, the continued frustration of Africans as they struggled for the basic necessities of life including food, water sources, dwelling space, shelter, pasture and salt-licks for their livestock; a quality, secure and stable livelihood, selfmastery and agency, dignity and respect; and freedom from fear led to anxiety and mounting petitions and call for redress, which, when unmet or unsatisfactorily addressed, led to armed resistance. But this is a rather simplistic and outdated analysis. Recent developments in the discipline of psychology have made it possible to come to an even more complex understanding of the psychology of oppression and experiential anxiety that produced amongst Africans a mentalité. Deleuzian scholarship is a good case in point.

Deleuzian scholarship, which derives from the work of the French Philosopher, Gilles Deleuze, has gained a lot of currency in the last decade. It presents a more complex understanding of human experience suggesting that it is best grasped as a form of multiplicity. ${ }^{200}$ In this sense, human experience constitutes of different but mediated parts or planes that are irreducible to one another. There are, therefore, a multiplicity of intersecting forms or planes of experience including the psychological plane; the spatial plane; and the social plane etc. The total sum of experience is equally affective, spatial, embodied, material, technological and so on. ${ }^{201}$ As such, what colonial psychiatry, using the unidimensional approach, narrowly called "psychological" referred to only one set of a multiplicity of planes of experience.

Put differently, the picture presented by colonial psychiatric analyses of Mau Mau was not only biased but also severely limited in its methodology. Limited as it was in its approach, colonial psychiatry was blind to intersecting planes of anxiety that made up the sum of the African colonial experience. Deleuzian analysis, then, should be deployed to scrutinize the actual African emotion that drove anti-colonial "resistance" and "nationalism" in Kenya and elsewhere. African societies found themselves being encroached by a harsh colonial policy and legal edifice

\footnotetext{
199 Ibid., 58.

200 Ibid., 57 \& 58.

201 Ibid.
} 
that produced an unfamiliar socioeconomic and political environment that they found difficult to navigate.

The crown land ordinances (1902/1915), for instance, shifted the ownership of land, previously an immovable public common, from Africans to the British crown. Further, it meant the physical removal of Africans and their livestock out of their physical spaces of habitation. This appropriation of land also meant that Africans had limited access to agricultural land, and therefore, denied their basic source of subsistence and livelihood. This had serious impingements and repercussions on their existence in as far as the physical space namely, land and other associated aspects of life such as the cattle complex, rivers, wells, salt-licks, forests etc. that together, formed their basic subsistence and acted as integral life-supports.

At the same time, the colonist, imbued with authority, promoted and reinvented the physical landscape to suit his/her own modern tastes. This meant even more evictions as the colonist installed the physical apparatus of empire and modernity namely game reserves, roads, the railway, harbors, new towns, forts and stockades, plantations among other incursions on the landscape. These were constructed at a heavy cost for the pre-European African socio-economic order. ${ }^{202}$ This also marked the arrival of "modernity" and the introduction of "relative time," the Western measurement of absolute time, an instrument effectively employed to extract African labor in hours'-work days. Moreover, it resulted in the creation of a world that emphasized the economic imperatives of the colonial capitalist market and monetary system with its strict insistence of honoring partial justice to the right of property and wealth. This was at the expense of, and out of balance with, natural humanity of ordinary laboring African people. ${ }^{203}$ The resultant colonial modernity, guarded by the usurpation of power, a racial hierarchy and deployment of violence, was one of socioeconomic inequalities in which settlers sat, prim and exclusively, at the top of the coterminous material conditions of life.

\footnotetext{
202 Glenn Hooper (ed.) Landscape and Empire, 1770-2000 (Burlington: Ashgate Publishing Company, 2005), 5, 8 \& 9.

203 Thompson, Customs in Common, 268 \& 274.
} 
The situation of colonial oppression and respective material well-being was manifest in space and place. On the one hand, the colonist settler resided in spacious houses in exclusive wealthy neighborhoods. Suburban streets were clean and brightly lit with well-manicured trees lining either side; there was seldom any litter thanks to cheap African labor; material objects and signifiers of modern sophistication including parked cars or bicycles reflected peace, order and organization; and seldom did the well-fed and well-dressed people, either in the huge boulevards or the spacious houses, feel hemmed in or crowded. In such neighborhoods, people were cordial and helpful to all as long they fit the requisite characteristics, usually racial. ${ }^{204}$

On the other had were congested workers quarters where one or two African families shared a single room and ghettoes or informal settlements where the oppressed lived in dilapidated tenements, hovels, and shacks. The streets, if paved, were rough and full of potholes, forbidding because they were poorly lit and dark; garbage collection was sporadic and there was litter everywhere; and one could catch a glimpse of the ill-fed and badly dressed denizens of such places. Their rural counterparts were crowded in "reservations" that served as a source of cheap labor. In both urban and rural settings was to be found squalor, the sight of malnourished children, poverty and disease and, for that reason, death hung in the air. ${ }^{205}$ African colonial societies in Kenya were a living specimen fossilized in impoverished, marginal and diseased spaces and places set in rosy background of a colonial modernity to which they contributed, but from which they were discriminatively shunned.

All the above, the institutionalized violence of the colonial conquest state (military, paramilitary and police); and the legal and policy architecture alienating both land and labor as well as imposing other strictures such as the movement of Africans, food and use of natural resources such as rivers and forests, was all part of a systematic negation of the African that denied him all attributes of humanity. What this meant was that, at different planes of experience (time, space and place), most Africans suffered experiential anxiety as a result of imperial transformation. Colonization was, for the majority of them, a catastrophe. For many, this was not the only catastrophe. Racial discrimination exacerbated this experience. Some could have

\footnotetext{
204 Bulhan, The Psychology of Oppression, 141 \& 169.

205 Ibid.
} 
afforded and been able to gain a place amongst the settlers because their education and socioeconomic means allowed them. They were, nevertheless, denied an equal place or share in the barefaced and racialized hierarchical modernity.

In particular, land alienation stood out as brutal and inconsiderate kind of spatial injustice. It is, therefore, important to reiterate here its psychological impact it must have had on Africans. At the height of the Mau Mau war in the 1950s, a leading settler politician, Lt.-Col. Ewart Grogan, proposed, in a legislative council debate concerning the progress of the Emergency, land alienation as weapon that, if employed, was sure to end it. For him, it was the only one weapon that was likely to have "the slightest effect" by providing a massed psychological shock to the Kikuyu ethnic group as a whole was the land. ${ }^{206}$

Grogan suggested that in the case of "treason" and "rebellion" such as the Mau Mau uprising, the crown reserved the right to bring the whole or part of the land unit back to the category of crown land. Then every single inhabitant would know that he was personally subject to the crown. But, more importantly, he clarified, Africans did not think of anything else except land. That was because their roots were in the land-everything derived from the land. The whole "tribal system" was like a tree that spreads from the land -the title of the land- and it was the very symbol of authority. Taking it away as punishment against the Kikuyu would, therefore, provide a massed psychological shock. ${ }^{207}$ This is an important and instructive point. The said desired psychological shock with respect to exaction of "deserved" punishment in the 1950s was a miniature of the old colonial plot of the "legal" alienation of African lands in 1902 and 1915. It had the same effect as the unwarranted illegal and systematic deprivation of a resource from which everything through the crown land ordinances. Indeed, the latter was even more detrimental considering that it was not "deserved" or "punitive." This point helps underscore the primacy of land alienation as, perhaps, the most painful plane of experiential distress.

The primacy of land among other resources cannot be underestimated in as far as it defines self-mastery or competent living and the efficacious security of livelihood. According to

\footnotetext{
206 Legco. Deb., LXIII (21 ${ }^{\text {st }}$ October 1954): $341 \& 342$.

207 Ibid.
} 
leading scholars of personality and the social branch of psychology in general, and Subjective Well-Being (SWB) in particular, societal resources, such as land, at people's disposal allow them to make progress in achieving their goals and enable them to lead a life of satisfaction and affective well-being. In this emergent field that studies people's cognitive and affective evaluations of their lives, it is suggested that income and human rights correlate with SWB because they affect the ability of individuals and communities to achieve diverse goals. ${ }^{208}$ Control of land among other vital natural, human and financial assets is, indeed, at the center of basic human rights and dignity. The loss of this central resource by African societies produced the mentalite of struggle across the board the only difference being its degree of ferment. This spirit questioned the colonial situation and order that engendered the psychology of oppression. This mental attitude of discontent and criticism of the colonial order was lodged in the African mind by the end of the second decade of the $20^{\text {th }}$ Century. Among the Kikuyu, this pyschosociological ferment came to violent fruition in the early 1950s. It is important to observe that it was quite self-evident as oppressed Mau Mau minds in chrysalis elsewhere in the colony. This is an argument that merits exposition.

\section{The Production of Mentalité of Struggle: Mau Mau Minds in Chrysalis}

The foregoing discussion above has been an attempt to approximate the African experience of ordinary people in the process of engaging everyday realities of colonial life, space and time. It demonstrates that African anxiety emanated from the world into which pre-European societies had suddenly been thrust. ${ }^{209}$ British policies and laws reconfigured space and social reality to suit imperial tastes. The inherent telekinesis of colonial capital moved African societies forward in time. The colonial landscape of roads, railway networks, harbors, forts, electric plants, townships and trading centers was strange and had created an altogether different set of problems to which Africans were unaccustomed. It simultaneously baffled and outraged the

\footnotetext{
${ }^{208}$ Ed Diener et. al., "Factors Predicting the Subjective Well-Being of Nations," Journal of Personality and Social Psychology 69 (1995): 851.

209 This is not to assume that there were a few "privileged" Africans who took advantage of, and thrived under, the new colonial order through various avenues (education, hard work, luck, beneficiaries through working closely with the colonial administration as chiefs, clerks, interpreters etc.). As earlier noted, however, this does not mean that they were absolutely content or equal with their white counterparts in every sense in the racially ordered hierarchy of colonial modernity and rural agrarian production. Indeed, most grievances of this class of Africans more often than not overlapped with the majority of people.
} 
African mind, and destabilized meaning and certainty. ${ }^{210}$ The legal and policy architecture, the falling apart of the African social fabric and the ensuing struggle over the morality of social differentiation was tragic for colonial societies. This is what the Mau Mau war was about. The war was a demonstration of the desire to reconfigure the ordering of the colonial state favorably. Certainly, it was a war of decolonization in which the demand of the colonized Kikuyu freedom fighters had one basic demand: the whole social and colonial structure being changed from the bottom up. ${ }^{211}$

As such, it was not inspired by the mental derangement of young Kikuyu men. ${ }^{212}$ This colonial rupture, characterized as it was by experiential anxiety in the process of transformation in space, place and time, constituted a profound psychic shock. When it was accompanied by the knowledge and experience of inequalities in what had become, in effect, white man's land, the ensuing envy and suspicion ensured that the shock passed into desperate fury and unrelenting outrage. ${ }^{213}$ It is important here to ponder on the expression of emotional distress occasioned by imperialism. As there exists no documentation in terms of diaries of individual experiences or communal narratives of discontent, the existing vocabulary of that could have been used to express the range of emotional distress has been relied upon in this study in its endeavor to reconstruct this unique but undocumented past. For the most part, this range of the vocabulary of emotional distress is related to the impact of the loss of land on African life in general.

Before, British incursion, land was always there like the air. It was the pre-European "bank" and "office" from which African societies not only drew sustenance, it was the cow that gave sustenance. In 1927, Lieutenant Colonel O.F. Watkins, a self-taught student of indigenous tenure, warned a group of Africans living ten miles outside Nairobi that colonialism that land titles would mean the creation of "barons" who would own the land on which the rest of the people would merely live until they were turned off. The African response had been that of incredulity: there was that roar of uncomprehending laughter. Europeans could not possible turn

\footnotetext{
${ }^{210}$ Hooper, Landscape and Empire, 1770-2000, 4.

${ }^{211}$ Frantz Fanon, The Wretched of the Earth (New York: Grove Press Inc., 1963), 29.

212 Lonsdale, "Mau Maus of the Mind," 147.

213 Thompson, Customs in Common, 257.
} 
them off, where would they go ${ }^{214}$ But they did: mother earth, which was the breast from most African societies suckled, had been rudely whipped right out of their mouths. The most important thing had been taken away from them. This is the kind of thing, the Kikuyu understood, that caused them to give out a heartrending cry because it could only mean one thing, "ng'aragu" (starvation). It was, as such, no small deprivation.

This caused great afflictions and occasioned insuperable distress. African hearts were as though dead. Colonialism, therefore, in as far as it affected land was "uriru." It was a calamitous catastrophe, a matter of great consternation, fear and bewilderment. Its impact must have also been thought of as "gicanjama": a calamity that was a cause of wonder. Its attendant policies such as the exaction of taxes, issuance of passes and individual registration, the spatial "organization" of the physical landscape into administrative units and African reservations and alienation of labor brought about "nduikano": a strain of pre-European social relations, values and virtues that brought them to a "breaking-point." Thus, British colonialism brought about "nduikaniro," a "snapping-point" or rupture of the old social and economic order of the past.

Moreover, the brutal application of these unjust laws and policies and measures of control and exploitation with an air of racial superiority was mortifying. The ultimate effect was that Africans felt that they had been heinously cheated, made a mock of, hated and looked down upon. The hallmark of this kind of treatment was dispossession. The majority of Africans, who were peasants, urban proletariat or house servants, were subjected to work in undignified conditions and treatment. Whereas before colonial times there were individuals or bands that wandered about aimlessly, with the creation of "rithafu" (the African reserve) and "rokiconi" (location), Africans oftentimes now found themselves butted by the law because of "vagrancy" After all, their movement, under colonialism, was constrained to specific administrative units. Not only were people dispossessed, but also constantly moved or displaced as well as constrained and confined in congested spaces. Overall, Africans were an insulted and scorned people whose inheritance had been swindled and their living spaces, houses and villages, occupied by white strangers. Under colonialism, life was an unfair and difficult burden.

${ }^{214}$ O.F. Watkins, “Land Tenure: A Reply to Dr. Leakey," East African Standard, October $27^{\text {th }} 1939$. 
Within a very short period of time, Africans had become like orphans who now had to buy water and fire wood among other essentials with money. This whole range of emotion and bitter experience is expressed through various derivatives of the word "nyarira," which means to be plundered or squandered. Under the weight of the imposition of this oppressive system, the Africans let out "mисаауо," a great groan or moaning in individual and communal angst and pain that they expressed in persistent cries, as prayers and petitions to the colonial authorities for redress. As the "anyamari," people under great suffering, poverty and destitution, they hoped that their cries for help would elicit timely, fair and just colonial redress that would ease their pain. This kind of experience of poverty and suffering, in and of itself, was enough for Africans to be a tinderbox of latent agitation that awaited an explosive combustion especially when and where it did not evoke empathetic and timely response.

Such words constitute an emotional register of colonial hardships and experience. It was, therefore, only natural for Africans to agitate especially with regard to issues such as land, more pay, taxation and individual registration among others. Their consistent petitions and outcry most of the times went unanswered or, when it was, it wasn't satisfactory enough. After all, under a racial regime, they were third rate "citizens." As a matter of fact, they were subservient colonial subjects. This, then, was the early beginnings of outrage, anger and African discontent against the oppressive colonial system. This mindset or attitude of struggle against the system in chrysalis finds validation in the manifestation of the same profound experiential distress in other ethnic groups caught up by the same colonial situation and social reality of grievous loss and deprivation. Put differently, other ethnic groups in the colony exhibited the same register of emotions that confirms the existence of a similar psychology of oppression and mentalite of struggle in formation. The following section below explores this sense of outrage and Mau Mau minds in chrysalis among the Luo and the Luhya.

\section{Languishing Minds: The Psychology of Oppression Illustrated}

The outrage with the colonial system, the desire for redress and justice, and psychology of oppression was widely shared in Kenya. Members of the Kanyakwar Luo clan, for example, made it clear that they sure would have, from the very start, given their lives for their land were 
it not for the fact that the British possessed the most formidable and latest weapons. ${ }^{215}$ With bitterness, they complained to the KLC in 1932 about merciless dispossession of Kanyakwar lands of Migosi, Nanga, Pandpieri, Dakakuoga and others that were transformed into the Kisumu Township with the passing of the 1902 and 1915 land ordinances. ${ }^{216}$ They appreciated British civilization but they argued that it did not solve the question of land which was the sole means of their livelihood. They regretted that their woes in this regard had started with a simple agreement between them and Charles W. Hobley who had asked for a small portion of Luo land at Kibuye to erect a government boma. They never thought it important to keep a copy of the agreement with Hobley since they never suspected that the word of a white man would be changed. Those testifying claimed that people really believed what they were told about the British: that they were the symbol of peace, justice, light and liberty. ${ }^{217}$ In the end, however, they had been dispossessed and left in a desolate state, being deprived of their ancient land, and thus denying them of their liberty and freedom that they had enjoyed for centuries. They were even forbidden to hold any gathering in their own area or collect funds to enable them to make necessary representations beneficial to them. This was whilst, in reality, their motive was to express their great feelings only. ${ }^{218}$

At the same time, another group of Luhya elders lamented that the amendment of the Native Lands Trust Ordinance, 1930, was contrary to the best interests of the community. They strongly protested against it, pointing out that when the government of Kenya enacted laws, no provision was made for African land security until this law which definitely promulgated African reserves. Under this proviso, as per section 2 (1) of the ordinance, their understanding was that designated reserves would be for the exclusive use of the Africans forever. However, any proposed law, past and present, and their revision, they felt, always by-passed the native authority. This they argued was inconsistent with common principles of justice and moral fairness of the British Empire. Certain sections of the law in question, they noted, were being repealed with regard to compensation by substituting money in lieu of land leaving the

\footnotetext{
215 "Members of the Kanyakwar Tribe" to the Carter commission, $7^{\text {th }}$ September 1932, Great Britain, Kenya Land Commission Evidence, 2152.

216 Ibid., 2151.

217 Ibid., 2150.

218 Ibid.
} 
petitioners in great distress. Moreover, money, they argued, could not fully compensate the land taken. $^{219}$

It was believed, furthermore, that the colonial administration had reneged on the pledge that reserves would be for their exclusive use because of its gold mining potential. The petitioners said that this land was their safeguard of the last resort and upon which their only hopes were pegged. They were especially in great distress of mind owing to the overflowing number of more than a thousand Europeans into north Kavirondo in search of gold. ${ }^{220}$ This led to overcrowding in an already congested area causing fear that their fate would be like that of Johannesburg in South Africa where Africans had been rendered landless or had very little land if any. For this reason, they were dreadful of the consequences that would overtake their agricultural life. There were resettlement difficulties already for individuals targeted to be disposed of their land for gold mining purposes. It was clear to them that their present and future needs had not adequately been provided for. Further, they also feared the breakdown of the African social fabric as good old customs and traditions inherited from their forefathers were eroded. $^{221}$

The same issue of compensation was a great concern for the Luo elders of Kisumu location among them chiefs Nikodemo Okore and Oliech Obiro, Osiro Opinya and Olang Ogada. Assisted by H.W. Innis, they complained that land that they had inherited from their fathers was continually being taken from them. In 1907, 462 acres of Luo land was given to the B.E.A Corporation as a result of which, some five-hundred people were obliged to give up their homes without compensation. They lamented that they not only lost their land and homes but also the graves of their ancestors, which had been left in the hands of strangers. This injustice, they intimated, continued to rankle their hearts as many of those who were driven off were still without land and had been compelled to make temporary homes elsewhere. ${ }^{222}$

\footnotetext{
219 "MEMORANDUM. Copy of Petition addressed to the House of Commons by Kavirondo Natives," Kenya Land Commission Evidence, 2137.

220 Ibid., 2138.

221 Ibid.

222 This is yet another memorandum from the Kanyakwar clan entitled, "The Elders of Kisumu Location," Kenya Land Commission Evidence, 2143.
} 
Specifically, they explained that their Kisian River land was now in the possession of an Indian. Two acres of this land at German Point had also been allotted to a Dr. Harloff who did not even live there yet they were deprived of its use. Moreover, they had also been deprived of a considerable area of grazing land which the Europeans of Kisumu appropriated for a golf course, trespass of which had some people prosecuted when their cattle or goats were found grazing on it. $^{223}$ Another one-hundred acres of land at Ojolo was, in 1906, given as a mission station site to the Roman Catholic Mission. In addition, land was also appropriated by the government for an aerodrome and more yet for a branch of railway that cut through the African reserve not to mention that earmarked for roads. ${ }^{224}$ According to mzee Osiro Opinya, the aerodrome alone had displaced three villages even after the governor had assured people that they would not be moved again for whatever reason. But since this promise, they had been moved four times, which eventually rendered them landless with nowhere to cultivate. ${ }^{225}$

While the Luo elders did not object to the necessary building of infrastructure, they pointed out that the reserve was already too small for the growing population and herds. Therefore, they hoped that His Majesty King George's government would consider the petition and restore Luo land and establish boundaries as their forefathers had left them. After all, had they not given themselves even unto death in defense of the Empire during the Great War and in the event of another war or any other needed service, wasn't their pledge of their faithful allegiance assured $?^{226}$ Despite these entreaties, little if anything was done to remedy their woes.

Closely related to the issue of compensation and resettlement was the complicated issue of transforming land tenure. The Native Chamber of Commerce, representing Central and South Kavirondo districts of Nyanza Province, protested that individual land title was not only complex and foreign to the African mind but also very expensive and its results ruinous to them. ${ }^{227}$ Their petition to the KLC argued that the initial costs of individual grants of title were too high and out

\footnotetext{
223 Ibid.

224 Ibid.

${ }^{225}$ Oral testimony given by Osiro Opinya to the Kenya Land Commission at Marenyu, Kenya Land Commission Evidence, 2172.

226 lbid.

227 "Memorandum. The Native Chamber of Commerce," to the Kenya Land Commission, 6th September 1932, Kenya Land Commission Evidence, 2144.
} 
of proportion to the capacity of average Africans not to mention the subsequent costs of transfers entailing heavy and legal stamp and registration. All this also meant that without proper safeguards, wealthier individuals and individual subgroups of the Luo people could legally dispossess the poor subgroups and individuals. Land, the chamber argued, was better organized under the old land holding system of communal ownership. Any departure from it would result, it was feared, to detribalization and the breakup of the social fabric of natives and economic ruin. ${ }^{228}$ One of the disadvantages of individual titles, they observed, would be Africans ceasing to think of the tribe as a whole. Instead selfishness would develop in the African's character. Subsequently, any imaginary encroachment in grazing area of agricultural shambas would be contested in the spot and in frequent cases of bloodshed and family would ensue.

\section{Conclusion}

From the articulation of grievance above in other regions other than Central Province, the region that was rocked by Mau Mau war, it is obvious that the experiences that over a long period of time fermented the trouble of the 1950s were shared and widespread. The cracks in the colonial edifice were obvious and well documented in numerous communications of African hardships and challenges especially with regard to land and the restriction of movement. If anyone was acutely aware of this national ferment of grievances, it was the colonial establishment in Nairobi and in London, where the government from time to time recommended commissions of enquiry into African problems. They were the chief architects of the colonial project that had caused untold suffering to the majority of Africans. If anyone knew and "understood" the concomitant African discontent and narratives of suffering, it was the British authorities.

They, therefore, had it long coming and, besides, they had the benefit of the attenuated imperial history of conquest and domination. From the outset, they expected such ferment of discontent to occur and manifest widely across the colony and elsewhere. This is one of the reasons exclusive political organization and ethno-regional administrative units were important: to avoid crosspollination of narratives of discontent. The British knew that the Mau Mau war was

228 Ibid., 2145. 
not an isolated case. Furthermore, they knew, but did not acknowledge it then or since, that it was not a case of Kikuyu social atavism. That they were able to portray it as such, it must be said, is a great propaganda success. Colonial records show all this, especially the apprehension that the war would ignite a colony-wide inter-ethnic anti-British uprising. It is on record that there was an attempt, as early as the 1920s, to link the frustrations and grievances the Kanyakwar clan pertaining to land with similar discontent among the Kikuyu.

The Kanyakwar clan had contact with the Young Kikuyu Association as early as the 1920s. Wakenya Abutho told the Carter commission that the Pinyowacho, a Luo movement, had collected money for petitions at the time of the "Kikuyu riot" in Nairobi in 1922. After this, the clan had sent one of their educated sons, John Odele, to Nairobi where he had private discussions with officials of the Young Kikuyu Association about the plight of the Kanyakwar. Abutho even stated that the Kikuyu Association had given Odele, the Kanyakwar clan treasurer, a cash donation. ${ }^{229}$ What is also even more interesting is that, like the Kikuyu, the Luo viewed land as their mother. In his testimony to the Carter commission, Aduse s/o Nyandoje told the KLC that a mother nourished her children with milk. ${ }^{230}$ The sense and degree of deprivation especially as it related to land was shared but at different extent of ferment as a socioeconomic grievance.

As such, the Mau Mau war was to the British a troublesome manifestation of economic malaise that was deeply felt in British colonies and even in at the very heart of empire during and after the Second World War. For both Nairobi and London, it was a warning flash behind which was illuminated haunting shadows of widespread discontent in British colonial holdings in East Africa. The similarity of experiences and African grievance that had led to the Mau Mau moment in the 1950s was aptly captured by the royal commission on East Africa. Although it was never made available to the public, this commission's investigations revealed Nandi, Kipsigis, Luo, Luhya, Somali and Kamba Mau Mau minds in incubation. The only reprieve being the administrative genius of governing geoethnic regions as sanitary and exclusive units that prevented the cross-fertilization of radical Mau Mau methods across the country and region. The

\footnotetext{
229 Ibid., 2155.

${ }^{230}$ Oral testimony given by Aduse Nyandoje to the Kenya Land Commission at Marenyu, Kenya Land Commission Evidence, 2169.
} 
next chapter will be devoted to an extensive discussion of Mau Maus of the mind of other ethnic groups other than the Kikuyu in Kenya as documented in the material collected by the Hugh Dow commission against the backdrop of the Mau Mau war in the 1950s. 


\section{Chapter IV - '52 Minds on Kenya's Destiny: The view from "the above"}

\section{Preamble:}

I do think it is time that a stern warning should be issued to the Africans....To slow down African ideas and hasten up European ones. ...Antagonists, black, white and brown, long ago perceived that the destiny of Kenya will be decided in Fleet Street, in Grub Street, in Westminster, Washington and the Kingsway Hall ....

The African would eventually have a very raw deal ...I think he would probably eventually be reduced to the remoter places in the territories much as peoples equipped with inferior qualities have in other countries. In other words I think the impact of western development would far outrun the capacity of the African to equip himself to stand up to it.

Letter to Michael Blundell from Kendall Ward, 26th April 1955. 


\section{Introduction}

This chapter is a significant part of what makes this study of the Mau Mau war rather unique, unusual and, therefore, unprecedented. That is in the sense that it has little to do with the actual "shooting war." Rather than discuss the war of the forest and the antagonists involved: British forces and divided Kikuyu opinion and ideological divide between Mau Mau fighters and so-called "loyalists," it explores and aspires to map-out a comprehensive view of African Mau Maus of the mind. I have endeavored herein to extensively identify and examine the bulk of evidence that illustrates that African discontent and potential for dissent was somewhat uniform across the colony and elsewhere in British East Africa.

Put simply, African colonial subjects had suffered from the colonial experience characterized by rupture of the pre-European socio-economic and political order and fabric with its safe-supports of mutual responsibility and self-mastery; dispossession with regard to land, alienation and exploitation of labor and proletarianization; marginalization and discrimination in the political arena despite being the majority; and the legal and policy strictures that, in the main, affected their relationship with, and access to, food, thus driving the cost of living beyond their reach. I boldly assert that there was, besides the physical Mau Mau of combat, a comparable and identical ideological twin of discontent, the Mau Mau of the mind.

There is, therefore, no drawing a line between the kind of strong experiential struggle that drove Mau Mau fighters to take arms and the deep-seated distaste with the colonial status quo safely concealed in forever hopeful minds that, entreaties and petitions directed to the colonial administration and London, would eventually alleviate the struggle of precarious everyday living. These pleas and prayers of the African population are well-captured by the East African Royal Commission (1953-1955) chaired by Hugh Dow, which assessed the situation in the region against the background of the physical Mau Mau combat. This commission helped to uncover grievances that the colonial state had allowed to simmer in the minds of suffering Africans and that the Mau Mau war acted upon.

In large part, this chapter unpacks and scrutinizes this body of evidence that illumines the shadowy outlines of African anguish and discontent concealed and limited to the realm of thought and suffering borne with stoicism. Besides this main aim of the chapter, I argue that hard times imbricated both the metropole where they were a continuation of war rationing, and the 
Britain's East African Empire. I also offer a brief review of the harsh and high cost of living in Kenya towards the end of the 1940s and at least two relatively objective assessments of the situation in East Africa in the early 1950s by independent socioeconomic and political analysts. These precede the obstructionist and obfuscating official explanation of the Mau Mau war by both Nairobi and London to the rest of the world. I briefly dwell on how colonial and imperial propaganda played out in the court of world opinion vis-à-vis Mau Mau especially in the manner that it was reported in newspapers around the globe. It is against this background then the material evidence and testimonies gathered by the Dow commission is unpacked and examined. Lastly, I discuss what it really meant to "defeat Mau Mau:" that is, through the colonial policy responses and reforms that it occasioned. In the main, it is argued that the war was waged against colonial injustices and succeeded in revealing associated ills and moral corruption of the system. However, it the same time, it also presented an opportunity for an imperial re-think of the colonial project, which was successfully repackaged with the result of strengthening the colonial state, which succeeded itself after independence.

As already suggested, the Mau Mau war was a lightning rod behind which, lying hidden, were shadows of discontent in the 1950s with their roots in the deep colonial past. These Mau Maus in mind and lineage of dissent was uncovered and captured by the East African Royal Commission (also referred to as the Dow commission) that was appointed in London at the behest of Sir Philip Mitchell, the Governor of Kenya, to investigate the social, economic and political conditions in the region. It is quite disappointing that the Dow commission's report was disproportionately thin considering the enormous amount of submissions amassed especially from hopeful Africans. Following the report's publication, British commentators in government and among the public debated its proposals. Left-wing critics denounced the document as a freemarket tract that proposed exposing Africans to the full blast of an agricultural and industrial revolution, similar to that which had inflicted suffering upon British workers in the nineteenth century, without attempting to cushion the effects. ${ }^{1}$ According to Hood, Africans presented to the commission contending historical narratives explaining the past, present, and future of East Africa. African witnesses took the opportunity to address the state, demanding redress for the

\footnotetext{
${ }^{1}$ Andrew James Hood, “Developing the East African: The East Africa Royal Commission, 1953-1955, and its critics" (Ph.D. dissertation, Rice University, 1997).
} 
injustices of colonialism. However, in their report, the commissioners suppressed the African dissent, largely ignored settler demands, and privileged much of the official narrative. The commission presented colonial development, achieved through multiracial cooperation, as the hope for East Africa's future. ${ }^{2}$

Put differently, the report revealed the full extent and intensity of African grievances in Kenya the language and tone of which echoed that used in numerous petitions of various groups of aggrieved Kikuyu and other Kenyans since the 1920s. The Dow commission was inundated by numerous humble and honest disclosures of simmering discontent and endured colonial hardships. In London, the report must have read as an imperial checkmate and end game, but various submissions and petitions were even more revealing. The view of the socio-economic and political conditions in East Africa in general, and Kenya in particular, from above was a sobering dose of reality especially against the spectacle of the Mau Mau war.

Based on a collection of African testimonies of suffering, this exercise by the Dow commission revealed an array of Mau Maus minds in chrysalis. The material collected by the commission illustrated the replication and production of Mau Mau psychology out of the colonial experiential cauldron, the only difference being the degree of ferment and the extent to which imperial subjects were willing to go to seek redress. The Dow report collected evidence from aggrieved individuals and groups from the region, which, for London, translated to imperial fault lines and a powder keg that could, at any time, be set alight by the war. Indeed, London had reason to appreciate the colonial administrative genius of administering imperial holdings and ethnic groups as exclusive sanitary units that could contain the cross-pollination of Mau Mau radicalism and dissent among other African groups in Kenya. But besides Britain's colonial woes in East Africa, London not only had to fight economic imperial troubles but also had to deal with serious financial fires on the home front.

\section{Imperial Imbrication of Existential Struggle: The Micro-economics of Bread and Butter}

The economic crisis that London had to oversee both at home and in its various imperial holdings since the end of the Second World War was felt throughout the British Empire. Not

${ }^{2}$ Ibid. 
even cleverly conceived and designed ethno-geographic and imperial boundaries could prevent imperial subjects from feeling the pinch of war-weariness that was experienced long after the end of the Second World War. At the end of World War II, Britain, hitherto the most powerful state that had been the leader in world affairs for over three hundred years, entered the last cycle in its orbit of decline. While it was still a powerful European state of reckon, the British Empire was in terminal decline. The country emerged from the Second World War with the psychology of a victor but its economic circumstances resembled those of a defeated country. Britain was literally bankrupt. After the war, Britain entered a "financial Dunkirk," according John Maynard Keynes, the chief economic advisor who was helping in the reconstruction process. ${ }^{3}$ The military demands made upon imperial Britain had devastated its economy. This was more so considering that most production and industry had been diverted towards the war effort. The consequent economic hardships affected not only the heart of empire but also its far-flung peripheral satellite economies where the old system of colonial governance was altered irreversibly by the tremendous economic, social and psychological consequences of the war. In India, for example, the war effort strained and ultimately reconfigured the very nature of the political economy of the colonial state. According to Yasmin Khan, British colonial administrators in India were overburdened and at the same time heavily constrained by a fiscally cautious regime. ${ }^{4}$

Meanwhile, back home, the British government, long after WWII, had to deal with domestic kitchen micro-economics of bread and butter. War-time commodity rationing was still fast in place in the country and dominated both talk in the streets and debates in parliament up to the mid-1950s. Food rations in Britain affected commodities such as bread, butter and margarine, meat and liver, bacon and ham, peas and other vegetables, and Christmas sweets. The British economy, even more than seven years after the Second World War, still was not completely out of the woods. Its people lived in uncertainty and questions about this situation still lingered and loomed large. The future, for some, was more than a little gloomy. It is interesting to note that the three most vocal politicians who were personally interested in these bread and butter issues were women parliamentarians.

\footnotetext{
${ }^{3}$ Correlli Barnett, "The Wasting of Britain's Marshall Aid," BBC History, (2011).

${ }^{4}$ Yasmine Khan, The Great Partition: The Making of India and Pakistan (New Haven: Yale University Press, 2007), $\mathrm{xx}$.
} 
At the beginning of December 1952, a dark and heavy fog hung over the city of London. On $8^{\text {th }}$ December, the fourth day of the dense killer London fog that left four-thousand people dead and even more later, Mrs. Jean Mann, a parliamentarian, complained that British margarine was below standard. Mrs. Mann asked the Minister of Food, Dr. Charles Hill, if he would import Norwegian margarine or, otherwise, find from Norway their recipe for margarine which was more palatable than that made in Britain. ${ }^{5}$ Margarine in Norway, Mrs. Mann said, really tasted like butter and had "a rather strong, sour-milk flavor." " Besides having to handle this question on the quality of British margarine, Dr. Hill also had to deal with concerns about its adequacy to meet the demand in the country: would he de-ration the commodity? ${ }^{7}$

Indeed, in the course of this debate, it was the general feeling that the actual take-up of rationed foods from the shops, especially by the poorer sections of the community was unsatisfactory. The Member of Parliament for Coventry, Miss Elaine Burton, wanted to know, in the view of the application by bakers for an increase in the price of bread, whether the minister would give an assurance that the cost of a loaf to the consumer would not be increased. Miss Burton argued that if the price of bread went up yet again, it would "further squeeze the standard of living of people" who were "already finding it hard to buy essential foods." 8 That is just how bad the economic situation was in Britain. While a lot of parliamentary debates focused on economic hardships and food shortage at home, it also discussed the growing reflection of the same problem in East Africa and Kenya, in particular. Indeed, London, for a while, had its thumb on East Africa's worrying economic pulse. British politicians and the government in London were increasingly concerned about the deteriorating situation in Kenya. This concern is what ultimately led to the appointment of the royal commission on East Africa.

Peter Freeman, the MP for Newport, for instance, asked Oliver Lyttelton, the Secretary of State for the colonies, a question about Kenya's agricultural workers' wages two days later. Freeman remarked that in some cases, farm workers were still being paid a wage of $6 \mathrm{~d}$. a day for a 60 or 65 hour week. Freeman posed, were such conditions not instrumental in bringing about

\footnotetext{
${ }^{5}$ Great Britain, Parliamentary Debates (Parl. Deb.) (Commons) 5th Ser., 509 (8 ${ }^{\text {th }}$ December 1952): 19-31, BNA: ZHC 2/1017.

${ }^{6}$ Ibid.

7 Ibid.

8 Ibid.
} 
the situation prevalent in Kenya more than anything else? Lyttelton said there was no statutory minimum wage for agricultural workers. The SofS explained that the average wage was 25 shillings per month plus rations at 20 shillings per month, and that most workers were also allowed to cultivate a plot on their employer's farms. Unsatisfied, Freeman wanted to know what steps Lyttelton was taking to improve that situation. ${ }^{9}$ Labor MP George Wigg asked the SofS whether he still held the view that the state of affairs in Kenya had nothing to with economic circumstances, especially in view of Lyttelton's statement that the average wage was $25 \mathrm{~s}$. a month. Lyttelton protested that Wigg was putting words in his mouth that he had never used. Illustrating the attitude of denial that was the official position on the crisis in both London and Nairobi, Lyttelton "clarified" what he meant by saying that the Mau Mau secret society was not the direct result of economic pressure. ${ }^{10}$ This statement caused uproar in the House. Supporting Wigg, Sir Richard Acland pointed out that the Church Missionary Society had circulated a report that very definitely stated that the economic and social conditions in Kenya were a major cause in bringing dissent to an endemic stage. ${ }^{11}$ Reginald Sorensen was yet another MP who lent his voice to this view. Sorensen told Lyttelton to appreciate that there was a psychological and moral factor and, therefore, a non-economic factor, which had some relationship to Mau Mau. ${ }^{12}$

Although Sorensen did not elaborate further, Frank Bowles provided an appreciable estimation of what were the deep springs of the movement. Bowles pointed out that the African marriage custom was affected by the breakup of families and bride wealth being paid in cash. He said that bridewealth, which was known to be as high as 100 British Pounds, was unaffordable considering that the average wage for an African agricultural worker on a farm was one pound a month. According to his calculations, it would take a wage laborer eight and a half years, if he spent nothing at all, to produce the purchase money. In as far as Bowles was concerned, the desire to get married had a serious effect upon the activities of people. Further, Bowles believed that it was a great mistake to assume that all the crimes which were taking place in Kenya were really due to Mau Mau. Bowles intimated that he thought that some of these crimes were purely and simply ordinary armed robbery and burglary by Africans in search of wealth, so that they

\footnotetext{
${ }^{9}$ Parl. Deb. (Commons) 5th Ser., 509 (10 ${ }^{\text {th }}$ December 1952): 443.

${ }^{10} \mathrm{Ibid}$.

${ }^{11}$ Ibid.

${ }^{12}$ Ibid.
} 
may find bridal price. This, Bowles said, was one of the things which had changed since the European settlers arrived in Kenya and was quite a serious matter, a remark that was greeted by laughter in the House. ${ }^{13}$

Apart from this specific change that ensured elusiveness of matrimony for many a man, there was far-reaching transformation of African systems of power, property and law with serious implications. The legal appropriation of land through the illegal imposition of institutions either protecting private property rights or extracting rents, occasioned socioeconomic and political hardships, which dominated legislative council debate in colonial Kenya since the mid1940s. This was compounded by the alienation of African labor and a gamut of legal restrictions that shrunk the pre-European cosmos. African institutions and principles upon which the stability of African societies depended were undermined and overturned. They were discarded and were no longer applicable leading to the unraveling of the socioeconomic and political fabric of African societies. With the breakdown of the system of entitlement and social ties defined by reciprocal duties, the bread-nexus was replaced by a cash-nexus that benefitted a few African big men close to, or who took advantage of, the colonial enterprise while causing the majority of people to suffer.

People, especially the poor in Kenya, could no longer ask African big men for relief or charity as a natural right that ensured their access to essential food supply. By the late 1940s and early 1950s, the latter had well-bought into the new system dominated by settler agrarian capitalism. The African economy of affection was significantly weakened. Wealthy Africans no longer felt bound by duty to meet their social obligations to their dependents. Since the market was the new dispenser of subsistence, the wealthy, both African and white, were now unbound by duty and felt that they now stood outside society. Thus the relationship of people to food was compromised since farmers had their eyes on the maximization of profits. ${ }^{14}$ As such, there was a feeling that certain sections of society in the colony were benefiting from other people's plight. The friction and conflict generated by land laws that determined land ownership and usage became the central area of the nation's life. ${ }^{15}$ Any debate focusing on the rising cost of living at

\footnotetext{
${ }^{13}$ Parl. Deb. (Commons) 5th Ser., 509 (16 ${ }^{\text {th }}$ December 1952): $1246 \& 1247$.

${ }^{14}$ Edward P. Thompson, Customs in Common (Pontypool: The Merlin Press, 1991), 229 \& 232.

15 Ibid., 189.
} 
the legislative council, therefore, could not avoid addressing this sea change that affected Africans for the most part.

The Member of Legislative council for Kenya’s bread-basket, Uasin Gishu, Lawrence Robert Maconochie Welwood, who was the embodiment of settler agrarian capitalism and landed interest in Kenya, took issue with African suffering as presented by the Cost of Living Commission. Welwood acknowledged that the European living standard in the colony was very high. Indeed, he stressed this fact in a 1951 debate on the cost of living. For that very reason, it was not in the European community that the cost of food was a major item in the cost of living. It was obvious to him that in that case, the lowest income group in the colony was the African, and it was the African's cost of living - mainly food costs, especially maize- which was a cause for concern. Welwood, however, went on to argue and challenge anybody on either side of the Council to contradict him, that the vast majority of Africans in the colony either grew their own food or were supplied with food in the form of rations by their employer.

Welwood further noted that there was a very small minority of urban dwelling Africans in Mombasa and Nairobi who had to buy food at the prevalent high prices of maize, the subsidy of which, without rationing, he rejected. He also rejected the firm belief that the main cost of living was the cost of food. Maconochie Welwood ventured that if one accepted that this was the case, what was then implied was that where the cost of food was the most expensive item in a person's living meant that that person was living to the lowest possible standard. He did not believe that this was the case. To the contrary, Welwood argued, the true cost of living to most people in the urban areas was undoubtedly rents and transport. He took issue with the idea to which most people in the world were apt to subscribe: that somebody else was making a large sum at their expense. This was the prevalent notion that all well-to-do Kenyan farmers were making very large profits. He conceded that, of course, the larger enterprises were making large profits in the same way as the larger manufacturers in industry were making large profits. As far as Welwood was concerned, it was obvious that it was the small man who, of course, had to struggle under the circumstances. ${ }^{16}$

${ }^{16}$ Colony and Protectorate of Kenya, Legislative Council Debates (Legco. Deb.), XLII (1 ${ }^{\text {th }}$ May 1951): 135-136 \& 139-140. 
For this reason, Welwood criticized the commission's report referring its views as "glimpses through the iron curtain." He was particularly irked by the commission's idea that the agricultural community should be treated as a separate entity -particularly parts of the industry that were prosperous- and, therefore, supposed to subsidize the producers of domestically consumed stuff, purely for the benefit of the consumer. ${ }^{17}$ Further, he said there was also a tendency for people to believe that the agricultural industry in Kenya could and should have produced food cheaper than anywhere else because of cheaper land and perhaps cheaper labor, which was misleading. Welwood, obviously arguing in favor of unfettered operation of agrarian capitalism profiting middling African and large white farmers whose fortunes and prosperity was on the rise, went on to state that beef, bacon and pork, and butter fat prices compared to those of other countries were much lower in Kenya. ${ }^{18}$ This implied that Kenyan farmers were far much better off exporting their produce than selling it as a loss at home. The Kenyan producer was not in fact receiving the enormous prices as the report purported. ${ }^{19}$

As an agriculturalist, Welwood felt duty-bound to challenge what was, to him, a futile attempt by the Cost of Living Commission to abolish the capitalist system for the farmer and retain it for everybody else. As far as he was concerned, it was this sort of disastrous compromise which was continually being attempted in Great Britain leading to inflation from which all were suffering. There was no middle path in the matter, Welwood argued. If someone was going to abolish capitalism, then they should just do so not merely for the basically essential industry of agriculture on which people lived but for all the industries. He did not believe that that sort of "financial massacre of the kulaks" of Kenya proposed by the commission would, in the long run, really achieve a high standard of living for the civil servant or a high standard of living for anybody else. As far as he was concerned, the commission was sitting in the position of Canute trying to prevent the tide from advancing, and naturally there was little that could be effected. $^{20}$

On the other side of the debate were active defenders of the African point of view from below like the member for the coast region, Cooke. Cooke said that he had distanced himself

\footnotetext{
17 Ibid., 136.

${ }^{18}$ Ibid., 137.

${ }^{19}$ Ibid., 138.

${ }^{20}$ Ibid., 140.
} 
from a number of candidates who, in their youthful exuberance in the elections of 1948, had made the question of the cost of living one of the principle planks in their platform. As an old campaigner, Cooke had learned that it was easy to promise but more difficult to perform. As such, he had personally kept more or less out of the controversy. Cooke expressed his disappointment since it had taken six months before the Cost of Living Commission findings were tabled for discussion after it had carried out investigations for two and a half years. Cooke lauded the government's cost of living allowances to government officials, but he made it clear that if the commission's report had been discussed, it would have been possible for the council to have found some means by which the community in general would benefit rather than one particular section of that community. Cooke categorically stated that the cost of living position was "Kenya's Number One" domestic problem and that it was up to the representatives of the people to see that that problem was speedily and properly resolved. ${ }^{21}$

Unlike his Uasin Gishu counterpart, who felt that the report was against agrarian capitalism, Cooke argued that the question of effecting food subsidies was a pertinent one since, for good or evil, the colony was a planned economy. Cooke stated that it was wrong for any section of the Kenyan community to arrogate to itself the right to say that they could plan this or that. This was especially because while the government planned to give farmers, and quite rightly, higher prices for their produce, it failed to plan to give the poor old consumer his right to a square deal. For Cooke, this seemed to be a misuse of the term "planning." 22 Three factors entered mainly into the cost of living in Kenya, namely rent of housing, the high cost of transport and local food. As far as he was concerned, the question of food subsidies was the most important. Cooke felt that subsidies were more effective than spending money on the cost of living allowances. If food was subsidized, there would be no transfer of the national income outside the country since $95 \%$ of the food consumed in the country was produced by Kenyan farmers. This would not affect the colony's balance of trade nor would it, Cooke argued, have affected Kenya's national income. It would merely have been a transfer of purchasing power from one section of the community to another. ${ }^{23}$

\footnotetext{
${ }^{21}$ Ibid., 119.

22 Ibid.

${ }^{23}$ Ibid., 121.
} 
As observed earlier above, it was the African's cost of living with respect to food costs and maize mainly that was the chief cause of suffering since the late 1940s in Kenya. Earlier on, in a February 1951 council motion initiated by Cooke, the proposal that maize be subsidized was defeated by a large majority. By May of the same year, the acting financial secretary drew considerable comfort from this fact. Referring to the February Cooke motion, the financial secretary "acknowledged" that the question of food subsidies could not be regarded as having been, in the wake of the defeat of the maize motion, finally disposed of. However, he ventured to suggest that world prices at the time militated against the introduction of food subsidies on a scale that would have had an appreciable effect on the cost of living. ${ }^{24}$

During the maize subsidy motion, Cooke argued that in Kenya, while accepting the principle that maize producers should receive a reasonable and economic price for their produce, there persisted the opinion that since maize was the staple food of the majority of the people in the country, which then affected the wage structure and with it the national economy, no increase in the price to the producer was to be passed on direct to the consumer. For this reason, Cooke recommended that any intended increase be met through the means of a subsidy from general revenue. $^{25}$ This insightful analysis and statement proves that, indeed, the question of basic survival with regard to the demand and supply of prime necessities of life had become the central area of the nation's life and its politics. The alteration of African land tenure and the disposition of labor through colonial laws had compromised livelihood and sustenance. This legislative council debate, which prefigured the breakout of the Mau Mau war, therefore, was not, per se, about the subsidization of maize. Rather, at the crux of the matter was the transformation of the relationship of people to food, which involves systems of power, property and law. This state of affairs occasioned anxiety and suffering that was felt throughout the country with regard to the ever-increasing rise of food prices. ${ }^{26}$

The economic pressure and difficulties had started to be felt especially around March 1948 which is when a motion was filed at the LegCo suggesting that prices were reigning very high throughout the country. It was then suggested that the government take action to control and alleviate the price of foodstuffs. Another motion, said to have more teeth, was brought to the

\footnotetext{
${ }^{24}$ Ibid., 114; and LegCo Deb., XLI (8 ${ }^{\text {th }}$ March 1951): 609-626.

${ }^{25}$ LegCo Deb., XLI (8 $8^{\text {th }}$ March 1951): 609.

${ }^{26}$ Ibid., 610.
} 
council in August of the same year requesting the government to take appropriate measures in this regard. The August motion resulted in the appointment of a select committee to deal with the raised concerns but its report the government neither considered nor brought a motion into the council either accepting it or rejecting it. As such, Cooke let it be known that the government was ignoring and flouting the council in what was a matter of grave concern: a subject of such great importance, which deserved immediate attention. Cooke charged that the rule of first things first ought to have applied since the issue concerned 99 per cent of the population of the country so vitally. ${ }^{27}$

As far as Cooke was concerned, there was no question of a precedent in the proposal. He asserted that those who were in Kenya in 1943 and 1944 remembered that in consequence of the food shortage, specially the cereal shortage, cereals had been imported from abroad and the council had voted a large sum of money towards a subsidy for cereals during those two years. ${ }^{28}$ As opposed to the time when those large sums of money were paid outside Kenya thus affecting the national income, if action was taken to pay money to stabilize the price of food at the beginning of the $1950 \mathrm{~s}$, it would mean internal movement of that money. ${ }^{29}$ In supporting his motion, Cooke referred to the findings of a select committee which had suggested by a majority, with only a minority of one against it, that there be a subsidization of food and maize in particular. One of the biggest opposition to the suggestion was the question of who would pay for the subsidy. Cooke argued that the consumer-taxpayer would foot the bill but the monies would circulate within the national economy.

Further, he believed that whether the price of maize went up or a subsidy was implemented, it was the consumer-taxpayer who picked the tab eventually. That, for example, if the price of maize went up, big government employers would ask for money from the Treasury and taxpayers would pay it back. Or big plantations, or the big producers, or employers of labor such as the docks and the shipping companies in Mombasa would have to pay more to their laborers. However, Cooke argued that it was a much easier procedure and much simpler if the

\footnotetext{
27 Ibid.

${ }^{28}$ Ibid.

${ }^{29}$ Ibid., 611.
} 
economy of the colony was not upset by having taxpayers pay through taxation into the Treasury and from the resulting collection, a fund formed to subsidize maize. ${ }^{30}$

At the time of this debate though, the national economy was already upset and there was a very real danger, especially where Africans were concerned, that where wages were raised and deflation followed, the African, and indeed a great many Europeans, would not see any reason for reducing wages again. A deflationary period would follow with the high wages still prevalent. ${ }^{31}$ This could be prevented, Cooke argued, if maize was subsidized. Moreover, Cooke stated that it was policy both in Britain and in Kenya that all contribute when it was a question of national interest to do so. He quoted the economic historian, Ephraim Lipson who propounded that: "The best method of assisting an infant industry or any other industry whose maintenance is considered necessary for national reasons is the payment of a subsidy from general taxation, since the burden ought to fall on the community as a whole and not on the section which consumes a particular product." 32 The effect of the rise in the price of maize on the African family was quite considerable. Cooke pointed out that the African man and wife with an average family of three found their cost of living rose to about 4.50 shillings a month. With the upcountry farmers in Kitale and elsewhere pressing for another rise in price, it was quite possible that at the turn of that year, there would be a rise of something like 10 shillings per family in the cost of living, which was a considerable sum of money that could upset the national economy. It would require the raising of wages. In closing his remarks, Cooke emphasized the thrust of his argument, which was that subsidies had the effect of taking money from one section of the community and transferring it to another. It was an internal transfer of money. It transferred purchasing power from one community (urban and poor African majority) to another (rural and especially white settler farmers with vested agrarian interests).

In supporting the motion, G. Usher, the member for Mombasa, stated that the high price of maize had the effect of increasing costs across all economic spheres including transport, house rent, woolen suits, and handling costs, particularly in a port town among other things. As a result, many peoples' hearts, including employers, were wrung by stories of families who could not

\footnotetext{
${ }^{30}$ Ibid., 612.

${ }^{31}$ This reflects white settler fears and economic thinking at the time that could be faulted by economic experts.

32 LegCo Deb., XLI (8 ${ }^{\text {th }}$ March 1951): 613.
} 
make ends meet. Africans in particular felt that the best possible thing was to have the essentials of life for him pegged. With the country being subjected to all kinds of unpleasantness and impossible situations beyond anyone's control, Usher felt that there was a need for a searching review of the national fiscal structure. Otherwise, Usher said, cryptically, there was the danger of wildebeests getting into aviaries. ${ }^{33}$ Of course, among the people who opposed the motion was Welwood. He argued that the growers of maize and wheat had performed the task of subsidizing foodstuffs in the colony for far too long. Welwood felt that in a world of inflation, food subsidies could be but only a temporary alleviation and would simply cripple the rest of the country. ${ }^{34}$

Further, the council could not sit down without allowing a measure of inflation to take place. This is the exact sort of argument that Cooke was against. In the May, 1951 debate on the cost of living, Cooke cited John Maynard Keynes acceptance of Vladimir Lenin's analysis of the role of inflation in a national economy. Lord Keynes had said: "Lenin ...declared that the best way to destroy the capitalist system was to debauch the currency. By a continuing process of inflation, governments can confiscate, secretly and unobserved, an important part of the wealth of their citizens. By this method they confiscate, but they confiscate arbitrarily .... Lenin was certainly right, there is no subtler, no surer means of overturning the existing basis of society than to debauch the currency. The process engages all the hidden forces of economic law on the side of destruction, and does it in a manner which not one man in a million is able to diagnose." 35 This was a strong argument that perhaps explains why Welwood offered two more alternatives besides inflation.

Besides inflation, Welwood suggested having industries as part of the economy that could pay for such food subsidies. Secondly, having farmers become major exporters of foodstuffs at a higher price when they could sell them at a lower price in the country. Another voice of opposition, the Member for Nyanza, T.R.L. Preston, agreed that cereal and maize farmers were already subsidizing the colony since they were selling their produce at well below world prices. At the same time, they continued to buy all the things needed for farming operations at world prices. Yet, whenever there was any question of a rise in price on anything

\footnotetext{
${ }^{33}$ LegCo Deb., XLI (8 $8^{\text {th }}$ March 1951): 614-615.

${ }^{34}$ LegCo Deb., XLI (8th March 1951): 614 \& 615.

${ }^{35}$ LegCo Deb., XLII (11 ${ }^{\text {th }}$ May 1951): 123.
} 
that was produced by farmers, it was said: "'Here are the wicked farmers exploiting the public of the Colony once again." 36 What those who successfully opposed this motion did not dispute was the fact that the rise in the price of maize did hurt the (urban) African, who suffered particularly as far as his family was concerned. However, it was argued, especially by those opposed to a maize subsidy, that in the African family budget, the increased cost of maize was not nearly as important as the cost of clothing. ${ }^{37}$ Moreover, it was felt by those opposing that there was no need for a maize subsidy since the council had agreed to implement cost of living allowances earlier on in the year.

The debate concerning the cost of living allowances as an alternative to subsidies in February 1951 illuminated the poor economic conditions in the country across all races. Besides this, the debate concerning it captured the reality of the early 1950s: the hard economic times, even in the LegCo, were seen through a racial prism. This because the review of the cost of living allowances was offered to the civil service disparately along racial lines. A particular salary attracted a different percentage of relief according to the race of the recipient. This led some members of the legislative council to argue that it was only fair to admit that if the cost of living had increased, it surely followed that it had increased for all races. The member for central area, the future chief justice C.B. Madan, for instance, said it was illogical to presume that the cost of living had increased more for Europeans and not so much for Asians and Africans. Madan leveled his attack on the European Elected Members defense of this state of affairs as iniquitous. ${ }^{38}$ Future African minister Appolo Ohanga added his voice with great eloquence stating that he did not think that proper justice had been done to the lowest paid officers who happened to be Africans in the civil service. Ohanga argued that the general hardship which was felt in the matter of cost of living was experienced by all people, be they highly paid or lowly paid officers, "but the greatest, by far the greatest sufferers," were the Africans who formed the lowest paid group.

\footnotetext{
${ }^{36}$ LegCo Deb., XLI (8th March 1951): 617 \& 618. Preston represented the extreme views of white settlers in marginally productive regions of the colony such as Londiani, Koru and Fort Tenan who required the assistance of the state to make profitable their agricultural enterprise.

${ }^{37}$ Ibid., 615, 616 \& 617.

${ }^{38}$ LegCo. Deb., XLI (27 ${ }^{\text {th }}$ February 1951): 352-354.
} 
However, senior members of the civil service, both European and Asians, had received the lion's share of the percentage increments to shield them from the dire economic times. On the other hand, for a large number of lower paid groups of Africans, the only way to exist with the reigning market prices that characterized the beginning of 1951 was to borrow and borrow as generously as they could on a very high percentage as a matter of necessity in order to live. As far as Ohanga was concerned, the suffering of Africans who formed the bulk of the lowest paid officers had, indeed, gone on for a long time before 1951. Ohanga believed that even such cost of living allowances were only a temporary relief to their suffering. He, therefore, suggested a salary increment so that Africans benefited more than people who received higher basic salaries than themselves. Even with that done, Ohanga added that it could not be lost sight of that the wage levels for the laborers or manual workers in Kenya were "absolutely uneconomic" and thus, could not go on as they were for a long time. ${ }^{39}$

These remarks echoed those by Preston while contributing to this debate that the poor economic situation could not be solved by mere cash increases to any one section of the community. As far as Preston was concerned, it was easier to meet the problem by a direct increase of salary, but he was convinced that nothing less than a more practical approach to the problem was going to achieve any permanent result or do anything to arrest the inflation, which the country faced. A focus purely on a cost of living allowance was, in his opinion, only designed to meet the urgent and immediate needs and was not adequate preparation for future challenges. Furthermore, the allowances proposed were tailored to give maximum relief to practically all civil servants of two communities. Worse still, Preston stated that the rising cost of living not only affected civil servants but also every man, woman and child in the colony. The last thing that anyone would wish, Preston pressed, was to create a class of people who were entirely sheltered from the economic blast. ${ }^{40}$

Like in the parliamentary debate trying to get to the bottom of the root cause of Mau Mau, the issue of marriage and family budgets emerged in Nairobi. Ohanga opposed the idea of family size being tied to the cost of living allowance over and above job qualifications. $\mathrm{He}$ argued that salaries of government officers be solely confined to qualifications regardless of how

\footnotetext{
${ }^{39}$ Ibid., 358-362.
}

${ }^{40}$ Ibid., 350-352. 
big their families were. The cost of living allowances committee explained it was displeased that an African with a hundred and fifty shillings a month with a wife and family did not have enough to enable him to run his house and to dress himself as expected. But Ohanga opposed family consideration because of racial discrimination that saw indifferential treatment between European, Asian and African families. This differentiation was defended by pointing out that in a social system that was still polygamous and without registration of births, would be African beneficiaries could not prove to the government their entitlement to the allowances suggested. Instead, the crafters of the allowance considered that the African bachelor was always paying out money for bride price and was, as such, at a disadvantage financially. But Ohanga held that marriage could not really be a criterion in determining salary scaling. According to him, the hardest hit people were the lowest paid people whether they were married or not. Ohanga had then gone on to say that if marriage was going to be an extra burden, he was quite sure it was a voluntary luxury that people could do with or without. ${ }^{41}$ This illustrates the casual manner with which the vital matter everyday economic survival for ordinary Kenyans, especially Africans was dealt.

\section{Hard Times: A Rear Mirror View}

Despite the lack of a serious longue durée analysis of the economic predicament in Kenya and especially how it affected Africans newly inducted into the colonial political economy, official concern was longstanding. In 1948, a group of nine legislative members under the chairmanship of E.A. Vasey was sitting to inquire into the cost of living and collected information from ordinary individuals from all races. Some of the information collected by the Vasey commission is worth highlighting here.

Giving evidence to the cost of living commission in Nairobi on $18^{\text {th }}$ November 1948 , one of the witnesses, a certain Miss Deverell, said that she thought that African clothing dismal and constituted the absolute minimum standard on which anybody could keep himself clothed. ${ }^{42}$ This point was amplified by Dedan N. Githege who read a memorandum composed together with two African colleagues who gave evidence to the commission. Githege informed the commission that the cost of living was very high for Africans, and this had gone on for far too long. As a result,

\footnotetext{
${ }^{41}$ Ibid., 361, 364 \& 366.

${ }^{42}$ Minutes of the $10^{\text {th }}$ Meeting of the Commission of Enquiry into the Cost of Living, Nairobi, $18^{\text {th }}$ November 1948, Papers of the Electors' Union and the European Elected Members Organization, RHO: Box 80/2 MSS Afr. s. 596.
} 
he added, Africans were walking around with clothes that could be regarded by other races as rags because most of their money was spent to buy food. ${ }^{43}$ Another African witness, Ruth Pascalli, told the commission that her husband, a Luhya man from Samia, was in tatters because he could not afford a new outfit. Pascalli also stated that none of her three children went to school because of the unaffordability of school fees. Her husband was on a minimum wage that could only sustain the family for one week. For the other three weeks of the month, the family survived on charity from friends. ${ }^{44}$

Further illustrating African poverty was evidence given by Dorcas, a Luo woman who lived in Kaloleni in a two-roomed municipal house. She told the commission that her family seldom bought clothes because they could not afford it. Most of Dorcas's family members, therefore, had one piece of clothing each although the smaller children wore no clothing at all. She also told the commission that she was not satisfied with the amount of food she and her family got because it was barely sufficient. ${ }^{45}$ Responding to a question from one of the commissioners, Dorcas was of the opinion that the government was behind the increase in the cost of living. ${ }^{46}$ The Githege memorandum demonstrated a keener understanding of the cause of the increase in the cost of living. The foursome attributed the high cost of living in Nairobi to the pressure from surrounding rural farming districts that had pushed the prices of goats, sheep, chickens, charcoal and wood fuel higher with detrimental effect on town dwellers. Further, they complained that a bag of posho (maize meal) of $200 \mathrm{lbs}$ was sold by African producers for 11.90 shillings but once in the market, African consumers were required to fork out 28 shillings for the same quantity. They pointed out that this margin of profit was too large. ${ }^{47}$

Jivraj Meralli, a businessman and past president of the Indian Chamber of Commerce, tied the high cost of living to the war. But Meralli also stated that to ease the situation, the control of the distribution of foodstuffs had to be abolished and free movement of foodstuffs

\footnotetext{
${ }^{43}$ Councilor Gakonyo, Dedan N. Githege, Mr. Alfred Wata Mayend and Mr. Muchoki Mukora, "The Cost of Living of Africans in Nairobi," Minutes of the 10th meeting of the Commission of Enquiry into the Cost of Living, Nairobi, $18^{\text {th }}$ November, 1948, Papers of the Elector's Union and the European Elected Members Organization, RHO: Box 80/2 MSS Afr. s. 596.

${ }^{44}$ Oral submission by Ruth Pascalli, Ibid.

${ }^{45}$ Oral submission by Dorcas, Ibid.

${ }^{46}$ Ibid.

${ }^{47}$ Councilor Gakonyo, Dedan N. Githege, Mr. Alfred Wata Mayend and Mr. Muchoki Mukora, "The Cost of Living of Africans in Nairobi," Papers of the Elector's Union and the European Elected Members Organization, RHO: Box 80/2 MSS Afr. s. 596.
} 
allowed between the East African territories. Meralli argued that the government should have moved to stop any exports of foodstuff unless it was absolutely certain that there was sufficient food for the needs of the country. He further opined that while the price controller had tried his best to keep prices down, the commercial community reaped consumers' heart and soul. ${ }^{48}$ Another witness, Kantilal P. Shah, said that he thought that the maize control and produce Control board was trading and taking more profit than any trader would. ${ }^{49}$ Similar sentiments were expressed some seven months later by Mr. Francis Khamisi, an outspoken African journalist who would be elected to the LegCo in 1958 and later played a prominent role in KADU. Khamisi told the committee that the cost of living among the African community had increased owing to the fact that the bare necessities of life "were so very expensive." Khamisi said that the cost of living in food had gone up and in many cases good food was unobtainable. He complained that a few days before the committee arrived in Mombasa, there had been no milk, cigarettes and soap adding that he thought that these things, had mostly gone right into the black market. There was also a great shortage of meat and fish and he had personally not had these for a long time. The cost of clothes had also gone up, in spite of the fact that the shops were full of them, continued Khamisi. This was either due to excessive customs duty or perhaps due to the margin of profit that traders charged for their goods. Africans like himself had been living the last two or three months without meat which then disappeared from the market. At the same time, fuel and charcoal were heavily priced against the meager African incomes. Khamisi also pointed out that African housing in the city was inadequate. As there was not enough, the consequence was that the existing houses had exorbitant rents and even if one could pay a lot it was difficult to get a room. ${ }^{50}$ With all these increases that Khamisi enumerated, it was obvious the minimum wage was inadequate. The minimum wage at the time was 40 shillings per month. Many of the Africans earned 50 shillings but even that was not enough to cover necessary expenses, which was a cause of anxiety.

\footnotetext{
48 "Minutes of the $5^{\text {th }}$ Meeting of the Commission of Enquiry into the Cost of Living, Nairobi, $11^{\text {th }}$ November 1948 , Papers of the Electors' Union and the European Elected Members Organization, RHO: Box 80/2, MSS Afr s. 596. 49 Ibid.

${ }^{50}$ Minutes of the $54^{\text {th }}$ meeting of the commission of inquiry of the Cost of Living held in the board room of the town hall, Mombasa, Thursday $2^{\text {nd }}$ June 1949. Papers of the Electors' Union and the European Elected members Organization, RHO: Box 80/2 MSS Afr. s. 596. Khamisi told the commission that one could not get a 12' x 18' room for less than $15 \mathrm{Ksh} /$ - a month.
} 
Some of these apprehensions were confirmed by J.F. Troughton who served in the colonial government as the member for finance. He also gave evidence before the commission. Troughton admitted before the commission that the government had, during the war, managed to keep the cost of living pegged down fairly well. But after the end of the war, grave difficulty was experienced in keeping the cost of living down due to increases in the cost of imported goods and also partly consequential on the demands made by primary producers of food crops particularly cereal and dairy produce. Indeed, the perception by many Africans, among them Dorcas, that the government was behind the high cost of living was validated. Troughton told the commission that prices were decided by the governor in council with advice from an executive commission presided over by the member for agriculture and member of finance. There was, Troughton intimated, a battle between him and the member for agriculture over the balance between consumer interests of keeping the cost of living down on the one hand, and farmers who wanted a fair price on their primary produce, on the other. In this duel, the member for finance admitted that he was losing the battle. Thus, Troughton was well aware of skewed deliberations at policy-decision making level that favored the white farming community at the expense of civil servants and the majority African consumers. ${ }^{51}$

Maize, Troughton noted, was a basic factor in the cost of living as it entered into the cost of production of everything else. Troughton confessed that the government had taken the decision that the price of maize should not be increased but the powerful white agrarian interests in Kenya disagreed. Troughton went on to admit that he thought that the prevalent weight was in favor of the producer adding that if producers were entitled to an increase in prices that should have taken the form of a subsidy. ${ }^{52}$ Such was the dire economic situation that foreshadowed the terrible 1950s. This state of affairs, embedded as it was in the Kenya colonial situation, did not escape the critical and analytical observation of a few keen eyes in the early 1950s.

\section{Colonial Origins of Mau Mau Minds: Some Earnest Observations}

While commendable, the government's attempt to collect broad-based evidence of everyday hardships pales in comparison to the views of Colin Legum, a correspondent for The Observer. In an extensive document, Legum demonstrated a fairly in-depth analytical

\footnotetext{
${ }^{51}$ Minutes of the $10^{\text {th }}$ meeting of the Commission of Enquiry into the Cost of Living, Nairobi, $27^{\text {th }}$ October 1948 , Papers of the Electors' Union and the European Elected members Organization, RHO: Box 80/2 MSS Afr. s. 596. 52 Ibid.
} 
understanding of the dynamics of the colonial political economy. Writing against the background of the outbreak of Mau Mau violence a few months earlier, this perceptive political commentator and critic of British imperialism in Africa, attributed the war to the extreme expression of genuinely felt land grievances. Legum argued that if people were going to be taken off the land it was necessary to eliminate the worst problems associated with urbanization and the onslaught on traditional African society. The colonial government needed to provide adequate housing, a living wage standard, and adequate social amenities. In addition, there was need to develop secondary industries closely associated with Kenya's agricultural production. These were to be established along cooperative lines to give Africans a share in the development and ownership of the new industries. ${ }^{53}$

Further, Legum argued that there was a need to find a place in urban areas for landless African peasants and for the establishment of a minimum wage policy that offered the prospect of maintaining a family decently; a reduction of the price of posho, the staple food of the colony which had risen sevenfold to 56 shillings since 1939; the provision of adequate housing; the elimination of all obstacles to the development of skill and the removal of color barriers in the Civil Service; and the intensification of technical training. The growth of Nairobi and the development of a black proletariat, mostly Kikuyu, with the inevitable concomitants of early industrial society -slums, low wages, insecurity of employment, high living costs- all were having a tremendous effect in the Kikuyu. ${ }^{54}$

However, the most remarkable aspect of this document is the accurate manner in which it captures the colonial transformation of African societies. Legum pointed out that migration, fragmentation of land, uneven development of land productivity, increasing population and diminishing land availability was having a profoundly disturbing effect on Africans, especially the Kikuyu whose traditional society always depended for its stability and for its progress on the closely knit family and clan system and the availability of new lands. Under colonialism, however, the family and clan system was beginning to break up resulting in fratricidal interfamily and inter-clan quarrels due to disputes over succession rights, land occupation and

\footnotetext{
${ }^{53}$ Colin Legum, "Mau Mau: An Analysis of Problems in Kikuyuland with Some Proposals to Deal with the Situation," The Observer, $20^{\text {th }}$ November 1952, BNA: CO 822/458.

54 Ibid.
} 
numerous other petty and serious issues over land usage. This was typical of peasant societies where they had been thrown out of relationship with their land.

This break-up of the closely-knit family and clan life of the Kikuyu meant the destruction of the foundation of Kikuyu society, the resultant stress and strain from which there was no escape. In the past, Legum noted, when a brother fell out with his family, he could move to new land, which was something that was not possible under British colonialism by the 1940s and 1950s if not much earlier. This situation thus resulted in bitter conflicts that were tearing the Kikuyu peasant society apart. The speed of disintegration had been increasing rapidly altering the state of equilibrium for the Kikuyu traditional peasant society, which was changing so drastically. There had developed, as a result among the Kikuyu, an increasing gulf between wealthy Kikuyu peasants and badly-off peasants. This disequilibrium further intensified the rate of change of the old society. ${ }^{55}$

This situation was exacerbated by the impact of European settlement and the concomitant legal, policy and attitudinal environment that supported white supremacy in Kenya. According to Legum, the high level of material welfare and the relative success of white settlement were both an inspiration and a challenge to Africans. It bred envy. The growth of both extreme and positive African nationalism was an expression of "anti-whiteism" and feelings of struggle for independence and advancement. These tendencies among the Kikuyu went as far back as the earliest Kikuyu political activism and consciousness under the leadership of Harry Thuku in the 1920 s. $^{56}$

According to Legum, the situation had become even more pronounced and explosive, especially in Kikuyuland, by the end of 1951. Citing the 1951 African Affairs Department annual report, Legum stated that the land problem among the Kikuyu and the northern Kamba had grown more difficult by the measure of another year of population increase among the two fertile ethnic groups. The number of landless men was greatest among the Kikuyu of Kiambu and Fort Hall. The report had pointed out that the Kikuyu could not expect to continue to live on the land. Nevertheless, it was hard not to sympathize with the Kikuyu who lost the means of rearing cattle and goats with all that those things meant to the social and magico-religious functions that made

\footnotetext{
${ }^{55}$ Ibid.
}

${ }^{56}$ Ibid. 
up the web of his traditional life. Africans lacked a proper and secure place in the modern colonial society. They were unwilling to give up the security traditionally meant for them while at the same time anxious to become part of the new urban life. For Legum, this situation called for a sympathetic understanding. The Africans were not only being required to change from selfreliant peasants to wage-dependent proletarians, but also to make the concomitant social and psychological adjustments which is something that they were either unable or unwilling to make. There is no gainsaying that it was a case of more of the latter than of the former.

As such, the rising tide of African nationalism was an inevitable product of the prevailing condition. It could, therefore, not be suppressed or ignored. The fact that it was negative and destructive meant it was a challenge to wise leadership and merited countermeasures that were not shortsighted and ill-tempered. ${ }^{57}$

Legum's perceptive understanding of the causes of the Mau Mau war was augmented by analysis of the same by Fenner Brockway, a Labour MP and longtime anti-colonialist. Brockway visited Kenya together with Leslie Hale, a fellow Labour member of parliament, for ten days at the height of the war. After conducting extensive consultations and meetings in Kenya, they were compelled to put together a report, which was not limited to this short visit but, also, informed by his longstanding interest in the colony's affairs. In Why Mau Mau?, Brockway argued that Mau Mau had arisen from a deep and continuing frustration, which was social, economic and psychological and one from which the African found that he could never escape. ${ }^{58}$

Further, Brockway noted, it would take some considerable time before such social frustration could be fully understood. But he added that as he and Hale spoke to Africans and tried to reach down to the cause of their bitterness, it became more and more apparent. It was framed within the idea that the British had destroyed the old tribal system through which African instincts, thoughts, and emotions found expression and failed to replace it by a satisfying substitute. ${ }^{59}$ For example, old democratic structures had been demolished and replaced with a low, impenetrable ceiling of administration which thrust Mau Mau grievances back upon the

\footnotetext{
${ }^{57}$ Ibid.

${ }^{58}$ Fenner Brockway, Why Mau Mau? An analysis and remedy, (London: Congress of Peoples Against Imperialism Centre, 1953), 2.

${ }^{59}$ Ibid.
} 
people. This state of affairs was compounded by economic frustration underpinned by acute land hunger. Brockway observed that to the African land was life as livelihood depended on it. For him, land hunger in Kenya was equivalent to unemployment in Britain. That is, unemployment without benefits, children allowances or other social services. Brockway intimated that when he visited Kikuyu areas and spoke to the people he could think of no other parallel more exact than conditions in the valleys of South Wales in the Hungry Thirties when seventy per cent unemployment drove the population to seek a livelihood elsewhere. Of the 11/4 million Kikuyus, half a million had had to leave their reserve because there was not land on which they could gain a living. ${ }^{60}$

Moreover, Kikuyus turned to the towns to seek a livelihood, yet some of them, like Nairobi, already had about 10,000 homeless Africans every night. Even when they had some form of housing, they were crowded in one-room dwellings with friends. These would be 10' by 10 ' rooms with no windows. In one particular room, the MPs found that three married couples were sleeping in it, their quarters limited to narrow beds behind curtains. In another rather architecturally picturesque newer housing estate, the members found a 15' by 12' room shared between two families: four adults and four children. Others yet, slept on the forms of the stalls in the squalid Burmah Market or dragged over their bodies what materials they could scrounge from the city dump heaps. ${ }^{61}$ Brockway also observed that posho, maize flour that was the staple food, had increased by $600 \%$ since 1938 . As such, the African population, driven from the land where they grew maize, could no longer buy enough maize flour to satisfy their pangs of hunger. Such was the existence of thousands of Africans who were cheap labor of the towns.

Therefore, from the foregoing, it can be averred that while a few Africans eased into the new order, the majority found it difficult to navigate the colonial capitalist system, which is something W. Hyde Clarke acknowledged when he testified before the Cost of Living Commission in 1949. Clarke stated that "the African" had been in touch with the cash system for only fifty years. In the pre-European past, barring harsh environmental catastrophes, "the African" considered it to be his divine right to eat and be housed. Africans during this period rarely went without food, and it was a new departure for him to earn something and to pay this

\footnotetext{
${ }^{60}$ Ibid., 3-4.
}

${ }^{61}$ Ibid., 6-7. 
out for things which he regarded as his prescribed right. ${ }^{62}$ Although this was a rather sweeping and simplistic view, it is, nevertheless, the closet one can come to an official acknowledgement that the altering of the mode and means of production but, more so, the alienation of land and labor, significantly affected the relationship of the majority of Africans to food. This was complicated by the racialised hierarchy of both the rural and urban colonial political economy and, thereby, biased authoritative distribution of public goods.

\section{In the Court of Global Public Opinion: The Official Mind on Mau Mau}

Despite this appreciation of the movement's springs in psychosocial roots and, therefore, the political-economic motivations of the war, there was blatant denial in official and unofficial circles in both London and Nairobi. The fact that Mau Mau methods were unconventional and murders and mutilations grotesque and horrid, meant that it was demonized. It was primitive with all its barbaric and bestial trappings and was the most virulent and infectious disease of the mind. ${ }^{63}$ While prominent white politicians representing settler interests were ready to acknowledge these economic roots, they did so with marked reservations. For example, in a letter to Lt. Col. Howard in 1953, Michael Blundell, a settler member of the legislative council and later a member of the war council, intimated such deep economic causes.

However, Blundell argued that while he believed that there was an element of economics in it, for a number of reasons he could not accept that this was the main reason, for the simple fact that most of the really hot-stuff oath administrators were rich men. ${ }^{64}$ There were those who recognized the essential of making a resolute attempt to tackle African economic and social troubles thus enabling them to be kept behind government. ${ }^{65}$ Others while sharing this sentiment argued that what was wanted was firm handling as opposed to the much talked about new services, new housing, bigger wages and more opportunities. This, at least, until Africans had come to their senses and all the subversive activity cleared up. After all, the government had to be most careful that the African did not get the impression that Europeans had had the fright of their lives as this could do immense harm. There was no doubt between many observers and

\footnotetext{
62 Testimony given by Hyde Clarke to the Cost of Living Committee, $15^{\text {th }}$ February 1949, Papers of the Electors' Union and the European Elected Members Organization, RHO: 80/2 MSS Afr. s. 596.

${ }^{63}$ LegCo. Deb., XLI (19 ${ }^{\text {th }}$ February 1954): 77.

${ }^{64}$ Michael Blundell to Lt.-Col. Howard, $13^{\text {th }}$ October 1953, Papers of Sir Michael Blundell, RHO: MSS. Afr. s. 746.

${ }^{65}$ Blundell to Hugh, $10^{\text {th }}$ September 1952, Papers of Sir Michael Blundell, RHO: MSS. Afr. s. 746.
} 
Europeans living in the colony at the time that other tribes were watching most carefully. As such, any sign of weakness would be fatal. ${ }^{66}$

There was, therefore, a deliberate attempt made to ensure that Mau Mau did not win the sympathy of other ethnic groups in Kenya and elsewhere in the world. Even extra care was taken not to dignify the "terrorist" movement by spreading the impression that Mau Mau was a band of ardent nationalists fighting for their land and rights against a group of bogus, upper-class, niggerhating, cocktail-drinking whites who had seized the Africans' lands and were sitting on them. ${ }^{67}$ This was the kind of impression given in a special series of articles by Edward and Majorie Ward in the BBC Radio Times, which was a radio journal that had the biggest circulation of any such genre in the world. This series had caused a lot of concern since it had the potential to damage the white man's political and economic project in Kenya against the Mau Mau troubles in the colony. According to the Secretary of the Electors' Union, Kendall Ward, in a letter to Blundell, it was part of a mounting attack on the European position which was not helped very much by some of the more stupid activities in Kenya political affairs. It was perturbing that all but a few Kenya Europeans were unaware, in light of such publicity, of the weakness of their position. They never troubled to learn how to influence the vast, sentimental electorates outside Kenya in whose power they were, whether they liked it or not.

Yet, their antagonists, black, white and brown in Kenya and elsewhere, had long ago perceived that the destiny of Kenya would be decided in Fleet Street, in Grub Street, in Westminster, Washington and the Kingsway Hall or wherever two or three are gathered together with a speech to make, a vote to catch, or a column to fill. ${ }^{68}$ The Mau Mau spectacle that mattered in such places was cast in light that ensured that the tide was rising against white settler interests in Kenya, which was attested by the BBC series among other factors. The Bandung conference, for instance, was one such important factor. It was clear to most observers of the conference that participating anti-imperial elements were going to reach an agreement in opposing colonialism, which was significant in that it would lead to the groundswell of the quite vicarious sense of guilt in colonial Kenya that colonies were right out of step with the trend of

\footnotetext{
${ }^{66}$ Letter from W.A.C. Bouwer of Chepkoilel to Michael Blundell, Papers of Sir Michael Blundell, RHO: MSS. Afr. s. 746.

${ }^{67}$ Kendall Ward to Michael Blundell, 26 ${ }^{\text {th }}$ April 1955, Papers of Sir Michael Blundell, RHO: MSS. Afr. s. 746.

68 Ibid.
} 
world events. The continuance of such colonial projects as Kenya would be seen as yet another cause for war and hatred both of which were manifest. In this regard, Mau Mau was winning in the field of world public opinion. ${ }^{69}$

Secondly, under the leadership of Eliud Mathu, the Kenya Guild had made demands to the European Economic Community that would, in both Kenya and Uganda, result in a large African demand for universal suffrage. Mbiu Koinange, who was in London during the emergency period where he had taken refuge, was Mau Mau's mouthpiece and was increasingly vaulted in circles that could only be described as being the vanguard of intellectualism. Koinange had even had a book published in the USA and was distributing a thousand copies in the UK. ${ }^{70}$ Consequently, the Mau Mau cause was gaining sympathy outside the colony, which alarmed not only settlers but also the colonial administration in Nairobi.

It was said that in Uganda, for example, at Christian missions Africans were praying for the success of their Mau Mau brethren, which was seen as evidence of the spread of the infection of the movement's virulent disease of the mind. ${ }^{71}$ Mau Mau reverberations were felt in the Congo where there was uneasiness among European inhabitants of the eastern border areas of that country. ${ }^{72}$ A memo sent on $18^{\text {th }}$ December 1952 by the Mogadishu Consulate to the African Department of the Foreign Office in London reported that there was a general feeling among the Somali population in the city at least as strongly inclined to be sympathetic with Mau Mau as it was with nationalist aspirations in North Africa. ${ }^{73}$

Indeed, the Mau Mau movement and its cause received a lot of positive international reception and coverage especially from Africa. The Lagos based West African Pilot, for example, carried, in 1952, a leading article entitled "Is this the Hand of Jacob?" It quoted a Reuter dispatch claiming that the police intelligence in Kenya was convinced that the organization was directed by brains that were not African and that overall control was perhaps exercised from outside. The Lagos paper, therefore, assumed that the Kenyan police thought that the African was generally

\footnotetext{
${ }^{69}$ Ibid.

${ }^{70}$ Ibid. Ward went on to suggest that Koinange, in his opinion, should have been neutralized or removed from the scene. It is known now, however, that this was much exaggerated.

${ }^{71}$ LegCo. Deb., XLI (19 ${ }^{\text {th }}$ February 1954): 76.

72 Courrier d'Afrique, $5^{\text {th }}$ November 1952.

${ }^{73}$ Memorandum from Mogadishu Consulate to the African Department, Foreign Office in London, $18^{\text {th }}$ December 1952, BNA: CO 822/448.
} 
inert. That he was a dog that barked, but did not usually bite. Now he had started to bite, the Kikuyu rebel must have borrowed his teeth from somewhere outside Africa! ${ }^{74}$

Another paper, the Daily Express in Accra, in one of their lead stories on $28^{\text {th }}$ October, said that with a little more ignition, the outbreak of Mau Mau violence would be an explosion that could be heard far and wide. Further, the Daily Express opined, the war was not a new invention; it was only the continuation of the revolution which had swept Europe, America, Oceania and Asia, out of which the spark was being seen in Africa, flaring up with immense intensity. Having traced, with more or less accuracy, the struggle for independence in various parts of the world, the paper said that Africa was the last of five continents emerging from slavery to nationhood. The article even suggested that "Mau Mau" in the Ewe language could be interpreted as an appeal or a supplication to God, "Mawu" being the word for "God" in that language. It referred to a statement which it attributed to the Secretary of State for the Colonies, Oliver Lyttelton, who was quoted as having said that, "however small a movement like this may be, it does not spring up unless there is some fairly deep cause."75

That, continued the paper, was exactly where it stood. Workers in the East African country, it pointed out, earned seven East African cents a day. Who, it posed, was to blame for this oppressive practice? Was it to be concluded that the people of Kenya hated white men so much that they had planned to murder them? Certainly not, it argued. The upheaval in Kenya, therefore, served as a warning to all colonial administrators as to what was in store for all. It had reached the boiling point and could explode. Prevention was in the granting of freedom to all colonial peoples and allowing them citizenship of the world without a bar of any sort. Those who chose to suppress the truth could do so at their own destruction. ${ }^{76}$

The Colonial Office and the colonial government were obviously concerned about this sweeping international sympathy and mounting attack on the European position in Kenya as a result of Mau Mau. Perhaps arising out of this growing attention focused on the goings on in Kenya in the press, both London and Nairobi got hostile and domestic and international propaganda was upped. An important communication from the Commonwealth Relations Office,

\footnotetext{
74 "Is this the Hand of Jacob?" West African Pilot, 28 $8^{\text {th }}$ October 1952.

${ }^{75}$ Daily Express, $28^{\text {th }}$ October 1952.

76 Ibid.
} 
"Kenya: Mau Mau," was drafted and circulated to senior CRO officials, the UK Delegation to the United Nations in New York, and high commissioners and ambassadors in Pakistan, India, Canada, Ceylon, New Zealand, USA and Australia among other countries. ${ }^{77}$ It was designed as an attempt to elicit, from all these imperial officers and the commonwealth, surveys from various regions of views, in their respective countries, on developments in Kenya. This was followed by redoubled efforts to present the "true" picture of what was really happening in Kenya in both London and Nairobi. The British Information Services, an agency of the British government, released damage control press briefings explaining that Mau Mau was a terrorist movement of Kikuyu who were bewildered by European civilization with the result being growing discontent in villages and unemployment, poverty and crime in the city of Nairobi. One such propaganda document mentioned the Hugh Dow commission that had been set up to look into the question of land and related issues. British diplomats pored over press articles from the Commonwealth carrying developments in Kenya with dedication. Their observations were relayed back to the CO for action. ${ }^{78}$

In one instance, it was decided that there was need to correct the Kansas City Star, which had made the underlying assumption Europeans were occupying lands from which Africans, specifically the Kikuyu, had been turned out. This, it was argued, was not the case because, when the British administration came to Kenya, it was a welter of warring tribes chasing one another over the country and the White Highlands, in particular, were populated, if at all, by a few nomadic Maasai, for whom ample provision was made elsewhere. All this, however, was not to deny that there was overcrowding in Kikuyu country. But this owed in large measure to the introduction of public order, the suppression of warfare, and social services, made possible by wealth created mainly by white settlement. ${ }^{79}$ The public relations coup from London and Nairobi was a resounding success especially with newspapers outside Africa and the Soviet Union. Soon, foreign media started outdoing London and Nairobi in explaining what Mau was all about.

For example, a Mrs. Malinowska, writing for the New York City based Life Magazine, and, perhaps, closely adhering to the official template prepared for various press outlets around

\footnotetext{
${ }^{77} \mathrm{CRO}$ to Commonwealth countries and British colonies, telegram, "KENYA: Mau Mau," $2^{\text {nd }}$ January 1953, BNA: CO 822/448.

${ }^{78}$ A CRO nondescript document marked for release on 7th November 1952, BNA: CO 822/448.

${ }^{79}$ C.Y. Carstairs to J.G. Boyd of the CO, $8^{\text {th }}$ November 1952, BNA: CO 822/448.
} 
the world, wrote: "The Kikuyu -through their inherent characteristics-have been ...more adversely affected by this phenomenon [primitive agricultural methods coupled with the rise of the population, European settlement and consequent development] than other tribes. Naturally quick, impatient and politically conscious, their feeling of frustration in the difficult and social situations arising from the development of the country has found expression in a reversion from education and Christianity to primitive tribal practices and superstitions." For this reason, the leaders of the movement were establishing their own courts in their attempt to usurp the functions of government. ${ }^{80}$

Another American paper referred to the Mau Mau as the criminal fringe of an Africa on the march. Quoting the Sunday Times, the paper explained the movement in terms of there being, throughout Africa, a breaking up of an old social order based in tribalism and primitive nomadic ways of life. This old order had crumbled under machines, technology, money, economy, modern transportation, systems of law and elective authority. But, as yet, the native Africans have not been able to find stability in a society based on European ideas. ${ }^{81}$

So, while the reality was approximated with some degree of accuracy, the next logical conclusion, that Africans wanted existential stability and a secure niche in the new modernized order, was not reached. Africans wanted to access and enjoy the facilities of modernity on an equal footing with other races. They also wanted ample accommodation quarters and higher wages; cash crops; trade licenses; the demand for educational opportunities formal as well as technical and vocational; demand for credit facilities to, and training for, farmers; and establishment of cotton ginneries. Needless to say, land was the single most important preoccupation as well. Instead, the myth of exoticism and primitivism had more currency and traction in the international court of public opinion.

That explains why, according to Detroit News, the war was being spurred by black magic. According to this American paper, the movement was, by employing terror, trying to drive out foreigners in order to recover the land. It went on to point out that the situation was roughly equivalent to the efforts of American Indians to stop white settlement of the American

\footnotetext{
80 "Note on Present Situation in Kenya," Life Magazine, $4^{\text {th }}$ November 1952.
}

81 "Kenya Terrorists Afflict Africa," Great Falls Tribune," $3^{\text {rd }}$ November 1952. 
continent, although the Africans were infinitely more powerful. ${ }^{82}$ Other papers were a little more balanced in their analysis. The US paper, Speedy Daily, while labeling Mau Mau a "terrorist" movement, noted that "some of Kenya's problems include European settlers pre-empting the best land, confining the great black tribes to reservations, lack of employment to meet the high birthrate of the natives, and segregations. Quoting Negley Farson's book, Last Chance in Africa, the Speedy Daily concluded that such a situation was bound to cause an explosion some time. ${ }^{83}$

The press in Western countries was, therefore, uncritically drinking from the brook of London and Nairobi propaganda, which was informed by Carother's report, Psychology of Mau Mau. As earlier noted, while admitting the destabilizing impact of colonial agromodernity, urbanization and erosion and corruption of indigenous African principles and institutions, which caused anxiety, Carothers argued that Mau Mau was an atavistic movement of crazed nut heads. In this rather biased psychological analysis, the role of animistic and magical modes of explanation in producing a childlike mentality and molding the "psychopathic" character of the nationalist rebels was emphasized. This is what then informed the popular perception of Mau Mau as a disease of the mind, a plague, a virulent infection and a sore that had to be cut out before it affected other loyal Africans in the region.

In Kenya, this was the official view and line of the Mau Mau war. The movement's oaths were bestial and their methods depraved beyond words. ${ }^{84}$ Kikuyu leaders, Eliud Mathu and Harry Thuku appealed to their people in the name of Jesus Christ to abandon things of which God Himself disapproved. Did they not see that the Mau Mau were vagabonds and spivs and hopeless persons? Thuku appealed to Kikuyu to abandon everything to do with that evil association of Mau Mau and work with the government to bring back peace of the land as of old. ${ }^{85}$ Thus Mau Mau was effectively criminalized and bastardized both at home and abroad.

Foreign press in the Soviet Union and India, however, were more critical. Komsomol Pravda devoted its "International Review" section to affairs in Kenya. The slant of the reporting was rather obvious: colonial oppression was causing discontent and protest against the regime of

\footnotetext{
82 "Black Magic Spurs African Terrorists," Detroit News, 1 ${ }^{\text {st }}$ November 1952.

${ }^{83}$ Speedy Daily, $28^{\text {th }}$ October 1952.

${ }^{84}$ LegCo. Deb., XLI (19 ${ }^{\text {th }}$ February 1954): 109.

${ }^{85}$ CRO to Commonwealth countries and British colonies, telegram, "KENYA: Mau Mau," BNA: CO 822/448.
} 
terror, poverty and deprivation of rights established by the British. Pravda added that Africans in Kenya were deprived of lands which for centuries their forefathers owned, and they were driven into reservations. ${ }^{86}$ Unlike Soviet newspapers, which were obviously motivated by ideological leanings, the Indian press was more balanced but critical of British imperial policy in a manner that approximated the situation. This can be attributed to India's experience under British imperialism for an even longer period than in Kenya. The Indian government was concerned about a series of damaging reports appearing daily in the newspapers. There, reaction in Indian press had been uniformly hostile even from normally responsible and friendly editors who commented bitterly that it was British policy that had led to the outbreak of Mau Mau. ${ }^{87}$ Two months later the prime minister was worried about bad press because it was increasingly linking events in Kenya with the situation in South Africa in the eyes of the Indian public. ${ }^{88}$ The British High Commissioner in India assured the Indian government that Britain aimed at getting order restored and then to tackle the root causes of the trouble and lay a sound basis for further social and economic advance. ${ }^{89}$

This was not convincing enough for the Indian government which thought that deductions from firm action which had had to be taken in Kenya were, of course, quite false. In the battlefield of Indian public opinion, military operations, arrests, round ups, shootings and confiscations of property in Kenya were seen as thrashing about wildly. ${ }^{90}$ The Times of India wrote that the colonial authorities were willfully exaggerating operations of the Mau Mau conspiracy seeking to utilize it for curbing political and economic aspirations of the African people. Quoting statements made by Jomo Kenyatta, it contrasted, at length, the desperate poverty of, and the restrictions placed on, Africans with the prosperity and freedom enjoyed by the European community, which enjoyed a monopoly of the most fertile area of Kenya, the highlands. Further, it stated that it was sheer desperation generated by failure to get their just grievances redressed that had driven Kenya's Africans to violence. The paper urged the UK government to take immediate steps to remedy legitimate grievances of the African people who had been cheated off their lands and rights of citizenship in their own country. It concluded by

\footnotetext{
${ }^{86}$ Komsomol Pravda, "What is happening in Kenya," $28^{\text {th }}$ October 1952.

${ }^{87}$ UK High Commission in India to the CRO, $23^{\text {rd }}$ October 1952, BNA: CO 822/448.

${ }^{88}$ UK High commissioner in India to the CRO from UK, "Kenya," $10^{\text {th }}$ December 1952, BNA: CO 822/448.

89 Ibid.

${ }^{90}$ UK High Commission in India to the CRO “Kenya," $5^{\text {th }}$ December 1952, BNA: CO 822/448.
} 
asserting that poverty and hunger could not be put down by the sword. ${ }^{91}$ Another Indian newspaper, the Statesman, while less critical, stressed that the proclamation of a state of emergency and strengthening of security forces would cause complex issues to be oversimplified. ${ }^{92}$

These kind of sentiments echoed similar observations from unexpected quarters in Kenya. Speaking at the LegCo, the member for the coast, Cooke, stated that he thought that a good deal of the unrest in Kenya was due to the fact colonial leadership had not anticipated African grievances in the past. As a result, such grievances, real or imagined, had been allowed to simmer in the minds of a dissident and aggrieved people. ${ }^{93}$ The Asian Member for Eastern Electoral Region, A.B Patel, made similar remarks. Patel argued that it was necessary to study the legitimate grievances and aspirations of the African community and to meet them where necessary because it was important in dealing with the nature of emergency that faced the country. ${ }^{94}$ Thus, even for white representatives like Cooke, it was not enough to win the physical battle against Mau Mau but also not to lose the confidence, not only of the Kikuyu, but also that of other ethnic groups in Kenya. ${ }^{95}$ There was apprehension the Mau Mau disease of the mind would spread to other parts of the country. Not only had the war beamed in headlines around the world. It had caused seismic political tremors that were felt in the colony.

In Nyanza, people were thirsting for education with the result being the rapid awakening of political consciousness. There were a great number of schools in that particular region, many of which were entirely run by African teachers and overseen by African inspectors. Some of these people were university-educated, and considering what had happened with independent schools in Kikuyuland, this was seen as a potential tinderbox. Mrs. Shaw, the member for Nyanza, told the LegCo that in a tour of the region, some of these educated people imbued with advanced ideas and African nationalism had openly supported the objects of Mau Mau. ${ }^{96}$ E.W. Crosskill, the Member for Mau, shared this view when he said that there was continual recrudescence of Mau Mau throughout the country. Crosskill told the Council that administrative

\footnotetext{
91 "Unrest in Kenya," Times of India, 24 ${ }^{\text {th }}$ October 1952.

92 Ibid.

${ }^{93}$ LegCo. Deb., XLI (19 ${ }^{\text {th }}$ February1954): 125.

${ }^{94}$ Ibid., 136.

95 Ibid., 144.

96 Ibid., 77.
} 
officers in Nyanza were very disturbed by the danger of infiltration of Mau Mau along the boundaries with the Rift Valley Province. Whereas this had initially been rumored, after extra vigilance by the Kenya Police and settlers, there was evidence of this spread had been found, which had been proclaimed in the press by the Kericho District Commissioner. The DC had stated that things were much worse in the "Lumbwa" area (presently Kipkelion) than had been suspected. ${ }^{97}$ As such, it was not lost on either settlers or the colonial authorities of the countrywide danger posed by the Mau Mau menace.

Indeed, the picture must have been even more worrying for the UK government and the Colonial Office in particular after the dispatch of the East African Royal Commission on Land, Population headed by Hugh Dow. As earlier noted, this commission was established at the behest of Sir Phillips Mitchell, the governor of Kenya, to investigate the social, economic and political conditions in the region. Actually, the urgent nature of this kind of inquiry as suggested quite early in the late 1940s, was underplayed. It only became imperative after the outbreak of the Mau Mau violence and, even then, London still dragged its feet over the matter. Nevertheless, evidence collected and testimonies heard by the commission revealed widespread discontent and grievances, which mirrored those expressed by the KCA, Kikuyu individuals and communities over the years.

\section{Mau Mau Minds from "The Above": A Nightmarish View}

The Dow commission findings presented a view from the top of an unsettling state of affairs in the colonial Kenya. The narratives of suffering and grievance that constituted the evidential material revealed Kenya Mau Maus of the mind in embryo. There was a groundswell of aggrieved voices demanding redress and justice from the British and colonial governments. This evidence was enough indication that all was not well in colonial Kenya. African submissions and evidence came from all over Kenya from the Maasai, Nandi, Kamba, Luhya, Keiyo, Marakwet, Taita and Luo among others. They contained grievances about land shortage and overcrowding in the African reserves; worker grievances such as demands for better accommodation quarters and higher wages; cash crops; trade licenses; the demand for educational opportunities formal as well as technical and vocational; a demand for credit facilities to, and training for, farmers; the establishment of cotton ginneries; the abolition of the

\footnotetext{
${ }^{97}$ Ibid., 71-74.
} 
maize and produce control board and the free movement of agricultural produce at the district and national levels; urban problems etc. It was evident that the colonial order and imperial legitimacy was in question, and a different future Kenya envisioned.

For example, in their submission, the Kanyakwar Luo clan that hailed from Kibuye Location, close to Kisumu Township, complained and expressed regret that even after about twenty or so years since the Carter land commission, the government had failed to respond to its petitions. This was in spite of the fact that the clan had repeatedly submitted grievances to successive colonial governors since 1915. The clan claimed legitimate ownership of the land upon which the township was located by ancestral, and thus, customary right. The land was theirs, they wrote, long before the advent of British colonialism. Yet, the government continued to turn a deaf ear and refused to give the matter due consideration even as the clan was by-passed by economic development in the area and the community, rendered redundant. The clan also protested that it was not in favor of modification of the form of land tenure and rights from the traditional one practiced by Africans to a new one. Further, that any arising land disputes be dealt with under that particular preferred land tenure system and rights. The clan was confident that this would conclusively prove that the land in question was its property hence its transfer was not subject to control under colonial law. ${ }^{98}$

The Kanyakwar refuted the Carter commission's conclusion that Kisumu was a market town that attracted agricultural produce from African farmers in the region. The commission had argued that, as such, the township was not a liability but was beneficial to the clan that lived near Kisumu market more than anyone else. They had easy access to perishables like eggs, milk and vegetables stated the commission. Kanyakwar told the Dow commission that while it appreciated Carter's observations, it had to disagree in entirety as it was absolutely incorrect to say that the clan enjoyed the benefits that accrued from the proximity of the market. If anything, it was those with land to cultivate who enjoyed the proceeds from the sale of their produce. The alienation of their land to pave way for the township with its attendant urban features such as administration posts, police lines, courts and the prison; railway station and houses; airport; Nyanza oil mill; a soap factory; European housing; water-treatment plant at Ujiji, now renamed "masikini” (poor);

\footnotetext{
${ }^{98}$ The Kanyakwar Clan, Luo Central Nyanza District, to the Dow commission, nd.; also see the Memorandum of the Kanyakwar Clan (Luo Tribe), Central Nyanza District, Nyanza Province, Kenya Colony, $13^{\text {th }}$ May 1953, BNA: C0 $892 / 6 / 1$.
} 
Kisumu hotel; football stadium; and European and Asian cemeteries had resulted the displacement of clan members. They were as a result scattered with every new extension of the township boundaries. Their submission contained a comprehensive list of families displaced for every of the urban developments listed above. ${ }^{99}$

This anguished Kanyakwar land claim was but only one of numerous similar claims made by a range of people acting in accord or as individuals. In their submission to the Dow commission, the Kipisigis of Kimulot in Kericho District stated that the hearts of many people were broken because they had been evicted from their lands and their houses burned down by colonial agents in 1927. The total number of houses burned, they claimed, was 1,641 in Kaptimdui-Kimulot, Kamongonjet, Kaptulgeny, Kibulgeny and Timbilil among other Kipsigis areas. On the basis of the loss of what they boasted was the best land in the colony with fine weather, the Kipsigis advised the commission that what the people of Kenya wanted was to live in their own lands which had been labeled "Crown Lands." When the Carter land commission held sittings in the early 1930s, these Kipsigis had demanded that their lands be returned. As in other African claims, the Carter commission's resolution had not been satisfactory. ${ }^{100}$ Although the recommendations of the Carter commission were accepted by the government and regarded as the basis of all land problems in the colony, they did not stop Africans from making land claims. Among the Kipsigis in the 1940s, Dini ya Mbojo, which was similar to DYM, alongside the Kipsigis Central Association continued to agitate for redress of land hunger. Both of these Kipsigis bodies were declared unlawful societies dangerous to the good government of the Colony in the late 1940s. ${ }^{101}$

Although the Kipsigis land claim at Kericho had been presented to and mentioned in executive council meetings during this time, no action had been taken. The Kipsigis submission to the Dow commission described this issue as having been very hot by 1951 because the appropriation of an estimated 7,250 acres of land belonging to the Kipsigis African District Council was simply unjustifiable. The little prevailing peace that had held since the late $1920 \mathrm{~s}$

\footnotetext{
${ }^{99}$ Memorandum of the Kanyakwar Clan (Luo Tribe), Central Nyanza District, Nyanza Province, Kenya Colony, 13th May 1953, BNA: C0 892/6/1.

${ }^{100}$ Kipsigis to the Royal Commission, The Things Which are Spoiling Peace Between People and Government, $29^{\text {th }}$ December 1953; also, Memoranda From the People in Kericho, $21^{\text {st }}$ December 1953, in Memoranda From the Public: General African Submissions, BNA: CO 892/5/4.

${ }^{101}$ Executive Council Meeting Minutes, $7^{\text {th }}$ May 1948: BNA: FCO 141/5528.
} 
evictions had been disturbed since the government pulled down more houses in KaptuigenyKamongonjet on $28^{\text {th }}$ February 1952. White farmers and tea growers had then been settled on this Kipsigis land. Yet, the Kipsigis argued, their population was growing bigger by the day with people having to farm ever smaller strips of land. Poverty and malnutrition was an everyday reality. ${ }^{102}$ They criticized the government for developing lackadaisical, discriminatory and covetous laws that only provoked hatred. ${ }^{103}$ It was pointed out that there was, at the time, no room for Kipsigis expansion southwards as was the case before the advent of colonialism. Taita arap Toweet, one of the first and most educated Kipsigis, argued in a personal submission that had the British not intervened, this southward migration would have reached Tanganyika. ${ }^{104}$

Similarly, the Keiyo and Marakwet protested in strong terms that they faced an existential threat as a result of land alienation. Land, they said, was everything to them. It determined whether one was rich or poor and if their children could be educated or remained ignorant. In their memorandum, they expressed their bitterness over the loss of their source of livelihood that had been theirs since time out of mind. They complained that they were crowded in a one mile broad strip together with their diminishing and lean cattle herds which had once been their mark of wealth. Old land boundaries were a constant ringing din in the ears of the old and young in their daily lives especially considering that the Carter commission had ignored their claims twenty years before, they said. The elders felt that although destocking was the "solution," it was a direct weapon designed to confine them in a crowded reserve and to keep them from demanding more land. As a result of all this, there was only sadness in Keiyo and Marakwet hearts. ${ }^{105}$

For their part, the Nandi Mau Maus of the mind expressed the desire to embrace advanced agricultural methods and transition from nomadic life to mixed farming. The progressive members of the ADC stated that they were anxious to go in this sound and economic direction towards this progressive land use. However, there were obstacles such as land leases and titles for security against which they could leverage for agricultural loans to develop their holdings. Further, the Nandi submission argued that no matter how the Nandi land unit was

\footnotetext{
102 Memoranda from the people in Kericho, BNA: CO 892/5/4.

${ }^{103}$ Siroin Kipsigis to Dow commission, $22^{\text {nd }}$ December 1953, BNA: CO 892/5/4.

104 Taita arap Toweet to the Dow commission, $14^{\text {th }}$ April 1953, BNA: CO 892/5/4.

${ }^{105}$ Memorandum to the Commission by Elgeyo and Marakwet Elders, 24 ${ }^{\text {th }}$ March 1953, BNA: CO 892/5/4.
} 
farmed, they anticipated a large landless population without an alternative means of livelihood. For that reason, they wanted Nandi land that had been retained by Europeans in Kipkarren and Kaimosi. While 13,000 acres of these farms had been returned to the Nandi in 1950, it was not enough. The Nandi considered that the award of these lands under the soldier settlement after the First World War was "a very big mistake." At the time, not only did the Nandi inhabitants in those areas lose land but they also had their homes destroyed. This then, they argued, was the justified foundation upon which they demanded for the mistake to be made good. ${ }^{106}$ At the same time, the series of punitive British military measure visited upon the Nandi was still fresh in their memory. They felt very strongly that their removal from their Tinderet lands as part of punishment for interfering with the construction of the Mombasa-Kisumu railway between 1898 and 1901, was not justifiable. They estimated that there was only 751 square miles of land against a population of 80,000 Nandi as per the 1948 census. At least 20,000 Nandi squatters were believed to be landless and lived on European farms. Some of these Nandi people, who could be found outside their reserve, had not immigrated "for sheer adventure."

The Maasai too were hopeful that "the impassable abyss of suspicion and resentment" between them and the British of half a century over their land woes, would be bridged by the Dow commission. Different sections of Maasai affected by the 1904 and 1911 treaties wrote impassioned and moving submissions. Under the leadership of Kirringol ole Risie, Maasai from Kajiado assured the London-appointed commission that the bitter memory of their forced eviction from Laikipia was still fresh and would continue to be in the future. Further, they blamed the Carter commission for being responsible for even more excisions of valuable land and making "diversionary additions of a few bits there and there." 107 One such dispossession was the Ololelai land, which was included in the Tsavo National Park without Maasai consent and the Ziwani Estate area. ${ }^{108}$ Kajiado Maasai also claimed that there had been further encroachment of the Athi River railway station eastwards. At the same time, the Kitengela and Mbagathi boundary set at the Mbagathi River, clearly laid down in the 1911 treaty, had been overstepped.

\footnotetext{
${ }^{106}$ Nandi African District Council to the East African Royal Commission, $1^{\text {st }}$ May 1953, BNA: CO 892/5/4.

${ }^{107}$ Kajiado Maasai to the East Africa Royal Commission, $10^{\text {th }}$ May 1953, BNA: C0 892/6/1; also see the individual submission by J. C. Likimani to the commission, $10^{\text {th }}$ May 1953, BNA: C0 892/6/1.

${ }^{108}$ Memorandum by Loitoktok chiefs and People, $5^{\text {th }}$ May 1953, BNA: C0 892/6/1.
} 
The Ngong boundary was shifting at an alarming rate and their protest in this regard had fallen on deaf ears. ${ }^{109}$

The Narok Maasai were even more combative and critical of government machinations with regard to land than the Kajiado group. They made it clear that they did not recognize the 1911 treaty, which they deemed as null and void. They cited the 1904 treaty that stated and assured the Maasai that the settlement would be honored as long as the Maasai existed. They indicated that it had only taken exactly six years and 261 days for this promise to be broken. Blame for the breach of this agreement was laid on the "political pressure of the Land-grabbing settlers." Narok Maasai made it clear that they saw this as a deliberate physical violation of the 1904 treaty, which they highly resented. ${ }^{110}$ In addition, they expressed grave suspicions with regard to what they termed "insidious moves" on even more appropriation of land in preparation for the creation of National Parks in Maasailand.

But it was the Loitoktok Maasai who were more eloquent on the issue of national parks and game reserves like Tsavo and the Amboseli. The Loitoktok Maasai stated that land was essential for their continued existence. As such, it was a great cause of concern that colonial conservationist policies were inimical to their economy, which was directly affected by their implementation. They hoped that the British would consider their requirements "more important than those wild animals." ${ }^{111}$ After all, if settlers could kill or drive away wild animals because they were a nuisance, why did the government want to make national parks or game reserves on the land that was left? They pointed out that it was the very people who removed game from their farms who appropriated Maasai land in order to protect wildlife for tourism. The Loitoktok did not see how tourists benefitted the country considering to the great sacrifices the Maasai were being forced to make for extensive sanctuaries for wild animals. The little fees paid to the ADC could not compare to their losses, in both human and material terms, they argued. While they once coexisted with, and exercised discretion with regard to wild animals, they lamented the

\footnotetext{
${ }^{109}$ Kajiado Maasai to the East Africa Royal Commission, 10 ${ }^{\text {th }}$ May 1953, BNA: C0 892/6/1.

${ }^{110}$ Maasai memorandum No. 1 on land grievances, $13^{\text {th }}$ March 1953, BNA: C0 892/6/1.

${ }^{111}$ Memorandum by Loitoktok Chiefs and People, $5^{\text {th }}$ May 1953, BNA: C0 892/6/1.
} 
fact that it was no longer within their power to take any action when they attacked people or livestock. ${ }^{112}$

Likewise, the Kamba of Kitui District expressed their displeasure about land alienated for conservation purposes. They claimed that land designated as Crown Land and other areas set aside for a national park had affected a quarter of a million people. The creation of national parks around 1948 had adversely affected the people of Kanziko-Ikutha locations, the Athi River and all the way south to the Kitui-Malindi boundary. The Tsavo National Park also affected the area south of Kibwezi. Kamba people, as a result, were left "to hang about in land hunger." The memo to the Dow commission called for immediate repeal of the Crown Lands Ordinance (1938) to relieve land hunger that the Kitui Kamba had suffered. ${ }^{113}$ The Taita of Taveta were also among many colonial people who made similar appeals. The Taita were "crying" for the land west and east of Lumi river part of which was possessed by the Ziwani Sisal Estate. But the land they needed most was in the area between Lumi and Salaita, which in Pre-European times had been used for settlement, bee keeping, cultivation and cattle grazing activities that were illegal under the new colonial order. The Taveta Taita were confident that these lands were rightfully theirs as inheritance from their forefathers. Yet, they were surrounded by Europeans on all sides "like people in an island" leaving a small area for their use. ${ }^{114}$

Besides the Taveta claim, there were other notable land claims made by groups of people who had lived and conducted trade in the along the East Africa coast line for years before British presence. Hadi Z. Bakari expressed fear and unease because the government had seized his plot of land at Mwandudu, Miritini, for example. This land had belonged to his father, Kituwe Ngome, who was illiterate and had, in old age, succumbed to dementia that Bakari attributed to a court case over the plot. Bakari argued that it was not fair for someone to lose his property simply because one was illiterate. Failure for plot No. 291 to be returned, Bakari said, would subject him to a hard life of poverty. ${ }^{115}$ Ahmed bin Stambul put in a letter on behalf of a dozen land claimants from Kilifi District. The land in question was in Kuruitu that covered the area

\footnotetext{
112 Ibid.

${ }^{113}$ Memorandum on Land, Economic and Trade from the Kitui Friendly Society, $19^{\text {th }}$ June 1953, BNA: C0 892/6/1.

${ }^{114}$ Memorandum: Shortage of Land Taveta received 22 ${ }^{\text {nd }}$ April 1953, BNA: C0 892/6/1.

${ }^{115}$ Hadi Z. Bakari, Land claim plot No. 291 Situated at Mwandudu, Miritini, $17^{\text {th }}$ July 1953, BNA: C0 892/6/1.
} 
from Vyewe to Kijangwani. Although the land had been passed to a succeeding generation, it had been designated Crown Land. ${ }^{116}$

As illustrated in the land claim examples discussed above, many communities in Kenya of the 1950s were perturbed and experiencing the same hardships as those that motivated the Mau Mau war. At the same time, however, there were other issues and grievances shared between various Kenyans that were highlighted in various African submissions to the Dow commission. Among these included the housing problem in main urban areas, among them Nairobi, Mombasa, Kisumu and Thika; the high cost of living and low wages; the demand for education and technical training; and the demand for markets for African agricultural produce among others.

As earlier noted, housing and the twin grievances, cost of living and low wages, had been a major issue of discontent especially, in the mid-1940s. The Christian Council of Kenya highlighted the plight of African urban workers, which was deplorable. It stated that anyone acquainted with housing conditions in Nairobi could substantiate and illustrate the state of urban housing from personal experience. Babies were known to be born in a room in which two or more married couples were housed. Adolescent girls slept in the same room as their fathers and brothers at the expense of decency and dignity. ${ }^{117}$ Nairobi councillor Kairu Ngure pointed out the acute shortage of African housing for male migrant labor, which could only get worse if the question of their families was also considered. ${ }^{118}$ The Kenya Federation of Trade Unions did exaggerate when it pointed out that, "more than 10,000 people" were on the Nairobi City Council housing waiting list since 1944. Some resorted to building shanty villages on the outskirts of the city, for example Buruburu, where 16,000 lived but from where they were evicted in 1951 by the city council. Other informal settlements included Kariobangi and Mathare Valley. ${ }^{119}$ Very few firms provided accommodation for their employees, the Kisumu African Commercial Employees Association, complained. Even when they did, it was usually a 10' X 10 ' room or even much smaller room. Such housing was of poor quality and inadequate yet employees were supposed to live happily and comfortably with their families. Further, argued

\footnotetext{
${ }^{116}$ Ahmed bin Stambul, Claim of land, $9^{\text {th }}$ April 1953, BNA: C0 892/6/1.

${ }^{117}$ S.A. Morrison, African Housing in Urban Centres, $31^{\text {st }}$ December 1954: KNA MSS/129/26.

118 Kairu Ngure, Memorandum on "Urbanized Africans in Towns," 29 ${ }^{\text {th }}$ December 1953, BNA: CO 892/5/4.

${ }^{119}$ Kenya Federation of Registered Trade Unions to the Royal Commission, $5^{\text {th }}$ May 1953, BNA: CO 892/5/4.
} 
the Kisumu Employees Association, the wages paid would not enable members to buy furniture and even if this were possible, it could not even fit the small space. African salaries, were thus, "a starving one," which forced them to rent a very dirty small room to keep out of the elements. It was a basic survival salary enabling Africans to tide over another day. ${ }^{120}$

This point was put before the commission even more bluntly by J.K. Rono who submitted an individual petition. Rono told the commission that his wage was very low yet he was "supposed" to live and lead a better life as any other person of other races. Like them, Rono would have wanted to live in a good house that was well furnished, possess a car, run a farm, educate his children in an international school, meet the needs of his family and meet his tax obligations. He posed, "How was he expected to get all these things with a low wage? Rono stated that what an African got was not in a true sense a wage. It was, a basic "Cost of living allowance." This was nothing at all: it did not cover the bare necessities of life. He, therefore, urged that wages for urban Africans be trebled and teachers recognized and rewarded for their public service. Rono suggested that teachers needed to be pensionable, and a minimum wage set up for agricultural workers permitting a progressively higher standard of life. ${ }^{121}$ These sentiments were echoed by Waminyaro, a barely literate peasant farmer from Kapsirowa in the Rift Valley Province. In his pencil scribbled submission made in broken Swahili, Waminyaro informed the commission that Africans were having troubles because they were suffering from the lack of all things. Their salaries were too low and insufficient to buy clothes or even food. ${ }^{122}$ Overall, no matter from what part of the colony submissions came or who wrote them, the grievances were more or less the same.

Few, however, put things in perspective as a memo sent by an anonymous writer from the East Africa Meteorological Department, "What is land to Africans." 123 This elaborated on the point made by many petitions that land was in the past, and continued to be, the African's

\footnotetext{
${ }^{120}$ Kisumu African Commercial Employee Association to the Royal Commission, 27 $7^{\text {th }}$ April 1953, BNA: CO $892 / 5 / 4$.

${ }^{121}$ J.K. Taita Rono letter to the Royal Commission, 26 ${ }^{\text {th }}$ December 1953, BNA: CO 892/5/4.

${ }^{122}$ Letter signed from Waminyaro of Kapsirowa, Hoey's Bridge to the Royal Commission, 11 ${ }^{\text {th }}$ May 1953 , CO $892 / 5 / 4$.

${ }^{123}$ Anonymous Memorandum from East Africa Meteorological Department to the Royal Commission, What is land to Africans, [sic] $16^{\text {th }}$ December 1953, BNA: CO 892/5/4.
} 
mother. ${ }^{124}$ That land to the African meant, and still meant, life. ${ }^{125}$ According to the African meteorological department writer, the value of land was intricately related with economic and social services in society. It was from the land that food including maize, millet, peas etc was grown and livestock reared. The writer explained that in pre-European Africa, food crops would be grown in one place to another when the soil was exhausted since there was plenty of land. There were no paddocks or fences to restrict the use of pastures for livestock or to separate land for food crops and communal grazing grounds. As such, there were plenty of healthy livestock owned by most people compared to the 1950s when they were few and weak and gave little milk. The crop yields were poor and land was in high demand. The writer continued thus:

As the British came and settled, there was no more moving from one place to place, people remained permanent to land they held and claimed.... Land therefore became a natural property with a fixed quantity and no quality.

Present Kenya is a place of competition of getting more, not of people of Kenya but of invaders. There are no regulation to condition the use of land especially African land. African population has grown higher because of British economic system which never evolved from African custom but was applied on African by the exploiters. The higher population indicates a low standard of living. Need has been enlarged by the exploiters and left them to be satisfied from sale of labour, making (African Land) a store of such labor, ....

The family is completely ruined....

Need had been multiplied and land which is the only human productive source has been thrown to ruins, ... even grains can't be produced enough to meet the needs, and the only substitute is labour sale....

All towns were erected by British pioneers except Mombasa. They either owned land by begging or simply erecting tents on sites where there was no claim. This ...made the European a landlord in cities and towns in Kenya, ... assisted by government of the time who proclaimed such lands. ... They found land free. ...I leave as a rentier to government while an Asian and Briton as masters and landlords. My salary is too low that buying and building a house even if I am free will be a dream. ${ }^{126}$

\footnotetext{
${ }^{124}$ Evanson Mureithi, Memorandum for the African Royal Commission, $18^{\text {th }}$ April 1953, BNA: CO 892/5/4.

125 Josiah D. Njue, Memorandum for the East African Royal Commission, 14 ${ }^{\text {th }}$ May 1953, BNA: CO 892/5/4.

${ }^{126}$ Anonymous memorandum from East Africa Meteorological Department, $16^{\text {th }}$ December 1953, BNA: CO 892/5/4. Also see, Josiah D. Njue Memorandum, $14^{\text {th }}$ May 1953, which at length discusses the old days when subsistence farming was the order of the day with special gardens for different crops. Unlike then, Njue now had chicken, pigs, wattle and banana trees, maize and beans and sugar-cane all in the same piece of land, BNA: CO 892/5/4.
} 
This letter encapsulated how most African people viewed their colonial plight and experienced their chaotic life characterized by misery. ${ }^{127}$ Where once individual livelihoods were guaranteed through entitlement of land held against the community, there was, under colonialism, individualism and fragmentation of land, which was a "baffling enigma."" 28

Besides the grievances discussed above, there were numerous other important ones that cannot be described in great detail. The Nakuru African Advisory Council, for example, was of the opinion that in all areas in the African land units, cash crop growing restrictions on coffee, tea, wheat and pyrethrum were to be scrapped. ${ }^{129}$ It was argued that the limitation of coffee growing to a hundred trees after every one year was a drawback and that planters be allowed to plant according to ability. ${ }^{130}$ Lamenting that Africans were in a position of poverty and slavery, which increased discontent, hatred and bitterness in people's hearts, the Kalenjin Union demanded the right of selling and buying things to and from abroad. Further, the union called for the abolition of the color-bar especially in as far as it affected the prices of African agricultural produce. They wanted maize, vegetables, chicken and eggs to be traded freely and their prices made equal whatever the color of the producer. ${ }^{131}$

\section{Defeating the Physical Mau Mau of the Forest: An Ever Stern Imperial Glare} In the 1950s, the Mau Mau threat was acknowledged by many, including Governor Baring, as a great problem that faced all the men and women in Kenya. ${ }^{132}$ The longer the Emergency played out, the greater the anxiety expressed by some European members in the legislative council who felt that the country was on the verge of a mighty cataclysm. For most people, the Emergency was a period of uncertainty in which the entire future of the country was at stake. ${ }^{133}$ Anxious members of the council, led by Michael Blundell, had called for urgent prosecution of the war and elimination of the enemy before he eliminated the government. ${ }^{134}$ This then was the beginning of a long debate in the course of 1954 about the progress and ending the emergency characterized by rabid fear. Defeating Mau Mau and the return to normalcy was

\footnotetext{
127 Shimo-la-Tewa People, Reserve for Shimo-la-Tewa People, $3^{\text {rd }}$ September 1953, BNA: CO 892/5/4.

128 Josiah D. Njue, Memorandum, 14 ${ }^{\text {th }}$ May 1953, BNA: CO 892/5/4.

${ }^{129}$ Memorandum of the Nakuru African Advisory Council, BNA: CO 892/5/4.

${ }^{130}$ Josiah D. Njue, Memorandum, 14 ${ }^{\text {th }}$ May 1953, BNA: CO 892/5/4.

${ }^{131}$ George Katam, President, Kalenjin Union, East African Royal Commission, 1953, BNA: CO 892/5/4.

${ }^{132}$ LegCo. Deb., LXIII (12 ${ }^{\text {th }}$ October 1954): 1

${ }^{133}$ LegCo. Deb., LXI (18 ${ }^{\text {th }}$ February 1954): 21, 22, 25-26.

${ }^{134}$ LegCo. Deb., LXI (18 ${ }^{\text {th }}$ February 1954): 21-36.
} 
of paramount importance. In the course of this debate, therefore, the most important question that emerged was what it really meant to defeat Mau Mau.

Under tremendous pressure from the Legislative Council and acting on its own imperative, the colonial government opened talks with the Mau Mau, which struck at the heart of the debate. Most settler members of the legislative council were opposed to negotiations that were in any manner designed to aid the objectives of the Mau Mau. ${ }^{135}$ Members called for the realization that the problem posed by the movement was more than a slight disturbance or disquiet. ${ }^{136}$ There was need for the government to deal with the threat with all the seriousness that the war deserved. When people resorted to force to achieve an objective, Blundell argued, then that force had to be met with force. ${ }^{137}$ This was supported by others who felt that to end the Emergency quickly, the only way to end lawlessness was through force. After all, military operations were being carried out by the best military experts in the British Empire with vast military experience. ${ }^{138}$

This aggressive view was, however, tempered by the recognition that winning a war did not entail the killing of the last man: that utter defeat of the enemy involved a measure of surrender, of course, on one's own terms being promulgated upon the loser. It was, therefore, not only enough to win in the physical field of arms but also in the mental and moral fields. ${ }^{139} \mathrm{Sir}$ Evelyn Baring, the Governor prosecuting the war on Mau Mau, had noted the same having spoken about a two-pronged attack on the Mau Mau. ${ }^{140}$

On the one hand, there was military force and, on the other, economic and social measures. It was clear to some that while the government was winning the physical battle it was in great danger of losing the spiritual battle and confidence of the Kikuyu and other ethnic groups. ${ }^{141}$ The colonial government had little chance of stamping-out Mau Mau and winning in

\footnotetext{
${ }^{135}$ LegCO. Deb., LXII (27 $7^{\text {th }}$ May 1954): 521. This was a motion moved by Group L.R. Captain Briggs to oppose talks with Mau Mau "criminals."

${ }^{136}$ LegCo. Deb., LXI (18 ${ }^{\text {th }}$ February 1954): 21-36

${ }^{137}$ LegCo. Deb., LXIII (21 ${ }^{\text {st }}$ October 1954): 359.

138 One of the members of the Legco supporting Blundell's position on this motion debate was Dr. Hassan.

${ }^{139}$ LegCo. Deb., LXII (27 $7^{\text {th }}$ May 1954): 540. This was Crosskill's contribution to the motion over "Talks with Mau Mau Criminals."

${ }^{140}$ LegCo. Deb., LXIII (12th October 1954): 1

${ }^{141}$ LegCo. Deb., LXI (19 ${ }^{\text {th }}$ February and $23^{\text {rd }}$ February 1954): 125 and $136 \& 144$, Cooke and Patel respective contributions to the debate on the "Urgent Necessity of Ending the Emergency."
} 
the psychological and moral fields considering the punitive measure of land forfeiture meted to individual forest fighters. This measure was the result of the colonial government's appreciation that Africans thought of nothing else other than land: the fact that Africans had their roots in the land from which everything else derived. The African social system was like a tree that spread from the title of land, which was the very symbol of authority. ${ }^{142}$ To deal with the movement's adherents, therefore, the government instituted a policy that penalized them speedily and with efficacy by announcing that they would forfeit their tribal land titles.

Furthermore, having noted that it was the long-term future of the colony that was at stake, the colonial government and European politicians sought to rebuild Kikuyu society, reorganize other ethnic groups and, thereby, the country's future, on "men of character, distinction, integrity and straightforwardness of outlook." Most such people had been on the side of the colonial state during the Emergency even though some, if not all of them, secretly wished for the same things that Mau Mau was fighting for. It was recognized that Kikuyu who had stood up to the Mau Mau movement needed a post-emergency and post-independence scheme that would bring them into a closer cooperation with the government in the subsequent reconstruction and limited reconfiguration of the state. It was essential to build on such men and no other men. It was upon these loyal people that the future of the country was to be built. Indeed, they were the people who had to benefit in the future. "Constructive" measures of reform, therefore, sought to plan beyond the troubles of the 1950 s without carrying the disadvantages that would make the last state worse or as bad as the first. ${ }^{143}$

Besides the foregoing issue regarding how to defeat the physical Mau Mau, government authorities understood that it represented a lot more. It was emblematic of colonial subjects returning the imperial gaze. It was a response to the colonial state's legal and policy architecture of restrictive space and time a circumscribing physical and psychological environment. Put differently, the forest struggle physically enacted and mimicked, through the investment and wielding of force the same colonial process that had created this hostile environment. This is something that authorities appreciated about Mau Maus of the mind, the ferment of which would reproduce physical combat.

\footnotetext{
${ }^{142}$ LegCo. Deb., LXIII (21 ${ }^{\text {st }}$ October 1954): $341 \& 342$.

${ }^{143}$ LegCo. Deb., LXI (18th February 1954): 27, 37, 59 \& 66.
} 
After all, there was a pervading desire among Africans, for the reconstruction and reconfiguration of the social relations and structure of power and, thereby, remaking the socioeconomic and political colonial order of the state. Colonial authorities in Nairobi and London moved swiftly to steal this "thunder from the mountains" and the potential violence in African minds. They took upon themselves the onus to "reconfigure" and "remake" the colonial state. Of course, this was with the stakes heavily laden in favor of the colonial order, British imperial interests and Africans loyal to them. To effectively reassert the ever stern imperial gaze and defeat the real Mau Mau of the forest and disarm that of the minds, the authorities undertook several limited agrarian and political, constitutional reforms. ${ }^{144}$ This was in a tenuous effort to maintain the status quo with the system rigged to highly favor white settlers. It meant recalibrating the system and changing the rules of the game to conceal this unjust and discriminatory system much more cleverly. This came out of the "realization" that things were "wrong" and actually, needed to be "fixed."

It was a well appreciated view albeit among a precious few, at least openly, that whatever the Kikuyu were, it was what British colonialism had made them. ${ }^{145}$ Further, it was quite clear that land was the key to a people's life. It was, therefore, "a real tragedy" that a few thousand Europeans had attempted to establish for themselves a permanent aristocracy in a land inhabited by and belonging to five million Africans. 12,000 square miles of the White Highlands was the monopoly of 3,000 Europeans. With the outbreak of Mau Mau, these settlers had to come to a realization that they had made their homes among millions of Africans who possessed the power to destroy them. ${ }^{146}$ The view of the forest Mau Mau and that of the mind from above did not lie. The Kenyan fire drew its fuel from land hunger among other affiliated chief sources including urban crowding, shortage of housing and the growth of slum-living; unemployment; the quest for universal free elementary education; poor African wages coupled with the steep cost of living such that a considerable proportion of the African population could not afford to buy the

\footnotetext{
${ }^{144}$ Since it is not the intention of this research to pursue the minute details concerning the arising disagreement and debate in the 1950s with regard to how far such reforms were supposed to go, this is not discussed herein.

145 To the best of my recollection while collecting evidence, this is from an anonymous and undated letter, "The Future of Kenya," KNA: CS/2/8/175. However, what can be deduced is that it was probably written by a liberal European of British extraction who was among the very first to travel to East Africa having set foot in Kenya, then the East African Protectorate, in 1902. Secondly, it was written in the 1960s as it mentions the independence of Tanganyika.

${ }^{146}$ Anonymous and nd., "The Future of Kenya," KNA: CS/2/8/175.
} 
elementary necessities of life; racial discrimination and the application of color-bar legislations with regard to land, residential areas and public places such as hotels, restaurants and bars; and universal adult suffrage. ${ }^{147}$

With regard to the issue of land, The Observer noted that land-hunger was to the African what unemployment was to the European. The paper referred to an official report on the conditions in Kiambu where $40 \%$ of its population was landless. The said report had also given warning that some 90,000 people there could be without means of support within a short time. This, the report had concluded was something that could not be faced with equanimity. Nevertheless, the report was never acted upon to remedy this most bitterly felt of land grievances especially in light of the reservation of the White Highlands for white settlers. ${ }^{148}$ It, therefore, came as no surprise that with the outbreak of Mau Mau, Governor Baring soon reported, on $25^{\text {th }}$ September, that active measures were to be taken in an attempt to "remedy" what was "wrong" in the colony. ${ }^{149}$ As soon as this statement was made, therefore, plans were under way to "alleviate" the plight and "better accommodate" Africans.

This could not be embarked upon too soon, nevertheless, lest it send the wrong signal to "restful" ethnic groups that Mau Mau was being rewarded. In the interim, therefore, the colonial state flexed its surveillance muscle to underscore its ever stern imperial glare. Under the Emergency regulations, after $20^{\text {th }}$ October 1952, measures were effected to exact collective punishment on Kikuyu and Embu populations to defeat Mau Mau. This included the confiscation of property of Mau Mau fighters, mass evictions and transfers of population, summary executions, Royal Air Force "blind" bombing, the passing of severe, if savage, sentences for infringements of regulations and hangings. ${ }^{150}$ According to Berman, entire villages suspected to provide moral and material support to Mau Mau were concentrated into stockades that were built on land confiscated from guerrilla fighters. By October 1955, more than a million people had

\footnotetext{
${ }^{147}$ Press Extracts: KNA/KEN/34/1; Eliud W. Mathu, F.W. Odede, M. Gikonyo, J.M. Ole Tameno and W.W.W. Awori, "The Kenya Situation: A Statement by the African Members of the Legislative Council," $15^{\mathrm{TH}}$ October 1952, KNA: MAC/KEN/33/4; Committee of the African Unofficial Members Organization, "Draft Programme on Kenya," undated: KNA MAC/KEN/34/1; and Eliud Mathu and Mbiyu Koinange, "The Situation in Kenya," $12^{\text {th }}$ September 1952: KNA MAC/KEN/33/4.

${ }^{148}$ The Observer, $26^{\text {th }}$ October 1952.

${ }^{149}$ Mathu, Odede, Gikonyo, Tameno and Awori, The Kenya Situation, 15 ${ }^{\text {th }}$ October 1952, KNA: MAC/KEN/33/4.

${ }^{150}$ Committee of the African Elected Members Organization, Draft Programme on Kenya, nd., KNA:

$\mathrm{MAC} / \mathrm{KEN} / 34 / 1$.
} 
been concentrated into 854 villages, and the program had proved a strategic success in bringing the mass of the population under firm control by the provincial administration and isolating the forest fighters from their base of support and supplies. ${ }^{151}$ In due course though, emphasis shifted from punitive measures, that were corollary to the war effort, to "remedial" long-term measures.

For a while, villages were used for the reconstruction of Kikuyu society. ${ }^{152}$ According to Berman, this was on a stable tri-class basis constituting of the wealthy elite, a solid and numerically dominant class of yeoman farmers and a lower class of landless artisans and laborers. This was all contained in a program for the consolidation and legal registration of peasant landholdings in the reserves coupled with a program widening peasant access to commodity production. ${ }^{153}$ This is what was to become the Swynnerton Plan, a long-term land consolidation, redistribution and resettlement program, which was to be implemented before and after independence. Steps were taken by the provincial administration to issue individual legal land titles to land. At the core of the program, in the mid-1950s, was the simple consolidation of scattered fragments of African land into single holdings. Within this agrarian reform strategy, elite loyalists were to become the anchor of Kikuyu society as solid yeoman farmers and landowners who knew they had much to lose if they flirted, however slightly, with the passions of their nationalistic "friends." 154 To this core pillar of the limited reconfiguration of the colonial political economy was added the responsibilities of employer-landlords. That is, it was hoped that these new class of yeoman farmers would be able to provide employment to the landless masses first in Kikuyu region and elsewhere. ${ }^{155}$

This process was also accompanied and complemented by the introduction of scientific and efficient methods of production. ${ }^{156}$ In as far as these measures were concerned, the "accommodations" involved did not involve extensive settlement of African populations that were bursting at the seams in their designated reserves. Rather, it was based on the ideas of a British agrarian "expert," Roger Swynnerton, about land utilization and the organization of field

\footnotetext{
${ }^{151}$ Bruce Berman, Control \& Crisis in Colonial Kenya: The Dialectic of Domination (James Currey: London, 1990), 366.

152 Ibid.

${ }^{153}$ Ibid.

${ }^{154}$ Branch, Defeating Mau Mau, Creating Kenya: Counterinsurgency, Civil War, and Decolonization (Cambridge: Cambridge University Press, 2009), 120.

155 Ibid.

156 Berman, Control \& Crisis in Colonial, 367.
} 
services that were put into practice in Kenya in the mid-1950s. ${ }^{157}$ According to agricultural "experts" such as Leslie Brown, it was calculated that, as a whole, not more than 5\% of the African lands was under sound land use. This was largely due to the fragmentation of holdings arising from inheritance customs which made sound farming a physical impossibility. The erosion, apparent overpopulation and poverty apparent in African areas were due to these factors not to the good old hardy chestnut that "Europeans stole all the best land from Africans." 158

With regard to commodity production, the Swynnerton recommendations lifted the controls and restrictions placed upon the main and most profitable cash-crops grown by Africans among them coffee, tea and pyrethrum. Tea was introduced on a very limited scale in 1953 in Nyeri district. The official logic was that land reforms in themselves would not avail much without provision for the material benefits of increased agricultural production. ${ }^{159}$ The Swynnerton Plan envisaged the expansion of African coffee production by some 5,000 acres a year to some 71,500 acres by 1968 ; the growth of tea production to 70,000 acres; and pyrethrum production to 48,300 acres in the same year, with significant increases in the production of pineapples, wattle and sugar. ${ }^{160}$ This was to be accompanied by the greatly expanded provision of credit, research and extension services, substantial investment in the development of soil quality and water resources. ${ }^{161}$ It was hoped that the colony’s national income that stood at $£ 107$ million a year in 1954 , would be increased by $£ 45$ million. According to the then Minister of Finance, Vasey, the basic principle was for 6 million African families to have farming units of approximately 10 acres a family, and to raise their average productivity in cash sales from ten British Pounds to $£ 100$ a year after providing for their own needs. ${ }^{162}$

As it has been noted by scholars, these changes did not go far enough to assuage Mau Mau minds. The Swynnerton Plan, according to Berman, had class significance. It made it possible for already energetic and rich Africans to acquire more land and "bad," and/or already

\footnotetext{
${ }^{157}$ Joseph M. Hodge, The Triumph of the Expert: Agrarian Doctrines of Development and the Legacies of British Colonialism (Athens: Ohio University Press, 2007), 222.

${ }^{158}$ Leslie Hilton Brown, The Development of African Agriculture, 10 ${ }^{\text {th }}$ June 1979, Oxford Development Records Project: The Development of African Agriculture in Kenya, RHO: MSS. Afr. (18).

${ }^{159}$ Ibid. Also see Berman, Control \& Crisis, 369. According to Leslie Brown, the figure under coffee in African areas was much lower than the Berman acreage: 3876 acres.

${ }^{160}$ Berman, Control \& Crisis in Colonial Kenya, 369.

161 Ibid.

162 East African Standard, 24 ${ }^{\text {th }}$ November 1954.
} 
poor Africans less, thus creating a landed and a landless class. This was tantamount to being the final colonial nod of approval to permanent dispossession of the landless on the assumption that they would be proletarianized and be absorbed within their reserves in local artisan production or as wage laborers. ${ }^{163}$

Furthermore, it preferred Kikuyu loyalists who had easier access to coffee seedlings, extension services and credit facilities and an already dominant position in the burgeoning local production co-operatives. Such access meant that this African class was able to buy more land, educate their children and set up businesses. ${ }^{164}$ It also assumed that "middle" peasants would actually become small capitalist producers, employing labor and tied by common class interest with the wealthier bourgeoisie whose political leadership they would accept. ${ }^{165}$ This partial package of reforms as conceived and undertaken in the 1950s was a chimera. ${ }^{166}$

While it was meant to demonstrate the colonial state's responsiveness to the needs of imperial subjects, it served to further entrench social inequality and historical injustice especially among the Kikuyu. It did so by providing loyalists with the means to reconstruct networks of patronage and the moral economy of central Kenya. These structures consolidated the strength of the loyalist elite long into the postcolonial period. ${ }^{167}$ As Branch aptly pointed out, economic, social and political rewards were elongated to, not only sustain loyalism through the final years of the Emergency, but to become the base for the moderate, modernizing and cautiously reformist platform within the nationalist movement once the outcome of the military conflict became clear. ${ }^{168}$

It is also important to observe herein that it is unfortunate that this agrarian reform was grossly biased in its implementation. The process was bedeviled by the unnecessary "counterrevolutionary" intention to punish Mau Mau fighters and supporters and reward loyalists. Some among the former group had their property, including cars and land, confiscated or requisitioned by the state. ${ }^{169}$ Mau Mau fighters, their families and supporters were embittered. This was

\footnotetext{
${ }^{163}$ Berman, Control \& Crisis, 369.

${ }^{164}$ Ibid., 370.

${ }^{165}$ Ibid., 370.

${ }^{166}$ Branch, Defeating Mau Mau, Creating Kenya, 120.

${ }^{167}$ Ibid.

${ }^{168}$ Ibid.

${ }^{169}$ Ibid., 121.
} 
especially so because even after independence, this selective, and thus flawed "reconfiguration" of the state, was not corrected. For them, they had fought the good and just fight and won, but it was the losing side that was awarded the trophy of the political tournament. This then is what explains continued postcolonial disillusionment, discontent and dissent. Indeed, it is this weakness within this centerpiece of the 1950s reforms that watered down accompanying constitutional and political reforms of the same period. It also undermined the full measure and meaning of independence much later.

At the time, the African Unofficial Members Organization (AUMO) was at the forefront of the demand for constitutional and political reforms. This group read the mood of the chaotic and restless political African opinion in the 1950s. In its demands, therefore, it was radical and bold. Besides calling for the end of racial discrimination; a halt to further alienation of land and the repeal of the Crown Land Ordinances; equal pay for equal qualifications and work; an increase of $33 \%$ in the minimum wage; and the introduction of free elementary education in Kenya, the group pressed the government to constitute a consultative body to deal with constitutional reforms in the colony. Failure to do so would only cause greater political frustration among Africans, it warned. Important components of proposed reforms of government included demands such as the institution of a common voters' roll as opposed to a one based on the different racial communities in Kenya -African, Asian, Arab and European; and the direct election of African members to, and parity for, Africans and non-Africans on the unofficial benches in the LegCo. ${ }^{170}$ Cumulatively, these among other core demands that would build up in the 1950s, were calls for nothing less than appropriate, proper and far-reaching reconfiguration and reconstruction of the state and government with regard to suffrage, civil rights and liberties, and the distribution of political power and responsibilities. They were first made public on the eve of the arrival, in Nairobi, of the then SofS, Oliver Lyttleton, on $30^{\text {th }}$ October 1952.

This visit by the SofS touched off what became a series of constitutional reforms at first aimed at re-centering European white settler and imperial interests in the colony. There was a blatant but subtle attempt to assure white settlers of their "inviolate" place in the racially tiered

\footnotetext{
${ }^{170}$ Mathu et al., The Kenya Situation, KNA: MAC/KEN/33/4; Committee of the AUMO, Draft Programme on Kenya, nd., KNA: MAC/KEN/34/1; and Times, 29 ${ }^{\text {th }}$ October 1952.
} 
socioeconomic and political hierarchy in Kenya. Besides the legal illegality that had literally made land ownership a white man's privilege, there was a renewed attempt to further entrench their preferment under the supreme law of the land. Lyttleton, who led this initial attempt that lasted between 1952 and 1954, spearheaded constitutional "changes" that prioritized the needs and interests of European settlers at the expense of all other races especially those of the African majority who stood to be the greatest losers. During these years, with very little consultation with other races, not that their opinions really mattered, Lyttleton crafted a constitution meant to placate settlers. ${ }^{171}$ The so-called Lyttleton constitution was meant to reorganize the Kenyan executive under a new "multiracial" state that was a euphemism for the continuation of the imperial status quo. ${ }^{172}$

Needless to say, under this "new constitutional order," the demands made by African members of the LegCo went unmet. The SofS did not grant their wish for three "cabinet" portfolios and under-secretaries in various ministries. ${ }^{173}$ In the pivotal talks of March 1954 that Lyttleton conducted, neither Nairobi nor, and especially London, was ready to countenance undoing the communal basis of the franchise, which would mean an untimely dissolution of empire. That was still in the offing in the future as the African insurmountable momentum for constitutional concessions that reflected the wishes of the African majority gained more traction in the early 1960s. In the meantime, outraged African politicians and populace had to contend with "an altered executive" branch of government that consolidated political power in the hands of Europeans. In addition to the three Elected European Members in government, the Lyttleton constitution provided for two nominated Europeans who would hold the prestigious portfolios of agriculture and finance. To Asians he offered two portfolios. ${ }^{174}$ Overall, the imposed Lyttleton constitution did little to change the planned racial ratio of ministers in the new council of ministers. ${ }^{175}$

\footnotetext{
${ }^{171}$ Robert Maxon, Britain and Kenya's Constitutions, 1950-1960 (Amherst: Cambria Press, 2011), 77.

172 "Multiracialism" was supposedly as system meant to enable the sharing of political power among racially defined groups through the initiation of what was termed as "mixed government." See Robert Maxon, Kenya's

Independence Constitution: Constitution-Making and End of Empire (Lanham: Farleigh Dickinson University Press, 2011), 8.

${ }^{173}$ Lyttleton turned down African request for a substantial number of ministers and undersecretaries, Maxon, Britain and Kenya's Constitutions, 70.

${ }^{174}$ Ibid.

${ }^{175}$ Ibid., 79.
} 
However, the one significant concession granted to African demands, the direct election of African LegCo members had unintended consequences. One of the unintended consequences was that it gave the impression that it was grooming future African leadership for take-over of government responsibilities. Secondly, it seemed calculated to head-off the more radical demands of African nationalism. Most importantly though, instead of ensuring British control, this Lyttleton compromise to Africans proved to be the start of the process that led to the failure of this constitution. It would lead to the more compromising constitution under a new SofS Alan Lennox-Boyd in the late 1950s culminating in further negotiations in London that opened the door to independence. However, what is even more instructive and of note, is the fact that the colonial state's initial and overall policy and institutional response to Mau Mau resulted in the strengthening of the colonial state's institutions.

This is perhaps even truer of the provincial administration, security apparatus and state instruments of surveillance and control in the 1950s. Lyttleton understood that countries were governed as much by tradition as force. ${ }^{176} \mathrm{He}$, therefore, reiterated that not all British territories in Africa could be governed by force even though this was wished. While the British had force, its uses were to be applied as far as the restoration of law and order was concerned. ${ }^{177}$ At the same time, Lyttleton must have realized that the maintenance of a contested "law and order" and a disproportionate multiracial state that denied franchise to the African majority and elections not based on a common roll, had to be protected. Such a flawed political system, which also featured a "reorganized" government that preferred Europeans, had to be maintained by a strong provincial administration.

This then explains why during his visit to Kenya in 1954, security issues were high in his agenda. ${ }^{178}$ It is for this very reason that Lyttleton chose to meet with the colony's provincial commissioners only a few days after his arrival. This at a time when Lyttleton demonstrated that he could afford to pay little heed to African demands. ${ }^{179}$ The "shooting war" was meant to teach those who threatened law and order a lesson. Once this war was won though, there was need to

\footnotetext{
${ }^{176}$ Lord Oliver Lyttleton, “Article by Lord Chandos for 'Optima,"” Cambridge Archives Center (CAC): CHAN II 4/18/2. This was a pragmatic influence of his political philosophy acquired from that of Benjamin Disraeli.

${ }^{177}$ Ibid.

${ }^{178}$ Maxon, Britain and Kenya's Constitutions, 68.

179 Ibid., 69.
} 
doubly strengthen the provincial administration. Subsequently, there was a brief period of an "ultimately illusory renaissance," during the Emergency, of the provincial administration. ${ }^{180}$

The strengthening of this sinew of government control in time of crisis was in stark contrast with the state of this institution at the beginning of the 1950s. The deterioration of the status and power of the field administration was markedly visible in the years before October 1952. ${ }^{181}$ This was after the functions and powers of the institution had witnessed massive expansion during the interwar years. In the context of the Mau Mau, the status and power of administrators appeared dramatically reversed and even expanded beyond what it had been in the interwar decades. Under Emergency regulations, administrators had both the punitive powers to quickly eliminate any opposition from Africans, and the authority to reassert their primacy over the field operations of the technical and specialist departments. They could do whatever they pleased. ${ }^{182}$

This renaissance of administrative power was undertaken through a deliberate colonial policy of "closer administration." It was brought to its climax with the reorganization and substantial expansion of the administrative infrastructure especially in the districts affected by the Mau Mau war such as Murang'a, Kiambu, Nyeri and others in Embu and Meru country. ${ }^{183}$ The peak of this reorganization coincided with the implementation of the Swynnerton Plan around 1955. There were 206 officers in the field in Central Province, 35 in the settled areas of Rift Valley, and 15 in Nairobi. The process of decentralizing the provincial administration, which had started even before the Emergency for purposes of closer control, was accelerated. Of all the state-strengthening reforms embarked upon in the 1950s, this renaissance of the colonial administrative apparatus was the one counterinsurgency measure more directly linked to statebuilding. It was also the safety valve upon which agrarian, political and constitutional reforms rested. As such, it was the most pivotal. Indeed, it was the cement that held together "the bureaucratic-executive state," which was the ultimate result of the reforms of the $1950 \mathrm{~s} .{ }^{184}$

\footnotetext{
${ }^{180}$ Berman, Control \& Crisis in Colonial Kenya, 363.

181 Ibid.

182 Ibid.

${ }^{183}$ Ibid., 363-364.

184 The use of this description of the overall effect of British colonial policy response to the Mau Mau rebellion, "the bureaucratic-executive state," is in the sense used by David Branch and Nicholas Cheeseman, "The Politics of
} 
In what turned out to be the decade of the eve of independence, there emerged a profoundly unbalanced legal and institutional landscape with regard to the strong sinews of a prefectural provincial administration; co-option of African elite and sympathetic sections of society who were rewarded with large farms and positions within the colonial administration; the creation of a dominant and wealthy African class that owned the all-important means of production, land, and that was allied to metropolitan transnational capital. ${ }^{185}$ The colonial state, therefore, seized the opportunity presented by the Mau Mau war to rejuvenate and morph into a bureaucratic-executive state in which popular anti-colonial forces and movements such as Mau Mau were literally disarmed and demobilized. At the twilight of the colonial era, therefore, the stage was set for the state, and its associated order, to succeed itself even with the granting of independence. It is for this reason that Branch and Cheeseman observed that the postcolonial state must be seen as a representation of the interests protected and promoted during the latter years of colonial rule. ${ }^{186}$ Some members of the African elite were rewarded with jobs in the provincial administration and civil service, legislature and farms. It is this group together with representatives of transnational capital that maintained political and economic control and who were amongst the chief beneficiaries of independence. ${ }^{187}$ This was a "successful" stroke of genius. But it was also a deceptive and blind triumph built on a false premise.

\section{Conclusion}

Granted, the government's punitive excesses at the height of the war; a reconstruction strategy; and a scheme for the future that rewarded African elites ready to play ball all worked out. Nevertheless, both short-term and long-term campaigns against armed forces of grievance and populist forces only succeeded in driving Mau Mau underground and allow discontent to continue to simmer in the unassailable realm of the mind.

Thus, the colonial and postcolonial governments had succeeded in creating conditions that enabled the movement to go underground and the resumption and continuation of activities and dissent at a later date of Mau Mau mind's own choosing. On the eve of independence, and in

Control in Kenya: Understanding the Bureaucratic-Executive State, 1952-78," Review of African Political Economy 33 (2006), 13-22.

${ }^{185}$ Ibid., 11-28.

186 Ibid.

${ }^{187}$ Ibid., 15. 
the period that followed, therefore, the Mau Mau movement, for one, was re-manufactured. Mau $\mathrm{Mau}$, in the sense of both the original movement and as a legacy of political dissent, continued to thrive in the immediate period after independence and beyond. Indeed, the postcolonial narrative of everyday ordinary people is one of the struggle for survival that represents the bifurcated postcolonial legacy of Mau Mau. In the immediate post-independence period, sections of the Kikuyu people that had taken active part in the armed struggle and others who had been sympathetic, were determined that Africans had not fought, suffered or died for the right to pay, at the prevailing market rate, for land that had been forcibly and illegally stolen. ${ }^{188}$

From the foregoing, it is crystal clear that African problems overlapped whatever part of the country one lived. African discontent with the colonial order in the 1950s was widely shared than previously thought or appreciated. As Taita arap Toweet noted in his submission, African problems were highly complex and all races feared to face the "naked truth and say exactly what" they felt. ${ }^{189}$ The opportunity provided by the Dow commission ensured, as Toweet aptly stated, that each and every party could fearlessly say what it was feeling, compare and empathize with different points of views and experience and offer ideas about Kenya's destiny. This, then, noted Toweet, was the disease of East Africa that had infected the minds of the people, which required decisive resolution. ${ }^{190}$

Viewed in this sense, the Mau Mau war was an existential struggle that reflected the mental torment and frustrations of various Kenyans in the 1950s and long after. The war was the physical manifestation of private everyday living in colonial Kenya, which was the site of this struggle for land, basic essentials of life, housing, healthcare and education. The view of the state of affairs in Kenya offered through the work of the Dow commission was unsettling and a source of great concern in both London and Nairobi. In its report, the commission observed that the many problems, which it examined, were highly complex and experienced throughout East

\footnotetext{
${ }^{188}$ Maina wa Kinyatti, History of Resistance in Kenya, 1884-2002 (Nairobi: Mau Mau Research Centre, 2008$), 349$. 189 Taita Toweet, "The Royal Commission," BNA: CO 892/5/4.The complexity of the many problems that the Dow commission was required to examine was something that it appreciated in its report but, as earlier noted, the needs and grievances of various African groups and interests were rather blatantly ignored.

${ }^{190}$ Ibid.
} 
Africa in a variety of settings. These problems were set against a physical and economic background which, by western standards, was of "unusual harshness."191

For this reason, although many were afraid to openly admit it, the fact that white settlers and the colonial government were locked in an intransigent mental and partly physical battle with the vast African population, was not lost on them. ${ }^{192}$ The colonial edifice erected upon institutional, legal, policy and attitudinal blue print of the idea of Kenya as a white man's country was being challenged. Even to white observers, especially those in Kenya, the "whole truth was that the whole country" was "in flux" and what would eventually come out of it, no one could say. What was certain, however, was that it would not be the Kenya of $1952 .{ }^{193}$ In this regard, as Sir Evelyn Baring would admit years later, the Mau Mau succeeded in breaking the log jam from the point of view of the Africans in both getting of the land and in defeating the settler idea of dominating the country politically. ${ }^{194}$ Thus, it was clear for many that Kenya, at the end of the Mau Mau war, was going to be a very different place from what it was before it started. That the country was not going to be the Kenya of the past as striking changes were going to take place. ${ }^{195}$ This, unfortunately, as the next chapter and this study argues, did not quite happen. Kenya continues to be a land of gross socioeconomic inequalities; unresolved historical injustices, especially with regard to land ownership and landlessness; various degrees of political oppression and suppression of voices of dissent; impunity; and the unrealized dream for the fruits of independence.

\footnotetext{
${ }^{191}$ East Africa Commission Report, Chapter 26: Conclusions, BNA: CO 892/4/18.

${ }^{192}$ Michael Blundell to L-Col. Howard, $13^{\text {th }}$ October 1953 in the Papers of Sir Michael Blundell, RHO: MSS. Afr. S. 746.

${ }^{193}$ Letter from Michael Blundell to C.U. Alport, $4^{\text {th }}$ February 1955, Papers of Michael Blundell, RHO: MSS. Afr. s. 746.

${ }^{194}$ Lord Howicke (Sir Evelyn Baring), interview by Dame Margery Perham, 19 ${ }^{\text {th }}$ November 1969, RHO: MSS. Afr. s. 1574.

${ }^{195}$ Ibid.
} 


\section{Chapter V - Drudgery in Pyrrhic Victory: Whither the Fruits of Independence?}

\section{Preamble}

...The seed we planted together with so much faith, hope, blood and tears: where is it now? I ask myself, where is the new force, what's the new force that will make the seed sprout and flower?

Ngugi wa Thiong'o, Petals of Blood, 46. 


\section{Introduction}

As noted in the previous chapter, the colonial state seized the opportunity presented by the Mau Mau war to rejuvenate and morph into a strong bureaucratic-executive state. It was a refurbished state that solidified, quite intact, the colonial political economy. Independence meant a "new old" order in which popular anti-colonial forces and movements such as Mau Mau were, literally disarmed and demobilized. Even with political independence, the agrarian, political and constitutional as well as administrative reforms of the mid-1950s, enabled the colonial state to succeed itself after the symbolic, if shambolic, gesture of independence. It was a hasty makebelieve colonial retreat that, however, left telltale institutional, legal and policy footprints.

In other words, the postcolonial state must be seen as a representation of the interests protected and promoted during the latter years of colonial rule. Disarmed, demobilized and demoralized forces of grievance and populist forces were, for a very short period of time, successfully muzzled especially by the promise of freedom. The physical and mental Mau Maus went underground and waited for the fruits of independence. It did not take long, however, for popular forces to realize that the system was still grossly rigged against them. Ordinary people's independence euphoric celebratory dance was thus short-lived, and their victory over the colonial state, pyrrhic. As such, discontent continued to simmer in the unassailable realm of the mind.

This, then, is what explains continued postcolonial disillusionment and various forms and shapes of post-independence discontent and dissent and the push-back from the system and its ideology of "law and order." The ensuing see-saw between the former and the latter to forge a state in which the stakes of all and sundry were adequately catered for forms the subject of this chapter. In examining these alternate voices and interests vis-à-vis the state, a unique set of archives have been used in combination to show the sleight of hand by both the metropolis and an imperialism-compliant post-independence African government.

\section{"Uhuru na Taabu": Shunted Track to Independence Decried}

In the immediate dawn of independence, a general mood of disillusionment set in as people descended from the foggy and giddy heights of excitement. Early manifestations of the stubborn spirit for the struggle for the full measure and meaning of independence, mentalité, were workers' strikes and devoted members of parliament. There was at this early dawn an undercurrent of political uneasiness and a strong sense of disappointment. This was underscored 
by a short-lived railway worker's strike that was feared would trigger widespread sympathy workers' strikes. ${ }^{1}$ This state of affairs was fanned by scathing political statements by parliamentary backbenchers who saw themselves as the watch-dogs of the people. ${ }^{2}$ This collection of radical members of parliament continued their attacks on the government for disregarding the needs of the poor and landless people. This critical section of people's representatives in parliament argued that, unlike government cabinet ministers and senior civil servants, poor people got nothing out of independence. ${ }^{3}$

Parliamentary back-benchers became the face and voice popular grievance. This criticism in early 1965 worried British diplomats who thought it was couched in unusually severe terms. The fact that the backbenchers had warned that they would throw out the government if it did not pay more attention to their radical call for something to be done, was thought of as severe criticism. At the same time though, it was also clear to British observers that President Jomo Kenyatta, and his moderate base, were getting out of touch with sentiment at the political grassroots. For H.S.H. Stanley, senior British diplomat, all these things were straws in the wind, which could blow towards quite serious tension and trouble for the new Kenyan government.

As such, government was well-advised to implement policies that would occupy and benefit the urban unemployed and rural under-employed. This was difficult but also a fundamental task for the Kenyan government. Stanley argued that as a government of an underdeveloped country, Kenyatta's government had to be seen to be doing something to improve the lot of the poor majority for whom independence had brought political but not tangible economic or social advance. Central to this problem was the question of land hunger. ${ }^{4}$

On 8th March 1965, at a Kenya African National Union (KANU) meeting in Kutus, Kirinyaga District, the chairman of the back benchers, Henry Wariithi, said that in spite of independence, many things had not yet changed. Wariithi was loudly applauded when he said, that thousands of Kenyan citizens had not yet tasted the fruits of independence and some had not even got the scent of it. Many deserved things such as land, free medical treatment and free

\footnotetext{
${ }^{1}$ Memorandum from H.S.H. Stanley to R.H. Hobden of the East African Political Department, Foreign Office, London, $10^{\text {th }}$ March 1965, BNA: DO 213/65.

${ }^{2}$ Kenya News Agency handout No. 161, BNA DO 213/65.

${ }^{3}$ Stanley memorandum to Hobden, $10^{\text {th }}$ March 1965, BNA: DO 213/65.

4 Ibid.
} 
education for which people had sacrificed in the struggle for independence, were a mirage. Neither had these same people been rewarded for their pains with appointments to positions of chief, headmen and other government positions. Three other speakers, Senators Tom Gichohi and Romano Gikunju and the Member of Parliament for Kirinyaga, G. Mbogo, stated that Africans who had been against independence were actually the ones who were now reaping all the benefits although they had not made any contribution. Another MP, G.G Kariuki, told the gathering that at the dawn of colonialism, European settlers had not purchased farms from Africans for cash but had given the conventional small presents such as beads, blankets and salt. Yet, Africans were now expected to buy their own farms even after "uhuru."

Moreover, at the same meeting, the radical politician, former Mau Mau enthusiast MP and assistant minister, Bildad Kaggia, claimed that he had left the government after seeing that nothing was being done to meet the needs of the people. Kaggia emphasized that he would continue to speak out for their behalf until they had the fruits of their hard work. Kaggia informed the crowd that he would conduct politics the same way as he had before independence. He assured his listeners that his brand of politics could, and would, not change because they were still fighting for the same things they had before independence, "farms and wealth." Kaggia was also known to argue that, unlike the other Kikuyu leaders, he had not been enriched by "uhuru." Another backbencher and a radical like Kaggia and Oginga Odinga, J.D. Kali, who was also the government whip, told the crowd that independence did not just mean getting a national flag and singing the national anthem. Rather, it was essential that citizens should get the fruits of independence which they had won by sweat and after long persecution. A.L. Gaciatta put things in comparative perspective noting that in newly independent Kenya, there were people who owned thousands of acres while others were dying of hunger. ${ }^{8}$

Elsewhere, speaking at the Lumumba Institute in Nairobi on April 7th, Assistant Minister T. Okelo Odongo stated that the main problem, and the next step, in independent Kenya was to achieve economic freedom. Odongo said that the Government of Kenya needed to deliberately

\footnotetext{
${ }^{5}$ Taifa Leo, $9^{\text {th }}$ March 1965.

${ }^{6}$ Ibid.

${ }^{7}$ Stanley to Norman Aspin of the East African Political Department (EAD), Commowealth Relations Office, $12^{\text {th }}$ April 1965, BNA: DO 213/65.

${ }^{8}$ Taifa Leo, $9^{\text {th }}$ March 1965.
} 
transfer economic power that had been held by foreigners to the African population. $\mathrm{He}$ expressed confidence that this goal was generally agreed upon with the only question being how this transfer was to be effected and the length of time it would take. However, Odongo was disappointed by the bickering that attended this debate thus complicating this process. This happened while the African population who fought for independence and KANU victory got impatient with waiting to reap the fruits of uhuru while Europeans and Asians were regrouping and claimed, publicly, their rights as Kenyan citizens within the constitution of Kenya. ${ }^{9}$

In parliament, the Kaggia-led radicals presented the plight of squatters, which reflected continued uneasiness over the central problem of landlessness and unemployment. There were reports of continued oathing among the Kikuyu in the Rift Valley, which derived from the dissatisfaction that Kenyatta's government had not produced any substantial benefits from independence for the poor and landless. ${ }^{10}$ There was yet another event that suggested that the Kikuyu were not solidly behind President Kenyatta. A group of leaders, freedom fighters and former Mau Mau field marshalls, gathered in Githunguri, Kiambu where they slaughtered a number of lambs and bulls to thank God for having helped the Kenyan people to achieve independence. The ceremony was held at the site of the former Kenya Teachers Training College, which had been central in the running of Independent Schools that were so important to the agitation that had led to Mau Mau. There were also reports of oathings in 1965 being conducted over a fairly wide area of Central and neighboring parts of Eastern Province. ${ }^{11}$

Therefore, Kenya, even after independence, remained a difficult country. The independent government was faced with the task of wrestling with the problem of reconciling popular ambitions with tough everyday-living economic realities. While Kenyatta had outmaneuvered the Kenya National Democratic Union (KADU) out of existence and reshuffled and expanded his cabinet in December 1964, there were still perceptible threats in Kenya. Despite the

\footnotetext{
${ }^{9}$ Kenya News Agency handout No. 223, BNA: DO 213/65.

${ }^{10}$ Stanley to Aspin, $1{ }^{\text {st }}$ March 1965, BNA: DO 213/65.

${ }^{11}$ C.H. Imray to Posnett of the CRO, $31^{\text {st }}$ January 1966, BNA: DO 213/65. Although oathing is part and parcel of Kikuyu historical tradition, it took a whole new political significance in the late 1940s and at the height of the Mau Mau war. As such, other post-Mau Mau war oaths such as in 1965 and after the assassination of Tom Mboya in 1969 boded ill.
} 
new confidence and regained control at the end of 1964, Kenyatta faced increasing discontent and disillusionment with independence among common people. ${ }^{12}$

At a meeting held in Murang'a early in April 1965, Kenyatta publicly humiliated Kaggia because of his constant anti-government stance. Turning to Kaggia, who was seated next to Paul Ngei, his fellow Kapenguria inmate who was now the Minister for Cooperatives and Marketing, Kenyatta said: "Kaggia, you are advocating free things, but we, together with Paul Ngei, were all in jail. If you go to Ngei's home he has planted a lot of coffee and other crops. What have you done for yourself? If you go to Fred Kubai's home, he has a big house and has a nice shamba. But you, Kaggia, what have you done for yourself? We were together with Kungu Karumba in jail, now he is running his own buses. What have you done for yourself Kaggia?” Kenyatta then went on to blame Kaggia for staying idle and advocating for free things. ${ }^{13}$

What Kenyatta did not mention is that he too had done quite a bit for himself and enjoyed it all. For example, Kenyatta reveled in a collection of big luxurious cars: a Rolls Royce from London's Motor Show, a Lincoln Convertible from American businessmen, and a Mercedes 600. Old KCA leaders, the unemployed and landless people among them former members of the Mau Mau, looked enviously at these smart cars enjoyed by the new leaders, which were, they felt, the fruits of their sacrifices. Also, by the time Kenyatta was released from prison, the colonial state was already building him a house at Gatundu. ${ }^{14}$ This is the kind of attitude that proved that Kenyatta and the moderates were out of touch with sentiment at the political grassroots. This public rebuke was ignorant of Kaggia's argument that it is not what political leaders had done for themselves that really mattered but, rather, what they had done for the people. ${ }^{15}$

As the then British High Commissioner and immediate former and, indeed, last British governor, Malcom MacDonald, saw it, radicals such as Kaggia and Oginga Odinga would not

\footnotetext{
${ }^{12}$ Note by R.M. Tesh, Kenya -internal scene, $12^{\text {th }}$ March 1965, BNA: DO 213/65. Granted, the president had many other problems including walking the tight rope of balancing the interests of the metropolis; those of the African class of wealthy elites colonially created at the height of the difficult and stormy 1950s; constructing, wielding and stamping political authority; and, perhaps more importantly, tempering the high expectations of the populace. The arising feeling of unfulfilled promise of independence and subsequent sense of betrayal, discontent and dissent was perhaps his greatest waking nightmare.

13 "Revolutionaries Warned: Kenyatta says 'I will fight again," East African Standard, $12^{\text {th }}$ April 1965.

${ }^{14}$ Jeremy Murray-Brown, Kenyatta (London: George Allen and Unwin Ltd., 1972), 306 \& 316.

${ }^{15}$ Ngugi wa Thiong'o, Writers in Politics: A Re-engagement With Issues of Literature and Society (Oxford: James Currey, 1997), 107.
} 
have had such a persuasive argument and strengthened position, which constituted a threatening situation, if there had not been large numbers of disgruntled poor people in various parts of the countryside who had expected to be given jobs, wages and land as soon as Kenya became independent. Needless to say, these people had received nothing of the kind. At the same time, such people would have accepted Mr. Kenyatta's appeals to them to remain patient if they had not seen numerous other people in Kenya receiving considerable gains from independence. However, they watched ministers and high government officials riding around in large cars, buying big houses, and purchasing extensive farms. They resented it all the more because "irresponsible" local politicians had assured them, in the 1963 General Election, that they also would receive a share of the good things of life on the day that colonialism was banished from Kenya. Although considerable sections of the population were already beginning to enjoy that share, other large bodies of people remained landless, jobless and poverty-stricken. "So," MacDonald, wrote, "a situation has arisen in which the Africans in the new Kenya were being divided into the 'haves' and the 'have-nots." The High Commissioner felt that the government needed to pursue policies which steadily reduced the amounts of unemployment and landlessness among the common people. ${ }^{16}$ MacDonald believed that Odinga and Kaggia and their left-wing colleagues were exploiting the discontents of have-nots. They were dabbling in a potentially dangerous and explosive brand of haves versus have-nots politics of which London was quite wary. But, as British diplomats saw it, such political radicals were harping on irrefutable everyday realities.

There was thus a groundswell of formidable challenges that faced the people and the government of Kenya after independence. For most people, independence was akin to rain laden clouds in the sky, a mirage that was quickly replaced by an empty and hot sweeping wind of hard times. This is the political imagery evoked by the popular independence slogan of "uhuru na kazi" (freedom and work) that was replaced by "uhuru na taabu" (freedom coupled to hardship). After all, there was soaring and searing unemployment and land hunger, and the unquenched desire, especially among the youths and former forest fighters, for the fruits of independence. ${ }^{17}$ For instance, on $16^{\text {th }}$ January 1964, a group of about five hundred men demonstrated in Nairobi

\footnotetext{
${ }^{16}$ Malcom MacDonald dispatch to the Foreign Office, The political situation in Kenya -II, May $5^{\text {th }} 1965$, BNA: DO 213/65.

${ }^{17}$ Stanley to Aspin, $29^{\text {th }}$ January 1964, BNA: DO 213/65.
} 
to demand for immediate government action to resolve the unemployment problem. One of the men addressed the crowd saying that though independence had come, there were still arrests of the unemployed in Nairobi who were being sent to the reserves against their will. This speech was received with applause and shouts of "uhuru na taabu" (freedom and suffering). The speaker further alleged that the government was doing nothing to create jobs and called upon ministers who owned expensive cars to sell them and distribute money to the poor. ${ }^{18}$

The euphoria that had greeted independence, therefore, had quickly turned as the unemployed and lower paid laborers had a rapid change of attitude. This caliber of people was disillusioned "as the magical changes they had expected under independence" had not occurred and, was, as a result, very critical of the government and, in particular, Jomo Kenyatta. ${ }^{19}$ Their independence hero and leader, they feared, had forgotten them: "Kenyatta has forgotten us," they said. Yet, "he and his ministers drive around in two or three cars, whereas we have no food in our stomachs." 20

As such, an atmosphere of relative deprivation was manifest and pervasive in both rural and urban settings in the initial years after Kenya's independence. Kenyans, especially former freedom fighters, had very high expectations with regard to land redistribution, which were not met. What they did not know is that before and soon after independence, Kenyan leading nationalists led by Kenyatta, had promised redress with regard to land. Kenyatta assured white settlers who wanted to live in Kenya that no radical land reforms were in the offing. This was back in 1963. At a meeting with about three hundred settlers in Nakuru held on $12^{\text {th }}$ August, Kenyatta had assured settlers that he subscribed to sanctity of private property and individual rights. ${ }^{21}$ Europeans who wished to leave the country after independence were to be compensated

\footnotetext{
${ }^{18}$ Imray to John K. Hickman, CRO London, $25^{\text {th }}$ January 1964, BNA: DO 213/65.

${ }^{19}$ Ibid. After this demonstration, Imray told Hickman, a ban was placed on meetings in Nairobi and other cities so it was unlikely that the unemployed were able to express themselves in public for a while.

${ }^{20}$ Ibid.

${ }^{21}$ Murray-Brown, Kenyatta, 309. Commenting on the small number of white settlers that Kenyatta addressed that day, this author correctly observed that, at the time, they always carried an influence disproportionate to their numbers. This was because they felt wrongly or rightly it was they and their predecessors who had made Kenya what it was. That is, the making of Kenya with regard to the deployment of capital and scientific knowledge and technology with regard to agriculture and the building of a modern infrastructure. However, it can also be argued that Africans in seeking redress of their grievances the most pressing of which was the return of their land and the exploitation of labor, also suffered enormous sacrifices that contributed to the making of Kenya. In this regard, it would seem that the making of Kenya by possession of land and the deployment of capital trumped an equally important contribution by Africans who paid for the process through dispossession, blood and sweat.
} 
at the prevailing market value. Those who wished to stay could do so without any fear of harassment or dispossession. After independence, Kenyatta's intolerance of extensive redistribution and land reform meant that the return of lost African land was pure political rhetoric. Land in post independent Kenya was to be paid for through the fruits of hard work and bought by aspiring African land owners. ${ }^{22}$ It was not going to be, as the radicals argued, a free gift or one of the low-hanging fruits of independence.

After independence, moreover, Kenyatta's government issued its blue print economic policy document, Sessional Paper No. 10, crafted by Tom Mboya in 1965. The path that this key policy paper proffered for Kenya's economic future was “African socialism.” However, in effect it was socialism in capitalist garbs. As students of Kenya's political history have observed, it was practically a development strategy based on the protection of private property and private foreign investment. ${ }^{23}$ Thus, with independence, Kenya became, arguably, a major capitalist hub in east and central Africa and attracted more foreign investments than any other African country. This was not lost on politicians like Odinga and Kaggia who soon leveled their criticism of this policy and Kenyatta's stance on the issue of land redistribution.

Both criticized the government's land resettlement policy. It is important to reiterate here that this kind of criticism was not entirely new. There was palpable and obvious continuity of this protest with that of earlier colonial times. It was particularly resonant with the anti-colonial criticism of the late 1940s that heated up in the mid-1950s. So grievance in the early years of independence, and long thereafter, was like these earlier times. Different African publics and their leaders continued to hanker for social justice with regard to land and the distribution of public goods. It was hoped that land acquired by white settlers would be returned and social services provided. But it is important to draw a subtle and important element of these sustained expectations and continued demands.

Both during late colonialism and in the early postcolonial period, African opinion was agreed that land in Kenya belonged to the African people but had been stolen. ${ }^{24}$ In their

\footnotetext{
${ }^{22}$ Daniel Branch, Kenya Between Hope and Despair, 1963-2011 (New Haven: Yale University Press, 2011), 9 and 17.

${ }^{23}$ Ibid., 54 .

${ }^{24}$ Cherry Gertzel, The Politics of Independent Kenya, 1963-8 (Nairobi: East African Publishing House, 1970), 45.
} 
numerous petitions to the colonial administration and submissions to various land commissions, Africans across the board had fought for the restoration of land from Europeans with Mau Mau bringing this struggle to a head. At last, victory had been won with the legal opening of the white highlands to African occupation in 1959. For many, independence was synonymous with the actual physical restoration of, and resettlement on, lost African land. This was the single most crucial prize of freedom from imperial rule to which would be added socioeconomic and political deliverables from the African independent government. This was the full extent and meaning of independence for most people.

However, between the outbreak of the bitter Mau Mau war and this victory, the context within which the land debate was argued had changed radically. ${ }^{25}$ Although the government was able to physically crush the Mau Mau movement, during the Emergency, Governor Sir Evelyn Baring had been forced to undertake far-reaching agricultural reforms geared at land consolidation. The main objective of the Swynnerton Plan was the reform of the tenure system, which entailed the consolidation and registration of land formerly held under African traditional tenure system. ${ }^{26}$ This is, then, what had radically shunted and shifted the African land problem and altered the kind of "social justice" meted out by Kenyatta's government. It was no longer a matter of making, as Africans saw it, the iron-clad and open-and-shut argument that social justice and natural law demanded the return of their land.

Rather, with the implementation of the Swynnerton Plan, "social justice" now required the recognition and respect of the individual right to property and ownership of land. This was in stark contrast to the high African expectations rooted in their collective experience of land dispossession at the advent of British colonialism. The principles of natural justice that demanded the return of land to them without any cost incurred by them or the government had been flagrantly flaunted. As some of the Mau Mau fighters perceived it, they had won the victory in a game of well-founded grievance but the trophy had been awarded to the losers. The masses' dance at the dawn of independence was but a bitter taste of pyrrhic victory. It was not lost on Africans, and especially forest fighters, that the context within which they had viewed the land issue on the eve of independence had changed. Now, the key question was no longer the return

${ }^{25}$ Ibid., 46 \& 48.

${ }^{26}$ Ibid., 47. 
of land from the Europeans to Africans. Instead, the question was to which Africans land was going to be transferred and on what terms at a market-price rate. ${ }^{27}$ This only served to further sharpen, and acutely so, long-simmering discontent and the psychic sense of loss that was now accentuated by what many people saw as arch political betrayal.

Thus, saying that African hopes and expectations had been dashed would be a serious understatement. Politicians who criticized this government policy believed that it had totally failed to deal satisfactorily with the practical question of land. Indeed, the government even admitted that the manner in which the settlement schemes policy as a whole had been designed was going to be more beneficial to leaving European farmers than it was to new African farmers. It was clear to many critics that these schemes settled the problems of European farmers instead of that of landless Africans. The schemes fell well short of resolving the issue landlessness and associated problems. Settlement schemes could not absorb former African farm hands that had been pushed out of the white highlands after $1945 .^{28}$

For instance, the touted million acre scheme only targeted one type of the scheduled area of the former white highlands, mixed farms, for African resettlement. A large section of the lower-potential lands in the former European areas still remained in their hands. ${ }^{29}$ Moreover, under the shunted prism of individual property rights and ownership through which the issue of land was now seen, the huge tracts of land outside the scheduled areas earmarked for settlement were bought by a small group of individuals, many of them politicians who amassed large acreages. There was not any form of safeguard or controls limiting the amount of land that individuals could own. As such, much of the land open for settlement easily ended up in the hands of a few African individuals who simply stepped into the shoes of former European owners. $^{30}$

For this reason, foremost critics like Odinga advocated for land redistribution of European large land holdings back to Africans as free gifts and fruits of independence. After all, the land had belonged to Africans in the past. It therefore, did not need to be bought. Rather, all

\footnotetext{
27 Ibid., 48.

${ }^{28}$ Ibid., 45.

${ }^{29}$ Ibid., 47.

${ }^{30}$ Ibid., 48 \& 49.
} 
that the government had to do was to requisition it as needed. ${ }^{31}$ Described as a clever and eloquent, sincere and a passionate extremist, Kaggia also advocated for the confiscation of farms from European settlers, and the giving of that land as a free gift of independence to landless Africans. ${ }^{32}$ On $2^{\text {nd }}$ April 1965, following a motion to set a landholding and ownership ceiling tabled by another radical back-bencher, the able and independent-minded Z.M Anyieni, Kaggia made an impassioned speech in support urging the government to do something to prevent rich individuals, both African and Asian, from buying up former European land. In the speech, Kaggia reminded the house his view that this land was to be distributed to the landless. ${ }^{33}$ Kaggia built on the argument by Anyieni that the independence struggle had been dominated by the determination of Africans to resume control of their lands. ${ }^{34}$ This is what independence really meant as far as they were concerned. Kaggia observed, with great concern, the attitude of a few money possessors who were buying as much land as possible in the former scheduled areas. Both, Anyieni and Kaggia, spoke with great passion about the yearning of the landless peasants for ownership of land adding that the land question remained one of the most emotive of all the issues which enter into the consideration of the African voters. ${ }^{35}$

For this reason, it was clear to many Kenyans and foreign observers that even after independence, the struggle for better living standards, a decent and dignified life, or even everyday survival was still on. In his letter of $29^{\text {th }}$ April 1964 to Aspin, Stanley observed that it appeared that it was a strain for the old man in his seventies, to find the right and very likely politically unpopular answers, and get them through a competitive cabinet. Thus the government of Kenya still faced formidable political and economic problems. Some of these, like unemployment, land hunger and the desire of the youth wingers and forest fighters for the fruits of independence not only drove a wedge between the Kikuyu and KANU but also created anxiety about the return of Mau Mau. ${ }^{36}$ Granted, the Mau Mau menace of the 1950s had been put down militarily; through policy measures affecting land and labor; and legal reforms leading to independence. This notwithstanding, unmet popular ambitions still threatened the cohesiveness

\footnotetext{
${ }^{31}$ Ibid., 47.

32 MacDonald, "The political situation in Kenya -II," 24 ${ }^{\text {th }}$ May 1965, BNA: DO 213/65.

${ }^{33}$ McBain to Tesh, Political Affairs -Kenya," $12^{\text {th }}$ April 1965, BNA: DO 213/65.

${ }^{34}$ Gertzel, Politics of Independence, 49.

${ }^{35}$ McBain to Tesh, $7^{\text {th }}$ April 1965, BNA: DO 213/65.

${ }^{36}$ Stanley to Aspin, 29th April 1964, BNA: DO 213/65.
} 
of Kenyan society. Therefore, the revolutionary attitude of the 1950s was prevalent and had really not died away. Indeed, the driving spirit of Mau Mau had not been defeated, an observation that resonates with the debate of the 1950s of what defeating the movement really entailed. It was quite clear that the spirit of struggle was still alive after independence and thereafter.

\section{The Ghost of Mau Mau Lurks: A Tarrying Reverie on Independence's Eve}

No sooner had the Mau Mau movement been put down than it re-emerged as the Kenya Land and Freedom Army (KLFA). Official correspondence between colonial authorities in Nairobi and their communication to London was unflattering in making the connection between the KLFA and the Mau Mau. Although the activities of the former began to be noticed after the end of the emergency, it traced its genealogy of grievance to early Kikuyu political agitation of the 1920s. A letter written by an unidentified Kiambu Kikuyu describing the aims of the KFLA also made this connection. It stated that members of the movement had been unhappy with the colonial order since 1920 at the time of Harry Thuku, which was characterized by bloodshed. It also made reference to similar sacrifice that had been made at the time of Chege Kibachia during a labor crisis in Uplands, probably in the 1940s. The worst experience, however, according to the anonymous writer, was between 1952 and 1959. After this period, it appeared that the back of African dissent had been broken. For that reason, there was need for a further step in the direction of resistance around 1960. After all, the author of the letter reasoned, if the first and second seed of resistance that had been planted in the 1920s had not yielded fruit in the 1920s or 1950s, it did not mean that people had given up all hope for change. ${ }^{37}$

This sort of continuity and genealogy of African grievance was corroborated by the colony's Director of Intelligence, M.C. Manby. According to Manby, it was clear that the KLFA was founded upon the ashes Mau Mau. It was intended to be a successor to the earlier organization. To support this, Manby cited a document dated $28^{\text {th }}$ July 1962 that had been found at the movement's Molo divisional headquarters. It stated that KLFA gun-makers would work as

\footnotetext{
${ }^{37}$ Memorandum by the Minister of Defence distributed to the Council of Ministers, The Kenya Land Freedom Army, $28^{\text {th }}$ July 1961, BNA: FCO 141/7114.
} 
they had in 1952, and all operations had to be kept secret for once bitten by the hyena, one needed not be bitten again. ${ }^{38}$

Moreover, its aims and methods were those of the Mau Mau. The KLFA was made up of ex-hard core detainees who had changed none of their thinking and methods and continued "to associate and conspire to achieve their ends by criminal means." 39 The KLFA was for this, among other reasons, considered by itself to be, and could be proved to be, synonymous with Mau Mau. For the minister of defense, the KLFA was not "like Mau Mau," which in essence, it was. It was a collection of un-reconciled Mau Mau adherents who had changed little if at all since they first became Mau Mau. It had taken root as soon as the sanctions of the emergency became less severe in the late 1957 and early 1958 using the land consolidation issue in Central Province as a means to spread subversion. With the formal ending of the emergency, Mau Mau members regrouped under various organizations, thus reviving the characteristic spirit of the movement and its force and bound by secret. Such discrete groups went by various names including Mutangiri or Atangiri (the care-taker/s), Kiama kia Muingi (Council of the People or Commoners Council), Ngwataniro ya Muingi (Fellowship of the People), Kenya Parliament, the Rift Valley Government and the Rift Valley Province Parliament. ${ }^{40}$

However, the only difference between the two, according to Manby, was that unlike Mau Mau, the KLFA did not expect to achieve its ambitions until the time of independence or soon afterwards. According to the analysis of the Kenya Intelligence Committee, Republic Day, which had been set for $12^{\text {th }}$ December 1964, provided a dateline for those who still thought that pressure could be applied on the government to provide the reward of independence. As such, before this particular date, subversive activities by groups affiliated or similar to the Land and Freedom Army were less in evidence. ${ }^{41}$ In other words, members of the KLFA hoped to obtain

\footnotetext{
${ }^{38}$ Manby to the Secretary of State, The aims of the Kenya Land Freedom Army, 19 ${ }^{\text {th }}$ November 1962, BNA: FCO $141 / 7114$.

${ }^{39}$ Document from Special Branch headquarters signed by the Director of Intelligence and Security, Subversive Tendencies, Actual and Potential Among the Kikuyu: An Appreciation, $13^{\text {th }}$ July 1961, covering the period between May and June 1961, BNA: FCO 141/7114.

${ }^{40}$ Memorandum by Minister of Defence, the Kenya Land Freedom Army, $28^{\text {th }}$ July 1961, BNA: FCO 141/7114. Also see Kinyatti, History of Resistance, 349. According to Kinyatti, this loose and confusing amalgam of bifurcated Mau Mau on the eve of independence were proscribed on July $8^{\text {th }} 1961$.

${ }^{41}$ Kenya Intelligence Committee, Monthly appreciation No. KIC. A (64) for the period between $7^{\text {th }}$ August and $8^{\text {th }}$ September 1964, BNA: DO 213/65.
} 
revenge on its former colonial opponents and would regard, at Kenya's full independence, any Kenya government not of its own making as its enemy. ${ }^{42}$

The KLFA, therefore, aimed at disrupting the political evolution of the country, which excluded them from enjoying the fruits of independence. According to Hezekiah Tumbo Mwai, one of the movement's members arrested, one of KLFA's stated objective was to infiltrate all levels of the Kenya African National Union. The KFLA was ready, if need be, to eliminate moderates in KANU. KADU was to be wiped out and all the land in the Rift Valley Province taken over. Even Jomo Kenyatta's life was not to be spared if he sold the country out. ${ }^{43}$ In a secretly distributed pamphlet, Kenya: Two Paths Ahead, the KLFA warned KANU militants and the popular masses of the possibility of falling victim to Britain's decolonization strategy. ${ }^{44}$ After independence, it planned to force all Europeans to leave the country including those in the civil service for whom there would no longer be a place in Kenya.

It was believed that genuine freedom as captured by the slogan ithaka na wiyathi (land and freedom), could only be attained by force through which the movement would take over government. In this way, there was assurance that Europeans would leave the country after independence and Africans be responsible for all the land, which they occupied under colonial rule. According to Njoroge Ngobe, an adherent of the organization from the Ndoswa Division of the KLFA, if this expression and expectation of freedom was delayed, the call would be given to fight.

According to Muthathi Njoroge, a KLFA youth winger from Ndoswa, the aim of the movement was to redistribute land among the people of Kenya after independence hence the insistence on compelling Europeans to leave and the need to completely drive out the British government from Kenya. ${ }^{45}$ Indeed, Two Paths Ahead called for national unity and independence based on a socialist programme. The KLFA saw the Swynnerton Plan, the colonial land reform for what it was: a means of rewarding and strengthening the position of colonial order and loyal

\footnotetext{
${ }^{42}$ Memorandum from the director of intelligence, Subversive Tendencies Among the Kikuyu: A Review of the Period $1^{\text {st }}$ February to $22^{\text {nd }}$ September $1962,27^{\text {th }}$ September 1962 , BNA: FCO 141/7114.

${ }^{43}$ Ibid.

${ }^{44}$ Kinyatti, History of Resistance, 349.

45 Manby, The aims of the Kenya Land Freedom Army, 19th November 1962, BNA: FCO 141/7114. Hezekiah Tumbo Mwai, Njoroge Ngobe and Mathathi Njoroge were among KLFA members arrested and from whom information was extracted by the Special Branch.
} 
elements in Kenya. They did not see political independence founded on such agrarian land reform as constituting genuine independence, which for them, barring other things, meant getting their land back. ${ }^{46}$

Furnished with KLFA intelligence to this effect, the colonial establishment appreciated the movement at face value. At a cabinet security meeting, the minister for defense noted that the basic reason behind the movement was a feeling of insecurity caused by landlessness and doubts about the imminent future ${ }^{47}$ Elsewhere, the minister observed that most members of the KLFA were professional criminals or racketeers, the chronically unemployed or a combination of such types. ${ }^{48}$ In a memorandum dispatched to London in October 1962, the governor expressed fear that delays in settlement and increased agricultural employment inevitably provided fertile ground for the spread of the KLFA infection. Unless the colonial administration in Nairobi rapidly expanded settlement schemes and, as a temporary expedient, transit settlements, the security situation could deteriorate rapidly. ${ }^{49}$ Authorities at the eve of independence were reconciled to, and acknowledged, the fact that even though intransigent, Kikuyu thoroughly imbued with Mau Mau contrived to seek their ambitions and livelihood through secret movements. ${ }^{50}$

This view seems to have been informed by intelligence gathered by a Special Branch informant who had infiltrated the KLFA Nairobi branch. On the basis of the information provided by the mole, B.E. Ruck, who was the acting director of intelligence, believed that one of the issues that concerned the KLFA Nairobi group was the poverty of Kikuyu living in Fort Hall District. At one of their secret meetings, the Nairobi branch was informed of such a great deal of hardship that many residents there were unable to buy the necessities of life or even send children to school. KLFA members agreed that a partial solution to this problem would be for a

\footnotetext{
${ }^{46}$ Kinyatti, History of Resistance, 349 \& 344.

${ }^{47}$ Extracts of Minutes of the $49^{\text {th }}$ security meeting held in Nairobi on $30^{\text {th }}$ October 1962, BNA: FCO 141/7114.

${ }^{48}$ Ibid.

${ }^{49}$ Governor to Webber, $10^{\text {th }}$ October 1962, BNA: FCO 141/7114.

${ }^{50}$ Memorandum from the Minister of Defense, the Kenya Land Freedom Army, $28^{\text {th }}$ July 1962, BNA: FCO $141 / 7114$.
} 
proportion of their regular proceeds through criminal activities be paid to a central fund. This money would then be used to ameliorate cases of hardship. ${ }^{51}$

What gave the colonial authorities the greatest headache, however, was just how widespread and loose the variations of bifurcated Mau Mau under the umbrella of the KLFA were. In retrospect, the colonial administration now reckoned that the original Mau Mau had itself been a movement made up of different groups having the same objective but using different names. It had been succeeded by other organizations, each of which in turn was known in different areas by names specific to that region. In addition to those previously mentioned above, bifurcated Mau Mau was known as Tano Tano, Kiama kia Hathara, Kiama kia Mbara, Kiama kia Ngero and Kiama kia Manyani among many others. These organizations attracted followers of varying commitment ranging from leading activists, lesser organizers and active supporters not to mention minor contributors and sympathizers from different parts of the country including Trans Nzoia, Kiambu, Nyeri, Meru, Fort Hall, Laikipia and Uasin Gishu to mention but a few.

Moreover, as separate entities from the original Mau Mau, these groups sought to provide moral and materiel support for fighters who remained at large at the end of the emergency in the Aberdare ranges, Mt. Kenya forest region and elsewhere. ${ }^{52}$ Ultimately, they hoped to join fighters led by Acholi, Field Marshals Mwariama, Baimungi and Salimu who were known to be in the forest. In readiness, some of these groups prepared through military drilling wearing badges of rank and carrying home-made firearms or sticks to represent rifles inside the forest or before gathered crowds on farms. During such drilling, the squads were inspected by leaders of the "government" and were confirmed as soldiers of the future army by members who regarded themselves as its leaders. ${ }^{53}$

Thus, even with independence on the way, the Mau Mau spirit still lurked abroad. As noted earlier, Kenyatta, who would become Kenya's first president, was not entirely trusted.

\footnotetext{
${ }^{51}$ Acting Director of Intelligence, B.E. Ruck to the Permanent Secretary of Defence, written around 1961 since it detailed different matters discussed in various meetings held by members of Fort Hall KANU Youth Wing and one in Nairobi on 29th August 1961. The issue of poverty and hardship in the district was discussed at a meeting reported to have been held, BNA: FCO 141/7114.

${ }_{52}$ Memorandum from the director of intelligence, Subversive Tendencies Among the Kikuyu, $27^{\text {th }}$ September 1962, BNA: FCO 141/7114.

${ }^{53}$ Ibid.
} 
Agents of these various movements were somewhat kept in touch with Kenyatta who advised caution or sought to moderate the radical attitude that they held. Manby, the Director of Intelligence and Security, suggested in a 1961 brief that he, together with the commissioner of police, be allowed to visit Jomo Kenyatta to show him a selection of revealing documents in the possession of the police detailing subversive activities. It was hoped by those inside and outside government circles that Kenyatta, while still in detention, would use his own influence in his own way to stamp out the idea of subversion and violence. ${ }^{54}$ In the interim period that Kenyatta stayed in Maralal before his release, the government even made it possible for him to broadcast to the people of Kenya to appeal for calm. It is likely that by this time, while governor Renison did not like Kenyatta one bit, a few people in the intelligence community in the colony, like Manby, recognized that Kenyatta's relationship with the European community, and especially settler farmers, was the key to their secure future in Kenya. ${ }^{55}$ Kenyatta was the best available coagulant symbol to fuse the diverse, competing and opposed interests of various publics at independence. Of course, if he failed or appeared to fail, a remnant British military detachment was readily available.

Besides giving white settlers assurances of his respect for the sanctity of private property and individual rights, one of Kenyatta's tasks just before his release, early in his premiership and presidency, was to sooth radical sentiments represented by bifurcated Mau Mau groups, coax members of the original forest fighters of the movement to come out of the forest and surrender

\footnotetext{
${ }^{54}$ Manby, Subversive Tendencies, Actual and Potential Among the Kikuyu, 13 ${ }^{\text {th }}$ July 1961, BNA: FCO 141/7114. It ought to be noted here that at the time, the colonial government had already initiated the process of releasing Jomo Kenyatta from custody and re-introducing him to the colonial politics and, ultimately, in preparation for leadership at Kenya's independence. This was the main reason behind moving Kenyatta from Lodwar where he had served most of his term to Maralal on $4^{\text {th }}$ April 1961 where he stayed until $14^{\text {th }}$ August, which is when he was relocated to his home region in Gatundu where the government was building him a new house. According to Murray-Brown, Kenyatta, 305, the time spent in Maralal was during which it became, an African Delphi. Maralal was chiefly a safari centre where Kenyatta received representatives of different political parties, of Christian denominations and of other religions, of racial communities and of world powers, lawyers, photographers, foreign visitors, friends, relatives, priests all who went to see him there. It is therefore, a possibility that the director of intelligence and the police commissioner may have paid homage to Kenya towards the end of the four months Kenyatta spent in Maralal between the time when this letter was written and August $14^{\text {th }}$, which is when he was relocated to his Gatundu home. It is also possible that Mbaria Kaniu, one of the leaders of the KLFA members from Fort Hall operating in Nairobi, might have met and shared the plans of the organization with regard to the seizure of land at independence a few weeks after Kenyatta was back in Gatundu on $27^{\text {th }}$ August. According to B.E Ruck in his letter, "Kikuyu subversion" to the PS, Secretary of Defense, the meeting had not gone very well. Mbaria was said to be angry with whatever Kenyatta remarks were about the said plan. This demonstrates that there was already political schism on the eve of independence between moderate forces of "order" and radical voices that wanted revolutionary change. ${ }^{55}$ Murray-Brown, Kenyatta, 306.
} 
their weapons and temper the high expectations of ordinary people with his call for Harambee (pooling/pulling together); his plea for all to forgive and forget the evils and experiences of the past; and charging people to celebrate and embrace "uhuru na kazi" (freedom and work). This especially considering the intelligence available to colonial authorities that Republic Day, which was on $12^{\text {th }}$ December 1964, provided the deadline for Mau Mau remnants to force the government to provide the fruits of independence. Thus, from the time of his release from restriction up to this date, Kenyatta was busy visiting various areas of the Mau Mau trouble to ease tensions and avoid this eventuality. Indeed, Kenyatta viewed the KLFA with deep hatred and was determined to crush it. ${ }^{56}$

Kenyatta's message at a mass rally at Githunguri during September 1963 is a good illustration of this important campaign and appeals. At this public rally, he said: "If reports in [imperialist] newspapers that some of you are going back to the forest, making guns, taking unlawful oaths, and preparing to create war after independence are true, I request all (G]ikuyu to stop doing such things. Let us have independence in peace. I am requesting you strongly not to hold any secret meetings or support subversive organizations. We are determined to have independence in peace, and we shall not allow hooligans [Mau Mau] to rule Kenya. We must have no hatred towards one another. Mau Mau was a disease that had been eradicated [by the British] and never be remembered again." 57 This must have been music in the ears of the settlers who chose to stay in Kenya and caretakers of British interests. It would be Kenyatta's refrain before and after independence but how successful it was with respect to those it was tailored to is in doubt.

\section{Face-off: Kenyatta and the Remnants of Mau Mau Forest Fighters}

While visiting Embu in August 1964, eight months after independence, Kenyatta issued a stern warning to forest fighters who had refused the government's amnesty and gone back to the forest. The government, he said, would take firm action against them. Kenyatta added that these freedom fighters were spoiling the nation's hard-won uhuru. Using one of his interactive methods, he got a full mandate from the crowd to bring the forest fighters under the full force of the law and order. In this Embu speech, Kenyatta also condemned illegal oath taking and

\footnotetext{
56 Kinyatti, History of Resistance, 359.

${ }^{57}$ Daily Nation, $7^{\text {th }}$ September 1963 as cited by Kinyatti, History of Resistance, 359-360.
} 
appealed to people to go back to the land reminding them that if they all did their best, there would be no unemployment or poverty. Good things like hospitals and road, Kenyatta said, would not come from heaven, hard work was essential. ${ }^{58}$ In the course of the Embu public meeting, Kenyatta received three sheep that had been stolen the night before and bows and arrows, actions which underlined the background of lawlessness that lurked in the forest around Meru and Embu.

At a rally in Nyeri, which had been one of the hotbeds of Mau Mau, Kenyatta, early the next year, warned against subversion. Using his question and answer style, Kenyatta got the crowd to agree that the government had done more for them after independence than the imperialists had done in seventy years and to deny that they were being helped by people speaking against his government. He charged people to work hard and obey the law and not to drink too much. ${ }^{59}$ During a similar visit to Meru and as a result of Kenyatta's appeal to the population not to help those who had returned to the forest, some of Acholi's forest fighters surrendered themselves. After this event, intelligence sources believed that Acholi's supporters did not number more than forty fighters. It was also reported that Baimungi, who was still in the forest, had returned to the Meru side of Mount Kenya but was still in touch with "malcontents" in Nyeri District who were associated with the Ngwataniro ya Muingi. By this time, the government had decided to investigate the Ngwataniro as a cooperative society with a view to deregister it if its books were not in order. Eventually, it was anticipated that with such efforts, the more sensible freedom fighters would be made to realize that they had more to hope for from working with the government that by opposing it. ${ }^{60}$

But Kenyatta did more than just assuage political feelings and check people's high expectations before the independence deadline and thereafter. He kept hammering-away at the shadowy remnants of Mau Mau that must have preoccupied him throughout the presidency as Kenyatta struggled to show the gains of being independent. Despite the obvious distance that had grown between him his beloved people, Kenyatta saw his relationship differently. He insisted

\footnotetext{
${ }^{58}$ Letter from M.G. Stephen to Tesh of the CRO, Prime Minister's Visit to Eastern Regions, 26 ${ }^{\text {th }}$ August 1964, BNA: DO 213/65.

${ }^{59}$ Stanley to Aspin, $1^{\text {st }}$ March 1965, BNA: DO 213/65.

${ }^{60}$ Kenya Intelligence Committee, Monthly appreciation No. KIC. A (64), for the period between $7^{\text {th }}$ August and $8^{\text {th }}$ September 1964, BNA: DO 213/65.
} 
that he had never grown away from the people, saying that he had met Kenyans at massive public rallies as fellow-men on common ground. For that reason, Kenyatta argued, Kenyans knew him only too well as he always had been: as one of them. In his speeches, Kenyatta sought to make Kenyans understand that the country was experiencing the natural growing pains of a young nation on the road of progress and national unity. There was, therefore, need to learn resilience. After all, victory in the twin areas of national unity and progress could not be laid upon the country like spreading a cloth on a table. ${ }^{61}$

At the same time, Kenyatta did not relent in reminding people to work hard for the fruits of independence. He shared his personal philosophy and belief that the best way to achieve worthwhile human ambitions was through hard work. That is what the people's call, uhuru na kazi, really meant for Kenyatta. ${ }^{62} \mathrm{He}$, therefore, cautioned against the deadly sin of slothfulness. Everyone had his or her contribution to make: after all, it was agreed by all that independence meant hard work. Progress required sacrifice and discipline. He urged people, especially rural stock who had immigrated to urban areas, to turn back to the land with this determination because it was the country's greatest asset. Kenyatta condemned those who "ran away" from rural areas choosing to "exploit" their relatives and friends in the big cities. This was akin to loitering and laziness and living off the sweat of others. ${ }^{63}$

Moreover, Kenyatta recognized that, before and at independence, Kenyans of all walks of life: the unemployed; farmers and businessmen; workers and students and public servants; the parents of the nation's children had high expectations of the auspicious transition. He assured all that neither he nor the party had forgotten to address the people's felt needs and expectations. Thus, on Kenyatta Day, $20^{\text {th }}$ October 1964, Kenyatta promised that his government would not rest until victory was won over the burden of poverty, the scourge of malnutrition and ill-health, the frustration of illiteracy and the demoralizing lack of economic opportunity. But he cautioned those that nursed high hopes against thinking that the government was not moving with enough speed towards meeting these goals. After all, Kenya had been an independent state for only ten

\footnotetext{
${ }^{61}$ Jomo Kenyatta, Suffering Without Bitterness: The Founding of the Kenya Nation (Nairobi: East African Publishing House, 1968), ix, x. This analogy, spreading a cloth on a table, is powerful because it shows that the President was not ignorant of the failure of his government to make the fruits of uhuru to be enjoyed by all and sundry in the country.

${ }^{62}$ Ibid., xiii.

${ }^{63}$ Kenyatta's television broadcast, $11^{\text {th }}$ September 1964, as recorded in Kenyatta, Suffering Without Bitterness, 234.
} 
months. Even with the assistance of miracles, it would be impossible to eliminate all past imperfections and injustices and to meet all modern aspirations and needs in such a short time. Towards the end of this speech, Kenyatta once again reminded people that the fruits of life were there so long as they applied themselves and worked to realize them. ${ }^{64}$

However, the toughest message that Kenyatta had to give, and for his listeners to stomach, was with regard to how people were to deal with the colonial past especially when it touched on the delicate matter of land loss. It must have been disheartening for those with high expectation of the restoration of their lands to hear the president say that Kenyans could not cry for more land while failing to develop that which they had. In effect, it meant that there was no more land to be issued arguing that the time for sloganeering and empty words had come to an end. ${ }^{65}$ Instead, Kenyatta proclaimed and charged the people that the foundation of Kenya's future lay in the theme of forgiving and forgetting. There was no point, the president said, to dwell on the past and stoking the fires of revenge or animosity and looking back on the scenes of anguish. Everyone was beholden to the important task of national integrity that was the stuff of the future. To be sure that his message got home, Kenyatta pointed out that he knew about there being murmurs in Kenya about the part played by one set of people, or another set of people, in the struggle for "uhuru." Talk about the contribution made, or refused, by this group or that. At times, he said, vindictive comments and fingers of scorn had been pointed at some selected race, or group or tribe. All this, Kenyatta said with a ring of finality, was unworthy of Kenya's future. ${ }^{66}$ Perhaps, these exhortations were appropriate at the time. Also, they illustrate the fact that the Father of the Nation, as he was referred, had not lost his sense of idealism that had fortified and sustained him in the many years that Kenyatta had sacrificed for his beloved country.

However, for many groups of people such exhortations were a bombshell that spelled doom. This included long-serving and dedicated veteran agitators like James Beauttah who had mentored young Kenyatta and his political career; it also included freedom fighters who, upon

\footnotetext{
${ }^{64}$ Kenyatta address on Kenyatta Day, $20^{\text {th }}$ October 1964 as recorded in Kenyatta, Suffering Without Bittering, 241, $242 \& 245$.

${ }^{65}$ Kenyatta's television broadcast, $11^{\text {th }}$ September 1964, as recorded in Kenyatta, Suffering Without Bittering, 234.

${ }^{66}$ Kenyatta address on Kenyatta Day, $20^{\text {th }}$ October 1964, as recorded in Kenyatta, Suffering Without Bittering, xv \& 241.
} 
emerging from the forest, found that the land consolidation of the mid-1950s had by-passed them. Most of them were also landless because of colonial punitive measures to possess their piece of land for public utility; families, wives and children, who had been left without male household heads as a result of the war; and, generally people who felt that independence had been a heavy cloud without rain. For such people, Kenyatta's messages were propaganda that fell on deaf ears. To others yet, it was, literally, inspiring music to their ears. Some sections of society greeted the message with great enthusiasm and went to considerable length to echo it through composition of music. Such people, usually independent musicians, bands made up of civil servants or members of the armed forces, internalized Kenyatta's message that viewed "uhuru" as a joyful moment as opposed to a somber one; a vigorous one rather than one to ruin with incessant brooding and unnecessary murmuring. It is important to focus on this internalization of this ideology of "law and order" by such groups and music.

\section{Onwards Ye "Gallant" Soldiers: Odes to the Colonial Ideology of Order}

The Kenya Police band is a great example of how a popular group internalized

Kenyatta's exhortations. The band composed and belted out the jingoistic song Kenya Nchi Yetu

(Our Country Kenya). The lyrics of this song are instructive and significant not only for the manner in which they captured and mirrored Kenyatta's vision for Kenya but also because the song was composed by members of the police force. The lyrics are as follows:

Kanyaga nchi yako kwa nguvu na raha, hilo ni hakikisho la raisi wetu. Zamani tuliwekwa nchi namba four, Sasa about tani tuko namba wani.

Nguvu zetu za Kenya ni umoja wetu, Mzee alibashiri tukahakikisha. Vitisho hata vipi sote tu tayari. Haki hatukuomba kwani tupoteze.

Kenya ni nchi nzuri kushinda zote, barani hata pwani twavutia kote. Mashamba hata mbuga ni unono kote, twaweza kutumia pahali popote.

Pori zetu za Kenya wanyama ni wengi, Wageni huwaona na donge twapata. Ni haki tuwalinde wasiharibiwe,
Stamp your land with pride and joy, Of this, the president is our surety. In the past, our country lagged behind, But, alas, about turn, we are now number one!

Kenya's strength is in our unity. Our old man predicted it, we now confirm it. Come whatever threat, we are all ready. We didn't fight for justice only to lose it.

Kenya's the best country of all, from upcountry and our coast. Our farms and the wild teems with life, What's more, they are all open for all.

Our national parks are full of wildlife, attracting tourists who bring foreign currency. It is important that we protect them from all harm, 
Hiyo sehemu kubwa uchumi wa Kenya.

Wako wapi wabeberu waone haya, Tuliyo yatimiza kwa miaka chache. Ni hao walisema hatuna akili, Na huku watunyonya afadhali kupe.
For they constitute a huge part of Kenya's economy.

For shame! Where are the colonial 'nay-sayers?'

They should see our swift achievements. Yet they said we were inept, while they sucked our blood: worse than ticks!

This song by the police band towed the line that Kenyatta's government had done more for the people in the few years after independence that the colonial government had ever accomplished. Indeed, it comically pushed the limits of the said success of independence by alluding that while colonial Kenya had little to show for, it was springing forward among leading countries. It also implied that the country had made a complete break with its colonial past characterized by colonial exploitation and subservience underlined by second class citizenship. What is more is that, in a patriotic expression of unbounded hope for the future, the song concludes that Kenya had to be the best country of all. With independence, the police band professed, the richly endowed farms and the general environment was now open to Africans without and fear of discrimination. This, then, is what called for the stomping of the land with great pride and joy, a privilege and right that was assured and undergirded by the president. This explains why it reigned supreme on the Kenyan airwaves thanks to the sole TV and radio station in the country, the Voice of Kenya (VoK). This was the case even long after independence in the Moi years. In the Kibaki decade, there was an attempt to recapture this moment when it boomed on loud speakers on national holidays, but there was an unmistakable hollow ring to it.

In a similarly titled song, another artist, Kaikai Kilonzo, offered up a prayer of benediction for Kenya, the country that was both a father and a mother to many. In his song, Kenya nchi yetu, Kilonzo pledged an oath of allegiance to always put Kenya first. The country, he sang, would always be in the sanctum of his most treasured thoughts. Like the police band, Kilonzo expressed hope that the newly independent state would attend to his wife and kids. He entrusted their welfare and wellbeing along with his "taabu na shida" (the difficulties and troubles of life) to the state. This artiste went further to charge that since both the "matajiri na masikini" (rich and poor) were equal human beings, strife that was occasioned by boastfulness and envy was to be avoided at all costs. Lastly, Kilonzo exhibited peculiar confidence of a simple musician by warning would be trouble makers that they and their plans were known and were under constant surveillance lest they ruin the country. If this was in a song by the police 
band or the Maroon Commandos, who were a military band, such an eventuality would not have been unusual or unfathomable.

The Maroon Commandos lend their unrivalled voice to the omnibus rallying cry of their boss, the commander-in-chief, in the form of a song that became the wakeup call every morning for several decades when it was aired by the VoK. This was the song "Amka Kumekucha" that dovetailed seamlessly with Kenyatta's call to every section of society to make their contribution to the task of building the nation. The Maroon Commandos were not only playing their role as soldiers but also were at the frontline of the army of Kenya's workers as they warned and appealed in their song thus:

Uvivu ni adui mkubwa wa ujenzi wa taifa, /Laziness is the greatest stumbling block of the task of nation-building,

Kwani ndicho kiini hasa kisababishacho njaa. Indeed, it is the main cause of hunger and starvation.

Ewe ndugu yangu we, amka kumekucha, /So, my brother, wake up it's dawn, Kamata njembe na panga twende shamba. /Arm yourself with your hoe and machete and go to the farm.

Hata wewe mwanangu, amka kumekucha, Kwani hizi ndizo saa za kwenda shule. Hata wewe karani, amka kumekucha, /Even you, son: wake up, it's dawn, /It is time for school.

/Even, you, office clerks, wake up, dawn has broken.

Kwani hizi ndizo saa za kwenda kazi. / it's time for work.

Jiepushe na uvivu, tujenge taifa...

/Let us all avoid laziness, so that we can build the nation....

...Elimu ndio msingi wa maendeleo.... $\quad$ /...Education is the foundation for progress....

As noted above, this song lent itself quite well to Jomo Kenyatta's rebuke against laziness, appeal for hard work and his call for all to contribute to the task of nation-building. Even more importantly, in a way, it was also a call to the work force not to look down upon working on the land as farmers. As such, it was in tandem with the president's call to go back to the land.

Daudi Kabaka's song, "Harambee, Harambee," was yet another song that fell within the nation-building motif. Like in the police band song, Kabaka shamed those who predicted that Kenya would become the country of "matata" (or fall into hard times). Instead, Kenyans were living a decent and dignified life ("watu wote wastarabu”). Kenyans, Kabaka sang, were contributing to the development of the country enthusiastically heeding Kenyatta's motto of 
pulling together ("wananchi harambee/tuvute pamoja"). This was the single-minded task that brought Kenyans together without discrimination ("hakuna ubaguzi") in a country where everyone from all races had their pride of place ("kila rangi tunaipenda").

However, while the above were the most notable songs of the nation-building genre that emerged after independence, it was the catchy classic "Jambo Bwana" jingle that captured the euphoric mood and forever encapsulated it a sculpture of song. The upbeat and spirited song sought to capture the independence spirit of Kenya, a new nation that extended to the world the warm greeting and invitation to a country where all was as well as one could wish or expect ("wageni mwakaribishwa Kenya yetu, hakuna matata"). There was no trouble at all, visitors were assured. The song promised potential visitors that Kenya was, indeed, a great, amazing and lovely country. Both foreign visitors and Kenyans were assured that all was well in Kenya. As noted earlier above, however, not everyone was singing along happily that there was no trouble at all in Kenya.

\section{The Real Voices of Kenya: "Matigari ma Njirungi"}

The Ngwataniro ya Muingi, which was based in Nyeri, was one group that did not mask their continued discontent and disappointment with the manner things were going on in Kenya after independence. Writing to Kenyatta on behalf of the organization two months after the achievement of self government, Mahugu Kiogora reminded the president of their meeting on $5^{\text {th }}$ August 1963 in which he expressed displeasure with the government's rather tough stance on forest fighters who still remained in the forest. Kiogora complained that Ngwataniro, even after twelve years of the struggle that had started in 1952, had known no peace. As far as they were concerned, they were still under Emergency laws and conditions, which made them really miserable. They felt sad and apprehensive about the way the country was going among other things. ${ }^{67}$ They were particularly disheartened by, and thereby, took issue with, Kenyatta's rather high-handed speech delivered at Kinoru Grounds, Meru on $24^{\text {th }}$ August 1964 in which the prime minister ordered that fighters who still had not surrendered even after independence be shot dead

\footnotetext{
${ }^{67}$ Mahugu Kiogora to Jomo Kenyatta, Tutiri Twakena Muthamaki Witu na Twonetio Ganga Mbute, $20^{\text {th }}$ September 1964, KNA: KA/6/60.The subject of the letter loosely translates to, Our Beloved Leader, We Are Not Yet Happy: We Are Still Under Violent Attack.
} 
on sight and finished off. ${ }^{68}$ Yet, at the said private meeting with him, Kiogora wrote, Kenyatta had assured him that as the master mind behind Mau Mau, he would not extinguish its "matigari" (the remnant of the freedom fighters). Then, Kiogora reminded Kenyatta, that he had advised that even if only three of his ilk remained, they would never join up with the selfish money-loving types who were being financed by enemies of freedom and were hell-bent on destroying the country. ${ }^{69}$

Such people, "Njuhiga" as he called them, Kiogora informed Kenyatta, had, nevertheless, taken advantage of the Kinoru speech to continue persecuting young men ("anake”) who were beginning to emerge from the forest to take their rightful place in independent Kenya. ${ }^{70}$ Indeed, it is from this letter that one discovers the real reason behind Kenyatta's visit to Meru on $24^{\text {th }}$ August 1964. All hell had broken loose, Kiogora narrated, four months before this visit when a disturbed state of affairs prevailed in which people were harassed and even killed by the "Njuhiga." 71 On 27 $7^{\text {th }}$ April 1964, the District Commissioner had summoned freedom fighters including Kiogora, Mwariama, Salimu and Chui and ordered them to return national flags that the prime minister had honored them with for the role they had played in the armed struggle for independence. The DC also demanded that they had to cut their long hair locks and to disperse or disband from their forest at Mucori. Further, the DC announced that Kikuyu, Embu and Meru fighters would get land in their home districts to which the young men informed him that the needy landless people had to be settled as an urgent priority. Baimungi, who was among the group of young men, asked Jackson Angaine, a Meru politician who also served in Kenyatta's cabinet, also present at the meeting whether it was Kenyatta who had asked for the return of the honorary flag. ${ }^{72}$ Apparently, Angaine had witnessed the ceremony in which Baimungi had been

\footnotetext{
${ }^{68}$ This public meeting in Meru was one of several that Kenyatta held in various parts of the Eastern region as reported by Stephen in his letter to Tesh of the CRO, "Prime Minister's Visit to Eastern regions," 26th August 1964, BNA: DO 213/65.

${ }^{69}$ The original Kikuyu word used in this sentence is "matikeringanire," which is today rarely, if ever, used by modern speakers of the language. T.G. Benson, Kikuyu-English Dictionary (London: Clarendon Press, 1964), 388, identifies the word as a derivative of the root word "ringa" that means "to join up."

70 "Njuhiga" referred to sections of society among the Kikuyu, Meru and Embu who had sided with the colonial state during the Emergency. The word means a wise person in a sarcastic way or a smart alec. See Benson, KikuyuEnglish Dictionary, 336.

${ }^{71}$ To describe what exactly happened, Kiogora uses a Kikuyu word, "kiungungwa," which is defined by Benson, Kikuyu-English Dictionary, 556 as a disturbed state of affairs prevailed in which people are harassed and a condition attended by irregularities.

${ }^{72}$ Baimungi's name appears as Waimiungi in the letter. Both names are a play on the Kikuyu words Muingi and Mungiki, which refer to a collectivity of people or the masses: see the word Mungiki, Kikuyu-English Dictionary,
} 
thus honored by the president and had also received a flag from Kenyatta. How, then, Baimungi posed, could Angaine turn around and dare to demand the flag back unceremoniously: had he returned his own to the president? That night, Kiogora alleged in the letter, the DC with the connivance of Angaine and Meru "Njuri Ncheke" (council of elders) who had earlier been at the meeting, raided the Mucori forest base of the group killing an unknown number of men.

It is for this reason that Kiogora and the "Ngwataniro" felt that the Emergency and colonialism had not quite yet ended. In a follow up trip to Nairobi on $29^{\text {th }}$ April 1964 to report this grievous trouble, Angaine demanded that Baimungi cut his hair locks before he took him to see Kenyatta. After this unfruitful mission, Baimungi returned to Meru, and the Mucori camp, whereupon arrival he found heavily armed policemen. At this point in his long letter, Kiogora rhetorically and patronizingly asked Kenyatta, Our dear leader, whoever leaves his children to be mauled by such sinister hyenas ordering them not to run so that they can be finished? Our beloved leader, did you honor us with the flag so that it could be a trophy fought over between the masses and Njuhiga? If he needed reminding, Kenyatta was informed that there was a section of people for whom his ascendance to power was a most feared ordeal. ${ }^{73}$ Such people were not any different from the colonialists. They were trying hard to drive a wedge between Kenyatta and the forest fighters, wrote Kiogora. Their aim was to completely undo the gains of the struggle by striking at its very roots. In this regard, they were looking for any excuse whatsoever to finish off the "matigari." In actual fact, full of yesteryear's hatred, these "Njuhiga" even went as far as boasting that the masses were still as oppressed as they had been during colonialism. ${ }^{74}$ "Ngwataniro" was alive to the fact that there seemed to be two competing visions and projections of independent Kenya: on the one hand was that of the selfish wealth-loving and lying types who had truck, and still did, with the colonial oppressors of the people. On the other, was that that could make genuine freedom and land a reality. If Kenyatta and his powerful

\footnotetext{
115. Also, the latter name, Waimiungi, has been slightly corrupted by interchanging letters. Otherwise, the correct spelling would be Wamuingi, which means "man of the people." The former name, Baimungi, was perhaps a nickname to conceal the owner's real identity. Baimungi is a fake name that demonstrates the ingenuity and reveals these young men's sense of humor: in it, the Sikh title prefixed before male names, Bhai was put before the Kikuyu word Muingi (Bhaimungi).

${ }^{73}$ See Kinyatti, History of Resistance, 354 who recounts an almost fictional-sounding dramatic moment of how Chief Njiiri wa Karanja, the leader of loyalists on the slopes of the Aberdares, reacted upon hearing on the radio that Kenyatta had been released. According to local gossip, Chief Njiiri, in anger, smashed the radio into pieces saying that it had lied to him all along that that bastard, Kenyatta, would never be released.

${ }^{74}$ In the original, "muingi orugito haria mamaturagia hindi ya wabeberu."
} 
sidekick, Mbiu Koinange who was the minister of state, allowed the former to triumph, that would be disastrous and a great misfortune that only spelled trouble for the masses.

For that reason, "Ngwataniro" looked up to Kenyatta and Mbiu with great expectations. Ngwataniro, Kiogora assured Kenyatta, had embraced the call of Harambee. ${ }^{75}$ They had also harkened the president's message of peace, which they were all for. However, the Njuhiga were courting trouble by using paid spies to gather intelligence about "Ngwataniro." This was known only too well because one such would-be informant turned out to be dedicated to the cause of the masses. He had brought evidence of attempts to be recruited in the form of cash that he had received from a Special Branch inspector in Nyeri. This was a plausible suspicion because, as already noted above, the Kenya Intelligence Committee report covering between $7^{\text {th }}$ August and $8^{\text {th }}$ August 1964 had recommended that "Ngwataniro" cooperative society be investigated with the view of deregistering it on whatever flimsy foundation possible. Kiogora's letter to Kenyatta was written less than two weeks later and, therefore, responding to a real and valid cause of concern.

"Ngwataniro" must have felt the need to present their case more forcefully almost a year later perhaps because their concerns were not attended to. Kiogora led fifty other members to submit a more belabored petition, this time closely cataloguing the collective suffering that they had experienced since 1952 including villigization, detention, providing farm labor in the land owned by Njuhiga, hanging and castration. Further, unlike before when Kiogora had painted their grievous trouble visited upon them by the DC and DO in the immediate post-colonial era in broad strokes, the petition provided 97 names of people who had been arrested. These arrests took place after Kenya had already become a republic within the 31-days amnesty period and ultimatum issued by the Kenyatta government for forest fighters to surrender. Before the end of this period had even ended, fighters trickling out of the forest were received with pointed guns like criminals, ordinary people were arrested, some war heroes were tried in court and a few

\footnotetext{
${ }^{75}$ Kiogora signed off the letter with the defunct word "Karambee," which is perhaps a derivative of the Kikuyu word "karambi" that means "heave ho." According to Benson, Kikuyu-English Dictionary, 369 "karambi" is a word shouted by a leader of a labor gang to prepare them all for the strain and ensure that they were ready to put their hands to the task at the same time.
} 
young men killed in the forest. The petition posed, Were prizes in a competition awarded to the winner or the defeated? Could one's inheritance be snatched away from him ${ }^{76}$

The people who were now demanding their rightful inheritance were the very same black people that went to the forest to fight in 1952. Yet, even after independence their name and repute had continuously been under attack and blackened by the "Njuhiga." This latter group did so to protect their position of local leadership and influence so that they could pursue their own selfish interests. Since colonialism had come to an end and a new independent government of black people established, was it possible to leave behind such exploitation through lies to follow just reason? If otherwise, the group felt that they had been used badly and yet fallen into disrepute without the chance to clear their names or explain their point of view. ${ }^{77}$ They reminded Kenyatta that he himself had been labeled a leader unto darkness and death by Governor Sir Patrick Renison: had the latter been right and was that the truth about Kenyatta? They told Kenyatta that as individuals who had sacrificed for independence for song, neither they nor the president could accept the despoiling of their selfless efforts. They intimated their grief to see the same agents of their suffering continue the same things inspired by hatred in colonial times while accusing them for the role they played. Had Kenyatta decreed that people could not get land because they had not surrendered? Could they not get loans for the same reason? Or not allowed to form development societies to buy land because they had not surrendered? These questions, like those of many others, were unanswered and unheeded.

\section{Petitions and Complaints to the President: A Multitude of Cries from Below}

The bitter and painful attempts of Clement Mukui Kimata to be cleared to start small scale tea farming put the woes of "Ngwataniro" in appreciable perspective. Even the officials handling the high volume of complaints and petitions at the prime minister's and later, President Kenyatta's office, could not deny that Kimata's frustrations were a classic example of how the colonial relics affected the ordinary man of the street. ${ }^{78}$ Towards independence, Kimata had secretly planted a small tea nursery of about six thousand seedlings in his small Gatundu farm as many other people were doing in anticipation of the end of colonial strictures on cash crop

\footnotetext{
${ }^{76}$ Petition signed by 50 people including Mahugu Kiogora to Kenyatta, $13^{\text {th }}$ August 1965 , KNA: KA/6/59.

${ }^{77}$ The exact phrase in the original Kikuyu is: "andu aria macambagio ni Njuhiga matwirwo thabuni wa gwithamba na ehia" (the people whose names have been blackened by the Njuhiga are like bath soap and criminals), Ibid.

${ }^{78}$ Internal document in the Prime Minister's office, The Way the Colonial Relics Work on the Ordinary Street Man: Pre- hhuru Events, $3^{\text {rd }}$ November 1964, KNA: KA/6/60. It details the plight of clement Mukui Kimata from Ruiru.
} 
growing. A month after Kenya became independent on $12^{\text {th }}$ December 1963, Kimata happily declared the existence of the small tea nursery to the assistant agricultural officer, the district agricultural officer and the acting tea officer. He sought their expert knowledge regarding tea farming, upon which all three agricultural officers visited his farm. At the farm, Kimata gave them some samples of the seedlings for further scrutiny. Soon, they were all praise and declared that the seedlings were of the best variety. However, Kimata's dream to start a tea farm was cut short on $8^{\text {th }}$ June $1964 .^{79}$

On that date, Kimata received a letter with the police letter head asking him to provide more information about the origins of his seedlings. Kimata promptly dismissed this demand in a response that argued that it was unwarranted. After all, said Kimata, had anyone reported his seedlings missing and suspected that he had stolen them? This was followed by a note of $31^{\text {st }}$ October 1964 that was directly delivered to him in a government vehicle informing him that he would be prosecuted. Under the Kenya Tea Development Authority standing laws, he apparently possessed an illegal nursery. It would appear to him, therefore, it did not really matter whether laws were made a million years or a second ago: they remained binding. As far as he was concerned though, it had only been illegal to own a tea nursery during colonialism. Further, people of good standing in the post-independence government were proud owners of tea farms but it was perturbing that when the same was done by "a forgotten desperate ordinary street man" like him, it was then illegal. Kimata attributed his tribulations to "an old colonial stooge and leading homeguard" also doubled up as some sort of agricultural instructor for both the colonial and independent governments. ${ }^{80}$

The said colonial stooge had threatened him that he would never plant any seedling from his nursery as long as he was in office. Kimata's life and sacrifice in detention camps during the Emergency years, he was told, would not help him in that regard. At times when his old detractor was drunk, he would boast that the power of colonial relics was stronger than that of the nationalist forces that had brought about the African government. This really affected the man because his seedlings were doing quite well without any sort of financial support from the government's ministry of agriculture. Yet there were those who benefited from agricultural loans

\footnotetext{
${ }^{79}$ Ibid.
}

${ }^{80}$ Ibid. 
of Ksh. 1/48 per tea stump and it did not really matter whether the trees grew or died, the credit facilities were still available to them. Kimata appealed for assistance to help resolve this issue. However, he said that he was already reconciled to his fate: even if he was imprisoned, he had tasted it before for the benefits of the fruits which his detractor was enjoying and boasting about although he had been on the side of the colonial state. ${ }^{81}$

Similarly, T.K. Kairu, who identified himself as the everyday "man on the street," wrote an equally angry letter to the Office of the President. The letter, he said, was his humble contribution to the noble cause the country was determined to realize: that is, meaningful unity and, more importantly, the economic welfare of people on the streets. Kairu observed that while some of his brothers were already enjoying the fruits of uhuru, those who had actually fought for it were still landless, or left without fathers and homeless. Freedom was a birthright that not even God, who had created all men equal, could take away. For this reason, he could not understand why some owned land whereas others like him had to sell their labor to them to earn their daily bread. Kairu, therefore, felt strongly that Kenya was not a democratic country but, rather, one steeped in capitalism. The government was led by many "Hungry Hyenas" that did not remember their children. The government of Kenya, it seemed, had soon forgotten its main mission and let its people down. Seventy five years of bearing the yoke of British colonialism had been replaced by one of black imperialism. Kenyatta's government only helped the rich to become richer: Indians, Europeans and rich Africans. Kairu asked, how long would it be before the poor men and women were able to enjoy the freedom that they had suffered for under colonialism and still endured under an African government? Clearly, it did not think of hapless widows and orphans. Kairu concluded his letter by saying that as long as he had overcome his fear to raise his voice to demand his right, he was ready for either rebuke or death. ${ }^{82}$

Like Kairu, another writer who identified himself as Citizen John Kamau Njuguna, said that if he had not answered the call to fight for the country for the sake of the welfare of fellow citizens, he would have been happy to remain "as silent as silent could be." However, the deep urge and quest for justice did not allow him that luxury. Quoting Shakespeare, Njuguna argued

\footnotetext{
81 Ibid.

${ }^{82}$ T. K. Kairu, "Man in the street," to Regional Government, $27^{\text {th }}$ June 1964, KNA: KA/6/48. Kairu identified himself as a jobseeker who had been searching for a job since 1956. His father had died when he was seven years of age.
} 
that in so doing, he was not just being another ungrateful murmurer: "the fault lies not in our

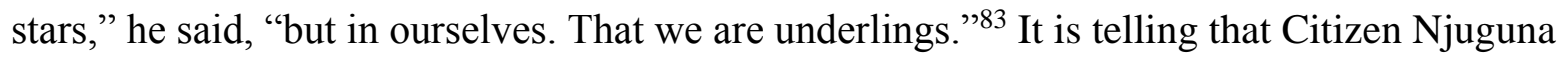
borrowed the words of Cassius to Brutus in Shakespeare's Julius Caesar when the former is trying to persuade the latter that it was in the best interest of the republic to stop their friend, Caesar, from becoming a monarch. In so doing, Cassius is torn between his love for his friend and what he felt was the higher duty to the republic. What is even more significant is the fact that Cassius went on to point out that as men, they were equal to Caesar, a fellow man. It would seem, therefore, the sentiment expressed by both Kairu and Njuguna that all born equal before God was, somewhat widely, held especially by former freedom fighters that had a sense of betrayal. ${ }^{84}$

This sense of betrayal was also expressed by another Nyeri based group of Mau Mau youth wingers from the North Tetu region. This was, probably, the group that had fought in that part of the Aberdare ranges alongside Dedan Kimathi. Like in many letters that found their way to Kenyatta's office, these young men said they were saddened by the rife news of land being given to the wealthy or those who had worked for the colonial state thus bypassing those who had sacrificed for an African government. They told Kenyatta that unlike such people with money, they had given up everything including employment and personal businesses for this noble cause. As a result, most of them had fallen through the money circulation system when they chose to go to the forest. Some of them had for this reason not handled money since 1952 because all they had cared for then was freedom.

Yet, when they individually made this commitment winning the cause was not a guarantee but they still made up their minds. They had resolved to go on with the struggle during the course of which they had to endure the biting cold, nakedness, hunger, and face the possibility of death among other hardships all for the sake of breaking the chains of colonial subservience. In spite of all these, they were witnessing land being allocated to those who had not sacrificed and carried on with their lives. Such people, at the height of the Emergency, did business as usual. Put differently, land was going to the rich who would not have hesitated to

\footnotetext{
${ }^{83}$ John Kamau Njuguna to the Permanent Secretary, Office of the President, $28^{\text {th }}$ September 1967, KNA: KA/6/14. This is apparently a quote from William Shakespeare's play, Julius Caesar, Act 1, Scene, 6. ${ }^{84}$ Ibid.
} 
exterminate freedom fighters. ${ }^{85}$ Some of these people were acquiring parcels of land set aside for the poor illegally through bribes yet they already were known landholders. Usually, it was people like the youth wingers who did not have enough money to purchase land or give bribes. Above this, they were already branded criminals ("kamene") and, therefore, looked down upon as social misfits. If this course of affairs involving the rich replacing white settlers continued, what would become of them? It was pointless, they felt, to have families that they could not support while it was they that had lit the torch of freedom. For that reason, they beseeched the government to provide a solution because they were at their wits end in this respect. ${ }^{86}$

The conglomeration of Nyeri County freedom fighters wrote to Kenyatta about two weeks after the Ichagachiru youth wingers. They strategically rallied behind General China who was of good standing and terms with Kenyatta. It was hoped that General China would be their spokesman and articulate their difficulties with regard to land. They also disputed rumors, which were circulating about their being against the government. They pledged their loyalty to Kenyatta saying that it would be tantamount to destroying what they had fought for to rise against his government. They went on to explain that that was the other reason why they had chosen General China: that is, to validate their loyalty because he was already working closely with the government. The usual appeal for more land allocations was made but, more importantly, they said they were perturbed that the Kenya Youth Service did not take Mau Mau youth wingers. Instead, it took on younger people who were too young to have participated in armed struggle. They stated that they were not complaining but were wondering how one could have fought for Kenya's freedom and then be easily forgotten. ${ }^{87}$

There were many people who shared this very sentiment. Four years after independence, Chege Gathimu observed that it seemed as if his ilk had been forgotten. The deterioration of their pecuniary affairs was enough evidence. Gathimu alluded to a meeting with the president on $5^{\text {th }}$ December 1966 in which the fate of former detainees was discussed. It was agreed that those that

\footnotetext{
${ }^{85}$ Ndiritu Rukwaro on behalf of other old Mau Mau youth wing from Ichagachiru village, Nyeri to the Secretary, the Prime Minister's Office, $2^{\text {nd }}$ June 1964, KNA: KA/6/48.

${ }^{86}$ Ibid.

${ }^{87}$ Nyeri District freedom fighters to the prime minister, Nyeri Freedom Fighters, $15^{\text {th }}$ June 1964, KNA: KA/6/48. Apparently, Kenyatta had offered an office in Nairobi to the group, which, however, the group declined because there had been a division amongst them. However, they requested the prime minister to allow them to open one in Nyeri. Part of the reason for this request was to set about writing the history of Mau Mau and to draw a comprehensive list of all those that had died in the war for land and freedom.
} 
had been released last had been classified "hard core" dissidents by the colonial administration and thus deserved perks commensurate to their suffering. However, they were facing the greatest post-independence hurdles. In their job hunting, most of them did not go beyond "hakuna kazi" (no vacancy) signs at various government and corporate offices. While his group in Nakuru appreciated that there was to be no free things, the money they had raised was not enough to buy their ideal piece of land in Subukia. ${ }^{88}$

However, three Limuru petitioners were not as understanding or as forgiving. Muya Njomo, Mbugua Wamunyu and Ndung'u Karu stated categorically in 1964 that the people's expectation underscored by the promises of political leadership before independence was land redistribution for all for free. Their attitude was combative and demanding because it went as far as instructing Kenyatta to build a new Kenya without "ubaguzi" (discrimination) between "matajiri" and "masikini" (the rich and poor). This, they believed, was the only way to relieve the misery of the landless. As things stood, however, Kenya was independent but they themselves were really not (independent). They still lived in the same dilapidated houses they had before independence. Independence had come only to the rich and famous who were proud owners of land and businesses. These things were out of reach for the "unknown" poor. The only way to actuate independence for all was to allocate the poor their own land and extend to them agricultural credit facilities. Until then, the needy section of society existed only as "watumwa" (slaves) of the rich. In addition, they asked the government to provide the promised seven years of free education. It was children of the poor that suffered since the government did not honor its promise. They asked the same with regard to the provision of healthcare. ${ }^{89}$

The plight of the Gikundike Farmers cooperative and the Muriithi clan casts the plight of the Limuru petitioners in sharp focus. This group was locked in a tangle over a piece of land, the Manyatta Farm in Kabete, which one of Kenyatta's cabinet ministers, Dr. Julius Kiano, was eying. At the intervention of people close to the president, Dr. Kiano promised Kenyatta that he would not pursue the purchase of the land by recognizing that Mbari ya Muriithi had been engaged in the process of acquiring it that preceded his interest in it. On following up the matter with Kiano at his office, the cooperative, made up of ordinary people, found that he had changed

\footnotetext{
${ }^{88}$ Chege Gathimu to Jomo Kenyatta, $27^{\text {th }}$ September 1967, KNA: KA/6/14.

${ }^{89}$ Muya Njomo, Mbugua Wamunyu and Ndung'u Karu to the Prime Minister, More and more trouble against unwealthy and landless people, $10^{\text {th }}$ March 1964, KNA: KA/6/48.
} 
his mind. This meant that Kiano would not let them buy his farm although it was adjacent to the mbari's small pieces of shambas. Moreover, this was despite the fact that it had been owned by the antecedents of the clan. According to the letter of complaint to Kenyatta, most of the people involved were jobless and had liquidated all their belongings and means of livelihood in the hope of recovering the piece of land. They appealed to the prime minister arguing that, unlike them, Kiano was a man of adequate means whereas only if the land fell into their hands would they be able to eke out a living. ${ }^{90}$ This was a situation that was played-out in many similar incidences across the country as some of the complaints cited above already attest.

However, few petitioners were as authoritative and caustic as the tough questions directed at Kenyatta by two long serving members of the KCA. One of them, Mathew Muguta from Murang'a qualified his biting criticism by noting that Kenyatta had won his respect in the late 1920s. Nevertheless, Muguta went on to remind the president of the deep roots of the struggle that reached back to the early 1920s and some of the people who were involved before Kenyatta came into the picture. Muguta's letter mentions how the KCA was formed and started its operations in secret in Kahuhia, Murang'a with Kenyatta only joining towards the end of the 1920s. Muguta said that he vividly remembered Kenyatta making his membership payment like everyone else. Citing Kikuyu wisdom, he reminded the president that it was custom to honor fathers by naming one's first born son after them: would Kenyatta thus honor veteran founders of the struggle for freedom, Muguta wondered. After all, they were the ones who had sent him to London the first time; while there, they had sent their material and moral support; and they had offered the same to Kenyatta when he was imprisoned. Why then Kenyatta had forgotten them so quickly after taking the reins of power? Was it not expected of the president to find after them? Or was it a case of sticking together in trouble but bolting after he had found his own? Muguta's letter was intended to remind Kenyatta about sheathing a club. ${ }^{91}$

\footnotetext{
${ }^{90}$ Gikundike Farmers, Lower Kabete to the Prime Minister, 22 ${ }^{\text {nd }}$ May 1964, KNA: KA/6/48.

${ }^{91}$ Mathew Muguta to the president, $10^{\text {th }}$ November 1965: KA/6/59. The combination of words used in one of this letter's sentences is rather cryptic and could mean different things: "marua maya ni magukuririkania njuguma njora-ine," which literally translates into, "this letter is to remind you of the club in the long knife sheath." It could be a mild threat that the weapons of the struggle were still girded around young men's waists for use or simply, to be meant as a reminder to Kenyatta of the role played by such young men. It could also have been used to tell Kenyatta to properly prioritize the distribution of rewards.
} 
Similarly, Albert Wakangu Munene told Kenyatta that he was aware of the appeal of the Father of the Nation that Kenyans forget the past and forgive their former oppressors. However, Munene categorically stated that there were exceptional cases the nature of which did not allow for such a blissful dismissal of the past and its scruples. Munene told Kenyatta that as one of the early members of the KCA, he had been targeted in 1937 for elimination but had survived a lethal injection, which, nevertheless, rendered him permanently crippled: his left side from the arm down was paralyzed. As such, his life was reduced to one of poverty and misery. To whom was he to turn to in his plight? Who would wipe his tears if not the new African government? What kind of judgment would posterity pass on its leaders if Munene, and many others like him, were left to weep their lives away into old age and death with only God as witness to their plight and misery? Would God and the ancestral spirits bless the government if they were left to die in humiliation and under the oppression of their own sons and grandsons who were leaders of the independent government that they had sacrificed to achieve $?^{92}$

Such questions must have also lingered, and played on another veteran founder of the KCA, James Beauttah's, mind until his death in old age as he persistently sought redress for suffering personal loss in property among other pecuniary woes from the Kenyatta government. In a letter to Mbiu Koinange, Beauttah said that as a long serving freedom fighter since the early 1920s, he was a man deserving praise and honor. Instead, the younger people who had taken over leadership of the struggle from older men like him, among them George K. Ndegwa and Joseph Kangethe, had forsaken and forgotten them. Power and honor had gone to people who did not deserve it at all. To gain favor, Beauttah tried to leverage some of the sacrifices he had made for the struggle early in life, for example, leaving service as a colonial clerk to liberate Kenya. He lamented the fact that after this goal had been achieved, he was thrown overboard like a stinking fish. In the letter, Beauttah expressed surprise that his old friend, Mbiu Koinange, had not remembered him or the sacrifices he had made during the nomination of the unofficial members of the county council or even as a member on any board. What is more is that KANU

\footnotetext{
92 Albert Wakangu Munene to the Prime Minister, Victimization for Love of Country, 19 ${ }^{\text {th }}$ May 1964, KNA: $\mathrm{KA} / 6 / 48$.
} 
had supported Kariuki Njiiri, the son of chief Njiiri who had supported the colonial state, to run for the LegCo elections in $1961 .^{93}$

In his wildest of dreams, Beauttah did not expect that Kenyatta would sympathize with his local opponents like Kariuki Njiiri considering that his father was a loyalist. ${ }^{94}$ While Kenyatta had already instructed the appropriate ministry to extend Beauttah a loan, nothing had come out of it probably, he thought, because some people in government hated him. The dominant theme in most of his letters, Beauttah laments that in the sharing of the fruits of independence, he had been completely overlooked by his old comrades with whom he had fought for a better future. ${ }^{95}$

Beauttah asked Eliud Mathu, then controller of State House and private secretary to the president, in another letter, what crime had he committed to deserve such treatment. Kenyatta's government, he complained, continued to ignore him. This was despite the fact that Beauttah's heart was unchanged and had remained where it stood on February $20^{\text {th }} 1950$ when nationalists, among them Kenyatta and Mathu, had congregated in Mbiu's home at Banana Hill. ${ }^{96}$ Time and again, therefore, Beauttah reiterated his struggle credentials in the hope of meriting favor and government help. In one of his early letters to Kenyatta, Beauttah reminded Kenyatta of the close relationship that they had enjoyed when they were working for the KCA. It was Beauttah and Joseph Kangethe who had been sent to receive Kenyatta in 1946 after fifteen years in Europe. Beauttah also reminded him of the fact that he had served as the vice president of KAU in Central Province. ${ }^{97}$ In the event that help was never forthcoming despite his checkered career as a freedom fighter, Beauttah was afraid, but also reconciled, to follow other unsung fallen heroes like Johana Karanja, George Ndegwa and Joseph Kangethe with whom he had suffered. These, he told Mathu, had already gone and he too, would join them sooner or later. Until then, people

\footnotetext{
${ }^{93}$ James Beauttah to the Secretary General, KANU, 12 ${ }^{\text {th }}$ December 1962, KNA: MSS/35/9. As one of the individuals who had spent the better part of his life fighting for freedom and land since KCA days, Beauttah expected the powers that be to sympathize with his situation and support him in his political aspirations.

${ }^{94}$ James Beauttah to Jomo Kenyatta, $31^{\text {st }}$ October 1962, KNA: MSS/35/9.

95 James Beauttah to Mbiu Koinange, $27^{\text {th }}$ January 1967, KNA: MSS/35/7.

96 James Beauttah to Eliud Mathu, 2nd July 1967, KNA: MSS/35/9.

${ }^{97}$ James Beauttah to Jomo Kenyatta, $31^{\text {st }}$ October 1962, KNA: MSS/35/9.
} 
around him were waiting to see whether Kenyatta's government would treat him like a true national hero that he was. ${ }^{98}$

However, these claims and demands for honor and recognition aside, Beauttah wanted nothing more than either the return of or compensation for 4.6 acres of land that the colonial government had confiscated from him at the height of the Mau Mau war. At any rate, most of the land that had been confiscated from the Mau Mau fighters had been returned to its original owners. Kenyatta had received his land back in Gatundu and his house that had been destroyed, rebuilt. Beauttah, therefore, could not see any reason why his case was any different. ${ }^{99}$ This piece of land had been sold off by the government for a song to the Maragwa County Council, which included it as part of the trading center. Beauttah argued that he had not accepted the twothousand and thirty shillings the council paid for the land. The transfer of land had taken place while he was still in detention in Marsabit, which is where the check had been sent. ${ }^{100}$ As such, he was in no position to negotiate for a better price.

Moreover, such an imposed sale of land, Beauttah argued, was not legally binding. He argued that compulsory acquisition of property by the government was subject to adequate compensation and, as such, the council had acted ultra vires by not giving a proper offer taking advantage of the Emergency and his vulnerable position in detention. Seeking the help of Jackson Angaine, the minister for land and settlement, Beauttah said that he would settle for a firm offer of 50,000 shillings less what the council had already paid. After all, he pointed out, the council was making almost as much money every month if not more in rents. ${ }^{101}$ In his response, Angaine attributed Beauttah's problem to the complex land consolidation process and advised him to resolve the issue with the council and not his ministry. ${ }^{102}$

As already noted, however, Beauttah's plight was the rule and not the exception. His woes were among a few documented cases of Africans who had suffered and sacrificed their all

\footnotetext{
98 James Beauttah to Eliud Mathu, $2^{\text {nd }}$ July 1967, KNA: MSS/35/9.

${ }^{99}$ Beauttah to the District Commissioner, Murang'a, Compensation for 4.6 Acres, Maragua Trading Centre, $18^{\text {th }}$ August 1966, KNA: MSS/35/9.

${ }^{100}$ Beauttah to the Murang'a County Council, Compensation 4.6 Acres, undated, KNA: MSS/35/9. In this letter, Beauttah argued that while he had accepted the check payment for his piece of land, this was just incidental with the aim of holding it until he was in a better position to negotiate a more acceptable and fair contract for the same. ${ }^{101}$ Beauttah to Jackson Angaine, Compensation of my 4.6 Acres -Maragwa T. centre, Maragwa, $17^{\text {th }}$ November 1966, KNA: MSS/35/9.

102 Angaine to Beauttah, Compensation: 4.6 acres -Maragua Trading Centre, $23^{\text {rd }}$ November 1966, KNA: MSS/35/9.
} 
in the cause of freedom. Mohamed Solano Agufa, a freedom fighter from Turbo, Mautuma Scheme shared the same post-colonial disillusionment. Agufa recalled, in a letter to Kenyatta, when the latter had visited Kakamega as the chairman of KAU in 1946. Kenyatta's car had gotten stuck and he had then hitched a ride in Agufa's car. During the emergency, the car was confiscated by the government and Agufa's personal driver arrested and imprisoned for six years. At this point, Agufa had joined the Mau Mau movement only leaving the forest after Kenyatta's call for people to surrender. In the interim, however, he had not only lost his car but had no shoes or clothes. Agufa told Kenyatta that he had nothing left: that he could not even provide for his family. It was, therefore, very surprising for him to hear Kenyatta say that there were no free things in independent Kenya. ${ }^{103}$

Kimani Njuku, another man who was, in February 1952, arrested, convicted and detained at the Githiga Detention Camp from where he was writing his letter on appeal, was not ashamed to share his experience of loss. Njuku had lost twenty-three head of cattle, which were confiscated by chief Wanjii of Murang'a. The said man also owned his land with what remained of it having been the site of an Emergency village. Moreover, he emerged to find his reputation tainted especially in the eyes of chief Wanjii. ${ }^{104}$ Like Njuku and as late as 1967, Njoroge Mbugua still hoped that the government would assist him to get one of his cherished possessions that he had lost after he and his brother were detained in 1953: a 1936 Ford V8 truck probably one of those dispensed with by the British army after the war. Apparently, when he started his search after his release in 1959, the Criminal Investigation Department had informed him that the car was somebody else's property. The attorney general, however, had recommended repossession by Mbugua. The car had been auctioned in Nairobi by Ismail Auctioneers on behalf of the government after his detention in July 1955 to a Mugo Njuguna Gichuhi of Thika. Following the decision by the attorney general, Mbugua sought compensation from the government. After all, it was the government that had sold it. ${ }^{105}$

Similarly, Gitao Kago asked Kenyatta to intervene in his favor in an attempt to get his car that had been taken by a white inspector of police, Moleneux of Thika, after his arrest in 1956.

\footnotetext{
${ }^{103}$ Mohamed Solano Agufa to Kenyatta, Celebration Kenyatta Day, undated, KNA: KA/6/59.

${ }^{104}$ Kimani Njuku to the Special Commissioner through the Officer in Charge, Githiga Detention Camp, My cattle and land, $23^{\text {rd }}$ August 1960, KNA: KA/6/48 .

105 Njoroge Mbugua to Kenyatta, $29^{\text {th }}$ September 1967, KNA: KA/6/14.
} 
Upon his release a year later, Kago embarked on a search for Inspector Moleneux who had since retired from the police force. Having found him, he had sought the help of the DC in Kiambu who had written numerous letters to Moleneux to either return the car or pay for it without avail. ${ }^{106}$ Livingstone G. Gatumbi from South Tetu also wanted to know from Kenyatta whether the people whose houses and property had been lost or destroyed during the emergency would be compensated: would the government, for example, consider building houses for them? ${ }^{107}$

Apart from such complaints from actual freedom fighters asking for their rightful share of the fruits of independence or compensation of lost property, relatives of those who died or were unaccounted for did the same. The best example would be that of missing General Stanley Mathenge's family. His son, Peter Mirugi Mathenge, wrote Kenyatta in 1967 telling him that the general was either lost or dead. Mathenge told the president that the time had come to launch a complaint to him and the government about the difficulties and troubles that were pressing down his weak and poor family that had been forgotten after uhuru. As the first born, Mathenge had tried various ways to earn a living and assist the family but his many attempts were "full of thorns and darkness." Times and things were much tougher than they had been before independence when he had been detained in approved schools and made to suffer on behalf of his dear father, Mathenge lamented. Then, he had naturally thought it was not for naught that both he and his father suffered because independence would reward their service "during the critical times of emergency." However, considering his position many years later, Mathenge and his family was severely disappointed. The war that he and his father had joined was succeeded by another endless war against poverty, which was the "reward." The family was like pelicans or homeless owls of the wilderness. Mathenge hoped that Kenyatta would help him get admitted in the army, the National Youth Service or any other form of employment within the government. Otherwise, the only other choice available was to resign himself to a life of crime. ${ }^{108}$

Indeed, crime was something that many young people threatened the president with as a survival mechanism of last resort. Edward Ngugi Gitao who was eighteen years of age told

\footnotetext{
106 Gitao Kago to Kenyatta, $8^{\text {th }}$ December 1964, KNA: KA/6/60.

${ }^{107}$ Livingston Gatumbi to the Prime Minister, $31^{\text {st }}$ December 1964, KNA: KA/6/60.

${ }^{108}$ Peter Mirugi Mathenge to Kenyatta, $12^{\text {th }}$ October 1967: KNA KA/6/14. Although Mathenge's mother had been allocated a plot through the settlement Mweiga Scheme, he complained that it was unproductive and, therefore, almost useless for farming purposes.
} 
Kenyatta that while his father had tried to give them an education, not all his siblings were able to pursue studies because his father was poor. Gitao started school in 1959 until 1965 and matriculated with an elementary certificate despite difficulties. However, he could not proceed further due to lack of money. Gitao still hoped that he would be able to make a contribution to the country in the future. In the interim, however, he feared that he would be forced to take to a life of crime in order to survive. ${ }^{109}$ James Mugo, who, in spite of passing his elementary school exams was forced to work as a cook, felt that hard times would force him to succumb to the temptation of having to steal food. ${ }^{110}$ John C. Kemiti Kamau wrote the president an eloquent letter expressing faith that "being the merciful father of" the nation, Kenyatta would not approve any of his subjects to be compelled to live a life of distress and underserved punishment.

Kamau's pursuit of medical studies in Yugoslavia had been cut short when the general living condition there became impossible. This was followed by a stream of unhappy students leaving the country and other East European countries especially with the promise from the Kenyan government to ensure the completion of their studies. Once home, however, they faced a ban on employment because the government feared that they had communist inclinations. Kamau, therefore, had spent thirty months without work or a means of livelihood and doubted whether the government had been serious about sending him back to school. Kamau told Kenyatta that no one could continue to live without food or money. His feeling was he would be no worse off in prison and that there were real possibilities that he would be tempted to indulge in crime for a living. ${ }^{111}$ There were numerous cases of promising students who were forced to drop out of school and take odd, under-paying jobs.

This state of affairs infuriated many former freedom fighters who felt that uhuru was a farce. They complained about their children who were "thrown away" by an uncaring government after their Kenya primary education exams. ${ }^{112}$ Mt. Kenya Freedom fighters requested Mbiu Koinange to take at least fifty young men for further studies since not so many people from the region had ever had such an opportunity. This was despite the fact that Kenyatta

\footnotetext{
${ }^{109}$ Edward Ngugi Gitao to Jomo Kenyatta, $21^{\text {st }}$ September 1967, KNA: KA/6/14.

${ }^{110}$ James Mugo to the Office of the President, $4^{\text {th }}$ October 1967, KNA: KA/6/14.

111 John C. Kemiti Kamau to Jomo Kenyatta, $5^{\text {th }}$ August 1967, KNA: KA/6/14.

112 Kikuyu, Embu and Meru freedom fighters to the Ministry of Foreign Affairs, 23 ${ }^{\text {rd }}$ June 1967, KNA: KA/6/14.
} 
had promised to sponsor nine young men for further studies. They expressed the hope that the government would rescue orphans and widows of freedom fighters and provide free education. ${ }^{113}$

Charles Muriithi Kuikui was such a needy twenty-one year old son of a freedom fighter who had been killed in the war. Kuikui had successfully finished standard seven and hoped that the government would award him funding to allow him to pursue his secondary education for free or award him a scholarship. ${ }^{114}$ Hailing from a poor and landless family where no one was employed, Christopher J. Njue and his three siblings were experiencing a similar fate. Njue's brother, Phinias J. Ndwiga, had finished his KPE in 1964 but being unable to pursue his education further, moved to Nairobi in search of technical training and employment without any luck. He kept being referred to various government ministries but no job offers were made. Njue had passed his KPE the following year but could not afford the annual school fees that amounted to six-hundred and eighty shillings. Eventually, he was suspended when he came short of 425 shillings. At this point, Njue sought assistance from Kenya government bursary scheme and was able to secure only a hundred shillings. In the ping pong that ensued, Njue shuffled between the Ministry of Education and the Embu County Council in the search for the outstanding fees. Eventually, the council told him that all secondary schools were under the central government and that, as such, the Embu County Council could do little to help him. Njue's attempts to join Starehe Boys Secondary, which catered for needy cases like him, yielded no fruits. For that reason he considered a career in the Kenya air force, navy or police. ${ }^{115}$

Perhaps, it is such perturbation and frustration that prompted a moving anaphoric letter from the "Four Corners of Kenya" in the same year. ${ }^{116}$ In this poetic letter, the ruling party was put in an awkward position in the face of a raft of successive rhetorical questions. Indeed, the letter was not only found to be provocative and embarrassing but also considered to be a security concern as did most of these letters that found their way to the Office of the President. "Dear KANU," the letter opened: "you are asked by the four corners of Kenya, when will the promises

\footnotetext{
${ }^{113}$ Mt. Kenya Freedom Fighters to the Minister of State and Pan-African Affairs, Mbiyu Koinange, $11^{\text {th }}$ January 1964: KNA KA/6/32.

114 Charles Muriithi Kuikui to Kenyatta, $26^{\text {th }}$ July 1966, KNA: KA/6/59.

${ }^{115}$ Christopher J. Njue to Office of the President, 30 $0^{\text {th }} 1967$, KNA: KA/6/14.

${ }^{116}$ Letter from the Four Corners of Kenya to KANU, $27^{\text {th }}$ July 1967, KNA: KA/6/14.
} 
be fulfiled [sic] which were made from 1952 to 12.12.64" [sic]. The Four Corners of Kenya then pressed:

KANU, what did you do after getting the fruits of Uhuru? Didn't we all agree to share the fruits thereof between each and every one of us!

KANU, the Four Corners of Kenya hereby asks, 'can the sweet taste on the tip of someone's tongue be transferred to somebody else's?'

KANU, men, women and children hereby ask you, 'do you, really, consider the task of land redistribution to be now complete?'

Consider: children in the village are starving when they leave school. Their fathers have nowhere to cultivate or even work to do. They do not even have clothes to cover their bare backs.

KANU, what happened? Aren't you the one who has the keys of the box bearing the fruits of independence?

KANU, do you remember the people who were detained; those who were in the forest; and those who died for the sake of the fruits of Uhuru? If you do, what should you do with the store of those fruits?

KANU, ... see, parents have nothing to give their children... even clothes, food and shelter.

Our children are now like dogs living off dustbins in the city. KANU, consider: if a mother has five children and gives food to only two of them leaving the rest to fend for themselves, would she be said to have, really, 'shared' the food?

Obviously not! The three children would be crying while the other two would have their stomachs full.

KANU, isn't that what you did with the fruits of Uhuru?

KANU, do you remember our Freedom Song: the one we sang in '52?

Oh, what great love we witnessed among children and women!

When a morsel of bean fell to the ground, they split it and shared it equally amongst themselves.

Oh, how we pray, how we pray and beseech fervently that it would be the same now as it was then. ${ }^{117}$

KANU, the blood spilt in the struggle for freedom cries out to you from the ground. And the voice of those who survived from Nyandarua to Embakasi joins up with that of the dead saying: 'don't you know that we still await the sweet taste the fruits of Freedom?'

117 This song was known as "the song of Ole Nguruone," which was a composition by squatters who worked on white settler farms near Nakuru. They had been expelled from these farms in the early 1940s and at the end of the Second World War. According to Ngugi wa Thiong'o, Dreams in a Time of War (New York: Pantheon Books, 2010), 126, it was a song of resistance, defiance and, at the same time, one of immeasurable sadness. It was popularized after most of these squatters returned to their origins in Central Province and had entered Kikuyu folklore by the time the Mau Mau war broke out in the 1950s. 
KANU, these letter echoes these cries of freedom: please reply to them soon. May be through radio, may be through the newspapers in order that all the Four Corners may hear it. $^{118}$

Torrents of such petitions and complaints poured into government offices, as it were, from all the four corners of Kenya. They reflected genuine aspirations of the people. They contained expectations and hope for a better future of independent Kenya. A few years into this beckoning future, however, apprehension and uncertainty prevailed where once faith and optimism resided. The torch and light of freedom that had been generated in the crucible of the struggle of freedom was soon extinguished a few years after independence. Independence euphoria and good will fast gave way into embers of disillusionment and frustration for most people. From the ashes of consumed dreams emerged blistering bitterness and a rising din of nagging questions. Such was the hidden sentiment and anguish in the subtext of the verse from the Four Corners of Kenya. To the new independent government and even London, which still firmly held the puppeteering strings, these rising Voices in the Dark were an unnerving knell. This then, is what prompted letter handlers and senior officers at the Office of the President to hastily forward such complaints and petitions to, ironically, the Ministry of Home Affairs and the police department. That was the exact "response" that the rather innocuous poetic letter from the Four Corners of Kenya elicited in official circles.

Such was the response of Cyrus K. Wanjohi's desperate note to the president. At a loss of how to get an audience with Kenyatta, Wanjohi furtively walked along the perimeter of the prime minister's official residence, State House, and stuck his letter in the chain link fence where he was sure someone would notice. In the note, Wanjohi expressed astonishment at seeing Kenyatta working hand in hand with the people who had supported British rule and opposed him who were now "enjoying" independence. This, Wanjohi said, was at the expense of those who had devoted their energy and lives to the independence movement. For this, he wished to congratulate Britain's imperial genius.

\footnotetext{
${ }^{118}$ Letter from the Four Corners of Kenya: KNA KA/6/14.This is a loose paraphrase of the original letter by the current author. However, in so doing, an attempt has been consciously made to maintain the original wording. At the same time, I have sought to also capture the spirit in which the words were written and also give them the poetic format or structure in which they appear.
} 
At the same time, he was glad that at that point in the young life of the nation, this state would serve as a good lesson. Wanjohi believed that in the future, people would not accept to devote their lives to a leader such as Kenyatta who did not even have an iota of pity for people who had just returned from the forest or had been detained for years who were helpless and naked. These had struggled together to liberate the country and had been maimed but they were now "shambaless and jobless." Wanjohi expressed his mental, social and financial suffering and accused Kenyatta before the almighty God for his propaganda, which had made many people to suffer and lose their lives. ${ }^{119}$ Needless to say, his letter caused great alarm and was immediately dispatched to the Director of Intelligence for his record and further investigation.

Still, his letter was only one among many others from the four corners of Kenya as ordinary Kenyans voiced their displeasure and discontent with how things were going. A section of such letters came from peasant farmers or squatters and farm workers who, even after independence, were treated with hostility by remaining settlers. Their bitterness measured no less than Wanjohi’s. It was “just like 1953,” Matindi Ticha from Kapcherop, Kitale opined. The pain that people bore there was reminiscent of the difficult years of the 1950s. The experience of squatters had stuck in time because they were being evicted from "seteras" who only gave them a seven-day notice to do so. Ticha was one of those who had been thus "chassen" by these "chassers of Africans." In the hope of swift justice, Ticha fearlessly mentioned R.J Furton and a "Manjester Medi of Horse Bridge" as two of the leading white settler culprits who were evicting Africans for no good reason at all. As a result, squatter children were not able to attend school because of these troubles. Why would the government not send someone like Oginga Odinga to resolve this struggle? ${ }^{120}$

Similarly, the citizen-squatters of Leshau were rather surprised by the action taken by their resident European settler-farmer, a Mr. Lewis, who refused to give them permission to mark Kenyatta Day celebrations in Nyahururu just a few days before they wrote. This was an affront that caused them great agony, they said. The said man had done the same during Madaraka Day, another Kenyan national holiday. Instead, he preferred his African farm hands to continue work on his wheat plantation. The petitioners were dismayed that the man did this in

\footnotetext{
${ }^{119}$ Cyrus K. Wanjohi to PM Kenyatta, $13^{\text {th }}$ April 1964, KNA: KA/6/48.

${ }^{120}$ A hand written letter from Matindi Ticha, Just Like 1953, which ended up in the OP, $12^{\text {th }}$ February 1964, KNA: $\mathrm{KA} / 6 / 32$.
} 
spite of the fact that he enjoyed the protection of the government. What was wheat compared to Kenyatta Day, they posed. ${ }^{121}$ Likewise, the Mau Mau War Council in Nyandarua echoed the same sentiment. They wrote: "although the national flag is flying, we" the "people of Ol Kalou settled area are so disturbed that we find it difficult to believe that the National flag is really flying." They were inconsolable due to evictions of squatters who were being removed from farms that they had lived on for thirty to fifty years especially after independence. They demanded that the government find them alternative settlement and allow them to deal with white settlers by force. Further, they found it rather absurd that in Nyandarua District, land was being allocated to the rich people instead of the poor. They applauded the words of Josiah Mwangi Kariuki, a popular politician, MP and a defender of the poor, who had raised similar concerns at a meeting at Ol Joro Orok on $18^{\text {th }}$ January. ${ }^{122}$ The struggle for independence that had started with the Norfolk Hotel shooting had been long and now the people had won their own flag. Nevertheless, they were just beginning to realize that the flag, really, did not mean anything anymore.

It was such events that reinforced the prevalent view held by many wananchi that colonial laws were still in force. Henry Namasaka from Turbo made a claim to this effect pointing to the fact that a white settler, C.B. Looman of Wattle Co., had destroyed African houses and forced them to leave his farm. ${ }^{123}$ Thirteen squatters had met the same fate when they were forced out of F.D.M. Erskine's farm in Kipkabus in the Rift Valley after the previous owner sold it. ${ }^{124}$

Namasaka's concerns were echoed by Kamiri Muraguri whose critical letters were quickly marked "P.A" (Police Action). ${ }^{125}$ Going beyond the former's claim, Muraguri insisted that Kenya needed to end colonial laws. As far as Muraguri was concerned, the government could little disguise the fact that it was not any different from the previous colonial

\footnotetext{
${ }^{121}$ Leshau Citizens filed in OP records, $25^{\text {th }}$ October 1967, KNA: KA/6/14. This letter was sent about five days after the said incident.

${ }^{122}$ Mau Mau War Council, Nyandarua to the Prime Minister, To the Father of the Nation, $21^{\text {st }}$ January 1964 , KNA: $\mathrm{KA} / 6 / 32$.

${ }^{123}$ Henry Namasaka to the Minister of Home Affairs, Mbiu Koinange, $21^{\text {st }}$ June 1967, KNA: KA/6/14.

${ }^{124}$ Henry Gachuro to Kenyatta, $30^{\text {th }}$ January 1964, KNA: KA/6/32.

${ }^{125}$ Some of the letters that were extremely critical of the government or the president were marked "P.A" meaning that they were forwarded for "Police Action" including investigation and probably arrests.
} 
administration in that regard. ${ }^{126}$ In another of his letters, Muraguri accused some of Kenyatta's ministers, like Julius Gikonyo Kiano and Njoroge Mungai, for not living up to policy promises made to the public; and the public's expectations. ${ }^{127}$ This was betrayal of the public, which could easily execute some these promises, for example, the restitution of African land or compensation for their loss. The people had resolved that land belonged to them and as such, the government was acting as a surety to that end. There was no debt that had to be paid to Europeans to pave the way for the resumption of African ownership of what was theirs by right, Muraguri argued. In exasperation, he asserted that the people had decided that they would no longer accept to be removed from the land. Evidently, the subject-issue of this letter, a mass eviction of squatters possibly at a place called Kamae, had been raised in an earlier letter from Muraguri, his very first to the president. ${ }^{128}$ In this first letter, Muraguri asked for Kenyatta's support in the form of provision of transport for the "war council" to ascertain if the evictions were true and if so, why ordinary men there were being mistreated. ${ }^{129}$

These sentiments were mirrored, and therefore, validated by similar strongly held views elsewhere in the country. SamsonWafula Wakoli wrote to the Minister for Information and Tourism, Achieng Oneko, on behalf of the DYM to notify him of the grave danger that was facing the country. From the "Dini ya Msabwa's point of view," colonialism was an ever continuing and a felt haunting presence, which ran deep roots in Kenya that needed removal. If these roots were not "smashed," people still had more suffering to endure even after independence. As it had done before independence, the society, wrote Wakoli, was still standing firm to defend freedom, peace, justice and security. Among the Luhya of Western Kenya, such sentiment as articulated by DYM was not isolated. ${ }^{130}$

A team of twelve elders representing their locations including South Maragoli, Bunyore, Tiriki, Isukha, Kisa and Marama turned to the government to secure their survival vis-à-vis the issue of land. While they had been at the forefront of fighting for land and independence since

\footnotetext{
${ }^{126}$ Kamiri Muraguri to Jomo Kenyatta, $24^{\text {th }}$ July 1967, KNA: KA/6/14.

${ }^{127}$ Muraguri to Jomo Kenyatta, 12 June 1967, KNA: KA/6/14.

${ }^{128}$ Muraguri to Jomo Kenyatta $5^{\text {th }}$ June 1967, KNA: KA/6/14.

129 This letter too was marked "P.A," KNA: KA/6/14.

${ }^{130}$ Samson Wafula Wakoli on behalf of DYM to the Minister for Information and Tourism, Achieng Oneko, $12^{\text {th }}$ September 1964, KNA: KA/6/33.
} 
1922, they had not received anything yet. ${ }^{131}$ In a letter on behalf of the Bunyore, Masinde Abbo asked Kenyatta to remember all the ordinary people of Kenya who were formerly down trodden. Abbo warned Kenyatta to be wary of self-seekers who wanted to be "the big bosses over" the rest of the people. If such people remained in public service, they would defraud Kenyatta and cheat ordinary people in the process. He, therefore, appealed to Kenyatta to provide opportunities for ordinary people like him. Abbo expressed faith that justice would be meted out and extended to Bunyore location where there was need for "quick change" since people had suffered so much injustice in the colonial era. Even after uhuru, he stated, colonialism still lingered in villages and the bush country. For example, there were chiefs who regarded ordinary people as a low caste, which was a stubborn and oppressive colonial dreg that had to be brought to an end. ${ }^{132}$

Further, reflecting the division among the Kikuyu between those who had supported the colonial state and its militant opposition, among the Luhya, Peter M. Aliarane wrote a letter to Kenyatta that was circulated among leading politicians from the region, among them Edward Khasakhala, Stanley Godia and Jonathan Muruli in support of Joshua Magotsi to be chief in Idakho Location. Aliarane said that Magotsi was a proven nationalist who had identified with the Mau Mau cause in 1952 for which reason he had been arrested and sentenced to six monthsimprisonment. He was also the first person from Kakamega to join Maragolians to form a KANU branch in North Nyanza together with J. Otiende and Seth Lugonzo. Moreover, Magotsi had fought for the right for Africans to plant tea in the area. ${ }^{133}$

Notably, a Tiriki writer requested Kenyatta to step in to mediate peace between the Maragoli and the Kalenjin adding that the struggle for milk and honey and bread and butter had ended with the termination of years of British colonialism. Unlike then when these things had been enjoyed by only white people, a time had come for Kenyans to enjoy them together in peace. ${ }^{134}$ Another Maragoli group, the Maragoli Hills Farmers Society, requested the government of Kenya to hand over Maragoli Forest for their use. This land, they said, had belonged to them before it was alienated without compensation. They appealed for the government to liberate them

\footnotetext{
${ }^{131}$ Boaz Samula, on behalf of the twelve elders, to the Prime Minister, $19^{\text {th }}$ November 1964, KNA: KA/6/33.

132 Masinde Abbo of Itumbu, Bunyore to Kenyatta, 20 ${ }^{\text {th }}$ December 1963, KNA: KA/6/33.

${ }^{133}$ Peter M. Aliarane, Chieftainship in Idakho Location, to the Minister of Home Affairs, $21^{\text {st }}$ July 1964 , KNA: KA/6/33.

${ }^{134}$ Benjamin, a member of the Bahai Committee in South Tiriki, Maragoli to Office of the Prime Minister, 1964, KNA: KA/6/33.
} 
from the chains that had been set upon them by the colonial government so that they could be able to join the rest of the people in celebrating " $u$ huru" once this yoke had been laid down. ${ }^{135}$

In addition to the above narratives of suffering from a cross-section of post-colonial Kenya society is an important category that needs special mention: women petitioners. Although these were not many, but women voices were raised for a review of their independence fortunes leveraging their claims against their contribution to the struggle that had made freedom possible. Indeed, playing upon women solidarity, one of the few petitions from women was not addressed to President Kenyatta but, rather, to Mama Ngina, who was Kenya's first lady. This letter was written by Wanjuku Wariku on behalf of the Women War Council from Murang'a, Nakuru, Nyeri, Meru, Nairobi, Kiambu and Nanyuki. Wariku expressed their shock because it seemed to them that Ngina had forgotten women who had played the crucial role of producing, and providing and moving food from ridge to ridge to forest fighters at the height of the Mau Mau struggle. They had been waiting on Kenyatta to whom they had consistently been writing since 1964 with no success. They had, therefore, decided to appeal directly to Ngina in the hope that she would pass on their petition to the president: perhaps, they feared, Kenyatta had not received any of their letters. ${ }^{136}$

Rebecca Njeri, a woman Mau Mau volunteer who had managed independent schools before the war, had been "instrumental in collecting funds and starting a school for Girls in Githunguri; and subsequently, had been arrested and later detained for her role as an organizer of Women's Wing of the struggle for independence, wrote Kenyatta a long and impassioned letter for the pardon of Harrison Njoroge Nguyai, her adopted son and "sole bread winner." Apparently, Nguyai who Njeri had adopted after the death of his father early in his childhood, had been arrested and convicted of receiving funds in a suspicious manner following which he was sentenced to serve a twelve-year prison term. However, after his case was heard by the High Court of Appeal, the sentence had been reduced to seven years, which Njeri felt was a long sentence. This meant that Nguyai would no longer be there to help her any more. Having spent

\footnotetext{
${ }^{135}$ Eli Ogola, the General Secretary of the Maragoli Hills Farmers Society to the Minister for Natural Resources, $5^{\text {th }}$ November 1963, KNA: KA/6/33.

${ }^{136}$ Wanjuku Wariku to Mama Ngina Kenyatta, 22 ${ }^{\text {nd }}$ April 1966, KNA: KA/6/59. The exact words in the original Kikuyu letter are: "Kimako Tondu Tuonaga Tawariganiirwo ni Atumia a Karai na Giciko" (we are stupefied by the fact that it seems to us that you forgot all about the women of the cooking pot and spoon).
} 
all her savings and borrowed money to try and provide the best defense for her son, Njeri was "quite helpless" and unable to support herself or her family that depended on her as their source of support. The worry of earning a living on account of the impending imprisonment was attended by health complications. There was no one to help her besides Nguyai in what Njeri referred to a "struggle of life and death."137

Further, beside the argument that Nguyai was the sole bread winner for her family, Njeri leveraged the plea for Kenyatta's intervention against the insightful observation that most male contributors to the "Freedom Struggle" had already "got their reward by getting lucrative positions and other means of income after the attainment of Uhuru." Since she was a woman, Njeri argued, she had not yet "reaped any fruit of Uhuru." Yet, until then, Njeri had not approached the president or any other department of his government for any favors. This was despite the fact that she had always known that she deserved some consideration on account of her role in the freedom struggle. In light of her contribution and service to the nation, Njeri hoped that Kenyatta would give the matter his full attention and grant pardon to Nguyai. ${ }^{138}$

\section{University Students: A Tertiary Decibel of Discontent Rejoins}

University students were another important source of early dissidence after independence. For example, following the infamous 1966 KANU Conference in Limuru that would remove the entire outspoken radical wing of the party, including Oginga Odinga and Bildad Kaggia, there developed serious student-government conflict with firm roots at the University of Nairobi. Before long, the subsequent momentum of opposition that germinated and took root at the time constantly infected the student body. A good case in point was when students invited Oginga Odinga to address them at Taifa Hall, which the government cancelled. This led to protracted student protest, which paralyzed university operations and culminated in the closure of the university. ${ }^{139}$ In 1966, the Kenya Students Union of the university led protest against the controversial issue of the acquisition of the mayor's expensive car. The mayor of Nairobi was set to incur the exorbitant expenditure of $£ 10,850$ for a Rolls Royce. In a letter to

\footnotetext{
${ }^{137}$ Rebecca Njeri to Kenyatta, $28^{\text {th }}$ October 1965 , KNA: KA/6/59.

${ }^{138}$ Ibid.

${ }^{139}$ Francis John Gichaga, Surviving the Academic Arena: My Complex Journey to the Apex (Nairobi: University of Nairobi Press, 2011), 145 \& 146.
} 
addressed to Kenyatta's minister for local government, students argued that dignity alone did not warrant such wasteful spending. ${ }^{140}$

Writing at the same time, F.R. Kithinji, a resident of Nairobi, told Lawrence Sagini, the minister, that such a huge amount of money was not to be spent without the consent of the public, which was opposed to the purchase. At any rate, millions of Africans were dying of hunger. The Nairobi City Council could do with a more economical car for the mayor. This ridiculous amount of money could be used to feed hungry countrymen who could not even afford shelter or the price for a square meal. The people of Kenya, it was argued, were greatly mistaken if they thought only of the dignity of a particular person instead of thinking of human dignity for all. How many beggars, hungry and unemployed people swarmed the very street which this economic monster would use? Had whoever authorized the spending of this money not at all thought of the dignity of the less unfortunate members of society? Yet, Kenyatta's government, time and again, appealed for self-sacrifice and people responded accordingly. Since this appeal was directed to everyone, the Kenya Students Union further argued, could not the mayor of Nairobi also sacrifice by feeling satisfied with whatever car he had at the time? The union countered the mayor's justification that the car he had was too old and difficult to maintain: if that was the case, it was not a bad idea to buy a new one. However, did the mayor purport that only a Rolls Royce was easy to maintain? Obviously, there were cheaper cars that were not costly to maintain. ${ }^{141}$

Further, students stated that it was not enough for the mayor to argue that the Nairobi City Council had done more for beggars than any other local authority. That, they said, was what was expected of the council. Moreover, it was many times richer than other local authorities. It could also not be said that the council had done all that could be done in that regard. The union, therefore, concluded by saying that there were better ways to use the money earmarked for a new car for the mayor. For example, it could be spent to feed at least two-hundred people for eight years. It was even enough to pay one year's school fees for about three thousand and six hundred

\footnotetext{
${ }^{140}$ C.M. Maranga, Secretary, Kenya Students Union, University College, Nairobi to Minister of Local Government, Mayor's car, $4^{\text {th }}$ February 1966, KNA: KA/6/59.

${ }^{141}$ F.R. Kithinji to Lawrence Sagini, Minister for Local Government, Who is Bigger: The Mayor or the President?, $27^{\text {th }}$ January 1966, KNA: KA/6/59.
} 
primary school children. These were the kind of service that was needed to satisfy tax-payers instead of buying such an expensive car for the mayor. ${ }^{142}$

\section{Kenya (Re)Imagined: Art in Life, and Life in Art}

Besides such narratives of continued suffering, unmet grievances and demands that reached to the time before independence and grievances and criticism leveled at Kenyatta and his government, whatever simmering and unspoken discontent that may have existed among ordinary Kenyans was captured and archived, and by extension, immortalized in creative works of fiction. The post-colonial Kenyan novel is especially distinctive among other works of fiction in this regard. This is because no area of a people's lives, including the very boundaries of their imagination, is unaffected by how society is organized, the whole operation and machinery of power. ${ }^{143}$ As one of Kenya's leading and veteran novelists Ngugi wa Thiong'o, has argued, a writer's subject matter is in itself, really, history. Indeed, writers as human beings are, themselves, a product of history, time and space. As such, Kenyan fictional writers based their work on what they observed both before and after independence. Their work, therefore, was a continuing commentary on their observation of how real people behaved or did; how they were changing or attempted to transform themselves. Fiction in general, and the novel in particular, is a form of analysis of the changing relations of production including power relations in a whole territory of concern to the writer. ${ }^{144}$ Indeed, as a collective body of work, Kenyan literature presents the postcolonial historian more and sharper insights into the moving spirit of an era to augment historical and political documents treating the same moment.

The Kenyan novel in particular, especially considering how steeped it is in its critical realist tradition, is important in this respect. ${ }^{145}$ Literature reflects social reality, which Ngugi as a novelist felt was an essential element of the creative process. ${ }^{146}$ This is so much so that some novels written during the colonial period can, and should be, considered to be part and parcel of the repertoire of the anti-imperial movement. Such work constituted a corpus of knowledge that could be tagged as "resistance literature" that affirmed the right of a people to, once again, seize

\footnotetext{
${ }_{142}$ Maranga to the Minister of Local Government, Mayor's car, 4th February 1966, KNA: KA/6/59.

${ }^{143}$ Thiong'o, Writers in Politics, 67.

${ }^{144}$ Ibid., 68.

${ }^{145}$ Ibid.

${ }^{146}$ Ibid., 70.
} 
the initiative in history, recover and, thereby, actuate their lost human agency. ${ }^{147}$ The social energy from the political, cultural and the social struggle in the colonial era, as discussed in the previous chapters, was transmitted into writer's work. As Ngugi aptly points out, in that era more so, writers were compelled by the harshness of the system to take a progressive stance: they were swept off their feet as it were by the dynamic force and vision of total national liberation. At a public lecture given as part of the department of literature series at the University of Nairobi in October 1975, Ngugi, in effect, told his audience that even after more than ten years of independence, the anti-imperial struggle was still on.

Put differently, writers had to join workers and poor peasant struggles that persisted after independence. The task of the writer, for Thiong'o, was to actively support and reflect the struggle of the working and peasant masses for "the total liberation of their labor power." Creative writing took place against the background of the masses' hope for a better and more egalitarian organized state. ${ }^{148}$ For that reason, writers were supposed to take their position alongside intellectuals, youth, students, religious leaders, workers and peasants in the postcolonial era and resolutely denounce and struggle against all the economic, political and cultural forces that condemned people to "starvation wages," landlessness, homelessness, nakedness, lack of adequate schooling and joblessness. Not to do so would implicate them with those forces, in post-colonial Kenya, that were determined to undermine to betray the spirit of Mau Mau. According to Thiong'o, Mau Mau was still the guiding spirit of the postcolonial struggle. ${ }^{149}$

This then is what Thiong'o set out to do as a novelist. Endowed with an acute sense of place; a curious and inquisitive mind; and a potent imagination, Thiong'o, at a very tender age saw, firsthand, the smoldering embers of pre-European African life and society in his village of Ngamba in the face of what he later came to view as an all-consuming and exploitative capitalist modernity. Thiong'o's work of fiction is an autobiographical recreation of the transformation of life in Ngama in time, space and time experience and the experiences wrought upon its peasant inhabitants. For example, the environment, life situations and experiences of young Njoroge, the central character in his second novel, Weep not Child, drew upon and captured the novelist's

\footnotetext{
${ }^{147}$ Ibid., 21.

148 Ibid., 73, 74 \& 75.

${ }^{149}$ Ibid., 111.
} 
own thoughts, fears and the hopes and terror of the Emergency and the Mau Mau war of independence, which was the background against which Thiong'o, and people of his generation, grew. ${ }^{150}$ The classic Thiong'o novel, therefore, aptly captured the drudgery and experiential struggle of African workers in Nairobi and, more so, that of rural folk. It explores and dramatizes the inner lives of real life characters caught up in a historical development of underdevelopment. ${ }^{151}$ Put differently, the Thiong'o novel is a fictional archive of narratives of suffering some of which have been extensively rendered above.

For instance, Petals of Blood, captures how Ilmorog, a remote, idyllic and tranquil and self-sufficient rural village, is transformed into a forest of concrete building where once of trees stood. Its single dirt track tarmacked and invaded by grasping outsiders as capital and concomitant modernity permeated and reworked its socioeconomic structure. The apparatus and infrastructure attendant to capital and modernity such as stone and glass buildings, roads, railways and land enclosure unravel both the physical environment and social fabric of Ilmorog. More importantly, the peasants in the novel represent people that Thiong'o had known while growing up in his village including his own mother, Wanjiku wa Ngugi. Indeed, according to Thiong'o, his mother was a good representative of the Kenyan peasantry. ${ }^{152}$ Growing up, the novelist recalled how his mother was always saying how expensive "things really were, sugarcanes, bananas, cloths and flour:" even simple things that the family needed to sustain their daily lives. Such was life and the experiences of ordinary people in Kenya not only before independence but also thereafter in the Kenyatta years and beyond.

In Petals of Blood, postcolonial Kenyan society is depicted as empty and anomalous. ${ }^{153}$ It was a society where values such as African traditional mutuality and moral obligation, which had previously bound individuals as a community, had been eviscerated. It was a country where man

\footnotetext{
150 Ibid., 84.

151 Ibid., 89.

152 Ibid., 85.

${ }^{153}$ Ngugi wa Thiong'o, Petals of Blood (London: Heinemann, 1977), 21-22: Thiong'o uses the image of the Theng'eta flower with petals of blood, or red petal without stigma or pistils. Hence, in essence, it was a flower with "nothing inside." Indeed, one of the main characters, Munira, a teacher who had taken his pupils to the field to study nature points out that actually, the student who had discovered the flower was wrong. Taking the flower, Munira observes that the color was not even red because the petals did not even have the fullness of the color. Moreover, it was not quite "empty" inside because it had a worm inside, which had eaten-out the flower rendering it unable to bear fruit.
} 
ate man. ${ }^{154}$ The names given to villains like "Kimeria" and "Chui," two men who represent the "priesthood" of capital in the novel belong to meat-eating predators: the hawk and cheetah, respectively. They presented the "priesthood" of haves in postcolonial Kenya who ensured that thousands and millions of acres remained in the "two hands of" the priest, "while the congregation" of have-nots moaned for an acre. Where there was once African mutuality and moral obligation, the priesthood decreed only "one ethical code: Greed and accumulation. ${ }^{155}$ Like in the analogy of the hollowed out flower with petals of blood, the manner in which Kenyan society was structured and organized with the whole operation and machinery of power in a few pair of hands, ensured that fruits of the process of production and collective industry could not be shared out widely and/or equally.

Besides Ngugi wa Thiong'o, another Kenyan novelist, Meja Mwangi, excelled in the 1970s in artfully capturing the urban anxiety and disorder of Nairobi, the citadel of power and a city of contrasts since colonial times. Mwangi's urban trilogy of novels that includes Kill me Quick, Going Down River Road and The Cockcroach Dance aptly track the trudge and tramp of the damned in the context of rapid urbanization that the country experienced since independence. ${ }^{156}$ Mwangi captures postcolonial urban disillusionment of ordinary Kenyans trapped in the city's marginal spaces such as Eastleigh, Kibera, Mathare Valley, Majengo, Pumwani among other poor neighborhoods Jericho, Jerusalem, Kariobangi South and Huruma that have since been encroached upon by the scourge of poverty. Life in these tough neighborhoods is cast and contrasted by Mwangi against that of wealthy green and shady highincome upmarket homes. As the epitome of the big cities in Kenya, Nairobi is painted in a binary dichotomy constituting north western suburbs of low density and high income and the south-east areas of high-density and low-income.

Moreover, Mwangi's body of work is a riveting account of the constant struggle for survival that characterizes life in not only Nairobi's neighborhoods above but also those in other major cities in Kenya. ${ }^{157}$ The archetype of the dispossessed, exploited and impoverished man in

\footnotetext{
154 "Eating" is a symbol of corruption in Kenya and Africa in general as extensively discussed by Jean-François Bayart, The State in Africa: Politics of the Belly (London: Longman, 2009).

155 Thiong'o, Petals, 163.

${ }^{156}$ J. Roger Kurtz, Urban Obsessions, Urban fears: The Postcolonial Kenyan Novel (Trenton: Africa World Press, Inc., 1998), 112.

${ }^{157}$ Ibid., 124.
} 
Mwangi's urban trilogy represented by characters Meja (Kill me Quick), Ben (Going Down River Road) and Dusman Gonzaga (Cockroach Dance) mirror the lives of some of the real life narratives discussed above. That is the narratives of suffering emergent in the letters that people like Njue and his brother Ndwiga and Kuikui sent to the President. Ordinary and everyday people recognized their plight all so well: they were people like Clement Kimata Mukui and T.K Kairu who, in their letters to Kenyatta, described themselves as "man on the street." It is important to note that people like Mukui and his tea-planting tribulations could easily have ended up in urban streets looking for work. Men like Kairu who described himself as jobseekers since 1956 could even have gone further to resort to a life of crime. As earlier noted, young men like the eighteen year old Edward Ngugi Gitao and James Mugo the cook, did not make it any secret, even in writing to Kenyatta, their intention or threat to turn to a life of crime in order to survive.

Such people are Mwangi's "lonely boys" and the silent, nameless and faceless ones. In the urban Mwangi novel, they are street boys and beggars, "chupa na debe" (mobile collectors of recyclable items such a bottles and plastic containers), the trash merchant, illicit liquor brewers, shoe-shiners, open air tailors and food peddlers, hawkers, taxi drivers, "jua kali" artisans, "mama mboga," (vegetable vendors) and the dark underworld of grime and crime. These are the milling crowds in the streets who appeared in the MacDonald dispatch to London as large numbers of disgruntled poor people that wanted to be given jobs, wages and land as soon as Kenya became independent.

In that dispatch, MacDonald told London that such disenfranchised and powerless people were envious of the rich who they saw driving around in large cars, buying big houses, and purchasing extensive farms. Therefore, they were resentful and discontented. In the letter to Kenyatta, Kairu, for instance, did not understand why some had to sell their labor while others owned more extensive farms than they could put to use. For people like Kairu, the manner in which the country was steeped in capitalism was synonymous with the lack of democracy. In his eyes, Kenyatta's government was constituted of hungry hyenas that did not remember their children. What is more is that, such people like Kairu had nothing to lose or fear: in his letter, he told the president that he was ready for both rebuke or death. MacDonald was correct to observe that in the hands of the leading radical members of parliament and politicians like Odinga, Kaggia and Josiah Mwangi Kariuki, men of the street were a tinderbox. 
J.M. Kariuki, in particular, deserves special mention both as the embodiment of the spirit of Mau Mau after independence and as the voice of the poor in Kenyan national politics. ${ }^{158} \mathrm{JM}$ was a Mau Mau freedom fighter, the experience of which was the subject of his autobiography, "Mau Mau" Detainee. In the book, JM wrote about what had moved him and others to join the movement viz.- the conviction that a stable social order could not be built on the poverty of millions. JM saw frustration born of poverty as the source of turmoil and violence. ${ }^{159}$ When the book first came out in 1963, it had a triumphant ring of hope that rose above the lucid and restrained tone of its rendering. ${ }^{160}$ Further, it resonated with the colonial experiences of most Kenyans across ethnic lines. From "Mau Mau" Detainee emerges a man who was imbued with the consciousness and understanding that he was part of the spirit and legacy of the history of resistance in Kenya. ${ }^{161}$ Even after independence, he emerged as the central figure in the constellation of politicians, most of them backbenchers in parliament, who continued to talk about rural and urban poverty and the plight of the marginalized majority in Kenya.

Consequently, Ngugi wa Thiong'o saw JM and his fate in 1975 as a key plank between the pitfalls of postcolonial Kenya and those of the colonial era. His brand of politics was the banner than carried the legacy and spirit of Mau Mau into post-independent Kenya. In his speeches he raised issues of the dispossessed and discontented who, despite land resettlement undertaken by the Kenyatta government, were still affected by the central economic problem of land hunger. By so doing, JM was championing the very problems of poverty and dispossession, which had rallied people around Mau Mau and against the British. ${ }^{162}$

In the early 1970s, JM led the charge against the small but powerful clique of greedy and self-seeking elite made up of politicians, civil servants and businessmen who had monopolized the fruits of independence. This criticism was encapsulated in the powerful imagery in his famous statement: "We do not want a Kenya of ten millionaires and ten million beggars." This criticism went to the heart of the problem with the manner in which the social organization of power and relations of production allowed the whole operation and machinery of power to be

\footnotetext{
158 J.M. Kariuki is from henceforth referred to as "JM" as he was popularly called by and known by his admirers.

159 Josiah Mwangi Kariuki, “Mau Mau” Detainee (Oxford: Oxford University Press, 1963), 178-179.

160 Thiong'o, Petals, 99.

161 Ibid., 103.

162 Ibid., $108 \& 109$.
} 
concentrated in the hands of the few. It also summed up the connection between the colonial and the postcolonial. ${ }^{163}$ Such constant attack of the manner the small Kenyan elite ran the country, blatant accumulation, amassment of wealth and attendant corruption won JM the hearts of former freedom fighters and the nation at large. It made him the embodiment of the rising tide of discontent and postcolonial dissent.

JM's scathing denunciations of high level corruption struck a chord among people. This was obvious even among foreign observers and analysts of national politics in Kenya. Around the time when he emerged as the poor's advocate in the early 1970s, the spirit of harambee that Kenyatta symbolized in the heady years after independence had already given way to an unprincipled scramble for power and riches among the new ruling class and surly, discontented rumblings among the people. As another MP put it in 1972: "There is a wholesale grabbing of money in Kenya.... These big men steal public funds, and they have friends of influence, and they get away with it." ${ }^{164}$ This was happening at a time ordinary people were hurting as a result of the rise in the cost of living.

The minimum wage in towns in 1973 had remained pegged to the 1967 cost of living figures, yet, according to veteran trade unionist Dennis Akumu, it had risen by $40 \%$ since then excluding the rent element. Moreover, as a result of city council rent increases and the rise in bus fares, the "wananchi" were hit hard. On top of this, the price of bread was going up by $2^{\text {nd }}$ September 1973 and that of milk later in the month. Akumu mirrored the opinion of most people in finding the government reaction to this disappointing. Ordinary wananchi blamed the government in general and Kenyatta's Minister of Finance, Mwai Kibaki, in particular for not having done anything to curb rising prices and exploitation by unscrupulous traders. Although, diplomats at the British High Commission feared that this discontent among ordinary people consisted a widespread threat in the unions or a serious political factor, the few elite it interviewed did see them as a serious threat. ${ }^{165}$

\footnotetext{
${ }^{163}$ Ibid.

${ }^{164}$ Jon Tinker, “Who’s killing Kenya's jumbos,” New Scientist, 22 ${ }^{\text {nd }}$ May 1975.

${ }^{165}$ N.J. MacSween to the Deputy High Commissioner, $31^{\text {st }}$ August 1973, BNA: DO 226/13. This memo was based on a conversation MacSween had had with Dennis Akumu in pursuit of the high commission's stipulated line of political inquiry.
} 
British diplomats, however, had a good reason to worry in the form of an anonymous "Letter to the Wananchi" that was forwarded to Information Research Department of the FCO for analysis. It was received at the British High Commission in Nairobi sometime in the second half on 1973. It was addressed to the editors of the Daily \& Sunday Telegraph who were believed to have the only original copy with the high commission having received only a carbon copy. It would later emerge that copies of the same letter, which was described by one diplomat as a skilled production, were being mailed from Copenhagen to random addresses, for example a shoe store in Mombasa. ${ }^{166}$ The Letter to the Wananchi, which was written by the Kenya "Revolutionary Army," threatened a "mass massacre in Kenya" at an undisclosed time in the future that would target the president and some of the members of his cabinet including Njoroge Mungai, Mwai Kibaki and Daniel Moi among others. According to the Revolutionary Army, they were slated for execution since they had all sold out to the British, other European countries and Asians. The letter picked out Kenyatta and Mungai and their supporters whom they accused for the "death of freedom fighters and, as such, would be tried as war criminals. It went on to say that "all big Kikuyus in the Government" were war criminals. Further, once the Revolutionary Army was in power, all agreements with foreign governments would be repudiated, the constitution suspended, and Kenyan citizenship stripped from all Europeans in Kenya. The constitution of Kenya, the letter said, was "a pure British paper." It advised foreigners who had come to Kenya after independence to leave and invited them to remember the fate of the Ruck family and the Lari massacre, which were brutal murders at the height of the Mau Mau war. ${ }^{167}$

Moreover, the letter stated that Africans in Kenya would not allow a small group of people to impose themselves by shutting the mouths of the opposition, detention without trial and the imprisonment of those who openly expressed their political views. Kenyatta was a tyrant and was a traitor together with his small group of followers. Kenyatta, it added, switched his stance and joined Europeans, Asians and Africans who had fought the struggle for freedom. He had brought back British colonial rule with an African stamp on it yet Kenyatta had been entrusted with leadership of Kenya with the expectation that he would bring about revolutionary changes. Instead he accepted bribery from the British government and white settlers and Asians.

\footnotetext{
166 W.L. Allison to Mr. Dawson, $7^{\text {th }}$ November 1973, BNA: DO 226/13.

${ }^{167}$ Letter from the Wananchi's Revolutionary Army in OP files, BNA: DO 226/13. The letter is extremely sketchy, in a terrible hand and hardly legible.
} 
It noted that Kenya had a military agreement with Britain and the country, therefore, continued to be under the colonial yoke. The Revolutionary Army reminded Kenyatta that independence was achieved by Africans and not by him as he was wont to claim. In fact, Kenyatta had done nothing. The letter claimed that on $20^{\text {th }}$ October 1952, more than 500 leaders were arrested and 350,000 freedom fighters lost their lives in Kenya's independence war.

The army's stated aims and reforms included removing loyalists and their sons and daughters from the national and local government; releasing all political detainees; confiscating Kikuyu home guard properties and restoration of those lost by freedom fighters including land; honoring and rewarding heroes of the independence struggle and compensating them for sacrifices made during the Mau Mau war. ${ }^{168}$ The group was railing at what they saw as the perpetuation of the corrupt colonial system founded as it was on criminal but "legal" and unjust foundations. It did not help much that the Kenyatta government was also perceived by many to be corrupt due to several allegations of grand profiteering and pilfering of state coffers. ${ }^{169}$ One of the most outspoken critics of the government, JM, who was also the face of popular forces from below, disappeared mysteriously, and later was found dead under highly suspicious circumstances.

\section{JM's Demise at the Altar of Graft}

Grassroots support for President Kenyatta and his government had sunk to unprecedented depths as the letter from the Wananchi Revolutionary Army attests. While this "anonymous" letter threatened radical action of military nature, the high cost of living hit many ordinary people hard and was experienced widely. The Kenyan economy in the early 1970s was poor, which significantly added to the resentments of many workers whose wages were increasingly falling behind the rises in the cost of living while the rich and powerful continued to prosper. ${ }^{170}$ As a

\footnotetext{
168 Ibid.

${ }^{169}$ Charles Hornsby, Kenya: A History Since Independence (London: I.B. Tauris, 2012), 312-316.

${ }^{170}$ Document marked Recent Incidents, $10^{\text {th }}$ March 1975, BNA: DO 226/15. The economic downturn was in the context of the international oil crisis of the early 1970s. It is during this time, for instance, where the price increases of edible oils soared to a breathtaking average of $200 \%$ causing uproar in parliament according to Christopher T. Hart to Symons, $25^{\text {th }}$ June 1975, BNA: DO 226/14. However, for rural folk who grew tea and coffee, the 1970s were good years. There was especially towards the end of that decade a boom in export crops especially coffee due to the blight of Brazilian coffee and elsewhere in Latin America. Maize, pineapples, cotton, sugar cane and cashewnuts all performed well to. There was, however, a shortage of maize in 1973, which coincided with drought in the north that in turn caused a glut of meat as pastoralists tried to sell undernourished animals, Hornsby, A History Since Independence, 248 \& 301.
} 
result, such feeling of discontent was widely shared across the country. However, the well to do could rest in the safety that at least some of the discontented people could help themselves because small scale corruption would become an accepted way of life but, fortunately, still far less than in many other countries. Moreover, most people were not ambitious for wealth or power. They simply wanted to live reasonably well in a state which they considered due to them. They could still grumble when others continued to amass wealth but they would not be driven to the sort of despair that inspired revolutions unless this process was clearly connected and seen as being responsible for worsening their own lot. ${ }^{171}$

Nevertheless, one thing could not be taken for granted. While Kenyatta's fortunes were waning, the popularity of JM was ever on the rise from the beginning of the 1970s. During this time, Antony Duff, the British High Commissioner, described JM, then an assistant minister for tourism, as a politician of boundless energy and formidable charisma for the simple people of all tribes. Duff saw JM as a man who, "undoubtedly," aspired to the presidency. It was believed that JM's popularity in the army was such that Kenyatta could not hope to survive if he dissolved parliament and attempted to rule with army support. ${ }^{172}$ Further, he pointed out that JM was one of the very few Kikuyu other than Kenyatta himself who could work outside tribal boundaries. However, because of his radical, if not yet militant, stance on the gap between the haves and the have-nots, Duff thought that JM was some sort of a "rogue politician" with "muddled ideas" and, as such, a professional enfant terrible. ${ }^{173}$ The politician's sudden demise under highly suspicious circumstances is testimony that JM was seen as an irritant by others apart from the British High Commissioner especially considering his constant attacks on high-level corruption and populist advocacy for the down trodden.

The politician's "mysterious" disappearance and confirmation of his assassination soon after, early in March 1975, came close at the heels of unusual events in the country's history and what was, perhaps, one of the greatest corruption scandals of the Kenyatta era. As earlier noted above, the difficult economic situation in the early 1970s, and especially in 1973, was

\footnotetext{
${ }^{171}$ Antony Duff to Hall, $31^{\text {st }}$ August 1973, which was a report of his discussion with George Githii about the Kenyatta succession debate and the internal political situation in the country, BNA: DO 226/13.

${ }^{172}$ Antony Duff to the Right Honorable Alec Douglas Home, Kenya: Rivalry for the Succession, 22 ${ }^{\text {nd }}$ October 1973, BNA: DO 226/13.

${ }^{173}$ Ibid.
} 
pressing. ${ }^{174}$ This is the background against which the Letter to the Wananchi should be seen. According to Antony Duff, Kenya's difficulties increased even more in 1974 but, in his view, the country remained one of the most stable and prosperous countries in Africa in a year that many countries fared much worse. However, the country's problems were pressing in, and far from setting out to confront them, Kenyatta's government allowed itself to drift and, moreover, did nothing to check the frightening speed with which greed and corruption were spreading through its own ranks and through the establishment as a whole. While most Kenyans were proud of what they had achieved since independence and wanted to build steadily on this, the government was yet to give a clearer lead for the future especially with regard to the question of how prosperity could be achieved for the benefit of all. If this state of affairs continued, the more the revolutionary attitude would continue to gain ground. ${ }^{175}$

In London, Duff's assessment was met with cynicism and criticism. For example, a senior diplomat at the East Africa Desk of the FCO, Desmond Wigan, countered that in a year when strikes were banned, the university closed for two long periods and parliament prorogued indefinitely and without explanation on the day it was assembled -and even critically, without passing the Finance Bill- Duff's analysis seemed to be "a strange assertion." ${ }^{\text {"176 }}$ Moreover, there were other worrying events and trends that had taken place in the course of the year including government taking over the control of maize distribution, devaluation of the Kenya shilling and university riots in April and August. The effect was that the public attitude toward the president continued to cool. Kenyatta's speeches were increasingly backward looking and struck even less response from the crowds than they had done in 1973.

It is worth noting that before Kenyatta Day celebrations in October 1973, Vice-president Daniel arap Moi had organized, through a parliamentary motion, for demonstrations of loyalty to

\footnotetext{
${ }^{174}$ According to Hornsby, A History Since Independence, 235-239, 245 although the Kenyan economy was maturing in the 1970s, issues of social justice, the improvement of the standard of living for all and redress of social inequalities remained unaddressed. Inflation also was rising: Kibaki, Kenyatta's finance minister, failed to persuade the Middle East to give Kenyans cheap oil and, therefore, had to raise most prices in the 1974 budget, and the knock-on effects continued into 1975. Basic commodities such as maize, bread and sugar were made subject to price controls in 1971 and these, according to Hornsby, were extended in 1974 to cover 150 commodities. However, this did not stop the rapid rise in inflation, which was driven up by rising import costs. At the same time, school leavers entering the job market had very few opportunities. Whereas 600,000 of them left school between 1969 and 1974, there were only 200,000 new jobs.

175 Antony Duff, “Kenya: Annual Reviews for 1974," $14^{\text {th }}$ January 1975, BNA: FCO 31/1886.

${ }^{176}$ Desmond Wigan to Neilson and M. Ewans, 23 ${ }^{\text {rd }}$ January 1975, BNA: FCO 31/1886.
} 
take place on the material day. This was as a result of growing apathy and lack of interest in such political events from ordinary people: pre-event public rallies were designed to serve the complementary roles of a demonstration of loyalty and act as an insurance against demonstrations of apathy as well as securing a good turnout at the national event presided over by Kenyatta. During the course of the speech at Uhuru Park, Kenyatta dwelled upon recurrent themes such as national unity and stability. In his Swahili speech, he attacked critics citing government achievements like government's announcement for incentives for farmers in the shape of raising wheat prices per bag. Hall, a British diplomat saw this as something which was no doubt also calculated to incentivize himself as a wheat farmer. Soon, in the course of his speech, the president started to repeat himself. At this point some dissident members of parliament at the back of the dais started to stream out. According to Hall, it was misadvised to hope that the same old dialogue formed from, more or less, the same old speech could captivate his audience. By the 1970s, this old repertoire must have been suffering from over exposure. ${ }^{177}$ This was exacerbated by increasing understanding of Kenyatta's failing abilities and awareness of his acquisitiveness and that of his family. Respect and affection was not entirely diminished amongst the populace as a whole, but they were weakening and the process was accelerated by the strong criticism that was being expressed more and more freely in private by educated Kenyans. ${ }^{178}$ By this time people in Kenya were literally wanted something new in the form of a break from difficult hard times: something that was affordable and ease their lives.

Yet, there was no reprieve. General malaise at the top and the self-seeking of the privileged few continued. In British diplomatic circles, it was feared that this state of affairs could lead to the breaking of the storm as the mass of Kenyans, who witnessed rampant corruption at the top, continued to be asked to await the less attractive economic future that appeared to wait for them. As a result, objective observers of the situation in Kenya were struck by a feeling of disquiet. ${ }^{179}$ At the beginning of 1975 , this concern was heightened by a series of unusual violent events. The year had started with JM Kariuki and his friends stepping up their criticism of the government. JM continued to draw public attention to the increasing gap between the rich and the poor and to excessive land acquisition by individuals. He even went further to

\footnotetext{
${ }^{177}$ P. B. Hall to S. Darling of the EAD, Kenyatta Day, $23^{\text {rd }}$ October 1973, BNA: DO 226/13.

${ }^{178}$ Duff, Kenya: Annual Reviews for 1974, $14^{\text {th }}$ January 1975, BNA: FCO 31/1886.

${ }^{179}$ M.K. Ewans of the EAD to Duff, $14^{\text {th }}$ February 1975, BNA: FCO 31/1886.
} 
advocate for reform, efforts which attracted support in many quarters. Although the president responded with counterattack, he was finding it increasingly difficult to control the National Assembly, which was influenced by the dissidents led by Martin Shikuku and Marie Jean Seroney. In February for example, two bombs exploded in Nairobi: one went off at the Starlight Club on $16^{\text {th }}$ and the second one at a tourist bureau near the Hilton Hotel four three days later. As the second bomb went off, JM was making a major policy speech in the national assembly. Around the same time, the president's seven hundred acres of wheat in Rongai went up in flames and some of his cattle were killed. On $1^{\text {st }}$ March, 26 people died in a third bomb explosion at a Nairobi bus station. A few days later, on $6^{\text {th }}$ March, a train derailed on the Mombasa-Nairobi track at Voi an act that was believed to be sabotage. ${ }^{180}$

These events took place against the background of rising discontent and government criticism, a political storm that many feared would break into an active subversion leading to a revolutionary situation before long. ${ }^{181}$ The situation was such that even the British High Commission toyed with the idea of intervening. Some diplomats contemplated possible ways of trying to persuade Kenyatta directly or indirectly that the self-seeking of the privileged few was in danger of creating serious tensions in the country. ${ }^{182}$ There was no organized movement as a result of discontent, but there were military elements, communist sympathizers and disaffected Kikuyu, among them former Mau Mau, who felt that they still had not had their dues. The root cause of these incidents was seen as internal dissatisfaction especially emanating from Kikuyu discontent. It was thus expected that the government would find itself facing growing difficulty not only from the usual critics but also from an increasing section of the population as a whole. $^{183}$

The bomb attacks were accompanied by a widespread antigovernment leaflet campaign, which was soon blamed on a clandestine group, the Maskini Liberation Organization a.k.a, The Wananchi, constituting ex-Mau Mau, university students, unemployed workers and landless

\footnotetext{
${ }^{180}$ Hart to H/C, The Disappearance of J.M. Kariuki, 10 ${ }^{\text {th }}$ March 1975, BNA: DO 226/15. Six train wagons containing petrol had derailed and burst into flames. Also see Hornsby, A History Since Independence, 281. ${ }^{181}$ Recent Incidents, $10^{\text {th }}$ March 1975, BNA: DO 226/15.

${ }^{182}$ P.R.A. Mansfield to M.K. Ewans, $12^{\text {th }}$ March 1975, BNA: DO 226/15. Further, the unstable situation led officials at the American Embassy in Nairobi to consider evacuating non-essential personnel, which caused their British counter-parts to contemplate doing so too. For this see letter from M.P.V. Hannam to H/C, $12^{\text {th }}$ March 1975, BNA: DO 226/15.

${ }^{183}$ Recent Incidents, $10^{\text {th }}$ March 1975.
} 
peasants, and by extension JM, implicitly. Although the Maskini Liberation Organization was not believed to exist or known to have publicized its aims, it was believed to be an attempt at freeing the poor from their poverty. ${ }^{184}$ While JM was hardly directly connected with the said "terrorists," if indeed they existed, it was his constant criticism summed up in his warning that Kenya could end up as a country of ten millionaires and ten million beggars that did. ${ }^{185}$ Some of the leaflets, which were being distributed in bars in Nyeri District, called for the assassination of the president and Mbiu Koinange. ${ }^{186}$ On $2^{\text {nd }}$ March, JM was trailed and picked up by, among others, a senior member of the security apparatus and a few weeks later, his badly mutilated body was found and identified.

JM's assassination served to add fuel to the flames that were raging in 1975. University students from the University of Nairobi and Kenyatta University College went on a rampage to protest JM's murder. Lectures were cancelled as students staged minor demonstrations. By so doing, they gave expression to the mood of defiance in the country at the time of his death. British Imperialist Forces Out!," shouted students of the University of Nairobi. They denounced lies and sang poems to the continuing struggle voicing their determination to take up the fallen sword of JM. They pledged themselves to continue the struggle against inequalities in Kenya. ${ }^{187}$ Expressing solidarity with parliament and condemning JM's murder, the University Guardian, called for the resignation of the government. This document accused Kenyatta, whom they referred as The Monarch, of receiving 70 million Ksh/- as compensation from the British for the time he had served in prison. They saw this as part of the reason why the president had no mercy for former detainees and "our man J.M." The University Guardian saluted, Total solidarity! Power to the people! Down with oppression! ${ }^{188}$

By April, it was clear to some observers that it seemed that the president had lost the will to govern and it was feared that it was only a matter of time before the establishment collapsed.

\footnotetext{
${ }^{184}$ Antony Duff to London, telegram, confidential, Kenya Internal, 13 ${ }^{\text {th }}$ March 1975, BNA: DO 226/15.

${ }^{185}$ London to Nairobi, telegram, Kenya's stability at risk, $1^{\text {st }}$ April 1975, BNA: DO 226/15.

${ }^{186}$ According to a memo from B.T. Holmes to the High Commissioner, Christopher T. Hart, $11^{\text {th }}$ April 1975, BNA: DO 226/15, the antigovernment leaflets and papers were cleverly produced to appear to be the work of students. Holmes suspected them to be the work of a politician; also see Hart to Holmes, $7^{\text {th }}$ April 1975, BNA: D0 226/15.

187 Thiong'o, Writers in Politics, 98; also see Gichuhi Maina Kirubi, “Turmoil in a University: An Analytical Study of the Conflicts, Confrontations and Strikes in the University of Nairobi and Kenyatta University College in the Republic of Kenya, 1960-1978," (PhD dissertation, Ohio University, 1983), 166.

188 University Guardian, $12^{\text {th }} \& 13^{\text {th }}$ March 1975, BNA: DO 226/15.
} 
The consequences of JM's assassination were rising tensions in the country, especially in Nyandarua from where he hailed, Nairobi and Nyeri. The people most affected by his demise were the underprivileged in society from all communities in Kenya who regarded JM, in some sense, as a champion of their rights who was prepared to challenge the establishment openly. Another section that affected was non-Kiambu Kikuyu who were now more aware that Kiambu Kikuyu were determined to prevent any rivals building up a position from which their political dominance could be challenged. ${ }^{189}$

In spite of open displeasure with the government, the Special Branch fed the president false information about the feeling of the "wananchi" both within and outside Nairobi: that all was well and that people were angry with other politicians for causing unrest in the country. The truth of the matter, however, was that the people were angry with the president, which was a potential source of serious trouble. ${ }^{190}$ According to rumors that did rounds in Nairobi, when Moi, on behalf of the government, tried to speak about the feeling of the people and the gap between them and the government, Kenyatta had stopped him at once and told him that no one could tell him about the "wananchi." Kenyatta told his vice-president that the "wananchi" supported his government. At the cabinet meeting where the exchange had taken place, everyone else had sat on their hands in gloomy silence. By some curious process of old age, the president had convinced himself that he was in touch with the public feeling and that all was well. ${ }^{191}$ It was clear to most observers, however, that the remarkable stability that the president had managed to superimpose on Kenya since independence was already breaking up especially over the crisis over the unexplained murder of JM, which was only one facet of the deepening chaos. Instead of addressing the root causes of growing discontent, Kenyatta's able, and mainly Kikuyu, ministers stifled them. ${ }^{192}$

For example, a leaflet written by "Ex-Freedom Fighters" with an angry tone surfaced in Nyeri at the end of March. It urged the people of Nyeri and Kenya to ponder and think more critically about the gangsters in power who had killed JM and wanted to cling onto power at all costs. They said that the people in power had driven the country into the open hands of Britain.

\footnotetext{
${ }^{189}$ Nairobi to London, telegram, $12^{\text {th }}$ March 1975, BNA: DO 226/15.

190 Thiong'o, Writers in Politics, 98.

${ }^{191}$ Duff to HofH, $2^{\text {nd }}$ April 1975, BNA: DO 226/15.

192 London to Nairobi, Kenya's Stability at Risk, $1^{\text {st }}$ April 1975, BNA: DO 226/15.
} 
Further, the writers of the letter said that this group of people would steal money and bank it in Europe where they would run if things ran out of hand leaving the country in trouble. These people talked and sang "harambee," which meant stifling opposition and criticism directed at it. The short history of independence after the British "left" only proved that they were "doublefaced turn coats." 193 They singled Kenyatta out and they called him "a money maniac ...a criminal ...a gambler...a leader to darkness and death." The ex-freedom fighters went on to say that JM had been killed because he was from Nyeri. People from the region were, therefore, insecure as long as "Kamau and Kissinger" remained in power: the letter hailed, out with traitors and renegades of independence! ${ }^{194}$ The freedom fighters had resolved to denounce Kenya's "socalled 'independence"” and start fighting again in the streets and farms attacking all foreign troops stationed in Nyandarua and Mt. Kenya. Secondly, all employed people, farmers and workers in offices were called upon to go on strike. After all, "Kamau" had done nothing for them except selling them. ${ }^{195}$

Just before he met his death, JM was at the center of one of the greatest corruption scandals of the Kenyatta regime. Just days after the politician disappeared, on $5^{\text {th }}$ March, customs officials at the Jomo Kenyatta International Airport confiscated up to 4,000 kilograms of an ivory shipment worth $\$ 140,000$ due to be flown to Hong Kong. Due to the relentless attrition of the Kenyan jumbo, a group of white conservationists commissioned a private investigation, which was done by Ian Parker who was known for his passion for the protection of elephants. Parker launched into the investigation with great relish. Casting his net wide, Parker analyzed East African and Hong Kong custom excise departments in an illegal poaching, ivory export and corruption network that also involved people in Europe. He estimated that the Kenyan government might have suffered a monetary loss during the years 1962 to 1973 of some $£ 12$. In a detailed report, Parker implicated several members of the Kenyatta family, Dr. Mungai, Paul Ngei and the attorney general in the scheme. ${ }^{196}$

\footnotetext{
${ }^{193}$ A widely circulated letter from Nyeri Ex-Freedom Fighters a copy of which ended up at the British High Commission, J.M., Nyeri and Kenya, 30 ${ }^{\text {th }}$ March 1975, BNA: DO 226/15.

194 Ibid.

195 The Kikuyu name "Kamau" used here referred directly to Kenyatta as it was his original name. It could, perhaps, also have referred to refer to his close Kiambu acolytes and his government by extension. "Kissinger" could have referred to Mbiu Koinange and, by extension, international imperialism in general and Britain's in particular. 196 Tinker, “Kenya's Jumbos," New Scientist, 22 nd May 1975. Also see P.R.A. Mansfield to M.K. Ewans, The Ivory Trade, $12^{\text {th }}$ February 1975, BNA: DO 226/17.
} 
This was a damning and authoritative document bearing statistics that left little room for argument for those mentioned in the ivory smuggling and export in Kenya. The circulation of the Ian Parker Report in Kenya was kept very tight and the government and British diplomatic circles hoped that there would be no intentional leaks to the press. ${ }^{197}$ However, foreseeing attempts to kill the story, Parker placed a detailed copy of the report in the safe of a prominent Kenyan businessman, probably Tony Dyer. ${ }^{198}$ Parker also tipped the Los Angeles Times, which, aware that their circulation in Kenya was limited, shared the story with The Observer of London. ${ }^{199}$ There were only two copies of the report in Kenya: apart from the Dyer copy, one had been given by Parker to the head of the Special Branch, James Kanyotu to deliver to the president. ${ }^{200}$ However, the existence of the report was fairy widely known in influential circles in the country. For example, JM and Bruce McKenzie both knew about it. Officials at the British High Commission also had reason to believe that the US Embassy had, in fact, leaked information about the existence of the report. ${ }^{201}$ The report that showed the way corruption started at the top and what Tinker called, the Kenyatta Royal Family, contributed to the uneasy state in Kenya at the beginning of 1975.

In August 1975, The Sunday Times ran a critical trilogy of articles entitled, "Kenya on the Brink," that were a vicious attack on perceived corruption of Kenyatta and the so-called, "Royal Family," almost opening a diplomatic row between Kenya and Britain. The articles simply spelled out what many people in Kenya had been saying for some time though with additional detail. The first article of the trilogy implicated Koinange in an illegal land transfer. It alleged that Agricultural Finance Corporation loan aid funds were being used by prominent people to obtain mortgages with which to buy British mixed farms. ${ }^{202}$ In addition, the articles revisited the subject of the involvement of Margaret and Ngina Kenyatta in the illegal export of ivory. When the out-going British Commissioner, Antony Duff, went to Mombasa for his farewell interview

\footnotetext{
${ }^{197}$ M.K. Ewans to Mansfield, $21^{\text {st }}$ February 1975, BNA: DO 226/17.

198 Tinker, "Kenya's Jumbos;" and Mansfield to Ewans, $5^{\text {th }}$ March 1975, BNA: DO 226/17. Also see Hornsby, A History Since Independence, 312-316.

199 P.R.A. Mansfield to M.K. Ewans, The Ivory Trade, $12^{\text {th }}$ February 1975, BNA: DO 226/17.

200 This copy according to Mansfield's letter to Ewans, $5^{\text {th }}$ March 1975, had all reference to Kenyatta deleted the pages having been taken out and replaced by other retyped versions. It was forwarded to Kenyatta in the hope that the president would grant the conservationists who had commissioned the report an interview. This never happened although Kenyatta got the report.

${ }^{201}$ Mansfield to Ewans, $5^{\text {th }}$ March 1975, BNA: DO 226/17.

${ }^{202}$ The Sunday Times, $10^{\text {th }}$ August 1975.
} 
with Kenyatta, he found James Kanyotu with the president who had in front of him two of the Sunday Times articles. Kenyatta dismissed the articles as nonsense, rubbish and "stupidities of the press." ${ }^{203}$ Although the government tried to confiscate copies of the offending newspaper, the British High Commission received numerous requests for the article even as a brisk trade in illicit copies sprung up. As a result, the articles became a major talking point in Kenya that month. ${ }^{204}$

There were many rebuttals made on behalf of the president by senior members of the Kenyan diplomatic corps. The Minister of foreign affairs for example, lashed out at those who had written the "exaggerated articles." 205 An even more telling and fascinating one came from the minister's deputy, Mwamzandi, who said it was quite wrong that vicious attacks should be made on Kenya and the head of state by foreigners. Mwamzandi had then reminded Mansfield about the large amounts of land that was still in the hands of Europeans in Kenya. ${ }^{206}$ In a another humoring rebuttal, an aide memoire prepared by the ministry argued that The Sunday Times had chosen to exclude from the public eye that members of Kenyatta's family tree were people of humble beginnings who had had to "struggle hard, together with the rest of the population in very difficult circumstances to emerge from the servitude of the past to lead a more dignified life."207

Further, it added that Kenyatta's extended family had not had the privilege to inherit accumulated wealth and titles or to enjoy exclusive education or automatic succession to the seat of power, which was a thinly veiled slight of the British monarchy. The memoire concluded by pointing out that the Kenyatta family was made up of ordinary people leading ordinary lives and earning their living through hard work. As such, they were not an exceptional lot and certainly not a Royal Family. ${ }^{208}$ Another senior officer from the ministry, L.O. Kibinge, told Mansfield that it was preposterous that the Sunday Times articles had said nothing about Lord Delamere's vast acres or the unfair balance of trade between Kenya and the UK. In the letter detailing the

\footnotetext{
${ }^{203}$ Sir Antony Duff memo to the Deputy High Commissioner, 26 ${ }^{\text {th }}$ August 1975, BNA DO 226/17.

${ }^{204}$ Mansfield to Ewans, $27^{\text {th }}$ August 1975, BNA: DO 226/17.

${ }^{205}$ C.D. Crabbie, Dr. Waiyaki and the Sunday Times, $4^{\text {th }}$ September 1975, BNA: DO 226/17.

${ }^{206}$ Letter from Mansfield to the Assistant High Commissioner, $8^{\text {th }}$ September 1975, BNA: DO 226/17.

207 Aide-mémoire from the Ministry of Foreign Affairs to the British High Commission and forwarded to the SofS, $13^{\text {th }}$ September 1975, BNA: DO 226/17.

208 The Aide-mémoire was a response to the "Royal Family" image painted by The Sunday Times articles.
} 
conversation in which this matter had come up, the Assistant High Commissioner scribbled that in terms of greed, the Kenyatta family was more uncontrollable Delamere to any reach. ${ }^{209}$ This meant that unlike, the embodiment of white settler acquisitiveness, the greed of the Kenyatta family was far much worse and unbridled.

The Sunday Times trilogy, however, was neither the first time, since JM's death, that the government and Kenyatta came under considerable attack over corruption charges nor was it the last of the year. Indeed, it would seem that the elimination of JM had served to attract scrutiny from both within and from the foreign press corp. For instance, Hart referred to new angles on corruption that had been uncovered by three members of parliament who furnished him with the details. ${ }^{210}$ A good example cited was the fact that corruption in agriculture was having grave effects. Maize was rotting in storage in the western part of the country when people were starving in Eastern Province. This was because the maize could not be moved in bulk without a permit and permits could only be obtained corruptly. At the same time, maize prizes to the producers were too low and farmers were going over to cash crops like coffee and pyrethrum which were more profitable. ${ }^{211}$

At the same time, there was, in the same ministry, a big grading racket. It was caused by the president's insistence on getting a good price for his wheat. One of his ministers, Angaine, was also said not to be willing to accept the true wheat grade. Angaine had sold some wheat from his farms near Timau, which was graded III but he had demanded that it be graded as I. While the Minister for Agriculture, Jeremiah Nyagah, had supported his grading officers in their decisions, this was overruled by Angaine's invocation of the president's authority. This kind of over-grading for big people meant that ordinary farmers received lower than justified grades to compensate. This was certainly the case with regard to small scale pig farmers. The bacon and pork factory at Uplands was in trouble over the same reason of over-grading. Big people got grade I for their pigs while ordinary farmers got much lower grades. This caused many farmers, particularly in Nyeri district, to get out of pig farming causing the factory to suffer from

\footnotetext{
${ }^{209}$ Mansfield to the AHC, Sunday Times articles, $2^{\text {nd }}$ September 1975, BNA: DO 226/17.

${ }^{210}$ Hart to Wallis, $17^{\text {th }}$ July 1975: DO 226/17. The three Members of Parliament were Dr. James Muriuki, Wafula Wabuge and Charles Rubia.

${ }^{211}$ Ibid.
} 
shortness of supply. The Kenya Meat Commission suffered for the same reason because there was a lot of slaughtering of pigs and cattle outside proper channels as a result of corruption. ${ }^{212}$

To make matters even worse, there was a food racket at Kenyatta College that involved Mama Ngina. Milk and vegetables had to be bought from her and sometimes the milk was already skimmed. Indeed, more vegetables than were required were sent, and those members of the college who dared complain were swiftly sacked. Such was the fate of Charles Rubia who, although an assistant minister, was removed from the college board when he protested. Also noted was Kenyatta's habit of not paying bills, which affected among others, the East African Power and Lighting and Benbros. Kenyatta did not pay for a large order from Benbros though he had made a vague promise to discuss the debt with them. As a result, the Treasury had been forced to compensate such firms out of public firms. There was also the well-known fact the president used three hundred prison workers on his farms free of charge. ${ }^{213}$

In addition, casinos owned by Kenyatta or members of the family were also a problem. One of the president's sons, Peter Kenyatta, was a partner in an International Casino and his father in the Casino de Paradise. Both were, allegedly, run by rival mafias: the son's by the Italian mafia and Kenyatta's, by an American-Korean gangster. Hart concluded by saying that he was of the impression that there were many previously profitable ventures that were being spoilt by the greed of the Kenyattas and their associates, a situation that, in the main, could be politically unsetting. ${ }^{214}$

High level government corruption was rife. John Keen who had been an assistant minister for works in Kenyatta's government, told a Reuters correspondent that he knew enough about corruption to write a fourth article for the Sunday Times. In his former position, Keen had been well placed to know what was going on in government circles. Keen said that the ministry of works had a debt owing of 8 million shillings for work done on Kenyatta's farms. This had been on the books for three years but had been moved around to conceal it from public discovery. Keen also added that 1.7 million Ksh/- of Treasury money had been spent by Kenyatta on his Casino de Paradise. Further, Kenyatta had given three choice plots near the Stag Hotel to

\footnotetext{
212 Ibid.

213 According to this Hart letter, the Commissioner of Prisons was also himself guilty of the same practice, Ibid. 214 Ibid.
} 
Mathenge, the Mayor and the town engineer. When the president had demanded them back after trying to undo the agreement under which they had been transferred, Mathenge refused at which point Kenyatta struck him with his walking staff in a fit of rage. Mathenge and others agreed to transfer their plots and were given poorer ones in a back street for compensation. A bank building started being built on the original plots soon after. ${ }^{215}$

The fact that the president, his family and their supporters were amassing some of the best property and agricultural land was a matter of private and some public comment. The president even went as far as putting pressure on foreign owned companies to employ his relations in top jobs at inflated salaries. ${ }^{216}$ Udi Gecaga, the president's close relation, was in a stockbroking company in the city and also on the board of Lonrho, the latter position of which he had secured through the application of Kenyatta's influence. The owner of the stockbroking company, Joseph Sebag, raised questions about Gecega's external yen account since such accounts were apparently rare, if not normally non-existent. ${ }^{217}$ Njoroge Mungai, another close relative and a government minister, was said to have started private profit making clinics with funds given in the USA to establish free clinic upon his return to Kenya from his studies abroad. $^{218}$

This state of affairs, when juxtaposed with Kenya's disturbing economic trends and social problems characterized by a population that was rising by an estimated rate of between $3.5 \%$ and $4.1 \%$ annually, created severe pressure in land, water, housing, education and employment; an economic growth that that was being devoted to urban rather than rural areas; and, as a result, with a mass population that still lived in villages with a low standard of living; all problems of which were rendered both more serious and more urgent as a result of the increase of oil prices and inflation in the developed world, makes for a grim contrast. ${ }^{219}$ On the one hand were rural peasants and a wage earning sector that was pressing for higher wages to

\footnotetext{
${ }^{215}$ Undated letter and unclear from and to whom, “Corruption -views of John Keen,” BNA: DO 226/17. The politician had been fired together with others including Kibisu and Muliro, the minister for public works, for voting against the government on the Kariuki Report.

216 "Personality notes," around May 1974, prepared probably by EAD as a brief for Ms. Joan Lestor, the Under Secretary for Foreign Affairs, ahead of her visit to East Africa, BNA: FCO 31/1637.

${ }^{217}$ D.J. White to Ms. S. Darling, $11^{\text {th }}$ December 1973, Activities of Lonrho in Kenya, BNA: FCO 31/1510. 218 "Personality notes."

${ }^{219}$ Ms. Lestor's Visit to Kenya, May 1974; see also FCO collection of files, Kenya: Form-at-a glance, BNA: FCO $31 / 2559$.
} 
meet increasing prices and, on the other, a group of privileged few politicians, cabinet ministers and civil servants who were far removed from the everyday realities and hardships of the people whose welfare was their responsibility to oversee. The enjoyment of the fruits independence, symbolized by the famous photograph of the Kenyatta, Tom Mboya and Kibaki victory-dance in the streets, was experienced by only a few in Kenya. This is well-captured by the words of Bertolt Brecht's poem, A Worker Reads History: at whose expense was Kenya's political and economic elite's victory dance? Kenya's local and national politics can be explained in terms of the arising tensions that were the result of continued socioeconomic inequalities, which were in turn the manifestation of distorted power structure and relations that reached back to the colonial era.

\section{Conclusion: Mau Mau Bread and Circus Affair as a National Political Staple}

The JM assassination in the mid-1970s was a poignant and significant moment in Kenya's history. An understanding the circumstance in which he was assassinated is fundamental to comprehending distributive politics in both the colonial and postcolonial era. JM, both with regard to local and national politics, was caught up in this crucible of tensions between the haves and have-nots that had dominated in colonial and postcolonial politics in Kenya and preoccupied the minds of many. Indeed, regardless of who was behind his elimination, his demise can and should be seen as a sacrifice at the altar of a new and popular Kenyan state for which many others since the dawn of British colonialism had dedicated their lives to. An understanding of the circumstances surrounding his demise, therefore, presents a unique insight into the nature of politics in the country. ${ }^{220}$ Besides the more popular explanation that JM was killed by the "Kikuyu tough crowd" from Kiambu, it was his brand of politics, a scion from the Mau Mau main stem, that so irritated the base of power which cost him his life. This can better be appreciated by looking at his personal past, regional politics in Nyeri and how this dovetailed with the national struggle that faced the majority of Kenyans.

As noted, JM was one of a very few former Mau Mau who rose to the heights of power after independence. He was a particularly notable one considering his level of education, keen powers of observation and eloquence. This history and stature did not endear him to some in

\footnotetext{
${ }^{220}$ It also prefigures that of Dr. Robert Ouko, President Moi's Minister of Foreign Affairs in the early 1990s in relatively similar circumstances. This assassination is discussed in the next chapter.
} 
Nyeri where JM had a huge following. His political adversary and contender for the parliamentary seat there, Peter Nderi, was the son of colonial chief Nderi who had been executed at the height of the Mau Mau war. One of his brothers, Ignatius Nderi, had been rising fast in the police force since in 1968 when he was only an assistant superintendent. In fact, Nderi rose through the ranks to become the Director of the Criminal Investigation Department. There was, therefore, naturally, like in many locales around the country, bad blood between the Nderi brothers and ex-Mau Maus like JM. Ignatius Nderi had a reputation, according to Nyeri locals, of having been unhinged by his father's death and of being very violent. ${ }^{221}$

Nyeri politics, which pitted former loyalists like the Nderis and supporters of Mau Mau reflected the old primary hallmark of Kikuyu politics since the awakening of the community's political consciousness especially in the third decade of the $20^{\text {th }}$ century. This central distinction and conflict that, was at once both dynastic and generational, was aptly captured by Clough's book Fighting Two Sides. ${ }^{222}$ It is this characteristic of Kikuyu politics that marked the dividing lines between loyalists and Mau Mau supporters and the attitude of which was carried down to the murder of JM in 1975 in which it was believed Ignatius Nderi played a leading role. ${ }^{223}$ It is this ghost of JM's, and therefore Mau Mau, brand of politics that continued to dominate and haunt Nyeri politics a few years after his death. It also cast a long shadow on Kenya's postcolonial political history. Local politics in Nyeri, in this sense, was a microcosm of national politics as it represented the same division between the haves and the have-nots that caused dissension in that region in 1952. This same divide was replicated and accentuated in national politics posing a risk to national stability. ${ }^{224}$

It is, therefore, not only possible but also appropriate and important to cast these divisions that existed within Nyeri society, historically, upon a wider national political purview. It represented other Kikuyu regions like Murang'a and Kiambu, which, indeed, had more than "a dynastic Montague versus Capulet" element. ${ }^{225}$ This societal tension and conflict was undulating and was the experience of millions of Kenyans caught up in local and national electoral battles.

\footnotetext{
${ }^{221}$ Hart to H/C, "Murder of J.M. Kariuki," $17^{\text {th }}$ March 1975, BNA: DO 226/15.

${ }^{222}$ Marshall S. Clough, Fighting Two Sides: Kenyan Chiefs and Politicians, 1918-1940 (Niwot: University Press of Colorado, 1990).

${ }^{223}$ Hart to Longrigg, Kenya, Mr. Moi's Presidency and Its Political Themes, $15^{\text {th }}$ March 1979, BNA: FCO 31/2557.

${ }^{224}$ Ibid.

${ }^{225}$ Ibid.
} 
Local politics dovetailed with national politics during electoral cycles that played on historical feelings and played up divisions that ran equally deep. As such, it is quite impossible not to see the wider divisions that spanned entire regions, provinces and the country at large. It is these divisions that JM and his Nyeri followers, such as Waruru Kanja and Joseph Mungai, tapped into. Indeed, these were same sentiments that had been previously exploited with marked success by Oginga Odinga and Bildad Kaggia who had taken the side of the majority against the more privileged minority. Thus, on the one hand, Kenyan politics could be seen as a dynastic, factional and even generational game. ${ }^{226}$

This view of Kenyan politics takes cognizance of the vast crowd of virtual spectators who threatened, time and again, and especially in the early and mid-1970s, to leap over the barriers and invade the pitch as they were encouraged and invited to do frequently by their wilder spirits among the players. Such people not only included radical politicians but also writers such as Ngugi wa Thiong'o. Such folk were perceived as inciting the crowd in this manner. Ngugi was feared to do so through his books and plays, which explains why he was detained, in January 1978, by Kenyatta. His novel, Petals of Blood, which had just been published, was thought to be able to inspire a future revolution. According to some, it described Kenya's history in Marxist terms and ended with a revolution against the established system. The government was "fortunate" that the novel's Kikuyu setting could very well mitigate its effect on other tribes. ${ }^{227}$ The irony of the said government "fortune" cannot be missed when one considers the fact that Kenya's national politics was, and still is, Kikuyu or local politics writ large.

The political awareness of the crowd, and the inherent explosive potential of mentalité, was appreciated by Kenyatta's attorney general who, speaking at the Royal Commonwealth Society, made it plain that people like Ngugi wa Thiong'o belonged in jail. According to Hart, Charles Njonjo may have as well added that such "dangerous agitators" would be killed as was Kariuki because their detention was regarded politically impossible. But the main point is that Njonjo was under no illusions about the dangers of the crowd joining in. ${ }^{228}$ Anyone who knew Kenya then, or purports to do so now, would do well to acknowledge and grasp the same fact. It

\footnotetext{
${ }^{226}$ Ibid.

${ }^{227}$ Report of the African Section, Research Department, The Extent of Soviet Influence in Kenya, July 1978, BNA: FCO 31/2330.

${ }^{228}$ Hart to H/C, Murder of J.M. Kariuki, $17^{\text {th }}$ March 1975, BNA: DO/226/15.
} 
is not important to establish whether or not the Maskini Liberation Organization was a real movement of the discontented.

By the same token, it matters little if this was the government's bogeyman to instill fear among the people. The bottom-line, and the political lesson that it underlined, as Njonjo's announcement made clear, was that there was palpable crowd-phobia among the ruling elite. Overall, it suffices to observe that this fear, that reigned supreme since the early 1950s, confirmed that the central fact of Kenyan politics was, and still is, the struggle for everyday bread and butter among ordinary people. Ironically, this fact of Kenyan politics is what then enables the leadership to win and retain the support of the potential mob. By so doing, the vision of the poor crowd, the Mau Mau minds of 1952, on the destiny of Kenya, was, and continues to be, effectively checkmated. Otherwise, there existed, and still exists, in Kenya, a potentially explosive situation.

This, then, has been the victory dance of the elite few: the triumph of the ideology of "law and order" over the exasperated popular vision of Kenyan statehood that ordinary people aspire to from below. With this triumph, the less-than-satisfactory power relations and experiential drudgery of yesteryears became a fossilized element and fixture of politics in Kenya. So was popular dissent that traced its roots to the 1950s and beyond: the spirit of Mau Mau lived, and continues to live, underground in Kenya's political soil.

Even Sir Evelyn Baring, in 1969 admitted in an interview that the Mau Mau war was motivated by psychological grievances. In effect, that the movement and what it represented was very thrusting. The people behind it were ambitious. They were up against Nairobi with all its wealth and luxury. These, by their views, fruits of modernity and independence from which they felt cut out. Baring pointed to the glaring fact that as long as there was a visible permanent European population in Kenya, people never believed they could ever get independence. ${ }^{229}$ This attitude among Kenyans, in view of the foregoing, did not change much even after independence. Whereas Baring had overseen a comprehensive and expensive agricultural reform of land consolidation that also included the introduction of cash-crop farming, irrigation farming and European-type cattle for Africans for the first time, changes that were complimented by political

${ }^{229}$ Lord Howicke (Sir Evelyn Baring),interview with Dame Margery Perham, $19^{\text {th }}$ November 1969, RHO: MSS. Afr. s. 1574. 
rights and privileges and upon which the independence government whose centerpiece was the Million Acre Scheme, built a vast swath of the people in Kenya remained landless, unemployed, and poor.

Thus, while Baring among many other people in Kenya and Britain expected Kenya at the end of the Mau Mau trouble to be a very different place from what it was before they ever started, the country more or less, even after independence, was not different enough for and to all. Even independence and an African-led government had not brought the kind of striking changes that most ordinary people had hoped for. As such, the Mau Mau struggle was still on: it was not yet "uhuru." Not with Kenyatta and, after the first president died in 1978. Not even under Kenya’s second President Daniel Toroitich arap Moi, going forward. 


\section{Chapter VI - Matigari ma Njirungi: Bifurcation, Atomization and Survival of the Mentalité of Struggle}

Preamble: From Mau Mau to Mungiki -

The Mungiki movement and sect has its origins in the early 1980s. It emerged to protect the interests of farmers in Central and the Rift Valley Provinces. It was also an expression of discontent with the manner in which the parents of the sect's young members were treated by Jomo Kenyatta even after they had made enormous sacrifices in the struggle for uhuru. It is for this reason that the movement referred themselves as Matigari ma Njirungi. That is, the heirremnants of Kenya's freedom fighters.

Peter Mwai (translated and paraphrased), "Maelezo Kuhusu Asili ya Mungiki,"Taifa Leo, $6^{\text {th }}$ March, 2009..$^{*}$

$1 *$ This Swahili title loosely translates thus: "Origins of the Mungiki Sect." 


\section{Introduction}

This chapter concerns itself with a discussion of discontent and dissent in the Moi years between 1978 and 2002 against the background of worsening economic difficulties; the disastrous drought of 1984; and increasing political problems. It argues that the locus of grassroots resistance against the Kenyan state shifted from the out-spoken criticism of the government to discrete expression of opposition by elite embodied by public intellectuals at universities, church leadership and a young crop of politicians and professionals in Nairobi especially after the attempted coup of 1982 by the Kenya Air Force. It points out that after this abortive coup, President Daniel arap Moi sought to mute all forms of dissent with relative success. This discussion asserts that despite constant and deliberate attempts to atomize all opposition, the mentalité of struggle prevailed. This "matigari" (remnant) of the Mau Mau spirit of struggle inaugurated by various anti-colonial, contra-state control and anti-status quo movements before and after independence, was carried on and dominated by underground movements such as Umoja and Mwakenya and equally, quite literally, found expression in song between the mid and late 1980s. Church leaders played a particularly significant role especially towards the end of the 1980s and thereafter, which needs close attention. This persistence of public criticism of, and struggle against, the state paved the way to the heated and open clamor for multipartism and call for democratic reforms in the early 1990s.

This struggle, covering the Moi years, is the core subject of this chapter that is organized in three overarching sections. The first broad section discusses and lays out the political and economic situation when Moi ascended into power in 1978, his brand of politics and political philosophy. The second analyzes political dissent between 1980 and 1992. The last focuses on "matigari ma njirungi" or isolated and muffled voices following the near-successful muzzling and bifurcation of progressive forces in Kenyan politics from the mid-1990s to $30^{\text {th }}$ December 2002, when Moi left office. Besides underground dissent and the role of pulpit in the 1980s, a discussion of the symbolic silent protest of coffee farmers who cut their trees during in the 1990s, is attempted. Put differently, this chapter introduces a period of Kenyan political history characterized by either organic bifurcation or forced atomization of dissent in the country during the Moi era, which is discussed further in the next chapter. 
As noted above, to fully appreciate how or why dissent was forced underground in the 1980s or the emergence of bifurcated political and workers' opposition of the post-1990s, there is need to preface the above discussion with the following: one, the state of the national economy during Kenyatta's twilight years and Moi's early days; his populism encapsulated by his political slogan Fuata Nyayo and political philosophy of Love, Peace and Unity; the impact of the drought of 1984 on the country's collective psyche; and the intellectual debate around the topic of what was happening to the Kenyan peasantry that was led by radical intellectuals such as Mukaru Ng'ang'a, Apollo Njonjo and Anyang Nyong'o in the early 1980s.

\section{Moi -early days: the political and economic situation}

When Daniel Arap Moi ascended to the helm of power, most people in Kenya greeted his presidency with a kind of spontaneous enthusiasm that contrasted sharply with the regimented respect that used to greet Kenyatta. Partly, this public acclaim is explained by the general welcome of the change of guard but, more so, as a protest, to some extent, against the Kenyatta legacy of the betrayal of post-independence rather than, necessarily, a positive expression of love and approval for the new president. ${ }^{2}$

For some, Moi seemed to exude a less forbidding charisma than Kenyatta. For other observers yet, he had none at all. But he cut the image of a brother to Kenyans where Kenyatta was a father and, towards the end, that of an apparently benevolent grandfather. While Kenyatta's Swahili and Kikuyu speeches were sometimes almost gibberish, he had delivered them with a spellbinding cadence and style especially when his blood was up. On the other hand, Moi's speeches were said to be as attractive as the barking of a large woolly dog, honest, and gruff but not in any way charismatic. Moi, therefore, lacked the aura that surrounded Kenyatta as freedom-fighter and founding father. He also had nothing of his predecessor's education or sophistication. ${ }^{3}$ His manner and bearing was described as dignified and Moi, certainly, looked presidential even if he did not sound the part of president. ${ }^{4}$

\footnotetext{
${ }^{2}$ Committee for the Release of Political Prisoners in Kenya (CRPPK), Repression Intensifies in Kenya Since the August 1st Coup Attempt (London: Rye Express, 1983) 18-19; also see Norman Miller and Rodger Yeager, Kenya: The Quest for Prosperity (Westview Press: Boulder, 1994), 98, who observe that the first five years of the Moi presidency encompassed a period of relative goodwill.

${ }^{3}$ Galia Sabar, Church State and Society in Kenya: From Mediation to Opposition, 1963-1993 (London: Frank Cass \& Co. Ltd., 2002), 177.

${ }^{4}$ Christopher T. Hart to Anthony J. Longrigg, $15^{\text {th }}$ March 1979, BNA: FCO 31/2557.
} 
A populist from the first instance, Moi liked how Kenyans responded to his new leadership during the early days of his presidency when he dashed around the country with restless energy. ${ }^{5}$ In his speeches, Moi demonstrated that he understood that Kenyan politics had increasingly become a bread and circus affair. He, therefore, made populist pronouncements in his bid to strive to retain the support of the potential mob. ${ }^{6}$ Thus, it was clear to the new president that it was most crucial for him to be seen to be standing with the public and their political leaders. ${ }^{7}$ Instincts of self-preservation also caused the various ethnic political elite in general, and specifically the Kikuyu, to extend him support because they foresaw what could happen if his presidency failed. The political class understood that such failure would ensure that the vision of the poor have-nots, the 1950s mob, would at last triumph. ${ }^{8}$

Nevertheless, this honeymoon period was declared over by the Weekly Review not so long thereafter. An article published by the authoritative news magazine noted that the economic difficulties that were facing the country were beginning to hurt Kenyans as early as the beginning of 1979. Luckily for the new president, his political popularity had not yet diminished downwards. After all, most Kenyans, particularly the poorer ones, still regarded the president with marked affection. This favorable public perception that Moi enjoyed was based on the conviction among ordinary Kenyans that he was doing his best in difficult circumstances, and therefore, deserved the benefit of doubt. According to some observers, this trust was based as much on a superfice as on substance but was, nonetheless, important. ${ }^{9}$ The general political attitude in Kenya was optimistic in the initial months of his rule. Kenyans showed little interest in a political debate built on issues. Rather, they wanted leaders in parliament, or better still in the cabinet, who would see that their ethnic regions got their full share of the national cake, particularly the development of water, roads, electricity and social projects that could transform their everyday lives. ${ }^{10}$

\footnotetext{
5 This kind of internal travel by the new president caused concern since if, "in addition to dashing all over Kenya," Moi took "to dashing all over the world," it would have been possible that he would not have found time to consider government problems at home seriously. Ibid.

${ }^{6}$ Ibid.

${ }^{7}$ C.D. Crabbie to the EAD, $22^{\text {nd }}$ February 1979, BNA: FCO 31/2557.

${ }^{8}$ Hart to Longrigg, $15^{\text {th }}$ March 1979 BNA:, FCO 31/2557.

${ }^{9}$ Crabbie to the EAD, $22{ }^{\text {nd }}$ February 1979, BNA: FCO 31/2557.

${ }^{10}$ Stanley Fingland to Lord Carrington of the FCO, nd., BNA: FCO 31/2557.
} 
This sort of expectation, mixed with Moi's brand of populist politics, worked wonders as people clung to the promise of hope for better times ahead. One of the people initially impressed by this populism in as far as it targeted corruption was Koigi Wamwere, a dissident thorn on the side of the previous Kenyatta regime, who president Moi had just released from detention. Wamwere is reported to have said, "It is now our hope that all the powerful and the rich individuals who have been elevated above the law will now be subjected to justice."11 This praise came to Moi even before he had shown any indication to move against some of those who had been closest to Kenyatta personally. As such, Kenyatta's family eventually escaped prosecution for their former malpractices. ${ }^{12}$

But as heady as these early days, weeks and months were, the strong political medicine that was Moi's brand of politics begun to wear off as tough economic times soon hit Kenya hard. The country was still faced by more basic challenges of sustaining real economic growth in the face of a population explosion; corruption was still a problem with the Harambee system encouraging practices that had dangers; and the level of consumer prices in Nairobi went up by $8.4 \%$ in 1979 , which was, however, a lower rate than in the previous year when they had been $12.3 \%$. These rises were sharpest for those of the upper income groups, with the price of fuel, electricity and transport services increasing by more than the average. In rural areas where most Kenyans still lived, prices rose more rapidly, perhaps indicating a less efficient trading system there. Indeed, between 1978 and 1979 there was a deepening economic recession that was accompanied by increasing illicit economic activity that became commonplace and official corruption proliferated. ${ }^{13}$

Worse still, 1980 opened inauspiciously for Kenya's new government with a combination of shortages of basic cereal foods that went unalleviated in most urban areas and repeated power

\footnotetext{
${ }^{11}$ Crabbie to the EAD, $22^{\text {nd }}$ February 1979, FCO 31/2557.

${ }^{12}$ At first, Moi kept more or less the cabinet inherited from Kenyatta including some politicians formerly strongly opposed to him and who still were potentially disloyal to him. Ibid. Eventually, however, he used the 1979 elections to rid himself of less committed cabinet colleagues and ensure lack of access of Kenyatta era remnants. He would also use his own private influence against them to wither their political power.

${ }^{13}$ Miller and Yeager, Quest for Prosperity, 100. According to Hornsby, A History Since Independence, 356, Moi had inherited a slow-motion economic crisis not of his own making, but which his initial expansionary and inclusive policies had worsened. The coffee boom of the 1970s was over and the early 1980s saw food shortages; price rises; foreign exchange crises no less due to the Iranian revolution that caused petrol shortages in 1979 and spot prices hit US $\$ 40$ per barrel; budget falls; and mounting debts. The ultimate result was that growth slowed and interest rates rose and capital formation declined.
} 
cuts principally affecting the manufacturing and industrial sectors as well as tourism to some extent, all of which were sufficiently damaging in and of themselves. ${ }^{14}$ During the first half of the 1980s, coffee and tea prices on the world market were falling, manufacturing and tourism, no less due to the energy crisis, had slowed, and there was a maize shortage to boot. Moreover, during 1980 the country registered an economic growth rate of less than 4 percent. The official index of consumer prices rose, over the first three months of 1980, at an annual rate of $23 \%$, $11 \%$, and $16 \%$ for the Nairobi lower, middle and upper income groups, respectively, with the sharpest increases again being for fuel, electricity and transportation. Official estimates quoted the rate of inflation of $15 \%$ for $1980 .{ }^{15}$

For its part, the government continued to rely on price controls for a wide range of consumer items considered necessities and there was continued debate about both the effectiveness of these controls that, in some places led to a black market, and the way they were administered, leading to some undesired market distortions. In particular, demand for milk and milk products outstripped supply. Generally, the question of food became common with the short-fall in harvest being shored up by emergency imports of grains and milk at a cost of $£ 35$ million that year alone. Indeed, the producer and retail prices of milk were increased by $42 \%$ and $23 \%$, respectively in an attempt to alleviate the milk shortages. The economic picture would grow even worse as retail prices rose dramatically affecting in addition to milk, fuel, sugar, rice and meat. The cumulative effect of a worsening energy crisis, scarcity of foreign currency, rising interest and food prices, inflation rates, mismanagement and blatant self-ingratiating graft was a faltering ability of ordinary Kenyans to feed themselves. ${ }^{16}$

Further providing evidence that the country was going through a bad patch, the food shortage became even more severe during 1980. Maize, the country's staple food, was in short supply with reports of some deaths from starvation in remote areas. It was clear to analysts and observers that a large quantity of maize in the region of 300,000 tons had to be imported before

\footnotetext{
${ }^{14}$ John H. Massingham to J.G. Wallace, EAD, 27 $7^{\text {th }}$ May 1980, “Kenya: Economic prospects,” BNA: FCO $31 / 2838$.

${ }^{15}$ Miller and Yeager, Quest for Prosperity, 100.

${ }^{16}$ Stanley Fingland, British High Commissioner's valedictory dispatch, $17^{\text {th }}$ July 1979, BNA: FC0 31/2557; also see Report of the Nairobi Group of Commercial Counselors of the Member States and Commission of the European Communities under the chairmanship of the embassy of Belgium, "The Kenya Economy," that covered the period between July 1979 and June 1980, BNA: FCO 31/2838. Also see Hornsby, A History Since Independence, 346, $356,359 \& 364$.
} 
the next maize crop was harvested in August and September of that year. ${ }^{17}$ The government was not even certain whether the purchase of such a large supply of maize was possible but what was certain was that there was going to be serious transportation and distribution problems. The government responded to this crisis by explaining that the shortage had been caused by the failure of the rains. In some circles, it was believed to have been actually man-made: that it arose from errors in pricing policy following a previous maize glut, which gave few incentives to farmers to plant. One of the effects of this food shortage was that the country experienced a series of strikes and threatened strikes by doctors, students, bank employees, and even professional musicians. ${ }^{18}$ For instance, there was student discontent with the catering arrangements at the University of Nairobi, which was closed in March 1980 following riots in the streets. ${ }^{19}$ Further, there were revelations about thefts of grain reserves and evidence of serious mismanagement in the provision of agricultural credit, storage and transport. ${ }^{20}$ In some circles, it was even alleged that the cause of the shortage of maize was as a result of highly placed officials and ministers close to Moi illegally exporting maize supplies for personal gain. ${ }^{21}$

Moreover, the rationing of electricity supplies that started at the beginning of the month of April was publicly attributed by the government to low water levels in the dams but it was also thought to be partly due to inadequate maintenance of equipment together with silting up of water dams caused by the failure to enforce soil erosion measures resulting in damage to water turbines. The ultimate effect of the electricity cuts was a serious fall-off in production: according to an estimate, this fall-off was as high as $30 \%$ and, in turn, it was expected to lead to further shortages of local manufactures and the need for more imports at the end of 1980. This electricity shortage was more serious on the coast where the tourism industry was concerned at the large number of cancellations that had been received. ${ }^{22}$

\footnotetext{
${ }^{17}$ Official Visits from UK to Kenya Files, BNA: FCO 31/2832, 1980-82; also Miller and Yeager, Quest for Prosperity, 98 \& 100.

${ }^{18}$ Miller and Yeager, Quest for Prosperity, 100. Rather than being reactionary populism, these protests prove that it was not just the poor who were experiencing harsh economic times but relatively privileged sections of society that were now slowly being imbued and manifesting the mentalité of struggle.

${ }^{19}$ Official Visits from UK to Kenya Files, BNA: FCO 31/2832.

${ }^{20}$ Miller and Yeager, Quest for Prosperity, 100.

${ }^{21}$ CRPPK, Repression Intensifies 4-5.

${ }^{22}$ High Commissioner J.R. Williams to J.A. Robson, EAD, $15^{\text {th }}$ April 1980, BNA: FCO 31/2832. According to Massingham to Wallace, $27^{\text {th }}$ May 1980, the restoration of power supply, and significant import of food supplies underwritten by the United States, would ultimately resolve the more pressing causes of concern.
} 
Rather than address these issues and explain them in an open way to wananchi, government ministers and the president himself did not take the electorate into their confidence on the shortages. It was even doubtful that ministers themselves were properly informed about shortages, and, as a result, the government and the president lost credibility. Indeed, Moi first of all said that there was actually no food shortage apart from that created by hoarders and profiteers. ${ }^{23}$ Not too long after this assertion, however, he assured the nation that overseas supplies would be brought to tide Kenya over until the next maize harvest. In his appeals for further external help, Moi did recognize this as the way to break Kenya's difficulties. ${ }^{24}$ In the meantime, long maize queues in the capital city, Nairobi, continued. If there is one thing that wananchi expected of a president, it was that he should not allow them to go hungry. ${ }^{25}$

While the issue festered, Moi was firmly in the saddle and had abandoned his cautious approach to questions on ethnic arithmetic. The Kikuyus for their part were becoming resentful of the way in which Moi was beginning to show favors to his own Kalenjin people with regard to official appointments and land allocations. Suffice it to say that with regard to the performance of the government in dealing with arising socio-economic problems or even explaining them properly to the electorate, it was not impressive. ${ }^{26}$ Indeed, the country's dire economic straits were aggravated by inept government handling of the problems ranging from manifestly misleading statements by the president himself through public quarrelling among senior ministers to sudden arbitrary reversals of policy decisions notably about commodity and fare prices. ${ }^{27}$ For this reason, foreign political observers were afraid that 1980 could well have been the year marking the end of Kenya's steady progress since independence, signaling a period of stagnation characterized by a drop in general living standards and increase in internal dissension. ${ }^{28}$ British diplomats in Nairobi and London were alive to the fact that what Moi saw as foreign appeals to relieve economic hard times would ultimately not aid a recovery national

\footnotetext{
${ }^{23}$ Williams to Robson, $15^{\text {th }}$ April 1980, BNA: FCO 31/2832.

${ }^{24}$ Fingland to Lord Carrington, nd., BNA: FCO 31/2557.

${ }^{25}$ Official Visits from UK to Kenya, BNA: FCO 31/2832.

26 Ibid.

${ }^{27}$ Massingham to Wallace, $27^{\text {th }}$ May 1980, FCO 31/2838.

${ }^{28}$ Official visits from UK to Kenya, BNA: FCO 31/2832.
} 
economic recovery or the process of development, which the president described as essential for national stability. ${ }^{29}$

If the government response was unimpressive, uncoordinated and a little more than clumsy, officials were all but completely ignorant about the worrying economic situation. There was some saving grace in that official thought was given to the government's five-year development plan, which these difficult times had slowed down. The Kenyan government acknowledged the country's economic difficulties and arising consequences, including that they would seriously increase before they started waning; these would result to a fall in low but slowly rising living standards and lead to increased unemployment. ${ }^{30}$ In the White Paper on Economic Prospects and Policies (Sessional Paper No.4), which was published on $14^{\text {th }}$ May 1980, was a succinct analysis of Kenya's economic problems and guidelines for their remedy. Even in diplomatic circles, Sessional Paper No.4 (1980) was thought to be encouraging for the realism with which the country's various problems were admitted and presented. Indeed, the frankness with which they were given expression was unusual and indicative of a renewed confidence within the government. What is more is that the paper was mercifully brief and admirably clear. ${ }^{31}$

Thus, this fundamentally encouraging publication, with fortitudinous honesty, admitted a whole range of government and national failures including reduced growth in the economy; falling agricultural production vis-à-vis high population growth, increased unemployment; and reduction in the share of the budget allocated to housing, social services, health, as well as the agricultural sector. The paper noted that agricultural policy faced two important challenges, the most immediate being to cope with an impending shortage of basic foods. The second and longterm challenge was to increase production and employment opportunities in agriculture in order to meet the needs of the country's rapidly growing population. Furthermore, the government admitted that during 1980, domestic production of food would not meet all the country's

\footnotetext{
${ }^{29}$ Fingland to Lord Carrington, BNA: FCO 31/2557.

30 Ibid.

${ }^{31}$ Massingham to Wallace, $27^{\text {th }}$ May 1980, BNA: FCO 31/2838.
} 
requirements for maize, wheat, rice, milk and meat. This was attributed to dry weather as the main reason occasioning the shortage in production. ${ }^{32}$

All these were seen as potential areas of discontent and possibly even national instability. But what served to either irk and bemuse or cause mirth in British diplomatic circles was that in the section on Food Policy, the paper perpetuated the myth that drought was the basic cause of food shortages. Whatever the case, this was seen to be as disappointing as it was false: the British were gravely concerned and afraid that even prominent Kenyans could fall victim of their own propaganda. An excellent example of government officials believing their own lies was that of the permanent secretary of industry who felt it necessary to describe in some detail to Sir Kenneth Clucas, who was the Permanent Secretary of the Department of Trade in the early years of the Thatcher Government, the impact of inadequate rains in 1979: it was the sole cause of the food shortage. This political refrain was easily dismissible, especially considering the fact that 1979 was a year of above average rainfall! The absence of commentary on the truly significant causes of agricultural shortfalls deemed dismissively as "other contributory causes" such as wrong pricing, failure to implement projects and even the change in farm tenure pattern was, for Massingham, disappointing even ominous. Further, the report did not contain anything that was surprising or new. What government officials like that permanent secretary had to say about the economic situation in Kenya was, by 1980, a familiar litany to foreigners as well as to Kenyans. $^{33}$

Indeed, the report was somewhat a rehash of the Government Sessional Paper No.4 of 1975 which five years earlier announced the grim economic realities that Kenyans faced. Indeed, this particular paper assumed a worrying tone of determinism about the country's economic prospects. It was also fateful. The paper, which appeared early that year, was founded on the theme of the inevitability of adverse effects on the rate and pattern of the government's planned development and, thus, called attention to the need for a program of austerity more severe than Kenya had yet experienced. For that reason, this particular paper outlined a strategy of a reduced rate of development, which paled in comparison with the country's previous high rate of

\footnotetext{
${ }^{32}$ Sessional Paper on Economic Prospects and Policies as cited and discussed in Ibid.

33 Ibid.
} 
expansion; curtailment of imports; promotion of exports; and restraint in wages and domestic prices amongst other measures. ${ }^{34}$

Although with the same dark projection of Kenya's future, the report of a commission constituted by the European Economic Community on the Kenyan economy between 1979 and June 1980 captured the accompanying sense of gloom. The report put literacy levels at $46 \%$ (1976); life expectancy at birth at 51.2 for males and 55.7 for females (1977); and GDP per capita of US \$390.9 (1979). Further, 1979 showed an economic downturn after the relative prosperity of the previous few years spurred by the coffee boom of the early 1970s. Although the price of coffee turned upwards in the second half of 1979, the volume of production recorded a fall. Tea, Kenya's other main export, was produced in larger quantities, but sold cheaper. This trend resulted in the strict implementation of measures taken at the end of 1978 to restrict imports so as to restore a more desirable balance of trade. By December 1979 foreign exchange reserves soared to 75 per cent higher than the previous year, which permitted a relaxation of some of these import controls. Lack of agricultural incentives, however, resulted in much lower production of some foods resulting to shortages of many basic foodstuffs. Overall, domestic and external indicators for the second half of 1980, according to the Europeans, were discouraging. ${ }^{35}$

Although the outgoing British High Commissioner expected the International Monetary Fund and IBRD to step in and save the day to enable Kenya to meet its economic needs and secure national stability, Fingland was not as optimistic as the Nairobi group of European commercial counselors. He expected the country to continue to face two difficult years ahead up to 1983 . In what would, in years to come, be a self-fulfilling prophetic observation confirmed, Fingland also stated that a reduction of corrupt practices was an essential part of a much needed improvement in administration, especially economic management if things were to be turned around. Further, he viewed corruption as constituting a latent political time-bomb. As noted earlier above, the steep dip in Kenya's economic fortunes less than twenty years since Mau Mau, and before its ghost was reckoned to be fully at rest, was a considerable cause for political concern. The economic realities of the day and such gloomy predictions led to fear that the end

\footnotetext{
${ }^{34}$ Sessional Paper No. 4 of 1975 as discussed by John Fingland in the draft summary of the Kenya: Annual Review, 1975, $2^{\text {nd }}$ January 1976, BNA: FCO 31/2020.

${ }^{35}$ Commission of the European Economic Community, Report on Kenyan Economy, July 1979-June 1980, BNA: FCO 31/2838.
} 
of Kenya's steady progress since independence and the beginning of a period of stagnation and a drop in general living standards could easily usher in and increased the likelihood of, political dissention. $^{36}$

In fact, this level of political insight and acumen, which characterized the British diplomatic corps analysis on the situation in Kenya, is not only impressive, but also with the benefit of hindsight, of outstanding precision. In his valedictory dispatch in which he bid farewell to Kenya, Fingland indicated that he did not think that the dire socio-economic condition presented as great a challenge to Kenya's future as did "a younger generation of politicians" who would try "to break out of the KANU single-party mould." 37 The outgoing high commissioner noted that at the time of Moi's first elections, there wasn't any cohesive group that posed an open challenge to his government on such issues of policy or principle. This validates the argument that Kenya's national politics was, as in the Kenyatta years, Kikuyu or local politics writ large. That is, it was a game characterized by dynastic, factional and even generational politics that threatened to "destabilize" the country according to pro-status quo forces.

Nonetheless, the president and his immediate colleagues seemed concerned that, in a new parliament likely to have a substantially changed membership, there could be such possible groups that would constitute focal points of political disharmony although not in the form of a formal opposition or threat to his government's prospects. Former nationalist leader, Oginga Odinga and his supporters were thought to present such a threat. It was feared, both in British diplomatic, and in Kenyan political, circles that he was a possible communist agent who could become the focal point of dissent about Kenya's economic system. If not that, it was feared that Odinga could easily galvanize and exploit the Luo political anti-government sentiments.

Further, for this British diplomat, while economic problems and, therefore, systemic or fundamental challenges presented, by far, Moi’s greatest long-term difficulty, the other attendant and even greater challenge would come from a younger generation of politicians with more radical aims sailing and dependent on a wave of populist appeal. These would try to break out of

\footnotetext{
${ }^{36}$ Stanley Fingland, British High Commissioner's valedictory despatch, $17^{\text {th }}$ July 1979, BNA FCO $31 / 2557$.

37 Ibid.
} 
the KANU mould of enforced political unity under a single party without any ideological or policy base. This, for Fingland, was even more likely as economic difficulties became direr. ${ }^{38}$

To weather the tough economic times and feared consequent national political instability that tested the legitimacy and effectiveness of Moi's government, the new president used various devices. As noted above, the more the national problems mounted, the more personal pressure the president must have felt, thus his need to wax lyrical taking his populism to dreamy heights. In the face of pressing difficulties that must have occupied his waking and sleeping time in the first few years, Moi, in a masterful stroke of political genius, coined the Nyayo philosophy and slogan, which, with passage of time, he refined into the vision of a new Kenya guided by elaborative pillars of love, peace and unity.

In addition, to be seen to drink what he preached and deliver to Kenyans his promised political Canaan, Moi, from time to time, gave well-timed but unplanned, or ill-planned-for, directives that surprised or shocked civil servants who scrambled and scrimmaged to implement such sudden decrees. To deal with mounting criticism directed at how his young government was managing Kenya's economy and his poor record, Moi superficially announced or authorized the introduction of measures designed to reinforce his political decision. ${ }^{39}$ These essentially populist measures were not necessarily appropriate ones given the economic climate into which the country was moving.

A good example was on $12^{\text {th }}$ December 1979 when he decreed that paid employment should be increased by $10 \%$, a popular gesture that ignored, or could have exacerbated, the generally unfavorable economic factors. ${ }^{40}$ As with similar promises, the danger always was that the president raised people's expectations beyond the government's capacity to fulfill them. In this instance, there were already about 118,000 applications that had been received by labor offices for the "new jobs" announced. Obviously, many must have been disappointed, since the most optimistic assessment at the time envisaged the creation of less than 60,000 new vacancies,

\footnotetext{
${ }^{38}$ Ibid.

${ }^{39}$ Massingham to Wallace, $27^{\text {th }}$ May 1980, BNA: FCO 31/2838.

${ }^{40}$ Ibid.
} 
of which at least 25,000 were in the already over-large, over-expensive and under-efficient public sector. ${ }^{41}$

Further, as the president's political spine firmed up, Moi begun to show signs of character as he emerged as his own man and, thus, could no longer be regarded as a puppet. One of the ways this manifested itself was Kalenjinization, a tendency that asserted itself notably with the appointment of Shadrack Kimalel as high commissioner and J.M. Sawe as deputy to the army commander and by J.K. Nzioka who was Kamba. In so doing, he overlooked many qualified better candidates from other ethnic groups leading to a feeling of marginalization and disaffection among them. ${ }^{42}$

In addition, Moi's restlessness, as exhibited in his many travels, was an asset. Domestically and abroad, he was seen as doing whatever was possible to alleviate the economic hardships in person. Nevertheless, these travels, mostly, were seen as a negation of duty as the accumulation and growth of problems piled up from the Kenyatta's last years. Trips were seen as delays tackling them, thus magnifying some of these problems, especially the economic and social ones. At the same token, perhaps, Moi needed to regularly get away to temporarily ease his mind, but the more time spent away abroad while problems increased and multiplied at home, could only cause the country's opinion of him to sour. ${ }^{43}$

Moreover, Moi's government was pursuing a policy of rearmament at the expense of economic reforms such as devaluation in the wake of economic hardships. ${ }^{44}$ To consolidate political power and retain control of the state and apparatus of government to effectively keep the lid on the potentially explosive situation, Moi strictly applied legislation restricting political activity through police activity; using the threat of the paramilitary General Service Unit (GSU) or even the army; and by avoiding the exciting of the population either by government politicians or their opponents. Some politicians, perceived to be "young upstart radicals," like Martin Shikuku, G.G Kariuki, George Anyona and Jean Marie Seroney, among others, were able to break the rules as Odinga had before them. ${ }^{45}$ Considering these devices and strategies, it was

\footnotetext{
41 Ibid.

${ }^{42}$ Hart to Longrigg, $15^{\text {th }}$ March 1979, BNA: FCO 31/2557.

43 Ibid.

44 According to a document in BNA: FCO 141/2589.

${ }^{45}$ Hart to Longrigg, $15^{\text {th }}$ March 1979, BNA: FCO 31/2557.
} 
clear that there was, in place, what was described by Hart as a hard but thin line of control. It was, as such, probably unlikely that chaos could be prevented if this line was broken. This was especially so in view of the new factor considered by observers to be the new source of potential disquiet: the growing ability of the armed forces to seize power if civil control looked like breaking down. ${ }^{46}$ Indeed, it was the Kenya Air Force branch of the armed forces that fired the first warning salvo that announced that all was not well in Moi’s Kenya.

\section{Flood Gates of New Dissent 0pen: The Attempted '82 Kenya Air Force}

As noted above, the mood in Kenya, as captured by British diplomatic correspondence, against a background of tough economic times and hardship was one of desperation tinged by rising and palpable tensions. If foreign diplomats observed and described the situation as "potentially explosive," poor economic management and inefficient administration as constituting a latent political time-bomb; the potential for the 1950s mob to pursue the vision of the poor-marginalized; and the real possibility of a military take over that was more likely than Professor Ngugi's peasant and workers' revolution, these were not abstract approximations of the political situation in Kenya. Rather, they were insightful analyses of not only the practical political reality but an accurate description of the everyday experiences of ordinary Kenyans and precise anticipation of what action such desperation might lead. It was clear that Kenyans, especially those of the younger generation, were getting agitated and restless about the economic situation, corruption and what they saw as maladministration and even the arrogance of Moi's government. Put differently, political instability paralleled and mirrored the economic slide: there was a marked withdrawal from the patron-client system as it hit lower levels and, as such, discontent increased. ${ }^{47}$

In view of the foregoing, senior British diplomats like High Commissioner Stanley Fingland were correct in suggesting that a discontented younger generation presented a great challenge in Kenya's future. Bearing more radical aims and deliberately assuming populist appeal, this restless generation would try and break out of the KANU mold of an enforced political unity under a single party without any real ideological or policy base. ${ }^{48}$ However, these

\footnotetext{
46 Ibid.

${ }^{47}$ Miller and Yeager, Quest for Prosperity, 100.

${ }^{48}$ Stanley Fingland British High Commissioner's valedictory dispatch, $17^{\text {th }}$ July 1979 , and Fingland to Lord Carrington, nd, BNA FCO 31/2557.
} 
British assessments of the situation and subsequent fears did not go far enough because disquiet and opposition was not restricted to only the young political class. In this particular regard, Christopher Hart, who foresaw the likelihood of military rule, was more accurate. Young men of the Kenya Air Force (KAF) would, on the morning of $1^{\text {st }}$ August 1982, not only try to take matters in their hands, but, quite literally, take over the running of government itself.

With a force of just under 3,000 strong, the attempted KAF coup d'état became, for a short duration, the embodiment of Kenya's fears and future hope that was reminiscent of the heady 1950s. Indeed, in staging this coup attempt, it was, in many ways, a microcosm of the 1950s colonial struggle played out within a much shorter time. ${ }^{49}$ This explains why so many people were arraigned, in the aftermath of the coup, with the charge of prematurely celebrating the fall of the regime. ${ }^{50}$ Although supposedly professional men of uniform, the young junior officers involved were not, in any way, shielded from witnessing and experiencing the serious economic crisis of the late 1970s and early 1980s. Indeed, they, like other Kenyans, must have felt and were egged on by the sharp point of what was seen as the beginning of the end of Kenya's steady progress since independence signaling the start of a period of stagnation, a drop in the general standards, and an increase in internal political dissension. ${ }^{51}$ Although at the core of KAF attempted coup were internal issues such as poor pay and living conditions; the declining quality of services; growing corruption in military procurement; Kikuyu dominance in the KAF leadership, Luo sentiments that went back to events between 1965 and 1969, which is when Kenyatta and the Luo kingpin Odinga parted ways; and a tinge of Odinga's socialist, antiwestern and redistributionist political ideals, the rebels cited rampant corruption, tribalism, nepotism, repression and disenfranchisement of the masses, particularly of the Luo, as the main drive behind their actions. ${ }^{52}$

When, in the morning the airmen stormed and temporarily took over VoK broadcasting station, the following statement (with my emphasis in italics) which echoed the call for social

\footnotetext{
${ }^{49}$ This was especially with regard to government response to the coup attempt, which included mass arrests, executions and disappearances, detention without trial and extensive searches of both urban estates and rural villages for looted goods and people implicated in the event. The images of detainees and search operations are particularly striking in this regard; also, in its "Around the World" section of the New York Times, the attempt was quite aptly reported as "an uprising;" Reuters, "145 were Killed in Kenyan Uprising," $11^{\text {th }}$ August 1982.

${ }^{50}$ CRPPK, Repression Intensifies in Kenya, 4-5.

${ }^{51}$ Official Visits from UK to Kenya, BNA: FCO 31/2832.

${ }^{52}$ Hornsby, A History Since Independence, 376, 378 and 382.
} 
justice and framed their actions in the language of grievance that harked back to British colonial days, was broadcast:-

I announce...the overthrow of the corrupt regime of Daniel arap Moi by the patriotic forces of our country. ... Our country is firmly under the control of our armed forces. Every care has been taken to make the revolution as bloodless as possible.

Over the past few years this country has been heading from an open to a closed inhuman and dictatorial society. The fundamental principles for which many of our people sacrificed their lives during the heroic struggle for independence have been compromised in the interests of a few greedy and irresponsible bandits.

Over the past few months we have witnessed with disgust the imposition of a de jure one-party system without the people's consent, arbitrary arrest and the detention of innocent citizens, censorship of the press, intimidation of individuals, and general violation of human rights.

This ruthless oppression and repression is reminiscent of the past colonial days which Kenyans thought were buried at independence. A gang of local tyrants has emerged whose only function is to terrorize and intimidate with senseless warnings. Rampant corruption, tribalism, nepotism have made life almost intolerable in our society. The economy of this country is in shambles due to corruption and mismanagement. The cost of living in Kenya today is among the highest in the world. Wananchi (citizens) can no longer afford to meet the basic requirements of life, due to exorbitant prices of basic necessities such as food, housing, housing rent, transport. Above all, Kenyans are among the highest taxed people in the world.

Wananchi, under these circumstances our armed forces have heeded the people's call to liberate our country once again from the forces of oppression and exploitation in order to restore liberty, dignity and social justice. In doing this, we have proved to the rest of the world that no individual or group of people can permanently subjugate or take away the freedom which our fathers and grandfathers so gallantly fought to bring to this country. Like the British imperialists, the same fate will befall whoever attempts to stamp out our freedom.... 53

After the coup ended in utter failure and with an unofficial estimate of between 600 and 1,800 dead and over 2,000 others in detention, a deeply shocked Moi returned to the seat of government, and immediately began his bid for a better and stronger grasp on political power and cracking down on all forms of dissent. Almost 2,000 air men were detained and 900 others court-martialed. ${ }^{54}$ Among those affected before and after the coup attempt included junior air

\footnotetext{
${ }^{53}$ Anyang' Nyong'o, "Struggles for Political Power and Class Contradictions in Kenya," Contemporary Marxism (Fall 1983): 154-155.

${ }^{54}$ Hornsby, A History Since Independence, 379.
} 
force officers among them Hezekiah Ochuka, Pancras Okumu Oteyo and James Dianga; university students among the very first arrested being Titus Adungosi Oloo (Chairman of the Students Organization of Nairobi University), Paddy Onyango, Francis Kinyua, Thomas Mutuse, Muga K'Olale, Onyango Oloo, Joseph Hongo, Oginga Ogego, Johnstone Simiyu; journalists like Otieno Mak’Onyango who was the Assistant Managing Editor of the Sunday Standard; politicians like Koigi Wamwere (MP, Nakuru North), Mark Bosire (MP, Wanjare, South Mugirango), Mathew Onyango Midika (MP, Nyando) and George Moseti Anyona (MP); lawyer John Khaminwa; intellectuals like Mukaru Ng’ang'a, Willy Munyoki Mutunga, Maina wa Kinyatti, Kamoje Wachira, Edward Oyugi, George Katama Mkangi, Al Amin Mohammed and Alfred Vincent Otieno; and Wang'ondu Kariuki, a civil servant in the Ministry of Health ,an activist in the peasant marketing cooperatives and editor of Mashambani, which was a Kikuyu language farmer's monthly magazine. ${ }^{55}$ According to Kinyatti, some of the lecturers above were Marxists who were persuaded that imperialism and its Kenya ruling class corollary could never relinquish power without an armed revolutionary struggle. In the mid-1970s, they had formed a clandestine party, the Workers' Party of Kenya, to enable the Kenyan people to be free by controlling the forces of production. They added to their numbers in the early $1980 \mathrm{~s} .{ }^{56}$

Besides arresting those it suspected to have been behind the attempted putsch, the shaken Moi regime went even further. Although most Kenyans hesitated in fear when news of the coup broke out, the Air Force announcement on the VoK had been greeted with celebrations around the country. ${ }^{57}$ University of Nairobi and Kenyatta University students came out on the streets to show solidarity with the young junior officers. Some civilians joined the KAF's revolt and punching the air with clenched fists, which was a sign of defiance and shouted the slogan, "Pambana!" (confront or struggle-on!). ${ }^{58}$

\footnotetext{
${ }^{55}$ CRPPK, Repression Intensifies in Kenya, 8-14; according to Friedrich Ebert Stiftung and Citizens for Justice, We Lived to Tell the Story: The Nyayo House Story (Nairobi: Friedrich Ebert Stiftung), 13, at least sixty nine students from Nairobi and Kenyatta universities were arrested after the Air Force abortive coup on August 1, 1982. Ultimately, hundreds of students were rounded up; also see "Release Otieno Mak'Onyango" and "Release Wang'ondu wa Kariuki," Ephemera Collection, Africa Middle East Division (AMED), Library of Congress (LoC), Release the Political Prisoners in Kenya (London: Rye Express), 5-9.

${ }^{56}$ Maina Kinyatti, History of Resistance in Kenya, 1884-2002 (Nairobi: Mau Mau Research Centre, 2008), 430-431.

${ }^{57}$ Friedrich Ebert Stiftung and Citizens for Justice, The Nyayo House Story, 17.

${ }^{58}$ Hornsby, A history Since Independence, 376.
} 
After the coup, people , across the country from Mombasa to Kisumu, were variously brought to court on charges of rejoicing sometimes framed as "creating a disturbance in a manner likely to cause a breach of the peace" because they prematurely celebrated the radio announcement of the fall of the Moi regime. There were at least seventy cases in the town of Kakamega, some of them including local councilors and former assistant ministers. ${ }^{59}$ The extent of the Moi-regime's massive arrests and detentions affecting professors, students, lawyers, politicians, peasants and workers was, in itself, testimony to the widespread unpopularity of the regime throughout the country. ${ }^{60}$ The coup attempt had revealed, especially to Moi's young romantic government, the full extent of popular dissatisfaction.

The two leading institutions for tertiary education, University of Nairobi and Kenyatta College, were shut down for a year and even more professors, lecturers and students put behind bars. Naturally averse to academics, Moi's anti-intellectualism after the coup attempt was reinforced and oppressive measures against them were reflected, spread and felt throughout the country's social strata. Moi then embarked upon the process of deconstructing the Kenyattacentric state dominated by Kikuyu elite and weeding out dissent that riddled the political elite and the security forces, thus setting the country in a new historical direction characterized, for the next decade, by extreme political oppression. ${ }^{61}$ The attempted putsch was the result of a rare mixture of the political elite, intellectual and security strands of dissent, with or without a tinge of socialist influences that had heretofore operated underground. Since this time in Kenya's history, such a show of solidarity has proved elusive. This is with the exception of the short-lived push for political pluralism in the early 1990s. This is because the president systematically proceeded to establish a surveillance and police state paralleled only by colonial times. Further, atomization of all forms of opposition was high in his political arithmetic of divide and rule and state control. Moi’s response to the coup attempt forced discontent underground.

\footnotetext{
${ }^{59}$ CRPPK, Repression Intensifies in Kenya, 5.

${ }^{60}$ Ibid.

${ }^{61}$ Hornsby, A History Since Independence, 380-383. Also see Branch, Between Hope and Despair, 162.
} 


\section{Pambana: Academic Debate on Kenyan Peasantry and the Mwakenya Decade}

By the end of the first decade of independence between 1973 and the mid-1970s, as earlier noted, there were critical national debates that saturated the classrooms and corridors of academia, which were radiated throughout the rest of the country. This was a result of a pervading disillusionment with national independence and those who took over power on the eve of independence.$^{62}$ It was a particularly depressing time for academics that ended up at University of Nairobi's Senior Common Room as early as eleven o'clock for a cup of coffee that would extend to one o'clock. After a short afternoon session of teaching they would stream back in by five o'clock to socialize over alcoholic and other beverages until long after dinner. ${ }^{63}$ The revolutionary writing of Ngugi wa Thiong'o traces the political division created in the Kenyan state, community and family right from the beginning of colonialism. This polarization was consolidated by 1920. In the post-colonial state, familial, communal and political division was strengthened by even more increasing class conflict. This is a theme to be found throughout Thiong'o's work. As such, the literary landscape painted by the author is underlined by the theme of betrayal. ${ }^{64}$

However, Thiong'o was not the only intellectual talking and writing about, and against, political betrayal. There were many voices, especially at the end of the 1970s and 1980s, who did the same. Constituting the ranks of these academic voices, were young intellectuals who were cutting their teeth in academia. The conservative intellectual Benjamin Kipkorir described them in his memoirs as "a crop of young radicalized academics fresh from the University of Dar es Salaam" many of whom did not have Ph.D.s and "who seemed to accept Marxist axioms as articles of faith." For Kipkorir, these were Young Turks who espoused Marxist views and were vociferously opposed to everything institutional. ${ }^{65}$ But in the ranks of this fresh academic blood were mid-level intellectuals, such as Micere Githae Mugo, who considered themselves revolutionary rebels as epitomized by Ngugi wa Thiong'o. These intellectual rebels saw

\footnotetext{
${ }^{62}$ Micere Githae Mugo, Writing and Speaking From the Heart of My Mind: Selected Essays and Speeches (New Jersey: Africa World Press , 2012), 15.

${ }^{63}$ Benjamin E. Kipkorir, Descent from Cherang'any Hills: memoirs of a reluctant academic (Nairobi: Macmillan Kenya, 2009), 247.

${ }^{64}$ James Stephen Robson, "Ngugi wa Thiong'o's Fight Against Colonialism and Neo-colonialism: An Exploration of the Theme of Betrayal," Master of Arts Thesis, Department of English, Simon Fraser University (December 1987).

${ }^{65}$ Kipkorir, Descent from Cherang'any Hills, 245.
} 
themselves as positioned at the battlefront of contending ideas and clashing frontiers of knowledge. For them, scholarship, research and learning were not neutral processes.

Rather, the generation of knowledge was a significant component of a deliberate agenda specifically designed by the system in power to support its economic base. Instead of succumbing to this propagation of the status quo's controlling ideas, these revolutionaries viewed themselves as advocates of the rights of ordinary people. Most of them were, as expected, influenced by Marxism-Leninism as an ideological framework of reference and, as such, saw themselves as "the vanguard" for revolutionary change in Kenya. ${ }^{66}$ Amongst others, these group of intellectuals included Peter Anyang Nyong'o, Apollo Njonjo, Mike Chege, E.S Atieno Odhiambo and Mukaru Ngang'a who were joined, in the late 1970s and early 1980s, by Mike Cowen and David Rosenburg in the exposition of the all crucial but intractable discussion of "the peasant question in Kenya."

With regard to the peasant question in Kenya, these scholars aligned themselves with the suffering, disillusioned and struggling masses and, by so doing, considered themselves their advocates. As such, working under the Marxist theoretical framework, these scholars sought to mend the psychic dismemberment wrought by colonialism and neo-colonialism. ${ }^{67}$ They had attended either mission schools or colonial/neo-colonial government schools where they imbibed education for domination and were taught to think without the people while thinking about them for the ulterior motives of domination and control. Nonetheless, these scholars purposed to tackle the question of the Kenyan peasantry in order to be able to adopt a certain political line, a certain program of action towards the urban poor but, more so, rural peasant farmers. ${ }^{68}$ Their intellectual and practical agenda was socioeconomic and political transformation of pauperized rural folk and the urban proletariats that they rubbed shoulders with in the city.

The educated African elite, therefore, refused to be conservative neo-colonial intellectual scions. This was despite the fact that they had been reared in an academic environment patterned

\footnotetext{
${ }^{66}$ Mugo, From the Heart of My Mind, 10.

${ }^{67}$ Ngugi wa Thiong'o, Something Torn and New: An African Renaissance (New York: Basic Civitas Books), 7.

${ }^{68}$ Mugo, From the Heart of My Mind, 10 -12; also see, Anyang Nyong'o, "What 'the Friends of the Peasants' are and How They Pose the Question of the Peasantry," Review of African Political Economy 8 (Spring, 1981 ): 17.
} 
along foreign cultural paradigms, which naturally alienated from their own people. In their personal and professional lives, they refused to live as if the life experiences of the suffering masses did not touch or affect them. ${ }^{69}$ Unlike Western-oriented conservative scholars, these radical intellectuals identified themselves with, and were imbued by, the spirit of struggle of the majority $50 \%$ of the population involved in agricultural production in the Kenyan peasant economy. For these revolutionary Marxist scholars, knowledge was useless until it was incorporated with the struggle of the masses against their oppressors. ${ }^{70}$ Put differently, they refused to be cut off from the social body by the neo-colonial ideology of self-abnegation characterized by a spirit of distancing themselves from Africa. ${ }^{71}$

As such, in their investigation on what was happening to the bulk of the Kenyan peasantry between $1978 / 79$ and what had happened to it in the past, they aimed at praxis by bridging theory and political practice. They argued that if the social dynamics and social structure of rural life in Kenya could be laid bare, then it would be possible to develop a specific political program of action for the liberation of the peasantry. ${ }^{72}$ In this social inquiry of the question of the peasantry, these friends of rural dwellers turned to Marxism as a theoretical tool that would enable them to unveil Kenya's prevailing social reality clearly. They sought to unmask appearances, utopian, adventurist, demagogic political programs and intellectual deceptions although they did not mention them in name as Kenyatta's Harambee or Moi's Nyayo philosophy of love, peace and unity in their academic papers. ${ }^{73}$ Far from outright criticism, theirs was the pairing of social analysis to a political program that was indispensable weapon for the liberation of the politically oppressed and economically exploited class in a world in which bourgeois outlooks continued to mystify social processes. They were inspired by theory that would unveil a clear path for political action that would change society. ${ }^{74}$

\footnotetext{
${ }^{69}$ Mugo, From the Heart of My Mind, 6.

${ }^{70}$ Nyong'o, "What 'the Friends of the Peasants' Are," 19.

71 Thiong'o, Something Torn and New, 27; also see Mugo, From the Heart of My Mind, 6.

72 Nyong'o, "What 'the Friends of the Peasants' Are," 17.

${ }^{73}$ Kinyatti, History of Resistance in Kenya, 437. Kinyatti dismissed Nyayoism, Moi's brand of philosophy, as a mindless, political slogan as opposed to an ideology.

${ }^{74}$ Nyong'o, "What 'the Friends of the Peasants' Are,", 17 \& 19.
} 
Furthermore, in engaging in social analysis, this group of scholars saw themselves as an intellectual vanguard that would facilitate the onset of class consciousness by empirically providing evidence about the existence of a peasantry in Kenya. From this class consciousness, they argued, would then spring political action for social change thus making it possible for this section of society to be able to realize its socio-economic and political interest. This preoccupation with the peasant question had been conceived in the course of a series of discussions on industrialization and agriculture in Africa at the Department of Government, University of Nairobi in the 1978/79 Academic Year. It resulted in the publication of this debate in the early 1980s, which in itself could be considered to be one of the fetal stages of the selfdeclared vanguardism for political change by this group of radical intellectuals. Following the laying out of a persuasive social analysis, the ruling class would then be made aware of the existence of classes; the politically oppressed; and the economically exploited awakened to a class struggle and, thus, enter into political battle with other classes for themselves.

The role of this intellectual vanguard, therefore, was to instigate this latent confrontation embedded in colonial and post-colonial contradictions that were now, however, framed within Marxist-Leninist terms. These scholars hoped to successfully ferment political action through concrete organization giving the peasant masses agency and a decisive role in history thus bringing about the desired political and socio-economic social change. This fit with precision the Marxist-Leninist revolutionary template that Moi's government was going to not only to frown upon, but also baulk at every turn and rout out short of using violence. In the global Cold War environment, in which Kenya, especially under Moi, allied itself to the West and Britain in particular, these intellectual Mau Maus were bound to fail even before they got started.

But before dealing with the government's stubborn reaction to this group, it is important to note its shortcomings. One of its greatest shortcomings was its romantic and poetic preoccupation with Marxist theory in particular and theorization in general. Thus, while its deduction of Kenya's social reality was proximate to the spirit of existential struggle for the bare necessities of life: clothes, food and shelter in Kenya, for some of them, revolutionary consciousness, as Micere Mugo observes, was just an intellectual game. According to Micere Mugo, they did not go to the fullest extent. They only went as far as cultivating personalities and 
lifestyles that defined what they perceived to be "revolutionary." Mugo argues that a number of them were even known to intimidate those around them with arrogant and alienating elitism while parading as saviors of their worlds. She charges that their personal idiosyncrasies aside, their pompous theorization generated knowledge and articulated experience that often failed to touch real living individuals. For that reason, this body of supposedly liberative knowledge remained the abstract monopoly of the learned. ${ }^{75}$

In other words, while this debate was timely, reflected the deep-seated concerns of Kenyans at large and encapsulated the intellectual hunger in the country, the highfalutin Marxist language in which it was cast meant the vanguard message was decoded making it difficult for everyday rural and street folk to decipher. Arguably, the analysis of everyday social reality estimated and fit the mold of the Mau Maus of the mind struggle of colonial and post-colonial Kenya. However, considering the fact that it was framed or packaged within Marxist-Leninist social analysis meant that it was lost to the majority of people in the country. Admittedly, this group sought to espouse a "persuasive social analysis," which would have been effective in its aim of, not just awakening peasant and working class consciousness, but rather, at least capturing it within limited and partial Marxist confines. But it failed even in the latter sense because it was not simple or clear enough. Instead, social reality of everyday socio-economic and political struggles in Kenya were encoded in abstract theoretical and fancy Marxist terms that parceled it out, such as mode of production and articulation between various modes of production; control of the means of production; alienation and articulation, and extraction of (surplus) of labor; historical determinism; proletariatization; penetration of capital in pre-capitalist social formations; and survival of some of pre-capitalist modes of production. There was, as such, a gap between this Marxist theorization of social reality and lived everyday reality of Kenyans.

As a result, theory and practice was not bridged. There was little, if any, practical impact in terms of their transformational agenda, made by this category of intellectuals on Kenya during the 1970s, and the 1980s in particular. What all this debate amounted to was these rebels just making noise among themselves on the campuses and other academic avenues ensuring that the government, for the most part, remained unperturbed. But real trouble for the government started

\footnotetext{
${ }^{75}$ Mugo, From the Heart of My Mind, 10-11.
} 
when these scholars, following the example of Thiong'o's staging in 1977 of the peasant play Ngahika Ndeenda, started organizing around and outside the university, crossing the academic fence in order to reach out to the community. This turned into a threat against the status quo and the integrity and monopoly of the ruling elite on the Kenyan state by outsiders. As a result political persecution and harassment became the order of the day. ${ }^{76}$

Like Ngugi, who had been detained by the Kenyatta government towards the end of 1977, this group was seen as crossing boundaries beyond which the government had not allowed or granted. Some of them awakened to the understanding that beyond their theorization, the people and students they taught were their constituent matrix and not mere objects of thought. This was the action-oriented category of progressive intellectuals who went all out to demystify their ivory tower status. ${ }^{77}$ They decoded their language when teaching their students and talking to members of their constituent communities in organized symposia in schools and colleges; when they initiated community projects and devised research methodologies that ensured the participation and the empowerment of the people. In so doing they were not just rebels in thought and in theory only but they became rebels in the practical sense. ${ }^{78}$

As Micere Mugo notes, however, they were naïve and already over-exposed to the state and its machinery. Thus, they easily succumbed to the state's widening net of repression, denial of academic freedom, censorship, gross human rights abuse and downright terror. Mugo sees this as a tactical and strategic failure on their part: she argues that progressive intellectuals failed in their capacity as Kenya's liberators because they failed to learn guerilla warfare tactics to avoid self-exposure. Heightened persecution of progressives and a number of detentions accompanied

\footnotetext{
${ }^{76}$ Ibid. Ngahika Ndeenda, which translates to "I will marry when I want," was Ngugi's first work in Kikuyu in which he sought to champion the use of Kenya's African languages for the expression of historical consciousness of the struggle against foreign domination in the cultures of Kenya's ethnic groups. Furthermore, Ngahika Ndeenda was staged at Kamiriithu at an open air theater designed and built by the peasants of that village to dramatize their history and colonial and post-colonial conditions that they and the people of Kenya suffered. The play brought out historical conflicts and tensions experienced by Kenyans in the Kikuyu language: according to Ngugi, the play looked at Kenyan history of struggle against imperialism with pride. In the play, peasant actors who lived a life of poverty sung about how they would see a brighter day when they went to heaven. After running for three months, it was unceremoniously banned by the district commissioner of Kiambu who cited reasons of national security. For more see Sidney J. Walker, "The African Writer and Social Change: A Case Study of Ngugi wa Thiong'o," Ph.D. Dissertation, Howard University (1984), 222, 225-226.

${ }^{77}$ Mugo, From the Heart of My Mind, 10-11.

${ }^{78}$ Ibid., 12.
} 
by torture, nevertheless, is what taught the rebels that they were dealing with a tyrannical system and needed new tactics. Like the Eneke bird that learned how to learn to fly without perching because men had learned to shoot without missing, under a repressive neocolonial atmosphere and hostile conditions, this progressive intelligentsia had to become guerilla intellectuals. ${ }^{79}$

Before they were arrested like their comrades, some of them, like Micere Mugo, Ngugi wa Thiong'o and Shiraz Durrani, flew like the Eneke bird to exile from where they continued to be advocates for the rights of ordinary people. From the safety of London (Ukenya), the USA, Scandinavian countries, Australia and elsewhere, they stayed in touch with a few courageous intellectuals who managed to cling onto their jobs and stay out of jail to continue the struggle through underground publications such as Cheche Kenya (1981); Pambana -an organ of the December Twelve Movement; Kenya: Register of Resistance (1986); Mwakenya: Draft Minimum Programme (1987); Mpatanishi -(The Arbiter) an underground newspaper, which was also the official central journal of Mwakenya; Mzalendo Mwakenya -the mass newspaper of the party; Pambana: legacy of resistance (a Unity Conference paper); and From Kimathi to Mwakenya: resistance in Kenya today (1987) among many others. ${ }^{80}$ Thus was born the underground movement Mwakenya and from its little known predecessor, the December Twelve Movement that carried the intellectual banner of what the Mau Mau movement, as the symbolic and violent embodiment of Mau Maus of the mind of anti-British colonialism, had championed in the 1950s. ${ }^{81}$

Mwakenya, the underground phase of what had been open intellectual dissent inside and outside universities, is an important strand of Matigari ma Njirungi or the multifaceted critical publics against the Kenyan state. As an underground dissident and critical public, Mwakenya was tactically preceded by the December Twelve (12) Movement with its publicity organ,

\footnotetext{
79 Ibid.

${ }^{80}$ Shiraz Durrani, “The Other Kenya: Underground and Alternative Literature," Collection Building, 16 (1997): 8183. Some of these publications are at times attributed to different clandestine movements. For instance, Durrani states that Mpatanishi was the official journal of Mwakenya whereas Nyayo House story, 22 \& 24, which was based on the recollections of activists, presents it as the ideological organ of the December Twelve Movement. Since the latter was the forerunner of Mwakenya the publication can be said to have been passed onto one movement to the other.

${ }^{81}$ Mwakenya was an abbreviation of the Swahili phrase Muungano wa Wazalendo wa Kuikomboa Kenya that translates to "Union of Patriots for the Liberation of Kenya."
} 
Pambana in the early 1980s. The December 12 Movement surfaced at the beginning of Nyayo era. It derived inspiration from the struggles that led to the historic breakthrough of $12^{\text {th }}$ December 1963 hence the name "December 12." According to the first issue of Pambana, December Twelve, 1963 was the day most Kenyan masses united with the hope of a new national reality, true independence. Unbeknownst to them, this was not to be. For the December 12 Movement, therefore, this signified betrayal and the continued need to push for a new higher unity and a revolutionary rebirth of the nation. ${ }^{82}$ Thus, it viewed itself as having roots and connections with the Kenya Land and Freedom Army (Mau Mau) of the 1950s. ${ }^{83}$

Further, it noted in its first issue of Pambana that this successful publication was a major milestone and even a turning point in Kenya's history because it was the first truly peoples' newspaper. This, it argued, constituted a step towards creating the people's own voice and institutions that served them. After all, the government controlled, foreign-owned press and "the laughable Voice of Kenya" always lied and misrepresented Kenya's reality and praised "every crime and evil act the ruling class" committed. In addition, these state organs apologized for the ruling class and continually attacked the people's struggles or at best ignored them. They only sought to sow confusion and disunity in their attempts to put a lid on trouble. This issue laid out the movement's stated aim, which was to tell the state that while the government was attempting to keep the people of Kenya down, they yearned for change, and not just any, but revolutionary change. ${ }^{84}$

Echoing this omnibus rallying cry for revolutionary change, moreover, Pambana stated that it would not accept any apologies for oppression or thievery and warned that it would forcefully represent the truth as seen from the majority poor and dispossessed Kenyans who had been completely ignored. It pledged itself to be militantly and proudly partisan in conveying the

\footnotetext{
${ }^{82}$ Pambana, "Our stand," (May, 1982), 6, LoC: Ephemera Collection, Africa Middle East Division (AMED). ${ }^{83}$ Umoja, Moi's Reign of Terror: A Decade of Nyayo Crimes Against the People of Kenya (London: United Movement for Democracy in Kenya, 1989), 2-3. At times, The December 12 Movement conflated its identity with that of The Committee for the Release of Political Prisoners in Kenya that was formed in London on $2^{\text {nd }}$ July 1982 as a response to rising concerns about the Government of Kenya's campaign of arrests, detentions and harassment of university lecturers, students, writers, lawyers, peasants, workers and Members of Parliament and the systematic attacks on intellectual, political and cultural life.

${ }^{84}$ Pambana Editorial, "Cheche: a spark can light a prairie fire," (May, 1982), 1, LoC: Ephemera Collection, Africa Middle East Division (AMED).
} 
views of the majority. It argued, in spite of their high expectations, that Kenyans had been massively betrayed. The revolution that they had launched with blood had been arrested and derailed. The Movement observed that almost twenty years after a fake independence was negotiated, the broad masses of Kenya were materially and politically worse off than ever before. ${ }^{85}$ Instead, the criminally corrupt ruling clique, sanctioned by KANU, had isolated itself from the concerns of Kenyans daily life and had, thus, committed a crime among many others, more brutal than any that British colonialism had: that is, they had silenced all opposition and deprived the people, forcibly, of the very right to participate in Kenya's national affairs. The sacred rights of expression and association had been cast aside. ${ }^{86}$

Further, the paper charged that KANU and its government had disorganized all spheres of economic production, scattered all communal efforts at organization and sowed unprincipled discord and enmity among the people of Kenya. Moreover, the government was looting unspeakable sums of money and national wealth and had sold out to international imperialist forces, all in the name of progress and prosperity and inane smatterings of "love, peace and unity." This, The December 12 Movement charged, was "NOT independence." Rather, it was neocolonialism at its worst form, yet Kenyans had fought many battles in order to precisely put an end to a similar situation in the past. As far The Movement was concerned, the symbolism of the fight for freedom was eloquent: the people did not wage war in order to end up worse off than they had been before. In that regard, it had been a serious error after independence not to thoroughly cleanse the people's ranks of pro-colonial elements that later regrouped, took over leadership and derailed the struggle to where it was in Kenya of the early 1980s ${ }^{87}$ But the lesson had been learned and building on the experience of this post-colonial disillusionment and betrayal, the same mistake would be avoided in the future as the cost was too great. ${ }^{88}$

\footnotetext{
85 Pambana, 5.

${ }^{86}$ Ibid. Although this was all rhetoric, the Moi regime did excel itself in reproducing the colonial surveillance and police state with its concomitant economic hardships and oppression, which was all the more disappointing because Kenya was independent. Ideally, such a colonial rehash was a thing of the past but it was not, under Moi unfortunately.

${ }^{87}$ Pambana, 5-6.

${ }^{88}$ Ibid.
} 
After all, independence for the Pambana group was sacred. It was, or should have been, revolutionary. It meant making a clean break and a new and unfettered start from the oppressive machinery of the past. It meant the establishment of a fiercely vigilant nation led by a strong peoples' organization that worked with the peoples' initiative in building a new society with new forms and new modes of thought. True independence would and should have released unbounded new energy and creativity. But this had never happened, and, as such, Kenya had no independence. Instead, the country was more dependent in 1983 than it had been before 1963 . Despite Kenya's considerable wealth, its people were starving, in debt and bankrupt. For that reason the struggle was still on: Kenyans had no alternative but to begin anew to continue the revolution that had been frustrated. This first issue of Pambana, therefore, urgently called Kenyans to marshal forces and prepare for a protracted counter-attack that would salvage and reconstruct their nation. This meant war: the movement's members were under no illusions that a class war was in the offing. ${ }^{89}$

Lastly, the newspaper made it clear that its message was tailored and targeted at all genuine Kenyan organizations and individuals that were fighting any and/or whatsoever aspect of local or imperialist reaction and specifically:

1. Small farmers and producers against government and "co-operative" theft and mismanagement;

2. Workers against IMF-enforced low wages and anti-strike controls;

3. Millions of unemployed in their right to employment.

4. Small businessmen against foreign monopolies;

5. Indigenous professionals against fake expatriate "skills;"

6. Teachers, students and pupils against irrelevant; authoritarian colonial education;

7. Committed intellectuals and journalists against official muzzling;

8. The poor and the landless in their demands for land reform

9. All poor people against ever-increasing rents, prices and declining real incomes;

10. The entire dispossessed population against a corrupt puppet government and

${ }^{89}$ Ibid. 
its ever-repressive police rule. ${ }^{90}$

Demonstrating that it was fairly well-informed with respect to some of the allegations, The December Twelve Movement leveled against the government, Pambana narrated stories in its "national news" section detailing some of these charges. For instance, it cited the sowing of ethnic and civil strife in the Nandi/Kakamega border area where Moi, apparently, dissolved many legitimate land transactions and suspended the Land Act and the respective clauses in the constitution for some sections of the Rift Valley, particularly Nandi, Trans Nzoia and Nakuru. Further, he proposed an elders tribunal to deal with all land disputes in the area thus setting affected communities on a collision course marked by chaos, bloodshed and death in Chepsanoi, Kapkangani, Moi's Ridge and Segero. ${ }^{91}$

In addition, it pointed to co-operative theft that affected many rural areas of Kenya, which were engulfed in protest as a result. Peasants and small-scale farmers, it argued, were thoroughly disgusted by the blatant theft of their farm income by co-operative and government officials. Some were reported to have uprooted, burned and not harvested their cash crops such as sugar in Nyanza; pyrethrum in Kisii; and coffee and tea in Central Kenya. ${ }^{92}$ In the case of rice in Mwea, farmers in 1981 refused to deliver grain to the rice mills because of low prices and non-payment of past dues. In many cases, small farmers fought off officials and the GSU was deployed to rough them up. This was a charge corroborated by historical production records.

According to Hornsby, the 1980s saw instability in the coffee industry although it remained to be the country's largest foreign exchange earner until 1989. The Kenya Planters Cooperative Union that was collectively owned by the farmers continued to be the sole processor and main miller and the Coffee Board the sole marketer and regulator. ${ }^{93}$ Kenya was overproducing coffee and was rewarded during $1984-86$ by a second spike in world coffee prices that

\footnotetext{
${ }^{90}$ Ibid., 10.

91 Ibid., 13.

92 This was a trend that would increasingly become a problem, especially with regard to coffee with farmers cutting their trees in the 1990s and small-scale tea farmers threatening to follow suit in 2008.

${ }^{93}$ Hornsby, A History Since Independence, 434.
} 
exceeded the 1976-7 boom, but 1986 was the end of this chance-profitability. ${ }^{94}$ Not only did world prices fall but farmers became increasingly dissatisfied as payments were "eaten" by the chain of coffee organizations, including county councils, local cooperatives, the KPCU and the Coffee Board. ${ }^{95}$ With regard to sugar, the sector was riddled with difficulties. In 1988, the Ramisi factory in Kwale collapsed as did Miwani in Kisumu. There were widespread problems including allegations of malpractice and misuse of funds from cooperatives, which especially affected the Kikuyu in Central Province, where they were best developed and contained about one-third of all rural cooperative members. With growing delays in the payment to farmers reflecting profitability and liquidity problems within the marketing chain, several cooperative unions collapsed. ${ }^{96}$

Further, sugar production in the country was inefficient and return to farmers low, despite the fact that retail prices remained well above world market prices. What is more is that this industry too was marred by a corrupt administrative environment with sugar imports being organized by insiders considering the wide gap between local and import prices. ${ }^{97}$ The Uplands Bacon Factory and the Kenya Meat Commission, that were both state-owned processers, collapsed in 1985 and were placed in private hands. ${ }^{98}$ Lastly, pyrethrum went through a period of boom but then went bust. Pyrethrum production peaked in 1983 at nearly 30,000 tons. However, in the same year, both world prices and demand collapsed, and the Pyrethrum Board was unable to pay growers. As a result, output would fall to 6,000 tons in $1986 .{ }^{99}$

Its criticism of cooperatives and specific political exposés of irregularities, maladministration and corruption in various agricultural sectors, shows that the December Twelve Movement was alive to everyday concerns and difficulties that small-scale farmers,

\footnotetext{
${ }^{94}$ Ibid., 434-435 \& 365. International Coffee quotas, reimposed in 1980, limited Kenya's coffee exports to 83,000 tonnes, which was below its actual production. As such, there was a mounting stock of unsold produce and little encouragement for further plantings.

95 Ibid.

96 Ibid., 370.

${ }^{97}$ Ibid., 436. According to Hornsby, this state of affairs was in part because European and the American preferential trade system depressed world prices and some producers exported surplus sugar at below cost. As a result, Kenya's demand exceeded supply and from 1985 onwards, despite two decades of investment, Kenya became a sugar importer again.

98 Ibid., 437.

${ }^{99}$ Ibid., 365.
} 
workers and unemployed had to contend with: it was not just the fruits of Uhuru that were trapped at the top but also that of their post-independence labor. As one of the leading clandestine critical publics that acted as the voice of the people in an increasingly hostile environment, the December Twelve Movement was excelled by, and/or rivaled by, Mwakenya.

Indeed, the exact nature of the relationship between the two is yet to be understood, although Mwakenya is believed to have been an offshoot of the shadowy December $12^{\text {th }}$ Movement. ${ }^{100}$ What is known, however, is that as underground outfits both were contiguous and overlapped in terms of membership and shared ideals of struggle although the name Mwakenya entered the national political arena in the mid-1980s. Even former activists within the movement do not agree on the exact dates or the origins of Mwakenya. Nevertheless, it is significant to note that there was contact between underground movements operating in Kenya and political activists and exiles abroad. They recognized the task of forging a united front and unity of all patriots to bring about political change. ${ }^{101}$ The strategy that Mwakenya deployed to this end was the publication and distribution of its underground literature aimed at the education and conscientization of the general public. The organization's main theme was to expose the regime and mobilize people for action. ${ }^{102}$ Although said to have been active as early as 1981 , the name "Mwakenya" was not known to the general public before $13^{\text {th }}$ February 1985 after which date a series of hard-hitting publications critical of the government followed. ${ }^{103}$ One of its earliest publications attributed to Mwakenya was Mpatanishi (The Arbiter) that was the movement's central organ established by $1982 .^{104}$

\footnotetext{
${ }^{100}$ Ibid., 414.

${ }^{101}$ Friedrich Ebert Stiftung and Citizens for Justice, The Nyayo House Story, 24. According to Durrani, "The Other Kenya," 81, the relationship between the two movements was, simply, that December Twelve Movement was the precursor of Mwakenya. In turn, according to Kinyatti, History of Resistance, 432December Twelve Movement was itself preceded by the Workers' Party of Kenya transformation of which happened in May 1982.

102 Stiftung and Citizens for Justice, The Nyayo House Story, 24.

${ }^{103}$ Durrani, "The Other Kenya," 81. Mwakenya was first mentioned in The Standard of $13^{\text {th }}$ February 1985. This seems to have been almost two weeks after the name "Mwakenya" was coined on $1^{\text {st }}$ February 1985 according to Nyayo House Story, 24.

${ }^{104}$ Friedrich Ebert Stiftung and Citizens for Justice, Nyayo House Story, 23. Also see Kinyatti, History of Resistance, $432 \&$ 433. According Kinyatti the monthly journal, Mpatanishi, was launched by the December Twelve Movement in 1983.
} 
Alongside Pambana, Mpatanishi played a crucial role of educating the masses about the nature of the struggle. They defined the ideological path of the struggle and identified what they saw as the enemy of the people. ${ }^{105}$ In its Draft Minimum Programme published in 1987, Mwakenya proffered the most far-reaching outline of the vision to guide resistance against Nyayoism and neo-colonialism. It stated the tasks and challenges that were facing Kenyan people in their struggle to realize what it described as the second and third stages of the National Liberation process. In essence, it laid out the central objective of the movement as bringing about a national democratic revolution as the spring board for meaningful social change. ${ }^{106}$

Furthermore, it saw its work as fostering the dramatic development of democracy as embodied in the emergence of worker/peasant based underground groups. For this to happen, the movement believed it needed to begin articulating an ideology that fully reflected the workers' struggle and, as such, become the real voice of the Kenyan people. ${ }^{107}$ In so doing, intellectual progressives and political activists saw themselves as fitting into the Mau Mau tradition of resistance in an ongoing struggle of the people for social justice and economic liberation. ${ }^{108}$ Indeed, Mwakenya's stance reflected the same anti-capitalist, anti-foreign, egalitarian, socialist, pro-Mau Mau strand of thought that can be traced from Oginga Odinga, Bildad Kaggia, J.M. Kariuki to Ngugi wa Thiong'o. ${ }^{109}$ Overall, therefore, early Mwakenya publications of 1980s sought to capture and provide as close a picture of the situation of the country as it was felt and experienced by the majority; to provide a barometer of the state of class struggle in Kenya; and to challenge the ideology of the ruling class. ${ }^{110}$

Besides these two leading underground movements, there were vocal organizations in the USA and Britain. Umoja, operating in London, was one such organization put together by Kenyan intellectual and political activists. In one of its signature publications, Umoja, which also styled itself as United Movement for Democracy in Kenya, put together a detailed summary of

\footnotetext{
105 Kinyatti, History of Resistance, 433.

106 Umoja, Moi's Reign of Terror, 3.

${ }^{107}$ Mwakenya Draft Minimum Programme, 13, as cited by Durrani in "The Other Kenya," 80.

${ }^{108}$ Kinyatti, History of Resistance, 434; also see Durrani, "The Other Kenya," 80.

${ }^{109}$ Hornsby, A History Since Independence, 415.

110 Durrani, "The Other Kenya," 80.
} 
what it termed a decade of Moi's Reign of Terror and crimes against the people of Kenya. ${ }^{111}$ In it, it criticized the celebration, by the Moi regime, of a decade on Nyayoism during which Kenyans were persistently urged to stand on their heads with shouts of "Nyayo juu" (Power to Nyayo). Umoja saw this celebration as a mockery of the struggle, which had inspired December Twelve movement. Nyayo's ten years, the group pointed out, had seen the most concerted efforts at colonial restoration with Moi as the colonial governor issuing orders from State House. In Moi's Reign of Terror, they supported this charge by arguing that the Moi government had surrendered the Kenyan economy to foreign Western control thus turning the country into the private property of a few foreign companies reminiscent of the Imperial British East African Company days; by outlawing all forms of political, social and cultural organizations that were people-based as in the days of Governor Sir Evelyn Baring around the same time Moi served as a member of the LegCo; by introducing the queue system of electing political chiefs (otherwise known as "member of parliament"); and by re-introducing the 8-4-4 system of education. ${ }^{112}$

It was on this basis, then, that Umoja, criticized Moi's symbols and conception of power and his vision of Kenya's future, which according to the movement, was derived from the colonial past that underpinned his ideological inclinations. It was no wonder, Umoja pressed, the first ten years of his rule had been a decade of economic, political, social and cultural crimes perpetrated against ordinary people. ${ }^{113}$ It labeled this period of Moi rule as "ten years of economic misery" even though the economy was hailed by backers in the west as an economic miracle specifically because there was an environment that was extremely favorable to foreign investment enabling multinational corporations (MNCs) to reap enormous profits. Yet, behind the façade of tall buildings lay the reality of the country's economic misery. ${ }^{114}$ Since independence, Umoja argued, Kenya had pursued an externally-oriented development strategy that had been inherited from colonialism. It relied on private enterprise and production for profit as the engine for growth. It also enriched a small class of Kenyans, but this strategy failed to meet even the most basic needs of the majority of Kenyans. ${ }^{115}$

\footnotetext{
${ }^{111}$ Umoja, Moi's Reign of Terror, 2.

112 Ibid.

113 Ibid.

114 Ibid., 5.

115 Ibid.
} 
Furthermore, Moi promised, when took power in 1978, to stop corruption but the evidence of his ten-year rule, noted Umoja, demonstrated what he really meant: as far as Umoja was concerned, Moi stopped corruption in as far as it enabled his close associates to engage in corrupt activities. ${ }^{116}$ This is an observation validated by other observers. According to Hornsby, while Moi's government promised to rid Kenya of corruption, it was worsened by his take over. ${ }^{117}$ Thus, corruption of the late 1980s was a little worse than in the 1970s. Moi followed Kenyatta's grabbing footsteps and overtook him by far. ${ }^{118}$ Elephant herds were decimated under Kenyatta not Moi. But the 10 per cent kickbacks of the Kenyatta era became 25\%-50\%, sinking some projects, while others appeared constructed primarily for the rent-seeking opportunities they gave. ${ }^{119}$

While the principle of elite corruption had been established under Kenyatta, Moi practised it on a grander scale, and could not have stopped it even if he tried. After all, his survival rested on fragile corruption based elite alliances, and to have broken these would probably have destroyed his government within months. ${ }^{120}$ Corruption had ended only in as far as the nexus of accumulation started, by 1982, shifting from the Kikuyu to the Kalenjin and with Moi himself rapidly acquiring assets, generally using other names. Like Kenyatta before him, Moi increasingly diverted resources into the off-book and parasitic sector of the economy in which insiders extracted resources from the state for private benefit via bribery, abuses of procurement and perks of office. ${ }^{121}$

Yet, while grand corruption was on the rise, Kenyans faced mass starvation in 1980 as the country could not feed itself, a contradiction that Umoja did not hesitate to highlight. Umoja pointed out that this was the first time since independence that Kenyans had been forced to queue for maize. Yet, they had corruption to thank for all their woes as it emerged that highly placed officials and ministers close to Moi had exported maize supplies for personal profit. In 1982,

\footnotetext{
${ }^{116}$ Ibid.

${ }^{117}$ Hornsby, A History Since Independence, 369.

${ }^{118}$ Umoja, Moi's Reign of Terror, 10.

${ }^{119}$ Hornsby, A History Since Independence, 441.

${ }^{120}$ Ibid., $369 \& 441$.

${ }^{121}$ Ibid., $369,371 \& 441$.
} 
alleged Umoja, Moi's most trusted lieutenant, Nicholas Biwott, was implicated in a corrupt $\$ 15$ million South African maize deal. ${ }^{122}$

In addition, the Moi government was reported by the controller and auditor-general to have lost Ksh. 420 million in hosting the $4^{\text {th }}$ All African Games in 1987 due to irregular tender awards, award and variation orders for construction and game facilities. A company owned by Ketan Somaia, a close business associate of Moi, was awarded a controversial transport tender during the games for which it was paid Ksh. 29.5 million. Although the company was paid the money in full, the controller and auditor-general reported that it did not provide enough vehicles and the games committee was forced to spend more money in hiring other vehicles. ${ }^{123}$ It is worth noting that between 1985 and 1991, Somaia's Dolphin Group grew to national prominence, with contracts to supply military equipment, computers and other goods. From a humble twenty-six year old shop-owner in Kisumu, Somaia acquired significant interests in a large number of companies including Firestone, Marshalls, Kobil Oil, Fox Theatres (East Africa Ltd), Commercial Bank of Africa, Royce Motors, Danny Construction, Rift Valley Hatcheries, Lima Limited, Transnational Bank, Trust Bank and Siginon Freight. ${ }^{124}$ Somaia was reputed to have secured procurement forms from the Office of the President with the spaces for prices left blank to be filled as he wished. ${ }^{125}$

Therefore, it was clear to government critics such as Umoja that the Moi regime was guilty of misusing the county's hard-earned foreign exchange for the acquisition of private companies. Umoja pointed out the fact that the illegal drain of Kenya's foreign exchange reserves had dramatically increased under Moi. The movement cited figures that it attributed to the International Monetary Fund (IMF) that observed that foreign currency deposits abroad had risen from Ksh. 14.8 billion in 1982; to Ksh. 67.5 billion in 1985; and Ksh. 80.6 billion in 1986. According to the said IMF figures, it was estimated that more than $\$ 4,000$ million were held in

\footnotetext{
${ }^{122}$ Umoja, Moi's Reign of Terror, 5, 6 \& 9.

${ }^{123}$ Ibid., 9-19.

${ }^{124}$ Ibid., 10 and Hornsby, A History Since Independence, 443.

${ }^{125}$ Hornsby, A History Since Independence, 443.
} 
overseas accounts. Further, Umoja cited World Bank estimates that in the first six months of 1988 alone, Kenya lost over $\$ 175$ million. ${ }^{126}$

All the while, Umoja further stated, land hunger was on the increase in Kenya. In absolute terms, there was more land hunger in Kenya than there had been during the colonial period. Millions of peasants continued to exist on small holdings, many on marginal land as land ownership continued to be skewed in favor of the wealthy. Ten per cent of Kenya's population, claimed Umoja, owned $73 \%$ of the land. 1.6 million hectares of land were estimated to be under plantation agriculture that was predominantly foreign-controlled by companies like Del Monte and Brooke Bond. One Greek landlord owned more than 13,000 acres in Taveta while many Kenyans were forced to be squatters there. Most land in the Coast Province was also owned by absentee landlords who purchased the land for speculative purposes. ${ }^{127}$

In light of this gross inequity and inequality, Umoja accused the IMF and World Bank of overseeing the misery of Kenyans, the majority of whom were poorer under Moi's rule. During his reign, shortages of basic foodstuffs and vital items like kerosene, and cooking gas became endemic. The 1980s saw food shortages, rising prices, foreign exchange crises, budget shortfalls and growing debt. ${ }^{128}$ Kenya became a nation overburdened by debt, which increased from around \$250 million in 1979 to $\$ 650$ million $1985 .{ }^{129}$ Umoja alleged that by 1989 , it was estimated at over $\$ 4$ billion. ${ }^{130}$ As a result, $32 \%$ of the national income from exports went to service this growing debt. Yet, by October 1985, Moi continued heavy borrowing from the IMF having been extended $\mathrm{Ksh} /=12,118$ billion credit. This loan brought with it IMF officials to plan and direct Kenya's economy, which resulted in loss of independence with regard to the national development priorities. The result was frequent devaluations of the Kenya currency that were undertaken under pressure from the IMF and World Bank. The Kenyan shilling was devalued in

\footnotetext{
${ }^{126}$ Umoja, Moi's Reign of Terror, 10.

127 Ibid., 11.

${ }^{128}$ Hornsby, A History Since Independence, 356 \& 360. Moi needed new sources of funds to ensure fiscal stability during the transition, and like a compulsive shopper, according to Hornsby, Kenya hurried from bank to bank. Where in 1978 Kenya owed US\$35 million in commercial debt to eight finance institutions and by 1983 it owed $\$ 340$ million to 14 different sources most of which were banks.

${ }^{129}$ Umoja, Reign of Terror, 11, figures are a little inflated but Hornsby, A History Since Independence, 360 gives more accurate ones. Hornsby notes that in 1982-83 Kenya's internal debt stood slightly over US\$450 million with US\$200 million in foreign debts in the same years.

${ }^{130}$ Umoja, Moi's Reign of Terror, 10.
} 
1982 by $15 \%$, which was the third devaluation in a matter of a few years. ${ }^{131}$ At 24 to the dollar in 1990, the shilling was worth less than a third of its value when Moi took office. ${ }^{132}$

Consequently, there was a decline in government spending on social services like health, education and housing. As a way out, the Moi government by the late 1990s was talking of the introduction of cost-sharing in these areas. Under Bretton Wood institutions economic prescriptions, anti-worker measures such as wage freezes, the privatization of state parastatals and the removal of price control of basic food items that led to worsening conditions for ordinary Kenyans were resorted to. ${ }^{133}$ As a result, housing remained a dream for millions of Kenyans. More than $30 \%$ of the population in Nairobi and Mombasa, Umoja argued, "lived in cardboard shanties" of Korogosho, Mathare, Majengo and other informal settlements or slums. Furthermore, 8.8 million Kenyans were too poor to afford adequate nutrition. In a decade since the beginning of Moi's rule, life expectancy declined from 57 to 54 years. Kenya was also classified by UNICEF among countries with high infant and child mortality rates and $30 \%$ of children suffered from malnutrition. Each year, more than 100,000 children under the age of five died as a result of poor food or lack of adequate medical care. ${ }^{134}$

As such, Umoja concluded, the Moi regime had proven itself incapable of meeting the meeting the basic needs of Kenyans, a huge section of whom lived under the most deplorable conditions deprived of food, clothing and shelter. They suffered from miserable wages that could not meet the most minimum needs such as clothes, food, transport, rent and school fees among others. Even professionals, like teachers and middle-ranking civil servants, had been hard-hit. Hospitals went without adequate or essential medical drugs and conditions got so bad that two or three patients were forced to share beds and mothers in maternity wards delivered on hard cement floors. ${ }^{135}$ Moi, as Hornsby observed, had inherited a slow-motion economic crisis not of his own making, but which his initial expansionary and inclusive policies had worsened. This

\footnotetext{
${ }^{131}$ Ibid., 12; also see Hornsby, A History Since Independence, 358. According to Hornsby under pressure from the IMF and World Bank, Kenya devalued the shilling in September 1981 and again in 1982.

132 Hornsby, A History Since Independence, 420.

${ }^{133}$ Umoja, Moi's Reign of Terror, 12.

${ }^{134}$ Ibid. These life expectancy estimates are confirmed by Hornsby, A History Since Independence, 579 although the period covered is 2000 when it stood at 52 years.

${ }^{135}$ Umoja, Moi's Reign of Terror, 12-13.
} 
coupled with his increasing personal insecurity that led to the strengthening of the bureaucraticexecutive state only increased his critics. This was especially the case as the economic situation continued to nosedive in the late 1980s and early 1990s. The church in Kenya, that had been quiet, stirred and ratcheted up its criticism adding to the rising crescendo of political opposition.

\section{Jolted into Political Action: The Church as a Critical Public}

In the early Moi years, the church in Kenya, like the rest of society, was indeed at the forefront of embracing the president as the defender of the poor, a fighter of corruption and the savior of non-Kikuyu from Kikuyu exploitation. ${ }^{136}$ A member of the African Inland Church (AIC), Moi identified himself as a devout Christian and defender of Christ. Building on this natural personal strength, Moi sought to use the church in Kenya as a crucial instrument of legitimization and invited it to play an active role in managing the country. As Moi saw it, it was the role of the church to help the government to maintain peace and order. Indeed, the church was part and parcel of the government a position that was affirmed by his vice-president who asserted that politics and religion were inseparable. ${ }^{137}$

For that reason, it would seem that the church did, initially, accept Moi's invitation at face value. ${ }^{138}$ After all, Moi apparently seemed to offer a less corrupt alternative and a leader with the will to spread the country's wealth to those who had been neglected and underprivileged in the former regime. ${ }^{139}$ Obviously, the idea of the country being ruled by a devout Christian who respected the churches and was guided by the philosophy of love, peace and unity was appealing. ${ }^{140}$ At best, the church seemed to have taken a wait-and-see stand in the early years of Moi's rule, and, perhaps, was even deluded by his Christian populist posturing. ${ }^{141}$ Thus, the churches seldom objected publicly to the Moi regime's growing coerciveness especially between 1980 and mid-1982 when he embarked upon an increasingly oppressive course. ${ }^{142}$ Sabar aptly catalogues the path to this course:

\footnotetext{
${ }^{136}$ Sabar, Church, State and Society in Kenya, 178.

${ }^{137}$ Ibid., 178-179.

${ }^{138}$ Sabar argues that there are no indications or evidence to prove otherwise. Ibid., 179.

${ }^{139}$ Ibid.

140 Ibid.

${ }^{141}$ Ibid., 181.

142 Ibid., 179.
} 
He limited the freedom of debate in parliament by threatening to 'take disciplinary action,' including use of the police, against KANU members who crossed the line between acceptable and unacceptable speech. He increased his personal control of KANU by promoting his supporters and not calling meetings of the party's governing bodies. He undertook a campaign against dissidents and 'political splinter-groups', using tactics such as rumour-mongering, false accusations of corruption and selective dismissals and appointments. He threatened and harassed journalists and editors, university students and faculty, and leaders of the Law Society of Kenya and other professional organizations who criticized.... He reintroduced detention without trial -a measure that he himself had suspended when he came to office in 1978.... He set in motion the process of making Kenya a de jure one-party state. ${ }^{143}$

Yet, through this all, the church in Kenya was largely silent with only a few lone voices being raised against these patent abuses and, even then, not very loudly. ${ }^{144}$

But, according to Sabar, this apathy cannot only be explained in terms of Moi's devoutness, brotherly demeanor or his attempts to co-opt the church. Rather, what she refers to as the Kenyan church's ambiguous and ambivalent mediative role in Kenyan politics ran much deeper in the country's history and, especially, the Kenyatta years. At independence, the church complimented the state by providing social services in the areas of education, healthcare and economic development. While it started speaking publicly on social and economic issues of the day and take a more critical stance in the 1970s, the church was never engaged in any in-depth, or comprehensive consideration of its overall role in society or vis-à-vis government. ${ }^{145}$ Rarely did the church challenge the overall structure of power and, at times, it seemed oblivious to the flawed socio-political structure. ${ }^{146}$

\footnotetext{
${ }^{143}$ Ibid.

144 Ibid., 180.

${ }^{145}$ Ibid., 150; Paul Gifford, Christianity, Politics and Public Life in Kenya (London, 2009), 227, in discussing why there has been so little prophetic Christianity in Kenya and the reason churches are so uncritical of the dysfunctional system of which they are such pillars makes the same observation: that is, that churches, especially the mainline ones see themselves primarily as service providers, which is where they focus their energy. But Gifford goes a step further to also explain that in some mainline churches, leaders resemble chiefs protecting the interests of their tribal churches in comparison with which issues of good governance are rather subsidiary; the fact that missionaries are so aware of the resentment towards them and as such keep their silence; and the conviction that the reason for the plight of the nation is exploitation on the part of the West and, thus, pay little or no attention to Kenya.

${ }^{146}$ Sabar, Church, State and Society in Kenya, 150; also see Gifford, Christianity, Politics and Public Life in Kenya, 228.
} 
However, the coup of 1982 was a turning point that radically altered this lethargic stance. ${ }^{147}$ The coup jolted the church, which now woke up to the dual threats of chaos and of military rule as well as the restrictive measures that Moi instituted in its aftermath, which dashed all hopes and expectations that the president had aroused when he first took office. ${ }^{148}$ Indeed, the church had gradually started to stir from its political slumber a little earlier when, in August 1981, Henry Okullu, who had been a thorn on the side of the Kenyatta government, hinted at an analogy between the greed and corruption of South Africa's rulers and Kenya's. ${ }^{149}$ It is quite notable that the church had taken a non-committal stance. It is possible that it may even have been deluded by Moi wearing his Christian credentials on his sleeves. However, the election of Manessas Kuria as archbishop in 1979 and Alexander Kipsang Muge as bishop in 1983 meant that the Anglican Church of Kenya, at least, was readying itself to play a more active role in state affairs. ${ }^{150}$

Before the coup, moreover, there is further indication that the church was changing its attitude. This is to be found in a document produced by the Anglican Church of Kenya in 1981, Recommendations on the Mission of the Church in the Changing Society. ${ }^{151}$ It was the outcome of the church's conference of thirty-six delegates. They declared both evangelism and socialpolitical involvement as part of Christian duty. Moreover, it stated that the church had a prophetic ministry to the state, in which it was to act as the conscience of the people, declaring God's will and rebuking error. ${ }^{152}$ This was a more radical statement of the church's role than previously enunciated. The document acknowledged the partnership between the state and the church with regard to development, education and health. However, the fact that it went as far as asserting that the church had to do everything possible to encourage the catering of the poor, famine stricken, refugees, the sick and all who were victims of unjust social structures meant that it was questioning the configuration of socio-political power in Kenya. ${ }^{153}$

\footnotetext{
${ }^{147}$ Sabar, Church, State and Society in Kenya, 184.

148 Ibid., 189.

${ }^{149}$ Ibid., 180. This was at a conference of the All African Council of Churches in Nairobi.

${ }^{150}$ Ibid., 181. According to Sabar, Muge showed radical proclivities in his criticisms of political corruption and detention without trial whereas Kuria, while expected to be more moderate than Okullu, promised to take a more active role than his predecessor to the position of Archbishop, Festo Olang'.

${ }^{151}$ Sabar, Church, State and Society in Kenya, 182.

152 Ibid.

${ }^{153}$ Ibid.
} 
But after the coup, the church emphatically stamped its role as a spokesman for the ordinary folk who were so caught up in the struggle for subsistence and survival in their everyday lives or so effectively politically gagged and cowered by the Moi regime, to do so themselves. Indeed, by so doing, it was ironically responding to the Moi government's invitation for the church to play a prominent role in Kenya's politics. In the aftermath of the coup, increasing rebukes of the state's abuse of power by the church dovetailed with intensified calls for nyayo by Moi who expected it to propagate the philosophy and, thus, build support and legitimization for his regime, to produce a new critical theology. ${ }^{154}$ The Church got a chance to layout this new theological stance when Moi asked the conglomeration of Christian denominations, operating under the umbrella of the National Council of Churches of Kenya (NCCK), and the Catholic Secretariat, to work together with the Ministry of Education to teach nyayo alongside religious education. ${ }^{155}$

Consequently, in 1983 the NCCK produced A Christian View of Politics in Kenya: Love, Peace and Unity. ${ }^{156}$ Rather than provide the regime with the theological legitimization it expected, the preface of the book posed, "Whose nyayo is the nation to follow?"157 In answering this question, the writers stated that the only human leaders in whose footsteps it was right to follow was one who was an imitator of Christ. This suggests that when it came to taking political positions lay people were to look to the church for direction. At the same time, noted the book, it was the duty of the church to assist, guide and encourage the president so that he could fulfill his duty of being a good imitator of Christ.

However, it was in addressing the three pillars of the nyayo philosophy of love, peace and unity that the church demonstrated this newfound and bold critical theology. In its interpretation of the love component of the philosophy, it posited that the ruling party, KANU, would have

\footnotetext{
154 Ibid., 185.

${ }^{155}$ Ibid. It is also probable that Moi made this move in response to Archibishop Kuria's call in September for the full participation and involvement of the churches in restoring peace and order after the coup.

${ }^{156}$ Sabar, Church, State and Society in Kenya, 185. The book was compiled from papers solicited by the Theological Department of the NCCK, which were then modified and molded into a coherent text. Although the NCCK commissioned the undertaking before the coup and before the government's request that it teach nyayo in schools, Sabar argues that it was clearly expanded afterwards.

157 As cited by Sabar, Church, State and Society in Kenya, 185.
} 
aptly modeled this nyayo call by opening the party to all who wanted to vie for its various organizational positions, in government and parliament. Further, it argued that Kenyans needed to be allowed to demonstrate their love for Kenya through active and responsible participation as opposed to perfunctory involvement in public affairs that only served to rubber stamp the existing authorities. ${ }^{158}$ The proper and practical application of nyayo philosophy of love was to be embodied in a participatory society in which Kenyans of all stations and circumstances were actively involved in the building of a true community. ${ }^{159}$

Moreover, with regard to the peace component of nyayo philosophy, the NCCK argued that this required the state to meet its obligations to the poor, needy and oppressed. Further, peace was to be structurally embedded in legal and judicial systems that were honest and just. ${ }^{160}$ It was suggested that there was no peace when opponents were sacked by the regime for supposedly being anti-nyayo. ${ }^{161}$ After all, peace in politics was exemplified by the free exchange of ideas and fairness in the political process.

Lastly, the book advocated for national unity built on celebration of diversity rather than a unity founded on the idea of the leader becoming consciously or unconsciously identical to a god, and his words, regarded as celestial decrees. Further, it argued that discrimination in job distribution and educational opportunities was detrimental to national unity. It was in this chapter espousing what unity meant to the church that the NCCK mentioned the abortive coup. While it did not censure the attempt, it did suggest that there may have been good reasons for it. ${ }^{162}$ This resonated and reinforced the call for a more just division of wealth and the renewal of Kenya's commitment to socialism and democracy that was published in a Roman Catholic bishops pastoral letter not very long after the attempted coup. ${ }^{163}$

So, even though the NCCK did not directly mention Moi, the church in Kenya had theologically crossed and/or bridged a significant historical threshold. Here was an official

\footnotetext{
${ }^{158}$ Ibid., 186.

${ }^{159}$ Ibid., 187.

${ }^{160}$ Ibid., 186.

${ }^{161}$ Ibid.

162 Ibid.

${ }^{163}$ Ibid., 183. This was on $10^{\text {th }}$ September 1982.
} 
document critical of the Moi regime and one that was intended for widespread circulation. ${ }^{164}$ Further, the church pulled no punches with regard to how the government was managing public affairs. Hereafter, the church plunged onto the national political stage taking on the government when and where other public actors, professionals and individuals were content to fight anonymously underground. This, also, came at a time when the bulk of the Kenyan population were effectively muzzled or simply cowed into political silence. Boldly, the church treaded into matters of electoral politics and other issues in the narrowly defined political realm. ${ }^{165}$ As Sabar notes, the NCCK, in this document and later sermons, emphasized the right and duty of Kenyans to participate in political processes and the need for the unimpeded expression of criticism.

Moreover, it took on an unapologetic tone. Rather than cooperate with the government to preside over a euphemistic peace and order and, thus, keep a tight leash on popular discontent, the Church emerged as the foremost dissident. ${ }^{166}$ Speaking behind the sacrosanct shield of the altar made the pulpit to emerge as a forum for the restoration of the government to correct order, right rule and back to and for the people. ${ }^{167}$ It was not lost on Moi that there was a sharp divergence of his expectations and those of the people as voiced by the church. But before he frantically attempted to shut the door of biting criticism that he himself had inadvertently opened, there was a deluge of righteous admonitions. Urged by the Anglican Church, the Catholic and Protestant churches joined the fray. Pastoral letters calling for a public campaign against corruption and calling for political pluralism as a pillar of truly democratic system were published. ${ }^{168}$ As a result, the Church became the omnibus for legal protest, political expression and civic involvement. ${ }^{169}$ It also provided Kenyans with a radical alternative to nyayoism and, further, acted as the final bulwark of increasingly circumscribed political space. ${ }^{170}$

By so doing, the Church acted as the sacred preserve and refuge of the Mau Mau spirit of Kenya's enduring liberation struggle. It was, literally, a vital plank, cornerstone and last line of

\footnotetext{
${ }^{164}$ Ibid., 187.

165 Ibid.

166 Ibid., 187-188.

${ }^{167}$ Ibid., 188-189; also see Timothy Njoya, "Pulpit as a Forum for the Restoration of Government," Unbound: An Interactive Journal of Christian Social Justice ( ${ }^{\text {st }}$ February 2012).

168 Sabar, Church, State and Society in Kenya, 188-189.

169 Ibid., 190.

${ }^{170}$ Ibid., 189-190.
} 
defense against the onslaught of individual freedoms and human rights restricted by Moi's oppressive government. One of the crucial battlefronts was the debate that preceded the controversial queue-voting system dubbed "mlolongo" (lining up) introduced by Moi for the 1988 election year.

\section{Mlolongo -Moi's Electoral 'Stroke of Genius': The Long-winded Exit}

The "mlolongo" system, if it can be so dignified, was conjured by Moi to exorcize political undesirables from the ruling party and parliament, replenish sycophantic talent and, hence, drown and blunt the din of growing public criticism by surrounding himself with a small but extremely loud group of party hacks and lackeys who competed to outdo each other in nyayo songs of praise. ${ }^{171}$ By sneaking-in the "mlongo" system in which voters were expected to stand in a line behind their preferred candidate for parliament or his/her portrait, in party-level elections conducted in that same manner, Moi single-handedly shifted and shaped political debate in Kenya for the rest of his presidency. The call for political pluralism, constitutional democracy and respect for human rights and freedom now took center-stage displacing everyday concerns and struggle appertaining to poor socio-economic conditions.

This shift of political priorities and demands reflected renewed optimism and, by extension, a new strategy for social change amongst Kenyans who reasoned that, perchance, if the political structure on which society rested could be amended, they could, at last, enter the promised kingdom that had been elusive since independence. The mlolongo debate, and the shambolic elections of 1988 that followed, marked the beginning of the long end of the Moi presidency. While political and constitutional gains were made after 1988; throughout the 1990s; and right up to Moi's exit from power in 2002, Kenya's economy floundered miserably and regressed. Dwindling economic fortunes squeezed large sectors of the population who did not benefit from state largesse or who were excluded by the government's pork barreled allocation of

\footnotetext{
${ }^{171}$ At an indistinct period during Moi's first decade in power, the nebulous term, slogan and policy-guiding radar, nyayo, which underscored the uncertain direction that he was taking the country, became synonymous with the man. Once just an idea and philosophy, nyayo took on the veritable flesh and blood image of President Moi who had given the word its political life and career, if not meaning. The philosophy now became, Nyayo, embodied in the person of the presidency especially in the effusion of political praises showered onto Moi by his political sycophants. The idea was the man and vice versa.
} 
social services dictated, as it was, by political retribution, ethnic discrimination and nepotism of both blood and opportunistic political elite-ties. ${ }^{172}$ It is also not surprising that 1988 was the turning point in the country's politics characterized by multiple voices and mass protests staged in literal political spaces such as the Kamunkunji grounds, Uhuru Park, city streets and empty work places that became theatres of grievance and anti-government opposition. After the rigged elections, popular loathing of Moi was widespread and barely contained especially in Central and Western provinces. ${ }^{173}$ But, more importantly, an informal culture of defiance gripped the country. ${ }^{174}$ Mass protest for political reforms and bifurcated sector or profession-specific airing of socio-economic grievances gradually squeezed through the closing political gates held open by the timely Samsonian involvement of the Church in politics towards the end of the 1980s.

\section{“Pambana!" With one Voice: The Veil of Multiparty Democracy and Atomization of Opposition}

As already noted, the Church, towards the end of the 1980s, was virtually the only organization in Kenya that could fearlessly bear the banner for Kenya's second liberation. ${ }^{175}$ Even as early as the 1970s the outspoken Anglican cleric Okullu advocated for the church to step back from society in order to make an independent and objective contribution in building a stable and right body politic. Besides criticizing the comfortable relationship between the church and the state; what he saw as the church standing alongside the powerful and the rich against the weak and the poor, Okullu, from early after Kenya had become a de facto one party state, stressed the importance of a multiparty system. As far as he was concerned, democracy meant there always being an opportunity provided for alternative government. ${ }^{176}$ Although Okullu had conspicuously been long silent over the issue of multipartyism since the early days of the republic, he compared the one-party dictatorships in Africa to those in Eastern Europe in a December 1989 sermon at a time when the latter were being assailed by street protests and were

\footnotetext{
172 Sabar, Church, State and Society in Kenya, 151.

${ }^{173}$ Ibid., 211.

174 Ibid.

175 Ibid., 189.

${ }^{176}$ Ibid. 163. Although Okullu had come early to an understanding of the value of multipartyism; had spoken out against the banning of the Kenya People's Party (KPU) in 1968; and had advocated for political pluralism in his book, Church and politics in East Africa (1974) he did not always maintain that this was an essential element of democracy according to Sabar, 212. Indeed, in his book Okullu conceded the possibility that democracy could be attained within a single-party system.
} 
on the verge of collapse. In his sermon, Okullu predicted that just as Nikolai Ceausescu had been overthrown in Romania, so too would African dictators be ousted out power in East Africa. ${ }^{177}$ This touched-off one of the most heated eras in Kenya's political history dubbed the "Second Liberation" struggle. Mau Mau songs made a comeback as new songs of/for a higher liberation and resistance against the Moi state were composed and flourished in the underground Nairobi music scene. ${ }^{178}$

Although the church's criticism had waxed hot and cold through the years, critical election-years seemed to provoke bold stances. Like most other Kenyan elections, the general elections of 1983 were rigged as Moi continued to rid himself, the party and the government of Kenyatta's men among them the powerful Charles Mugane Njonjo. Blatant and targeted rigging occasioned accusations of the elections as a fraud: they were assailed as mismanaged, unfair and unfree. Archbishop Kuria went as far as arguing that although Kenya had been politically independent for twenty years, it was important for Kenyans to ask themselves whether social, economic, and intellectual freedom had been obtained: were Kenyans free? As Sabar points out, this became a common refrain that rose to a new crescendo in the run up to and after the 1988 mlolongo elections. ${ }^{179}$ After this and other monstrosities of the 1980 s, the country was entering a new political dispensation and tide that even the self-styled strongman Moi could not turn back. Kenya, at the end of the tumultuous 1980s was poised to enter into an even more turbulent decade of resistance against the state characterized by chaos, bloodshed and confusion as people agitated and milled to enter a socio-economic and political Canaan, which, they believed could be heralded by constitutional and political reforms. Evidence of this widespread discontent was everywhere for Moi to witness. ${ }^{180}$ In late 1989 and early 1990 s, there were student demonstrations at the University of Nairobi, which turned violent and a workers' strike in Ruiru a peri-urban industrial town a few miles outside Nairobi. ${ }^{181}$

\footnotetext{
177 Sabar, Church, State and Society in Kenya, 213.

${ }^{178}$ Hornsby, A History Since Independence, 478.

${ }^{179}$ Sabar, Church, State and Society in Kenya, 184. This criticism, as Sabar points out, was from an Anglican Church leadership that had demonstrated their reluctance to denounce the intimidation and fraud that accompanied elections during Kenyatta's term.

${ }^{180}$ Branch, Between Hope and Despair, 184.

181 Ibid.
} 
This era of chaos and confusion was inadvertently captured by Bishop David Mukuba Gitari's sermon of end April 1989 entitled, "God of Order, not of Confusion."182 Talking to his flock in Kirinyaga, the cleric pointed out that the process of selection of leaders was very important. Gitari told his listeners that for leaders to command respect, they had to be chosen in accordance to constitutional stipulations; and that leaders had to have the interests of the people at heart. Moi, he said, had demonstrated that he could respond to Kenyans' hardships: for instance, when the president realized that coffee farmers had not been paid anything for six months, he had directed that Ksh. 1.2 billion be paid out to them at once. ${ }^{183}$

This, the bishop noted, had come as a great relief to those families whose children had been suspended from school because they were unable to pay school fees. In like manner, leaders needed to show a genuine concern for the poor, oppressed and the hungry. Further, they were not just to be obeyed unconditionally: obedience was to be merited in all things lawful. They were not to be obeyed when their actions and decrees were unlawful. Gitari also remarked that local, regional and national election chaos left no doubt that there was a leadership crisis in Kenya. ${ }^{184}$ In concluding the sermon, no doubt leaving his audience guessing whether he was referring to election-meddling administrative officers or their boss, the president, Gitari said: "when one individual thinks he has the indisputable mandate to determine people's political destiny, thus denying us the opportunity to exercise the very rights for which Kenyans fought and won at independence, we get very confused. We are being tossed about by the political whims of one person ...this is confusion; and our God is not a God of confusion.” Boldly, Gitari told his audience that there was need for peace in Kirinyaga and the nation: this, he added, was not the passive acceptance of things. Rather, it was a path to peace that called for the confrontation of situations and seeking to correct things where they had gone wrong. ${ }^{185}$ As Hornsby aptly observed, an increasingly angry and loud voice was emanating the pulpit and in particular Gitari's altar, as the church in Kenya edged closer to a call for open resistance to the state. ${ }^{186}$

\footnotetext{
182 David Gitari, In Season and Out of Season: Sermons to a Nation (Eugene: Wipf and Stock, 1996), 81.

183 Ibid., 84.

184 Ibid.

185 Ibid., 85.

${ }^{186}$ Hornsby, A History Since Independence, 480.
} 
A week later, Gitari told another congregation that peace would not come if KANU was evaded. He told his listeners that he was ready to wear his red cassock and the clergy in their black robes would escort him to appear before the party to air their concerns regarding recent developments within it. This statement came at a time when the country had witnessed one of the most blatant election malpractices in the full glare of national publicity. In September 1988 Kenneth Matiba had been rigged out of Kanu chairmanship in Murang'a in favor of Joseph Kamotho. In a forced by-election in Kiharu, Murang'a held in December of the same year, the incumbent MP, Matiba, was rigged out in favor of KANU's choice, Gidraph Mweru. ${ }^{187}$ As a result, Matiba dramatically resigned his cabinet post and was subsequently expelled from KANU. Facing-off Mweru in February 1989, a visibly shaken Julius Gikonyo Kiano was seen on television when Mweru was announced the winner although it was evident that far fewer people had queued to support him than the number who supported Kiano's line. The latter received over $90 \%$ of the queue vote only to be declared the loser, in an election that epitomized the Moi regime's contempt for democracy. ${ }^{188}$

But, Gitari did not specifically speak to this controversy. Instead, in his sermon of $9^{\text {th }}$ April 1989, he chose to espouse on the meaning of shalom, peace. The bishop taught his congregants that peace meant welfare and well-being at their best and at their highest. It was one of the beatitudes and all those who did anything to increase the well-being and welfare of the world were blessed. Participating in social transformation, Gitari said, was God-ordained: this was through various ways. It included scientists seeking for a cure for HIV/Aids and other deadly diseases; toiling on the land so that the hungry could be fed; and when tea farmers cried out that they were losing many kilos of picked tea-leaves because of delays in delivery to the factories, and someone heard those cries and responded positively, wasn't that the way of peace? ${ }^{189}$

Another critical voice coming from the church around this time was that of the Rt. Rev. Alexander Kipsano Muge. Unlike Okullu and Gitari, he was not viscerally opposed to single-

\footnotetext{
${ }^{187}$ Ibid., 461.

${ }^{188}$ Gitari, In Season and Out of Season, 86 \& 88; also see, Hornsby, A History Since Independence, 461.

${ }^{189}$ Gitari, In Season and Out of Season, 88.
} 
party politics but he wanted to see the ruling party clean itself up. Muge was adamantly opposed to corruption and land-grabbing. ${ }^{190}$ Witnessing soaring prices of essential goods such as maize, sugar, rice and meat beyond the reach of poor Kenyans and the resultant dovetailing between arising discontent and political dissidence between 1988 and 1990, Muge was worried about the temper of the times and the direction that Moi and KANU appeared to be headed in this regard. ${ }^{191}$ Moi and KANU had countered demands for political pluralism, opening up democratic space and human rights with increased political repression, and economic corruption continued unabated, which brought the country to the brink of looming disaster. The din of political protest was emerging from its underground years to reach unprecedented decibels in the late 1980s. However, this coincided with the apogee of a culture of governance that rewarded sycophancy, loyalty, and subservience and punished innovation, merit, critical analysis and independent thought. It had roots in the colonial era although it was refined and reinforced in the Kenyatta and Moi eras. ${ }^{192}$ As a result, the mood in the country in the late 1980s and early 1990s was sour as the consolidated status quo forces alloyed by British economic and geopolitical interests faced-off a loose but uniformly angry and frustrated groundswell of political protest.

For his part, Muge was convinced that there was no one in Moi's cabinet who was for change and political reform. Nevertheless, rather than bring change without the Moi regime, he was ready to entrust Moi's government with badly needed rectification of the country's socioeconomic and political situation. ${ }^{193}$ Giving his testimony before the KANU Review Committee that was chaired by Moi's number two, Vice-President George Saitoti, Muge demanded an end to corruption and land grabbing by powerful government figures; advocated for a two-term limit on presidential tenure; and restoration of the independence of the judiciary. Before this testimony, Muge had published his modest net worth and asked other cabinet ministers to follow suit. Muge had also warned the government of famine in West Pokot, which was part of his Nandi diocese, but the government denied this charge that was only part of a bigger cyclical regional crisis affecting the north-west and north-eastern Kenya. ${ }^{194}$

\footnotetext{
${ }^{190}$ Smith Hempstone, Rogue Ambassador: An African Memoir (Sewanee: University of the South Press, 1997$)$, 53.

${ }^{191}$ Ibid., 55.

192 Hornsby, A History Since Independence, 458.

193 Hempstone, Rogue Ambassador, 55.

194 Ibid., 117-118.
} 
To this Anglican voice was added that of Rev. Dr. Timothy Njoya of the Presbyterian Church to whom preaching radical political sermons was not new. In a New Year's Eve sermon in 1989, Njoya conjoined Okullu when he observed that the events in Eastern Europe demonstrated that one-party states failed to meet the needs of their people; were "matigari" isolated as there were from popular opinion; and were, therefore, inherently undemocratic. Njoya then made a direct call for the repeal of Section 2A of the Kenyan constitution, which had been enacted after the attempted Air Force coup of 1982 making the country a de jure one-party state. ${ }^{195}$ For Njoya, it was only a matter of time before the changes that had occurred in Eastern Europe could be seen in Kenya. ${ }^{196}$ Like Okullu and Gitari, Njoya called for the reintroduction of a multiparty system.

However, it is important to linger here to note that the Okullu-Njoya reference to the general events in Eastern Europe and, more specifically, the dramatic execution of the Ceausescus on $25^{\text {th }}$ December 1989 must have caused Moi a great deal of anxiety. Njoya's timing of this comparison must have struck raw nerves and aroused panic in both Moi and his political cohorts coming, as it did, only a short six days after this climactic spectacle of the bloody Romanian Revolution. Although there exists no evidence for it as yet, Moi, like most leaders around the world including in the West, had succumbed to Ceausescu's foreign policy genius of openness towards the rest of the non-Communist world and had made a trip to Bucharest in 1988. Indeed, it was after this visit that Moi returned to Kenya to declare that KANU was baba na mama (father and mother) thus elevating the ruling party above all national institutions and organs of the state with him as pater patrice, the ultimate patriarch at the head of the table of an informal national patron-client network and embodiment of the authoritative allocation state largesse. ${ }^{197}$

Thus, the Okullu-Njonjo comparison was not farfetched. For Romanians, Ceausescu was a political tyrant and a disaster economically just as Moi had managed to become in a matter of

\footnotetext{
195 Sabar, Church, State and Society in Kenya, 211; also see Hornsby, A History Since Independence, 471.

${ }^{196}$ Hornsby, A History Since Independence, 471; also see Branch, Between Hope and Despair, 184.

${ }^{197}$ Njonjo Kihuria, "Bedan Mbugua Recalls Muge’s Last Words,” The Star, $14^{\text {th }}$ August 2013.
} 
one decade. Parallels drawn by both clerics were made, perhaps, because Moi, like Ceausescu, had, in a very few years, elevated himself to the status of a deus homo, a man-god who lived in amplitude at the expense of the majority of suffering and struggling ordinary Kenyans. ${ }^{198}$ Like other Western-leaning African strong men, among them Mobutu Sese Seko, who nurtured various degrees of admiration for the personality cult around Ceausescu, the disgraceful fall from power, must have caused Moi great concern, anxiety or both. ${ }^{199}$ The Ceausescus, with whom Moi had dined only a few months before, had been hurriedly tried, convicted and executed by a firing squad all on Christmas Day 1989 for presiding over an oppressive regime, "genocide" and criminal abuse of power. In all probability, Moi, his sycophantic following and state intelligence organs, did not take the comparison between what was happening in Kenya with the democratic wave of change sweeping through Eastern Europe and certainly, not with revolutionary Romania, lying down or lightly. Even worse, the fall of the Ceausescus, after twenty-four years at the helm, had inadvertently started in a provincial city where a protest by the parishioners of an obscure Calvinist pastor somehow exploded into the nationwide revolt that in nine days ended in their execution. ${ }^{200}$ Hence, to hear and face similar criticism and comparison coming from the church had to be more than just unnerving: the writing on the wall in Romanian revolutionary blood invoked by the two clerics was not a political analogy that the Moi state could afford to ignore.

But the Church was not the only source of the demand for radical political reform and protest. There was both individual and collective organizational and institutional activism and resistance of urban middle-class lawyers, especially those involved in defending detained political dissidents among them John Khaminwa, Paul Muite, Gibson Kamau Kuria, Kiraitu

\footnotetext{
198 Jack Perkins, "Nikolai Ceausescu: The Unrepentant Tyrant," Biography: Absolute Power Week Documentary Series (21 $1^{\text {st }}$ September 2000).

${ }^{199}$ According to a Country Study on Zaire, Library of Congress, $15^{\text {th }}$ October 2006, Mobutu was a close ally and personal friend of Ceausescu. Indeed, the relationship between them was not only from state-to-state but also partyto-party ties that remained until the fall and execution of Ceausescu. According to this study, Mobutu seems to have admired the personality cult around his Balkan counterpart. The fall of the latter vividly presented on Kinshasa television, reportedly made a strong impression upon Mobutu whose announcement of democratization followed shortly thereafter. Popular humor in Kinshasa speculated upon the future of "Mobutu Sesesescu." Apart from the courageous comparisons made by Okullu and Njoya, there is anecdotal little in Kenyan social circles and or in the media that evidences how the news of the Romania's Revolution was received in Kenya or by Moi's inner circle. ${ }^{200}$ Donald G. Mcneil Jr, "Romania's Revolution of 1989: An Enduring Enigma," New York Times, $31^{\text {st }}$ December 1999.
} 
Murungi, Martha Karua and Gitobu Imanyara, university professors and students, sections of the business community, journalists, the "jua kali" sector and street vendors and human rights NonGovernmental Organizations (NGOs). ${ }^{201}$

But, besides this concerted effort and convergence of voices and political resistance against the postcolonial state, there is the little understood and underappreciated role of a member of the Moi cabinet in the late 1980s: Robert Ouko. Ouko, Moi's minister for Foreign Affairs, was the one exception to Muge's conviction that there was no one in Moi's cabinet that was self-critical about how the country was being ran. Indeed, both their tragic and mysterious end of lives was for more or less the same reasons.

Ouko's mysterious disappearance and the discovery of his badly mutilated body was, by its own merit, a driver for political change in Kenya. ${ }^{202}$ It was also reminiscent and similar to the disappearance and murder of J.M. Kariuki who had, in the early 1970s, emerged onto the national political stage as a leading and ardent advocate of the poor; as a lone voice in the wilderness warning against class formation in Kenya, and, therefore, against the emergence of ten millionaires and ten million beggars. ${ }^{203}$ Although not nearly as popular as JM, Ouko cut an image of a well-polished politician with a cultivated sense of responsibility expected of an able public administrator that he was. However, he had acquiesced in the excesses of the 1980s although he had not personally benefited from them in a particularly obvious manner. ${ }^{204}$ To date, two outstanding questions about who killed Ouko and why remain, and his heinous murder, as such, is one of Kenya's unresolved political mysteries.

As might be expected, many explanations and conspiracies of the Ouko assassination abound. However, one of the more eloquent explanations supporting that his elimination was not

\footnotetext{
${ }^{201}$ Sabar, Church, State and Society, 210-211; Kinyatti, History of Resistance in Kenya, 452-453 \& 463; Branch, Between Hope and Despair, 181. Also see the highly analytical and impressive work done by Robert M. Press, Peaceful Resistance: Advancing Human Rights and Democratic Freedoms (Burlington: Ashgate, 2006), 67-118. 202 Hornsby, A History Since Independence, 472.

${ }^{203}$ Kwendo Opanga, "Assassinations Since Independence," Daily Nation, $17^{\text {th }}$ February 1990, 5; “A mysterious death," Weekly Review, $23^{\text {rd }}$ February 1990, 3. Also see David William Cohen and E.S Atieno Odhiambo, The Risks of Knowledge: Investigations into the Death of the Hon. Minister John Robert Ouko in Kenya, 1990 (Athens: Ohio University Press, 2004), 3-7.

${ }^{204}$ Hornsby, A History Since Independence, 473.
} 
the "work of anti-government forces" is the silence, omission and failure of the government of Kenya to honor and respect a senior cabinet minister by flying the national flag at half-mast despite his suspicious death coming at least two weeks after being part of the president's unofficial visit to the U.S. ${ }^{205}$ This, then, is what lends credence and weight to the theory that Ouko was murdered because he had met privately with President George H. Bush and/or James Baker when Moi was not accorded the same privilege; accusations leveled against him for having been given special security protection while in Washington, DC; and having taken over the press conference in Washington at which both the president and Ouko had appeared. Most of all, however, the main accusation was what state secrets had Ouko revealed to the Americans. Whatever the reason/s for his assassination, a more central question has become, "what did Ouko know?"206

In this regard, Ouko's sister noted that, upon returning from the formally private trip for the annual Congressional Prayer Breakfast in Washington, Ouko appeared agitated, very distressed and depressed. Ouko is said to have even commented that the corruption allegations and US press interviews would kill him. ${ }^{207}$ According to Detective Superintendent John Troon, who led a Scotland Yard investigation team into the murder, a corruption dossier on which Ouko had been working regarding the rehabilitation of the Kisumu molasses plant that adversely mentioned his cabinet colleague Nicholas Biwott and Moi by extension was key. ${ }^{208}$ Ouko and Biwott, apparently, had clashed over the demands to BAK, an Italian-Swiss consulting firm, for large commissions over reviving the factory. ${ }^{209}$ The Italian-Swiss bank had been cut out of the deal. It is said that angry exchanges between Ouko and Biwott in which mutual threats were made had followed. ${ }^{210}$

More importantly for Cohen and Odhiambo, it is not the apparent revelations of corruption or the threats thereof that consumed Ouko's life. Whatever allegations of corruption he had against his colleagues, the main issue, as Muge insightfully estimated, was that he had

\footnotetext{
205 Hempstone, Rogue Ambassador, 64-71.

${ }^{206}$ Ibid., 64-71; also see Cohen and Odhiambo, Risks of Knowledge, 254-271.

${ }^{207}$ Hornsby, A History Since Independence, 475.

${ }^{208}$ Ibid., 474; also see Hempstone, Rogue Ambassador, 66-69.

${ }^{209}$ Hornsby, A History Since Independence, 474.

${ }^{210}$ Ibid.
} 
been, and was, until his fallout, an insider. In his experience working in Moi's cabinet, Ouko garnered, experienced and, therefore, knew first hand, and perhaps more and understood better than any of the regime's critics from without, "a vast array of contexts," the language of comprehension of the state and of state power as constituted in almost innocent and everyday realms of appointments, bank deposits, commercial deals, contracts, conversations, franchises, friendships, locks and keys and what is expected in the economies of relations among servants and masters and among patrons and clients. ${ }^{211}$ Ouko just knew too much and was, as such, a liability to the Moi regime.

Even without a political spat about an international investment deal gone awry, the slightest indication that Ouko would break ranks and resign as a highly placed government official with such inside knowledge made him a credible threat. Ouko's knowledge was more potent than any critique of the Kenyan postcolonial state that had come, overtime, from the likes of Oginga Odinga's Not yet Uhuru or the collective works of Ngugi wa Thiong'o. ${ }^{212}$ Such critiques from within the postcolonial left, or other critical publics for that matter, decontextualized and removed observations of the inner-workings of the state and state power from a conjecturing-distance had no purchase or value against the kind of knowledge that Ouko had. His was a far-reaching and detailed knowledge of textured practices of managing state administrations, development projects, foreign investments, consultations, commercial agencies, bank accounts, and so forth. ${ }^{213}$ Ouko possessed extraordinary details concerning international contracting, finance, transnational clientelism and such. ${ }^{214}$

As noted above, Ouko did not have the monopoly of this knowledge since different sections of society ranging from the Kenyan underground opposition, which was criminalized or exiled, and the Kenyan church, that was warned to keep off politics, had long railed against grand government corruption and maladministration. Such critical publics had dedicated themselves to this Mau Mau tradition of postcolonial state critique. But Ouko had an insider's view of just how highly conventionalized, naturalized and systematized such corrupt practices,

\footnotetext{
${ }^{211}$ Cohen and Odhiambo, Risks of Knowledge, 269.

${ }^{212}$ Ibid.

${ }^{213}$ Ibid.

${ }^{214}$ Ibid.
} 
through which men and women in power in Kenya sought to extend their power and amass their wealth. ${ }^{215}$ Ouko had been a small fish that had swum in the murky-black shark infested liquid mass of local, national and international fiscal networks gnarled by corruption that has its headwaters in the criminal foundations of the colonial state, the structural and attitudinal edifice of which ordered social and political life in Kenya, and affected and dictated the country's collective psyche. ${ }^{216}$

Such precise and textualized knowledge in the form of file folders and briefcases, records of faxes, photocopies of official correspondence, account numbers, formal and informal conversations and other carefully detailed histories in the hands of a renegade government minister was damning. ${ }^{217}$ As a new or late convert to this critical Mau Mau mold of mind and postcolonial resistance against the state, Ouko discovered, a little too late for his own survival, that such thickly layered and rendered knowledge in his hands was far more deadly than the fulsome postcolonial critiques that had led so many of his fellow countrymen and women into detention, torture, and asylum. ${ }^{218}$

But the clamor for political change in Kenya in the early 1990s was about to depart the well-trodden and, more often than not, self-sacrificial path of direct postcolonial critique of the state couched in the language of grievance ideologically and genealogically tied to the Mau Mau liberation struggle. Hailed by his platitude-effusing cronies as a politician with a giraffesque long political neck that could see far back in Kenya's history and into the country's future, Moi deftly recalibrated this distraction from the demand for basic human rights or "maisha mazuri" (the

215 Ibid.

${ }^{216}$ I owe the inspiration and use of this powerful political imagery and analogy in no small measure to Peter Pomerantsev's, "Diary," a letter contribution to the London Review of Books (Vol. 35 No. 23, 5" December 2013) in which he concisely and incisively captures, in a nutshell, what he refers to as sistema. That is, "the liquid mass of networks, corruptions and evasions -elusive yet instantly recognizable to members- which has ordered the politics and social psychology of Russian civilization since tsarist times." Further, I found that this imagery aptly captures parallel experiences of Kenyans who have long endured suffering under the decay that pervaded in the country even after independence. Also, this parallel evokes the song "Mai ni Maruru" (The Water is Bitter) composed by Ishmael Nga'ng'a, the founder and leader of the Gathaithi Church Choir in the 1970s. Kimani Njogu, "Religious Versification: From Depoliticisation to Repoliticisation," (ed. Kimani Njogu and Herve Maupeu) Songs and Politics in Eastern Africa, (Nairobi: French Institute for Research in Africa, 2007), 11, describes the song, which came out in the Kenyatta years, as an invitation and attempt to mobilize the country to reexamine itself in the face of glaring social difficulties occasioned and accentuated by corruption and a self-serving leadership.

${ }^{217}$ Cohen and Odhiambo, Risks of Knowledge, 270.

218 Ibid. 
good life) for all: instead, he pushed subsidiary political rights and constitutional reforms into a debate about regionalism (majimboism) and divisive ethnic politics.

At the same time, Moi seemed to know that the US and Britain trusted him, as a longtested ally, more than the little known youthful political dissidents, popularly referred to by the media as Young Turks, who were of unknown quantity and quality. Even the meddling and, thus, self-acclaimed rogue American ambassador to Kenya, Smith Hempstone, preferred the more cautious path of a decent regard for other people's lives by finding an evolutionary rather than a revolutionary solution to the country's pressing, and potentially explosive, socio-economic and political problems. ${ }^{219}$ Hempstone's attitude, which approximated the U.S-Africa foreign policy stance regarding the democratic wave that swept throughout Africa in the early 1990s, was trying to work with what was readily available in terms of political leadership before trying to overturn the apple cart. ${ }^{220}$ But totter, the cart did, as this wave of democratic change swept across the land and more and more people believed it was time to stand up and be counted. The streets, and other hallowed spaces of resistance struggle against state oppression, corruption and hard economic times, became sites of enactments of people-power and political agency.

\section{Saba Saba Days and After: Amplified Voices for Political Reforms Betrayed}

The well-laden apple cart of British national interest, which had successfully been protected since the historic hoodwinking of the nation through the granting of political independence in 1963, had to be safe-guarded against Mau Mau "politics of bread and circus" taking hold in Kenya of the 1990s. During the heady political days of bloody running street battles between state security apparatuses and political masses agitating from multipartyism and constitutional reforms that started in earnest on $7^{\text {th }}$ July 1990, hence"saba saba" (seventh of the seventh month), hand-wringing British diplomats in Nairobi and London did not yet utter a word against the government's rather high-handed deployment of state violence. ${ }^{221}$

\footnotetext{
${ }^{219}$ Hornsby, A History Since Independence, 481: in an interview with Charles Hornsby, the brilliant James Orengo suggested that there was tacit and covert support from the U.S Embassy for the burgeoning Kenyan opposition to come together within a united political movement, Forum for the Restoration of Democracy (FORD), as opposed to a political party.

${ }^{220}$ Hempstone, Rogue Ambassador, 40.

${ }^{221}$ Ibid., 102-112 for more details about "Saba Saba”; also see Branch, Between Hope and Despair, 193-195; and Hornsby's A History Since Independence, 476-478. Former KANU members and Members of Parliament, Kenneth
} 
According to Hempstone, the white population in Kenya, made up mostly of Britons who chose to settle in Kenya after independence, and the educated elites, while aware of Moi's warts and wens, and alarmed by the anger of the masses, increasingly accepted Moi at his own evaluation, as their one shield against three days of violence and chaos in major cities and towns in Kenya: Nairobi, Nakuru, Thika and Nyeri, which left no less than a hundred people dead. ${ }^{222}$ In as far as they were concerned, Moi was not the principal cause of unrest because of his rigidity and heavy-handedness. Rather, their greatest fear and threat was the savagery of the rioting African have-nots at the behest of "upstart" political dissidents. ${ }^{223}$ It was this sort of attitude that, even in the sullen silence and tight lips, emanated from the British High Commission in the midst of the sour political mood in Kenya. After all, Britain had a far greater economic stake in Kenya than the U.S, with \$1 billion in investment to the former's \$200 million, and a much greater volume of trade to lose if things spiraled out of control. ${ }^{224}$ So, for Britain, the status quo, and "law and order" that was well-guarded since independence, had to be protected. Rowdy and “destabilizing" politics of bread and circus had to be avoided at all costs.

As such, Sir John Johnson, the British High Commissioner, preferred "order" to freedom. ${ }^{225}$ Despite the fierce and bloody state response to popular agitation in the Saba Saba

Matiba and Charles Rubia, catalyzed the long-repressed demand for multi-party democracy into a mass movement, which credibly and for the first time, threatened the elite's control and hold onto state power. With the support of the church, various concerned professional people, and more importantly, the mass of disgruntled urban poor. These two wealthy and articulate leaders announced that they would hold a mass rally at Kamukunji grounds on $7^{\text {th }}$ July 1990 a meeting that the government declared illegal and forcefully clamped down. On an unrelated note, until the end of the usual thirty-year rule regarding official, diplomatic and/or government documents release, scholars and the public have to be content with the little available information in media reports in Britain and Kenya about the role or lack thereof on the part of the British with regard to the crisis of the Kenyan state and government in the early 1990 s. However, Hempstone's memoirs give a general sense of which political basket the British entrusted their eggs of geo-political and economic interest.

${ }^{222}$ Hempstone, Rogue Ambassador, 37; also see Hornsby, A History Since Independence, 477. This is understanding reminiscent of the Kenyatta speech to white settlers in Nakuru as independence approached urging and reassuring them that their long-standing farming and business interests in the country would be looked after by his African-led government

${ }^{223}$ Hempstone, Rogue Ambassador, 37.

${ }^{224}$ Ibid., 109.

${ }^{225}$ Ibid., 39 \& 119. When Bishop Muge was mysteriously, and under questionable circumstances, killed in a road accident on $14^{\text {th }}$ August 1990, Sir John Johnson despite being Anglican like his (Episcopalian) American counterpart did not attend the Anglican primate's funeral. Hempstone hazards the reason why this decision was made as being because the high commissioner would not have wanted to be caught at the memorial service for someone opposed to Moi's policies. 
riots that were a critical moment in the fight for multiparty democracy revealing the groundswell of anger against the Moi-Kanu regime, Britain did not immediately and/or openly reprimand the government of Kenya. It is also probable that British diplomats in Nairobi had a low opinion of political dissidents and felt, "quite naturally" that it was safer to have political change come only through president Moi. This differed from the American position as articulated by its ambassador who felt that change had to be brought about despite Moi, especially if he dragged his feet if an explosion was to be avoided. ${ }^{226}$

Further, according to Ambassador Hempstone, London feared that if the British government stood up to Moi, whom it had always supported, he could, like Idi Amin in the early 1970s, expel the 40,000-strong Kenyan Asian community most of whom were eligible to seek refuge in Britain. ${ }^{27}$ The British, therefore, had ample reason to be worried about the political state of affairs in Kenya. While Moi was certainly their preferred man to bring the country back to 'order' and manage democratic political and constitutional change, they did not admire the crude and deadly manner in which Saba Saba-type of street protests that characterized the early 1990s were handled.

Towards the end of 1991, therefore, as Hornsby notes, the British began to question their stance. They too soon joined many Western diplomats who supported the loose federation of forces that was coalescing around a new popular movement, the Forum for the Restoration of Democracy, that brought together lawyers, academics, clergy, journalists and politicians and embodied the wishes, dreams and aspirations of the people. ${ }^{228}$ Early during the clamor for multipartism in 1990, the lessons of the dawning reality of the end of a bipolar world were too fresh or a little too complex for the tough Moi regime to decipher. The "party-elite's bubble of invincibility and infallibility" guarded by Moi's state intelligence and security agencies enabled the president to warn FORD supporters that the outfit was an illegal organization whose

\footnotetext{
${ }^{226}$ Hempstone, Rogue Ambassador, 247.

${ }^{227}$ Ibid., $109 \& 251$. With the ever tightening noose of political repressing, detention, harassment, torture among other cruel curbs against growing opposition and demand for the repeal of Article 2 (a) of the Kenya constitution in the last of 1990, the British would finally join other Western nations to publicly excoriate Moi's government Hempstone believed, for the first time since independence.

${ }^{228}$ Hornsby, A History Since Independence, 481-482; also see Kinyatti, History of Resistance, 452-453.
} 
members were liable to arrests. ${ }^{229}$ For Moi, those advocating for multipartyism were scatterbrains who had "something missing in their heads." ${ }^{230}$ In 1991, Moi called on his security apparatus to crush FORD's supporters like rats. ${ }^{231}$ As such, although FORD support was widespread, it had remained underground at first. This explains why Kinyatti, a hardened and long-suffering intellectual and political detainee of Marxist persuasion, viewed professionals and clergy joining the chorus for political pluralism as latter-day progressives that, in the troubled 1980 s, had been stranded on the banks of the river of cowardice. ${ }^{232}$

Further, for Kinyatti, seemingly betraying more of his enduring Marxist political-activist persona than his academic thinking cap, FORD, initially spearheaded by Oginga Odinga, had the support of the constitutional reformist, petty-bourgeois intellectuals. ${ }^{233}$ Such a loose collection of people, as far as Kinyatti was concerned, was not prepared to go far enough to bring about political change. In as much as these democratic agents agitated, their campaign was not for the abolition of the oppressive neocolonial system, but, rather, for mere political pluralism and constitutional reform. ${ }^{234}$ Their bid served only to add to the flavor already featuring other ingredients such as human rights organizations and NGOs as well as international financial institutions that were 'imperialist' and supported the neocolonial state and order. In Kinyatti's opinion, their hidden mission in supporting political and constitutional reforms was to dilute and jettison a more fundamental democratic and social revolution. Kinyatti insightfully concluded that this would end up perpetuating Moism in Kenya without Moi. ${ }^{235}$

At any rate, the British and other Western capitals had taken note and followed the cue provided by international financial institutions (IFIs) that had, for years, tried to persuade Kenya since the early 1980 s to fix Kenya's problems by reducing corruption, liberalizing the economy and cutting the civil service through Structural Adjustment Programmes (SAPs). ${ }^{236}$ At some point in the 1990s, IFIs came to view Africa's problems not as primarily economic but also

\footnotetext{
${ }^{229}$ Hornsby, A History Since Independence, 482 \& 484.

${ }^{230}$ Branch, Between Hope and Despair, 184.

${ }^{231}$ Hornsby, A History Since Independence, 482.

${ }^{232}$ Kinyatti, History of Resistance in Kenya, 452.

233 Ibid., 453.

234 Ibid.

235 Ibid.

${ }^{236}$ Hornsby, A History Since Independence, $467 \& 478$.
} 
political. Kenya, among other African states, required democratic politics . By 1989, the World Bank was arguing that political legitimacy and consensus were a precondition for sustainable development, and this in the 1990s became a prerequisite before the West could undo its foreign aid purse strings. ${ }^{237}$

Throughout the 1980s, the patrimonial Moi-state responded grudgingly to this external international financial stimulus. The Moi government wanted to protect its own interest and leave intact its patronage network, which, apparently, was the president's only formula for steering and controlling a "unified" and "orderly" nation. So, by 1987, the government had sold only $20 \%$ of Kenya Commercial Bank (KCB) and another $10 \%$ in $1990 .{ }^{238}$ But, unfortunately for Moi, the end of the Cold War, which was also a triumph of international liberal capitalism, coincided in a timely way, with the internal call political pluralism in 1990. Moi now had to not only deal with IFIs but Western governments that strengthened the position of the former on the conditionality of loans and financial aid on the opening up of democratic space in Kenya.

This was the end of the road for Moi's decade-long dictatorship: his little game plan was up. The IMF, the World Bank and Kenya's foreign paymasters had caught up with him and checkmated his government. No longer could he utter the magical word (often a ruse) "communists," a label used to mute, criminalize and, therefore, detain and suppress lawfully, legitimate voices for social justice, democratization and peace as he had before 1989. ${ }^{239}$ Moi's government could not, hereinafter, get away with its highhanded and oppressive ways of the 1980s. The West prioritized political and economic reforms as a condition for aid. ${ }^{240}$ The conditionalities were the reintroduction of political pluralism; respect for human rights and freedom of assembly; liberalization of the marketing of agricultural products especially cash crops; extensive privatization of government parastatals and removal of their politically appointed managers; budget cuts; civil service reforms; limiting of the number of teachers; and cracking down on government corruption, all of which would come to be referred to as

\footnotetext{
${ }^{237}$ Ibid., 467. Hornsby correctly observes that the patrimonial, authoritarian state would stifle economic liberalization and, as such, only competitive politics and diminution of that state could free Africa.

${ }^{238}$ Hornsby, A History Since Independence, 470.

239 Branch, Between Hope and Despair, 184.

${ }^{240}$ Ibid., 185. According Hornsby, A History Since Independence, 486, whereas IFI assistance to governments had long in theory been dependent only on economic criteria, in practice, the two issues now became intertwined.
} 
constituting "good governance." ${ }^{241}$ Denmark froze new aid to Kenya in October 1991after the discovery of gross anomalies: Ksh. one billion to aid development projects was found not to have produced anything over a period of 17 years. ${ }^{242}$ A month later, Britain linked, explicitly, aid to Kenya to democratic progress. ${ }^{243}$ The informal Paris Club, which has served as a central pillar of the international fiscal architecture since the mid-1950s composed of the world's strongest economies met for the second time in a year in November 1991 to decide Kenya's fate. ${ }^{244}$ At their November 1990 meeting, the Club had considered cutting aid because of human rights concerns, but despite the Saba Saba crisis and political detentions, they decided that the country’s economic performance was satisfactory and extended US \$1 billion for $1991 .^{245}$

However, by this second meeting bilateral and multilateral donors had had enough, especially as far as their twin yardsticks for aid, political reform and economic management, were concerned. The donors, therefore, suspended balance of payments and rapid disbursement of aid to the government of Kenya's surprise. ${ }^{246}$ According to Hornsby, this suspension caused a fiscal crisis. The Ministry of Finance reported that the government was short Ksh. 12.2 billion during 1991-2. Kenyan leadership was shocked by this decision and psychologically affected. ${ }^{247}$ The head of state was in a spin as his "Kenya according to Moi" that had lasted less than a decade was quickly unfurling before his very eyes. But, the extent to which this measure, alongside increasing diplomatic pressure brought to bear on Kenyan government changed the culture is disputed.

Nevertheless, what is clear is that, not so long after this decision, the government eased restrictions on, and political harassment of, FORD leaders. At a Kanu national delegates meeting held in Kasarani in December 1991, Moi surprised the nation by decreeing the "annulment" of Section 2 (a) of the Kenyan constitution, thus reintroducing multiparty democracy. By this time FORD, which was originally constituted a the informal alliance of lawyers and academics who

\footnotetext{
${ }^{241}$ Branch, Between Hope and Despair, 185; also see Hornsby, A History Since Independence, 486 \& 504.

${ }^{242}$ Hornsby, A History Since Independence, 485.

243 Ibid., 486.

${ }^{244}$ Remarks by Agustín Carstens, Deputy Managing Director, IMF, "The Paris Club, the IMF and Debt Sustainability," at Dinner Marking 50th Anniversary of the Paris Club, Paris, June 14, 2006.

245 Hornsby, A History Since Independence, 478.

${ }^{246}$ Ibid., 486.

${ }^{247}$ Ibid.
} 
gathered around veteran politicians Oginga Odinga, Martin Shikuku and Masinde Muliro, among others, with the support of members of the clergy had already dovetailed with the Matiba-Rubia 1990s popular movement. Towards the end of the year, Mwai Kibaki who had been demoted from the position of Vice-President launched his own party, the Democratic Party of Kenya. There were also other smaller parties as 1992 rolled around: the Social Democratic Party and the Kenya Social Congress. Ominously, in an interview with the BBC, a few days after repealing Section 2 (a) Moi stated that multipartyism would never produce stability in Africa. ${ }^{248}$

Meanwhile, the Kenyan economy, suffering from perennial structural weaknesses and the freeze on donor aid, was in an all-time doldrums. Between 1989 and 1990, the standard of living of the average Kenyan slipped by $16 \%$. Over the same time, unemployment skyrocketed to an estimated $40 \%$; Kenya's trade deficit rose to $\$ 1.3$ billion; foreign investment was stagnant and domestic investment was in decline with capital flight reaching \$2.6 billion, which was more than twice the amount earned annually for all Kenya's exports. Inflation was soaring at $25 \%$ annually. ${ }^{249}$ Kenya's import volume of all items including goods and services was at an all-time low and export of items including goods and services was at $6.5 \% .{ }^{250}$ During the same time, the population in the north eastern region of the country was facing mass starvation. Livestock losses by inhabitant pastoral communities in the region, who are largely dependent on their animals for food, after a period of twenty-one months without rain, exceeded $90 \%$. As a result, about $75 \%$ of children as young as five years old were suffering from malnutrition. ${ }^{251}$

By mid-1992, with government food relief trickling into the region from Nairobi, the population there was plagued by epidemics of measles and dysentery among others leaving people without anything to hope for and very little to fear. ${ }^{252}$ Visiting the region in space of twelve months between June 1991 and June 1992, the U.S ambassador saw firsthand what he termed 'a slice of hell.' A senior local dignitary, Sheikh Abdullah, told Hempstone that it seemed as if it was Allah's will for the people to face death by starvation, a fate to which they were

\footnotetext{
248 Ibid., 487.

${ }^{249}$ Hempstone, Rogue Ambassador, 249.

${ }^{250}$ Economy Watch: Kenya Economic Statistics and Indicators, 1991.

${ }^{251}$ Hempstone, Rogue Ambassador, 207.

252 Ibid., 207-209.
} 
prepared to submit. After all, their livestock were all but gone; there was nothing in the local shops to buy; and, in any case, they had no money to buy anything with. Their future was bleak. $^{253}$

But, what people like Abdullah did not know was that the Kenyan economy in the early 1990s had suffered a severe and long-lasting damage affecting the very poor in society. ${ }^{254}$ This was as a result of the suspended donor aid and the negative impact of SAPs administered to liberalize the economy, a situation that was compounded by the Goldenberg corruption scandal in which at least US \$400 million was funneled from the Central Bank of Kenya (CBK). This bleak situation was exacerbated by politically instigated ethnic violence before and after the first multiparty elections in December 1992. This violence was experienced in different parts of the country but particularly intense in the Rift Valley Province, which is Kenya's breadbasket. Due to poor rains and ethnic violence, there was a $4.5 \%$ drop in agricultural output, which would fall further in 1993. ${ }^{255}$ As a result, Kenya's central pillar of export service and, thereby, by far the largest foreign exchange earner, tourism, was negatively impacted, this further contributed to this dire economic straits. For the first time, Kenya defaulted on its foreign debt. ${ }^{256}$ Kenya was a socio-economic and political basket case.

With regard to the foregoing, the Western governments-supported and international finance-administered SAPs were a bitter pill for Kenya to swallow. Initiated by the World Bank and International Monetary Fund in Kenya since 1988 and especially the early 1990s, SAPs transformed many aspects of everyday life of ordinary Kenyans. ${ }^{257}$ These programmes further exacerbated the economic condition. SAPs, in the late 1980s and early 1990s, were linked to the high rate of income inequality, inflation, unemployment and mass retrenchment of civil servants and thus further accentuating the low living standards especially with regard to basic material resources of half the country's rural and urban families. ${ }^{258}$ Over and above the problem of

\footnotetext{
${ }^{253}$ Ibid., 211.

${ }^{254}$ Hornsby, A History Since Independence, 505.

255 Ibid., 506.

256 Ibid.

257 Joseph Kipkemboi Rono, “The Impact of the Structural Adjustment Programmes on Kenyan Society," Journal of Social Development in Africa 17 (January 2002): 81.

${ }^{258}$ Ibid.
} 
inflationary pressures, structural adjustment programmes contributed to the marginalization of the poor in the distribution of educational and health benefits. ${ }^{259}$ The Government of Kenya was forced to introduce cost sharing for social services, a measure that was unpopular among Kenyans. ${ }^{260}$ Outpatient charges were imposed for medical services at most hospitals and between 1991-2, the government stopped paying full tuition fees for university students. ${ }^{261}$ The implications of such drastic stipulations, hastily implemented, were long-lasting structural damage. The health sector had continued to be under-financed reducing its ability to ensure an adequate level of healthcare for the population. Even at the turn of the $21^{\text {st }}$ Century, among those Kenyans who were ill and did not choose to seek care, $44 \%$ were hindered by cost. Another $18 \%$ were hindered by the long distance to the nearest health facility. ${ }^{262}$

With that said, the government, to its own credit, was not blind to such hardships facing the country especially in as far as they touched upon budgetary and implications for state coffers. Indeed, the very survival of the Moi government, considering the groundswell of domestic opposition, relied upon quick-thinking and ingenuity. With foreign aid cutoff, a new source of badly-needed government revenue had to be devised to survive the international fiscal onslaught and local political opposition. At the same time the government faced-off with the Bretton Wood institutions and the Paris Club between the 1990-2, someone at the Central Bank of Kenya, government circles and business community drew attention to the growing volume of gold and precious jewels passing through Nairobi's black market and other goods coming from Angola, Sudan, Rwanda and the Congo. ${ }^{263}$

In a master stroke of sheer genius, it was decided that if, with all due diligence, this black market export of gold could be made legal, it could easily rival government revenues from indirect tax imposed on the coffee boom of the 1970s, even when tea earnings of the same period were factored in (approximately valued at KSh.9.5 billion in 1977). ${ }^{264}$ But there was one slight problem: illegal dollar earning from black market gold sold abroad could buy more shillings than

\footnotetext{
${ }^{259}$ Ibid., 84.

${ }^{260}$ Hornsby, A History Since Independence, 470.

${ }^{261}$ Ibid., 470-1.

${ }^{262}$ KPMG, "Kenya -Country Profile," (South Africa): 3.

${ }^{263}$ Hornsby, A History Since Independence, 506.

${ }^{264}$ Ibid., 291-2 \& 302.
} 
legal ones. ${ }^{265}$ This initial hurdle was, however, quickly resolved when one of the key proponents of this great idea, the twenty-five year-old Kamlesh Pattni, got the rare opportunity to share it with the president himself. The gap between the foreseen disadvantage of the legally good dollar over the bad with regard to the purchase of the badly coveted Kenyan shilling was sealed with the simple but authoritative brandish of the president's "fimbo ya nyayo": Moi agreed to increase the level of export compensation on these precious items from $20 \%$ to $35 \%$ to stop the bleeding of clean money from the legal exchange rate. ${ }^{266}$ This new venture was afloat and in business as Goldenberg International Limited with a monopoly of gold and diamonds by $1990 .{ }^{267}$ Unfortunately, the Export Compensation Act, which regulated the compensation for nontraditional exports was never adjusted from $20 \%$, which meant that the compensatory payments made to the company for the legal export of gold and precious jewels, was illegal. ${ }^{268}$

This notwithstanding, since Goldenberg had somewhat been able to guarantee the government a minimum annual earnings of US $\$ 50$ million, it was business as usual. But, to further complicate the legal implications of this scandalous looting of state coffers in the making, not only did the government authorize the secret increase in export compensation by $15 \%$, by mid-1991, Goldenberg was falsifying invoices, massively overvaluing the gold being exported in order to gain extra export compensation. Indeed, towards the end of the year, the company was illegally importing gold in order to re-export at inflated prices. Ultimately, even the falsification of invoices was found to be rather unnecessary and the illegal importation of gold logistically cumbersome and involving. There was no need to export any gold at all in order to claim import compensation; to keep records documenting payment of custom duties; or to prove that buying companies in Switzerland or Dubai actually existed. It was a free for all scheme to print money with the result being the 'exports' of gold reached Ksh.13 billion (US $\$ 400$ million) ${ }^{269}$ Fiscal wisdom, conventional leadership and management principles, and ethical norms such as responsibility and accountability had been pushed to the margins or simply ignored. As a result, the margins of universal norms were pushed to the limit and ruptured with impunity. Inflation

\footnotetext{
${ }^{265}$ Ibid., 506.

266 Ibid.

${ }^{267}$ Ibid., 506-7; also see Branch, Between Hope and Despair, 217-221.

${ }^{268}$ Hornsby, A History Since Independence, 507.

${ }^{269}$ Ibid., 507-8.
} 
became ever worse as the shilling was debauched. As a result of Goldenberg, all Kenyans were made $30 \%$ poorer, and the country's gross domestic product slashed by $10 \% .{ }^{270}$ But, what mattered was that the government was somewhat able to circumvent the turning off of foreign investments, and the urgent domestic imperative of triumphing over the growing political opposition.

\section{After Surviving Woes Foreign and Domestic With Cash: Politics of Atomization and Bifurcation}

Now the Moi regime had a war chest full of dollars to fund and fight in the first general elections after a decade of one-party rule in 1992. Moi's team had stumbled upon a winning political strategy: manufactured, or better still, conjured-up, money was aplenty to campaign for Kanu candidates around the country and to ensure that the party retained the presidency. Besides this financial arsenal Moi needed more political ammunition to come out at the top. He and his political generals found a ready weapon in an enduring political debate and concept that he had helped forge back in the second half of 1961. This was majimboism: the idea of regional autonomy that had been frustrated and extirpated from Kenya's independence constitution in1964.

As earlier noted, Moi in a BBC interview had, even immediately after returning pluralism, stated that multipartyism would reignite ethnic tensions in Kenya. This was not to suggest that there had been no latent structural ethnic tensions simmering beneath the calm of independent Kenya politics. Besides the obvious mainstream challenge discussed above, as articulated by various critical publics, regarding the unfinished business of the need to address poverty; landlessness springing from the central issue of historical legal, and therefore, structural colonial, and perpetuated postcolonial, injustice; unemployment and gross economic inequalities in Kenyan society, Moi had either been pragmatic enough to stir the murky waters of the dysfunction instituted by the imperial misconstruction of the Kenyan state or had simply waited to exploit it himself at an opportune time.

\footnotetext{
270 John Lonsdale, "Compromised Critics: Religion in Kenya's Politics," in Religion and Politics in Kenya: Essays in Honor of a Meddlesome Priest, ed. Ben Knighton, (New York: Palgrave Macmillan, 2009), 61.
} 
Nevertheless, both Moi and his predecessor had ably, with both personal verve and the iron fist of security apparatus, managed to keep the country united despite the obvious tensions regarding redistribution of the former white highlands, which was compounded by postcolonial land resettlement schemes that papered-over the social justice issue restoring for free stolen ancestral lands during colonialism underscored by the principle of 'willing seller, willing buyer.' This policy favored colonial Kikuyu migrant labor that formed land-buying companies to purchase parts of the former White Highlands. It also meant that those able to buy land could do so anywhere in the country. People could, therefore, buy and settle in land that did not necessarily "belong" to them ancestrally or as an ethnic community. The postcolonial state was structurally and ethnically fissured due to this perceived intermixing. Deliberate or calculated misunderstanding of what majimboism entailed was a potentially divisive and explosive issue.

Moreover, the country had been kept "united" despite the unresolved imperial loose ends regarding administrative geo-ethnic boundaries that most ethnic groups in Kenya expected to coincide with the habitual ancestral communal land as it existed at the dawn of British colonialism. Whereas Moi had been pragmatic in this regard and content to suppress opposition by criminalizing it and branding it "communist," the shift of the measure of his geopolitical utility in the post-Cold War era, which strengthened political discontent and dissidence necessitated dividing the country up in order to retain power. ${ }^{271}$ This strategy was aimed at breaking up the old colonial political nightmare for minority ethnic groups that had haunted Moi and his allies who shared the same fear of postcolonial domination of the Kikuyu and the Luo, the two biggest communities. Central and Nyanza regions were the two regions that harbored the deepest dissatisfaction and hostility to the Moi regime and provided widespread support for FORD. Throughout 1992, the government tried to play up ethnic tensions between the two communities, which had long-parted ways in the late 1960s. ${ }^{272}$

Whether intended or not, this ethno-political strategy meant to weaken the opposition as well as win the 1992 elections spiraled out of control and ignited embittered waters of simmering grievance in 'Mau Mau minds'. Instead of holding itself accountable for demarcating acceptable

${ }^{271}$ Hornsby, A History Since Independence, 497.

${ }^{272}$ Ibid., 484 \& 497. 
geo-ethnic administrative units or restoring lands 'stolen' during colonialism thus approaching landlessness as an outstanding pan-ethnic and shared national issue of contention, the state allowed long-standing discontent of the imperial and immediate postcolonial eras to be vented and addressed against 'foreign' settlers who were legally or otherwise not living in their communal ancestral lands. As far as the Moi state was concerned, it was not the long outstanding structural issues of historical injustice with regard to land that were in question.

Rather, it was multipartyism that was unworkable in multi-ethnic societies such as Kenya. Moi and Kanu were instigating old geo-ethnic fears and rivalries: the psychological ground for the planting of this seed of hatred and discord had always been fertile since colonial times. The Kalenjin had long suppressed their desire for the former white highlands, which they considered to be rightfully theirs ancestrally; in the Mt. Elgon region, pro-Kanu Saboat and Teso were set to remove pro-opposition Bukusu; whereas at the Coast, pro-government elements were poised to eject "watu wa bara" (upcountry people) who did not belong. ${ }^{273}$ Thus, instead of heeding the plea in the 1970s Christian song, The Water is Bitter, to render the water consumable through a Mosaic healing act of systematically resolving historical injustices, president Moi authored confusion and disorder as a strategy of political survival. ${ }^{274}$ According to Branch, this political strategy had first presented itself at parliament where a close ally of Nicholas Biwott and MP for Wajir, Noor Abdi Ogle, in a speech in July 1991 explicitly linked implementation of majimboism with the survival of Kanu and the one-party system. ${ }^{275}$ According to Ogle majimboism would meet most Kenyan's demands for change and at the same time remove popular support for multipartyism. ${ }^{276}$

Not long thereafter, Joseph Misoi, a Kalenjin politician and (Keiyo) Uasin Gishu MP echoed the same sentiments. During the remaining months of the year, there were a series of mass rallies in the Rift Valley demanding the reinstitution of a federal political system. Fanned to the limit, ethnic tensions burst out into open violence on $29^{\text {th }}$ October after a series of "majimbo"

\footnotetext{
${ }^{273}$ Ibid., 481-3, 490-3 \& Branch, Between Hope and Despair, 202-206, 212-215.

${ }^{274}$ See Branch, Between hope and despair, 199, for more about the use of disorder as a political instrument and the deliberate instigation of violence by states for political ends.

275 Branch, Between Hope and Despair, 197.

276 Ibid.
} 
rallies when local Nandi ganged against a mixed group of other communities who had lived in Metetei Farm, Nandi district since the 1970s. In a matter of a few weeks, Metetei Farm violence spread to other former White Highlands multi-ethnic settlements in the district finally spilling into Kericho where Luos came under attack. The trouble also spread to Trans-Nzoia with attacks on the Luhya. By December, ethnic violence spread its tentacles to Mt. Elgon in Bungoma District where the Bukusu came under attack from the Saboat and Teso. In this region, like in Meteitei Farm, tensions went back to the 1960s.

At the beginning of 1992, the violence in Bungoma and Trans-Nzoia was particularly intense as the Saboat and Pokot who had allegedly been ejected from their lands in the first years of colonial rule resolved to recover their "stolen lands." Moi who had been aloof all this time, broke his silence in January 1992 and told Kenyans and international media that the tribal clashes were as a result of the reintroduction of pluralism. ${ }^{277}$ In a popular anecdote that started doing rounds in hushed conversations in the streets, it was said that while flying in a military helicopter in the Rift Valley, and witnessing plumes of smoke from burning huts, Moi casually dismissed the deplorable destruction of life and property with a single sentence in Swahili, "wacha wajikaange na mafuta yao wenyewe" (Oh, well, let them deep fry in a problem of their own-making).

With literal ethnic fires alight in Kericho, Nandi, Trans-Nzoia and Bungoma, between March and April, two more natural flashpoints were engulfed: the multi-ethnic settlements of Molo and Olenguruone in Nakuru District. After rallies in February 1992 by William Ntimama, a Maasai leader and Kipsigis hardliner, Kipkalya arap Kones, the tribal clashes spread to the Narok-Kipsigis-Kisii border where the Gusii community, which had lived in the area since independence was the main victim. At a previous rally in 1991, Ntimama from Narok District and a Maasai "big wig" warned the Kikuyu residents in Maasai communal districts of Kajiado, Narok and elsewhere to "lie low like an envelope" or else they would suffer the consequences.

${ }^{277}$ Ibid., 202-206 and Hornsby, A History Since Independence, 481-3, 490-3 \&. 
Kikuyus and other communities that supported the opposition were "madoa doa" (spots) that had to be cleansed or expunged violently. ${ }^{278}$

Rather than do anything about the escalating violence, there was no government response. ${ }^{279}$ Although the violence abated towards the December 1992 elections, it reemerged in the same flashpoints and spread elsewhere in the country. For example, in the coast region after the Kanu hawk Sharif Nassir indicated that he supported majimboism. ${ }^{280}$ Indeed, ethnic clashes became a nasty Kenya tradition surrounding the spectre of electoral cycle with the exception of 2002 and 2013. This political nightmare for especially affected families in some of these regions repeated itself prior to and after 1997 and reached the anti-climax in hotly contested elections of 2007. A blow by blow account of this political violence and its various manifestations has been ably written about by Hornsby and Branch. But the individual thoughts and reactions of Kenyans who were watching this tragic unfolding political drama of 1990s from a distance is yet to complete the picture.

\section{The People's Voice After Political Atomization and Bifurcation}

As observed, FORD was a loose federation of disparate individuals with regard to their ethnicity, political evolution and experiences and age. This amalgam of elements did not blend together. It was not even united enough in its hatred against the Moi-Kanu regime. It was a fractious coalition from the beginning. It also faced the grueling demands of consolidating and organizing a united front against the Moi regime. As a result, it soon disintegrated into a threeway leadership struggle between its politically ambitious lights including Oginga Odinga (supported by Paul Muite and Gitobu Imanyara); Masinde Muliro; and a coalition formed with Kenneth Matiba and Martin Shikuku at the helm. Towards the of 1990, Mwai Kibaki announced

\footnotetext{
${ }^{278}$ Hornsby, A History Since Independence, 490. According to the Republic of Kenya, Report of the Judicial Commission Appointed to Inquire into Tribal Clashes in Kenya (Nairobi: Government Printer, July 1999), 50-51, at a KANU mammoth political rally in Narok held on $28^{\text {th }}$ September 1991, Ntimama said that FORD, the NDP and multiparty politics was buried. All Moi's men, ministers and KANU party leaders, had resolved to fight together and follow the president together. "Majimbo "had existed at independence and had been done away with; if "majimbo" ended, multiparty politics was also supposed to end, or else, "We will use rungus [cudgels] if this will be the effective way of ending talk about this multiparty. This I have said on this platform and I am repeating it: the violence of saba saba was not a mild drinking party."

${ }^{279}$ Hornsby, A History Since Independence, 481 \& 490.

${ }^{280}$ Branch, Between Hope and Despair, 198.
} 
the formation of the Democratic Party of Kenya (DP). Opposition parties thereafter would continue to reproduce and splinter with every election in amoebic fission fashion. ${ }^{281}$

It is important to underscore that this multi-fission of opposition parties was not pegged on issues or based upon differing political ideals about social justice, land reforms, and thus incongruent alternative visions of Kenya's future. Yet, ordinary Kenyans continued to quest for prosperity and looked up to them to deliver the Promised Land. Rather than document individual rivalries involved in the breakup of opposition parties and their competition for state power, which dominates historical debate of the political history of Kenya in the 1990s, I have endeavored to focus on isolated people's voices from below ("matigari ma njirungi") with regard to their thoughts and attitude towards elite politics; their continued quest for nationhood, national unity and prosperity; and their enduring pleas for issue-centered politics revolving around basic human needs and rights.

While political big wigs locked horns, as African proverbial wisdom goes, the people understood that they were the grass upon which their ethnic kingpins painfully trod. People celebrated and appreciated the opening up of political space in the early 1990s, since they, relatively, had little to fear compared to the oppressive 1980s when they had to look over their shoulders before speaking about anything politically sensitive. Unlike the oppressive phase of the Moi years, parents no longer warned their children what was spoken between mutually trusting relatives and friends in the safety and privacy of their family house and other gatherings. Professors at universities, while they continued to be cautious in the 1990s, did not have to fear as they did that if they misspoke or were not understood, intelligence agents disguised as students would get them into trouble.

Thus, people were glad that multipartyism had opened many mouths that were otherwise shot with fear. ${ }^{282}$ Quite a number of them wrote to various mainstream print media to participate in the democratic process and make political commentary on various issues. Some of these

\footnotetext{
${ }^{281}$ For more about this political atomization of parties of opposition parties, the tracking of which makes for a rather somber intellectual task see Hornsby, A History Since Independence, 493; Miller and Yeager, The Quest for Prosperity, 107-110; and Branch, Between Hope and Despair, 208-211.

282 J.L.O. Oraro, “Majimbo Debate," The Weekly Review, $7^{\text {th }}$ January 1994.
} 
letters to the editors of leading national newspapers reflected the public's disillusionment with political pluralism. This disillusionment was reflected in a myriad of letters sent to editors expressing puzzlement at the turn of events: writers asked many searching questions about the state of society and where Kenya was headed. Lonsdale also aptly captured another reaction besides the general sinking feeling at the deep end of the curve of the euphoria of multiparty politics in 1992 and the end of the Moi years in 2002. It is not so much that Kenyans have been disillusioned. Rather, after being on an unpredictable roller-coaster and cycles between hopeful highs and despairing lows, and many false-starts, ordinary people had become "unillusioned" cynics. ${ }^{283}$ This political attitude, when it does not consign individual Kenyans to political apathy and lethargy, provoked scathing commentary directed at various objects of criticism.

One of these objects in the 1990s was expression of disappointment with democracy and the democratic process itself. Some Kenyans felt that greedy opportunists had hijacked pluralism. It was felt that the birth of multipartyism was mocked by a culture of intolerance that made it impossible for democracy to take root. As a result, it was felt that ordinary Kenyans had to be forgiven for being skeptical of multiparty politics in the manner in which it was being implemented. ${ }^{284}$ Indeed, some writers questioned the very meaning of democracy itself. Either Kenyan democracy as experienced in Kenya was a still birth or the political elite did not understand that it meant government for the people through their elected representatives. ${ }^{285}$ The representatives of the people as mid-wives of democracy, the leaders had shirked their role, to do right by hopeful ordinary Kenyans. They had let down the electorate and faithful followers simultaneously killing multipartyism. Democratization had fallen far out of what most perceived as the superior Western template.

As a result, the objects of democracy, such as justice and freedom that ordinary Kenyans still had within their sights, had been sidelined. Representatives needed to go back home and ask people what it was that they needed. ${ }^{286}$ Otherwise, multipartyism was of no benefit if it did not

\footnotetext{
${ }^{283}$ Lonsdale, "Compromised Critics," 62.

284 J.M. Mungai, “Opportunists Hijack Pluralism, Sunday Nation, 19 ${ }^{\text {th }}$ September 1993; also see Sylvester Wogah Nyakwara, "Opposition Leaders Must Act Now," Daily Nation,” 8 ${ }^{\text {th }}$ December 1995.

285 Otieno mak' Ajina Awino, "Meaning of Democracy Being Misinterpreted," Kenya Times, $18^{\text {th }}$ November 1993 ; also see, Daina D.N., "Leaders Stifling Our Democracy,” Daily Nation, $23^{\text {rd }}$ March 1994.

${ }^{286}$ Seth wa Amboga, "What Next After the Alliance," Kenya Times, $14^{\text {th }}$ December 1995.
} 
address rampant unemployment; improve education, health, water and other welfare services such as fighting the introduction of Value Added Tax, which reduced the purchasing power of wananchi; and people's poverty. All people witnessed on the national political platform were wrangling defections and by-elections. ${ }^{287}$

Other writers yet were dismissive of the ruling class in general. Historically, it was felt that, collectively, Kenyans's greatest failure was their inability to contemplate their leaders with the distrust and suspicion that they deserved. According to Victor Kimani, Kenyans, since 1963, had nurtured high hopes and faith in their ability to govern themselves prudently. Their common future was securely in their hands. Unfortunately, they had placed too much trust in certain institutions and forgotten that human nature was essentially selfish and greedy. ${ }^{288}$ Kimani, contributing to The Nairobi Law Monthly further observed:

...Whatever peace we have is due to the foresight and good will of the common man who pays his tax without questioning how it is misappropriated; who lives with heaps of garbage in the city without demanding that he elects the councilors; who pays toll charges after wrecking his vehicle in pot-holes. Kanu is not the author of peace. In fact we had more peace when Kanu was dormant since we had less dissidents, subversives, sedition and no foreign masters.

Power inspires strange ideas in the hearts and minds of men. Those who rise to giddy heights, almost always through the unfair influence of fate, attribute their positions to exceptional intelligence, hard work and acute foresight. Very few of them ever look back to contemplate their humble beginnings and ordinary endowments. Filled with outrageous misconceptions, they regard themselves as superior and infallible, and will not accept wise counsel or learned opinions. They become the ultimate authorities on every subject under the sun. ${ }^{289}$

Although Kimani was writing before the advent of multiparty politics, his critical sentiments outlived the oppressive one-party era.

Kimani's sentiments were echoed soon after the general elections of 1992 . Writing to the Daily Nation in January, Chrispine Oyuga stated that it was about time Kenyans did away with its crop of politicians for the sake of the country's future. After all, it was an open secret that political leaders in both Kanu and in the opposition misunderstood the essence of democracy.

\footnotetext{
${ }^{287}$ Zenudin Ali Mohamed, "No Benefit for Multipartyism," Daily Nation, 30 ${ }^{\text {th }}$ January 1996.

${ }^{288}$ Victor Kimani, “Let Us Reason Together," The Nairobi Law Monthly (No. 33, June 1991).

289 Ibid.
} 
This was laid bare in the defections and re-defections from one party to another. It was clear that most of them did not care about party manifestos and policy issues. Instead, they followed their own egos. Greedy ones were simply bought-off by Kanu. Oyuga went as far as suggesting that Kenyan society had failed to produce great statesmen who were true nationalists and patriots. The country needed new blood. Most leaders were engaged in destroying the achievements of decades of self-rule even as the economy continued to deteriorate at their greedy hands. There was something wrong with the political elite. The majority of politicians represented nobody but themselves. The state of the country was such that there was very little to show for since independence. One could be right to say Uhuru had not yet arrived. ${ }^{290}$

Indeed, the ideals for which Mau Mau fought for were far from being attained. Dedan Kimathi was most assuredly turning in his grave, while Kenyans were celebrating a hollow independence. ${ }^{291}$ The personal agenda of the powers that be continued to suppress the benefits that could be achieved through the creation of democratic institutions. Instead of concerning themselves with serving ordinary people, politicians were bandying words over majimboism, tribal supremacy, rival ethnic alliances, who "ate" and who controlled what, all of which were distractions that were bad ingredients for any nation working towards the betterment of its people. ${ }^{292}$ Those who selflessly fought for independence were to be highly regarded. They had qualities unsurpassed by any contemporary politician. They endured pain and suffering to give ordinary people and posterity "a life of joy and freedom." When one visualized the dreams freedom fighters had for the country encompassing the improvement of their children's education; security and prosperity for posterity; a moral society; freedom for all irrespective of tribal, religious and economic differences, all calculated to make Kenya a better place, and compared them with the prevailing reality, it was difficult to hold back tears of disappointment. ${ }^{293}$

\footnotetext{
${ }^{290}$ Chrispine Oyuga, "Polls: Leaders Let Kenyans Down," Daily Nation, $19^{\text {th }}$ January 1993; also see George Wanyonyi, "Kenya Needs New Blood," The Economic Review, December $6^{\text {th }}-12^{\text {th }} 1993$.

${ }^{291}$ Wanyonyi, “Kenya Needs New Blood," The Economic Review, December 6" $-12^{\text {th }} 1993$.

292 James Wachira, "Kenya Needs a New Agenda," The Economic Review, February $7^{\text {th }}-13^{\text {th }} 1994$.

293 Ibid.
} 
But for a selfless self-declared "Septuagenarian" writing from Nairobi, the problem of leadership started at independence. This writer admitted that s/he "hated politicians from the very early days of independence because I saw the first seeds of corruption which I knew would eventually destroy our country...."294 This contributor also admitted to not having been to any church since 1947 despite being a Christian. There were just too many "hypocrites consummate sinners." Most people who entered the corridors of power after independence were Christians of sorts but they succumbed to corruption and lost all sense of honesty, uprightness and probity. With time, they became progressively worse in their quest for even greater power and wealth. Their lust by the 1990s had reached insatiable levels. Just like a leopard could not change its spots, these time-worn politicians and demagogues could not change their ways and nothing good could ever be expected from them. They thrived on corruption, which was the root of all the problems and hardships Kenyans were experiencing. It was the height of naiveté to expect them to eradicate this since all they cared for was the selfish pursuit of personal wealth. ${ }^{295}$ It is not difficult to imagine that Septuagenarian had president Moi and Goldenberg in mind as he penned this scathing criticism. Ironically, despite the enormity and economic impact of the scandal, Moi continued, all things considered, to claim to be not only Christian, but one who was born again. ${ }^{296}$

In fact, the person of the president bore the brunt of most of the criticism as did his party and government throughout the 1990s. One writer defended the Catholic Church's criticism and wise counsel to Moi's government as forthright, truthful, far-sighted, constructive and progressive. The church had found the Government in the "out-patient unit" but as time progressed its "health" had deteriorated and both "the Government and the country" were "in the intensive care unit, very sick!" ${ }^{297}$ This analogy of the country having been rendered a "sick" basket case was prevalent especially when people recovered their voices in the early 1990s. "Kenya is sick," an emotional letter contribution from Nelson Tenia of Eldoret, was particularly eloquent and poetic:

Kenya is sick and naked! Yet our leaders both in the party and Parliament are zealously singing in praise of its own wonderful progress unsurpassed anywhere in the

\footnotetext{
${ }^{294}$ Septuagenarian, “Time for the Young to Wake Up," Daily Nation, $28^{\text {th }}$ December 1993.

${ }^{295}$ Ibid.

${ }^{296}$ Lonsdale, "Compromised Critics," 61.

${ }^{297}$ Michael Mwaura Kimani, "Government Should Heed Counsel,” Daily Nation, $15^{\text {th }}$ April 1995.
} 
world. Kenya is sick and naked! Witness resolutions parrot-like "passed" [sic] by illiterate and semi-illiterate Kanu delegates that recently met at Kasarani. The President said anyone except criminals, bankrupts[sic] and the insane can run for elective posts ....

Kenya is sick and naked! What is Mr. Fred Gumo's mission at the City Hall? To supervise accumulation of garbage in each estate of Nairobi? To ascertain that each road, street, walk, alley, lane and close is made just impassable by pot holes? Kenya is sick and naked. Witness ...civil servants from the top to bottom their apathy!

Kenya is sick and naked! Look at the state of our roads in the country side, yet wananchi especially farmers pay taxes promptly, with a smile! Where does toll money go? What about V.A.T and sevice charge? Is it any wonder that corruption is now institutionalized? Is it any wonder that grabbing of land by the mighty is carried out with the blessing of the Government? Does the cry of the weak and voiceless wananchi mean anything in Ukambani and elsewhere?

Kenya is sick and naked! ....Our so-called representatives in Parliament and outside have resorted to condemnation of Mr. Jaramogi Odinga, Bishop Timothy Njoya, NCCK, CPK, LSK and advocates of multiparty. They have resorted to name-calling "disgruntled elements," "lackeys of foreign masters," "Jimmy Rogers," ...etc. Yet our cities and towns are rotting with garbage, our roads are near impassable, our graduates are jobless, our farmers cannot afford inputs -in general our country is falling to pieces!

Kenya is sick and naked! Our foreign currency -earned with our sweat- has been stashed away by the mighty rulers in foreign banks- talk of stooges!

... Our leaders both small and big are blind. They are unaware that their deeds are leading this country to the brink of destruction. Their greed and wealth and power have made them blind and insensitive. Even some clergy and lawyers have joined the bandwagon of looters -they say; "We are all in the same boat, so let us all share the loot."

The loot? Where is patriotism our so-called MP's profess to us? ...

Kenya is sick and naked. Development of our country is lop-sided. Power, construction of tarmarc roads, telephone services are places where they are least needed because $\mathrm{X}$ or Y or X are Nyayo followers, so they must enjoy the loot to their constituencies ....

Who says Kenyans will fight if many parties are introduced but sick minds! I am a Nandi and I live side by side with Kikuyus, Luhyas, Luos and Turkanas and we are all happy building a prosperous Kenya. We have intermarried. We do business together...

What ...do we do to save Kenya?

What do we do to clothe it?

...Let us have a convention of lawyers, teachers, student leaders, women representatives, workers unions, councilors and MPs.

Let them sit down at a big round table and seriously, intelligently, impartially, cooly map out the 'Kenya we Want.'

We need...change. We need meaningful change. A change that will take us into the $21^{\text {st }}$ Century where [sic] educated civilised and leaders with ideas at the helm of our nation. ${ }^{298}$

\footnotetext{
${ }^{298}$ Nelson Tenia, "Kenya is Sick," The Nairobi Law Monthly (No. 35, August 1991). Road booths were erected on main highways in Kenya to exact a road tax, for what or why, it was not quite clear but the government must have raised quite a handsome amount of money.
} 
It was also around this time that the Peter Kigia, a musician who composed and sang in his vernacular Kikuyu, lodged a bitter denunciation of the Kanu-Moi regime, Reke Tumanwo, which echoed the sentiments above.

Umuthe ndauga reke tumanwo Akorwo wi witu, reke tumanwo ...Ihinda ria muriano riu ni-ithiru

Ndira hiya hiya, ngacura, Ngatheka theka, ngarira Ni-kuimbirirwo ni marakara Kurwo ndihinya ingiagutandika Nginya ugunde ujathimure

Unduirie irima-ini ria nduma Ndageria kwiruta ukajokia ukwo

Uherithagia ta Gitonga Lazaro Ndiyage u-ruiteki nie Wanyakiumba

Njiragwo daguire na ngoi

Ndirabogotha thiomi njeru, Ndukone ta-thukite mutwe Nongu-kwira uringi, Ndirakwihoka Uhana Judasi wakunyaniire Jesu Akimwendi thendi mirongo etatu

...Harusi yetu na 'yekeke' ...Imevunjika...!
/I declare today, 'We must part ways' /Even if we are once one, we must part ways /You cannot prey upon us any much longer

/I'm burning, burning: burning to char, /I start to laugh, but then I cry, /Because of the exploding anger within /If I had the power, I would beat you up /To give you a taste of your own medicine -that would make you sneeze

/You consigned me to a dark dungeon /Every time I tried to pick myself up, you kicked me back down /You treat me like Lazarus by the rich man /Subjected to eat breadcrumbs off your table because I am a lesser being /All explained with, 'You were born fool.'

/But now, I am speaking a new language /And don't you think I have gone crazy /It's just to tell you again, 'I don't trust you' /Because you are like Judas who betrayed Jesus /Sold for thirty pieces of silver

/Let's get a divorce /It's over!

(Sings in new unintelligible 'new tongues' with only a few Swahili-Kikuyu words discernable)

...'Na-koma rungu-ye,' ...

... 'Pole,' ...na-turungi bila sukari
/....I have been sleeping on the cold floor under your bed....

/...You say, "Sorry," but I still drink my usual sugarless black-tea.${ }^{299}$

But while most of such biting criticism was directed at Moi and his government, members of the opposition, especially Members of Parliament, were not spared. With high

${ }^{299}$ Peter Kigia, "Reke Tumanwo," Youtube, $18^{\text {th }}$ June 2009. 
expectations from the new parties, public opinion was that the opposition had failed. Most people pointed out correctly that it was not enough to heap on Moi for everything that was wrong in the country. Members of the opposition failed to embrace moderation to enable them to press issues objectively for the general welfare of society. To the contrary, they prioritized scandalizing the president in order to boost their own public profiles.

Further, it was argued that hatred directed at the president would not propel society to success, especially when it was at the expense of the hard work of nation-building; integrity; professionalism. "Moi-must go" slogans, sponsoring motions of no confidence in parliament and hindering government-sponsored motions was not enough. ${ }^{300}$ Moi's removal was a non-issue. The question the court of public opinion wanted answered, especially in the mid-1990s as the country was poised to hold another election in 1997, was "Who" told the opposition "that President Moi" was "a problem to Kenyans? Why should they waste time on such an issue?" There were perceptive minds that understood that Kenya's socioeconomic and political problems were fundamentally structural and historical in nature. Many Kenyans, therefore, were audibly wondering whether there was any higher purpose other than the mere removal of Moi from power that motivated apparent opposition unity, much spoken about in the 1990s but never actuated. ${ }^{301}$ Like the ruling party Kanu, the opposition was not issue or longue durée oriented in terms of thinking of resolving the country's problems. Instead, talk of opposition-unity was mainly over dislodging Moi from power that many considered ridiculous and laughable. The main opposition parties lacked a concrete agenda on which to build an alliance ahead of the 1997 general elections. ${ }^{302}$ This specter was self-immolation by the opposition. ${ }^{303}$

In fact, most of them had been ardent Kanu turn-coats who joined the opposition only after falling out of grace. After decamping they derailed the democratic process since the undemocratic gene of the ancien régime characteristic of post-independence governments was deeply ingrained in them. As a result, this group of individuals betrayed the process of change that millions of Kenya wanted. They spoiled the opportunity, in 1992, to remove Kanu from

\footnotetext{
${ }^{300}$ Simmi Kimaru, "Where the Opposition Has Failed," Daily Nation, $2^{\text {nd }}$ November 1994.

${ }^{301}$ Seth wa Amboga, "What After the Alliance," Kenya Times, 14 ${ }^{\text {th }}$ December 1995.

302 Abadalla Mwahani, "What's the Aim of the Alliance?” Daily Nation, $21^{\text {st }}$ March 1996.

303 John Bundotich, “Opposition’s Self-immolation,” Kenya Times, $12^{\text {th }}$ March 1996.
} 
power constitutionally. This failure was because of the blind lust for power. ${ }^{304}$ The idea of opposition unity was a wisp because Kenyans did not expect them to compromise on settling on any one leader: they all wanted to be president and were, therefore, not expected to give each other a chance. Moreover, internally, the parties were undemocratic. ${ }^{305}$

While the opposition was thus engaged in an elusive quest to form a strategic alliance against the Moi-Kanu regime, the people were scattered like a flock without a shepherd. There was no credible opposition party or leader to offer direction. Even if an alliance was forthcoming, it was observed that the prime movers driving such a bid would ultimately fail to accommodate groups that had tirelessly advocated good governance and justice. These included NGOs, churches, academics, farmers, unregistered parties, human rights activists and students among others. Yet, without such sections of society, any such coalition of opposition forces was inadequate because it discounted "the participation of all people who had fought" were "still fighting for the liberation of Kenyans from the claws of the neo-colonial monster." ${ }^{306}$ It was a sea change that was expected of the opposition and not merely a matter of fielding a single candidate to propel somebody to State House. It is a real cure to the suffering of the helpless hungry poor "lumpen proletariat" or "marginalidados" that was expected. ${ }^{307}$ What Kenya needed was "a surgeon to clean the wounds of decay and inject a new sense of values to match the ideals advocated by the Mau Mau freedom fighters who spilled their blood to liberate the common man from exploitation by a small clique of colonialists." 308

\section{What the Common Man Needed: Liberation by Surgeon Mau Mau Freedom Fighters}

The mwananchi, the common man, understood democracy. Ordinary people understood that change had to come from citizens themselves. Some Kenyans writing to newspapers in the 1990s demonstrated that they had internalized the ideals of democracy. Indeed, they improved

\footnotetext{
${ }^{304}$ Nyakwara, "Opposition Leaders Must Act Now."

305 Wilson M. Wadia, “Opposition Has Played its Role,” Daily Nation, $7^{\text {th }}$ January 1995.

306 Odoyo Makanyayiera, "Do Kenyans Need this Alliance?" Daily Nation, 14 ${ }^{\text {th }}$ March 1996; Kimaru, "Where the Opposition Has Failed.”

307 Ibid.

${ }^{308}$ Wanyonyi, “Kenya Needs New Blood,” The Economic Review, December 6 ${ }^{\text {th }}-12^{\text {th }} 1993$.
} 
upon the original Mau Mau language of grievance elevating it with an appeal to the adherence and satisfaction of basic human rights. Some letters pointed out all men are created equal and were, therefore, endowed with certain inalienable rights. Among these, argued Isaac Babu Gitonga from Mombasa, included life, liberty and the pursuit of happiness. It is for this precise reason that governments were created among men, deriving their just powers from the consent of the people. If then the government was 'destructive of these ends' it was the people's right to change it and institute a new government. Otherwise, imposing changes from the top was dictatorship. ${ }^{309}$

So, whereas there were voices of despair, there were others more enduring that understood the inner working of democracy. What was needed was an organic or bottom-up and popular movement where society had a core leadership that articulated the burning issues of the day and their solutions. ${ }^{310}$ Such a movement would not be the outcome of a "single event" or constitute one. If this was not clear, the vivid lesson of post-Uhuru, Kenya whereby bystanders stood over the reins of power after successful but bloody liberation struggle, would be lost. It was for this reason why after independence, "democracy" took a wrong turn. The "fundamental ideals" of independence, namely getting rid of poverty, disease and injustices under colonial rule were shelved. ${ }^{311}$ Instead of waging war against "the imperialist," a new drama unfolded: power struggles, social injustice and the misappropriation of public funds.

Therefore, what was needed to turn things around was an emergent generation of young leaders that was credibly nationalist and democratic; that was committed to a new and democratic constitution; the rule of law; the elimination of social inequalities repeal of all oppressive laws; rejuvenation of educational and health systems, among other imperatives. ${ }^{312}$

Put differently, Kenyans needed a better more compassionate and responsive government. The public had the good sense to know that there was something fundamentally wrong in a society that emphasized the work ethic and yet failed to provide jobs for those willing

\footnotetext{
${ }^{309}$ Isaac Babu Gitonga, “Change Must Come From Citizens,” Daily Nation, 12 ${ }^{\text {th }}$ December 1994.

${ }^{310}$ Kabando wa Kabando, "New Political Thinking a Must," Daily Nation, $7^{\text {th }}$ May 1995.

311 Reverend Moses Akuku, "Hard Road to Democracy," The Standard, $25^{\text {th }}$ May 1993.

312 Ibid.
} 
and able to work. ${ }^{313}$ Beyond this structural malaise, it was felt that there was "a serious breakdown of...norms" that governed society. This was to be found in the general feared trend towards a pervasive psychology of self-interest that left no place for national and public good. It was a society where people seemed to be governed by the principle of survival for the fittest: this, unfortunately, also meant that everyone had to bear their own cross. Since this was the case, what chance did poor Kenyans have under the country's economic condition?

Further, this also meant that Kenya was a country for the rich where the poor continued to get poorer while the wealthy amassed even more creating a chasm between them. ${ }^{314}$ There was too much emphasis on individual rights in Kenya at the expense of communal obligations. As such, some Kenyans expected a little too much with regard to their own individual satisfaction, which was pursued without the obligation to give anything back to society in return. ${ }^{315}$ Surely, the people had endured "the State's painful bruises." It was about time that the government did something to spare them more injustices. ${ }^{316}$

The vision of, and therefore what the mwananchi expected by looking up to the state from below, was best summed up in the following letter excerpt:

Good governance is in large measure the appropriate and productive use of a country's resources with the full knowledge, and for the benefit of, the nation's citizens. The wananchi are entitled to know, either through public information (the media), or their elected representatives, how the government performs its functions, how tenders are let, for example, or how public money us safeguarded and spent for the good of society without being diverted to private use. Citizens are also entitled from their government certain guarantees of security from arbitrary arrest, extralegal restraint of the media, marauding bands intent on burning houses and chasing them off their land. Finally, good governance carries with it a certain commitment to provide services for the common good of society; fair elections, education, healthcare fiscal accountability and transportation infrastructure, to name a few.

The above list is far from exhaustive. It is, rather, a general disposition on the part of the government to look out for the welfare of the wananchi as a whole and not just a select few. Every elected official who lives up to his or her oath of office to serve the

\footnotetext{
313 Charles Maina Kariuki, “Kenyans Need Better Government,” Daily Nation, 5 th July 1995.

${ }^{314}$ Ibid. Also see Harrison Nthange Nguyo, "Kenyan Society Needs Redemption," Daily Nation, 19 ${ }^{\text {th }}$ September 1995.

${ }^{315}$ Kariuki, "Kenyans Need Better Government." The original text is muddled and a little confusing. This is my own paraphrase carried out with the aim of adhering as closely as possible to, and committed to enhance the articulation of, what the writer had in mind.

316 Nguyo, “Kenyan Society Needs Redemption,” Daily Nation, 19 ${ }^{\text {th }}$ September 1995.
} 
people of Kenya is exhibiting good governance, .... Ultimately, good governance places the responsibility of the government in the hands of the people who in turn hold the government accountable for its policy decisions and actions. ${ }^{317}$

\section{Conclusion}

When Moi came to power, many hailed him as a God-fearing Moses who would lead them to the Promised Land of socioeconomic prosperity, a life of civic virtue and civil liberties. $\mathrm{He}$ cut the figure of a compassionate and responsive political statesman. This image and expectations, however, were soon dashed. It's a fact that president Moi had inherited an economy already experiencing a downturn in difficult international economic times. But his initial expansionary and inclusive policies worsened the situation. Economic misdemeanors and mal-administration characterized by grand corruption brought the country's economy to its knees.

This, without fail, stirred unstinting political opposition from various quarters including the intelligentsia, the Church, the professions and ordinary everyday citizens who bore the brunt of the harsh economic times associated with the Moi era. The attempted coup was the stimuli Moi needed to show his true colors. For the most part of the 1980s, the country was thrown back to times not very much unlike colonial days. State security apparatuses were strengthened and Kenya, by every measure, became a surveillance and police state. The Moi regime then ran roughshod on people's subsidiary political rights and basic rights. Whereas the tide turned against the regime in the early 1990s, Moi managed to cling onto power. On the one hand, he implanted the recommended SAPs that worsened an already bad economic situation, which fueled his opposition. On the other, to survive and remain at the helm, like in the colonial era, Moi used divisive politics along ethno-regional lines, turning people's bitter frustrations against each other. Moi, "without much effort," had managed to turn the clock back. Rather than resolve the longstanding problem of land ownership and use, the president used this as a tool for political manipulation. Organized political opposition did not, itself, withstand this device of control, and coupled with individual ambitions and raw power hunger, was atomized and trounced in two elections.

317 T.J. Dowling, Press Officer, US Embassy, "What Good Governance Entails," The Economic Review, October $4^{\text {th }}$ $-10^{\text {th }} 1993$. 
But that was just as well because, the political class seemed to have lost sight of what really mattered to ordinary citizens: the rule of law and repeal of oppressive laws; the elimination of social inequalities; the rejuvenation of educational and health systems, proper infrastructure among other basic human right imperatives of day to day life. Although in the minority throughout the 1990s, there were a few perceptive minds that kept the flickering light and mentalité of struggle on. Although isolated as "matigari ma njirungi," they understood that Kenya's socioeconomic and political problems were fundamentally structural and historical in nature. This was the spirit with which Kenyans went to the 2002 polls that removed Moi. Although, once again, elite divisions and political bickering put a damper on it, this attitude of ongoing struggle remained alive in the first decade of the $21^{\text {st }}$ Century under the new administration of President Mwai Kibaki. Although manifesting itself in various ways, and not always acting in accord, the mentalité of struggle survived the worst of times, in the 1990s, and thrived in the Kibaki years of "bado mapambano" (the struggle is still on). 


\section{Chapter VII - Bado Mapambano, Solidarity Forever: Latter Day Travails of Critical Publics}

\section{Preamble}

Inchi yetu ita filisika na ufisadi

Na tusipo chunga, ni sisi tutaishi kwa umaskini

Bado mapambano, Mapambano

Si ni aibu katiba itufiche haki zetu

Serikali imeshindwa kutimiza wajibu wake kwa wananchi

Bado mapambano, Mapambano

Twende sote!

Maneno yao matamu, laikini bila matendo

Kilicho na mwanzo haikosi mwisho

Hawajui kwamba sisi ndio tegemeo, viogonzi wa leo.

Simama dada...vijana msilale

...Bado Mapambano...

...Kenya ni yetu....
/ Our country, Kenya, will be impoverished by corruption /and if we don't watch out, we will live in poverty.

/The struggle is still on, struggle-on.

/Isn't it a shame that the constitution is blind to our rights!

/The government has failed to fulfil its obligationto the public.

/The struggle is still on, struggle-on.

/Let's all join in!

/Their lips drip sweet words, just idle words without action. /Little do they know, every beginning has an end

for we are the hope,

the leaders of the day.

/Rise up sister...don't slumber young people ...the struggle is still on...

...Kenya belongs to us....

“Mapambano,” by Inka, Youtube Video, Published 16 $6^{\text {th }}$ July 2012. 
This chapter begins with an overview of the general state of the Kenyan economy after the Goldenberg scandal and the last six Moi years. This background analysis is extended to the Mwai Kibaki years (December 2002 to April 2013) during which there was economic growth but half the country's population remained trapped in poverty. Unfortunately, even after Moi's departure, government was marred by corruption scandals that eclipsed Goldenberg. This period of Kenyan history has elicited mixed views with some seeing the country as being back on the path of progress and the future. ${ }^{1}$ Others have argued that despite this transition, "nothing actually really changed." 2 The political and socioeconomic continuities and discontinuities are already engaging historians and other public commentators and observers in Kenya and abroad. Be that what it may, the everyday experiences and struggles of ordinary Kenyans remain the litmus test of whatever change, or the lack thereof, has impact on their lives.

The crucible of socioeconomic hardship, as experienced by various cadres of public employees ranging from university lecturers; elementary and high school teachers; doctors and nurses; and, with all due concern, disaffection in the ranks of the country's police force, is most eloquent on this score. Thus, the discontent in these, among others sections of Kenyan society and the formal and informal sectors of the economy, as expressed through perennial strike action, serve a common thread that runs, not only between the Moi and Kibaki years, but also one that harks back to the anti-colonial struggles embodied by the Mau Mau war. This, then, is what forms the subject of this chapter. In addition, this discourse extends to the mushrooming of rural and urban militias as well as rampant crime, which is another manifestation of economic and social malaise. The entire spectrum of such youth groups is beyond the scope of this discussion. However, it is important to point out that of the over thirty or so militias banned by the government, most of them were client-patron private armies engaged by rival politicians for election campaigns and "security."

Nevertheless, three movements stand out because as they do not fit within this mold. They are Mungiki, a movement that, despite tracing its roots to the early 1980s, reached its zenith in

\footnotetext{
${ }^{1}$ Charles Hornsby, Kenya: A history since independence (London: I.B Tauris, 2012), 697, sees the period as Kenya going "back to the future."

${ }^{2}$ Daniel Branch, Kenya: Between Hope and Despair, 1963-2011 (New Haven: Yale University Press, 2011) 247 argues that nothing really changed after Moi.
} 
the mid-2000s, the Saboat Land Army in the Mt. Elgon region and the Mombasa Republican Council (MRC) both of which can be traced to the intermittent post-election violence during the two multiparty election cycles in the 1990s. Generally, militias are a result of the poor state of the economy, which is the foremost source of risk for youth according to a World Bank report. ${ }^{3}$ Constituting the majority of new entrants into the labor market with approximately 500,000 young people joining the labor force every year, only a small portion of them are able to secure employment in the formal sector due to poor economic growth. ${ }^{4}$ While this is true of these three groups, they developed directly as a result of the deep-seated, unresolved problem of land. Secondly, while from time to time the Mungiki and the MRC have been courted by politicians, they emerged independently of the political class. The nurture and roots of their discontent is explored as part and parcel of economic and social malaise.

Lastly, an important aspect of investing the impact of the poor state of the Kenyan economy on the population is scrutinizing pop culture in Kenya. Art and music, especially, have become acutely socially and politically conscious. The harshness of socioeconomic life is reflected in various art forms. This examination of the production of popular culture from the late 1990s to 2013 will be limited to the music of various Kenyan artistes including Kalamashaka, Eric Wainaina, Ukooflani Mau Mau, Just A Band, Lisa Oduor Noah, Jahcoozi, Jaguar, Necessary Noize and Watumwa among others. In addition, graffiti, photography and cartoons will be examined. Further, analysis is extended to the emerging politics of social communication through platforms for political action provided by social networking sites (SNSs) like Facebook and Twitter. Kenya has caught up with the global explosion of the World Wide Web, technology that in recent times has been used to bring pressure to bear on the government by teachers, doctors and nurses or Kenyans themselves expressing solidarity with strikes. The radical secessionist MRC, constituting the technology savvy youth, promoted its objectives through their Facebook page.

However, there are virtual protest movements and critical publics that champion various causes through SNSs. These include the Wanjiku Revolution, Pawa254, Bunge la Wananchi and

\footnotetext{
${ }^{3}$ Chapter 4, "Underlying Risk and Protective Factors That Affect Young Kenyans," 38, World Bank document published on http://siteresources.worldbank.org/INTUNITFESSD/Resources/Chapter4_Edited_MCMay30_.pdf based on a field study in Kenya evidently undertaken around 2006.

4 Ibid.
} 
Unga Revolution. Individual Kenyans and groups have also put to use e-Petitions, especially the globally available GoPetitions site. ${ }^{5}$ Together, these new virtual avenues of protest and political agitation that are contiguous with the actual physical reality play out in everyday spaces of historical struggle including the Freedom Corner in Uhuru Park, Nairobi streets and Parliament. Despite this interconnection, they are herein treated as manifestations of eDemocracy at work in Kenyan crowd politics from below. The emerging sociopolitical discourse dovetails with other categories of formal and informal critical publics above, all of which collectively decry socioeconomic inequality and marginalization, injustice, the poor state of the economy, corruption and political repression. Put differently, the mentalité of struggle encapsulated in the single Swahili words "matatizo" or "mashaka” (problems/uncertainty).

\section{An Economy on Its Knees: Moi's Twilight Years and After}

Kenya's structural reform programs since the 1980s guaranteed substantial capital flows from the IMF, the World Bank and Western donors, but controversial political developments and continued human rights violations in the second half of the 1990s put these in jeopardy. ${ }^{6}$ Although Kenya continued to be the most industrialized country in East Africa during this time, agricultural production remained the cornerstone of the economy. In this period, the sector was contributing close to $30 \%$ of total output, employed over $70 \%$ of the labor force in primary and secondary activities, and was contributing more than half of the country's foreign exchange earnings while providing a substantial part of its food requirements. ${ }^{7}$ Small farms contributed $70-$ $80 \%$ of agricultural GDP. In 1995 tea accounted for $18 \%$ of merchandise export, while coffee contributed 15\%. But it was tourism that was Kenya's most important foreign exchange earner bringing $\$ 486$ in $1995 .{ }^{8}$ In the 1990 s, tea superseded coffee as the country's most important cash-crop and export earner. Indeed, this trend started much earlier in the 1980s. ${ }^{9}$

\footnotetext{
${ }^{5}$ www.gopetition.com has 23 million users around the world among them Kenyans. Whereas petitions lodged on the site focus on animal welfare, arts and entertainment, culture, gaming, Kenyan ePetitions have been on international affairs (revolving around the International Criminal Court cases of President Uhuru Muigai Kenyatta and Deputy President, William Samoei Ruto); justice; law reform; and national affairs and politics touching on education and health issues.

${ }^{6}$ The Economist Intelligence Unit Limited, “Country Risk Service Report: $4^{\text {th }}$ Quarter, 1996," (18 ${ }^{\text {th }}$ December 1996), 2.

${ }^{7}$ Ibid.

${ }^{8}$ Ibid. also see Hornsby, A History Since Independence, 572.

${ }^{9}$ Hornsby, A History Since Independence, 575.
} 
However, in contrast, the hallmark of the second half of the 1990s was the pauperization of small coffee farmers and general doldrums for the sector. Coffee price regulation based on future markets in 1990s coincided with declining national production volumes. Producer prices were cut by half without commensurate decrease in overhead processing and marketing costs. Coffee production was in decline for five consecutive years after $1988 .{ }^{10}$ This decline was more pronounced in smallholder farms where it declined by $47 \% .{ }^{11}$ Although prices reached their highest since 1977 between 1995 and 1997, Kenya's global market share was marred by preference for less acidic coffee and technological disadvantage. ${ }^{12}$ This, coupled with incomplete and incompetent liberalization of the coffee sector was attended by misappropriation; halving of coffee prices, between 1999 and 2002, meant farmers were paid less than they spent raising the crop; drought conditions; poor road infrastructure; currency devaluation and inflation; and debt incurred by farmers to buy inputs, advance payments, factory development and finance crop picking owed to the EU and World Bank all spelled doom. Thousands of smallholders uprooted their coffee trees and opted to grow food instead. Others who retained their coffee farms neglected them resulting in abject poverty in coffee growing areas. The effect in Central Province was particularly severe, with poverty, crime and social problems on the increase. The gross margins per farm were not enough for family sustenance let alone enough to send children to elementary and high school. ${ }^{13}$

Moreover, for more or less similar reasons, including market dynamics affecting pricing, drought, liberalization and deregulation, maize, rice and wheat production stagnated and was barely enough to meet the demand for food in Kenya. ${ }^{14}$ The situation was compounded by El Niño flooding phenomenon in 1997-98 explained as a symptom of global climate change together with increased population growth and general environmental degradation. This resulted in intermittent food shortages and even famine in some regions. ${ }^{15}$ Between 2.5 and 3 million Kenyans faced starvation between 1997 and 2011. For example, President Moi declared drought

\footnotetext{
${ }^{10}$ Ibid., 574; also see Andrew M. Karanja and James K. Nyoro, “Coffee Prices and Regulation and Their Impact on Livelihoods of Rural Community in Kenya," (Tegemeo Institute of Agricultural Policy and Development, Egerton University, October 2002), 6.

${ }^{11}$ Karanja and Nyoro, "Coffee Prices and Regulation," 5.

${ }^{12}$ Ibid.

${ }^{13}$ Hornsby, A History Since Independence, 574 \& 575; Karanja and Nyoro, "Coffee Prices and Regulation,” 6.

${ }^{14}$ Hornsby, A History Since Independence, 572 \& 573.

${ }^{15}$ Ibid., 574.
} 
conditions in Northeastern, Central and Rift Valley provinces a national disaster at the end of January 1997. ${ }^{16}$

At the same time, prospects for economic growth were dwindling. Whereas economic recovery and growth had been projected at $5 \%$ in 1999, it was revised downwards to $3.5 \%$. This was due to El Niño effects, continued stagnation of export volumes and a slow recovery for badly hit tourism revenue and a boom in imports. ${ }^{17}$ But the state of things was even gloomier as a result of expected slippage in macroeconomic discipline in the run-up to the second multiparty elections of 1997. This was reflected in rising inflation, monetary growth and government expenditure. ${ }^{18}$ It was estimated that between 1991 and 1997, the government lost Ksh. 475 billion (US $\$ 9$ billion) in fraud, theft and illegal spending. ${ }^{19}$ A politically intense general election year, 1997 witnessed attendant ethnic cleansing. One of the violent incidents occurred during the marking of the seventh anniversary of Saba Saba riots of 1990.

On $7^{\text {th }}$ July 1997, a series of major rallies were held across the country on what was the anniversary of the Saba Saba riots that accompanied the pressure for a multiparty system. The police and security apparatus in Nairobi attempted to suppress any demonstration, occasioning pitched battles in the city. As a result, more than fourteen people lost their lives. This was followed by more violent confrontation between protesters and police on August $8^{\text {th }}$ during a one-day national strike held to press for reform. The most serious disruption occurred in Nairobi where hundreds of youths went on a rampage and confronted the police. On $13^{\text {th }}$ August, the violence shifted to the coastal region where between 70 and 100 people were killed. ${ }^{20} \mathrm{~A}$ thousand Mijikenda, including people with military or para-military backgrounds who had been in training preceding the event, raided a police station in Mombasa. ${ }^{21}$ In November, there was similar ethnic violence in Trans-Mara District far away from the coast. ${ }^{22}$ Ethnic clashes

\footnotetext{
${ }^{16}$ The Economist Intelligence Unit Limited, "Country Risk Service Report: 4th Quarter, 1996," 3.

${ }^{17}$ The Economist Intelligence Unit Limited, "Country Risk Service Report: $1^{\text {st }}$ Quarter, 1998," (13 ${ }^{\text {th }}$ February 1998), 1.

${ }^{18}$ The Economist Intelligence Unit Limited, “Country Risk Service Report: $3^{\text {rd }}$ Quarter, 1996," $\left(24^{\text {th }}\right.$ September 1996), 1.

${ }^{19}$ Hornsby, A History Since Independence, 584.

${ }^{20}$ The Economist Intelligence Unit Limited, “Country Risk Service Report: $3^{\text {rd }}$ Quarter, 1997,” (20 ${ }^{\text {th }}$ August 1997), 2.

${ }^{21}$ Hornsby, A History Since Independence, 602.

${ }^{22}$ Ibid., 603.
} 
continued in various parts of the country even after the 1997 election and in spite of Moi's promise in his swearing-in ceremony that his new and last term would be more "peoplesensitive." ${ }^{23}$ Unabated violence bore serious implications not only for the Kenyans trying to grapple with life but also the economy.

These political developments and gross abuse of human rights jeopardized foreign inflow of capital in the form of aid and foreign investments and negatively impacted the tourism sector. Due to concern over the budget deficit and inflationary tendencies, the second tranche of the IMF's \$216 Enhanced Structural Adjustment Facility (ESAF) had not been released as scheduled in $1996 .{ }^{24}$ In 1997, however, the IMF simply suspended ESAF further undermining investor confidence and adding even more pressure on the currency. This combined with the tense and unstable political atmosphere to produce negative repercussions for the country's economic outlook. Economic growth was anticipated to drop to $3.1 \%$, which was below the rate of demographic expansion for the first time since $1994 .^{25}$ The health sector was seriously affected by this economic downward spiral. Expenditure on pensions, health care and social benefits fell from $2.6 \%$ of GDP in 1990 to $2 \%$ in 1996 . By this time, as Hornsby appropriately observes, the minimal safety net against poverty, ignorance and disease promised in the 1960s had long ago frayed away. ${ }^{26}$ As a result of a combination of factors including the spread of HIV/Aids, population growth, economic stagnation and SAPs, life expectancy in Kenya fell from 60 to 52 years. The rapid spread of HIV by 1996 affected between 7.5 and 8\% of Kenyan adults; and increasing cases of malaria, especially due to El Niño rains, were major contributing factors. ${ }^{27}$ The government was culpable and accountable for the bad times because it did precious little to mitigate the situation. Furthermore, grand corruption and poor management of public affairs were still the order of the day during this period.

Indeed, government corruption was on the rise. Various government parastatals were funneling funds to political accounts. ${ }^{28}$ It was on the management of public land that corruption

\footnotetext{
${ }^{23}$ The Economist Intelligence Unit Limited, “Country Risk Service Report: $1^{\text {st }}$ Quarter, 1998," (13 ${ }^{\text {th }}$ February 1998), 2. 
was particularly rampant. In the capital, the Nairobi County Council grabbed and sold virtually all open space or public institutions including road reserves, cemeteries, school playing grounds and community parks. ${ }^{29}$ In the Mau Forest Complex and Karura Forest, legal and illegal excisions were allocated. Parastatals were forced to buy such land at inflated prices from middlemen with the accruing difference feathering elite fiscal nests. ${ }^{30}$

\section{New Government, Same Old Systemic Rot: Kibaki's Elusive Mop-up}

Moi's old number two in the 1980s, Mwai Kibaki, ascended to power, thus becoming the country's third president on the emphatic multi-ethnic support and goodwill forged in the lastditch pre-2002 elections strategic political alliance. ${ }^{31}$ While his ascendance to power triggered the imagination that anything and everything was now possible with Moi's exit, Kenya's economic woes and government corruption continued. To his credit and that of his administration, however, Kenya's economic growth rebounded from 2002 levels to about 7\% by 2007. Kibaki's government also made strides towards judiciary and constitutional reforms crowned with the promulgation of a new Constitution of Kenya in 2010. Other modest successes included civil service reform, free primary education and improvement in the availability of drugs and health provision. ${ }^{32}$

Kibaki enumerated the successes of his first and second administrations based on voluntary or forced multi-party coalitions when he led Kenyans to celebrate forty-nine years of independence. On this occasion of Jamuhuri Day celebrations on $12^{\text {th }}$ December 2012, Kibaki reminded Kenyans of the serious economic challenges the country was facing when he came to power. Despite this, he said that his government was able to keep the GDP growth rate between $7 \%$ in 2007 and 5\%. This economic record rested on the twin blueprints of Economic Recovery

\footnotetext{
${ }^{29}$ Ibid., 585.

${ }^{30}$ Ibid.

${ }^{31}$ Mwai Kibaki was able to defeat Uhuru Kenyatta whom Moi had fronted as his preferred candidate in the 2002 presidential elections. An amalgam of opposition forces had coalesced including leading veteran politicians Raila Odinga, Wamalwa Kijana, Charity Kaluki Ngilu and disgruntled former KANU leaders under the National Rainbow Coalition. This, however, soon unraveled resulting in irreconcilable differences between politicians allied to Raila and those who remained loyal to Kibaki. As a result, the two faced off in the inconclusive and controversial presidential elections in 2007, which occasioned a period blood-letting that was unprecedented in its ferocity and proportions. It was a great reprieve that it was curbed in good time as it could have been far much worse. Hornsby and Branch have detailed this troubled period of Kenya's history characterized by unbridled and bilious political bickering pitting the ruling class against one another. As a result of the Post-Election Violence, GDP growth rate slipped in a matter of months from $7 \%$ to $4.5 \%$ in 2008.

${ }^{32}$ Hornsby, A History Since Independence, 702-707.
} 
Strategy for Wealth and Employment Creation and the Kenya Vision 2030, inaugurated to transform the nation into a middle-income country. Under this economic development strategy, the agricultural sector recovered from a $-3 \%$ growth rate to $6 \%$. This, according to the speech, had reduced national poverty levels from $56 \%$ to $46 \%$ and buoyed food security levels. Kibaki was also proud of efforts to reduce over-reliance on rain-fed production through the rehabilitation of irrigation schemes such as Bura, Hola, West Kano, Mwea, Nzoia, Ahero and Katilu, all of which increased the area under irrigation by 150,000 hectares. He further stated that his government had created new schemes in the swamp in Yala, Turkana, Kibwezi, Masinga and Kiambere. ${ }^{33}$

In addition, Kibaki showcased the expansion of the national tax revenue base. In 2002, he said, the national budget was Ksh. 250 billion yet tax revenues stood at Ksh. 180 billion. The Moi government had plugged in the shortfall with the help of foreign donor funding. By 2012, tax revenue had increased significantly to Ksh700 billion, thus enabling the government to fund over $95 \%$ of the national budget, which meant relative economic independence. Further, he pointed to attempts to rehabilitate and expand the road and railway transport system and energy and telecommunications infrastructure to ease the movement of goods and people to increase production and trade opportunities. With regard to electricity connections, the president pointed out that since he took the reins of power, these had increased from 600,000 to over 2 million. Towards the end of his administration, Kibaki unveiled the Lamu Port-South Sudan-Ethiopia Transport project that includes the laying of a railway track from Lamu to Kenya's two neighbors in the north. His government had also acted to increase the capacity of the old port of Mombasa in addition to the construction of a new one in Lamu. ${ }^{34}$

Another centerpiece that Kibaki mentioned was the fact that in ten years mobile phone users had grown from less than a million to 30 million; and internet users from 250,000 to 14 million. There were more radio and television stations during this time: the former increasing to 81 and the later to 19 . The president also mentioned an interesting economic achievement that he described as "financial inclusivity." He explained it in terms of increasing the number of people with access to financial services from 1 million people to over 20 million Kenyans. This referred

\footnotetext{
${ }^{33}$ Kibaki speech, Youtube, Published, $12^{\text {th }}$ December 2012.

34 Ibid.
} 
to people with access to capital and credit facilities to pursue different entrepreneurial ventures through the revolutionary mobile telephony solutions and the expansion of the banking industry. ${ }^{35}$ Whereas the veracity of these figures of financial inclusivity go unquestioned, the intensity of agitation for more pay from various formal professional and informal sectors, and popular culture that offer a rare snapshot of the experience of everyday socioeconomic realities tell and constitute quite a different narrative.

Moreover, systemic government corruption proved to be quite a different kind of animal to slay in a decennary fell swoop. Despite the new government's commitment to the fight against corruption and for openness, there was an insatiable demand for money to feed the political machine which undermined this bid. ${ }^{36}$ Indeed, as Branch aptly observed, for all the rhetorical boasts of change and reform, the new government was unwilling to fundamentally address corruption. ${ }^{37}$ Hornsby made the same observation going further to point out that Kibaki's government had adopted the same kleptocratic attitude to state funds as its predecessors. ${ }^{38}$ These remarks are in reference to the Anglo-Leasing scandal, which rocked the Kibaki administration hardly two years after it took over the running of government. The details of what it entailed have been exhaustively discussed in Michela Wrong's book, It's Our Turn to Eat, which is the story of how Kibaki anti-corruption tsar, John Githongo, uncovered a corruption scandal in which the government and the people of Kenya were set to lose from \$700 million to over \$1 billion. ${ }^{39}$

In a nutshell, Anglo-Leasing was "a Moi-era horse" entailing an "unsavoury picture of bloated procurement." 40 It was the product of old corruption networks into which Kibaki's new men in government eased themselves in or adopted although some of the malfeasance was also new. ${ }^{41}$ In a speech entitled "Some Bread and Butter Questions," that the British High Commissioner delivered to the British Business Association in July 2004, Sir Edward Clay accused those in government who were eating "like gluttons" when it was hoped that corruption

\footnotetext{
35 Ibid.

${ }^{36}$ Hornsby, A History Since Independence, 697 \& 705-707; also see Branch, Between Hope and Despair, $260-263$.

${ }^{37}$ Branch, Between Hope and Despair, 252.

${ }^{38}$ Hornsby, A History Since Independence, 725.

${ }^{39}$ Ibid., 725-727 and Branch, Between Hope and Despair, 253-54.

${ }^{40}$ Michela Wrong, It's Our Turn To Eat: The Story of a Kenyan Whistle-blower (London: Fourth Estate, 2009$), 200$.

${ }^{41}$ Ibid. Also see Branch, Between Hope and Despair, 253.
} 
carried over from Moi-years would not be rammed into people's faces. This, he said, was out of a combination of arrogance, greed and panic. The top British diplomat went on to add that while those involved expected that people would not see, or notice, or would forgive them a bit of gluttony, they could hardly expect people not to care when their gluttony caused them to vomit all over their shoes. ${ }^{42}$

In all, the scandal involved at least eighteen contracts from various government departments, including finance, transport and internal security. All were described as "sensitive" or security-related and included a digital multi-channel communications network for the prison service; new helicopters; a secure communications system, computer and video equipment and security vehicles for the police; a state-of-the-art frigate built in Spain for the Kenyan navy; a data network and internet service satellite link for the Kenya Post Office; a top-secret military surveillance system dubbed "Project Nexus"; a forensic laboratory for the Criminal Investigations Department; an early-warning radar system for the meteorological department etc. ${ }^{43}$ Most of these contracts were based on the principle of debt financing and, therefore, did not require parliamentary approval. ${ }^{44}$ Twelve of these contracts were master-minded by someone in the former Moi regime but, as noted, he had found a cozy home under the Kibaki government. As such, they followed the Goldenberg formula whereby the government of Kenya was set to pay tripled-up prices to a legal but non-existent British lease finance company, Anglo-Leasing. Investigations also revealed a web of other fake companies, which were linked to Indian business families that worked with the Moi-Kanu regime. ${ }^{45}$

All said, these contracts "were worth a gulp-inducing 56.3 billion shillings $(\$ 751$ million)." ${ }^{46}$ This everyday struggle, like government corruption, was carried over, unbroken, from the Moi into the Kibaki era and took on different faces depending on where it was played out and by whom. Needless to say, meantime, it was ordinary Kenyans struggling to eke a living who stoically bore the brunt of grand government corruption. Most Kenyans were not going to watch from the sidelines and not criticize the government for grand corruption, the increasing

\footnotetext{
${ }^{42}$ Wrong, Our Turn to Eat, 201-202.

${ }^{43}$ Ibid., 165.

${ }^{44}$ Hornsby, A History Since Independence, 726.

${ }^{45}$ Ibid.

${ }^{46}$ Wrong, Our Turn to Eat, 165.
} 
cost of living and gross socioeconomic inequalities and social inequity. Indeed, the mentalité of struggle usually associated with the rural and urban poor sections of society, gripped professionals who would, otherwise, be thought of as a "privileged" group. But they too, including university professors, elementary and high school teachers, doctors and nurses, felt the pinch of increasingly hard economic times. Imbued by the spirit of the struggle of everydayliving, they turned to public criticism of the government in boardrooms, staff-rooms and the streets. This harvest of workers' strikes can and should be understood in light of the hard economic times that started falling upon Kenyans from the early 1990s. They deserve close scrutiny because their case illustrates that very few in Kenyan society have been left unscathed.

\section{A Harvest of Workers' Strikes: Universities Academic Staff Union (UASU), Teachers, Doctors and Nurses}

Since late 1993 when UASU went on a protracted strike to protest against the government's decision not to register their union, the organization that represents faculty from Kenya's public universities has in numerous instances engaged the government over the issue of decent emoluments commensurate to their service in shaping the country's best minds and future workforce. The union's existence was predicated upon the improvement of the terms of service as well as the improvement of the relationship between its members, each university council and the students. ${ }^{47}$ The government's response had been to move to prevent academics from organizing themselves into a trade union. This uncompromising stance was seen as partly a product of the then prevalent conception by the state of the nature of trade unions. As perceived by the state, trade unions in Kenya's highly stratified society stood as the number one threat to the status quo. ${ }^{48}$ Not only was the state, at the time, the employer of public university teaching and non-teaching staff, but it assumed the right to control those who worked for it; the right to be the only voice; and the right to demand complete allegiance from them especially in the era of multiparty politics. From the government's point of view, the idea that any group of government employees could organize a trade union to better bargain around the terms of service was an anathema. $^{49}$

\footnotetext{
${ }^{47}$ Alamin Mazrui and Willy Mutunga, "The State vs. The Academic Union in Postcolonial Kenya," Review of African Political Economy 22 (1995): 257.

${ }^{48}$ Ibid., 258.

49 Ibid.
} 
But such demands were not unwarranted, especially in light of the adverse impact of the 1980s and 1990s cycles of SAPs on the education and health sectors. Like most state employees, professors, doctors, pharmacists, registered nurses and teachers suffered the consequences, as a result of SAPs, reduced budget spending and welfare expenditures, freezes on wages, inflation and numerous devaluations of the national currency, among other economic hardships. Education's share of government recurrent expenditure fell from 35.9\% in 1985/86 to $34.9 \%$ in 1995/96. ${ }^{50}$ Moreover, whereas the American dollar was worth about eighteen shillings in the 1980s, in 1993, the dollar was about eighty Kenya shillings. ${ }^{51}$ These, among other measures, led to a massive laying-off of non-teaching staff and a disgruntled, over-worked teaching staff who, as a result of SAPs, had to contend with an increasing teacher to pupil ratio, which was particularly high at tertiary institutions. ${ }^{52}$ Staff salaries and their purchasing power were considerably affected. ${ }^{53}$ Furthermore, discontented professors had to contend with an astonishing state of disrepair of institutional facilities. There were recurrent problems relating to water shortage in the halls of residence and teaching buildings, electricity shortages and a general shortage of resources necessary to run universities. ${ }^{54}$ Overall national economic downturn and the issue of improvement of welfare put UASU on an intermittent fight with the government that has lasted twenty years since the first major strike in November 1993.

Although most universities resorted to partial privatization by initiating Module II (Parallel) degree programs through which privately sponsored students could register for courses, the income thus generated did not go far enough to stem institutional problems. As a result, UASU and affiliated teaching and non-teaching staff unions at various public universities were part of a wave of labor unrest experienced in 2012, plunging the education and health sectors into turmoil. During this strike, eleven-thousand teaching and non-teaching staff downed their tools. This included four-thousand lecturers from 19 public universities and colleges. ${ }^{55} \mathrm{UASU}$ officials, having earlier succeeded in bringing the government to agree on a four year Collective

\footnotetext{
${ }^{50}$ Isaac W. Muasya, “The Impact of Structural Adjustment Programmes (SAPs) on Education in Kenya," International Journal of Arts and Commerce 1 (2012): 13.

${ }^{51}$ Francis John Gichaga, Surviving the Academic Arena: My Complex Journey to the Apex (Nairobi: University of Nairobi Press, 2011), 176.

${ }^{52}$ Muasya, "Impact of Structural Adjustment Programmes," 13.

${ }^{53}$ Gichaga, Surviving the Academic Arena, 176.

${ }^{54}$ Ibid., 121-122.

${ }^{55}$ Nation Team, “University Staff Walk Out as Unrest Spreads,” Daily Nation, 6 ${ }^{\text {th }}$ September 2012.
} 
Bargaining Agreement (CBA) in 2008/9, resorted to industrial unrest to force the government to honor its part of this deal to double basic pay and improve allowances. The union officials felt that theirs had been a history of failed promises and vowed to no longer tolerate dishonesty.

One of the officials, Charles Mukhwaya, the secretary general of the Universities Nonteaching Staff Union (UNTESU), accused the government of being insensitive to the plight of its workers since it was unmoved by their cries. They argued that the government and university councils were dodging two pending CBAs of 2010/11 and 2012/14, and demanded that the parties return to the negotiating table. ${ }^{56}$ Further, the union demanded a new salary structure that would double the basic pay of lecturers and improvement of allowances by more than $100 \%$. A return to work formula was reached when the unions signed a Ksh7.8 billion deal towards the end of September 2012. ${ }^{57}$

Their elementary school teachers union colleagues in Kenya National Union of Teachers (KNUT), who settled on a 1997 Salary Agreement were, however, not so fortunate. On $29^{\text {th }}$ August 2012, after a KNUT advisory council meeting, the union called for a strike set to coincide with the opening, on $3^{\text {rd }}$ September, of the third and final term of the year. This was amid resolute singing of the characteristic Bado mapambano chorus associated with striking workers in Kenya. In fact, the struggle for Kenyan teachers ran deep in the country's history. Indeed, it mirrored that of anti-colonial movements since the first seed of organizing teachers under one organization was planted through the initiative of James Gichuru and Eliud Mathu in 1934. Their organization and KNUT's precursor, the Kenya African Teachers Union (KATU), quickly fizzled out under the pressure of British colonial authorities. ${ }^{58}$ Although Makerere and Kagumo colleges produced high caliber teachers enabling the proliferation of Christian denominational or provincial unions, they were not allowed to form or organize a representative national body. This state of affairs was noticed by a member of the LegCo, Daniel Moi, who had been a teacher himself. In 1957 he sponsored a LegCo motion requesting the government to help teachers to form a national body, which led to the formation and registration of KNUT as a trade union in 1959. For a while, the foremost policy demand in the 1960s was a single employer for

\footnotetext{
${ }^{56}$ Ramadhan Rajab, “Lecturers Strike On, UASU Boss Declares,” The Star, $6^{\text {th }}$ September 2012.

${ }^{57}$ Nation Team, "University Staff Walk Out."

${ }^{58}$ According to the KNUT Website, "History," (2013). There is yet to be a thorough examination of trade union history in Kenya in general and KNUT in particular.
} 
all teachers. ${ }^{59}$ A series of strikes led to the establishment of the Teachers Service Commission in 1967. However, it is notable that the most enduring pre-independence demand behind the unionization of teachers, pay increment and teachers' pension, has remained a constant refrain.

Since KNUT's fourth strike, staged from $4^{\text {th }}$ to $11^{\text {th }} 1969$, all future strikes were dominated by calls for better remuneration. The 1969 strike was as a result of the government's initial unwillingness to implement the recommendations of the Teachers Service Remuneration Committee, which the government had instituted to negotiate several issues that teachers had been raising over the years. ${ }^{60}$ The national teachers' strike of 1997, in which they demanded a $300 \%$ pay increment, coincided with general elections. The president, who during the early years of his presidency was fond of styling himself "Teacher Number One," accused his political opponents of instigating the strike. As a re-election tactic Moi and Kanu quickly acceded to this demand and also agreed to the payment of pensions due to 1997 teacher retirees. ${ }^{61}$ This deal was sealed and weighted by the Legal Notice 534 of 1997.

This deal was signed, on government side, by the head of public service, permanent secretary (treasury) and the solicitor-general. It guaranteed the raising of salaries between $150 \%$ and $200 \%$ following the recommendations of the Teachers Service Remuneration Committee. This was to be undertaken in five installments staggered or paid in five phases and was set to cost the government Ksh. 47 billion. It also covered various allowances. It was, however, not registered with the Industrial Court as demanded by the law, which compromised its legality. At any rate, the government soon reneged on the deal, and by October 1998, the teachers were on the streets yet again. The Kibaki administration inherited the intermittent problem that on occasion brought learning in elementary and high schools to a grinding halt. Teachers issued a strike notice towards the end of 2000 timed to coincide with the opening of schools in 2001 but called it off. This was not the case in October 2002 when there was a two-week strike demanding that the 1997 salary increment deal be honored. The teachers complained that they were living on starvation wages while politicians continued to award themselves hefty salaries. ${ }^{62}$ At the time,

\footnotetext{
59 Ibid.

${ }^{60}$ Kibiwott Koross, “History of Teachers' Strikes Since Independence," The Star, $3{ }^{\text {rd }}$ September 2012.

${ }^{61} \mathrm{Ibid}$; also see, KNUT letter to Njeru Githae, Minister for Finance, $19^{\text {th }}$ October 2012, KNUT Website.

${ }^{62}$ Okoth Osewe, “240,000 Teachers on Strike," Committee for Workers' International, $3{ }^{\text {rd }}$ October 2002.
} 
MPs were earning more than half a million shillings (US \$6,330) a month after they hiked their wages with little due regard to the state of the economy. ${ }^{63}$

The out-of-step advance-retreat dance between KNUT and the government continued. As it did, it was increasingly characterized by a rising crescendo as elementary and high school teachers' union reminded members not to sleep. After all, the struggle was still on (bado mapambano). By September 2011, Kenyan teachers were still in the trenches of continued struggle lamenting inadequate staffing especially in light of the influx of students since the introduction of free primary school education in January 2002. This was repeated yet again in September 2012 reinstating their demand for a 300\% pay hike and responsibility allowance of between 30 to $50 \%$ for senior, deputy and head teachers. During this strike, the then KNUT secretary general David Okuta said that it was clear that teachers never earned an increment without "sweating." 64 Okuta went on to add that it was not that teachers loved going on strike. Rather, strike-action was testament to how badly teachers had been treated "since time immemorial." Yet, there was no need to even have to negotiate for a salary increment since it was a right, Okuta said: the government had taken teachers for granted for far too long. ${ }^{65}$

But, teachers were not alone. It would seem, regrettably, that renderers of essential public services were, generally, being taken for granted because the health sector too had over time not been spared by strikes. At the end of his second five-year term, president Kibaki was unable to stem the downward spiral that came at the heels of the SAPs. At the beginning of September 2012, when there was labor unrest led by teachers and workers in public universities, doctors in public hospitals also announced that they would stop treating patients. Doctors were demanding that the government rescind the suspension of 303 trainee medics at two Nairobi hospitals. ${ }^{66}$ This protest, nevertheless, was quite mild considering the "myriad of bedevilments to the health sector in Kenya" precipitating a dire situation facing the country. ${ }^{67}$

\footnotetext{
${ }^{63}$ Ibid.

${ }^{64}$ Koross, "History of Teachers' Strikes."

${ }^{65}$ Ibid.

${ }^{66}$ Nation Team, "University Staff Walk Out."

${ }^{67}$ Aruyaru Stanley Mwenda, "From a Dream to a Resounding Reality: The Inception of a Doctors Union in Kenya," Pan African Medical Journal (2012): 2.
} 
With the adoption of SAPs from the 1980s, access to better healthcare remained elusive to many Kenyans. ${ }^{68}$ As of 2012, there were, in Kenya, a total of 8,000 doctors of whom only 2,300 were in the public hospitals to cater for the majority of the country's population of at least 40 million. This left the country in a desperate situation as far as meeting the World Health Organization (WHO) recommended doctor-patient ratio of 1:1000 is concerned. This means that no less than 40,000 doctors are required to meet this WHO ratio. ${ }^{69}$ Besides this sorry state of affairs, the introduction of user fees as part of SAP reforms meant ignominious death for poor people who could not pay the steep cost of medical services. The withdrawal of external support that necessitated government cuts in its expenditure on social services, compounded by massive corruption and mismanagement of resources, overall, caused an unprecedented deterioration in public health services and diversion of medication and equipment to private clinics. ${ }^{70}$

For instance, Treasury allocated only $15 \%$ of the national budget to healthcare in the 2011/2012 financial year. ${ }^{71}$ As a result, the quantity and quality of medical services has deteriorated substantially, negatively affecting Kenyans in general and particularly the poor and other vulnerable groups. ${ }^{72}$ For over twenty years, therefore, doctors had felt the need to influence the running of the health sector and improve health services in Kenya. ${ }^{73}$ Their concern over the years was expressed through the need to unionize to be better able to engage the government with regard to various health sector policy challenges. In Kenya's history, there has been no union to stand up to the government to agitate for better terms of service or better funding of the health sector. ${ }^{74}$

The dream for a union was realized after two grueling years of determination and resilience in August 2011. ${ }^{75}$ The Kenya Medical Practitioners, Pharmacists and Dentists Union (KMPDU) immediately set about to engage government on outstanding demands and concerns

\footnotetext{
${ }^{68}$ Edward Oyugi, “An Obscene Inequality,” Kenya Social Watch Group Website (2000).

${ }^{69}$ Mwenda, "From a Dream to a Resounding Reality," 2.

${ }^{70}$ Oyugi, "An Obscene Inequality," Kenya Social Watch Group Website (2000).

${ }^{71}$ Mwenda, "From a Dream to a Resounding Reality," 2. It is common knowledge that this remains the case as a result the long-term effects of SAPs of the 1990s and, to some extent, the fact that the country remains securitystate. Subsequently, security accounts for more than $40 \%$ of public expenditure annually.

72 Joseph Kipkemboi Rono, “The Impact of the Structural Adjustment Programmes on Kenyan society," Journal of social development in Africa 17 (January 2002): 94.

${ }^{73}$ Mwenda, "From a Dream to a Resounding Reality," 1-2.

${ }^{74}$ Ibid.

${ }^{75}$ Ibid.
} 
by organizing "the most successful doctor's strike in the history of Kenya" in December $2011 .^{76}$ It decried lack of health facilities citing the fact that radiotherapy for various types of cancer was only accessible in the capital city while dialysis was available in selected few centres in the country, which was out of sync with the high number of patients requiring such intervention. The union also complained of inhuman working conditions of residents in the Kenyan teaching hospitals including working long hours, day and night when on call for no pay, which is something doctors interpreted as nothing else but slavery. ${ }^{77}$ Doctors felt that they were not only underpaid but also overworked.

Further, they attributed the movement of the majority of trained doctors from public hospitals to the private health sector or immigration abroad to seek a better life to poor remuneration by government. Indeed, in the wake of the December 2011 strike, the government acknowledged that up to three-quarters of doctors usually leave the government payroll three years after joining the public health sector. After all, new graduate medics entered public service with a basic salary of $\$ 350$ dollars per month. Up to $80 \%$ of doctor attrition in public hospitals was due to resignations as they sought greener pastures. ${ }^{78}$ Such demands and concerns reflected and foreshadowed the self-sacrifice and suffering of other healthcare workers.

Between 1997 and December 2013, there were no less than five nurse strikes demanding for better pay or, like teachers, the implementation of agreed-upon salary increments and the improvement of services in the country's ill-equipped public hospitals. Three of these strikes were within months of each other in 2012. One of them, the health care workers strike of September 2012, coincided with the general labor unrest in the country. In the course of the strike, health workers called to attention gross inequalities in public service emoluments. They pointed to the fact that politicians made about $\$ 130,000$ a year while doctors earned $\$ 36,000$ a year. ${ }^{79}$ Besides the thinly veiled call for the harmonization of salaries across the board in the government wage bill, the country's 25,000 nurses continued to protest at the end of the year that the government was adamant with regard to the issues raised. One of these was its refusal to register the Kenya National Union of Nurses (KNUN) to make it possible for the organization to

\footnotetext{
76 Ibid., 4.

${ }^{77}$ Ibid., 2.

78 Ibid., 2 \& 3.

79 "Health Care Workers on Strike for the Whole Class," Advance the Struggle Website, 9 th $^{\text {th }}$ October 2012.
} 
enter into a collective bargaining agreement with the government on behalf of workers. Nurses argued that this was in clear violation of the nurses' constitutional rights. ${ }^{80}$

By the end of the Kibaki era, the demands of nurses and health workers remained unmet. "Aluta Continua," charged a blog posted on the KNUN website against the background of yet another strike in December 2013. The message thanked members for their solidarity and support urging them to gather on $16^{\text {th }}$ December to solidify KNUN demands and push further calls. ${ }^{81}$ At the same time, a day after the country celebrated 50 years of independence, another message on the KNUN portal called on members to attend the alternative meeting to protest Kenya being “sick@50." ${ }^{82}$ Worker's strike focused on emoluments and working conditions are a manifestation and an illustration of deeper seated social malaise. This is more so considering that they represent a relatively well-to-do section of society. When one pries deeper into this bitter trunk of protest, one finds an even more bitter struggle underneath the surface that has direct or indirect connections with historical injustices of the colonial era. The Mungiki, Saboat Land Defense Force and the Mombasa Republican Council represent prime examples of such a farreaching genealogy of grievance and social protest.

\section{Neo-Mau Maus of the Mind: Mungiki, Saboat Defense Force (SLDF) and the Mombasa Republican Council (MRC)}

The stability and future survival of the Kenyan state is in question in the $21^{\text {st }}$ century more than at any other time in its history. This is especially considering the country's worst political crisis since independence between $30^{\text {th }}$ December and the end of February 2008. At least 1,500 people were killed in what was dubbed post-election violence (PEV) following a hotly contested presidential election. Thus, at the local, regional, national and international levels this climax of inter-ethnic violence that has manifested itself since reversion to multiparty politics in the 1990s was explained in terms of shifting historical ethnic rivalry between the Kikuyu, Luo and the Kalenjin among other groups allied to them. This, however, is a gross oversimplification of the complex, intractable and yet unresolved historical issue of land ownership and distribution in Kenya. As such, if violence is to be prevented from escalating into an even greater catastrophe,

\footnotetext{
80 "Nurses in Kenya begin nationwide strike from Monday $3^{\text {rd }}$, December 2012," Kenya National Union of Nurses Website, $1^{\text {st }}$ December 2012.

81 "Aluta Continua," KNUN Website, $13^{\text {th }}$ December 2013.

82 "Clarion Call," KNUN Website, 13 ${ }^{\text {th }}$ December 2013.
} 
the deep historical springs of ethnic conflict over the issue of land, among other public resources, needs to be addressed.

Land continues to be both a popular desire and a source of divisions in Kenya. ${ }^{83}$ It continues to present the greatest challenge to any administration since independence. This is not least due to the fact that the land demarcation and registration process that was begun in the 1950s is still incomplete. ${ }^{84}$ To further complicate this issue, there exists no national policy. Drafting one would be a daunting task. The matter of a national land policy is delicate as there is the possible risk that it would, more likely than not, reopen every major land-related problem in Kenya's history from the British conquest through the settlement schemes of the 1960s to the ethnic clashes from the early 1990 s to $2007 / 08 .{ }^{85}$

While the political elite have avoided addressing the issue of a national land policy, some, if not most of them, have not left "untouched" public and trust lands some of which have been un-procedurally and, therefore, illegally appropriated. A commission appointed to investigate land abuses of the past in 2003, the Ndung'u commission, "was political dynamite" when it was reluctantly published by the Kibaki government in December 2004. This report indicted virtually every senior KANU leader, including Moi, his family, politicians, civil servants and military officers for profiting from illegal government land transactions, housing allocations and forest excisions. ${ }^{86}$ Thus, while land rights and land laws remain a tinderbox, state and communal trust land has continued to be stolen. ${ }^{87}$ This then is what has been at the heart of the intermittent "ethnic clashes" that are thought to be expressions of spontaneous bursts of political action at the behest of elite ethnic kingpins. ${ }^{88}$

As noted above, however, this is superficial and, as referred to by Edward Oyugi et al, an instrumentalist assessment of the problem. Different ethnic groups especially, the Kikuyu, Kalenjin, Mijikenda and Maasai from central, Rift Valley and coastal regions continue to suffer from the centennial effects resulting from British land alienation at the onset of colonialism in

\footnotetext{
${ }^{83}$ Hornsby, A History Since Independence, 716.

84 Ibid.

${ }^{85}$ Ibid.

${ }^{86}$ Ibid., 707-708.

${ }^{87}$ Ibid., 665.

${ }^{88}$ Edward Oyugi et al, "Mired in the Unsolved National Question," Social Watch Website (2008).
} 
the 1900s. It is not surprising then that these regions have become theatres of continued agitation and, at times, violent opposition to the state. At other times, organized youth groups have not only opposed the government, using intimidating and thinly veiled violent rhetoric, but also warned rival ethnic groups perceived to be threats to their socioeconomic well-being. Although the Kenyan government has banned at least thirty five such vigilantes in rural, peri-urban and urban localities, only the most problematic ones have been selected for brief discussion herein.

\section{Mungiki: Scavenging the Interstices of the State}

The Mungiki movement and Kikuyu spiritual sect has its origins in the early 1980s. It emerged to protect the interests of farmers in Central and the Rift Valley provinces. It was also an expression of discontent with the manner in which the parents of the sect's young members were treated by Jomo Kenyatta even after they had made enormous sacrifices in the struggle for uhuru. It is for this reason that the movement referred themselves as Matigari ma Njirungi. That is, the heir-remnants of Kenya's freedom fighters. ${ }^{89}$ The group perceives itself as the real daughters and sons of Mau Mau. ${ }^{90}$ It originated around the prophecies of their charismatic leader, Maina Njenga, who advocated for a return to a traditional Kikuyu way of life. ${ }^{91}$ According to the founder, he among others saw visions in which they were commanded to call upon the Kikuyu and all Africans to go back to their roots thus forsaking the ways of the white man. ${ }^{92}$

Lexicographically, the movement derives its name from the Kikuyu word "muingi" that refers, generally, to "the masses," "community" or "general public." It is a derivative of the Kikuyu word for "many," "much" or "more." "93 By adding the suffix "ki" at the end of the word, it takes on a whole new meaning of "totality or fullness of all imaginable public-measure" thus implying the total mobilization of everyone and everything in the community: "muingi-ki." This usage and conception of "community" has generated and lent the language a new derivative or mutated word "mungiki." The term "mungiki" is, therefore, not just a mere description but an action word with profound political implications since it could also refer to "the people's

\footnotetext{
${ }^{89}$ Peter Mwai, “Maelezo Kuhusu Asili ya Mungiki,”Taifa Leo, 6" March 2009.

90 Jillo Kadida, "Police Arrest Rowdy Members of Banned Sect," Sunday Nation, 5" October 2003.

${ }^{91}$ Ross Kemp, “A Kenya Special,” Documentary for SKY 1 TV, Youtube, Published 1 ${ }^{\text {st }}$ December 2009.

92 Branch, Between Hope and Despair, 236.

93 T.G. Benson, Kikuyu-English dictionary (Oxford: Clarendon Press, 1964), 188.
} 
uprising." ${ }^{.94}$ As such, it is a powerful and intoxicating, if illusory, conception or connotation of the inherent and unstoppable agency of the masses. In effect, it means that once society has been mobilized and has its political consciousness awakened, it cannot be contained. This then is far from the benign and inert "mass of people" to a dynamic movement of the public towards a stated tangible objective.

Originally, the group started as an innocuous and even idealistic commune in the Rift Valley region out of the diasporic Kikuyu who worked there, first, as farm hands in the second decade of the $20^{\text {th }}$ century, and in the 1960s as part of the million acre settlement scheme. In the early 1990s, the group was somewhat militarized in the face of the cyclical violence threats calculated to remove Kikuyus from the region by the Kalenjin during the 1992 and 1997 election years. From 1995, however, Mungiki gained political notoriety in the collective public mind when it was accused by the High Court of oath-taking in the region's Laikipia District. ${ }^{95}$ Since the mid-1990s, Mungiki, "as with their Mau Mau grandfathers," quickly gained a negative reputation as a lawless and, therefore, criminal secret society that was atavistic in nature. ${ }^{96}$ This was in reference to their belief in traditional Kikuyu practices including "baptism," taking religious oaths and female genital mutilation (FGM) among other backward rituals. ${ }^{97}$ Like the Mau Mau antecedent, Mungiki as a social science and historical subject is already arousing potentially controversial academic discourse about how it ought to be approached..$^{98}$

As important as the question of "methodology" is concerned, it is crucial to understand Mungiki against the broad historical mentalité of struggle continuum. In so doing, this social

\footnotetext{
${ }^{94}$ The closest other word that has the same implied meaning is "umururukia" which literally means the streamingout or flooding of people or ants, Ibid., 542. I differ in my usage of the term with the rather awkward and clumsy interpretation of meaning of the term by Ben Knighton in his, "Muingiki Madness," (ed.) Ben Knighton, Religion and Politics in Kenya: Essays in Honor of a Meddlesome Priest (New York: Palgrave Macmillan, 2009), 224. Knighton posits that "Mungiki" is the Anglicized term of the Kikuyu "Muingiki" but, as noted, there is no such word in the language unless the inflectional suffix is taken into consideration. Rather, "muingi" is a complete description of "the masses" exaggerated to an idyllic new level of fullness with the suffix, "ki" with the effect and meaning: "the people's uprising."

95 "Oath-taking charge: 58 released on Ksh. 50,000 Bond," Daily Nation, 16 ${ }^{\text {th }}$ February 1995.

${ }^{96}$ Knighton, "Muingiki Madness,"234.

${ }^{97}$ According to a former Kikuyu Ndaragwa MP, Mwangi Gichuki, the group was a religious cult that was terrorizing residents in parts of Nyandarua District. Gichuki, according to a newspaper report, said the group was causing fear among women in Ol Kalau constituency by threatening to circumcise them under the guise of preserving Kikuyu traditions. As such, the group was violent, retrogressive, uncouth and disgusting, Daily Nation Team, "Ex-MP Tells of Terror Cult," $17^{\text {th }}$ November 1997.

${ }^{98}$ Knighton, "Muingiki Madness," urges for the need to see it less through a secular materialistic and opportunistic prism in favor of a perspective that aims to see how the religious and the political have intertwined in the movement.
} 
malaise is no less different from the DYM and the Mau Mau anti-colonial movements that were returning the imperial gaze or retorting to a racialized and, thus a hierarchical, modernity that was exclusive in nature. In addition, the movement is not different from other rural and urban contemporary movements behind the ethnic clashes in the Mt. Elgon region, which "matured" into the Saboat Land Defense Force (SLDF); the attack on upcountry people in the coast region in the early 1990s that fomented into the Mombasa Republican Council (MRC); and similar electoral cycle violence in Trans Nzoia and Bungoma in the 1990s. While the common denominator with intermittent rural ethnic-cleansing violence is marginalization of the youth and land hunger, Mungiki is unique in considering its urban base and perennial nature. ${ }^{99}$

Put differently, Mungiki is a microcosm of the resultant social ferment when electricity, education and cleaned tap water, all epitomes of modernization among many others, are exclusive to a few in society and remain undelivered to the marginalized majority of people. Some among its ranks have argued that they have felt the duty to mobilize and bring economic, political and social changes in society so that the masses can control their destiny. ${ }^{100}$ For his part, Maina Njenga sees Mungiki as providing a voice for the demands of the poor for good governance to attain justice and prosperity, according to Branch. There cannot be peace when people are jobless, the founding member of Mungiki observed. ${ }^{101}$ Neglected and ignored by the state in ungoverned urban and peri-urban areas where the presence of the state is remote, the movement usurped unto itself "state power" in an underground extortive economy.

As far as Mungiki was concerned, the urban poor, especially the youth who lived in ghettoes, were reduced by the state to nothing. For this reason, Mungiki leaders mobilized them to recognize the need for welfare in the face of the common problem, poverty, since the government did not meet this need. ${ }^{102}$ The aim behind imposing protection and operational fees on public transport was, therefore, explained by the need to eke an "honest living" of troops of termini, bus-stops and public vehicle-routes collectors. ${ }^{103}$ Besides this, members of the movement provided rural "road-repairs;" provided "security" to slum dwellers at a fee of Ksh. 30

\footnotetext{
99 The MRC and SLDF could also well prove to be intractable long-term problems to the state.

${ }^{100}$ Remarks made in 2000 and attributed to Ndura Waruinge, the group's national coordinator by Branch, Between Hope and Despair, 237.

101 Ibid.

102 Kemp, “Kenya Special,” Documentary.

${ }^{103}$ Branch, Between Hope and Despair, 238.
} 
per house; provided electricity tapped unbeknownst from the Kenya Power \& Lighting Company for Ksh. 300 per month per bulb; and also provided clean tap water in some areas without the knowledge of the Nairobi Water Company.

Thus, the movement was effective offering something that the government did not provide to the poor living in informal slum settlements. ${ }^{104}$ Moreover, in a classic image of scavenging the ungoverned crevices of the state, hordes of poverty-stricken Mungiki employees rummaged through the enormous toxic heap, the Dandora waste landfill. ${ }^{105}$ In a tour of the site arranged by ranking members of the group, Ross Kemp was informed that up to a thousand people scraped a living sifting through the rotting waste. According to his Mungiki guide, one kilogram of plastic recyclable material fetched eight pence sterling (Ksh. 10). The aim of the movement, Kemp was told, was to target the collection of half the country's 55,000 tons of such waste, which could yield up to $\$ 2300 .{ }^{106}$ According to the journalist, excepting the movement's horrid use of fear, violence, murder and intimidation, Mungiki seemed to offer not only hope but also jobs for the marginalized.

This notwithstanding, by the start of the $21^{\text {st }}$ century, the group had run afoul with the state. It had imitated the state in spaces without the stamp of government authority to an intolerable degree. Furthermore, by 2002 the group had increased to between one and two million-strong making it a formidable political movement. It did not help that the group's cause served to attempt the mitigation of the huge gap between the rich and the poor. The latter had been ignored by the ruling elite since independence with wealth remaining in the hands of a small group of people. This left the vast majority of the population in abject poverty that the Mungiki attempted to make bearable while spinning-off profits for the organization. But the more it became powerful, the more politicized and political it became. With increasing confidence, it was possible for ranking members to argue that Kenya was really not free. It was not surprising that there was a rapid rise of members of the group who claimed to represent millions who felt that they had been ignored by successive regimes. ${ }^{107}$ It is at this point that the

\footnotetext{
104 Kemp, "Kenya Special."

105 Ibid.

106 This is as per the present author's calculations based on rough estimates of figures mentioned in the Kemp documentary.

107 Kemp, "Kenya Special."
} 
government saw the movement as a threat to security, especially considering the group's growing revolutionary change rhetoric and fervor.

Furthermore, as a violent Kikuyu-focused group, Mungiki raised echoes of Mau Mau. ${ }^{108}$ Besides being banned in 2000 and following sporadic resurgence and continuation of its mafialike activity, Mungiki was forcefully clamped down in 2007/08. Criminalized like its Mau Mau Kikuyu antecedent, Mungiki in the Mathare, Dandora and Kayole of Nairobi was suppressed especially by often retaliatory and punitive police and GSU exercises reminiscent of Operation Anvil in the 1950s. Thanks to its religious and political "chameleonic" behavior that has seen the movement involved in high-level presidential campaigns in 2002 on the side of Moi's preferred successor, Uhuru Kenyatta; conversion to Islam; and later Pentecostal Christianity; and rehabilitation of the founding member, Mungiki has found a degree of relative political validation. This has been accompanied by temporary rapprochement between Mungiki and the establishment and a security crackdown reprieve. ${ }^{109}$

In spite of this beguiling lull, it remains worrying that the state has dealt with Mungiki as a security threat. That is, under the assumption that Mungiki only contributes to a violence that filled the space or gap left by the state. Following this under-appreciation of the socioeconomic and historical springs of the movement, it is assumed by state security decision-makers that the movement will disintegrate every time there is a police "crackdown" and after its extortive income stream shutoff. As such, it is erroneously thought that the movement, among many other similar organizations, is not to be dealt with through complex and long-term state policy. ${ }^{110}$ Both the state and the media err, as the British did in the 1950s, by criminalizing the threat posed by the movement. It is forgotten that Mungiki sees itself not as a "crazed" criminal gang, but as an alternative socioeconomic and political force for a new order. This is a new order that will sweep away the degeneration, economic theft, corruption, and two-timing of the West that has afflicted Africa. ${ }^{11}$

\footnotetext{
${ }^{108}$ Hornsby, A History Since Independence, 676.

${ }^{109}$ Branch, Between Hope and Despair, 236-137; also see Hornsby, A History Since Independence, 676-677.

${ }^{110}$ Knighton, "Muingiki Madness,"232-234.

111 Ibid.
} 
Like Mau Mau, which imitated the colonial state and sought to criminalize British administration in the 1950s, members view the establishment of the day and political elite as corrupt. ${ }^{112}$ In this light, government crackdowns, in their estimation, are out of fear that the most neglected people in society have realized that, together, they can do something to help themselves by providing security, food, housing and hope. ${ }^{113}$ In addition, it remains an uncomfortable fact that, despite their crude and violent methods, the Mungiki movement is highly organized and has done what the government has failed to do. That is galvanize the poor. For close observers who have taken interest in the phenomenon like Kemp, the countless efforts by the government to wipe Mungiki out are self-serving. This notwithstanding, the movement seems to be growing stronger. Kemp aptly notes that, as Kenya stands in the throes of the $21^{\text {st }}$ Century, this is an important time in the country's modern history. This is in the sense that Kenya seems poised for a revolution of some kind. ${ }^{114}$ What is certain though is that people, such as Kemp met and interviewed, are prepared to sacrifice their own lives for the chance for something better. One such person is a former prostitute and Mungiki women coordinator who went by the name Florence. She said chillingly, “...Even if they take away my baby...kill my baby.... I will never go back ...never [sic]!"115

\section{The Sabaot Land Defense Force: "All the Men are Gone"}

In its activities, the SLDF, which is an armed group that emerged in and around the December 2002 elections, is very similar in its activities to the majimboist groups that were armed by the state in 1991-92 and again in 1996-97 to drive out non-Kalenjin groups (mostly Luhya) from Mt. Elgon. ${ }^{116}$ According to a Human Rights Watch report, the SLDF, like many other armed groups in Kenya, served twin purposes: it was at once land-related and also furthered political aims of its local leadership beneficiaries. Historically, the land issue was touched off in December 1991 when pro-ruling party Kanu Sabaot and Teso allied against the

\footnotetext{
112 Kemp, "Kenya Special."

113 Ibid.

114 Ibid.

115 Ibid.

116 This is according to the Kenyan NGO Western Kenyan Human Rights Watch (WKHRW) as cited by Human Rights Watch, “'All the men have gone:' war crimes in Kenya's Mt. Elgon conflict,” (New York: Human Rights Watch, 2008), 14. It is important to point out that this issue has not been addressed and studied methodically as yet. The sources relied upon herein are not exactly historical accounts and are, as such, incomplete as sources used to inform this study.
} 
pro-opposition Bukusu who had bought land in previously Sabaot areas on the mountain. ${ }^{117}$ According to Hornsby, Saboat politicians in the early 1990s called on the community to drive out others and on $24^{\text {th }}$ December they began to burn the houses on non-Sabaot. This violence perpetrated against the Bukusu worsened in the first few months of 1992 with the small region having one of the highest death tolls in a period of Kenya's history characterized by ethnic cleansing. The Sabaots were armed with bows and arrows and occasionally guns. But this violence was neither sudden nor spontaneous as it was deeply rooted in colonial history. At the dawn of colonial rule, claimed the Sabaot and Pokot, they had been removed from Trans-Nzoia and had remained determined to recover their "stolen lands." 118

The region in dispute is on the slopes of Mt. Elgon, which is Kenya's second highest peak. The region is, or was, primarily inhabited by members of the Sabaot community but also has other inhabitants including the Ogiek, Bukusu, Teso and Sebei among other Kalenjin and Nilotics and Bantu-speaking groups. ${ }^{119}$ Originally, the area was inhabited by the Sabaots from whom the British colonial government appropriated land for settler farms in the 1920s and 1930s. They were resettled in Chepkitale and Chepyuk but the Sabaots, never losing sight of their original land, presented grievances to the Kenya Land Commission in the early 1930s. According to the HRW report, while the British acknowledged their case, as they did in many others, they discussed a compensation package that was never implemented. ${ }^{120}$

The problem was compounded in 1968 when the independent government reduced the area available for the expanding population at Chepkitale by designating it as a game reserve thus forcing a second removal. Once again, this violation was undertaken without any consultation or compensation. ${ }^{121}$ When the Sabaots petitioned the government in 1971, the state initiated a resettlement program in Chepyuk where a group from the first colonial removal already was living in squalid conditions due to population growth and without official land titles. ${ }^{122}$ The HRW report points out that the government was trying to force the inhabitants of two villages into an overpopulated area already occupied by other settlers. To further complicate

\footnotetext{
${ }^{117}$ Hornsby, A History Since Independence, 490.

118 Ibid.

${ }^{119}$ HRW, “All the Men have Gone," 11.

${ }^{120}$ Ibid., 12.

121 Ibid.

122 Ibid.
} 
this matter, the resettlement exercise was left in the hands of local chiefs, local land officials and provincial administrators, councilors and MPs, many of whom were accused of corrupt practices in the process. ${ }^{123}$

Thus, the original Chepkitale Sabaot, who were uprooted with no place to call their own, were still disgruntled at the end of the 1970s and most of the 1980s. Yet, the Moi government in the late 1980s would attempt to evict both groups in a settlement scheme known as Chepyuk II. At this point, the Chepkitale group, like they had done in 1979, attempted to return there in 1988, but they were forcefully repulsed by the police since the area was now a game reserve. ${ }^{124}$ This then is the background against which the issue was touched off in the majimbo-motivated ethnic violence surrounding the multiparty elections in 1991/92. In 1993, Moi annulled the Chepyuk settlement scheme and ordered the creation of a third, Chepyuk III. But then the population had increased even further and people had been living for more than a generation on land whose status had not been formalized. Like earlier settlement attempts, Chepyuk III was controversial and complicated. As such, it was never fully implemented and it remained a dormant but emotive and divisive issue throughout the 1990s. The original problem occasioning land hunger and exacerbating suffering was unresolved and anger was growing. ${ }^{125}$

The majimboist ethnic cleansing strategy to remove non-Kalenjin groups from the region failed both in 1992 and 1997 election cycles. Thus, in the run-up to the 2002 election and the 2005 referendum on the constitution, the Chepyuk settlement was a major political campaign plank. Chepyuk III was implemented, but, according to a Kenya Land Alliance report in 2007, the process was again marred by massive irregularities. ${ }^{126}$ The SLDF was already in place and started carrying out its first strikes in 2005/06 in the wake of the implementation of phase III of the resettlement program. ${ }^{127}$ This fresh wave of organized military action was aimed at resisting government attempts to reallocate land and/or evict squatters in the Chepyuk area of Mt. Elgon.

\footnotetext{
123 Ibid.

124 Ibid., 12-13.

125 Ibid., 13.

${ }^{126}$ Kenya Land Alliance, Land Update (2007) as cited by HRW, "All the Men Have Gone,” 13.

${ }^{127}$ HRW, "All the Men Have Gone,"14; also see HRW, "Kenya: Army and Rebel Militias Commit War Crimes in Mt. Elgon,” Human Rights Watch Portal, posted on $3^{\text {rd }}$ April 2008.
} 
In the process, the Sabaot militia killed more than 600 civilians and terrorized the local population though physical threats, assaults, levied "taxes," meting out their version of justice, and seizure and destruction of property. ${ }^{128}$ Taking advantage of either felt or assumed government absence in the region, the militia became the administering authority with the exception being that their laws were, reputedly, crazy. ${ }^{129}$ Indeed, in its operations and methods, the SLDF was reminiscent of the Mau Mau and its affiliated Kenya Land and Freedom Army (KLFA) and Mungiki. Its leader, Wycliffe Matakwei, who would later be killed in the counterstrike by the state, and Benson Chesikaki, a local leader, went around recruiting boys to join the SLDF. They said all young men had to go for training. Many of them did not and had to flee to save their lives. ${ }^{130}$ In its recruitment campaigns, the SLDF broke into homes and kidnapped males at gun point and told women that they would not see them again. Many of them actually were never seen again. There were numerous media reports of prominent politicians, chiefs, and others supposedly executed in broad daylight by the SLDF. A February 2008 operation uncovered mass graves in the Mt. Elgon forest, apparently victims of the SLDF. The group was also known to round up livestock and seize property including land. ${ }^{131}$ Not only did the militia kill hundreds perceived to oppose them or their objectives. They also tortured and maimed inhabitants who broke their code. They also forbade alcohol drinking. Taxes were imposed on all with a regular income including civil servants who paid between Ksh. 3,000 and 10,000 per month (\$50-150) depending on their rank. But more so, the armed group attacked individuals already locked in landownership disputes with allies of SLDF or those who hired the group to resolve outstanding issues. During this time, land theft was rife. ${ }^{132}$

In its retort, the government launched a Kenya Defense Force (KDF) military operation dubbed Okoa Maisha (Save Lives). Despite its apparently innocuous title, its counterinsurgency methods, including arbitrary mass arrests and detention, extra-judicial killings and torture, mirrored that the government's handling of the Mungiki threat and also British colonial administration measures against the Mau Mau. When the KDF was deployed in March 2008, local residents initially welcomed attempts to deal with the rebellion. But scores of witnesses

\footnotetext{
${ }^{128}$ HRW, "Army and Rebel Militias Commit War Crimes in Mt. Elgon."

${ }^{129}$ HRW, “All the Men Have Gone," 19.

${ }^{130}$ Ibid.

${ }^{131}$ HRW, "Army and Rebel Militias Commit War Crimes in Mt. Elgon."

132 “All the Men Have Gone," 20 \& 24-25.
} 
later told human rights organizations that the army pursued the strategy of mass flushing out and roundup of all males under the age of 15 years in the region. Once rounded up, they were "screened" at the Kapkota military base in Cheptais division of Mt. Elgon district. Part of this "screening" exercise must have involved various forms of torture. HRW interviewed mortuary attendants who were receiving bodies that they believed were coming from Kapkota. HRW learned that the bodies showed visible signs of torture such as welts, bruising, swollen faces, broken wrists and rope burns around the wrists. Preliminary investigations by these organizations suggested that the military detained thousands, tortured hundreds and unlawfully killed dozens of people. ${ }^{133}$

As a result, a total of at least 116,222 people were displaced in Mt. Elgon and neighboring districts, which was almost the entire population of Mt. Elgon. ${ }^{134}$ As a result of SLDF chaos and violence and the KDF operation "Save Lives," women complained that there was no a man left on the mountain. Mt. Elgon was a mountain of women. All the men had gone. ${ }^{135}$ Operation Save Lives only served to botch up and complicate even further an emotive and intricate matter of historical colonial and post-colonial injustices grafted, as it were, intricately upon each other. This did not go unobserved as some in the media noted that the inadequate, late, and unfortunately, military response as opposed to well considered policy resolution had all the hallmarks of other lawless state clampdowns including unexplained illegal killings of Mungiki suspects in 2007. ${ }^{136}$ After apparent "successful" crushing of the SLDF and Mungiki, the Kenyan state continued to bumble over another outstanding land-related issue pertaining to the coast region, the Mombasa Republican Council.

\section{MRC: The Secessionist "Pwani si Kenya” Campaign}

The MRC is a popular movement and composed of mainly "Costerian" youth that burgeoned in the aftermath of Kenya's bungled and violent 2007 elections. Unlike the Mungiki and the SLDF, it is distinct in that it aims at exploring the use of civil society channels to formalize their grievances related to land and exclusion from employment. ${ }^{137}$ There is evidence,

\footnotetext{
133 Ibid.

${ }^{134}$ HRW, “All the Men Have Gone," 19.

135 Ibid., 29; also HRW, "Army and Rebel Militias Commit War crimes in Mt. Elgon.”

${ }^{136}$ HRW, "All the Men Have Gone," 44.

${ }^{137}$ Paul Goldsmith, "The Mombasa Republican Council -Conflict assessment: Threats and Opportunities for Engagement (November 2011), 7 \& 20. While the researcher does a remarkable and commendable job at
} 
that, initially, training a youth militia did figure in the MRC strategy and remains an active option conditional on how the state deals with the group. ${ }^{138}$ This is even more likely considering MRC's incendiary and violent rhetoric on SNSs like Facebook, which buttresses letter-writing and petitions as the group's preferred modus operandi. Indeed, the potential for violence being touched off is high and the problem of ethnic antagonism problematic in the prevailing conditions since the 2007 elections characterized by violence around the country. ${ }^{139}$

Although the group disputes it, the MRC, like the SLDF, emerged from the immediate background of the majimboist rhetoric and violence of the 1990s. MRC leaders deny any link with past gangs and militias like the Kaya Bombo attacks of 1997, and those of the present. Statements by some MRC members indicate that this de-linking strategy is more about method than objective since the movement, like other expressions of discontent in the region, pursues a historical injustice agenda that reaches back to $1895 .{ }^{140}$

The MRC traces its "Pwani si Kenya" (Coast is not in Kenya) campaign back to the 1895 and 1963 agreements between the Omani Sultan of Zanzibar who controlled the ten mile strip off his Zanzibari suzerainty, the British and the independent government of Kenya. In the first instance, in 1895, the strip of land that was under the dominion of the sultanate of Zanzibar since the 1820s was transferred to the British imperial control and administration. The region became part of the British East Africa Protectorate. In the eyes of the critical public in the coast, this agreement was always considered a form of bribery designed to facilitate colonization of the interior. ${ }^{141}$ At any rate, this agreement, the British colonial office later argued, was made by the Sultan not in his personal capacity. Rather, it was in his capacity as sovereign. It was, therefore, binding on the Sultan and on all other constitutional authorities in Zanzibar irrespective of any constitutional changes. ${ }^{142}$ Needless to say, the British government, by virtue of the agreement, administered the coastal strip, for all purposes, together with the protectorate and later colony as

documenting the long history of dispossession in the coastal region of the country, the report still remains an incomplete historical report of this subject.

${ }^{138}$ Ibid., 27 \& 28.

${ }^{139}$ Ibid.

${ }^{140}$ Ibid., 5 \& 26.

${ }^{141}$ Ibid., 8.

${ }^{142}$ F.D. Webber to Sir Patrick Renison, $17^{\text {th }}$ November 1961, BNA: CO 894/1. 
a single political unit. ${ }^{143}$ This external rule was marked by primary colonial resistance that lasted until the second decade of the $20^{\text {th }}$ century. Although the coast legally remained as a protectorate administered by the British on behalf of the Sultan even after Kenya became a colony in 1920, the imperial experience by Africans was uniform.

Like elsewhere in the country, indigenous African lands in the coast were alienated through a series of imperial ordinances. Similarly, affected communities joined other British colonial subjects in presenting their land grievances to the Kenya Land Commission, which ruled as follows: "There is a strong feeling on the coast that the needs of its people have received scant attention from the Government in Nairobi. The coast people complain that land development, communications, social welfare... have lagged very much behind their counterparts in the European Highlands and African reserves." "144 Despite this, lost lands were neither compensated nor restituted. Attention to the issues of the coastal economy and society, like elsewhere in the country, slipped into the background. ${ }^{145}$ But still the coast was, unlike the rest of the British colonial holding, a protectorate, a situation that presented an imperial headache on the eve of decolonization.

On the eve of independence, the British, not wishing to leave the potentially incendiary matter of the coastal strip to an untested independent government, appointed Sir James Robertson in 1961 to carry out an inquiry concerning the issue. The commission was charged with the anticipation of the problem of integrating the coastal protectorate into an independent Kenya. ${ }^{146}$ From the onset, its findings were a foregone conclusion. The prevalent attitude in both Nairobi and London was that the only practicable alternative is for the coastal strip to be integrated fully with the rest of the country if the country as a whole was to progress. ${ }^{147}$ However, it was acknowledged that there were/are circumstances peculiar to the coast and these had to be safeguarded. The provincial commissioner in the early 1960s, for example, felt strongly that to meet the legitimate and very real anxieties of the coastal minorities certain

\footnotetext{
${ }^{143}$ Council of Ministers' Paper, "Future of the Kenya Protectorate: Memorandum by the Cabinet Office," September 1961, BNA: CO 894/1.

${ }^{144}$ As cited in Goldsmith, "The Mombasa Republican Council -Conflict Assessment," 9.

145 Ibid., 10.

146 Ibid.

${ }^{147}$ Draft leaflet dictated by the provincial commissioner, Coast over the telephone on $15^{\text {th }}$ December 1961 , BNA: FCO 141/6836.
} 
safeguards had to be given them. One such peculiarity was the fact that in the region Islam was not only a faith but also a way of life. ${ }^{148}$

But, importantly, in fulfilling his mandate, Robertson also recommended that "A code of human rights...be 'entrenched' in the Constitution safe-guarding the exercise of all those rights universally regarded as the heritage of all inhabitants of free and democratic societies." 149 It advocated the establishment of a coast land board to guide the government and legislature on land policy in regard to, among other things, the disposal and use of public lands; the best use of uncultivated privately owned lands; the settlement of disputes between landlords and tenants; and the transfer of land owned by local coastal people to persons from outside the strip and foreigners. ${ }^{150}$

Furthermore, the report documented the greatest fears that coastal minorities, including the Swahili, Asians and Arabs, had expressed. That unless their titles were acknowledged and preserved, their lands would be invaded and taken from them by squatters and invaders from upcountry. Despite numerous pleas from sections of the public that the commission and the British consider the preservation of a large measure of coastal autonomy by members of the Coastal League and Citizens of the Mwambao, this call was rejected. ${ }^{151}$ This is the background against which the 1963 Memorandum of Understanding between the Sultan of Zanzibar and Prime Minister Jomo Kenyatta was reached. This agreement formally transferred the sultan's sovereignty over the coast to independent Kenya along the outlines of his original agreement with the British in 1895. Of course, this transfer was on the assumption that Kenya would pay due heed to provisions and safeguards of the Carter and Robertson commissions. ${ }^{152}$

This was the end of ambitions for internal self-rule for the region that gave way to unprecedented increase of unmitigated anxieties. Coast minorities' fears had motivated them to join Kenya African Democratic Union (KADU), a political alliance constituting of minority ethnic groups advocating for majimboism on the eve of independence. Notably though, and

\footnotetext{
148 Ibid.

${ }^{149}$ Goldsmith, “The Mombasa Republican Council -conflict assessment,” 10.

${ }^{150}$ Ibid.

${ }^{151}$ Letter from the group to Secretary of State for the Colonies through Government House, Nairobi, written around 1961, BNA: FCO 141/6836.

152 Goldsmith, "The Mombasa Republican Council -Conflict Assessment," 11.
} 
instructively, while KADU advocated for majimboism, it was not secessionist. Nevertheless, at the time, some form of autonomy from the mainland was all they could hope for. However, with their failure to separate the coastal strip from the mainland, the fear of losing control of land and key economic resources gradually became real especially in the decades following independence. ${ }^{153}$ Despite the fact that the Mau Mau movement had highlighted the volatile nature of the land problem in central province and elsewhere, the new Kenyatta government soon dashed the hopes and aspirations of Kenyans.

In the Mau Mau mind, which was a pervasive general expectation in Kenya, independence meant the restoration or redistribution of stolen lands. People across the country who had petitioned the colonial government, and made numerous submissions to different commissions, anticipated the independent government would meet their popular expectations. But there still existed the erroneous notion and colonial template that Kenya was an economy largely based on estate agriculture, the prerogative of which government was charged with protecting. ${ }^{154}$ So, like in the colonial era, in postcolonial Kenya, land was treated as a primary factor of economic production. This was at the expense of, and counter to, the expansion of land under indigenous cultivation. ${ }^{155}$ It was, therefore, possible for a few individuals to own vast tracts of land without any set limit, and as absentee landlords to boot, especially at the coast. Kenyatta's denial of the relevance and even the existence of the Mau Mau movement, which was emblematic of popular expectations, was a symbolic subversion of the same. ${ }^{156}$ This betrayal was a crucial precursor to the steadfast appropriation of large tracts of arable land throughout the country in order to solidify elite positions as wealthy land barons. ${ }^{157}$

As noted elsewhere herein, the three-tiered policy of dealing with the issue of land in the immediate post-independent period did not go far enough. In the first two programs of the Million Acres Scheme, land was allocated to yeoman farmers and peasants who received 12 to 20 and 8 acres of land, respectively. The former received the best lands whereas the latter were

\footnotetext{
153 Ibid., 4.

${ }^{154}$ Goldsmith, "The Mombasa Republican Council -conflict assessment”, 12. This as noted was an assumption because, in the long-term, it was hoped that the bulk of agricultural production would be undertaken by small-scale farmers as it had been in the first dozen years of the $20^{\text {th }}$ century.

155 Goldsmith, "The Mombasa Republican Council -conflict assessment," 16.

156 Aaron Rosenberg, "The Literature of Song: Kantai and Wainaina's 'Joka' as Syncretic Multi-text," Journal of the African Literature Association 1.2 (Sum/Fall 2007): 113.

${ }^{157}$ Ibid.
} 
settled in less favorable areas. But, importantly, most of the profitable estates in the coffee and tea producing areas were transferred to the new political elite loyal to the Kenyatta regime, and Moi later. ${ }^{158}$ In the coast, as in the Rift Valley, surplus land provided valuable resources for elite patronage. As such, various settlement schemes in the coast provided a vent for landless peasants from upcountry and, once in place, the upcountry settler-base encouraged the migration of family members, kith and kin. ${ }^{159}$

According to Paul Goldsmith, 57\% of the 12 hectares plot allocations in the Kwale Settlement Scheme went to Kambas and only 33\% to indigenous Mijikenda; the Lake Kenyatta Scheme in Mpeketoni Lamu was used to resettle landless households from Kiambu; Kikuyu expelled from Tanzania in 1978 were settled on the Diani Scheme; and the Shimba Hills Scheme raised issues when title deeds ended up being awarded to outsiders while indigenous farmers were left out. ${ }^{160}$ By the early 1970s, the cumulative layers of historical injustices perpetrated against indigenous people of the coast were being openly voiced in parliament but there was no redress. With intensification of problems resulting from real and perceived biases, a special commission was formed to investigate these land issues in $1978 .{ }^{161}$ The commission reported that there were between 75,000 and 100,000 squatters occupying some $6.5 \%$ of state and private land on the coast as follows: $61.5 \%$ in Kilifi; $18.8 \%$ in Kwale; $12.8 \%$ in Mombasa; and 6.9\% in Taita. ${ }^{162}$ The greatest failure of the report was the claim that landlessness in the region started before colonialism. ${ }^{163}$ But one thing was clear. That is the growing market for land driven by non-agricultural interest undermined peasant agriculture. ${ }^{164}$

Despite more settlement schemes, like the ambitious Magarini Scheme, the long-standing land conundrum there persisted. ${ }^{165}$ The perception by locals is that such schemes are vehicles for importing even more upcountry settlers. But research also reveals that this is just more than a perception. From 2001 to 2011, in-migration to Lamu district by outsiders alone is estimated to

\footnotetext{
158 Goldsmith, "The Mombasa Republican Council -Conflict Assessment," 13.

159 Ibid.

${ }^{160}$ Ibid.

161 Ibid.

162 Ibid., 14.

163 Ibid.

164 Ibid.

165 Ibid., 15.
} 
have contributed to population increase by $18 \% .{ }^{166}$ Legal small land holders in the region also face other impediments such as agricultural costs, which add to their sense of insecurity and uncertainty, and due to unemployment, there is lack of off-farm income to buttress on-farm investment. Such socioeconomic obstacles then segue into other issues of poor education facilities and real and perceived biased access to opportunities that exacerbate the plight of coastal communities. ${ }^{167}$ In 2011 Goldsmith observed that the overall result is that the peasantry has found itself "caught in a deepening cycle of poverty and deprivation. Landlessness and social exclusion form a volatile matrix in a region where outsiders dominate economically."168

This is the historical context against which the ethnic and electoral Kaya Bombo violence broke out in August 1997. The spate of violence in the Rift Valley in 1992 was widely assumed to be the template for political violence in the coast. ${ }^{169}$ The exact regions affected were Likoni in Mombasa and the adjacent Kwale District. More specifically, places hit by the violence in Kwale included Kubo, Kinango and Matuga. ${ }^{170}$ Others included Mshomoroni, Kongowea, Kisauni, Mtwapa and as far out as Malindi and Taita Taveta where "watu wa bara" as upcountry residents are called, and their property were attacked. ${ }^{171}$ Among those affected were Kamba farmers in the Shimba Hills some of whom also worked in holiday beach hotels; Kikuyus, most of whom were business people scattered in small towns and some were also land owners; and Luos concentrated in quarries and stone-cutting industries. ${ }^{172}$

Of course, the violence was perpetrated by Wapwani as coastal people refer themselves, especially the indigenous youth, who were, on the whole, unemployed, idle and hungry: this constituted a fertile ground which was waiting to be exploited politically to wreak vengeance upon the perceived upcountry oppressors. ${ }^{173}$ There was a deep seated feeling among the Mijikenda people that their land and jobs had been stolen, first by Arabs in the precolonial era and upcountry people in the $20^{\text {th }}$ century. ${ }^{174}$ As noted above, they are one of the most

\footnotetext{
166 Ibid.

${ }^{167}$ Ibid., 14-15.

168 Ibid., 16.

169 Ibid., 26.

${ }^{170}$ Republic of Kenya, Report of the judicial commission appointed to inquire into tribal clashes in Kenya (Nairobi: Government Printer 1999), 233.

${ }^{171}$ Goldsmith, "The Mombasa Republican Council -Conflict Assessment,"18.

172 Republic of Kenya, Report of the judicial commission, 233-234.

173 Ibid., 234.

${ }^{174}$ Hornsby, A History Since Independence, 602.
} 
economically disadvantaged of rural Kenyans with little political influence and few cash-crops, and their major asset, the coast itself, had long been lost to the political elites. ${ }^{175}$ The region is perhaps the only area in Kenya where one can find international opulence and African poverty separated by a mere 500 meters. ${ }^{176}$ Indeed, four of the six coastal counties rank among the 15 poorest districts in the country. ${ }^{177}$

At the time, the anti-upcountry sentiment that swept the region was useful for the Moi government. The Kaya Bombo violence, like other ethnic cleansing campaigns of the 1990s, exemplified how the government of the day used discontent to promote its own political agenda. ${ }^{178}$ At the same time, as Hornsby aptly ventured, the violence was "part of a broader plan to reassert "mwambao" -coastal autonomy- as in the run-up to independence." 179 It is in this light that the violence that accompanied the 2007 polls should be seen and interpreted. After all, the flashpoints of the second spate of violence overlapped with the same places where it had broken out in 1997. Apart from Changamwe, Magongo, Bamburi and Bombolulu that were new to violence, places like Mshomoroni and Kisauni had already had a foretaste in 1997. Kilifi, Kaloleni and Malindi which had experienced the 1997 violence remained relatively calm in $2007 .{ }^{180}$ It should not come as a surprise that some of these locales were the epicenter of MRC support, which include the peri-urban area of Mombasa. MRC presence was also felt as far as Taita-Taveta and Lamu where the volatile land and social exclusion matrix runs deep. ${ }^{181}$ The attempt by the MRC to delink itself from the Kaya Bombo 1997-violent vision of the coast is therefore, weak.

Nevertheless, it is appreciable that the MRC correctly recognizes that Kaya Bombo was a case of state-driven violence and that incitement by government ministers and leaders was responsible. ${ }^{182}$ The MRC's attempt to de-link itself from the Kaya Bombo violence is more about method than objective: in any case, the vision of restoring the layered historical sovereignty of

\footnotetext{
175 Ibid.

${ }^{176}$ An observation attributed to Raymond Matiba by Goldsmith, "The Mombasa Republican Council -Conflict Assessment," 22.

177 Goldsmith, "The Mombasa Republican Council -Conflict Assessment," 16.

178 Ibid., 18.

${ }^{179}$ Hornsby, A History Since Independence, 602.

${ }^{180}$ Goldsmith, "The Mombasa Republican Council -Conflict Assessment,"18 \& 20.

181 Ibid., 28.

182 Ibid., 26.
} 
the regions still remains. ${ }^{183}$ Like the Coastal League and Citizens of the Mwambao call for autonomy, the MRC strategy centers on the Pwani Huru or Pwani si Kenya campaign. ${ }^{184}$ It echoes the early 1960s call for secession, which represents "a holistic view of post-independence trajectory." 185 According to Goldsmith, this secessionist campaign has created a kind of gestalt in that it subordinates the host of grievances and problems that are typically debated on their own basis to a single point: the historical injustices are ever so eloquent and, naturally, commend themselves to the MRC cause.

However, one thing that has changed is the method of working towards the longstanding vision. Since the problem of the coast is rooted in ill/legal historical agreements, the MRC has resorted to the use of legal challenges to defend coastal interests. They group places a high premium on "the contested legal agreements approach" while at the same time demonstrating understanding of its implications across the wider social and political spectrum. ${ }^{186}$ This explains why letter-writing, petitions and reliance on SNSs are the preferred method for the MRC. All these methods are a natural extension of the formality of their court cases; grassroots mobilization campaign; awareness-creation; and currying favor in the court of public opinion for their cause. One of their petition-related publicity stunts was their announcement that they intended to send, in June 2012, a delegation to the British queen. This plan to send a delegation to Queen Elizabeth II coincided with the queen's Diamond Jubilee celebration. ${ }^{187}$ The said delegation was intended to deliver a memorandum about their land grievances dating back to British colonialism era and secession cause. ${ }^{188}$ According to the MRC secretary general, Randu Nzai, to goal behind the ambitious mission was to present treaties signed with the British colonial government in their possession to the queen, and thereupon, state the case of the historical injustices that the coast region had suffered since independence. ${ }^{189}$

Despite the potentially swaying moral rationale behind their struggle, the MRC cause was, unfortunately, lost before it even started. ${ }^{190}$ This was because of various reasons. Foremost, the

\footnotetext{
183 Ibid., 5.

184 Ibid., 22.

185 Ibid.

186 Ibid.

${ }^{187}$ Bozo Jenje, “Kenya: Secessionist Group On a Mission to Meet the Queen,” Daily Nation, $27^{\text {th }}$ February 2012.

188 Ibid.

189 Ibid.

190 Goldsmith, "The Mombasa Republican Council -Conflict Assessment,” 22.
} 
fact that the coast is an intrinsic part of the nation's identity that features prominently in the campaigns to promote Kenya's tourism industry. ${ }^{191}$ Even more important than this is the extraterritorial nature of economic state assets such as the port of Mombasa that is connected to the rest of the country and the Eastern African region by the Mombasa-Kisumu railway; the Mzima Water Pipeline; and the Kenya Petroleum Refinery and Pipeline.

In addition, the region is militarily pivotal. It is home to the Kenya Navy. It is also significant in terms of global geopolitics. Furthermore, unlike the MRC, the state has an institutional memory in criminal investigation department records and surveillance by the National Security and Intelligence Service that complement the work of regular police. Whatever evidential linkages that such state security apparatus have fly in the face of the convenient dissassociative strategic stance that the MRC has taken vis-à-vis the Kaya Bombo and 2007 spates of violence. Furthermore, it does not help the movement's cause, and this is supported by reports in Kenyan press, that the movement dallied with the idea of violence as a vehicle for its cause. It is on record that the training of a youth militia did initially figure in the MRC strategy, which remains an active option. ${ }^{192}$ Thus, while the movement is avowedly non-violent and evidently pursues its cause through the legal channels, such impediments of public and state perception are difficult to shake-off.

This state of affairs is complicated due to the religious composition of the region. The bulk of the population in the coast is Muslim. Quite naturally, a significant portion of its 100,000 strong members and millions more of its general support base are Muslim. This religious composition and the timing of the Pwani si Kenya campaign against the backdrop of "the growing assertiveness of Islam worldwide" has not augured well for MRC. ${ }^{193}$ It also goes without saying that MRC's secessionist agenda has coincided with the global "War on Terror" of which Kenya is seen as an ally by the West. This has further served to undermine the cause of the movement. ${ }^{194}$

\footnotetext{
191 Ibid.

192 Ibid., 27-28.

${ }^{193}$ Hornsby, A History Since Independence, 602.

${ }^{194}$ Goldsmith, "The Mombasa Republican Council -Conflict Assessment," 19.
} 
In light of the foregoing, the government did not find it difficult to criminalize and heavily crackdown on the MRC. The movement was one of the "gangs" banned by the government in 2008, albeit the only group to successfully challenge this in a court of law. ${ }^{195}$ In mid-October 2012, the government embarked on an operation that left two alleged MRC members dead and at least 35 members arrested and arraigned in court. Among those arrested was the MRC chairman, Omar Mwamnuadzi and his wife, supposedly after a gun fight with security forces. Mwamnuadzi was charged with fire arms possession and incitement to violence.

Following a wave of arrests in Kwale, two more people were killed on $28^{\text {th }}$ October 2012 including a Muslim cleric in police raid in Mombasa. As noted above, there are genuine fears of internationalization of grievances and continuing tensions in the coast. While nothing suggests any overlap with the Al Shabaab extremist and terrorist group, there are suspected cases of individual linkages with Islamist organizations. However, there is no evidence to prove that the MRC actively supports Islamist or jihadi groups in Kenya. ${ }^{196}$ Despite initial success that resulted in a temporary suspension of the ban on the MRC, its legal status is amorphous although it is still in existence and, as ever, attuned to its search for justice. Official government redress remains a gaping hole and a veritable powder keg. In the title of his paper published in 2010, Mwandawiro Mghanga, a political activist since his undergraduate studies at the University of Nairobi and a former MP from the region, aptly summarized the prevailing situation with reference to classical Swahili wisdom: "Usipoziba ufa utajenga ukuta" (meaning: proper and timely redress of an issue averts catastrophe). ${ }^{197}$

Indeed, it is appropriate that the complex and intricate historical problem in the coast is encapsulated in a simple nugget of Swahili wisdom. African societies are particularly verbal as they communicate and preserve their experiences through oracy. The MRC has grown and thrived mainly through word of mouth forming a thick, if impregnable, canvass of entangled informal relations of friends and neighbors. ${ }^{198}$ The region's Taarab music is a unique cultural tradition that young people, not necessarily associated with the MRC, have used to preserve the

\footnotetext{
195 Ibid., 23; the ban on the MRC was temporarily lifted after the High Court ruled in its favor in June/July 2012. The movement was banned four months later at the instigation of the state.

196 Goldsmith, "The Mombasa Republican Council -Conflict Assessment," 27.

197 The Swahili saying is the equivalent of the English proverb, "A stitch in time saves nine." It literally translates to, If you don't repair a hole in the fence, you will be compelled to build an entirely new brick wall.

${ }_{198}$ Goldsmith, "The Mombasa Republican Council -Conflict Assessment," 28.
} 
memory of their collective experience of socioeconomic suffering and political struggle. Whatever the fate of the MRC, the mentalité of struggle in oracy will survive as long as grievance persists. This reality is borne in the functional rendition of "Bado Mapambano" song used especially in workers' strikes discussed earlier above.

In the Taarab coast version that was part of the 2007 elections, young people archived their suffering by singing, "We have suffered from extreme poverty; from unemployment; we are denied passports to travel abroad, even national identity cards; we are barely surviving in this life of hardship. We want majimbo, (and) not that we want to evict others on the basis of tribe or race. People of Mvita, unite as one; don't you slumber Wapwani, don't even dare, the struggle is still on." ${ }^{199}$ Such archiving of the attendant struggles of everyday life are not unique to the coast. Urban youth in the marginalized neighborhoods that are the hotbed of the Mungiki express a high level of awareness of the gap between the rich and poor through hip-hop poetry. ${ }^{200}$ In some of these impoverished ghettoes in the periphery of the cityscape, a Mau Mau mentalité has emerged expressed in the spoken word. When young people here gather informally to dance, sing, talk and gossip against this background of hardship, "a new permutation of Mau Mau ideology through poetry" that is hugely popular and fashionable has emerged. ${ }^{201}$ Popular culture is a notable trend of expression of everyday experiences in a language that, directly or indirectly, alludes to the original struggle of the $1950 \mathrm{~s}$ in the $21^{\text {st }}$ century. For this reason, it warrants not just listening but also critical intellectual attention. Indeed, policy makers in government need to sit-up and listen even more closely. It is imperative, therefore, to focus on the spirit of struggle as expressed in popular youth culture.

\section{"Matatizo" in Popular Youth Culture: Music and Social Change in Kenya}

The Kenyan art scene and the verbal and performing arts including drama, music, myths, legends and family histories are going through a renaissance. ${ }^{202}$ Binyavanga Wainaina, a promising writer who has been part of this literary revolution, has observed that these creative impulse marks the indigenous expressive power of the Kenyan people. ${ }^{203}$ Indeed, oracy, which is

\footnotetext{
199 “Bado Mapambano," Balala and Orange Democratic Party song, Youtube, Published April 2008.

${ }^{200}$ Awinda Otieno, "Mungiki: Neo-Mau Mau and the Prospects for Democracy in Kenya," Review of African Political Economy 34 (September 2007): 528.

${ }^{201}$ Ibid.

202 Rosenberg, "The Literature of Song," 1.

${ }^{203}$ As cited by Aaron Rosenberg, Ibid.
} 
the art or communication skill of using the spoken word either in verse, poetry, song or even conversations, is a verbal tradition that constitutes the main heritage consumed by the majority of African people. ${ }^{204}$ It permeates throughout African societies as they narrate stories and histories of their everyday experiences. As such it constitutes a corpus of verbal texts of history, law, philosophy, politics and economics. ${ }^{205}$ Oracy, therefore, is a living archive of the everyday life experiences of people.

But more importantly, this verbal art of oracy bears even more significance when productively used by highly skilled communicators with a functional purpose. Some politically conscious verbal and performing artists have employed their functional creativity to deliberately preserve and communicate complex and, at times, controversial historical realities. ${ }^{206} \mathrm{Put}$ differently, while adhering to the utilitarian and aesthetic prerogatives various oral genres, skillful artists have incorporated socioeconomic and political commentary to targeted audiences and especially the youth. When they are not the artists themselves, young people, especially those in the margins of society, are the target of lyrical political empowerment through verbal art. In recent times, scholars in Kenyan literary discourse have noted this new and potentially radical trend. ${ }^{207}$

Of particular interest is the nature of popular culture which has opened it up for literary analysis. Skilful verbal and performing artists in Kenya have been noted for their ability and compulsion to cross generic and formal boundaries and to effect the syncretic combination of elements from various forms of expression. ${ }^{208}$ According to Rosenberg, they have problematized the conventional academic understanding of literary form due to their employment of "hybrid and recombinatory" techniques. This has changed the understanding of the ways in which intertextuality, hypertextuality, and transtextuality are carried out in Kenyan contexts. ${ }^{209}$

The most remarkable aspect of the renaissance of the orature is the mutual interpermeation of literary and verbal texts while playing-up the rich canvass and continuum of the

\footnotetext{
${ }^{204}$ Micere Githae Mugo, Writing and Speaking From the Heart of My Mind (Trenton: Africa World Press, 2012), 208.

205 Ibid.

206 Ibid, 232; Rosenberg, “The Literature of Song," 114.

${ }^{207}$ Rosenberg, "The Literature of Song," 108.

${ }^{208}$ Ibid.

${ }^{209}$ Ibid.
} 
historical context. This is such that it is futile to attempt to divorce the historical and literary from the art of the spoken word. This is especially considering that communication in Kenyan society is mostly oral, technology notwithstanding. ${ }^{210}$ Indeed, this is a characteristic of Kenyan life that has been bolstered by the internet and telephonic revolutions. Now, more than perhaps ever before, Kenyans are transacting themselves orally; imagining themselves in an oral way; and especially in the way they write and sing. ${ }^{211}$

This signature aspect of contemporary in life in Kenya should be brought to the service of the task of writing the country's history. This corpus of inter-permeating texts provides an avenue for the scholar of Kenya's modern history to enter vicariously into the often bitter everyday life experiences of ordinary Kenyans. ${ }^{212}$ It offers a rare and unique window into the mentalité of struggle that imbues Kenyan society. After all, the spoken word and the performing arts act as experiential reservoirs. Within them is encapsulated the zeitgeist of the land of slightly more than a century-long. This is especially true of the music scene since the end of Moi era in 2002.

Before then, people, due to political intolerance and repression, were effectively muted. There developed, particularly in the Moi years, a culture of silence. ${ }^{213}$ It is not that Kenyans completely lost their signature oral transactions of themselves. Rather, the language, songs, dances and mannerisms were evolved to express the cult of presidential worship. ${ }^{214}$ According to Micere Mugo, the president was omnipotent, and this was reinforced by a culture of sycophancy and groveling worship that called for absolute obedience and submission. Moi was a living deity, "Mtukufu Rais" (the Almighty President); "the Father of the Nation;" "Teacher Number One."

During this time, creativity in general, and songs in particular, swelled with flattery. Some of the songs were transmogrified Swahili church songs of praise and supplication which were now directed to a human deity on the presidential dais. At a passing out parade at the Kiganjo Police College in Nyeri in the 1980s, the resident police choir sang, "Macho ya Moi ni makali

\footnotetext{
${ }^{210}$ Ibid., 112.

211 Ibid.

212 John Lonsdale, “Compromised Critics," Religion in Kenya's Politics," in Religion and Politics in Kenya: Essays in Honor of a Meddlesome Priest, ed. Ben Knighton (New York: Palgrave Macmillan, 2009), 62.

${ }^{213}$ Mugo, Writing and Speaking From the Heart, 200.

214 Ibid.
} 
sana. Yanaona Waalimu/Madaktari/polisi, ni makali sana" (meaning that Moi had sharp piercing and watchful eyes that roved back and forth observing teachers, doctors and the police among other government workers). ${ }^{215}$ The police choir was actually only one of many mass choirs of school children, college students and employees of public institutions formed nationwide under the government's orders when Moi took the reins of power. ${ }^{216}$ These were invariably coerced into publicly reiterating, through song and dance, the eternity and invincibility of Moi's dictatorship as part of divine providence.

Masolo observes that these choir groups and their direct political evocations of their songs intensified after the 1982 coup. ${ }^{217}$ One such song was "Tawala Kenya" (Rule Kenya) composed and directed by Mwalimu Thomas Wasonga and performed by his Mombasa Teachers' Mass Choir. In this song, Moi's leadership was validated and affirmed and his name worshiped. ${ }^{218}$ Professor Arthur Mudogo Kemoli of the Kenyatta University Choir composed a similar song in praise of "Fimbo ya Nyayo" (Moi's traditional cudgel signifying authority and leadership). Moi is reputed to have a great passion for music, which was behind the establishment of the Permanent Presidential Music Commission in 1988 with offices across the road from State House. It was charged with the preservation, development and promotion of all aspects of music and dance; to spearhead the growth and development of the industry and contribute to the understanding of Kenyan musical arts and expression. ${ }^{219}$ Mwalimu Wasonga left teaching to serve this commission rising through the ranks to Deputy Director by $2012 .{ }^{220}$ The importance of music and dance was, therefore, not lost on the Moi regime.

\footnotetext{
${ }^{215}$ As a young Boy Scout at a local primary school, I was privileged to have a front seat view annually whenever the president graced the "pass-out" parade of new police graduates from the Kiganjo College. At the time, as a young man, I too subscribed to this general view and never broached the subject with my father who was a traffic police instructor at the college.

${ }^{216}$ D.A Masolo, "Presencing the Past and Remembering the Present: Social Features of Popular Music in Kenya," in Music and the Racial Imagination, ed. Ronald M. Radano and Philip V. Bohlman (Chicago: University of Chicago Press, 2001), 370.

${ }^{217}$ Ibid.

${ }^{218}$ Some of the prominent lyrics in the song are: "Unaongoza vyema; peleka Kenya mbele; and tunamsifu Moi." (Your leadership is great/steer the country forward/we praise Moi). Also see "Enzi Zao: Thomas Wasonga," Citizen TV story, Youtube, Published, $17^{\text {th }}$ September 2011.

${ }^{219}$ See the Ministry of State for National Heritage and Culture website for more on this outfit. It was however, transformed into the Department of Music in 2008.

${ }^{220}$ Citizen TV, "Enzi Zao: Thomas Wasonga."
} 
However, a new generation of Kenyan performing artists emerged in the post-Moi era. These artists are intent on creating musical works which reflect and define what it really means to be Kenyan, which is a radical break from the culture of silence of the past. ${ }^{221}$ Such artists have been insisting on a holistic conception of reality as opposed to the compartmentalization of phenomena. The text of their work is progressive as opposed to reactionary. It expresses sensitive concerns such as human rights; homelessness, ghettoization and hunger and people's general quality of life; and expresses outrage against corruption and obnoxious, illegal, individualistic accumulation of wealth. In engaging in the composition and performance of competent verbal texts of history, this generation of artists is bringing great skillfulness in imaginative, technical and organizational abilities to bear. ${ }^{222}$ These "socially significant performers' do not happy to just entertain.",223

Rather, using entertainment, they frequently aim and are sometimes able, to raise the awareness level of their audience in order to teach and educate. Their compositions and performances evoke and organize collective memories and present experiences of place with intensity, unmatched power and simplicity. ${ }^{224}$ In their hands, the verbal texts become powerful and profound expressive artistic tools. ${ }^{225}$ According to Masolo, such music and performances transcend "the oppositions of time together with their respective social orders." Put differently, this kind of collective work presences the past while at the same time familiarizes the present. Being entertained by such musical performances becomes a means for transcending geographical, political, cultural and social limitations. The audience re-engages with, and feels that they are part of, the creative work "as the words of the music reconstruct an imaginatively familiar world complete with its historical structures invoked by the meanings in the lyrics of the songs." Masolo further insightfully observed that, specific songs stir conversations of specific reminisces through which identities are then constructed or socially and historically decisions made. ${ }^{226}$

\footnotetext{
${ }^{221}$ Rosenberg, "The Literature of Song," 110.

${ }^{222}$ Mugo, Writing and Speaking From the Heart, 208, 209, 211, 215 \& 230.

${ }^{223}$ Ibid., 232; also see Masolo, "Presencing the Past and Remembering the Present," 372.

${ }^{224}$ Mugo, Writing and Speaking From the Heart, 232; and Masolo, "Presencing the Past and Remembering the Present," 372.

${ }^{225}$ Mugo, Writing and Speaking From the Heart, 232; and Rosenberg, "The Literature of Song," 111.

${ }^{226}$ Masolo, "Presencing the Past and Remembering the Present," 372.
} 
Rosenberg aptly captures this delicate process of creative work in his remarkable investigation of the creation of the song "Joka" by Parselelo Kantai and Eric Wainaina. 227 "Joka" represents progressive and integrated social action predicated upon fictionalized historicity. As a creative writer, Kantai researched the historical problems experienced by people who were brought, on the Uganda Railway or winding colonial roads, to Nairobi from the rural areas with the promise of work; a promise of a decent place to stay; and the promise of a better life. ${ }^{228}$ In what demonstrates hypertextuality and transtextuality, both artists produced reciprocal narratives: Kantai produced his celebrated short story, "Comrade Lemma and the black Jerusalem boy's band," while Wainaina recorded the poetic and musical work, "Joka." 229 Kantai and Wainaina collaborated, after copious research, to create a song that 'if a historian should happen to listen...they will say, "Yes, that's true.",230

In writing "Joka," Wainaina deliberately made it an objective to tap into the collective memory of Kenyans and, in so doing, also presence the past in a way that made the present familiar. To approximate the lived experiences of Kenyans as accurately as possible, he studied recording artists that were active and had an impact on the formulation of Kenyan society in the 1970s. In a sense, he entered into the mindscape of 1970s Kenya through the doorway of the intellectual environment of musicians. ${ }^{231}$ This provides ample evidence of the ability of music to penetrate a people's mentalité. Or, as Rosenberg describes it, the manner in which music and song function as aesthetic praxes while simultaneously providing sociocultural insights about the communities from which they emerge.

In "Joka," Wainaina lifts his listeners, through its performance, from the $21^{\text {st }}$ century Kenya to the society of 1970 s Kenya. ${ }^{232}$ Indeed, perhaps to an even earlier time. His listeners travel back to the dawn of British colonialism, when the Iron Snake, the Uganda Railway, became the bane of soon-to-be colonial Kenya British imperial subjects. In its wake, after climbing and winding from the low-lying eastern plateau from the coastal plain; through

\footnotetext{
${ }^{227}$ Rosenberg, "The Literature of Song," 108-128. The Swahili word "Joka" loosely translates to "snake" but the implied meaning here is the "iron snake." That is, the Uganda Railway constructed by the British at the turn of the $19^{\text {th }}$ century.

${ }^{228}$ Rosenberg, "The Literature of Song," 113.

${ }^{229}$ Ibid., 109-110.

${ }^{230}$ Ibid., 113.

${ }^{231}$ Ibid., 114-115.

${ }^{232}$ Ibid., 115.
} 
scattered shrubs, hills and elevated formations of Taita Taveta, Kasigau, Machakos, and Kitui; through the swampy Nairobi plains; on the lush side of the Aberdare Ranges while making its precarious way down to floor of the Rift Valley towards the Mau Escarpment; through the fertile highlands to the western Uasin Gishu plateau; and all the way to the shores of Lake Victoria, the Lunatic Express, Wainaina's Joka, left a bitter exploited people bereft of their land, labor and, most of all freedom. They were transformed by "Joka" into colonial subjects who could no longer be authors of their own destiny. The Iron Snake, "Joka," blighted the land and herded workers in Nairobi, which was "kambi ya utumwa" (camp of slave labor). ${ }^{233}$ One cannot listen to "Joka" without a new appreciation of various informal settlements that dot Nairobi like Kibera, Mathare and Sinai among others, as modern-day and postcolonial slave camps.

Such is the seriousness that Wainaina brings to the entertainment industry. The prolific artist, handily one Kenya's best and African's finest musicians, pulled back his "Love and protest" album delaying it for three years. He was determined to put out a record that completely reflected what it is he wanted to say musically and lyrically. ${ }^{234}$ Perhaps, to be able to breath life into some of the everyday encounters and experiences affecting him or people he knows. In a blog piece on his Website, Wainaina narrates such a heartrending incidence. He recounts how a young child died at a "leading" government/national hospital in Nairobi because there was no meningitis medicine to treat him. His parents were too poor to afford the treatment that cost about $\$ 210 .{ }^{235}$ Further, the artist stated:

The problems we face in Kenya are huge. We need to make quality healthcare affordable or free for all Kenyans, we need to reform our education system, we need to improve housing on all levels, we need to guarantee food security, we need to invest in renewable energy, we need to safeguard the peaceful coexistence of majority Christians and minority Muslims. The task ahead and presently with us is vast.

...The government is the great equalizer between those who are born into privilege (and who probably work hard too) and those who are born into situations that beleaguer all attempts at self-improvement.

Right now, if you are born poor in Kenya you will probably die poor. But a domestic worker needs to know that when she shows up at her local clinic her baby will get the attention it deserves. A rape victim needs to know that the courts will provide justice. A

\footnotetext{
${ }^{233}$ Ghettoes and urban slums, especially in Nairobi where the bulk of the population live could be interpreted to be present-day working camps.

${ }^{234}$ Eric Wainaina Official Website, "Discography: Love and Protest."

235 Ibid., "Gema Does Not Represent Me!"
} 
university student needs to know that a lecturer will turn up to class, teach him and judge his efforts fairly. The debate ...is about building ... structures that will outlive individuals and provide for citizens in perpetuity. It's not about Uhuru. It's not about Ruto. They are... irrelevant to this debate. I can't overstate it. I can't shout it loudly enough!! [sic]. ${ }^{236}$ These are some of the reflections and observations that must have inspired most songs in all of his three albums: "Sawa Sawa" (2001), "Twende Twende" (2006) and Love and Protest (2011). Songs in these albums can be grouped into three archetypal categories that are microcosms of politically conscious music in Kenya. There are songs that invoke the memory and spirit behind the Mau Mau struggle in what is an unbroken continuity with the present; songs that are receptacles of the collective trudge of Kenyans' crucible of experience of life as an everyday struggle; and lastly, songs that seek to empower and mobilize people, especially the youth.

Among the time-warping artists who evoke and organize collective Mau Mau memory of struggle and present experiences of Kenya with intensity, is the group Ukoo Flani Mau Mau. Its very name is a political riddle. While it could mean many things, it could basically refer to the artists being an extension or clan of the Mau Mau freedom fighters. The name of the group literally translates to (We are) a certain clan, Mau Mau. Their song, and especially the music video that dramatizes it, "Angalia Saa" (Look at the Times), is a classic example of the transcendence of the opposition of time. At the beginning of the song, the group dedicates it to all Kenyan heroes who struggled against British colonialism but have never been honored. The music video performative subtext suggests that although chronological time has moved forward, the hard and harsh times embodied by the Mau Mau struggle remain. That the times have not changed.

To demonstrate this, video clips from colonial government department of information propaganda films against the Mau Mau in the 1950s are juxtaposed with contemporary street riots. ${ }^{237}$ Black and white footage from the 1950s, used in the "Angalia Saa" music video, shows

\footnotetext{
236 Ibid.

237 This footage was used in the 1950s by African Film Productions, Ltd. to produce the 19 minutes documentary film, "Mau Mau" (September, 1954). In the Colonial Film Website (accessed $31^{\text {st }}$ December 2013) Colonial Film, a British Empire film archiving project in the U.K, cites an East African Standard 17 $7^{\text {th }}$ September 1954 article that reported that the documentary film, "Mau Mau," was made by African Film Productions, Ltd., mainly for European audiences. It was also meant to be shown in Kenya African locations. The article explained that a $16 \mathrm{~mm}$ copy of the film had been supplied to the Department of Information, who then intended to show the film to a few Kikuyu people and Europeans closely connected with the tribe. According to their reactions to it, the report added, "it might be given a wider showing." The film is easily accessible and segments of it appear in different lengths on Youtube.
} 
British military operations "underway" in the rural areas and in Nairobi. There are also video images of arrested Mau Mau suspects in the open ground but behind barbed wire fences waiting to be screened. With the help of actors, Ukoo Flani Mau Mau dramatizes these screening camps in the present. They recreate such a camp and perform the song in the restricted space effectively delivering their message: the times have not really changed. As the story unfolds, Ndungi Githuku, a human rights activist, actor and poet who styles locks like a Mau Mau fighter, watches, hides and runs from an unfolding rural anti-Mau Mau operation in the 1950s.

A video text, "1982 coup" pops up as a crowd of Kenyans are herded by anti-riot security personnel with their hands up. Like at the height of the Emergency period in the 1950s, they too are screened. Another text, "People's Power-NOW" appears against the background of more images of street arrests. Towards the end of the video, Githuku is no longer running from antiMau Mau British colonial military operations in the 1950s. Instead, his furtive run has brought him to the present in which he is evading arrest by anti-riot police and the GSU in the streets of Nairobi. At the end of the video, the audience discovers that this main actor, Githuku, is playing Dedan Kimathi. Like the leader of the movement in the 1950s, he is arrested. In a powerful visual subtext, Githuku dramatizes the moment captured in the Kimathi photo that was taken not long after his arrest. The photo is the enduring image seared in Kenya's collective Mau Mau memory.

The photograph shows Kimathi lying on a stretcher with a white man alongside showing the jacket of leopard skin and cap that he was wearing when he was shot and captured. ${ }^{238}$ This is the moment that Githuku re-enacts. But even more than this, using special effects, the two bodies, Kimathi's and Githuku's, are visually overlapped. But the latter's image, faded perhaps to symbolize Kimathi's or Mau Mau spirit of struggle, rises out of the former. This powerful imagery synchronizes the "distant" event in the past, which was the moment of both Kimathi's personal defeat and that of Mau Mau, with the present. Both, Kimathi and the Mau Mau struggle, are thus symbolically liberated. In this sense, it is also a transformative artistic gesture. This gesture also presences this historical moment of defeat while simultaneously familiarizing the

\footnotetext{
${ }^{238}$ For more on this watch, "Kenya: Mau Mau Chief Captured," Pathé News (London: British Pathé) on the British Pathé Website.
} 
present by asking the audience to Look at the Times. It demonstrates that times have not changed. Moreover, it powerfully suggests that the struggle is still on.

In point of fact, the lyrical critical public in music embodies this struggle in a flawless time continuum. Indeed, musicians trumpet the latter day travails of other critical publics among them university professors, doctors and nurses and teachers. Eric Wainaina's "Nchi ya kitu kidogo" (Land of bribes) in collaboration with the group, Reddykyulas, which popularized political satire TV theatre at turn of the $21^{\text {st }}$ Century, laments systemic corruption that pervades throughout all levels of society. The song is preceded by a plaintive but angry rant by one of the Reddykyulas' three artists, John Kiarie, as Demethiu from Muthurwa.

The explosive rant expresses exasperation with all the hardships occasioned by the rot of corruption that engulfs society. It poses the big question that dominates the Kenyan mindscape, “Kitu gani hii?" (What is this all about?). In this plaintive monologue, Demethiu complains of waking up in the morning to "double-rationing" of electricity and water meaning that his house has none of the two essentials; a once tarmacked road resembles clods of freshly cultivated land; police on the beat want small bribes, so do chiefs (authorities in charge of the small administrative units) but bigger, social service providers too and thieves who usually want everything once they get you. ${ }^{239}$ "How was he to carry on?" Demethiu poses at the end.

Building on this lament, Wainaina gives a list of most likely places people are expected to give small bribes, including issuance of road licenses and national identity cards; having a child admitted to a public school; and even courts of law. Meanwhile, there is no medicine to treat patients at the Kenyatta National Hospital; hospital workers there go unpaid for months on end and resort to selling marked hospital beddings to survive; and other poorly paid urban workers try to spread their meagre wages to buy food, shoes and school textbooks. All this, he concludes, serves to hinder progress. This is more or less the same theme he treats in his "Who is to blame?" song.

${ }^{239}$ The renowned British historian of Kenya, John Lonsdale, recounts his own mugging encounter with petty thieves ending up in the impoverished neighborhood of Bahati, which ironically means (generally good) luck. In a chapter he described how three young men, claiming to be in the police drug squad, left him penniless, without his passport and his three weeks' worth in the archives in 1994. John Lonsdale, "Compromised Critics," in Religion and Politicts in Kenya ed. Ben Knighton (New York: Palgrave Macmillan, 2009), 85. 
In this song, Wainaina once again deploys Reddykyulas' political satire and empathizes with other critical publics. The track is preceded by yet another generic tax-exhaustion rant that struggling ordinary Kenyans find familiar. The rant, "T.A.V," which stands for the sarcasmloaded 'Tax Added Value,' is against a slew of unnecessary taxes that make no sense. ${ }^{240}$ It puts the blame on government connivance in devising taxes that cannot be understood among them "pay as you earn; earn as you pay; marriage tax; pedestrian tax; zebra-crossing tax; traffic lights tax; value added tax; and tax added value" all culled from meagre wages. At the end of the day, all that one is left with is the salary-slip, the ranter complains. It humorizes otherwise real and bitter everyday experiences of life. It augments the picture the artist aims to paint using words. It identifies with the historic struggles of university students who choke on mounting frustration as they mourn the sorry state of the nation that politicians deny. Wainaina laments that, to survive, school teachers are forced to run small businesses trying to make an extra shilling or two.

Otherwise, total devotion to excellence at their place of work when there's no bread on the table or money for shoes, would be impossible.

Apart from such songs, there is a category of music that is a collective register of struggle. Mejja, whose songs lie in between comic theatre and music proper, dedicates his "Majengo" to various marginalized urban neighborhoods in Nairobi. Indeed, the term "majengo" is a generic reference to informal settlements that have historically mushroomed in major cities around the country. If you like, these are Eric Wainaina's slave camps for cities' cheap manual and casual labor in "Joka." "Majengo" pays tribute to all who live in such places and make a living doing odd jobs such as pushing cargo-ladden carts called "mkokoteni," hawkers, "chupa na ndebes" or those who eke out a living by collecting recyclable metals, bottles and plastic containers, and even petty thieves. ${ }^{241}$ This is quite a significant number of people since about three quarters of the Nairobi's population live, usually without land tenure, in Huruma, Mathare and Kibera slums, which is less than $5 \%$ of urban land. In addition, they have no access to clean water,

\footnotetext{
240 "T.A.V" is a play on the acronym, "V.A.T," for "value added tax." This could mean nothing at all although it could, at the same time, be a particularly subtle way of implying that in Kenya everything is taxable. That those in authority are able to conjure up and contrive any manner and number of taxes. It is another way of saying, "taxes are invaluable." Thus, for those who collect, taxes are everything. For those who have to pay them, they have to dig to the very bottom of their pockets and give everything.

${ }^{241}$ According to Sagepage Uncolonized, "The Mkokoteni Economy," $28^{\text {th }}$ June 2013, the term "Mkokoteni" comes from the roots Swahili word "kokota" that means "to drag." The history of the business goes back to colonial Kenya when good-carts were pulled by beasts of the beats of labor like donkeys and cows. It remains an integral part of Nairobi's urban transport with the exception that mkokoteni pushers are the human versions of beasts of burden.
} 
proper plumbing, healthcare and other basic services. Slum residents are more susceptible to crime and violence. ${ }^{242}$ They also suffer a great incidence of disease and higher rates of mortality. According to the Anna Tibaijuka, the Under-Secretary of the United Nations Human Settlements Programme (UN-Habitat), 150 out of every 1,000 children in such neighborhoods die under the age of five. ${ }^{243}$

Mejja's song captures the plight of the people, especially the youth, who live such precarious lives. In "Majengo," the listener peers into a day in the lives of this urban population. The artist provides the rationale behind urban crime. Mejja presents the dilemma that faces impoverished youth especially when they are unable to sell their itinerant wares, scrap metal and recyclables. Usually, this means that they and their families spend the night with an empty belly. It all boils down to making the option between doing an odd job, vandalizing various public installations or downright stealing. The artist dramatizes petty burglary arguing that it is impossible to sleep hungry yet there are people who seem to live well in plenty. In between the cryptic sheng (a Swahili-based cant and slang that is a mixture, mainly English and other Kenyan languages) rap, Mejja actually says that such crime makes sense. It ensures that the petty thief and peers "survive" by making ends meet. Such a person becomes the superstar of a life spent hustling.

${ }^{242}$ Generator 21, "Chukua Hatua," an unattributed and undated article published by the online magazine.

${ }^{243}$ As quoted, Ibid. 


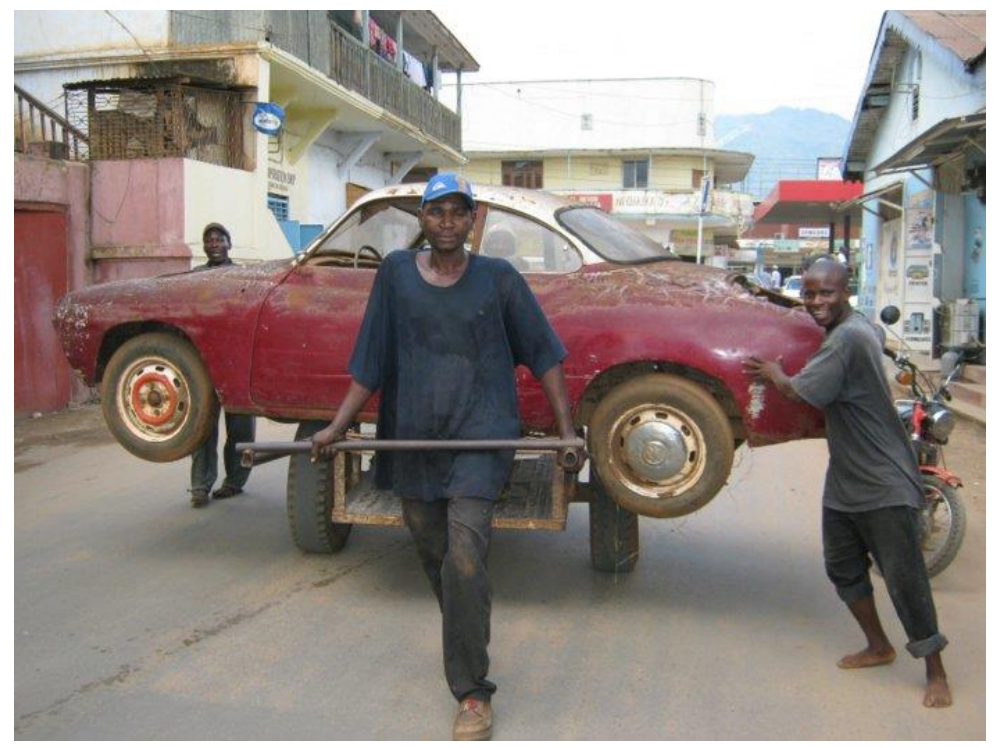

Figure 7.1: Mkokoteni pushers pulling an old car to sell as scrap metal244

The aggressive pursuit of informal and at times shady and illegal business deals is a thematic fixture on the Kenyan hip-hop scene as in the West. The songs "Salary," "Shillingi ya Kenya" and "Bless My Room" by Nameless, Daddy Owen and the group Necessary Noize, respectively, illustrate this. The visual text at the beginning of the "Salary" music video invites the audience to "a day in the life of a hustler." Like "Majengo," it is dedicated to matatu crews, shoe-shiners, farmers, market mamas and the working blue-collar class in general who go about trying to eke out a living. "Salary" is not so much about formal employment as it is about a paying day job to put a meal on the table. It is a precarious livelihood that necessitates one to live on a prayer as people struggle to find their way through the day. ${ }^{245}$ It exhorts the blue-collar working class to work hard to feed their families. It is a theme espoused by Kevin Wyre and Nazizi Hirji of the group Necessary Noize in one of their early tracks, "Bless My Room." The song is actually part prayer of ghetto youth. They are asked to pray and "watch all their problems fade away." Perhaps influenced the Rastafari movement, the group attributes the struggle to put food on the table on the "Babylon system" that brings about such "sufferation," tension and oppression in the nation.

\footnotetext{
244 Sagepage Uncolonized, "The Mkokoteni Economy."

245 The song strikes a chord with Bon Jovi's "Livin' on a Prayer" in which Tommy, a dock worker out on a job because of a union strike has to depend on Gina, his lover. Tommy is out of luck and life is tough. Gina, therefore, spends all day working at the diner working for her man and brings home her pay for love.
} 
Indeed, observation of extreme suffering brings secular artistes to the point of prayer. This is illustrated by the group Kalamashaka in their song "Niokoe" (Save Me). It is interesting no note that the group's name, Kalamashaka literally translates “To Eat Trouble," referring to an intense experience of hard times. The song "Niokoe" complains that a life of such trouble without means is not one worth living. Yet, it is not because of lack of trying and working hard. After all, so the artists profess, they are university educated but still find no employment. Venturing out every day in the morning is intimidating and frustrating because of the suffering that awaits them out there, including police harassment. The artist Daddy Owen in "Shillingi ya Kenya" simply revolts against the monetized-living spent in the futile cyclical chasing after the Kenyan shilling. It plays up the mentalité of struggle populated by street hawkers and "mkokoteni" cart pushers and ends up with supplication for a break.

In music, therefore, what seems to be unmitigated suffering produces an almost fatalist attitude towards life. In the music video "Matatizo" (problems) by Just A Band, the actor Eric Thimba, bids farewell to his brother before he is tortured to death. It transports the audience to the dark years of the Moi regime by revisiting the infamous flooded and dark dungeons of Nyayo House of the 1990s where Thimba is undergoing various forms of torture. Thimba tells the brother not to worry and stoically "assures" him that he is at home whatever happens. After all, he was "matatizo"-hardened because suffering comes to all without warning. It was normal to have to struggle. In the end, Thimba dies. ${ }^{246}$

This fatalism is also reflected in Wainaina's "Mashaka" (uncertainty). "Problems just follow me," he sings. Wainaina paints different life situations occasioning vexing suffering that people in the informal economic sector face. These include the forceful removal of hawkers from the Central Business District; lack of employment despite the official government principle that "nothing is for free"; homelessness; and hunger and general lack of peace of mind. In spite of the engulfing darkness, sadness and madness of it all, he believes that the struggles are going to end

\footnotetext{
246 The Nyayo House basement torture chambers was where Moi detained most of his political opponents, proponents of a democratic political system, human rights activists and those who were courageous enough to speak out against his dictatorship, corruption and malpractices in the 1980s and 1990s. Among some of the victims of Nyayo House include Kennethe Matiba who almost died in the chambers, Charles Rubia, Shem Ogola, Professor Edward Oyugi, Njeru Kathangu, Raila Odinga, Maurice Adongo Ogony, just to mention but a few. For a more detailed account on this meticulously planned pillar for political torture built using public funds to punish and kill Kenyans who were deemed to be enemies of the state see Friedrich Ebert Stiftung and Citizens for Justice, We Lived to Tell the Story: The Nyayo House Story (Nairobi: Friedrich Ebert Stiftung).
} 
someday. This glimmer of hope is echoed by "Msoto Millions" (Innumerable Troubles) by Ukoo Flani and Jahcoozi. Despite being unable to earn their keep; the lack of bread and butter; children dying of malnutrition; and official denial of the prevalence of such "matata," the artists urge, "struggle on." This spirit of fighting on is also evident in "Room For Me" by Lisa Oduor, Just A Band and Jahcoozi. They ask the world whether it can feel, see and hear them: does it have a little room? If everyone is eating, “can you please bring my plate?” they pose. Although the struggle is tiring and the fight rough, there is determined resolve to choke-hold on reality and onto hopes and dreams. Behind this fighting spirit, therefore, is determination not to wallow and succumb to allied odds in life through individual and group agency.

As such, it is not all gloom. Kenyan artistes recognize that the poetry of music can break open locked chambers of possibility, restore numbed zones to feeling and, thus, recharge desire. Music has reflected upon the long and unbroken history and lineage of grievance since colonial times, and acted as a reservoir of memory of Kenyan's collective experiential trudge of life. But it has also acted as an antidote to the sometimes overwhelming fatalism of everyday life experiences. Some Kenyan songs are paragons of Arts of the Possible. Music in Kenya has been used to mobilize and awaken movements against demolarizing power and despondency. ${ }^{247}$ Hiphop poetry and the arts act, not just as a coping mechanism, but also as a form of didactic resistance. ${ }^{248}$ Explaining the inspiration behind his album "Love + Protest," Wainaina made reference to Che Guevara's statement that "the true revolutionary is guided by the greatest feelings of love." 249 In the album is the song "Revolution Time," which calls on young men who "have got plans; ...have got dreams; ...got visions," and who are fed up with the smelly status quo, to sign up for revolution.

Besides, what other options do they have? Shrug their shoulders in indifference? Sit down and suck their teeth? Take positions on the fence? Wainaina urges that something needs to be done because, how could one play when the ground is uneven? When the rules are made behind your back? When the judge, the jury and the referee are the beneficiary? How could one run

\footnotetext{
${ }^{247}$ Ideas attributed to Adreinne Rich in her two books What is Found There: Notebooks on Poetry and Politics and Arts of the Possible as cited by Lauren Shaw, Songs and Social Change in Latin America (Lanham: Lexington, 2013), 152.

248 Otieno, "Mungiki, 'Neo-Mau Mau’ and Prospects for Democracy in Kenya," 529.

${ }^{249}$ Eric Wainaina Official Website, "Love + Protest Press Release (Summary)."
} 
when they had never walked? How can one learn to think if s/he was never allowed to speak? All this, for Wainaina, meant that the law of the jungle was prevalent in the city where the cries of the people met no pity. It is, therefore, imperative for people to stand up for revolution. It is "Revolution Time." It is time for the widow, the orphan, the needy and the sick to take a stand for a better nation to expose all the wolves in sheep's clothing. This is the labor of love that lasted three extra years for Wainaina to bring to fruition. To be able to inform wananchi that:

It's a revolution time, .... solution time, .... moving time

Wake up, we are losing time.

We wanna see the fruits in time Don't you sleep, it's a waking time Revolution time.

The same message is reverberated by various "Bado Mapambano" song versions done by coastal youth and groups Inka and Watumwa. In their rendition, Watumwa vow to fear no more, remain silent or lie down and slumber. It was time to ensure that justice was done for Internally Displaced People and slum dwellers. This version reasserts the fulfilment and meeting of basic needs such as food, housing and clothes as a right.

Over and beyond the entertainment industry, there is an ever-rising din making these demands against the state and the political elite. There is a vibrant and prolific youth internet-age protest movement that draws inspiration from the same mentalité situations behind Kenyan hiphop. As noted, one of President Kibaki's proud hallmark achievements was the growth of internet usage from a quarter of a million to about 14 million people. Regardless of acknowledgement or the lack of knowledge thereof, this widespread use has amplified protest voices from the technological savvy critical public.

\section{Nuggets of Mentalité in an Age of eDemocracy}

The internet world as exemplified by use of SNS has seen the proliferation of virtual communities. The oral transaction, in everyday life, of identities and national politics has emigrated to the World Wide Web. Social media, as well as other new media, have generated a virtual infrastructure where people meet and transact business as well as carry on conversations. 
The experience of everyday life has been reproduced virtually with significant effect. This is illustrated by the MRC, which is not only a social movement with an existential physical identity but is also a virtual community. The crisis of citizenship behind the group's call for secession has also mediated action and interaction to an exclusive virtual identity on Facebook. Actual physical mobilization is not only through word of mouth and direct contact between friends but also through use of this particular popular site..$^{250}$

There is, therefore, the group's physical existence as individuals and movement and in relatively felt virtual network geared towards an imagined ideal that is coterminous with an eventual actual or physical autonomous community. The collective imagined future of the coastal region is propagated and enhanced by this virtual presence (See a map of the region covered by the desired autonomy in Figure 2 below, which was posted on Facebook). ${ }^{251}$

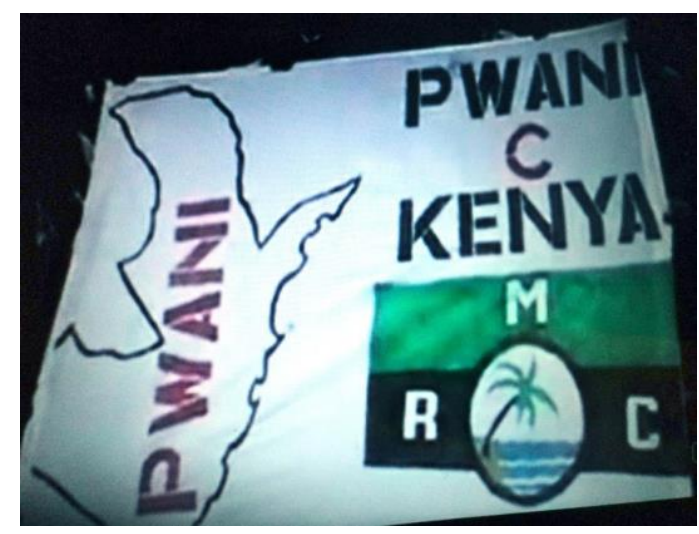

Figure 7.2: (C) MRC: Pwani si Kenya virtually imagined

This is a strategy has been used by striking doctors and nurses as well. However, the activities of three other closely affiliated virtual communities are worth pointing out considering this same ability to traverse between the virtual and physical experiences. These include the Wanjiku Revolution, Unga Revolution and Pawa254.

\footnotetext{
${ }^{250}$ MRC's internet presence started on $26^{\text {th }}$ May 2011 when it apparently opened an account on Facebook. Its stated mission thereon is to become an independent nation as any other in the world.

${ }^{251}$ This photo was posted on Facebook on $7^{\text {th }}$ November 2012.
} 


\section{Wanjiku Revolution Kenya}

The activities of this virtual public critic are mostly textual and visual. The group describes itself as an agitator for the respect worthy citizens of Kenya. It is apparent from the group profile that it strongly identifies itself as the genuine Kenya nation. The identity of Wanjiku Revolution is coterminous with the real Kenya and its actual owners, the wananchi as opposed to the ruling elite. The latter are often portrayed in the site as a greedy and selfish bunch: M/Pigs. ${ }^{252}$

According to the basic information identifiers, a standard requirement to start a virtual Facebook community, the "group was born on $12^{\text {th }}$ December 1963." This is a little veiled assertion of its identity as truly Kenyan because this is the date of the country's independence. Obviously, there was no Facebook then. Also, the group is apparently effeminate. With regard to this sex choice, the inherent political meaning and symbolism of the Kikuyu female name, "Wanjiku," is instructive. The term "Wanjiku" entered popular political parlance and discourse in the 1990s at the height of the call for constitutional reforms. Then, it was argued, especially by progressive forces in the opposition, that the ideal constitution was one that met the basic needs and reflected the wishes of the ordinary citizen embodied by a lowly and humble, if impoverished woman, "Wanjiku." In popular culture, "Wanjiku," who more often than not has always gotten the short end of the stick since independence, has been popularized by the cartoon artist Gado (see Figure 3 below).

\footnotetext{
${ }^{252}$ This is a play on words that is Orwellian in inspiration. Kenyan representatives of the electorate for a long time, before the 2010 Constitution, were, and have always been, Members of Parliament (MPs). They are portrayed as greedy "pigs," hence "M/Pigs." This is especially considering that since the late 1990s, the first order of business for new and old MPs always seems to be a self-awarded salary raise.
} 


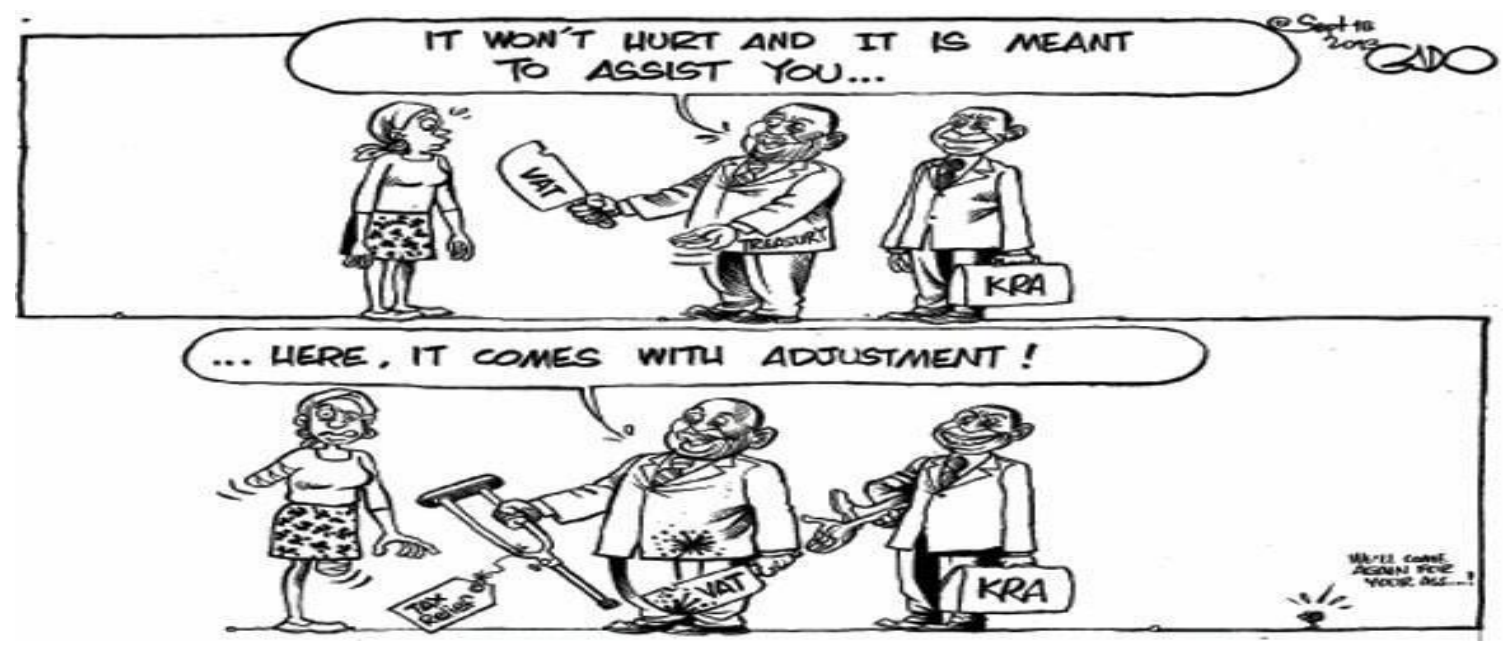

Figure 7.3: @ Gado: Wanjiku being exploited by suggested Value Added Tax

Wanjiku Revolution Kenya aims to advance the cause of the ordinary citizen by engaging in various topical issues of the day. Around the days marking 50 years since the country attained self-rule and gained independence in 2013, this movement, in concert with affiliated groups and internet users in general, initiated the viral "HungryAt50" campaign. This was on the sidelines of pompous government-sponsored national celebrations. The campaign claimed that although the country was arguably a regional economic powerhouse, it was disturbing that sections of the country were still food insecure. This necessitated heavy dependence on food aid and was sanctioned by successive regime inefficiencies (See Figure below). In as far as the group is concerned, the obtaining situation that prevailed at the dawn of independence regrettably remains true of the country despite the march of time. 


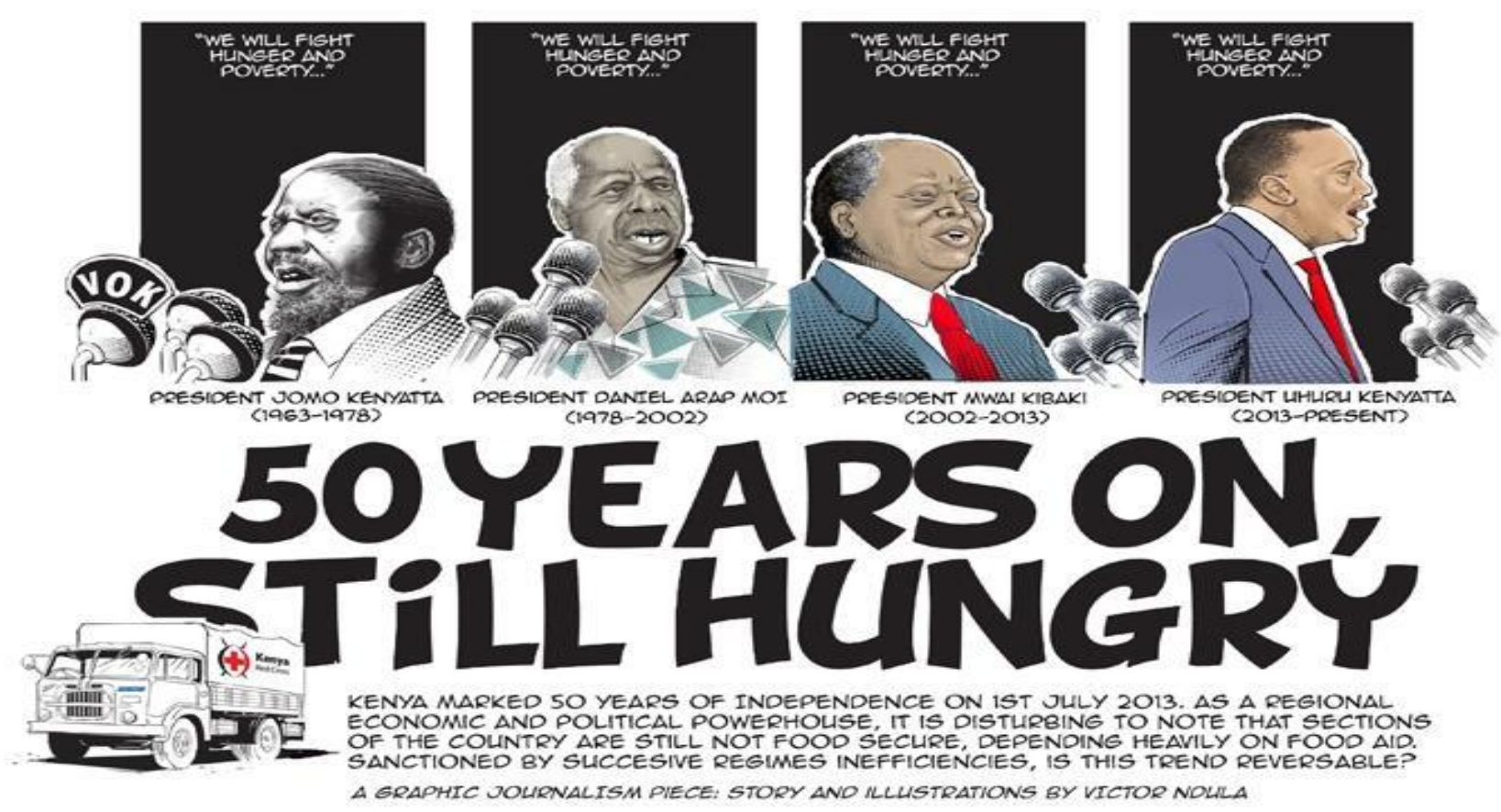

Figure 7.4: Source: Wanjiku Revolution Kenya, $9^{\text {th }}$ December 2013.

This was accompanied by a searching and critical observation that appeared on the social networking site Facebook around the same time -viz.

1) Kuna wale walio pigania Uhuru, na kuna wale walio nyakua Uhuru ule;

2) Kuna wale walio pigania mashamba, na kuna wale walio nyakua mashamba yale;

3) Kuna wale walio pigana na dhuluma, na kuna wale walio tekeleza dhuluma zile;

4) Kuna wale walio simamia haki, na kuna wale walio simama kidete na ukoloni;

5) Kuna wale walio tupwa korokoroni, na kuna wale walio salia kuwasifu mabeberu;

6) Kuna wale walio pinga umasikini, na kuna wale waliosababisha umasikini huo;

7) Kuna wale walio teswa kuikomoboa Kenya tena; kuna wale walio nufa bila jasho;

8) Kuna wale walio pigania Katiba mpya; kuna wale walio ipinga Katiba ile;

9) Kuna wale walio pigania haki za mpito; kuna wale walio pinga mapendekezo yale;

10) Kuna wale walio unga kesi za dhuluma ya utu; kuna wale walio pinga kesi zile.

Essentially, it states that in Kenya, there still prevails a status quo that reaches back to the dawn of independence:

1. There are those who fought for freedom, and there are those who grabbed and stole that freedom.

2. There are those who fought for land, and there are those that grabbed that land.

3. There are those who fought against oppression and injustice, and there are those who perpetrated it.

4. There are those who stood for justice, and those who were steadfast in their support of the colonial order. 
5. There are those who were detained, and those who remained content in their praise British colonists

6. There are those who fought against poverty, and those who were its very cause.

7. There are those who were tortured in the course of the "Second Liberation," and those who benefitted without breaking a sweat.

8. There are those who fought for a new constitution, and those who blocked that constitution.

9. There are those who fought for redress for historical injustices, and those who opposed such a process.

10. There are those on the side of the case against repression and the breach of human rights, and those who opposed such cases.

In its internet campaigns and social protest communication, Wanjiku Revolution works closely with Unga Revolution among other SNSs allies.

\section{Unga Revolution}

As noted, this virtual community works closely with Wanjiku Revolution. It's stated mission and campaign is the end of poverty and hunger, not as a form of government charity but as a basic human right and as an act of justice. One of its demands and slogan is for the government to recognize that "Food is a Right." It works closely with marginalized urban youth and guilds such as (Nairobi) Hawkers Association, Boda Boda Association and Wamama Mashinani (grassroots mamas). They are engaged in raising the runaway inequalities that exist in society. In particular, they have opposed self-aggrandizement in the form of unilateral salary increments by MPs. This is held up against the support of the political elite to stand up against the imposition of value added tax and Parliament's reluctance to have taxes imposed on MP salaries in 2012. Like most other groups, they have heavily relied on the use of visual illustrations to highlight socioeconomic inequalities (see Figure 4 below about the 
disproportional allocation of budgetary funds).

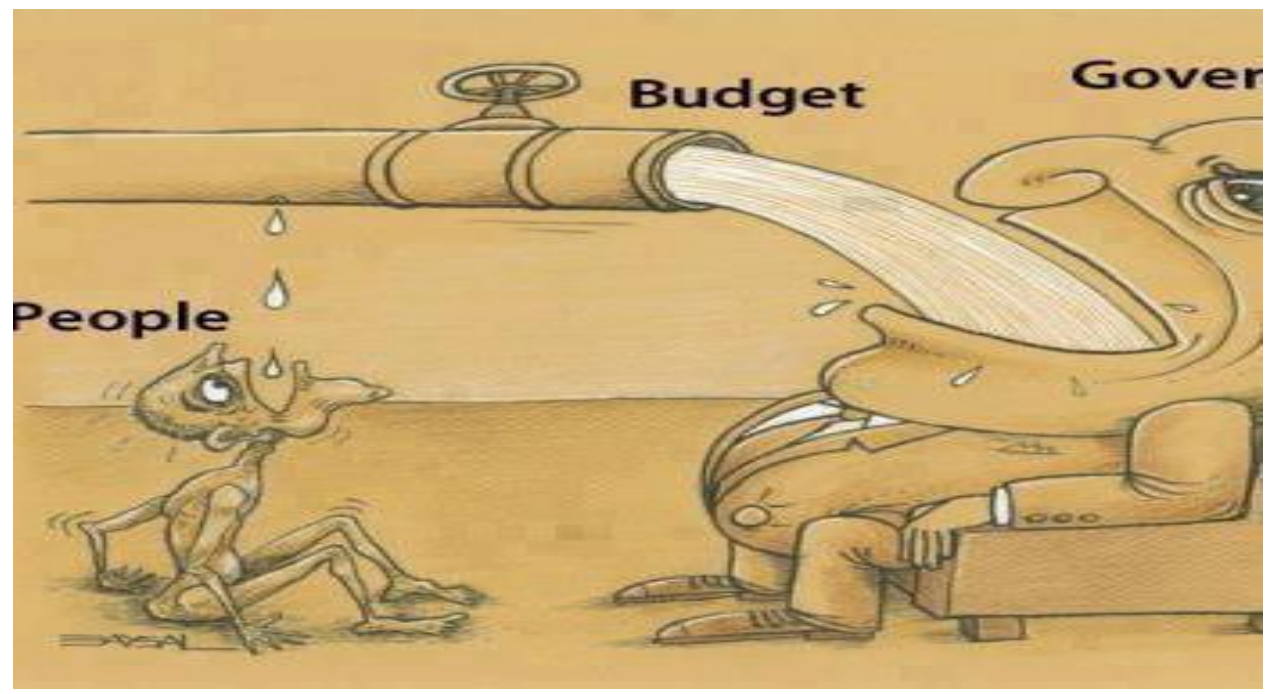

Figure 7.5: Disproportionate allocation of budgetary spending. ${ }^{253}$

The group first came to national prominence when they organized a symbolic march on

Harambee Avenue where most government offices, including the Office of the President and parliament are located. The youthful crowd was armed with empty plastic plates among other kitchenware. Unga Revolution, as their name suggests (it means maize flour the main staple food for most families) was protesting the high cost of basic essentials.
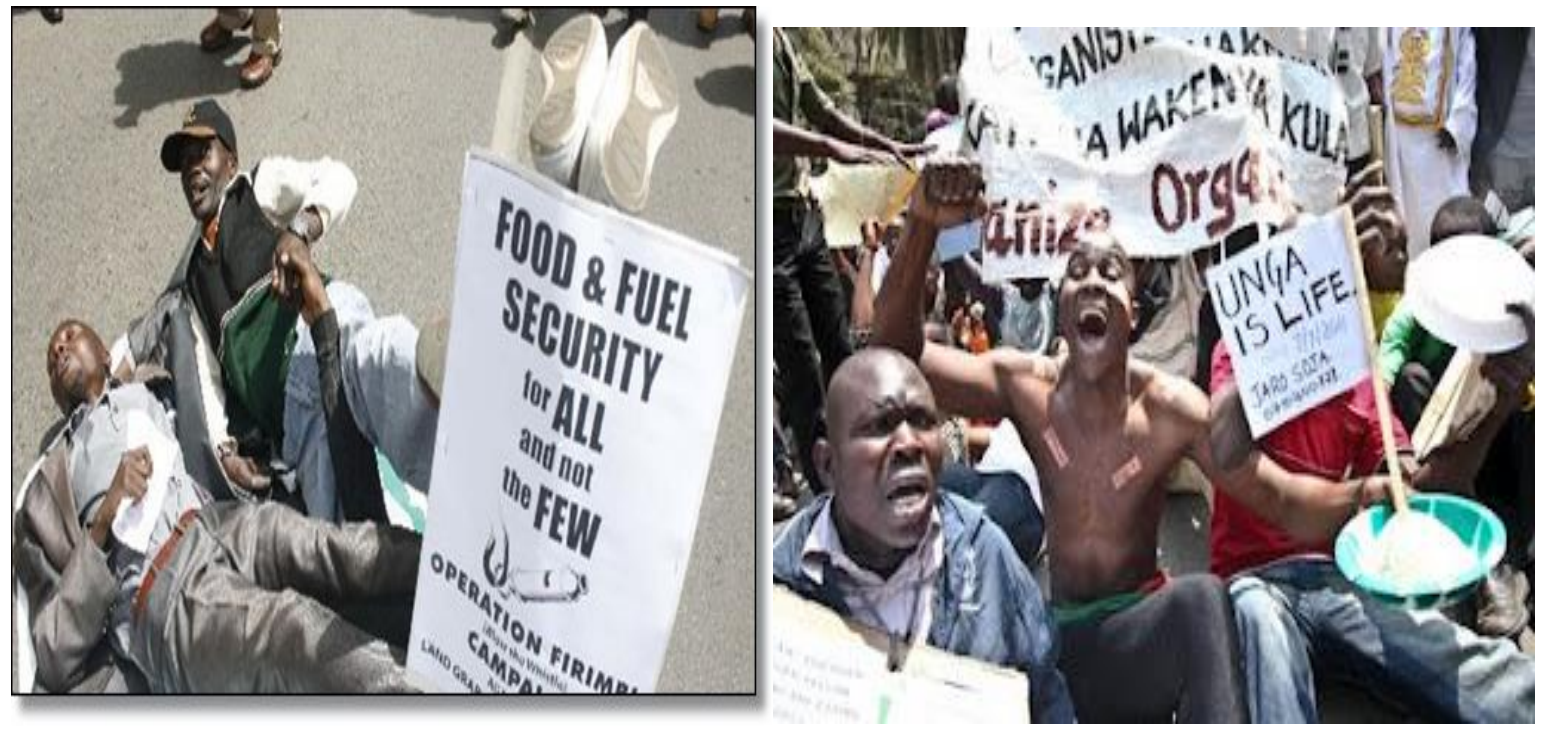

Figures 7.6: @Unga Revolution: a Facebook photo of a demonstration against the high cost of living. ${ }^{254}$

${ }^{253}$ It is rather difficult to correctively attribute some of the pictures and graphics used online by such groups due to their viral nature. However, this graphic was retrieved from the Facebook photo album of Unga Revolution.

${ }^{254}$ Unga Revolution, Facebook Photo Albums. 


\section{Pawa254: Harnessing Art for Social Impact and Beyond}

Pawa254 is the handiwork of a young charismatic and award-winning photo journalist, Boniface Mwangi. ${ }^{255}$ His political activism was ignited when he witnessed, firsthand, the Post Election Violence in 2007/2008. At great risk to himself, Mwangi documented the unfolding gory ethnic violence that in terms of potential magnitude, was the country's worst. This was a turning point for the young photographer. He launched Picha Mtaani, a nationwide street exhibition of photographs that he had taken during the violence. This was an individual initiative designed to provide an opportunity for Kenyans to reflect on the national tragedy. Despite its apparently harmless intentions, this campaign was hampered by government officials.

Unthwarted, Mwangi has since organized various public mobilization campaigns to not only foster peace, but also against social inequality and grand corruption. He exemplifies contemporary critical publics that are exploring the technological infrastructure afforded by public social networking sites to mobilize youth. In a media interview, Mwangi expressed disappointment with the Kenyan "talking-shop." He pointed to the fact that Kenyans talked a lot grumbling as they do on "Twitter, Facebook, blogs and offline in pubs, 'chamaz' and 'barazas'....all they do is talk." Mwangi felt that it was about time people stopped talking and do something. ${ }^{256} \mathrm{He}$ set up Kenya Ni Kwetu to tap into ideas for social action using visual art to shed light on issues of social justice. Under the auspices of Pawa254, there have been various street demonstrations with their genesis from both virtual and physical interactions and sharing of ideas.

One of the creative initiatives undertaken was a discrete "anonymous Vulture Graffiti" blitz of covering strategic parts of Nairobi early in 2012 such as the wall of the City Market. This was an unprecedented classy street demonstration, unique especially because it was employing a public art form. In this sense, it was a radical break with the traditional pitched battles between various publics and anti-riot units. It censured the political class for bad governance, rampant corruption and exploitation of public office to the detriment of the rest of the people. ${ }^{257}$ One of

\footnotetext{
255 The name is a creative and cryptic one that basically means "Empower Kenyans" or "Empower Kenya." It is derived from the English word "power" and Kenya's country code, "+254."

${ }^{256}$ James Smart, "A Chat With the Men Behind the Graffiti Murals in Nairobi," The Headliner, NTV Kenya, Youtube, Published March 2012.

${ }^{257}$ Pawa254, "Vulture Graffiti Timelapse," Youtube, Published on June $29^{\text {th }} 2013$. The video documents the creative use of art as a medium of communicating public outrage as well as grassroots mobilization.
} 
the graffiti texts read: "MP's, screwing Kenyans since 1963." More critically, the idea and image of a vulture was used to characterize and satirize the Kenyan politician. The street graffiti carried a radical message to Kenyans to stand up for their rights and recognize their leaders for what they are. ${ }^{258}$ More importantly, it listed a litany of all that had gone wrong in the past. This included corruption scandals like Goldenberg, Anglo-Leasing, Triton and land-grabbing, ethnic cleansing violence and more (See Figure below). The graffiti reminded Kenyans that it was the young generation that had ended the Nyayo era. It was not impossible to do the same if such ills persisted: power rested with the people. The massive conversation pieces simply highlighted what most people voiced in their own quiet corners. ${ }^{259}$ But the Pawa254 and Wanjiku Revolution campaign was led by an army of artistes with the main aim of getting the average Kenyan talking. ${ }^{260}$

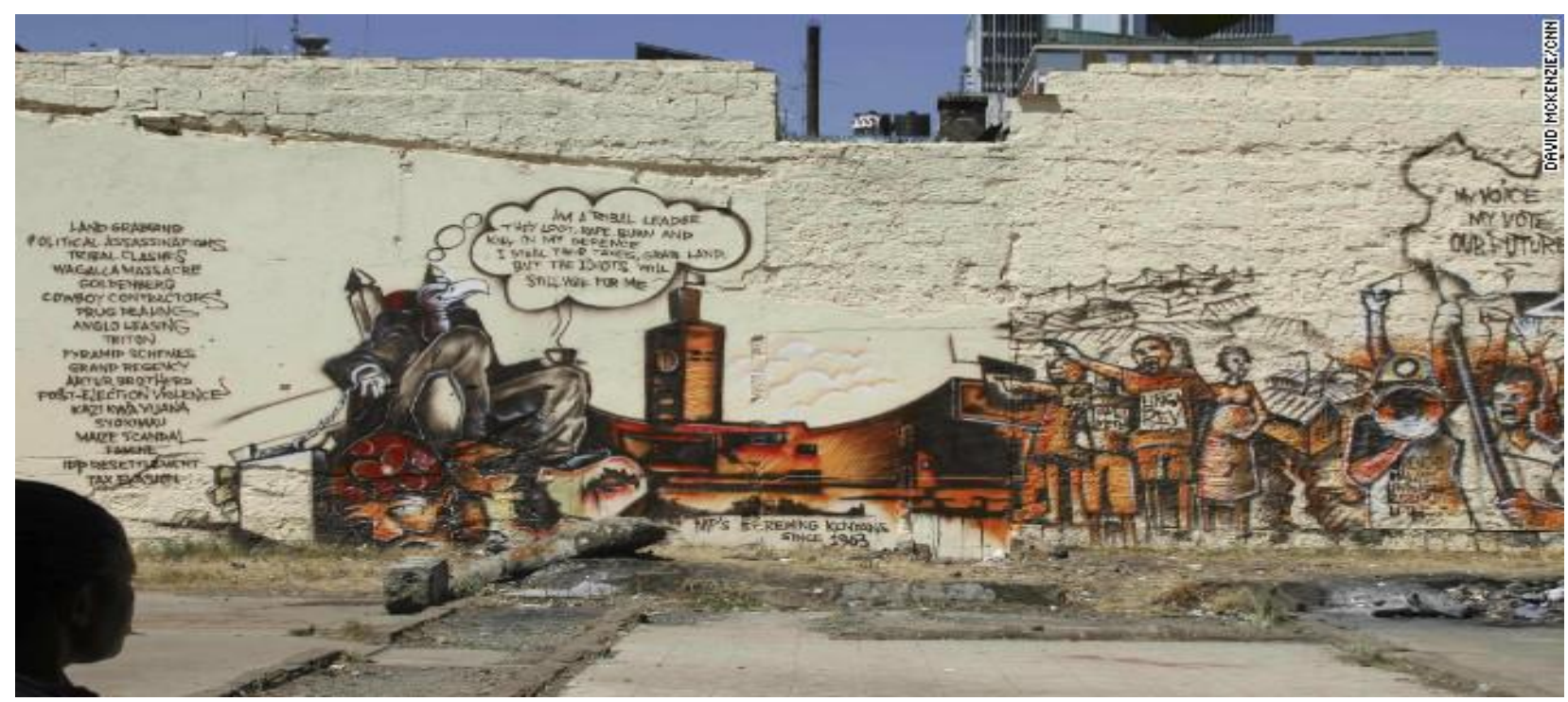

Figure 7.7: Street graffiti by Pawa254

\footnotetext{
${ }^{258}$ Ibid.

259 James Smart, "Graffiti Murals in Nairobi."

${ }^{260}$ Ibid.
} 


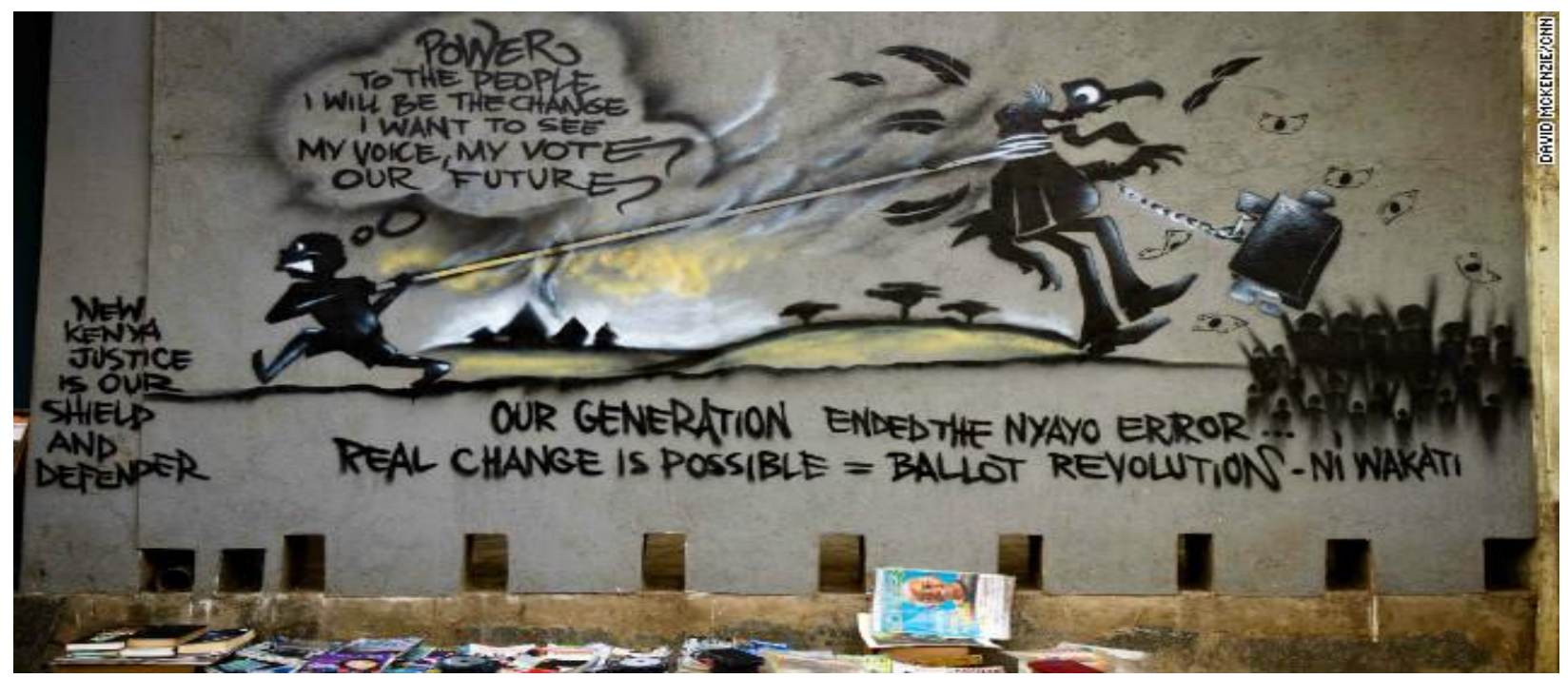

Figure 7.8: Part of the 2012 graffiti blitz in select Nairobi streets. ${ }^{261}$

The 2012 graffiti blitz was followed by street protest campaigns organized by Pawa254 aimed at sitting MP. These were kicked off by the "Love Protest" in June 2012. This was followed by two Occupy Parliament campaigns and culminating in 'the mPigs' protest against yet another planned MP salary review upwards. These usually attracted hundreds of university students, especially from Nairobi-based colleges Kenya Polytechnic and University of Nairobi students.

\section{Conclusion:}

Despite the Kibaki-years economic intermission and respite, the majority of Kenyans, 50\% of the rural and urban population, continue to endure and experience untold hardships. The burgeoning middleclass has, for a very long time, been stagnant and purposely, perhaps, stymied especially in the Moi years. After more than 50 years of independence, most of them are beginning to bemoan the great disparities in wealth and gross income inequalities. Yet the quest for prosperity, as it was at independence, is shared by all and sundry. Kenyans across the board, the faceless and nameless rural and urban folk as well as the lower and upper middle classes, are imbued by the spirit of everyday struggle as they contend with a runaway cost of living. In taking out their frustrations in the public sphere, it is the professionals -teachers, lecturers, doctors and nurses- who have, in the last few years been the eloquent voice of latter day travails of various critical publics. Instead of dismissing such protest as the gripping of already privileged and the

\footnotetext{
${ }^{261}$ Pawa254, 2012.
} 
educated, these social protestations should be used as a parameter with which to gauge the intensity of lesser endowed and underprivileged people for whom everyday survival is precarious, if not downright, a matter of life and death.

Although, the methods resorted to by Mungiki and SLDF, and the threat posed by the secessionist MRC, are regrettable, they should be seen in that light. This study has not attempted to detail the individual, family, village and group micro-histories of the people behind these three movements. However, it asserts that most of them could and do trace their experiential suffering in life, directly or indirectly, to historical injustices of the colonial era. Thus, there is a genealogy of grievance that continues to feed their everyday frustrations and author their life-actions including extortion, crime, violence and the criticisms and challenges posed to the state itself. In this sense, these three groups are reminiscent of the Mau Mau minds, in deed and thought. This permeation of the spirit of struggle throughout society in Kenya is reflected in popular culture. It is a culture that, in the $21^{\text {st }}$ Century, is informed by anti-colonial struggle and memory of the past that has been creatively organized and powerfully juxtaposed with contemporary experience of Kenya as a lived place and space with intensity. Various forms of art, including music, poetry, cartoons, paintings and pictures, graffiti and SNS are time-bending genres and mediums of social protest. These media are being harnessed by a generation that is reconstructing the complete Kenyan experience guided by the spirit of struggle that is pushing from below to reconstitute and remake the nation to reflect the true aspirations, dreams and hopes of the majority of Kenyans. More than professional strike action and militias, a significant number of young people in the country are eloquently putting things in perspective.

They are invoking the memory and spirit behind the Mau Mau struggle which has the effect of "presencing" the past while at the same time familiarizing the present. Furthermore, they lend their mind and voice, thereby acting as receptacles, to the collective trudge of Kenyans' crucible of experience as an everyday struggle. In the long-term, there is likelihood that their creative work will resonate with other disgruntled elements and critical publics breaking out into a veritable Wanjiku Revolution that will forge a popular Kenyan state. This is a vision of a united country regardless of age, gender, ethnicity or creed; a vision of a united country where the past is openly and fearlessly confronted, thrashed out and due justice meted and old wounds embalmed and healed; a united country where public goods such as civil 
liberties, civic virtue, basic human rights and social services such as health, education and infrastructure are accessible for all.

The old game of musical chairs has outlived itself in Kenya. There is a new song in the air. It is a song that seeks to empower and mobilize ordinary citizens, especially the youth. People in Kenya are stirring up to the solidarity forged in the crucible of the struggle for freedom and independence from the yoke of European imperialism. For them, the struggle is still on: its solidarity forever for equity and equality in the distribution of public goods. 


\section{Chapter VIII - The Long Kenyan Century: A People's Elusive Quest for "the Good Life"}

\section{Preamble}

All this was a long time ago, I remember, ...But set down

This set down

This: were we lead all that way for

Birth or Death? There was a birth, certainly,

We had evidence and no doubt. I have seen birth and death, But had thought they were different; this Birth was

Hard and bitter agony for us, like Death, our death.

We returned to our places, these Kingdoms,

But no longer at ease here, in the old dispensation,

With an alien people clutching their gods.

I should be glad of another death.

- T.S. Eliot, The Journey of the Magi 


\section{Where the Dance Is}

According to legend, something pregnant with powerful symbolism happened on the day Kenya achieved internal self-government. On that momentous day, $12^{\text {th }}$ December 1964 it is said the country's new flag became momentarily stuck as it was being run up the flag pole. ${ }^{1}$ That morning, the Union Jack had been brought down for the last time at a large midnight ceremony attended by tens of thousands at Uhuru Gardens in Nairobi. There was wild cheering, celebration with singing and dancing as "freedom" was ushered with pomp and a thousand fireworks that lit up the night's sky and the gathered throng of people's beaming faces. The spotlight rested atop the flag post "awaiting the bold flattering of Kenya's new red, green, and black dawn." At this point, Prince Philip, there to represent the Queen, turned to Prime Minister Jomo Kenyatta and whispered, "It's not too late to change your mind."3

But even this slight embarrassing moment could not dampen the mood at the venue and around millions of hearths around the country. There was unbridled hope as Kenya was poised at the starting line of a beckoning and bright future as an independent country. The flag was finally flying high at the venue and simultaneously at Mt. Kenya, the highest point on the country's landscape, to even more fireworks muffled by thunderous cheering as if from one throat. Many hearts were gladdened and brimmed with joy.

If there is one thing that Kenyans excel in, besides their world record shuttering longdistance races reputation, it is celebrations. No opportunity is left unexploited for joyous partying. Independence celebrations and ceremonies were held almost without respite throughout independence week. But the period of most intensive pageantry and dedication extended from $11^{\text {th }}$ to $14^{\text {th }}$ December a few months later when the country became a republic on $12^{\text {th }}$ December $1964 .^{4}$

In a broadcast to the nation earlier that day, the Kenyatta told Kenyans, who actually needed no reminding, to greet the planned moment at midnight with festivity and rejoicing. ${ }^{5}$ In

\footnotetext{
${ }^{1}$ Giles Bolton, Africa Doesn't Matter: How the West has Failed the Poorest Continent and what we Can Do About It (New York: Arcade, 2007), 35.

${ }^{2}$ Ibid.

${ }^{3}$ Ibid.

${ }^{4}$ Jomo Kenyatta, Suffering Without Bitterness: The Founding of the Kenya Nation (Nairobi: East African Publishing House, 1968), 249.

${ }^{5}$ Ibid., 251.
} 
this address, he reiterated that becoming a republic was a significant milestone on the road to independence. It meant "absolute freedom" of Africans running their own government, parliament and making all decisions affecting the country's security and progress. It also meant sovereignty "not only in fact, but also in appearance." The unique and historic decision of the main opposition party, KADU, to join the government, he said, bode well for building of "one strong Kenya [sic] nation for the benefit of all, with leeway still for constructive self-criticism amongst ourselves." Kenyatta went on to promise that he and his ministers were "guided by a single inspiration: to raise the living standards of the people." His government's single task was "to attack as fiercely" as it could the enemies of malnutrition and sickness, illiteracy and economic frustration. Such was the commitment with which to thrust open the gateways of hope always looking out towards new frontiers of economic and social opportunity for every man, woman and child. ${ }^{7}$

As in his numerous rhetoric laden speeches made throughout that year, the president told Kenyans that the government could not be expected to fulfill this commitment alone. The people's understanding and contribution was needed. People that year had responded to the triumphant call of harambee to pool resources and drive the country forward in a spirit of promoting self-reliance. "Uhuru na kazi" (freedom and work) was the slogan and omnibus rallying cry towards this goal. It pointed to the rewards of hard work that were greater and more accessible with independence. "Uhuru na kazi" was to be the guiding spirit expected to imbue everyone from the grassroots all the way up. This would be buttressed by individual and collective discipline with thoughts of duty and morality. Eventually, the desired Kenyan state that everyone yearned for would emerge. One that would ensure national dignity, freedom, greater human respect founded on the belief in individual human rights. Human respect extended beyond what a man was or what he did to what he owned and cherished.

These sentiments were echoed in his address later that day in his inauguration ceremony. The president hailed and heralded the birth of the Kenyan state. ${ }^{9}$ In this speech, Kenyatta dug deep within his recesses of his person in what was his most important address to the nation.

\footnotetext{
${ }^{6}$ Ibid.

${ }^{7}$ Ibid., 253.

${ }^{8}$ Ibid., 253-254.

${ }^{9}$ Kenyatta's inaugural address Ibid., 255.
} 
There was a sense that he cared deeply that all, with him at the helm, work together to forge a strong, stable and united African state. He led the people in imagining a Kenyan state in which all participated in government, commerce and industry and the proper usage of land. Having done so, however, Kenyatta went on to aptly caution that this "image in our minds" was not enough. It was but a design and dreams were no refuge. There was need for vigor of practical initiative to turn this image into reality. ${ }^{10}$ The guiding light of enlightenment, service and dignity was enough to quell divisive forces of racialism and bigotry. Freedom and unity were pillars of the state. The state was all the people of Kenya. They were no longer Kikuyu, Kamba, Giriama, Kipsigis, Maasai, English, Asian or Somali. That is because the state embodied equality and respect and cut through racial and ethnic distinctions. A moment in time had arrived when all were able to achieve their individual and group goals and thereby command their own destiny and rediscover their own voice. ${ }^{11}$

These words were the soft pouring rain on parched land that had not tasted water for years. They were well-weighted and well-meaning. But then, they were just words, unfortunately. During these heady days, however, the smell of freedom was in the air and restored agency and voice palpable. Caught up in the contagious euphoria, everything was achievable collectively. People at all levels of life were imbued by an all-consuming optimism. There was absolute certainty that acting together, they could make things happen. They were not just full of brimming hope but also commitment. Teachers, doctors, nurses, lawyers, architects, engineers, writers and many other vocations were going to serve the nation. ${ }^{12}$ With the simple act of lowering the Union Jack, and hoisting of the new flag, British colonialism ended. All its ills and ethos "were over."

In the place of the indignities, humiliation and oppression of colonialism, everyone was, once again, bound together in the restored social fabric underlined by mutual reciprocity and well-being. All committed to each other in the African spirit of mutual concern underscored by the notion of the binding African philosophy of life: "I am because we are and since we are, therefore I am.” Everyone was one's brother's or sister's keeper from the president reaching

\footnotetext{
${ }^{10}$ Ibid., 256.

${ }^{11}$ Ibid., 255-256.

${ }^{12}$ Micere Mugo, Writing and Speaking from the Heart of My Mind: Selected Essays and Speeches (New Jersey: Africa World Press, 2012), 223.
} 
down to the grassroots and back again. ${ }^{13}$ This was an aspiration of Mau Mau struggle. The armed freedom struggle had occasioned a severe food shortage. This led to the composition of a Mau Mau song that urged and charged people to split the little food there was even if it was a single morsel of a bean in the spirit of sharing. ${ }^{14}$

Indeed, this was the spirit of sharing that harambee attempted to harness. For a while, the president inspired and ably led harambee development projects in which communities pooled their efforts, skills and financial resources in order to build schools and sponsor and send bright students to national high schools, public universities and studies abroad; bridges; hospitals; roads; cattle-dips; and water projects were initiated. People sought to ensure individual as well as collective survival and growth. It was a historic and successful moment in which human rights in the center front inspired by this collective vision and fanned by a spirit of accountability between the individual and the group. ${ }^{15}$

But the music soon stopped. Independence, and its accompanying rosy brave new world that it initially heralded, actually turned out to be only a game of musical chairs. It was a most embittering farce for most people. It did not take much or long for people to realize and appropriately recognize what the "transition" was: flag independence. Kenyatta had even honored a few Mau Mau fighters with national flags but then that is all they received for their effort and sacrifices. They felt betrayed. In a powerful analogy, they complained that it seemed as if they were like unrewarded soccer players.

Those who fought colonial "order," as discussed in chapter four, had reentered society only to find that they were still landless in a rural world now realigned by land consolidation and freehold title. ${ }^{16}$ Despite having played and won the game, the trophy was awarded to spectators. Some in government, as discussed in chapter 5, even wanted the symbolic gift of the national flag returned. This action led a few among freedom fighters to complain directly to the president thus: "Our dear leader, whoever leaves his children to be mauled by such sinister hyenas ordering them not to run so that they can be finished? Our beloved leader, did you honor us with

\footnotetext{
${ }^{13}$ Ibid., 213.

${ }^{14}$ Ibid., 214.

15 Ibid.

${ }^{16}$ John Lonsdale, "Mau Maus of the Mind: Making Mau Mau and Remaking Kenya," Journal of African History 31 (1990): 420.
} 
the flag so that it could be a trophy fought over between the masses and Njuhiga (the educated elite)?"17 Independence did not quite fix the criminal, albeit "legal," policy foundations of the edifice that is the postcolonial Kenya state. The historical and structural injustice, especially with regard to the sensitive issue of land was addressed on the basis of the principle of "willing seller, willing buyer." This bore "justice" for the white settlers, most of whom were compensated for their loss of land. Saying that Africans who expected the restoration of their ancestral lands were dismayed is an underestimation of their independence plight.

The litmus test for independence was the practical enjoyment of the fruits of independence of which the president talked about: land restoration and redistribution; dignity; freedom from ignorance, poverty and disease, malnutrition, and economic frustration; and greater human respect founded on the belief in individual human rights. As Kenyatta had said, these were obstacles to an improved standard of living for all. They were thus to be attacked fiercely. They were and have been with measured success.

Unfortunately, what has been fiercely and consistently attacked, since independence, without a shadow of uncertainty are state coffers and commons such as game parks, wildlife especially elephants and rhinos, land, both public and private and forests. This has rather prominently featured the small class of the political elite and their cronies. It has involved a great deal of undisciplined and unhinged greed. This is true of all the three different regimes after independence. Long forgotten is the sense of individual and collective discipline with thoughts of duty and morality of which Kenyatta spoke.

Mutual reciprocity, collective destiny and agency through participation in government, commerce and industry in the spirit of harambee have been dislocated. This spirit has been replaced by primitive capitalism of the educated and political elite. It involves individualistic grabbing of wealth by the powerful. The poor and powerless in postcolonial Kenya have not enjoyed the quality of human rights which is the enclosed or exclusive preserve of the wealthy. ${ }^{18}$ The dancing and celebration that accompanied independence was enjoyed by those at the top of

\footnotetext{
${ }^{17}$ Mahugu Kiogora to Jomo Kenyatta, “Tutiri Twakena Muthamaki Witu na Twonetio Ganga Mbute,"20 ${ }^{\text {th }}$ September 1964, KNA: KA/6/60.The subject of the letter loosely translates to, Our Beloved Leader, We Are Not Yet Happy: We Are Still Under Violent Attack.

${ }^{18}$ Mugo, Writing and Speaking from the Heart of My Mind, 210.
} 
the wealth pyramid. It is this group that hijacked the fruits of independence at the expense of the greater majority of people in society. Land, employment, the best education and healthcare, civil liberties and civic responsibility became stuck, like the flag at independence. The only difference between the flag on the pole and these fruits of independence, however, being that the latter were not either trapped mid-way or at the bottom, but rather, at the very top. This, it would also seem, was not by ill-design but as a result of sheer elite greed. This, during and after 50 years of independence, is clear to all and sundry. The state belongs to only a clique of people who control its resources. The image and dream of the state for all that inspired protest and sacrifices before and during Mau Mau, has been effectively frustrated since independence. It has been replaced by the attitude of "to each, his own." This is based upon a rigged, unjust system with its headwaters in the criminal foundations of the colonial state.

\section{Kenya in the Making: An Amorphous Postcolonial State}

It would seem that the pathological colonial ethos transfigured the national psyche. The image of the state that Kenyatta strove to painstakingly draw is forever elusive. Different sections of society are no longer committed to a common destiny. They have, instead, turned against each other. This has been especially the case between different ethnic groups, more so on the touchy issue of land. Striving for an improved standard of life is now seen through the narrow prism of professions, trades and group interests. Individualized greed as an attitude has infected ordinary people. ${ }^{19}$ The independence dream of all for one and one for all has been effectively shunted aside. There is a prevalent outlook of life that emphasizes the idea of everyone unto his own. Whole sections of society have been effectively atomized, especially in the Moi-years and the tumultuous 1990s. Different ethnic groups, teachers, doctors, nurses, lawyers, architects, university professors and students, hawkers, matatu crews etc. who yearn for the same thing, basic human rights defined by quality of life, do not see eye to eye on this bread and butter issue.

It is, however, quite clear that there are two distinct ideologies competing for prominence in the construction of the Kenyan state. On the one hand is the elite ideology of law and order.

\footnotetext{
${ }^{19}$ This has given rise to a system crafted by criminal minds. This unbridled individualism is captured by the angry song "System ya Majambazi" (system of pirates and robbers) by the group Mashifta. In the song, the group indicts society for wanton greed. The lyrics are rather unnerving because the attitude is that since the system is broken, ghetto youth like Mashifta are also majambazi.
} 
On the other, is the counter-ideology of the state as conceived and perpetrated by the elite. The former aims at preserving and maintaining the order inaugurated by the British colonial state. It is this "order" based, as it was, on the strength of the illegality of legality especially appertaining to land that was in dispute during the Mau Mau 1950s. The Mau Mau war was a seminal moment in which the Kenyan state was in the throes of formation. The war and the British counterinsurgency, supported by a section of loyal Kikuyu, was an exercise in state-building. ${ }^{20}$ The Mau Mau war was and continues to epitomize the quest for popular statehood. It was a serious attempt to reconfigure socioeconomic, the political order and power structure although it failed utterly in this regard.

The war, and the politics of these turbulent times, provided an opportunity for a fresh start but it had the exact opposite effect. Indeed, it only served to strengthen the prevailing order although minimal concessions and compromises including independence were made. Suffice it to say, that Kikuyu loyalists and moderate politicians, among them Kenyatta who were amenable to the colonial project, provided the personnel to postcolonial state institutions. ${ }^{21}$ The end result has been a security or surveillance state that is keener on political control and reactionary response to crises as opposed on the provision of public welfare.

To stifle dissent and curb the demand for the restoration and redistribution of land, among other grievances, what the state emphasized, and still does, is the central importance of the respect for and sanctity of property rights. The "small" matter of the grand British colonial "legal" heist involving land and labor was to be forgiven and forgotten. These "christianly" virtues were the foundational themes upon which the future was to be built. There was no need to dwell on the past as that would only stoke fires of revenge and animosity by "looking back on scenes of anguish." "Uhuru” for Kenya had to be joyful, not somber. ${ }^{22}$ It also reminded people that the fruits of independence were there for as long as one had the strength to seek them through hard work. ${ }^{23}$ That is what "uhuru na kazi" meant. This message was tailored specifically to deal the high expectations for land restoration and redistribution. Land in post independent

\footnotetext{
${ }^{20}$ Daniel Branch, Defeating Mau Mau, Creating Kenya: Counterinsurgency, Civil War and Decolonization (Cambridge: Cambridge University Press, 2009), 218.

21 Ibid.

${ }^{22}$ Kenyatta, Suffering Without Bitterness, xv.

${ }^{23}$ Ibid., 245.
} 
Kenya was to be paid for through the fruits of hard work and bought by aspiring African land owners. Nothing was free. Formidable challenges that faced the country, such as nation-building, unemployment, land hunger, malnutrition and economic frustration could be cured through hard work.

It is slothfulness, therefore, that was a much greater problem according to this ideology. In the same breath, it argued that colonialism was over and with it, all sense of exploitation. The nation-building project and progress being sought was that of Kenyans by working for themselves. People had no one else to rely upon but themselves. Independence was thus not simply an opportunity but also a challenge. It was never mentioned that colonialism was akin to taking food right out a child's mouth and telling it to work to earn a living. Here it is important to remind the reader that colonial capitalism, and its primitive postcolonial corollary, forever altered and broke-down the relationship between people and food. Needless to say, this was a bitter pill to swallow.

Nevertheless, it has been a consistent political message. While clamping down on the underground movements of the 1980s and the huge wave of opposition in the 1990s, Moi's refrain was the need for a unified nation of "law and order." Kibaki too was fond of reminding people that Kenya was a working nation. This started early during his political term in the highest office in the land. In his address to the nation in June 2003 on the annual celebration of the attainment of self-government, he reiterated that the era of free things was over. Kenyans, therefore, had to work hard together. Whoever did not want to work hard and wanted free things had to surely want to leave the country. Hard work was necessary to repair the institutions, revamp the economy, mend the constitution and fend for one's family. ${ }^{24}$

All this time, nonetheless, there has been mute silence on the authors of law and order regarding the selfish and wanton acquisitiveness of the educated and political elite; primitive capitalism and the inherent moral depravity of grand corruption; the government's glaring unresponsiveness and the unrepresentative nature of the political system; and the centralizing control of the state, especially with regard to development. Indeed, these identifiers stand out as

\footnotetext{
${ }^{24}$ Branch, Defeating Mau Mau, 219.
} 
the insignia on the shoulder board of the elite who command and control state institutions and patrol the hallways of power.

The counter-ideology of official state-building by the elite has, before and since independence, been espoused by various critical publics. These various groups that have formed the subject of this research constitute the anti-colonial and anti-state ideological legacy of the Mau Mau struggle. They are spurred by the desire to acquire individual and group agency and, thereby, be in control or their own destiny and resources; they desire people-driven and centered development and equity and equality; economic democracy and empowerment; basic human rights such as decent housing, clean water, quality education and healthcare among other social services; and freedom from hunger and malnutrition.

For most Kenyans, these are signifiers of progress, civic responsibility and civil liberty: real "uhuru." These represent a genealogy of grievance that reaches back to the dawn of colonialism when the majority of the population in Kenya was permanently dispossessed. This, therefore, can be said to represent a generational struggle and discontent with deep historical roots in structural injustice propagated under colonialism and maintained long after independence. If only one listens carefully, there has always been, in Kenya, this soft but stern voice of public opinion. ${ }^{25}$ This is what the task of this study has been. To peer into and enter the everyday experiences of ordinary people and, by so doing, truly step inside, and authoritatively capture, their untold and painful experiential anxieties and everyday frustrations. These stern voices of dissent are heard throughout the country's past.

At the genesis of Kenya as a colonial project over 100 years ago, the ancestors of political dissent did not fully understood the state or harbor a lot of sympathy for the idle poor. But they knew the difference between fertile self-mastery in leaders and barren greed; they had a keen regard for the personal autonomies which, under the law, give citizenship a chance of selfmastery. ${ }^{26}$ In the absence of self-mastery measured by the production and delivery of signifiers of progress, civic responsibility and civil liberty by the state, people did not and will not render to it loyalty, obedience or recognize it as legitimate. Rather, various critical publics will

\footnotetext{
${ }^{25}$ Bruce Berman and John Lonsdale, Unhappy Valley: Conflict in Kenya \& Africa (James Currey: Oxford, 1992), 467. ${ }^{26}$ Ibid., 468.
} 
continue, as they have in the past, to couch their demands in a language that "demands an argued accountability of power that the ideology of order will not accept."27

Whatever form of organization this spirit of discontent has taken over the years, it has always been criminalized by the ideology of law and order. These competing ideologies have resulted in an amorphous and an unstable postcolonial state "peacefully" sustained only by the investment of force. The postcolonial state, not unlike the British colonial state, is founded on violence to institute "order" and impose ruling institutions from above. As such, it has had to rely on various security apparatuses for continued stability. This unabated historical continuity is evidenced by the prominence of violence in Kenya's long century. ${ }^{28}$

\section{Statehood? The Security and Surveillance State versus "Stateness"}

Fifty years since independence and more than fifty years before then, attempts at statebuilding have been disastrous. So was the botched up decolonization process that was rigged from the start. ${ }^{29}$ In this sense, the state-weakness and failure is structural and, therefore, wellworked in the nature of the state. In terms of institutionalization, plural democracy, macroeconomics and securitization, it is a distant imitation of the European welfare state. The Kenya is a shell or an eviscerated state lacking in the key and core functions besides "security" like welfare. It is an extractive and extroverted state, which serves the interests of international finance and the national elite respectively. ${ }^{30}$ As a top-bottom structure of control, it exists for these collaborative interests. Mismanagement of the economy and maladministration has severely limited the exactness of the approximation European state model. The result has been state decay and the blighting of the lives of Kenyans. ${ }^{31}$ The only reprieve from implosion over the years has been the development of the state as a surveillance state.

To say that Kenya is a police state is an understatement. As far as statehood goes, its most prominent element of "statehood" is the disproportionate investment of force. Indeed, this

\footnotetext{
${ }^{27}$ Ibid, 467.

${ }^{28}$ John Lonsdale, "Compromised Critics," in Religion and Politics in Kenya: Essays in Honor of a Meddlesome Priest ed. Ben Knighton (New York: Palgrave Macmillan, 2009), 57 \& 58.

${ }^{29}$ Ibid., 58.

30 Jean-Francois Bayart, "Africa in the World: A History of Extraversion," African Affairs 99 (2000): 217-267; Daniel Branch, Kenya: Between Hope and Despair, 1963-2011 (2011), 122; and Daniel Branch and Nicholas Cheeseman, "The Politics of Control in Kenya: Understanding the Bureaucratic-Executive State, 1952-78," Review of African Political Economy 33 (2006), 13-22.

${ }^{31}$ Lonsdale, "Compromised Critics," 58.
} 
has been one of the most enduring legacies of the colonial "conquest state." As a modern state, Kenya has evolved as it was forged through the investment of force. At the onset of British imperialism, the genesis of the modern state was the "pacification" of the territory and its inhabitants through military violence as an enactment and demonstration of power and might. This opened the door for the establishment of the modalities of colonial state surveillance. This included elements such as the physical presence of a small detachment of British forces, an African paramilitary police force and a colonial administrative structure with its associated bureaucratic enactments of control and authority such as the "tribal police."

Since its early inception, therefore, political "order" in Kenya has been buttressed by the material display of force and spatialization of the force monopolized by the state. The outbreak of the Mau Mau war resulted in the strengthening of the military sinew of power. In a moment of the self-doubt when he faced one of his greatest political tests after the assassination of Tom Mboya in 1969, Kenyatta brought out military tanks and ordered the flying of the Kenya Air Force jets as a further demonstration of force and control. What emerged was a surveillance state that reached its zenith in the Moi regime, especially in the 1980s and 1990s. Throughout Kenya's history, pass-by marches by various military, police and paramilitary forces and air force fly-bys during national holidays have been center-stage. This martial celebration of Kenya is an exaggeration of this aspect of statehood. This exercise of power, especially by individual politicians and regimes that have abused power; and benefitted from the control of state institutions and resources; spawned corruption, is what has inspired widespread grassroots discontent. The state is the driver of the accumulation process and the most important dispenser of patronage and resources. Control over the state in Kenya has, moreover, become the central preoccupation of politics in Kenya. ${ }^{32}$

Because the spatial and social uneven development was fostered during imperialism, a time during which ethnic inequalities were magnified, ethnic competition and the concomitant ethnic conflict has become the most important mode of political contestation in the postcolonial period. ${ }^{33}$ This is what has, at the level of ethnic affiliation, diminished and atomized grassroots discontent. National politics and competition for public goods is configured along ethnic lines,

\footnotetext{
${ }^{32}$ Roger Southall, "Reforming the State? Kleptocracy \& the Political Transition in Kenya," Review of the African Economy 26 (1999): 93.

${ }^{33}$ Ibid., 93-94.
} 
thus dissipating whatever inherent appeal the counter-ideology of popular statehood might have. As a result, people of different ethnic groups, although equally dispossessed and excluded from the power and socioeconomic privilege, do not see eye to eye. So much so that there is a prevalent political anecdote that it is better for one to be devoured by a familiar ethnic hyena s/he knows than by another hyena from another ethnic group. Public awareness of common or crosscutting predicaments, especially with regard to land hunger and shared limitations with regard to self-mastery have, habitually, been drowned and deterred by "high-political resort to the auction room of tribalism." 34 Instead of singular focus on the overdue resolution of historical injustices especially those that regard land, the political elite recalibrate this central issue sitting at the top of the politics of bread and butter in terms of "them" against "us." An analysis of Kenyan politics that focuses on, and stops at, ethnic conflict for this reason, must, therefore, be rather shallow and misleading. Without a doubt, it is as shallow and misleading like the colonial, and indeed many scholarly explanations of Mau Mau that saw minority manipulation of mass opinion rather than a dynamic process. ${ }^{35}$

At another level, various critical publics, although imbued by the same spirit of Mau Mau struggle for improved standards of life, do not work in concert to press the state. Critical publics such as teachers, university professors, doctors and nurses including even more radical and defiant Mau Mau minds such as Mungiki and the SLDF, have argued the same issues but "with different metaphors." 36 They have been, for that reason, successfully contained by the securitysurveillance state while the radical and more violent manifestations of Mau Mau minds have been violently crushed through state force. All this has served to further masculinize the securitized nature of the postcolonial state. This has been at the expense of the real and deep nature of Kenya's politics of "stateness."

\footnotetext{
${ }^{34}$ Berman and Lonsdale, Unhappy Valley, 468. This recalibration of the deep politics of bread and butter to ethnicized politics has come at the high price of intermittent violent ethnic conflict and bloodshed especially since the early 1990s (as discussed in chapter six). It has fostered divisiveness and weakened nation-building with regard to integration of various ethnic group components that constitute the Kenyan population.

${ }^{35}$ Berman and Lonsdale, Unhappy Valley, 466. I have argued, in chapter seven, within the context of recurrent ethnic violence around election cycles especially in the 1990s, that ethnic conflict is but a symptom of a much deeper structural violence rooted in unresolved historical problems and criminal injustices that stem from the colonial era.

${ }^{36}$ Berman and Lonsdale, Unhappy Valley, 468.
} 
"Stateness" here implies looking beyond the basic and traditional elements of statehood. It suggests the urgent need to qualify institutional entities we call states on the basis of territoriality, possession of monopoly of force, population and government. In its place, especially in the case of Kenya among many other imperial colonies around the world, functional and citizen sensitive and responsible statehood is crucial. That is "stateness" in the modern sense, which emphasizes the capacity and ability of the state to fulfil its expected roles with regard to its internal population besides security and "order" that preserves a flawed status quo. While the Kenyan state has relatively fulfilled roles such as controlling its borders and territory and providing basic security, it has bumbled in as far as the promotion of general welfare and social services. ${ }^{37}$

In the Kenyan case, moreover, law reform is one of the most significant aspects of stateness. It is a political imperative to address colonial historical injustice with regard to the allimportant land question. Indeed, the politics of land in Kenya is perhaps the most fundamental aspect of constitutional order and state character. This is because land policy and illegal legality was at the center of the colonial state-building project that remains more or less intact. British colonial land laws were critical to the role of the state in defining property rights. By extension, they were decisive in shaping the locus and character of political authority in modern Africa. The successes and limitations of the nation-building project must begin and end with respect to them.

In this sense, reforming the rules of land tenure means redefining and reconfiguring relationships between and within communities, and between communities and the state. ${ }^{38}$ The reconstitution of land policy and overhaul of existing land tenure legislation is at the core of the debate around the nature of citizenship; political mobilization; and the future. ${ }^{39}$ Fixing systems of power, property and law in Africa, and Kenya in particular, lies at the heart of restoration of the relationship between people and food. After all, Africa's "food problem" is not one of food production, which should necessitate increasing it. Rather, it is one of guaranteeing access to food, resources and/or the distribution of output. ${ }^{40}$ Indeed, reinstitution of land is key to the

\footnotetext{
${ }^{37}$ Brennan M. Kraxberger, "The United States and Africa: Shifting Geopolitics in an 'Age of Terror," Africa Today 52 (2005): 51.

${ }^{38}$ Catherine Boone, "Property and Constitutional Order: Land Tenure Reform and the Future of the African State," African Affairs 106 (2007): 558 \& 560.

${ }^{39}$ Ibid., 558.

${ }^{40}$ Ray Bush, "The Politics of Food and Starvation," Review of African Political Economy 23 (1996): 170.
} 
reestablishment of individual and group agency. This is true meaning of "uhuru": substantive freedom constituting and defined by the quality of life.

The primacy of land among other resources cannot be underestimated in as far as it defines competent living, securing efficacious livelihood and giving people a voice. According to leading scholars of personality and social psychology, and subjective well-being (SWB) in particular, societal resources at people's disposal allow them to make progress in achieving their goals and enable them to lead a life of satisfaction and affective well-being. ${ }^{41}$ In this emergent field that studies people's cognitive and affective evaluations of their lives, it is suggested that income and human rights correlate with SWB because they affect the ability of individuals and communities to achieve diverse goals. ${ }^{42}$ As such, control of land, among other vital natural, human and financial assets, is, indeed, at the center of basic human rights and dignity.

\section{Popular Statehood: Human Rights, Dignity and Decency}

At the core of the quest for popular statehood and politics in Kenya has been the desire for competent living or self-sufficiency that allows for self-mastery in the sense of forging individual and communal destinies. That is agency as defined by competence and having a voice. ${ }^{43}$ Since early colonial days, besides the ownership and management of various rural assets such as land and livestock, people have always wanted an active, felt and visible presence in the formal and free market system that is the epitome of modernity. They have wanted and demanded fairness of access in this regard, which is what caused the terrors of Mau Mau in the 1950s. This is an attitude that goes beyond the cultural argument pertaining to reciprocity within society and between the rich and the poor in particular. It goes beyond the argument about how greedy or socially ir/responsible the wealthy are or how lazy or worthy the poor are. It is about the raising of voices to counter the latter rhetoric of the ideology of order and working nation intended to shore up the status quo. Indeed, it is this status quo that they seek to dismantle and reorder or restructure the social order. ${ }^{44}$

\footnotetext{
${ }^{41}$ Ed Diener, et. al., "Factors Predicting the Subjective Well-Being of Nations," Journal of Personality and Social Psychology 69 (1995): 851.

42 Ibid.

${ }^{43}$ Mary Ann Brocklesby, et. al., "Raising Voice -Securing a Livelihood: The Role of Diverse Voices in Developing Secure Livelihoods in Pastoral Areas in Ethiopia," Institute of Development Studies Working Paper 2010 (2010): 3.

${ }^{44}$ Angelique Haugerud, The Culture of Politics in Modern Kenya (Cambridge: Cambridge University Press, 1995), $10 \& 11$.
} 
Competent living means agency defined by connections between the rural and urban areas and mobility of individuals between them; and visibility and audibility in action and decision-making especially affecting people's everyday lives. ${ }^{45}$ Further, it means having diverse income sources, access to paid employment in urban and rural areas and access to group financial insurance. What this all comes down to is the fulfilment of basic human rights and human dignity defined in terms of having a bulwark against hard times based on relative but sustainable wealth for everyday sustenance. ${ }^{46}$ This is an idea of development and freedom that goes beyond ideas of social, economic and political capital to embrace Amartya Sen's notion of capability and agency. ${ }^{47}$ In this sense, real "uhuru" meant, and means, enabling development that ensures that children are well-brought up and educated in proper schools and good health. ${ }^{48}$ Studies have proven that the SWB of nations correlate with income, rights, and the degree to which basic needs are fulfilled for the majority of citizens. ${ }^{49}$ Income allows people to achieve their material goals whereas rights and equality mean that a greater percentage of citizens have freedom and opportunity to pursue a wide range of goals. ${ }^{50}$ In this sense, the Mau Mau war was waged as a section of the Kikuyu sought and demanded ownership and management of land, livestock, an active, felt, visible and appreciated presence in the formal and free cash-crops market and a place in the colonially inaugurated modernity.

The Mau Mau rebellion was not waged, as the settlers and the colonial government believed, because of the inability of the Kikuyu's to adapt to the demands of modernization. ${ }^{51}$ Rather, it was a protest against an unequal hierarchical and racial distribution of the benefits of the accruing goodies of modernization. This study has attempted to demonstrate that freedom fighters were against colonial modernity's concomitant dispossession and racial exclusion. They hoped to rectify and reconfigure the socioeconomic structure and relations of power (see chapters two, three and four). Furthermore, in as much as the pre-European village life and social

\footnotetext{
${ }^{45}$ Brocklesby, "Raising Voice -Securing a Livelihood," 3 \& 26.

46 Ibid.

${ }^{47}$ Ibid.

48 Ibid.

49 Diener, "Subjective Well-Being of Nations," 863.

${ }^{50}$ Ibid.

${ }^{51}$ Charles Hornsby, Kenya: A History Since Independence (London: I.B. Tauris, 2012), 46.
} 
fabric had been disrupted and ruptured, the war was not waged to bring back this "Edenic" era of Africa.

It bespoke, instead, resentment towards the state because of its restrictions and constraints with regard to accumulation and diversification of rural and urban socioeconomic activities including the disposal of individual and group labor. ${ }^{52}$ This, then, is how Mau Mau minds in Kenya's long history spanning over a century ought to be understood. Critical publics in the nation's anti-colonial struggle; the populist dissidents of Kenyatta's policies in the 1960s and the underground movements; the muffled voices of the 1990s; and the whole range of resistance voices of the 2000s are all a part of Kenya's long oppositional history of dissent and struggles for voice, competent living, over rural assets and especially land, political rights, individual and communal self-mastery, political authority and ideology. ${ }^{53}$ These myriad voices of protest from below in history, at present and in the future, are all a call for an end to the injustice of dispossession and exclusionism. They demand the basic material security and substantive uplift, daily amenities and efficiencies availed by modernity including tapped clean water, three square meals, decent housing, good education, health and roads, electricity and civil liberties and civic responsibility. Put differently, their place in time.

In this respect, the few listed markers of modernity signify and herald the golden hour of arrival. In Kenya, as elsewhere in the majority of places in the world, it is an arrival that is long belated. Furthermore, it is an arrival that remains an elusive quest for relative prosperity and progress in Kenya and Africa in general. The under-privileged in society are not asking to be wealthy, for egalitarianism or strict economic equality. They agitate and criticize the state in the hope that it acts as the great equalizer between those who are born into privilege, and who probably work hard too, and those who are born into situations that beleaguer all attempts at selfimprovement. Political agitation is for the provision of the appropriate opportunities for material uplift to break from the vicious cycle of generational poverty. Theirs is a basic human rights demand cast in light of very real and historical injustices felt every waking day appropriately held against the state and, by extension, the international financial regime. It is a demand for the

\footnotetext{
${ }^{52}$ Haugerud, The Culture of Politics in Modern Kenya, 11.

${ }^{53}$ Ibid., 18.
} 
state and, by extension, the international financial grid, to reconcile the interests and the dignity of each individual with the interests and dignity of everyone. ${ }^{54}$

It is a call that flies in the face of the official ideology of order that only emphasizes work and duty. In this regard, it fits quite tidily with various international human rights texts and the United Nationals Declaration of Human Rights (UNDHR). Chapter 29 (1) of the UDHR notes that "everyone has duties to the community in which alone the free and full development of his personality is possible." 55 But then it also observes in Article 25 (1) that everyone has the right to a standard of living adequate for the health and well-being of himself and of his family, including food, clothing, housing and medical care and necessary social services, and the right to security in the event of unemployment, sickness, disability, widowhood, old age or other lack of livelihood in circumstances beyond his control. ${ }^{56}$ The Bill of Rights has always been an integral part of the Kenyan state and is adequately provided for in the constitution.

It is enshrined in Chapter 4 Sections 19 (2) and (3), which recognize that the importance of protecting human rights and fundamental freedoms is to preserve the dignity of individuals and communities and to promote social justice and the realization of the potential of all human beings. ${ }^{57}$ These economic and social rights are further elaborated in Article 43 of the constitution. They include the right to the highest attainable standard of health, which includes the right to health care services; accessible and adequate housing and to reasonable standards of sanitation; freedom from hunger and to have adequate food of acceptable quality clean and safe water; and to education. ${ }^{58}$ Since the state commits itself to the solemn and fundamental duty of observing, respecting, protecting, promoting and fulfilling the rights and fundamental freedom guaranteed under Article 43, it is paramount that it is seen to do so especially with regard to righting glaring historical injustices. One of the most significant objectives of this study has been to demonstrate that the unresolved issue of land politics is fundamental to constitutional order and the character of the Kenyan state. It is heartening that one of the fundamental themes of the

\footnotetext{
${ }^{54}$ Christopher McCrudden, "Human Dignity and Judicial Interpretation of Human Rights," The European Journal of International Law 19 (2008): 660.

${ }^{55}$ United Nations, The Universal Declaration of Human Rights, Article 29.

${ }^{56}$ Ibid., Article 25 (1).

${ }^{57}$ Republic of Kenya, Kenya Gazette Supplement: The Constitution of Kenya, 2010 (Nairobi: Government Printer, 2010), 20.

${ }^{58}$ Ibid., 32.
} 
country's 2010 constitution is justice. ${ }^{59}$ In the process of making this constitution for the better part of the first decade of the $21^{\text {st }}$ Century, the Constitution of Kenya Review Commission (CKRC) heard from people many stories of injustice dating back to a century and a half. ${ }^{60}$ These are individual and communal narratives involving land theft and that of other property, communal violence politically motivated killing and displacement of people, torture, discrimination against, and exclusion of minorities, and a perverted political and legal system under which impunity flourished. ${ }^{61}$ Such micro-narratives have been at the core of this study and constitute the mentalité of struggle.

\section{Epilogue -Remedying the Illegality of Colonial Legality: A Very Tall Order}

In talking to the CKRC, people expressed the desire to have a constitution to redress past and continuing injustices. But Kenya inherited a colonial legacy that created differentiation and conflict of interests among its people as a matter of policy. It is a legacy that led to the uneven development of regions and communities. The postcolonial Kenyan state is still heavily reliant upon the instruments of coercion and primitive accumulation. ${ }^{62}$ It is, therefore, a state that still does not recognize the intrinsic worth of the individual. Indeed, individuals and communities exist for the state and the privileged few who control its apparatus. Yet, the opposite, the state being seen to exist for the sake of individuals is the desired ideal. ${ }^{63}$ This is because even after the country's independence in 1963, and since, the colonial surveillance state was not transformed in its essence. It continued to dominate society and rely on coercion. ${ }^{64}$

According to Ghai what this means is that in Kenya's postcolonial history there has been no need to practice democracy or respect for human rights. The principal role of the state has been the accumulation of wealth, which has continued unabated, only having taken crude and personalized forms after independence. "With universal franchise came not genuine democracy but the ethnicization of politics, accompanied by violence serving to obscure the underlying

\footnotetext{
59 Yash Pal Ghai, "Ethnicity, Nationhood and Pluralism: The 2010 Kenya Constitution," in Ethnicty, Nationhood and Pluralism: Kenyan Perspectives eds. Yash Pal Ghai \& Jill Cottrell Ghai (Ottawa: Global Centre for Pluralism, 2013), 105.

60 Ibid.

61 Ibid.

62 Ibid.

${ }^{63}$ McCrudden, "Human Dignity," 679.

${ }^{64}$ Ghai, "Ethnicity, Nationhood and Pluralism," 87.
} 
process and reality of inequality and powerlessness." ${ }^{\prime 65}$ As such, Ghai notes, the state is closely associated with the politics of eating. This goes beyond the gastronomic implications of Francois-Bayart's Politics of the Belly. It implies a network of relations of patronage and incentives and sanctions that sustain individual greed and cronyism. ${ }^{66}$ In many ways, therefore, the severe physical loss of land, its coterminous pauperization through the coercion of labor and aggregated mental torment inflicted since the inauguration of the colonial state remains a painful wound as fresh today as it was then.

There exists, in the place of the hostile, constraining and oppressive colonial legal and policy architecture, an availing and provident one today. This is an indisputable fact.

Nevertheless, the coterminous values of human dignity and human rights thus enshrined remain a pipe dream for many Kenyans. The majority of them still live with all types of inhuman humiliation and degradation, lack of individual or communal choice with regard to selffulfillment, autonomy or self-realization and the existence of the necessary conditions for everyone to have their essential needs satisfied. ${ }^{67}$ This will continue to cause great resentment among the marginalized who feel alienated from the state targeted at the arrogant privileged who think that the state belongs to them. ${ }^{6}$

Yet there is a silver lining. As built, the constitution serves two critical functions: that of nation building and state building. Questions of justice such as citizenship values, rights and relationships among communities belong to the former while the latter refers to institutions for representation, power sharing, accountability and litigation among other things. ${ }^{69}$ Thus, there is a possibility that justice, the building of national solidarity bound by common values and a commitment to fairness for all might yet triumph. It is true, as Ghai aptly notes, that a constitution in itself cannot guarantee its own effectiveness. It is also true that the new constitutional order was imposed on the recalcitrant ruling elite, which is entrusted with the responsibility for its implementation. There is evidence that under Kenya's fourth president Uhuru Kenyatta, the son of the country's first, and his deputy, William S. Ruto, there are

\footnotetext{
65 Ibid.

${ }^{66}$ Ibid.

${ }^{67}$ McCrudden, "Human Dignity," 686.

${ }^{68}$ Ghai, "Ethnicity, Nationhood and Pluralism," 105.

${ }^{69}$ Ibid.
} 
sections of the elite hell-bent on frustrating the full measure of constitutional implementation. Forces of the old colonial order not only control the state but also key sectors of society through bribery, vast commercial and financial empires, manipulation of ethnicity, intimidation, armed force and more. ${ }^{70}$

But the mentalite of struggle in the crucible of Kenya's colonial and postcolonial experience has produced a spirit that never sleeps. It is the unyielding Mau Mau spirit that says "bado mapambano" (the struggle is still on). It is a Mau Mau mind that forever points to openings and opportunities for the people to bring about change through participation, petitions, sensible use of the vote, contesting for public offices, recourse to courts and solidarity. ${ }^{71}$ Although it is no place for the historian to make predictions, on the strength of historical hindsight, the people by wielding this document will, eventually, emerge triumphant in this battle and struggle for the good life in Kenya.

With that said, it is crucial to point out that every single soul in Kenya is locked in a intricate, mutual and an eternal dance of life. It is certainly not a dirge. State House, Nairobi is where the dance is; going down River Road, one witnesses that the dance is also there in the streets of the capital; on the lush green former white highlands in the great Rift Valley and Central Kenya is where the dance is; on the old beaches of the coast is where the dance is; on the shores of Lake Nam Lolwe and beyond is where the dance is; on the slopes of Mr. Elgon, the Aberdare Ranges and Mt. Kenya is where the dance is; it is also in the oil and water rich land around Lk. Turkana; and it is the same dance is in the semi-arid region of the north eastern part of the country. This is the mournful-sweet dance of the forgotten voices in Kenya's ruefully long century. Distinct are the drum beats of the Mau Mau war as it sits in the middle of the country's historical trajectory. It a dance filled with the bitter-sweet sounding drums that remind all, that care to listen, of the wide open field of unfulfilled dreams of an all-inclusive state. It is a lockstep dance. This is the dance of mutual reciprocity. It is a dance about how life ties people up in knots

${ }^{70}$ Ibid., 106.

71 Ibid. 
and about the dream of untying an intricate knot together. In so doing, their touch is gentle, humorous; and the ends of the knotted strings are always left mysteriously loose. ${ }^{72}$

\section{BIBLIOGRAPHY}

\section{Primary Sources}

\section{Archival Sources}

Kenya National Archives

KA/6/14 Complaints and Petitions to the President.

KA/6/32 Complaints and Petitions.

KA/6/33 Complaints and Petitions to the Prime Minister, Western Region.

KA/6/48 Complaints and Petitions to the Prime Minister, Central Province.

KA/6/59 Complaints and Petitions to the Prime Minister, Central Region.

KA/6/60 Complaints and Petitions.

KEN/34/1 Press Extracts.

MAC/KEN/33/4 African Elected Members Correspondence

DC/MKS 10B/13/1 District Report: Machakos

DC/MRU/1/4/5 District Report: Meru

MAA/8/106 Mumenyereri.

MSS/35/7 Correpondence Between James Beauttah and Others, 1966-1967.

MSS/35/9 James Beauttah: Loose Papers

\footnotetext{
72 This imagery of the knot and the dance is borrowed from the brilliant race relations researcher and expert, and novelist from Sri Lanka, Ambalavaner Sivanandan, Where the Dance Is (London: Arcadia Books, 2000).
} 
MSS/43/6 Kikuyu Highlands Squatters, Land Lords Association Correspondences, 1947-1952.

MSS/43/11 Undated Correspondence.

MSS/115/7/36 A Comment on the Official Records of Kenya (Archives) by M.P.K. Sorrenson.

MSS/129/26 Rehabilitation of Social Problems of Mau Mau History, 1953-1964.

VQ/16/5 Intelligence Reports.

British National Archives

CO533/115 Colonial Office: Kenya Original Correspondence

CO 533/154 Colonial Office: Kenya Original Correspondence

CO 533/193 Colonial Office: Kenya Original Correspondence

CO 533/422/1 Colonial Office: Kenya Original Correspondence. Johnstone Kenyatta: memorandum on grievances of Kikuyu Central Association.

CO 533/543/2 Colonial Office: Kenya Original Correspondence. Petitions and Memorials: Kikuyu People (1945-1947)

CO 533/543/4 Colonial Office: Kenya Original Correspondence. Petitions and Memorials: Kikuyu People.

CO 533/543/6 Colonial Office: Kenya Original Correspondence. Petitions: Kikuyu Central Association Kikuyu Grievances.

CO 822/448 Colonial Office: East Africa: Original Correspondence. External repercussions of the Mau Mau situation in Kenya.

CO 822/458 Colonial Office: East Africa: Original Correspondence. Memorandum by Colin Legum of the "Observer" newspaper about the background to Mau Mau.

C0 892/6/1 Colonial Office: East Africa Royal Commission (Dow Commission):

Correspondence and Papers. Kenya. Memoranda from the public: African claims to specific areas of land.

DO 226/13 Dominions Office: High Commission and Consular Archives, Kenya: Internal Affairs.

DO 226/14 Dominions Office: High Commission and Consular Archives, Kenya: National Assembly of Kenya. 
DO 226/15 Dominions Office: High Commission and Consular Archives, Kenya: Internal political affairs in Kenya.

FCO 31/1510 Foreign and Commonwealth Office: East Africa Department: KENYA. Activities of Lonrho Ltd in Kenya

FCO 31/1637 Foreign and Commonwealth Office: East Africa Department: Visit of Joan Lester, UK Parliamentary Under Secretary of State for Foreign and Commonwealth Affairs, to Kenya and Zambia, 23-30 May 1974

FCO 31/1886 Foreign and Commonwealth Office: East Africa Department: Registered Files (P and JE Series). Kenya: annual review for 1974

FCO 31/2020 Foreign and Commonwealth Office: KENYA. Kenya: annual review for 1975

FCO 31/2330 Foreign and Commonwealth Office: East Africa Department: KENYA. Soviet subversion in Kenya

FCO 31/2557 Foreign and Commonwealth Office: East Africa Department: KENYA. Internal situation in Kenya

FCO 31/2559 Foreign and Commonwealth Office: East Africa Department: Registered Files (P and JE Series). KENYA. Kenya: form-at-a-glance

FCO 31/2832 Foreign and Commonwealth Office: East Africa Department: KENYA. Official visits from the UK to Kenya

FCO 31/2838 Foreign and Commonwealth Office: East Africa Department: KENYA. Economy of Kenya

FCO 141/5523 Foreign and Commonwealth Office and predecessors: Records of Former Colonial Administrations: Kenya: minutes of Executive Council meetings held at Government House, 1943

FCO 141/5528 Foreign and Commonwealth Office and predecessors: Records of Former Colonial Administrations: Kenya: minutes of Executive Council meetings held at Government House, 1948.

FCO 141/6836 Foreign and Commonwealth Office: Records of Former Colonial Administrations: Migrated Archives. KENYA. Kenya: future of the Coastal Strip (Kenya Protectorate); report of the Commissioner, James Wilson Robertson

FCO 141/7114 Foreign and Commonwealth Office and predecessors: Records of Former Colonial Administrations: Migrated Archives. KENYA. Kenya Land Freedom Army

\section{Books}


Gichaga, Francis, J. Surviving the Academic Arena: My Complex Journey to the Apex (Nairobi: University of Nairobi Press, 2011).

Hempstone, Smith. Rogue Ambassador: An African Memoir (Sewanee: University of the South Press, 1997).

Kariuki, Josiah M. “Mau Mau” Detainee (Oxford: Oxford University Press, 1963).

Kipkorir, Benjamin E. Descent from Cherang'any Hills: Memoirs of a Reluctant Academic (Nairobi: Macmillan Kenya, 2009).

Odinga, A.Oginga. Not Yet Uhuru: The Autobiography of Oginga Odinga (London, Heinemann, 1967).

Thiong'o, Ngugi. Dreams in a Time of War (New York: Pantheon Books, 2010).

\section{Government Publications}

\section{COLONY AND PROTECTORATE OF KENYA}

Carothers, John C. The Psychology of Mau Mau (Nairobi: Government Printer, 1954).

Corfield, Frank, D. The Origins and Growth of Mau Mau, Sessional Paper No. 5 (Nairobi:

Government Printer, 1959-60)

Legislative Council Debates XLI (1951).

Legislative Council Debates XLII (1951).

Legislative Council Debates LXI (1951).

Legislative Council Debates LXII (1958).

REPUBLIC OF KENYA

Kenya Gazette Supplement: The Constitution of Kenya, 2010 (Nairobi: Government Printer, 2010).

Report of the Judicial Commission Appointed to Inquire into Tribal Clashes in Kenya (Nairobi: Government Printer, July 1999).

GREAT BRITAIN

Parliamentary Debates (Commons) $5^{\text {th }}$ Series 509 (1952);

\section{SECONDARY SOURCES}

\section{Unpublished Material}

Brocklesby, M. A. et. al., "Raising Voice -Securing a Livelihood: The Role of Diverse Voices in Developing Secure Livelihoods in Pastoral Areas in Ethiopia," Institute of Development Studies Working Paper 2010 (2010). 
Hood, Andrew J. "Developing the East African: The East Africa Royal Commission, 1953-1955, and its Critics" (Ph.D. dissertation, Rice University, 1997).

Karanja, Andrew M. and Nyoro, James K. "Coffee Prices and Regulation and Their Impact on Livelihoods of Rural Community in Kenya," (Tegemeo Institute of Agricultural Policy and Development, Egerton University, October 2002)

Kirubi, Gichuhi M. "Turmoil in a University: An Analytical Study of the Conflicts, Confrontations and Strikes in the University of Nairobi and Kenyatta University College in the Republic of Kenya, 1960-1978," (PhD dissertation, Ohio University, 1983).

Llyod, Thomas. University of Endinburgh, "Making 'Mau Mau': Remaking Kikuyus; Remaking Kenya?" Paper Presented at the Researching the Colonial and Postcolonial Workshop, nd.

Ogendo, H.W.Okoth. "The Political Economy of Land Law -An Essay in the Legal Organization of Underdevelopment in Kenya, 1895-1974," Ph.D Dissertation, Law School, Yale University (1978),

Raggio, Osvaldo."From the Natives' Point of View: Microhistory, Local Politics, and the State," Paper presented at Clark Library Conference (Los Angeles, 1997).

Robson, James S. 'Ngugi wa Thiong'o's Fight Against Colonialism and Neo-colonialism: An Exploration of the Theme of Betrayal," Master of Arts Thesis, Department of English, Simon Fraser University (December 1987).

Walker, Sidney J. "The African Writer and Social Change: A Case Study of Ngugi wa Thiong'o," Ph.D Dissertation, Howard University (1984).

\section{Published}

\section{Books}

Anderson, David. Histories of the Hanged: Britain's Dirty war in Kenya and the End of Empire (London: Phoenix, 2005).

Anderson, Fred. Crucible of War: The Seven Years' War and the Fate of Empire in British North America, 1754-1766 (New York: Vintage, 2000).

Bayart, Jean- François. Ellis S. and Hibou, B. (trans. Stephen Ellis) The Criminalization of the State in Africa (Bloomington: Indiana University Press, 1999).

Bayart, Jean- François. The State in Africa: The Politics of the Belly (Cambridge: Polity Press, 2009).

Benson, T.G. Kikuyu-English Dictionary (Oxford: Clarendon Press, 1964).

Berman, Bruce. Control and Crisis in Colonial Kenya: The Dialectic of Domination (London: James Currey, 1990). 
Berman, Bruce and Lonsdale, John. Unhappy Valley: Conflict in Kenya \& Africa (James Currey: Oxford, 1992).

Bolton, Gile. Africa Doesn't Matter: How the West has Failed the Poorest Continent and what we Can Do About It (New York: Arcade, 2007).

Branch, Daniel. Defeating Mau Mau, Creating Kenya: Counterinsurgency, Civil War and Decolonization (Cambridge: Cambridge University Press, 2009).

Kenya: Between Hope and Despair, 1963-2011 (Yale: Yale University Press, 2011).

Brewer, John. The Sinews of Power: War, Money and the English State, 1688-1783 (Cambridge: Harvard University Press, 1988).

Brockway, Fenner. Why Mau Mau? An Analysis and Remedy (London: Congress of Peoples Against Imperialism Centre, 1953).

Buijtenhuijs, Robert. Mau Mau Twenty Years After: The Myth and the Survivors (The Hague: Mounton \& Co., 1973).

Bulhan, Hussein A. Frantz Fanon and the Psychology of Oppression (New York: Plenum Press, 1985).

Clough, Marshall S. Fighting Two Sides: Kenyan Chiefs and Politicians, 1918-1940 (Niwot: University Press of Colorado, 1990).

Cohen, David William, and E.S.Atieno Odhiambo. The Risks of Knowledge: Investigations into the Death of the Hon. Minister John Robert Ouko in Kenya, 1990 (Athens: Ohio University Press, 2004).

Committee for the Release of Political Prisoners in Kenya. Repression Intensifies in Kenya Since the August 1st Coup Attempt (London: Rye Express, 1983).

Colley, Linda. Britons: Forging the Nation, 1707-1837 (New Haven and London: Yale University Press, 1992).

Edgerton, Robert B. Mau Mau: An African Crucible (The Free Press, New York, 1989).

Ekiert, Grzegorz. The State Against Society: Political Crises and their Aftermath in East Central Europe (Princeton: Princeton University press, 1996).

Elkins, Caroline. Imperial Reckoning: The Untold story of Britain's Gulag in Kenya (New York: Henry Holt and Co., 2005).

Englebert, Pierre. Africa: Unity, Sovereignty and Sorrow (Boulder: Lynne Rienner Publishers, 2009).

State Legitimacy and Development in Africa (Boulder: Lynne Rienner, 2002).

Fanon, Frantz. The Wretched of the Earth (New York: Grove Press Inc., 1963), 
Furedi, Frank. The Mau Mau War in Perspective (London: James Currey, 1989).

Gardner, Leigh A. Taxing Colonial Africa: The Political Economy of British Imperialism (Oxford: Oxford University Press, 2012), 4.

Gertzel, Cherry. The Politics of Independent Kenya, 1963-8 (Nairobi: East African Publishing House, 1970).

Gifford, Paul. Christianity, Politics and Public Life in Kenya (London, 2009).

Gitari, David. In Season and Out of Season: Sermons to a Nation (Eugene: Wipf and Stock, 1996).

Ginzburg, Carlo. The Cheese and the Worms: The Cosmos of a Sixteenth-Century Miller (Baltimore: Johns Hopkins University Press, 1992).

Gurr, Ted Robert. Why Men Rebel (Princeton: Princeton University Press, 1970).

Hall, Catherine. Civilising Subjects: Colony and Metropole in the English Imagination, 18301867 (Chicago: University of Chicago Press, 2002).

Haugerud, Angelique. The Culture of Politics in Modern Kenya (Cambridge: Cambridge University Press, 1995).

Hodge, Joseph M. The Triumph of the Expert: Agrarian Doctrines of Development and the Legacies of British Colonialism (Athens: Ohio University Press, 2007).

Hornsby, Charles. Kenya: A History Since Independence (London: I.B. Tauris, 2012).

Jackson, Robert H. and Carl G. Rosberg. Personal Rule in Black Africa: Prince, Autocrat, Prophet, Tyrant (Berkeley: University of California Press, 1982).

Kanogo, Tabitha. Squatters and the roots of Mau Mau (Nairobi Heinmann, 1987).

Khan, Yasmine. The Great Partitions: The Making of India and Pakistan (New Haven: Yale University Press, 2007).

Kenyatta, Jomo. Suffering Without Bitterness: The Founding of the Kenya Nation (Nairobi: East African Publishing House, 1968).

Knight, Carl. (ed.) Responsibility and Distributive Justice (Oxford: Oxford University Press, 2011).

Kinyatti, Maina. History of Resistance in Kenya, 1884-2002 (Nairobi: Mau Mau Research Centre, 2008).

Thunder from the Mountains: Mau Mau Patriotic Songs (London: Zed Press, 1980). 
Kurtz, J. Roger. Urban Obsessions, Urban fears: The Postcolonial Kenyan Novel (Trenton: Africa World Press, Inc., 1998).

Legum, Colin. Africa Since Independence (Bloomington: Indiana University Press, 1999).

Leys, Norman. Kenya (London: The Hogarth Press, 1926).

Maloba, Wanyubari O. Mau Mau and Kenya: An Analysis of a Peasant Revolt (Nairobi: East African Educational Publishers, 1993).

Maxon, Robert M. Britain and Kenya's Constitutions, 1950-1960 (Amherst: Cambria Press, 2011).

Kenya's Independence Constitution: Constitution-Making and End of Empire (Lanham: Farleigh Dickinson University Press, 2011).

Struggle for Kenya: The Loss and Reassertion of Imperial Initiative, 1912-1923 (New

Jersey: Fairleigh Dickinson University Press, 1993).

McCulloch, Jock. Colonial Psychiatry and 'the African Mind' (Cambridge: Cambridge University, 1995).

Metcalf, Thomas R. Ideologies of the Raj (New York: Cambridge University Press, 1997).

Miller, Norman. and Rodger Yeager. Kenya: The Quest for Prosperity (Westview Press: Boulder, 1994).

Mugo, Micere G. Writing and Speaking From the Heart of My Mind: Selected Essays and Speeches (New Jersey: Africa World Press , 2012).

Odhiambo, E.S.Atieno. Siasa: Politics and Nationalism in E.A, 1905-1939 (Nairobi: Kenya Literature Bureau, 1981).

Ogot, Bethwell A. and William R. Ochieng. Decolonization \& Independence in Kenya, 1940-93 eds. (London: James Currey, 1995).

Press, Robert M. Peaceful Resistance: Advancing Human Rights and Democratic Freedoms (Burlington: Ashgate, 2006).

Rosberg, Carl and John Nottingham. The Myth of "Mau Mau:" Nationalism in Kenya (New York: Praeger, 1966).

Sabar, Galia. Church State and Society in Kenya: From Mediation to Opposition, 1963-1993 (London: Frank Cass \& Co. Ltd., 2002).

Sen, Amartya. Development as Freedom (New York: Anchor Books, 1999).

Shaw, Lauren. Songs and Social Change in Latin America (Lanham: Lexington, 2013).

Sivanandan, Ambalavaner. Where the Dance Is (London: Arcadia Books, 2000). 
Sorrenson, M.P.K. Origins of European Settlement in Kenya (Oxford: Oxford University Press, 1968).

Spruyt, Hendrik. The Sovereign State and its Competitors (New Jersey: Princeton University Press, 1994).

Stiftung, Friedrich Ebert and Citizens for Justice. We Lived to Tell the Story: The Nyayo House Story (Nairobi: Friedrich Ebert Stiftung) nd.

Stone, Lawrence. An Imperial state at War: Britain From 1689 to 1815 (London \& New York: Routledge, 1994).

Thiong'o, Ngugi. Petals of Blood (Nairobi: Heinemann, 1977).

2009). Something Torn and New: An African Renaissance (New York: Basic Civitas Books, Writers in Politics: A Re-engagement with Issues of Literature and Society (Oxford: James Currey, 1997).

Thompson, Edward P. Customs in Common (Pontypool: The Merlin Press, 1991).

Throup, David W. Economic and Social Origins of Mau Mau (London: James Currey, 1987),

Tilly, Charles. The Formation of National States in Western Europe (Princeton: Princeton University Press, 1975).

Tignor, Robert L. The Colonial Transformation of Kenya: The Kamba, Kikuyu and the Maasai from 1900 to 1939 (Princeton: Princeton University Press, 1976).

Umoja. Moi's Reign of Terror: A Decade of Nyayo Crimes Against the People of Kenya (London: United Movement for Democracy in Kenya, 1989).

Waihenya, Waithaka and Teresia Ndikaru. A Voice Unstilled: Ndingi Mwana'a Nzeki (Nairobi: Longhorn, 2009).

Wrong, Michela. It's Our Turn To Eat: The Story of a Kenyan Whistle-blower (London: Fourth Estate, 2009).

Young, Crawford. The African Colonial State in Comparative Perspective (New Haven: Yale University Press, 1994).

\section{Articles and Chapters}

Akuku, Moses. "Hard Road to Democracy," The Standard, $25^{\text {th }}$ May 1993.

“A Mysterious Death,” Weekly Review, 23 ${ }^{\text {rd }}$ February 1990.

Anderson, David M. "Mau Mau in the High Court and the 'Lost' British Empire Archives: Colonial Conspiracy or Bureaucratic Bungle?" The Journal of Imperial and Commonwealth History 39 (2011), 699-716. 
Amboga, Seth. "What Next After the Alliance," Kenya Times, 14 ${ }^{\text {th }}$ December 1995.

Asens, Jaume and Pisarello, Gerardo. "The Illegality of Power," Blog Article, $17^{\text {th }}$ February 2012.

Austin, Gareth. "The 'Reversal of Fortune' Thesis and the Compression of History: Perspectives from African and Comparative Economic History," Journal of International Development 20 (2008), 996-1027.

Awino, Otieno Ajina A. "Meaning of Democracy Being Misinterpreted," Kenya Times, 18th November 1993 "Meaning of Democracy Being Misinterpreted," Kenya Times, $18^{\text {th }}$ November 1993.

Barnett, Correlli. “The Wasting of Britain's Marshall Aid,” BBC History, (2011).

Bayart, Jean- François. "Africa in the World: A History of Extraversion,” African Affairs 99 (2000).

“Black Magic Spurs African Terrorists,” Detroit News, $1^{\text {st }}$ November 1952.

Boone, Catherine. "Property and Constitutional Order: Land Tenure Reform and the Future of the African State," African Affairs 106 (2007).

Branch, David and Nicholas Cheeseman. "The Politics of Control in Kenya: Understanding the Bureaucratic-Executive State, 1952-78," Review of African Political Economy 33 (2006), 11-31.

Bundotich, John. “Opposition's Self-immolation,” Kenya Times, $12^{\text {th }}$ March 1996.

Bush, Ray. "The Politics of Food and Starvation," Review of African Political Economy 23 (1996), 169-195.

Collier Ruth B. and David Collier. "The African State at the End of the Twentieth Century: Parameters of the Critical Juncture," in The African State at a Critical Juncture: Between Disintegration and Reconfiguration (eds.) Villalon, L.A., and Huxtable, P.A., (London: Lynne Rienner, 1998).

Courrier d'Afrique, $5^{\text {th }}$ November 1952

Cooper, Frederick. "Review Article: Mau Mau and the Discourses of Decolonization," Journal of African History 29 (1988).

Daily Express, 28 ${ }^{\text {th }}$ October 1952.

“Ex-MP Tells of Terror Cult,” Daily Nation Team, 17 $7^{\text {th }}$ November 1997.

“Oath-taking charge: 58 released on Ksh. 50,000 Bond," Daily Nation, $16^{\text {th }}$ February 1995.

“University Staff Walk Out as Unrest Spreads," Daily Nation Team, 6 ${ }^{\text {th }}$ September 2012.

Daina D.N. “Leaders Stifling Our Democracy,” Daily Nation, 23 ${ }^{\text {rd }}$ March 1994. 
Dalton, George. "Traditional Economic Systems," in The African Experience, I (eds.) John N. Paden, and Edward W. Soja, (Northwestern University Press: Evanston, 1970).

Diener, Ed. et. al. "Factors Predicting the Subjective Well-Being of Nations," Journal of Personality and Social Psychology 69 (1995).

Diener, E., et. al. "Wealth and Happiness Across the World: Material Prosperity Predicts Life, Evaluation, Whereas Psychosocial Prosperity Predicts Positive Feeling" Journal of Personality Social Psychology 99 (2010): 52-61.

Dowling, T.J. "What Good Governance Entails," The Economic Review, $4^{\text {th }}-10^{\text {th }}$ October 1993.

Durrani, Shiraz. "The Other Kenya: Underground and Alternative Literature," Collection Building, 16 (1997):

East African Standard, $24^{\text {th }}$ November 1954.

“Native Labour” East African Standard, $8^{\text {th }}$ February 1913.

"Revolutionaries Warned: Kenyatta says 'I will fight again,"” East African Standard, $12^{\text {th }}$ April 1965.

Ghai, Yash P. "Ethnicity, Nationhood and Pluralism: The 2010 Kenya Constitution," in Ethnicty, Nationhood and Pluralism: Kenyan Perspectives (eds.) Yash P. Ghai. and Jill C. Ghai (Ottawa: Global Centre for Pluralism, 2013).

Gitonga, Isaac B. “Change Must Come From Citizens,” Daily Nation, 12 $2^{\text {th }}$ December 1994.

Hooper, Glenn. (ed.) Landscape and Empire, 1770-2000 (Burlington: Ashgate Publishing Company, 2005).

Goldsmith, Paul. "The Mombasa Republican Council -Conflict assessment: Threats and Opportunities for Engagement," (November 2011).

Human Rights Watch. "All the men have gone:' War crimes in Kenya's Mt. Elgon conflict," (New York: Human Rights Watch, 2008).

Human Rights Watch. "Kenya: Army and Rebel Militias Commit War Crimes in Mt. Elgon," Human Rights Watch Portal (April 2008).

"Is this the Hand of Jacob?" West African Pilot, $28^{\text {th }}$ October 1952.

Jenje, Bozo.“Kenya: Secessionist Group On a Mission to Meet the Queen," Daily Nation, 27th February 2012.

Kabando, Kabando. "New Political Thinking a Must," Daily Nation, $7^{\text {th }}$ May 1995.

Kadida, Jillo. "Police Arrest Rowdy Members of Banned Sect," Sunday Nation, $5^{\text {th }}$ October 2003.

Kariuki, Charles M. “Kenyans Need Better Government,” Daily Nation, 5" July 1995. 
"Kenya Terrorists Afflict Africa," Great Falls Tribune, $3^{\text {rd }}$ November 1952.

Kihuria, Njonjo. “Bedan Mbugua Recalls Muge's Last Words," The Star, 14 $4^{\text {th }}$ August 2013.

Kimani, Michael M. “Government Should Heed Counsel,” Daily Nation, 15 ${ }^{\text {th }}$ April 1995.

Kimani, Victor. "Let Us Reason Together," The Nairobi Law Monthly (No. 33, June 1991).

Kimaru, Simmi. "Where the Opposition Has Failed," Daily Nation, 2nd November 1994.

Kinyatti, Maina. "Mau Mau: The Peak of African Nationalism in Kenya," Kenya Historical Review 5, no. 2 (1977).

Knighton, Ben. "Muingiki Madness," Religion and Politics in Kenya: Essays in Honor of a Meddlesome Priest (ed.) Knighton, B., (New York: Palgrave Macmillan, 2009).

Koross, Kibiwott. "History of Teachers' Strikes Since Independence," The Star, $3^{\text {rd }}$ September 2012.

KPMG. "Kenya -Country Profile," (South Africa): 3, nd.

Kraxberger, Brennan M."The United States and Africa: Shifting Geopolitics in an 'Age of Terror,"” Africa Today 52 (2005).

Legum, Colin. "Mau Mau: An Analysis of Problems in Kikuyuland with Some Proposals to Deal with the Situation," The Observer, $20^{\text {th }}$ November 1952.

Lipsedge, Maurice. "Colonial Psychiatry and 'The African Mind,"” BMJ 312 (1996).

Lonsdale John. "Conquest State, 1895-1904," in A Modern History of Kenya, 1895-1980 (ed.) William R. Ochieng' (London: Evan Brothers, 1989).

"Compromised Critics," in Religion and Politics in Kenya: Essays in Honor of a Meddlesome Priest (ed.) Knighton, B., (NewYork: Palgrave, 2009),

"Mau Mau and Nationhood," in Mau Mau and Nationhood: Arms, Authority and Narration (eds.) Atieno E.S. Odhiambo and John Lonsdale (Oxford: James Currey, 2003).

"Mau Maus of the Mind: Making Mau Mau and Remaking Kenya," Journal of African History 31 (1990).

Makanyayiera, Odoyo. “Do Kenyans Need this Alliance?” Daily Nation, 14 ${ }^{\text {th }}$ March 1996.

Masolo, D.A. "Presencing the Past and Remembering the Present: Social Features of Popular Music in Kenya," in Music and the Racial Imagination (ed.) Radano, R.M., \& Bohlman, P.V., (Chicago: University of Chicago Press, 2001).

Maxon, Robert M. "Agriculture," in Themes in Kenyan History (ed.) William R. Ochieng' (James Currey: Ohio University Press, 1990).

Mazrui, Ali and Willy Mutunga "The State vs. The Academic Union in Postcolonial Kenya," Review of African Political Economy 22 (1995). 
McCrudden, Chrsitopher. "Human Dignity and Judicial Interpretation of Human Rights," The European Journal of International Law 19 (2008).

McGrath, Laura, and Paula Reavey and Steven D. Brown. "The Scenes and Spaces of Anxiety: Embodied Expressions of Distress in Public and Private Fora," Emotion, Space and Society 1 (2008).

Mcneil, Donald J. "Romania's Revolution of 1989: An Enduring Enigma," New York Times, $31^{\text {st }}$ December 1999.

Mohamed, Zenudin A. "No Benefit for Multipartyism,” Daily Nation, 30th January 1996.

Muasya, Isaac W. "The Impact of Structural Adjustment Programmes (SAPs) on Education in Kenya," International Journal of Arts and Commerce 1 (2012).

Mungai, J.M. “Opportunists Hijack Pluralism, Sunday Nation, 19 ${ }^{\text {th }}$ September 1993.

Mwai, Peter. “Maelezo Kuhusu Asili ya Mungiki," Taifa Leo, 6th March, 2009.

Mwahani, Abadalla. "What's the Aim of the Alliance?” Daily Nation, $21^{\text {st }}$ March 1996.

Mwenda, Aruyaru S. "From a Dream to a Resounding Reality: The Inception of a Doctors Union in Kenya," Pan African Medical Journal (2012).

Ng'ang'a, Mukaru. "Mau Mau, Loyalists and Politics in Murang'a, 1952-1970," Kenya Historical Review 5, no. 2 (1977).

Nguyo, Harrison N. "Kenyan Society Needs Redemption,” Daily Nation, $19^{\text {th }}$ September 1995.

Njogu, Kimani. "Religious Versification: From Depoliticisation to Repoliticisation," in Songs and Politics in Eastern Africa (ed.) Kimani Njogu and Herve Maupeu (Nairobi: French Institute for Research in Africa, 2007).

Njoya, Timothy. "Pulpit as a Forum for the Restoration of Government," Unbound: An Interactive Journal of Christian Social Justice (1st February 2012).

"Note on Present Situation in Kenya," Life Magazine, $4^{\text {th }}$ November 1952.

Nyakwara, Sylvester W. “Opposition Leaders Must Act Now," Daily Nation," $8^{\text {th }}$ December 1995.

Nyong'o, Anyang. "Struggles for Political Power and Class Contradictions in Kenya," Contemporary Marxism (Fall 1983).

"What 'the Friends of the Peasants' are and How They Pose the Question of the Peasantry," Review of African Political Economy 8 (Spring, 1981).

Ochieng', William R. "Food Production in the Pre-Colonial Period," in Themes in Kenyan History (ed.) William R. Ochieng' (James Currey: Ohio University Press, 1990). 
Odhiambo, E.S.Atieno. "Formative Years, 1945-55," in Decolonization and independence in Kenya, 1940-93 (eds.) Bethwel A. Ogot and William R. Ochieng' (London: James Currey, 1995).

"Inventing Kenya," in Decolonization and Independence in Kenya, 1940-93 (eds.)

William, R. Ochieng' and Bethwell A. Ogot (London: James Currey, 1995).

"The Production of History in Kenya: The Mau Mau Debate," Canadian Journal of African Studies 25, No. 2 (1991).

Ogendo, H.W. Okoth. "The Tragic African Commons: A Century of Expropriation, Suppression and Subversion," University of Nairobi Law Journal 1 (2003).

Ogot, Bethwell A. "Mau Mau and Nationhood: The Untold Story," in Mau Mau and Nationhood: Arms, Authority and Narration (eds.) E.S. Atieno Odhiambo and John Lonsdale (Oxford: James Currey, 2003).

Oraro, J.L.O., “Majimbo Debate,” The Weekly Review, 7 $7^{\text {th }}$ January 1994.

Osewe, Okoth. “240,000 Teachers on Strike," Committee for Workers' International, 3 rd October 2002.

Otieno, Awinda. "Mungiki: Neo-Mau Mau and the Prospects for Democracy in Kenya," Review of African Political Economy 34 (September 2007).

Oyuga, Chrispine. "Polls: Leaders Let Kenyans Down,” Daily Nation, $19^{\text {th }}$ January 1993.

Oyugi,W. “An Obscene Inequality,” Kenya Social Watch Group Website (2000).

Oyugi, Walter et al. "Mired in the Unsolved National Question," Social Watch Website (2008).

Pomerantsev, Peter. "Diary,” London Review of Books 35, 5 th $^{\text {December }} 2013$.

Rajab, Ramadhan. "Lecturers Strike On, UASU Boss Declares," The Star, 6 ${ }^{\text {th }}$ September 2012.

Rono,Joseph K. "The Impact of the Structural Adjustment Programmes on Kenyan Society," Journal of Social Development in Africa 17 (January 2002).

Rosenberg, Aaron."The Literature of Song: Kantai and Wainaina's 'Joka' as Syncretic Multitext," Journal of the African Literature Association 1.2 (Sum/Fall 2007), 108-128.

Schroth, Jörg. "Distributive Justice and Welfarism in Utilitarianism," Inquiry: An Interdisciplinary Journal of Philosophy 51 (2008).

Sen, Amartya. "Equality of What?," in Amartya Sen, Choice, Welfare and Measurement (Cambridge: Cambridge University Press, 1982).

Septuagenarian. "Time for the Young to Wake Up," Daily Nation, $28^{\text {th }}$ December 1993

Southall, Roger. "Reforming the State? Kleptocracy \& the Political Transition in Kenya," Review of the African Economy 26 (1999). 
Speedy Daily, 28 ${ }^{\text {th }}$ October 1952

Stoler, Ann Laura, and Frederick Cooper. "Between Metropole and Colony: Rethinking a Research Agenda," in The tensions of Empire (eds.) Frederick Cooper and Ann Laura Stoler (Berkeley: University of California Press, 1997).

Tenia, Nelson. "Kenya is Sick," The Nairobi Law Monthly (No. 35, August 1991).

The Economist Intelligence Unit Limited, "Country Risk Service Report: $4^{\text {th }}$ Quarter, 1996," (18th December 1996).

The Economist Intelligence Unit Limited, "Country Risk Service Report: 1st Quarter, 1998," (13th February 1998).

The Economist Intelligence Unit Limited, "Country Risk Service Report: 3rd Quarter, 1996," (24th September 1996).

The Economist Intelligence Unit Limited, "Country Risk Service Report: 3rd Quarter, 1997," (20th August 1997).

The Observer, $26^{\text {th }}$ October 1952.

Tinker, Jon. “Who’s killing Kenya's jumbos,” New Scientist, $22^{\text {nd }}$ May 1975.

Thompson, Spurgeon. "Returning the Gaze: Culture and the Politics of Surveillance in Ireland," International Journal of English Studies 2 (2002), 95-107.

"Unrest in Kenya," Times of India, 24 ${ }^{\text {th }}$ October 1952.

Wachira, James. "Kenya Needs a New Agenda," The Economic Review, $7^{\text {th }}-13^{\text {th }}$ February 1994.

Wadia, Wilson M. “Opposition Has Played its Role,” Daily Nation, $7^{\text {th }}$ January 1995.

Wanyonyi, George. "Kenya Needs New Blood," The Economic Review, $6^{\text {th }}-12^{\text {th }}$ December1993.

Watkins, Oscar Ferris. "Land Tenure: A Reply to Dr. Leakey," East African Standard, October 27th 1939.

"What is happening in Kenya," Komsomol Pravda, $28^{\text {th }}$ October 1952. 